Universidade de São Paulo

Museu de Arqueologia e Etnologia

Programa de Pós-Graduação em Arqueologia

Mariana Alves Pereira Cristante

\title{
Práticas Funerárias de Grupos de Línguas Tupi-Guarani: Análise de Contextos das Regiões do Paranapanema e Alto Paraná
}

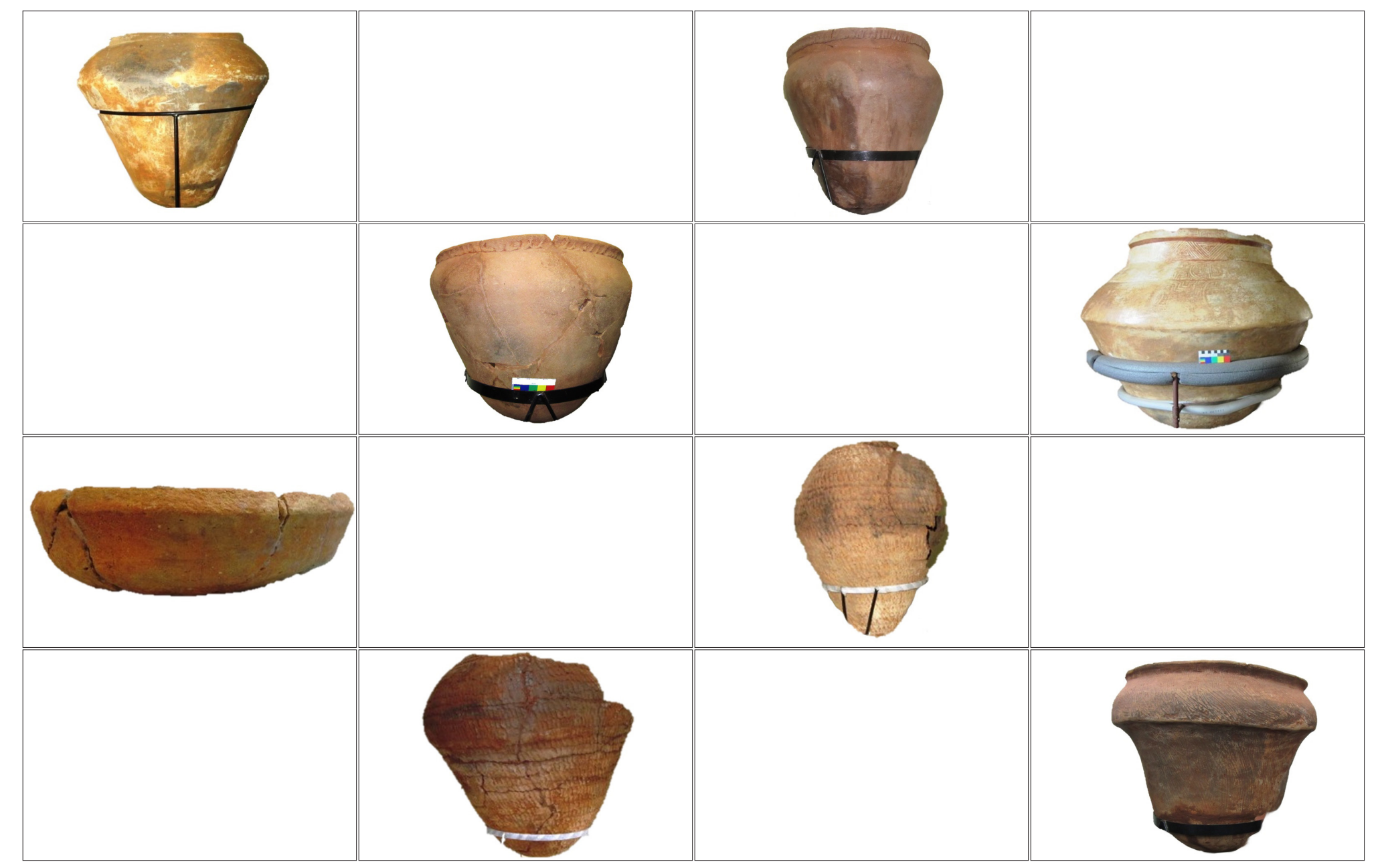




\author{
Universidade de São Paulo \\ Museu de Arqueologia e Etnologia \\ Programa de Pós-Graduação em Arqueologia
}

MARIANA ALVES PEREIRA CRISTANTE

\title{
Práticas funerárias de grupos de línguas Tupi-Guarani: análise de contextos das regiões do Paranapanema e alto Paraná
}

Dissertação apresentada ao Museu de Arqueologia e Etnologia da Universidade de São Paulo para a obtenção do título de mestre em Arqueologia.

Área de Concentração: Arqueologia

Orientadora: Prof. Dra. Marisa Coutinho Afonso

Linha de Pesquisa: Arqueologia e Ambiente

Versão Revisada

São Paulo 
Autorizo a reprodução e divulgação total ou parcial deste trabalho, por qualquer meio convencional ou eletrônico, para fins de estudo e pesquisa, desde que citada a fonte.

Catalogação na publicação

Serviço de Biblioteca e Documentação

Museu de Arqueologia e Etnologia 
CRISTANTE, M. A. P. Práticas funerárias de grupos de línguas Tupi-Guarani: análise de contextos das regiões do Paranapanema e alto Paraná. 2017. Dissertação (Mestrado em Arqueologia) - Museu de Arqueologia e Etnologia, Universidade de São Paulo, São Paulo, 2017.

Aprovado em:

\section{Banca Examinadora}

Prof. Dr.:

Instituição:

Julgamento:

Prof. Dr.:

Instituição:

Julgamento:

Prof. Dr.:

Instituição:

Julgamento: 
À minha família, pelo constante apoio $\mathrm{e}$ inspiração. 


\section{Agradecimentos}

Essa dissertação só foi possível devido à ajuda de muitas pessoas. Agradeço à Prof. Marisa Coutinho Afonso pela orientação e oportunidade. À Prof. Verônica Wesolowski de Aguiar e Santos pela ajuda importante com as análises, e na qualificação. Ao Prof. Francisco Noelli pelas orientações e referências bibliográficas, que foram importantes para esse trabalho. Ao Prof. Sérgio Francisco Monteiro da Silva, pelas orientações e ajuda. À Prof. Neide Barrocá Faccio pela ajuda e orientações, que foram importantes nas análises, e pela gentileza. À Prof. Fabíola Silva pelos conselhos na qualificação.

Agradeço aos funcionários da biblioteca do MAE/USP (Museu de Arqueologia e Etnologia), em especial ao Hélio, pela ajuda imprescindível, sem a qual eu não teria conseguido encontrar grande parte das referências bibliográficas. Também aos funcionários da seção acadêmica e administrativo do MAE, sem os quais nenhuma dissertação ou tese lá seria possível. Ao Prof. Astolfo Araújo pela autorização de pesquisa no Centro Regional de Arqueologia Ambiental de Piraju, ao técnico João Carlos Alves. Aos técnicos do MAE/USP que possibilitaram e facilitaram a análise do material: Carla Gilbertoni, Dária Barreto, Paulo Jacob, Regivaldo, Francisca Figols, Cristina Demartini e Sandra.

À Prof. Ruth Kunzli pela oportunidade de analisar o material no CEMAARQ (Centro de Museologia, Antropologia e Arqueologia), ao Jean Cabrera por toda a ajuda e informações cedidas para esta dissertação, à técnica Nikele pela ajuda durante a análise do material nesse museu. Agradeço à funcionária Dete, do MAI (Museu de Arqueologia de Iepê) pela ajuda e assistência durante minhas análises do material nesse museu, bem como ao seu marido pela ajuda com o trabalho "braçal" que permitiu a realização das medições.

Às arqueólogas, arqueólogos, técnicos e estagiários que realizaram as pesquisas, análises, coletas de dados contextuais, sem as quais essas práticas funerárias estariam perdidas.

Agradeço ao Glauco Constantino Perez, pela ajuda com os mapas. A Gabriele Barbosa dos Santos, pela diagramação e ajuda com algumas das imagens, 
além do constante apoio. A Júlia Ahmed pelas edições e pelo apoio nos momentos finais desta dissertação. Aos colegas e amigos com quem troquei ideias, que ajudaram com o material, a pensar a dissertação e deram apoio para sua realização, entre eles Juliana Fujimoto, Danielle Russo, Ernesto Sumi, Emerson Nobre, Marina Di Giusto, Letícia Ribeiro.

À Prof. Marília Xavier Cury, que um dia me disse que eu podia sonhar alto e chegar mais longe. Ao sensei Yasuyuki Sasaki (in memorian), que me ensinou, entre tantas coisas, que o esforço, determinação e persistência têm o poder de transformar nossas limitações em coisas que jamais imaginávamos antes.

À CAPES pela bolsa de estudos.

À minha família, pelo constante apoio nessa empreitada, pela força e inspiração. 


\section{Resumo}

CRISTANTE, M. A. P. Práticas funerárias de grupos de línguas Tupi-Guarani: análise de contextos das regiões do Paranapanema e alto Paraná. 2017. Dissertação (Mestrado em Arqueologia) - Museu de Arqueologia e Etnologia, Universidade de São Paulo, São Paulo, 2017.

O objetivo dessa dissertação é entender quais são e como se dão os padrões de variabilidade de contextos funerários dos grupos Guarani e Tupinambá, com foco na região da bacia dos rios Paranapanema e alto Paraná. Para tal, fizemos um levantamento bibliográfico de sítios com contextos funerários, escavados por diversos arqueólogos e arqueólogas, que se localizam nos estados de São Paulo, Paraná, Mato Grosso do Sul e Rio de Janeiro. Desses sítios, escolhemos aqueles que possuíam mais informação e material disponível para análise como a base para nossas considerações. Analisamos material cerâmico e remanescentes humanos, e fizemos um levantamento de práticas funerárias de grupos Tupinambá e diversos grupos Guarani a partir de fontes etnohistóricas. Os dados analisados demonstram que a variabilidade das práticas funerárias desses grupos é constituída por continuidades e descontinuidades, elementos básicos que se repetem e elementos que se distinguem. Esses elementos estão presentes na cerâmica, na espacialidade funerária, e conversam com padrões de assentamento. Eles mostram como grupos Guarani e Tupinambá ocuparam áreas ao longo do Paranapanema e afluentes, formando diferentes ocupações que por vezes podem ter existido em um período próximo, no qual esses dois grupos - ou ao menos pessoas que faziam cerâmicas desses dois tipos - podem ter convivido.

Palavras-chave: grupos Tupinambá e Guarani, contextos funerários, cerâmica, remanescentes humanos 


\begin{abstract}
CRISTANTE, M. A. P. Funerary Practices of Tupi-Guarani groups: analysis of contexts of Paranapanema and upper Paraná river basins regions. 2017. Dissertação (Mestrado em Arqueologia) - Museu de Arqueologia e Etnologia, Universidade de São Paulo, São Paulo, 2017.

The aim of this dissertation is to understand what are and how are the patterns of variability of the funerary contexts of Guarani and Tupinambá groups, focused on the region of the Paranapanema and upper Paraná rivers basins. For such purpose we had conducted an extensive literature review of sites with funerary contexts, excavated by different archaeologists, located in São Paulo, Paraná, Mato Grosso do Sul and Rio de Janeiro states. From these sites we selected those who had more information and material available for analysis as the basis of the research. We analyzed pottery and human remains, and we consulted ethnohistorical sources about funerary practices of Tupinambá groups and several Guarani groups. The analyzed data demonstrate that the variability of the funerary practices of these groups is constituted by continuities and discontinuities, basic elements that are repeated and elements that are distinguished. These elements are present in pottery, funerary spatiality and settlement patterns. They show how Guarani and Tupinambá groups occupied areas along the Paranapanema and tributaries, forming different occupations that may have existed, in some cases, in a near period, in which these two groups - or people who produced these two different types of pottery - may have coexisted.
\end{abstract}

Key words: Tupinambá and Guarani groups, funerary contexts, pottery, human remains 


\section{Lista de figuras}

Figura 1: Mapa elaborado por Morais que mostra a confluência de diferentes grupos no estado de São Paulo.

Figura 2: Mapa que mostra as áreas de ocorrência dos conjuntos cerâmicos separados por Corrêa.

Figura 3: Recorte do mapa etno-histórico de Curt Nimuendajú, mostrando a região de São Paulo e arredores.

Figura 4: Desenho esquemático de sepultamento na Bolívia, feito por Nordenskiöld em 1913.

Figura 5: Sepultamento de um "pai de família” Tupinambá 134

Figura 6: Beberagens e danças funerárias dos Tupinambá, segundo Thevet.

Figura 7: Sepultamento de Tupinambás mortos por doença, região do litoral, entre São Vicente e o Rio de Janeiro, segundo Hans Staden

Figura 8: Sepultamento Guarani no Paraguai, final do século XIX 135

Figura 9: Croqui com a localização aproximada dos sítios descritos nessa dissertação que possuíam informação para tal.

Figuras 10 e 11: Localização do sítio Salto Grande do Paranapanema 158

Figura 12: Planta do sítio Jango Luiz 159

Figuras 13 e 14: Vasilha do sítio Jango Luiz com a borda quebrada. E desenho das vasilhas encontradas por Pallestrini no sítio 160

Figura 15: Vasilhas funerárias do sítio Panema. 160

Figura 16: Vasilha que servia como tampa no conjunto funerário do sítio Panema

Figura 17: Área do sítio Lagoa São Paulo 2........................................ 164

Figura 18: Espacialidade regional das formas................................ 172

Figura 19: Camuci do sítio Prassévichus ....................................... 173

Figuras 20 e 21: Urna do sítio Salto Grande do Paranapanema................. 181 
Figura 22: Urna encontrada no bairro Cascavel, Piraju. Acervo Centro Regional de Piraju

Figuras 23-24: Urna retirada de contexto, proveniente do sítio Nunes .... 196

Figuras 25- 27: Vasilha encontrada em ocorrência no município de Rosana.....196

Figuras 28-31: Vasilha do sítio Lopes, com fragmentos de ossos humanos dentro

Figuras 32-34: Vasilha do sítio Romanini, com fragmentos de ossos dentro .... 197

Figura 35: Contexto funerário IV do Sítio Prassévichus

Figura 36: Contexto indeterminado do Sítio Prassévichus, com ausência de vasilhas ao redor ou próximas à urna e à tampa

Figura 37: Contexto indeterminado do Sítio Prassévichus, com duas tampas .. 213

Figura 38: Escavação do sepultamento I - Sítio Fonseca ......................... 215

Figura 39: Escavação do sepultamento II - Sítio Fonseca

Figura 40: Escavação do interior da urna II - Sítio Fonseca

Figura 41: Escavação do interior da urna II - Sítio Fonseca (continuação) . 219

Figura 42: Escavação do sepultamento III - Sítio Fonseca

Figura 43: Evidenciação das urnas V e VI, Sítio Fonseca

Figuras 44-46: Fragmento de concha (família Tonnidae), dente de porco do mato e ponta de osso com pedúnculo, encontrados no sedimento em que estavam os sepultamentos 1 e 2

Figura 47: Local onde foi encontrada a urna do Salto Grande analisada por nós ...224

Figuras 48 e 49: Dentes encontrados dentro de vasilha aberta do sítio Itaguá .... 228

Figura 50: Esquema do contexto funerário 3 do sítio Alves. 228

Figuras 51: Esquema do contexto funerários 4 escavação da urna 4 do sítio Alves, com evidenciação de vasilhas.

Figura 52: Croqui da abertura de unidades de escavação onde se evidenciaram contextos funerários no sítio Lagoa São Paulo 2.

Figura 53: Croqui de unidades de escavação que contêm contextos funerários 
Figura 54: Escavação do contexto funerário 1, sítio Pernilongo

Figura 55: Tembetá e adornos em resina encontrados ao lado de bloco de basalto, próximos ao contexto funerário 1 , sítio Pernilongo.

Figura 56: Fragmentos diversos do primeiro sepultamento encontrado no sítio Lagoa São Paulo $2 * 9$

Figuras 57 e 58: Fundo da urna onde se encontrava o sepultamento (vistas da face interna e externa, respectivamente. O restante foi arrancado por máquina da olaria

Figuras 59 e 60: Fragmentos dos dentes do PS - 09 251

Figuras 61-63: PS - 09. Primeiros molares superior e inferior esquerdos, primeiros molares superior e inferior direitos, incisivos frontais superiores 251

Figura 64: Diferentes morfologias de urnas funerárias encontradas na região de Araruama $(\mathrm{RJ})$

Figura 65: Contexto funerário do sítio Morro Grande, e que há vasilhas associadas a uma fogueira.

Figuras 66 e 67: Foto do contexto funerário I da aldeia Morro Grande, e desenhos das vasilhas de acompanhamento funerário 273

Figuras 68-73: Contexto funerário II da aldeia Morro Grande 274

Figuras 74: Contexto funerário II da aldeia Morro Grande 275

Figuras 75-79: Contexto funerário III da aldeia Morro Grande, e desenhos das vasilhas escavadas.

Figura 80: Contexto funerário do sítio Morro Grande

Figura 81: Contexto funerário V da aldeia Morro Grande 277

Figuras 82-87: Contexto funerário escavado no sítio Bananeiras, forma da urna, pingente encontrado no contexto e vasilhas de acompanhamento funerário..... 278

Figuras 88 e 89: Contexto funerário escavado na aldeia Serrano e "cama" de argila encontrada sob urna funerária no mesmo sítio

Figuras 90 e 91: Morfologia de urna funerária do sítio Serrano 279

Figura 92: Possível sepultamento primário dentro de urna no sítio Serrano 280

Figura 93: Localização dos contextos funerários e outros vestígios arqueológicos no sítio São José 
Figuras 94 e 95: Fragmento e vasilha fragmentada encontrados em contextos funerários da aldeia São José

Figura 96: Planta do sítio Franco de Godoy, evidenciando manchas de terra preta e locais das estruturas funerárias

Figura 97: Urna funerária do sítio Franco de Godoy ............................. 284

Figura 98: Urna do sítio Franco de Godoy

Figuras 99-102: Urnas e possíveis urnas provenientes de coleções, da região do noroeste do estado de São Paulo

Figura 103: Urna funerária e tampa provenientes de coleção, do noroeste de São Paulo

Figuras 104 e 105: Tampa e vasilha com ossos humanos dentro encontrada no município de Salto (SP)

Figura 106: Áreas de decapagem $(\mathrm{AD})$ do sítio Rio Ivinhema 1

Figura 107: Estrutura funerária da área de decapagem 4 e vasilha associada

Figuras 108-113: Estrutura funerária da área de decapagem 4, em que o indivíduo se encontrava dentro da urna, com ossos longos mal preservados e crânio coberto por vasilha (cambuchí), crânio, urna e vasilhas associadas reconstituídas

Figura 114 e 115: Estrutura funerária da área de decapagem 3, e vasilhas encontradas a alguns metros de distância desta, sítio Rio Ivinhema $1 . .$.

Figuras 116-118: Urna corrugada e vasilhas/fragmentos de vasilhas associados ao contexto, área de decapagem 3 , sítio Rio Ivinhema 1

Figura 119: Vasilhas próximas ao contexto funerário da AD3

Figuras 120 e 121: Estrutura funerária do sítio Alto Paraná 8, e vasilhas que a compunham

Figura 122 : Parte de contexto funerário encontrado na margem do rio Samambaia, MS, no sítio MT-IV-1

Figura 123 : Exemplos de vasilhas utilizadas como urnas funerárias e tampas no sítio MT-IV-1

Figura 124: Exemplos de vasilhas utilizadas como urnas funerárias no sítio MT-IV-1 
Figura 125: Vasilhas encontradas em contextos funerários

Figura 126: Vasilhas encontradas em contextos funerários

Figura 127: Desenho do contexto funerário encontrado por Chmyz no sítio PR FI 148 (Caranguejeiras)

Figura 128: Artefatos encontrados em contexto funerário no sítio PR FI 148 (Caranguejeiras) 300

Figura 129: Planta do sítio PR FO 24 (Ilha do Alemão 1) 301

Figura 130: Contexto funerário escavado do sítio PR FO 24 (Ilha do Alemão1) ... 301

Figura 131: Croqui do sítio PR NL 7 - Pesqueiro Barragem de Rosana 304 


\section{Lista de pranchas}

Prancha 1: Urna do contexto funerários do sítio Itaguá ................................ 177

Pranchas 2-4: Vasilhas dos contextos funerários do sítio Fonseca ................... 177

Pranchas 5-7: Vasilhas dos contextos funerários do sítio Prassévichus ............ 179

Pranchas 8-12: Vasilhas dos contextos funerários do sítio Alves ..................... 182

Pranchas 13-15: Vasilhas dos contextos funerários do sítio Aguinha .............. 188

Pranchas 16-19: Vasilhas dos contextos funerários do sítio Pernilongo ........... 191

Prancha 20: Vasilhas de contextos funerários do sítio Pernilongo ................... 195

Prancha 21: Vasilha do sítio Canuto (1 ou 2) ............................................... 198

Prancha 22: Urna do sítio Lagoa São Paulo 2 .............................................. 198

Pranchas 23 e 24: Abrasão em forma circular próxima à base ......................... 204

Prancha 25: Abrasão na face externa da base ............................................... 206

Prancha 26: Marcas de uso na parte interna de um dos lados da base ............. 207

Prancha 27: Abrasão na parte interna da base …………………................. 208

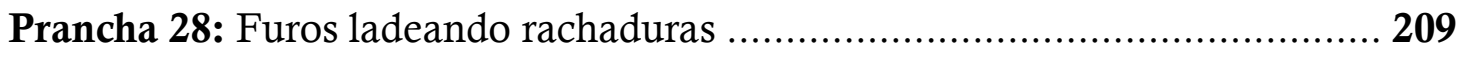

Prancha 29: Contexto funerário IV do sítio Prassévichus ............................... 214

Prancha 30: Fragmentos cerâmicos associados a sepultamento do sítio Salto

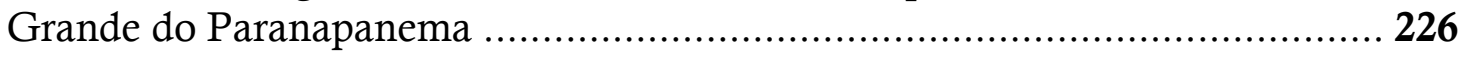

Prancha 31: Desenhos dos contextos funerários do sítio Alves, com as respectivas

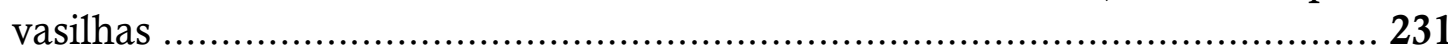

Pranchas 32 e 33: Contextos funerários I e II do sitio Aguinha ....................... 240

Pranchas 34 e 35: Contextos funerários I e II do sítio Pernilongo .................... 243

Pranchas 36-40: Vasilhas funerárias na planta do sítio .................................. 244

Prancha 41: Ossos humanos provenientes do sítio Alves ............................... 249

Prancha 42: Remanescentes humanos encontrados no segundo sepultamento

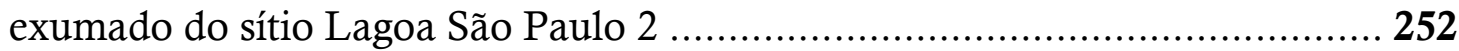


Pranchas 43 e 44: Ossos do sepultamento 2 do sítio Fonseca

Pranchas 45 e 46: Ossos do sepultamento 2 do sítio Silveira ....................... 259

Pranchas 47 e 48: Ossos do sepultamento 1 do Salto Grande ..................... 262

Prancha 49: Ossos do indivíduo 2 do sítio Salto Grande ........................... 264

Pranchas 50 e 51: Ossos do sepultamento do sítio Panema ........................ 268 


\section{Lista de quadros}

Quadro 1: Vasilhas Guarani já encontradas em contexto funerário e suas respectivas funções básicas

Quadro 2: Autores das fontes primárias sobre práticas funerárias, suas respectivas regiões visitadas e épocas de observação

Quadro 3: Resumo das práticas funerárias

Quadro 4: Gestos funerários e grupos descritos

Quadro 5: Locais de sepultamento ............................................... 130

Quadro 6: Gestos pós-funerários.................................................. 133

Quadro 7: Sítios principais analisados .......................................... 149

Quadro 8: Sítios secundários................................................... 152

Quadro 9: Cronologia para os sítios principais e secundários que possuem datas

Quadro 10: Contextos funerários do sítio Lagoa São Paulo 2

Quadro 11: Informações sobre a presença de ossos humanos nos contextos analisados

Quadro 12: Tipos de contextos funerários Tupinambá e Guarani que já foram escavados. 


\section{Lista de gráficos}

Gráfico 1: Tipos e número de vasilhas usadas como urnas por sítio .......... 174

Gráfico 2: Tratamentos de superfícies internas das urnas de cada sítio ...... 175

Gráfico 3: Tratamentos de superfícies externas das urnas de cada sítio ...... 175

Gráfico 4: Classes de vasilhas anexas por sítio .................................. 200

Gráfico 5: Tratamentos de superfície interna das vasilhas anexas ............. 200

Gráfico 6: Tratamentos de superfície externa das vasilhas anexas ............. 201 


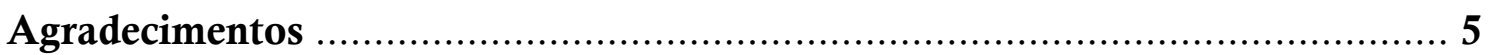

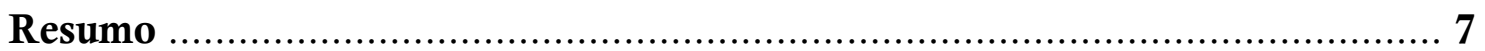

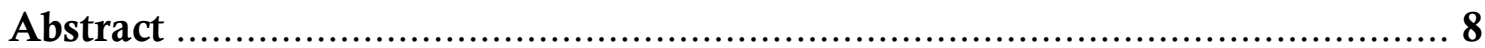

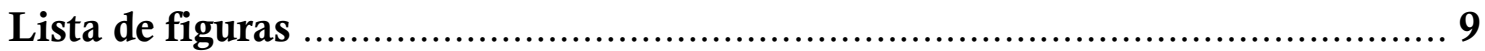

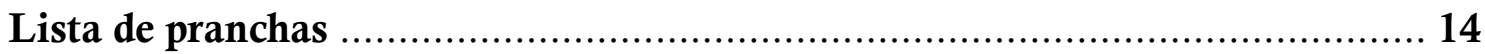

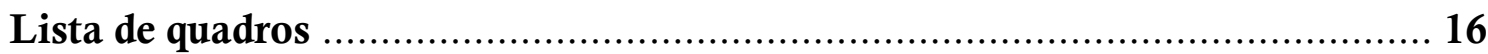

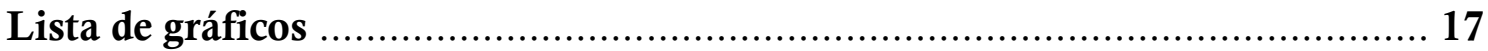

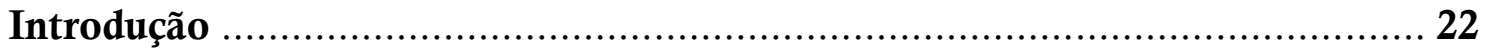

Capítulo I. A REGIÃO

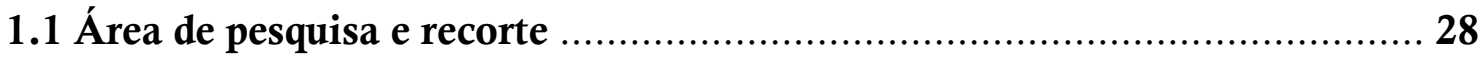

1.2 As pesquisas arqueológicas nos contextos analisados ............................... 30

1.2.1 Bacia do rio Paranapanema …….......................................................... 30

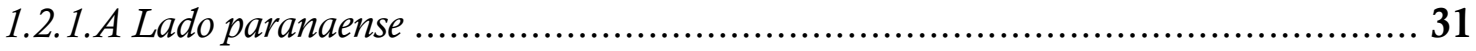

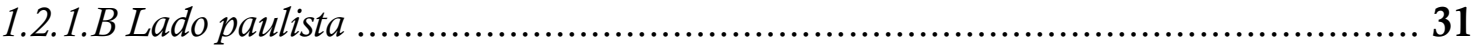

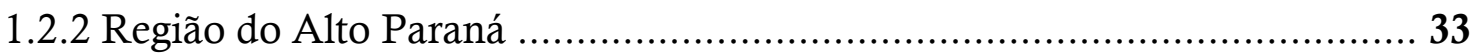

1.3 O estado de São Paulo: um mosaico de confluências ................................... 34

1.4 Breve levantamento etnohistórico para as regióes do Paranapanema e Alto

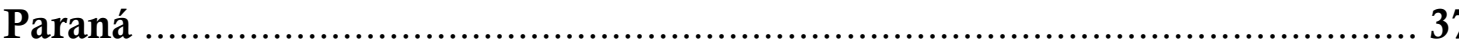

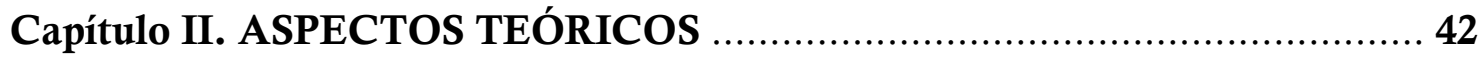

2.1 Uma Arqueologia dos Vivos Através da Morte .........................................4

2.1.1 Síntese histórica dos estudos sobre contextos funerários............................. 45

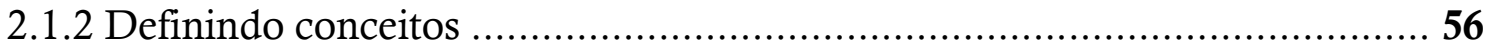




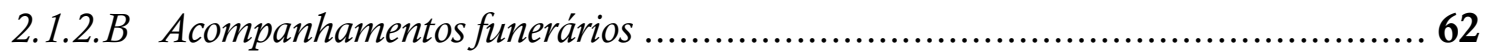

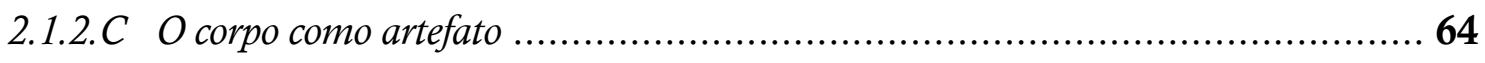

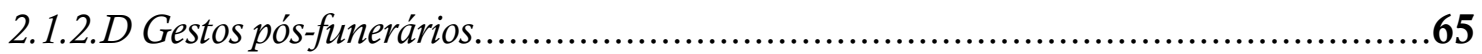

2.1.3 Os processos do sepultamento ...........................................67

2.1.4 A mudança diacrônica nas práticas mortuárias ..................................... 71

2.1.5 Análise espacial de contextos mortuários ..................................... 72

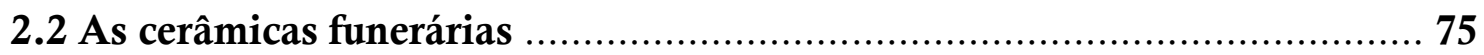

2.2.1 A variabilidade dos artefatos funerários .......................................... 75

2.2.2 Análise das marcas de uso das vasilhas funerárias Tupi-Guarani .............. 77

2.3 Ética no estudo de contextos funerários ......................................... 79

Capítulo III. MÉTODOS ............................................................... 86

3.1 Entendendo a variabilidade: análise multidimensional dos sepultamentos . 86

3.2 Análise do material cerâmico ................................................. 91

3.3 Análise dos remanescentes humanos .......................................... 92

Capítulo IV. OS TUPI-GUARANI E A MORTE ................................ 97

4.1 A arqueologia de grupos Tupi-Guarani: questões pertinentes ................ 97

4.2 Pesquisas e abordagens teóricas sobre a morte Tupi-Guarani e as urnas

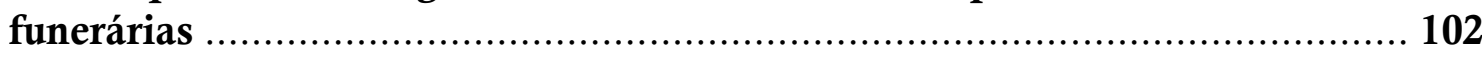

4.3 Práticas funerárias de grupos Tupi de regiões ao sul do Brasil: o que dizem as

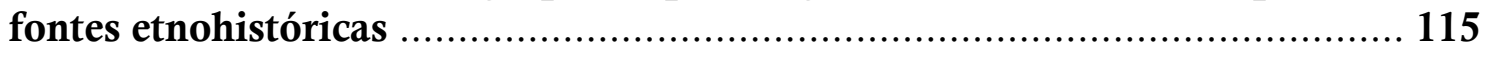

4.3.1 Analogias etnográficas ................................................... 116

4.3.2 Análise de fontes primárias e secundárias .................................... 117

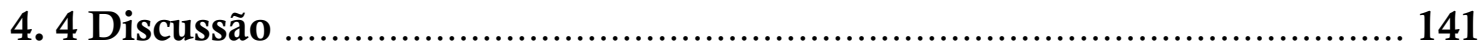




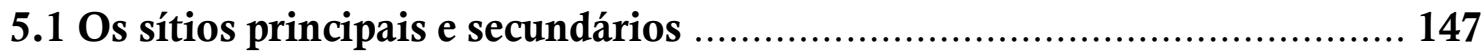

5.1.1 Aspectos gerais: sítios Tupinambá e Guarani ....................................... 147

5.1.2 Características e áreas de implantação dos sítios ..................................... 164

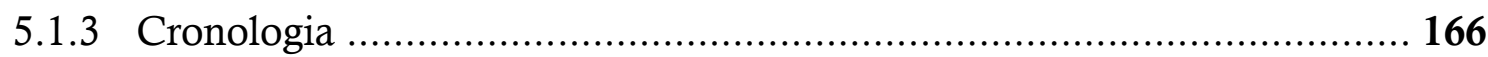

5.1.4 Análise do material cerâmico e marcas de uso ...................................... 168

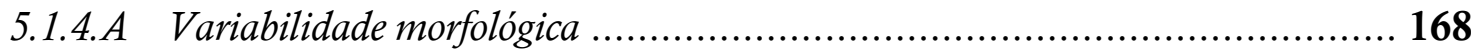

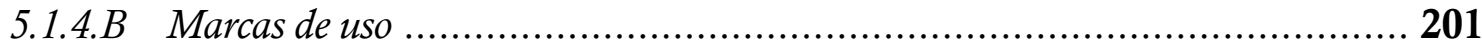

5.1.5 Análise da espacialidade funerária entre os sítios Tupinambá e Guarani...... 210

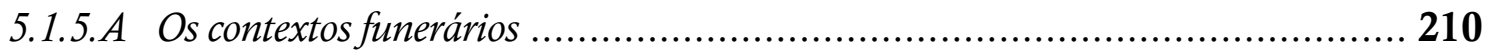

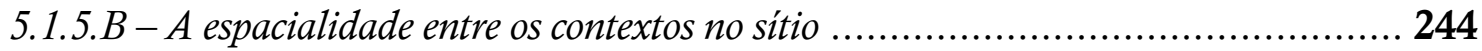

5.1.6 Análise dos remanescentes humanos ………...................................... 247

5.2 Os outros sítios com contextos funerários Guarani e Tupinambá ……..... 270

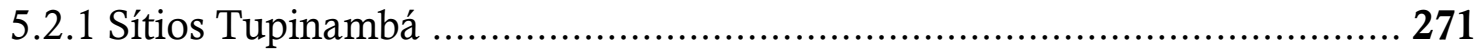

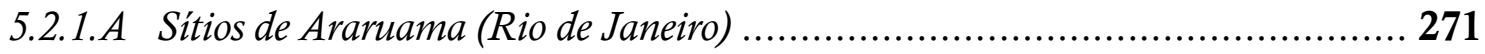

5.2.1.B Sítios e coleções do noroeste de São Paulo ............................................... 282

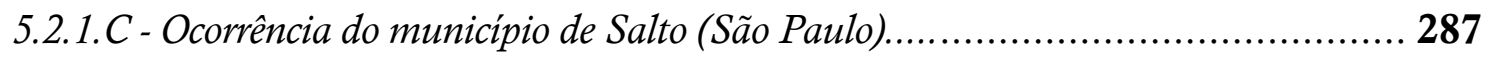

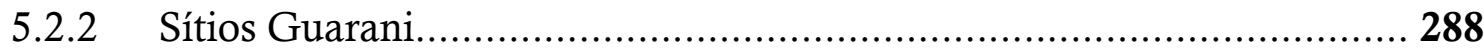

5.2.2.A Sítios do Baixo Paranapanema e Alto Paraná (São Paulo e Mato Grosso do Sul) .... 288

5.2.2.B Sítio da região de Itaipu - PR FI 148 (Caranguejeiras) ................................ 397

5.2.3 Sítios sem classificação em Tupinambá e Guarani ................................. 300

5.3 Discussão: as continuidades e descontinuidades dos Guarani e Tupinambá ... 307

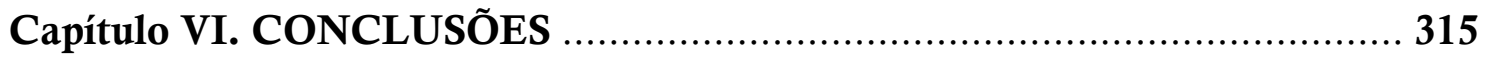

6.1 Os grupos Guarani e Tupinambá da região do Paranapanema ............... 315

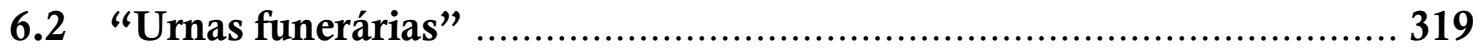


6.3 Contextos funerários Tupinambá e Guarani: possibilidades e problemas

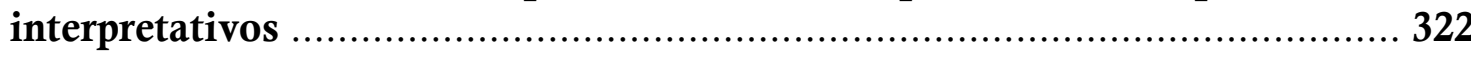

6.3.1 Contextos funerários, mudanças diacrônicas e materialidade..............324

6.3.2 Gestos pós-funerários, sepultamentos secundários e a importância dos mortos.

Considerações Finais

Referências bibliográficas

APÊNDICES

Apêndice A: Ficha de análise do material cerâmico

Apêndice B: Inventário ósseo e dentário dos indivíduos analisados na dissertação e fichas de diagnóstico de sexo e idade preenchidas

ANEXOS

Anexo A - Projetos Arqueológicos da Região do Alto Paraná

Anexo B - Fichas de análise preliminar e inventário ósseo e dentário de remanescentes humanos

Anexo C - Fichas para diagnóstico de sexo e idade de remanescentes humanos 


\section{Introdução}

Entre os Tupi-Guarani a morte é algo extremamente importante, e os mortos possuem um papel fundamental no mundo dos vivos. Por isso, é de se estranhar que, na Arqueologia desses grupos no Brasil, o tema das práticas mortuárias e dos conceitos em relação à morte ainda seja incipiente. Os contextos funerários, em especial as cerâmicas funerárias, sempre foram muito marcantes no estudo desses grupos. Sobre cerâmicas funerárias foram construídas tipologias, modelos de origem e expansão.

Há inúmeras questões muito básicas sobre esses contextos funerários Tupinambá e Guarani que não possuem respostas: quais os padrões funerários? Quem era sepultado de certo jeito, quem o era de outro? Qual o papel sociopolítico desses indivíduos sepultados e desses sepultamentos? Quais as agências que esses sepultamentos e esses mortos possuíam para os vivos?

Quando iniciamos essa pesquisa, pensamos em tentar responder à primeira pergunta para os contextos das regiões do Paranapanema e alto Paraná. Queríamos saber qual era a variabilidade dos contextos e cerâmicas funerárias. Para isso, resolvemos fazer um levantamento de contextos funerários, analisando cerâmicas e remanescentes humanos aos quais conseguimos ter acesso. Isso porque sentíamos falta de uma sistematização de dados que possibilitasse observar quais padrões existiam, como esses padrões estavam dispersos no espaço, como mudavam com o tempo.

Escolhemos uma região que conta com um grande número de pesquisas arqueológicas, que é a bacia do Paranapanema e alto Paraná, realizadas em grande parte com uma metodologia que possibilitou a documentação dos contextos funerários. A partir dessa região, expandimos para outros sítios de outras áreas, para assim podermos ter mais dados para comparação e observação de padrões.

Além disso, essa região do Paranapanema também é interessante por ser uma área de fronteira, de acordo com os atuais modelos, entre grupos que faziam cerâmicas Tupinambá e Guarani, além de ser fronteira com outros grupos, como os Jê. Assim, além das questões já apresentadas, os contextos funerários dessa região suscitam outras: as práticas funerárias sofreriam influência no contato entre Tupinambá e Guarani? Como 
poderíamos pensar a relação entre produção de um determinado tipo de cerâmica, etnicidades locais (pensando-as como dinâmicas e situacionais), línguas, e concepções compartilhadas pelos Tupi (à maneira como sugerem autores como Viveiros de Castro [1986])? Essas são questões que só agora começam a ser exploradas, e muito ainda está por ser feito. Há autores que acreditam que tais relações não podem ser feitas, mas no nosso caso acreditamos que, tomando o devido cuidado, é possível fazer certas associações.

Esse levantamento nos levou a 35 sítios e ocorrências com contextos funerários descritos, dos quais escolhemos 17 para analisar as 49 vasilhas cerâmicas funerárias inteiras e os 9 indivíduos encontrados nas reservas técnicas e exposições de museus. Esses museus são o Museu de Arqueologia e Etnologia da Universidade de São Paulo (MAE/USP), em São Paulo; Centro Regional de Arqueologia Ambiental Mário Neme, em Piraju; Centro de Museologia, Antropologia e Arqueologia (CEMAARQ), em Presidente Prudente; e Museu de Arqueologia de Iepê (MAI), em Iepê.

Nesses 35 sítios e ocorrências arqueológicas, o total de contextos funerários presumidos é de 119. No entanto, há muitos problemas com esse número. Ele representa o total somado de contextos que foram contabilizados como funerários pelos autores das diversas publicações que consultamos. Entretanto, não há como ter certeza absoluta se todos são funerários de fato, pois nem todos foram encontrados com remanescentes humanos na época de suas escavações, que dariam essa certeza de ser um contexto pelo menos mortuário. Além disso, muitos não possuem sequer a informação da presença ou ausência de remanescentes humanos. E, além desses fatores, há também um grande número de contextos que foram contabilizados em alguma publicação, mas que não encontramos descrições para cada um individualmente.

Essa falta de descrições de muitos contextos talvez se dê por motivos de ordem prática: urgência na escavação, contexto impactado demais, vasilhas e ossos retirados do lugar por moradores da área, etc. Não há como sabermos quais desses problemas houve na época da escavação.

Outro problema é o conceito de contexto funerário, que dependendo do autor não está claro. Autoras como Kashimoto (2007), consideram que todas as vasilhas, grandes e pequenas, associadas espacial e estratigraficamente, fazem parte do mesmo contexto funerário. Então, esses autores contabilizam como um contexto funerário cada 
agrupamento de vasilhas em que pelo menos uma contenha remanescentes humanos, ou então em que haja o mesmo padrão de outros contextos similares nos quais foram encontrados remanescentes humanos.

Nessa dissertação, adotamos uma concepção similar a essa: consideramos como contexto funerário cada estrutura composta por uma vasilha inteira coberta por tampa, ou composta por um agrupamento de vasilhas inteiras em que pelo menos uma esteja coberta por tampa e as outras estejam localizadas ao lado desta ou então dentro. Dessas estruturas, algumas continham ossos dentro, outras não, e outras não é possível sabermos. Devido a essa incerteza, colocamos que alguns contextos são de fato funerários e outros são apenas possivelmente funerários. No entanto, os possivelmente funerários são compostos por estruturas muito parecidas com as dos funerários de fato: grandes vasilhas com tampas, várias vasilhas uma ao lado da outra, uma grande vasilha com outras menores dentro, etc. Em alguns casos, essas estruturas muito parecidas ocorrem no mesmo sítio: um contexto apresenta ossos humanos, mas o outro não os apresenta. Desse modo, estamos concordando com os arqueólogos que os escavaram, inferindo que esses contextos sem ossos também sejam funerários devido à sua similaridade com os outros. Processos tafonômicos e culturais diversos podem ter sido responsáveis pelo desaparecimento desses ossos.

Assim, estamos considerando que contextos compostos por um agrupamento de vasilhas inteiras, na qual haja pelo menos uma que seja ou tenha sido um dia coberta por uma tampa - mas não necessariamente, pois esta pode ter se perdido -, ou por uma única vasilha, dependendo de certas condições contextuais que podem variar conforme processos tafonômicos, sejam funerários ou possivelmente funerários. No entanto, é preciso partir do pressuposto de que passaram por diversos gestos e processos naturais, que podem variar de contexto para contexto, e que podem ter levado inclusive ao desaparecimento dos ossos, movimentação das vasilhas, quebramento e desaparecimento da tampa, quebramento da urna, etc.

Portanto, temos uma base, uma ideia do que seja um contexto funerário (ou mortuário) de sítios associados a grupos Tupi-Guarani, que é a recorrente presença de vasilhas com tampas, e vasilhas associadas entre si sendo que pelo menos uma no passado conteve remanescentes humanos e as outras poderiam - segundo as fontes etnohistóricas - conter alimentos e bebidas, ou serem também parte dos pertences do 
morto. Além desses tipos de contextos, há também outros que são recorrentes, que são aqueles compostos por remanescentes humanos fora de vasilhas cerâmicas, mas associados a vasilhas que estariam cobrindo seus crânios, ou que poderiam ter se movido para baixo dos mesmos.

Baseado na recorrência de achados assim, acreditamos que um contexto funerário de grupos Tupi, ou pelo menos Tupi-Guarani, possa ser inferido mesmo quando não há ossos humanos nele.

Nos 17 sítios e ocorrências nos quais fizemos análise de algum tipo de material arqueológico, o número de contextos como ossos humanos é 16 (8 sítios Guarani e 8 Tupinambá). Somado ao número de contextos possivelmente funerários, esses sítios e ocorrências apresentaram um total de 43 contextos. Um dos sítios, o Silveira, não apresentava de fato um contexto funerário, e sim apenas um esqueleto descontextualizado (ou para o qual não encontramos maiores informações).

Nos outros 18 sítios, aqueles que não analisamos material e apenas lemos as descrições dos contextos funerários, foram relatados 76 .

A fragmentação de informações, multiplicidade de critérios e discrepância na precisão das descrições foram os maiores problemas enfrentados por nós em nossa sistematização dos dados sobre contextos funerários. $\mathrm{E}$, desses 16 , pudemos inferir que pelo menos 1 passou por, além de processos funerários e tafonômicos, também por processos pós-funerários que podem tê-lo alterado significativamente.

A maioria dos contextos funerários de grupos Tupi em geral é encontrada já impactada por moradores locais, o que gera as inúmeras vasilhas descontextualizadas que há nos museus. Um motivo para isso é a velha crença de que as vasilhas podiam ser baús do tesouro. Outro fator, cada vez mais presente, é o incremento da tecnologia agrícola, que faz com que máquinas tenham a capacidade de escavar, em uma grande área, uma larga camada da superfície do solo, destruindo qualquer contexto pelo qual passem por cima. Fatores como esses provavelmente geraram a perda de centenas de contextos, e talvez a ideia de que os sepultamentos em urna sejam raros venha mais de uma baixíssima amostragem no registro arqueológico do que de um fato. Por isso a necessidade do registro completo dos contextos funerários Tupi, pois cada contexto que resta é precioso. 
A perda de contextos se soma à discrepância entre os métodos de escavação, objetivos e conceitos em relação aos contextos funerários, e essas provavelmente são as principais causas do nosso desconhecimento a respeito das práticas funerárias Tupi. Como o conceito do que seja um contexto funerário Tupi é variável, e os objetivos de pesquisa e métodos de escavação também variam muito, o que temos são retratos bastante parciais das práticas funerárias, pontuais, difíceis de serem sistematizados. As descrições que chagam até nos, os materiais presentes nas reservas técnicas dos museus e nas exposições, são o resultado do fazer arqueológico, que determina as possibilidades de interpretação.

Nessa dissertação, buscamos adotar um conceito definido de contexto funerário, e pensamos num método e numa chave de análise para nossos dados - baseado no que geralmente é feito na arqueologia das práticas funerárias e adaptado para os grupos Tupi. Essa experiência se mostrou útil e frutífera.

Os contextos funerários precisam ser entendidos como entidades dinâmicas, locais que passaram por diversos processos, tanto relacionados com o funeral quanto não relacionados a ele. As práticas funerárias - aquelas ligadas especificamente ao funeral, que tinham como objetivo dar um destino adequado ao morto - são apenas uma pequena parte de todos os processos que ocorreram nos contextos funerários. Esses outros processos podem ser naturais, gestos pós-funerários e gestos extra funerários. Os processos naturais são aqueles que ocorrem com o corpo desde o momento da morte e continuam a ocorrer durante todo o tempo no sepultamento que não são ações humanas. Os gestos pós-funerários são relativos à abertura da sepultura para os mais diversos fins (veneração, retirada de ossos, mudança dos ossos de lugar, etc.), que não estão diretamente ligados ao funeral. E gestos extra funerários seriam aqueles em que o corpo não é sepultado de fato, e sim passa por outras ações (perda, abandono, remoção de partes do corpo, etc.). Um sepultamento pode ter passado por vários desses processos. É preciso separar o que são gestos de processos naturais, e dentro dos gestos separar que tipos de gestos podem ser (se funerários ou não) (WeissKrejci, 2011).

Desse modo, os contextos funerários de grupos Tupi precisam ser entendidos como fruto desses processos todos, um campo de práticas e gestos que podem trazer muitas informações sobre os grupos que habitaram aquele sítio. Isso poderia inclusive 
trazer contribuições para as discussões clássicas sobre os sepultamentos dos grupos da família Tupi-Guarani, iniciadas por Métraux (2012 [1928], 1947, 1979) e levadas adiante por César $(1966,1975)$ e Noelli (1993).

Por isso, devem ser analisados como um todo, considerando-se o máximo de informações e elementos que estiverem disponíveis. Isso permite a recuperação de uma série de gestos que envolvem o corpo, mas também envolvem as cerâmicas e outros materiais produzidos por esses grupos. A associação dos gestos com as cerâmicas se mostrou útil para que pudéssemos distinguir diferentes conjuntos entre os contextos funerários.

As análises do material nos remeteram às sugestões dos autores que defendem a existência de grupos não só Guarani, como também Tupinambá na bacia do Paranapanema, como Brochado (1984), Noelli (1993) e Corrêa (2014). Notamos que o padrão regional das cerâmicas podia ser associado com o dos contextos funerários.

Além do levantamento de contextos e da análise de material, queríamos saber também quais práticas funerárias havia entre os grupos Tupinambá e Guarani, para que assim pudéssemos ter possibilidades de interpretação. Assim, fizemos uma pesquisa em fontes etnohistóricas e etnográficas, que nos levou a encontrar diversas ações e gestos em relação aos mortos. Essas descrições de práticas trazem uma gama de possibilidades para se interpretar os contextos arqueológicos, e junto trazem uma série de questões também. 


\section{Capítulo I \\ A REGIÃO}

\section{1 Área de pesquisa e recorte}

Para esta pesquisa estamos trabalhando com regiões que estão localizadas dentro dos estados de São Paulo, Paraná, Mato Grosso do Sul e Rio de Janeiro. O foco principal é a área da bacia do rio Paranapanema, e parte da bacia do alto rio Paraná, numa região próxima à foz do primeiro rio, e que divide os estados de São Paulo e Mato Grosso do Sul. Porém, informações de outras regiões, como a de Araruama (RJ), áreas do noroeste de São Paulo, do Mato Grosso do Sul e do Paraná, retiradas das publicações sobre sítios dessas áreas, também foram utilizadas para compor um quadro de práticas e contextos funerários de grupos Tupinambá e Guarani.

A escolha das regiões se deu porque nelas aconteceram muitos trabalhos arqueológicos desde décadas atrás, o que possibilitou um grande número de informações sobre contextos funerários. Fizemos um intenso levantamento bibliográfico sobre os contextos funerários encontrados nessas regiões, e chegamos a uma série de informações.

Todo o material cerâmico e ósseo analisado por nós é proveniente de sítios do estado de São Paulo, não por causa de alguma preferência nossa, mas porque foram aqueles em que pude ter acesso ao material para análise.

Nossa análise foi feita apenas com material proveniente de contextos funerários. Não analisamos cerâmicas não funerárias, pois cada sítio principal conta com milhares de fragmentos cerâmicos. Portanto, nossas considerações se dão principalmente em cima desse material e das práticas funerárias. O mapa 1 traz a localização aproximada dos sítios cujo material cerâmico e/ou ósseo analisamos. Os pontos foram plotados de acordo com o município de casa sítio, pois não tínhamos a localização exata de todos. 
Mapa 1: Sítios que tiveram seu material cerâmico e/ou ósseo analisado. Elaboração: Mariana Cristante e Glauco Perez.

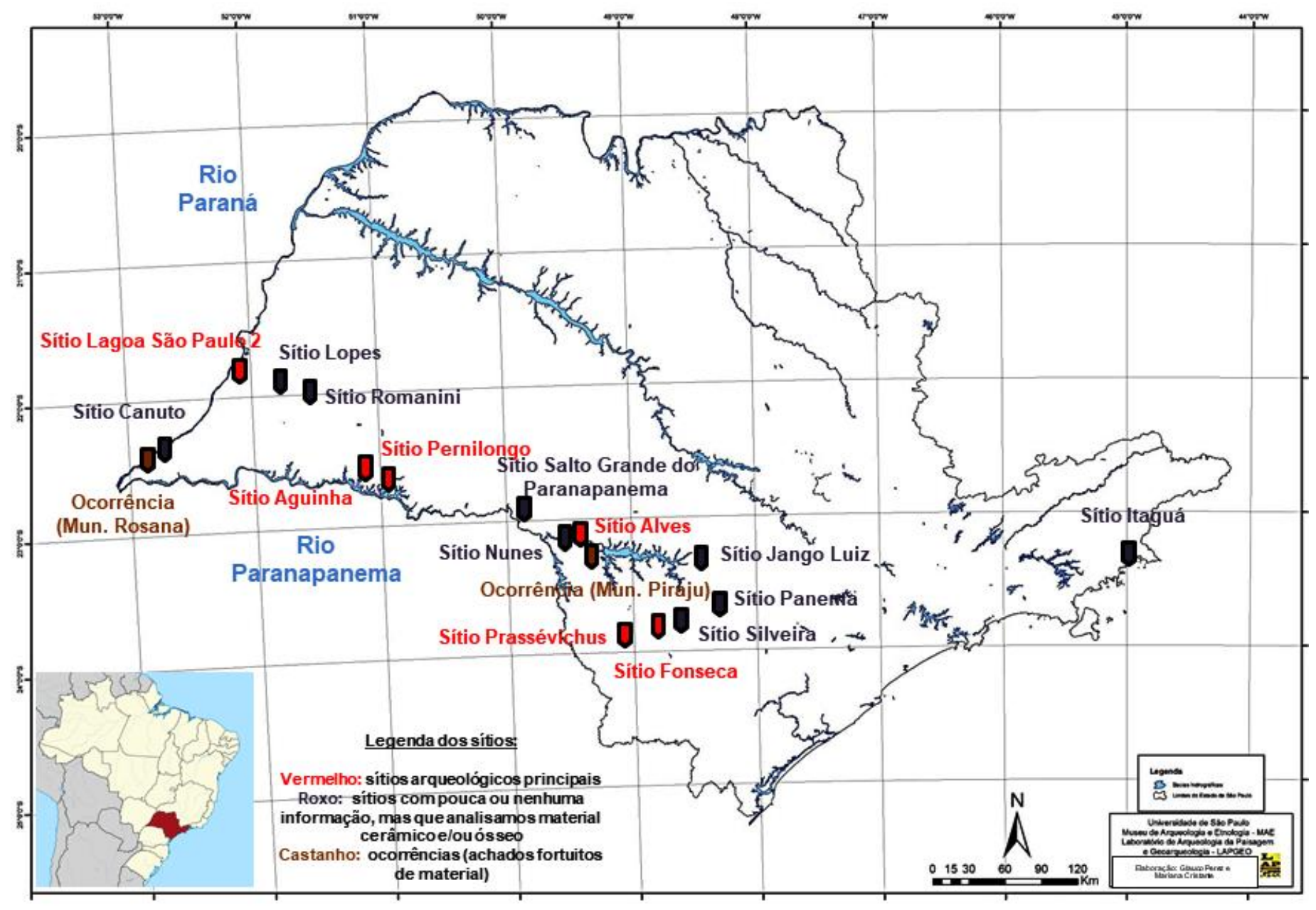

Neste trabalho fizemos um recorte temático e bibliográfico que apoie as questões que pretendemos trabalhar. Não temos a intenção de buscar a organização social nos contextos funerários, pois não possuímos um controle cronológico confiável dos mesmos para saber se há contemporaneidade e quais são as diferenças cronológicas entre um contexto e outro. Consideramos que a organização social de grupos do tronco Tupi (seja Tupi-Guarani ou não), sua relação com as práticas funerárias e como seria o registro arqueológico resultante dessas práticas são questões que ainda não temos elementos suficientes para trabalhar.

Também não pretendemos englobar detalhes dos aspectos simbólicos sobre a morte, o mundo dos mortos e o simbolismo funerário de grupos Guarani e Tupinambá. Julgamos que esse campo de pesquisa seria complexo e amplo demais, e não receberia a devida atenção nesse mestrado. A análise dos contextos e das etnografias está focada, sobretudo, em aspectos comportamentais, de ações e gestos funerários. Consideramos mais interessante primeiro saber quais práticas havia e como elas poderiam estar 
representadas no registro arqueológico em uma certa região. Então, optamos por trabalhar com a espacialidade regional funerária e suas continuidades e descontinuidades em termos, especialmente, de cerâmicas e comportamentos funerários, em uma perspectiva sincrônica e diacrônica.

A escolha desse recorte se deu porque sentimos falta de pesquisas que sistematizem e tratem da espacialidade dos contextos funerários de grupos Tupi, tanto no âmbito do sítio quanto entre vários sítios comparativamente. Isso provavelmente se dá, por um lado, porque os contextos funerários Tupi em geral são encontrados isoladamente, muitas vezes por pessoas da comunidade local, e em pouquíssimos casos são encontrados intactos, o que diminui a quantidade de informações que podem ser retiradas deles. Por outro lado, sabe-se que as pesquisas arqueológicas no Brasil, na maioria das vezes, não realizam um estudo aprofundado dos contextos funerários como nos traz Mendonça de Souza (2001) e Mendonça de Souza \& RodriguesCarvalho (2013) - em parte ignorando-os e tratando-os quase como um incômodo, algo que atrapalha a pesquisa, pois a escavação e interpretação de contextos funerários necessitam de mais tempo, conhecimentos e uma metodologia mais específicos.

Acreditamos que a análise da espacialidade regional funerária, com todas as dimensões que inclui seja o primeiro passo para que se possam tornar mais concretas as práticas funerárias, saindo do nível do abstrato, e a partir daí possam ser traçadas considerações sobre aspectos simbólicos e, talvez, sobre a estrutura social desses grupos. Mas, além disso, seria possível traçar considerações sobre as mudanças sincrônicas e diacrônicas nas práticas funerárias, o que traria uma perspectiva história para elas, e também sobre processos que levariam à formação daquele registro arqueológico.

\subsection{As pesquisas arqueológicas nos contextos analisados}

\subsubsection{Bacia do rio Paranapanema}

Essa região conta com um grande número de pesquisas, pois é um local muito estudado pela arqueologia paulista. Iremos citar principalmente as pesquisas relacionadas diretamente aos contextos funerários com os quais estamos trabalhando. Explanações mais completas a respeito da arqueologia no Paranapanema podem ser encontradas em Morais (1999) e Faccio (1998, 2011). 


\subsubsection{A Lado paranaense}

Pesquisas arqueológicas na região da bacia do Paranapanema se iniciaram na década de 1950, mas foi a partir de 1960 que elas se intensificaram.

Nas áreas paranaenses atingidas pelas usinas hidrelétricas de Rosana e Taquaruçu - localizadas no Baixo e Médio Paranapanema - elas começaram a ser realizadas nas décadas de 1960 e 1970. Entre 1961 e 1963, Ondemar Blasi conduziu pesquisas nas ruínas da redução de Santo Inácio Menor. Nos anos de 1983 e 1984, Igor Chmyz realizou trabalhos nas áreas que seriam atingidas pelas duas usinas (Chmyz, 1984).

Em 1964, pesquisas arqueológicas foram realizadas por Chmyz nas proximidades da cidade de Salto Grande-SP, para a construção da usina hidrelétrica de mesmo nome. Entre 1965 e 1968, para a construção da usina hidrelétrica de Chavantes-SP foi estruturado o 'Projeto de Salvamento Arqueológico do Rio Itararé', que abrangia parte do rio Paranapanema, e foi executado pelo Centro de Ensino e Pesquisas Arqueológicas da Universidade Federal do Paraná, sob coordenação desse pesquisador. Em princípios de 1970, Chmyz realizou trabalhos arqueológicos no Baixo Paranapanema, prospectando dois trechos: um situado nos arredores da foz do rio Pirapó, e o outro mais abaixo.

Com a implantação do Pronapa (Programa Nacional de Pesquisas Arqueológicas), entre 1965 e 1970, os estudos de Chmyz no vale do Paranapanema tornaram-se parte desse programa. Trechos foram selecionados para se evidenciar sítios arqueológicos até então desconhecidos, e ampliar e sistematizar os dados já existentes. Os trechos tiveram como centro a foz do rio Itararé, os municípios de Salto Grande, Porto do Cedro, a foz do Rio das Cinzas, a foz do Rio Tibagi, a foz do rio Pirapó e a foz do Ribeirão do Diabo, além da foz do próprio Paranapanema, no rio Paraná (Chmyz, 1984).

\subsubsection{B Lado paulista}

Também dentro do âmbito do Pronapa, Silvia Maranca - arqueóloga do Museu Paulista da Universidade de São Paulo - realizava, no lado paulista da bacia, prospecções no alto e médio vale do Paranapanema. No final da década de 1960, ela pesquisava a região da sub-bacia do Rio Verde. Em meados da década de 1970, André Prous professor da Universidade Federal de Minas Gerais - também fez pesquisas na região do Paranapanema, mapeando algumas casas subterrâneas no trecho superior da bacia. 
O maior e mais longo estudo arqueológico da região é o Projeto Paranapanema. A primeira fase do projeto se caracterizou pelo levantamento, prospecção e escavação de diversos sítios no Alto e Médio Paranapanema. A segunda foi marcada pelos grandes levantamentos e salvamentos arqueológicos em áreas impactadas, especialmente pelas construções de usinas hidrelétricas ao longo de toda a área do rio, que vêm sendo implantadas há várias décadas. Nesse período ocorreram diversas parcerias entre a Universidade de São Paulo, a Unesp - Universidade Estadual Paulista, governos municipais (em especial a prefeitura do município de Piraju-SP) e a antiga CESP (Companhia Energética de São Paulo).

A partir de 1993, o projeto adquire uma interdisciplinaridade e passa a se preocupar com os temas: ocupação, desenvolvimento e meio ambiente. A preservação do patrimônio torna-se prioridade, juntamente com a pesquisa arqueológica. Assim, passa a englobar as relações do patrimônio arqueológico com o meio físico e as comunidades, entendendo que patrimônio cultural e ambiental devem estar de maneira combinada. Tinha como objetivo a "[...] definição, análise e síntese dos cenários da ocupação humana na bacia do rio Paranapanema nos respectivos contextos ambientais, culturais e paisagísticos." (Morais, 1998).

Os sítios das regiões do alto, médio e baixo curso do rio, escavados no Projeto Paranapanema, foram classificados como pertencentes ao "sistema regional de povoamento Guarani". Esse conceito provém da Geografia, e é utilizado para se referir à "[...] dispersão das populações pelo ecúmeno terrestre e à consequente produção de paisagens, com a construção de cenários que se sucedem.” (Morais, 1998).

Morais entende a ocupação dos Guarani como um sistema que produziu recortes paisagísticos com forte identidade regional, perfeitamente adaptados ao ambiente da transição entre as zonas tropical e temperada.

Sob a coordenação de Morais, o projeto constituiu equipes locais através da assinatura de convênios. O convênio com a Unesp - Universidade Estadual Paulista consolidou uma equipe sediada em Presidente Prudente, que desde 2002 é coordenada pela arqueóloga Neide Barrocá Faccio. Ela fundou o Museu de Arqueologia de Iepê-SP, localizado na cidade de mesmo nome, e em 2005 criou o Laboratório de Arqueologia Guarani (LAG) localizado na Unesp de Presidente Prudente-SP (Baco, 2012). 
O Projeto Paranapanema (ProjPar) engloba uma área de 19,1\% do território do estado de São Paulo e 104 sedes administrativas nesse estado. Em 1999 haviam sido identificadas 30 instituições museológicas na área do projeto (Chiari, 1999).

\subsubsection{Região do Alto Paraná}

A região do Alto rio Paraná, na área da divisa entre os estados de São Paulo e Mato Grosso do Sul, conta com diversos projetos de pesquisa. Um dos maiores foi o projeto Porto Primavera, realizado como salvamento para a construção da usina hidrelétrica de mesmo nome. Este grande projeto foi dividido em lado paulista (coordenado pela Prof. Dra. Ruth Kunzli) e lado sul-matogrossense (coordenado pelos Profs. Drs. Emília Kashimoto e Gilson Martins). Abrange áreas dos estados de São Paulo e Mato Grosso do Sul, de regiões da bacia do Alto Paraná, e conta com equipes de arqueólogos dos dois estados.

No lado paulista, o objetivo é "[...] identificar, resgatar e analisar os cenários das ocupações humanas e seu meio ambiente na área da formação do lago da Usina Hidrelétrica de Porto Primavera - SP" (Cabrera, 2015).

Em São Paulo, o projeto teve duas etapas. Na primeira, realizada entre $1997 \mathrm{e}$ 2002, através de um contrato entre a antiga CESP (Companhia Energética de São Paulo) e a Fundacte (Fundação de Ciência, Tecnologia e Educação) da Unesp (Universidade Estadual Paulista) - foram localizados 99 sítios e 135 ocorrências arqueológicas. Desses sítios, 15 foram escavados, e 58 mil peças foram catalogadas (Cabrera, 2015, p. 47).

Entre 2003 e 2005, diante de relatos de material arqueológico encontrado nas margens e nas águas do rio Paraná, certamente devido à ação de processos erosivos nas suas margens, a equipe da FCT, com apoio da CESP, realizou uma segunda vistoria ao longo da margem paulista (etapa 2), encontrando mais 8 sítios em estado emergencial, com material inclusive no leito do rio e manchas de terra preta associadas com material arqueológico (Cabrera, 2015, p. 48).

Além deste estudo, na área do alto rio Paraná aconteceu o Projeto $10^{\mathrm{a}}$ Região, coordenado pela arqueóloga Ruth Kunzli, responsável pela demarcação dos sítios Lopes e Romanini, dos quais analisamos vasilhas. O mapa do anexo A, de autoria de Kashimoto (2007), traz os projetos arqueológicos que ocorreram na região do Paranapanema e Alto Paraná. Os projetos encontram-se no anexo A. 


\subsection{O estado de São Paulo: um mosaico de confluências}

A região do atual estado de São Paulo é considerada por muitos arqueólogos como uma área de confluências culturais e de fronteiras entre grupos Guarani, Tupi (Tupinambá) e Jê. Métraux e Brochado, há tempos, já delimitaram a fronteira entre grupos Guarani e Tupinambá no estado de São Paulo (Moraes, 2007). A região parece ser uma área limite entre contextos arqueológicos inicialmente definidos para outras regiões do país, tanto sul, quanto norte e centro-oeste; e o que as pesquisas sugerem é que grupos humanos de diferentes regiões foram para essa área, tornando-a repleta de limites regionais (Afonso, 2008-2009).

Apesar da existência desses limites, há muitas dúvidas sobre as fronteiras culturais, como sua distribuição geográfica, cronologia, grupos humanos envolvidos e os tipos de fronteiras (Afonso, 2008-2009). Ainda é muito incipiente o estudo, por exemplo, de sítios que possuem materiais que por muito tempo foram chamados de "intrusivos", ou seja, materiais estranhos em relação à maioria definida para aquele sítio (em termos de tradições culturais) - muitas vezes materiais considerados Jê (Aratu, Itararé) em sítios Guarani.

Há a presença de sítios Guarani nas bacias do rio Santo Anastácio, Aguapeí e do Peixe. Para Chmyz (2002), a separação entre Guarani e Tupinambá no litoral estaria, pelo menos, na região da baía de Paranaguá, no Paraná. No contexto do Projeto Porto Primavera, lado de Mato Grosso do Sul, Kashimoto e Martins identificaram que essa área de separação entre os dois grupos linguísticos estende-se pelo intervalo entre os rio Tietê (SP) e Pardo (MS) (Kashimoto \& Martins, 2005).

No leste do estado, na bacia do rio Mogi-Guaçu, Moraes (2007) considera que há materiais cerâmicos que atestam a presença de grupos diferentes, tanto Tupinambá quanto Guarani. Ela denomina esses conjuntos cerâmicos como Tupi do Interior, que teriam mais características Tupinambá do que Guarani, e possuiriam um largo espectro temporal que vai até a época da colonização. As formas camuci e nhaempepó encontradas lá, em contextos funerários, são muito similares às que se encontram nos sítios do Alto Paranapanema (Fonseca, Prassévichus), também em contextos funerários.

Já na região do vale do Paranapanema, segundo Morais (1999), Chmyz (2002), Afonso (2006) e Faccio (2011), entre outros, a área que dividiria Guarani e Tupinambá estaria ao norte desse rio, tendo sido este vale e o do Alto Paraná (até próximo à 
confluência com o rio Pardo) ocupados por grupos Guarani, enquanto o vale do Médio Tietê e regiões mais ao norte teriam sido ocupados por grupos Tupinambá. O mapa da figura 1 mostra esse modelo, trazendo também uma área de influências recíprocas entre os sistemas Guarani e Tupinambá, que ficaria mais próxima do vale do Tietê, fazendo uma curva para o sul de São Paulo, mas ainda assim permanecendo ao norte do Paranapanema.

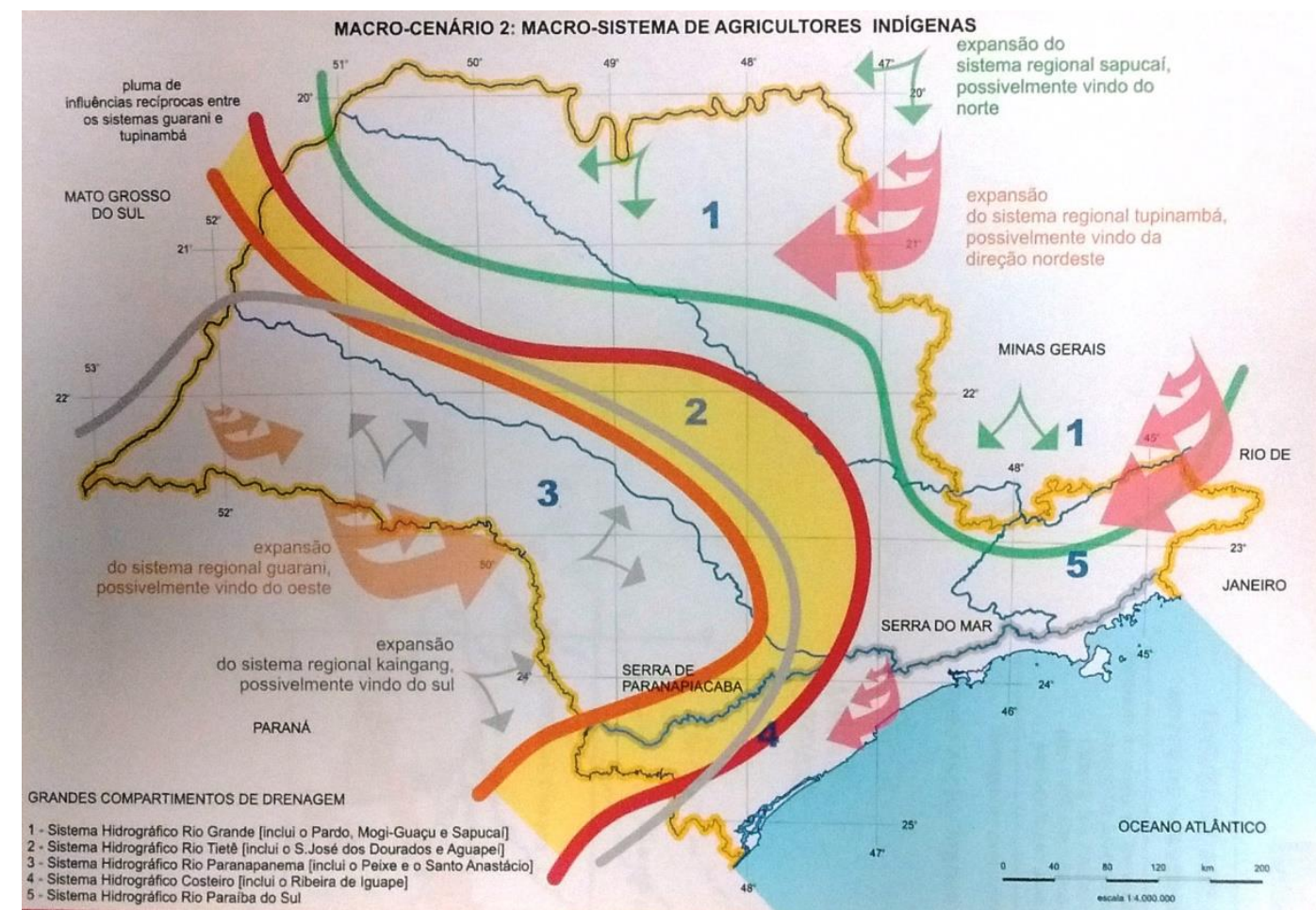

Figura 1: Mapa elaborado por Morais que mostra a confluência de diferentes grupos no estado de São Paulo. De acordo com este modelo, a região do Alto Paranapanema seria habitada apenas por grupos Guarani, o que algumas pesquisas mais recentes têm questionado.

No entanto, segundo Noelli (1993), Brochado reconsidera suas afirmativas de 1984, colocando os sítios do Alto Paranapanema escavados por Pallestrini como Tupinambá, por causa da forma e tratamento de superfície das vasilhas. Segundo Brochado, a Subtradição Guarani teria se expandido pela bacia do Paraguai, e através do baixo rio Paraná teria se dispersado pelo Paranapanema e alto Paraná. A região do Paranapanema seria uma área de fronteiras entre Guarani e Tupinambá, sendo que o alto-médio curso seria habitado por grupos portadores de cerâmicas tanto Guarani quanto Tupinambá, enquanto a região do baixo curso e a região analisada por nós do alto Paraná seriam habitadas principalmente por grupos Guarani (Noelli, 1993). 
As pesquisas de Moraes (2007), que faz um minucioso levantamento bibliográfico, também apontam que os dados do Paranapanema precisam ser revistos, pois há a presença de materiais que podem estar associados aos Tupinambá. Corrêa (2014), ao analisar a forma e tratamento da superfície de vasilhas, também coloca o Alto Paranapanema como uma região Tupinambá. A figura 2 mostra a espacialidade encontrada por Corrêa para as diversas cerâmicas Tupi, pelo Brasil a fora, entre elas algumas do Paranapanema. $\mathrm{O}$ autor coloca a área de convivência e influências desde a região próxima à baía de Paranaguá, estado do Paraná e litoral de São Paulo, Alto e Médio Paranapanema e por uma extensa região do oeste paulista.

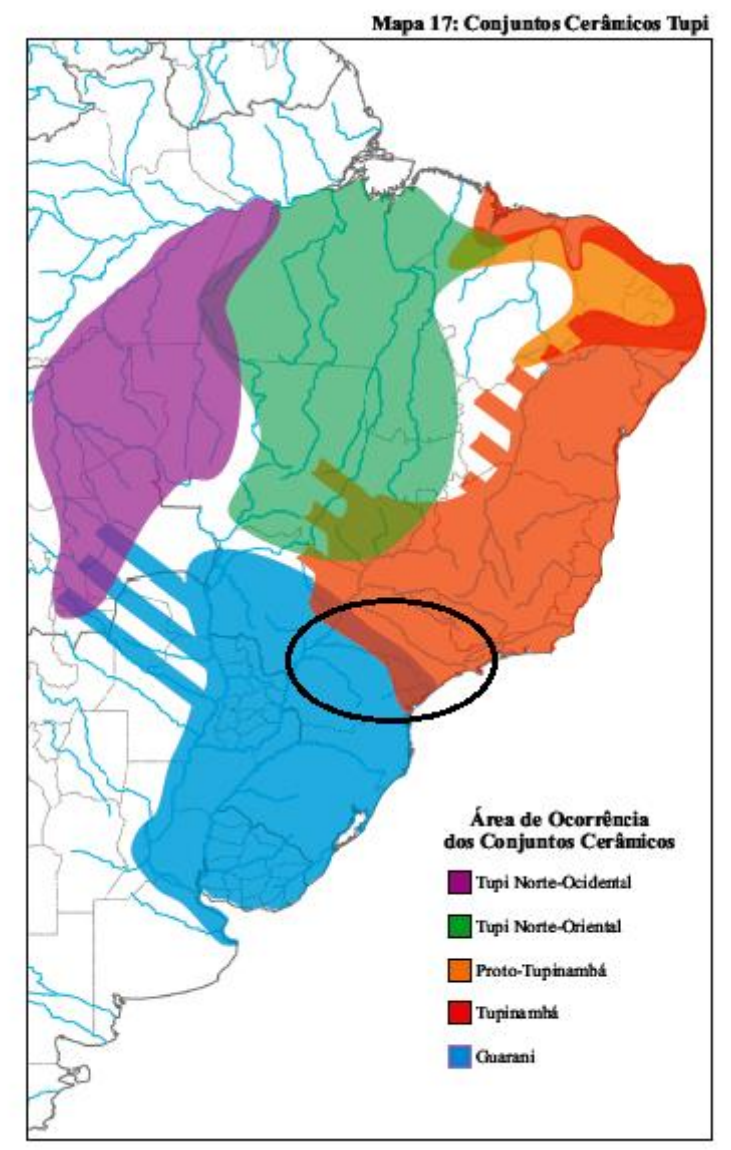

Figura 2: Mapa que mostra as áreas de ocorrência dos conjuntos cerâmicos separados por Corrêa. Na região do Paranapanema e Alto Paraná, destacada por nós, há uma confluência de áreas de ocorrência de cerâmicas Guarani e Tupinambá que se estende, dentro da região do estado de São Paulo, pelo Alto e Médio Paranapanema e também pelo Alto Paraná. Fonte: Corrêa (2014).

Como estamos observando, a região do atual estado de São Paulo apresenta um mosaico de confluências, que estamos apenas começando a entender melhor, apesar do grande número de pesquisas. A partir do trabalho de Moraes (2007), podemos ver que a simples associação de cerâmicas a subtradições Tupinambá e Guarani, sem uma análise 
mais aprofundada dos conjuntos e suas particularidades, não é suficiente para entendermos a ocupação e a história dos grupos ceramistas que habitaram certas regiões. As pesquisas da autora demonstram que grupos que poderiam ser Tupinambá, porém com uma produção cerâmica diferente de outros Tupinambá (como os do Rio de Janeiro), habitaram a região do Alto e Médio rio Mogi-Guaçu.

E, como nos traz Afonso (2008-2009), o limite entre Tupinambá e Guarani em São Paulo continua como um tema em discussão. As pesquisas de Moraes (2007) demonstram que as cerâmicas de certos sítios no Alto e Médio Mogi-Guaçu poderiam ser classificadas como Tupinambá, mas são diferentes de outras cerâmicas Tupinambá, como as do Rio de Janeiro. Como poderíamos, então, entender isso? Um Tupinambá com particularidades regionais? E quais poderiam ser essas particularidades do Tupinambá (ou do Guarani), em diferentes regiões e tempos?

\subsection{Breve levantamento etnohistórico para as regiões do Paranapanema e}

\section{Alto Paraná}

De acordo com Kashimoto \& Martins (2005), a ocupação das regiões do Paranapanema e Alto Paraná apresenta como datas mais antigas o nível lítico do sítio Brito, no Médio Paranapanema, que é cerca de 7000 AP, e uma datação obtida durante o Projeto Porto Primavera (MS), de 6000 AP. Alguns sítios do Paranapanema e Alto Paraná apresentam níveis líticos sobrepostos por níveis cerâmicos, o que demonstra que as mesmas áreas foram ocupadas primeiro por grupos pré-ceramistas e depois por ceramistas, que começaram a se instalar nessas regiões há cerca de 2000 a 1500 AP. A datação de cerâmicas coletadas de níveis estratigráficos mais profundos do sítio Brasilândia 11, no Alto Paraná, é de 2100 AP; no entanto, não se tem conhecimento se essas cerâmicas eram de grupos Tupi (Kashimoto \& Martins, 2005). As datas mais antigas para grupos Tupi na região do Alto Paraná estão em torno de 1500 AP (Kashimoto \& Martins, 2005), e a mais antiga para a região do Paranapanema é 2030£200 AP (feita por Termoluminescência), para o sítio Panema. Nesse mesmo sítio, um fragmento ósseo humano do único sepultamento encontrado foi datado (por

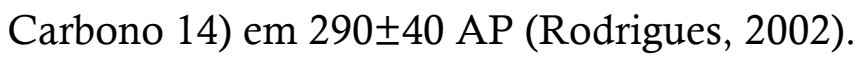


Etimologicamente, paranapanema significa 'grande rio imprestável'.

para-nã: semelhante ao mar ou grande rio

panema: ruim, imprestável, inútil

Talvez o Paranapanema tivesse sido nomeado assim devido às numerosas corredeiras e cachoeiras que dificultavam a sua navegação. No entanto, diante da pesquisa arqueológica, ele se mostra como uma grande via de movimentação de grupos humanos através dos tempos (Chmyz, 1984, p. 9).

$\mathrm{Na}$ época em que os primeiros colonizadores chegaram ao Vale do Paraná e Paranapanema, essas regiões estavam densamente povoadas por grupos indígenas, em especial Guarani (Kashimoto \& Martins, 2005). Segundo Faccio (2011), na região habitavam os Kaingang (também chamados de Coroados em textos mais antigos), os Guarani (chamados comumente em fontes históricas de Cayuás e Kaiguas), e os Xavantes ou Otis (também chamados de Oti-Xavantes no mapa linguístico de Nimuendajú). Os primeiros habitavam as vertentes do rio do Peixe, os segundos as vertentes do Paranapanema, e os terceiros o platô central.

A figura 3 é um recorte do mapa etno-histórico e linguístico de Curt Nimuendajú, que abrange a região do estado de São Paulo. Através dele vemos que a região das bacias do Paranapanema e Alto Paraná possuem registro de terem sido habitadas, ao menos até meados do século XX, por grupos falantes de línguas Guarani (tronco Tupi) em regiões do Baixo, Médio e Alto Paranapanema, e também no Alto Paraná; Kaingang (tronco Macro-Jê) no Paranapanema; Oti-Xavante no Paranapanema; Kaiapó (tronco Macro-Jê) no Alto Paraná, Ofaié-Xavante (tronco Macro-Jê) também no Alto Paraná, e Guaianá (tronco Macro-Jê) no alto Paranapanema. 


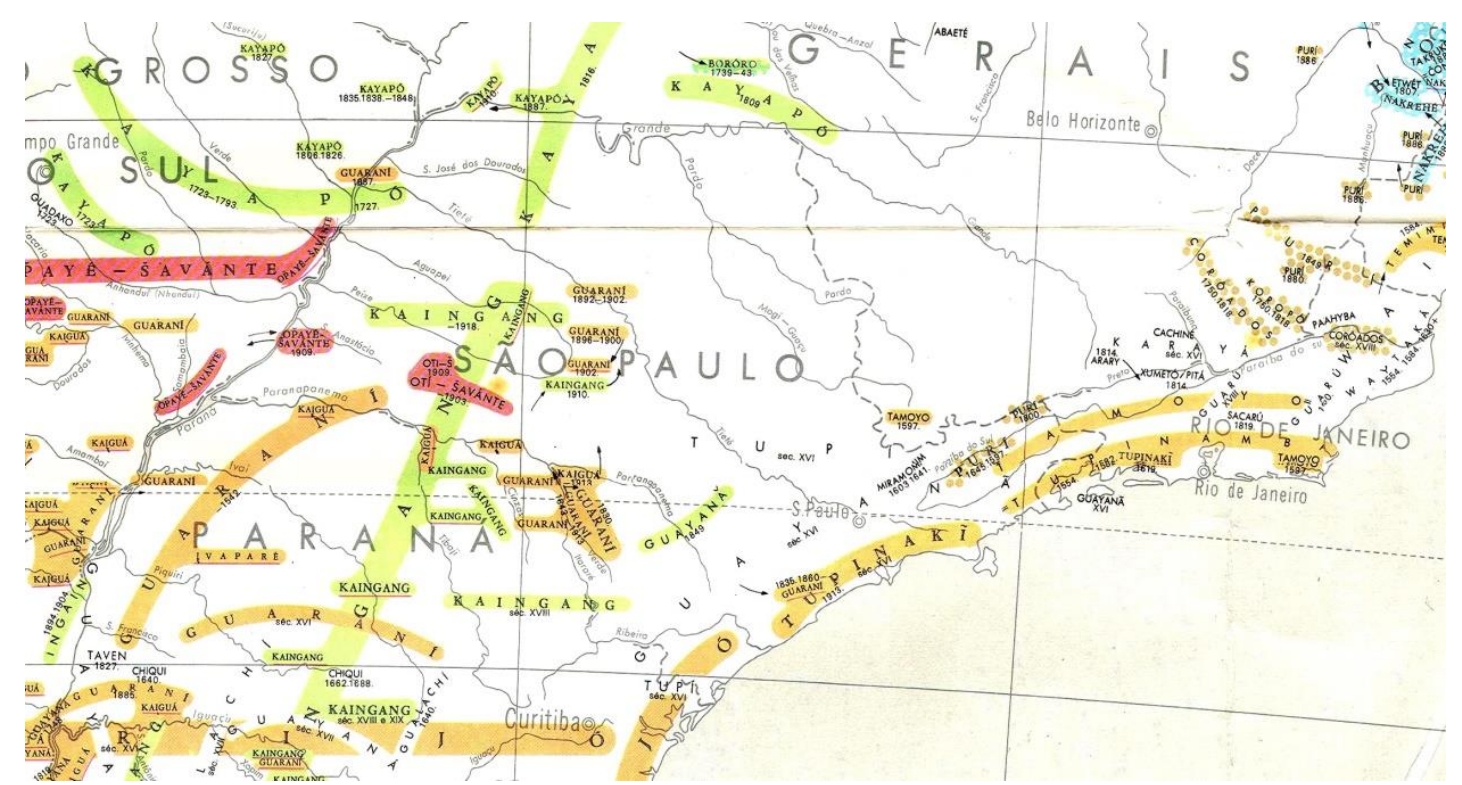

Figura 3: Recorte do mapa etno-histórico de Curt Nimuendajú, mostrando a região de São Paulo e arredores. Fonte: Nimuendajú (1981).

Edmundo Krug, um viajante oriundo de São Paulo que passou um tempo viajando pelo Paranapanema no início do século XX, relata que encontrou índios Coroados (Kaingang), um aldeamento de Cayuás (Guarani), Xavantes e "Kaigang”. Ele descreve os Coroados e "Kaigang" como índios bravos, não catequizados, que andavam nus e viviam em cabanas de madeira e palha. Os Guarani foram descritos pelo viajante como índios trabalhadores (pois trabalhavam para fazendeiros brancos em parte do tempo) que usavam roupas (Krug, 1924). Isso demonstra as diferenças na visão do colonizador branco em relação aos diferentes grupos indígenas da região. Outros relatos sobre os Kaingang foram reunidos por Rodrigues (2007), e demostram essa diferença na visão sobre os Guarani com relação aos Kaingang, além da situação de matança imposta aos segundos na primeira metade do século XX devido à expansão da cafeicultura para o oeste paulista.

Os Guarani, como já é conhecido, ocupavam no século XVI enormes territórios descontínuos nas áreas dos estados do RS, SC, PR, SP e MS, inclusive áreas do Paranapanema e Alto Paraná. Ao contrário da visão muitas vezes propagada pelos missionários e colonizadores, eles desenvolviam seu modo de vida com o intuito de proporcionar a produção e reprodução de sua identidade e maneira de ser. Sua população era bastante numerosa, mas o processo de depopulação apenas no primeiro século da colonização foi brutal. Viviam em aldeias dispersas pelo território, várias delas ligadas por laços de consanguinidade e aliança. Essas alianças não eram fixas nem rígidas, sendo constantemente modificadas. As aldeias e locais de povoamento não eram 
fixos, havendo a mudança de local de tempos em tempos. A ocupação do território se dava de acordo com as estratégias de manejo ambiental que caracterizam os Guarani (Noelli, 1993; Rodrigues, 2002). Edmundo Krug (1924) relata que eles habitavam as duas margens do Paranapanema, até além da margem esquerda do rio Tibagi e próximo à Serra do Diabo, no estado de São Paulo. Ele diz que eles viviam amistosamente com os "Coroados".

Os Ofaié-Xavante tiveram suas primeiras etnografias feitas em meados do século XIX. Não se conhece nada sobre seu modo de vida antes do contato, e não há nem pesquisas arqueológicas a respeito. As etnografias dizem que eles possuíam um modo de vida baseado na caça, pesca e coleta, e que se deslocavam de maneira itinerante pelo território. Vivem há séculos na região sul e sudeste do atual estado de Mato Grosso do Sul, tendo sofrido vários deslocamentos em virtude das frentes colonizadoras. Em meados do século XX, quando Nimuendajú teve contato com eles, eram pouco numerosos e estavam em processo de desintegração étnica por causa do contato com a colonização. Seus territórios foram sendo cada vez mais tomados pela frente de expansão. Atualmente tiveram um crescimento demográfico e é uma das muitas etnias a lutar pelo direito a terras no Mato Grosso do Sul (Kashimoto \& Martins, 2005).

Foram os espanhóis, especialmente os jesuítas, nos séculos XVI e XVII, que reconheceram e mapearam os rios da região onde hoje é o estado do Paraná, entre eles o rio Paranapanema. Em 1610 os jesuítas fundaram, na confluência do Ribeirão Santo Inácio com o Paranapanema, a redução de Santo Inácio Menor (ou do Ipaumbucu). Na foz do rio Pirapó, fundaram uma capela que posteriormente se tornaria a redução de Nossa Senhora do Loreto. De acordo com relatos, em 1617 havia 800 "famílias" de índios na primeira redução, sendo que 500 crianças frequentavam a escola. A última redução contava com 700 "famílias" de índios, sendo de 450 o número de crianças que frequentavam a escola. Em 1620, a população das duas reduções era calculada em 8000 índios (Chmyz, 1984).

Os estabelecimentos jesuíticos logo atraíram a atenção dos bandeirantes. Devido ao risco de ataques, as reduções passaram a ser protegidas por paliçadas e os padres compravam armas e as distribuíam aos índios para a defesa. Entre 1610 e 1615, houve as primeiras incursões na região do Guairá com o objetivo de caçar índios para serem vendidos como mão de obra escrava. Para evitar o aumento da resistência à caça aos 
índios, o então governador do Paraguai proibiu que os habitantes de Ciudad Real e Vila Rica del Spiritu Sancto vendessem armas e pólvora aos padres. Em 1631, apenas essas duas reduções jesuíticas permaneciam intactas no Guairá, ambas agora com a estimativa de 5000 índios aldeados. Suas cercanias contavam com outros 7000 índios estimados, refugiados das outras reduções destruídas da região. Devido aos ataques que destruíram as reduções, e diante da impossibilidade de salvá-las, o governador provincial, Francisco Vazquez Trujillo, e o superior das reduções, Antônio Ruiz de Montoya, decidiram abandoná-las. Estima-se que na época 12.000 índios embarcaram em 700 balsas e muitas canoas (Chmyz, 1984).

No século XIX e início do século XX, conforme mostram relatos e o mapa de Nimuendajú, haviam diversos grupos indígenas nas regiões do Paranapanema e Alto Paraná, mas a sua própria história é pouco conhecida (se vieram de outras regiões ou não, e quando); em parte por causa das intensas transformações geradas pela colonização. Mas, segundo Kashimoto \& Martins (2005), sabe-se que a pressão das frentes colonizadoras provocou o deslocamento de todos os grupos, muitas vezes acirrando conflitos interétnicos com a extinção de alguns grupos. As colônias jesuíticas do Guairá, os ciclos das bandeiras paulistas - aprisionando indígenas para a escravidão - a expansão da pecuária e da cafeicultura foram alterando bastante as configurações sociais dos grupos indígenas; o que determinou a configuração que os etnógrafos da primeira e segunda metade do século XX descreveram. 


\section{Capítulo II ASPECTOS TEÓRICOS}

Vou te encontrar vestida de cetim

Pois em qualquer lugar

Esperas só por mim

E no teu beijo

Provar o gosto estranho

Que eu quero e não desejo

Mas tenho que encontrar

Vem, mas demore a chegar

Eu te detesto e amo

Morte, morte, morte que talvez

Seja o segredo desta vida

(Raul Seixas - Canto para a minha morte)

O estudo da morte, isto é, das práticas dos vivos em relação aos mortos, ainda é incipiente no Brasil, contando com poucos trabalhos sobre esse tema específico. Estudos arqueológicos sobre a morte Tupi são ainda mais raros. A preocupação em se recuperar os detalhes dos contextos funerários ainda é uma exceção à regra, existente principalmente em pesquisas relacionadas a sambaquis e grupos como os das grutas da região de Lagoa Santa (MG).

Algumas das pesquisas que possuíam o objetivo de realizar uma escavação cuidadosa dos contextos Tupi são os trabalhos de Pallestrini (1969, 1975 e 1983-1984), Chmyz (1974, 1979, 1983), Piedade \& Soares (2000), Buarque (2009, 2016), Müller \& Mendonça de Souza (2011), e Rapp Py-Daniel (2015). Existem outros trabalhos pontuais de escavações em urnas, bem como outros trabalhos em sítios arqueológicos que acabaram também englobando contextos funerários, como aqueles citados por Rizzardo \& Schmitz (2015). Para a região sul do Brasil, há alguns trabalhos que tratam especificamente de práticas funerárias de grupos Tupi, como os apontamentos de Montardo (1995) e Rizzardo \& Schmitz (2015). Sobre aspectos teórico-metodológicos de uma arqueologia funerária Tupi, há os apontamentos de Noelli (1993) e para os contextos funerários Guarani, existe o trabalho de Montardo \& Noelli (1995-1996).

O tema da morte e das práticas funerárias é muito amplo, e não poderia ser diferente, já que se trata de algo tão fundamental em qualquer sociedade. Ele traz consigo diversos temas de pesquisa que envolvem diversos recortes e formulações 
teóricas. Para essa pesquisa, sentimos a necessidade de buscar as definições da arqueologia da morte e a história da pesquisa em contextos funerários, para entender como esse tema é abordado. Algo básico também é uma compreensão dos processos pelos quais passa um contexto funerário, que envolvem os gestos funerários, pósfunerários e não funerários que ocorrem para a formação daquele contexto; além dos processos tafonômicos - que é o conjunto de processos pelo qual um corpo passa depois de ser sepultado ou descartado.

A análise da mudança diacrônica nas práticas funerárias dá uma dimensão temporal para as mesmas, não apenas localizando-as historicamente como também chamando a atenção para o fato de que mudam, e por isso não devem ser entendidas como algo atemporal. O quão intensas ou frequentes são essas mudanças, ou o contrário, o quão estáveis são as práticas, que é uma discussão antiga na arqueologia de contextos funerários, não será extensamente trabalhado aqui por falta de espaço e de tempo. Já a análise da espacialidade funerária, além de trazer uma perspectiva contextual, também é fundamental para entendermos um pouco alguns dos processos acima mencionados e inferirmos comportamentos envolvendo pessoas e artefatos, bem como diferenças e semelhanças regionais.

A análise dos artefatos é algo fundamental no estudo de contextos funerários Tupi, pois são justamente os artefatos cerâmicos o elemento numericamente mais marcante neles. Não queremos com isso dizer que os ossos devem ser, de alguma forma, deixados de lado. Se a análise de esqueletos humanos exige conhecimentos da Bioarqueologia, a análise dos artefatos em contexto funerário exige conhecimentos a respeito da variabilidade cerâmica e seus significados, a variabilidade lítica e de outros materiais. Além disso, exige que se leve em consideração os processos de formação do registro arqueológico e a história de vida dos artefatos funerários.

A variabilidade artefatual é aqui analisada em termos da variabilidade tecnológica, ou seja, procuramos fazer uma análise da tecnologia cerâmica de todas as vasilhas encontradas em contextos funerários. Essa análise tecnológica pode ajudar a encontrarmos diferenças nos modos de se empregar cerâmicas em contextos funerários por grupos produtores de cerâmicas distintas, o que, juntamente com as diferenças entre as práticas funerárias, pode indicar diferentes identidades de grupos, se não étnicas, pelo menos nos modos de sepultamento. 
A variabilidade artefatual, tecnológica e a história de vida dos artefatos de contextos funerários são, para nós, elementos fundamentais, pois juntamente com a análise contextual (espacial e temporal) e dos remanescentes humanos é possível traçar um panorama das práticas funerárias e grupos que as realizaram. Se um contexto não é uma foto, mas sim a somatória de diversos processos, pensamos que é preciso primeiro entender esses processos, ou seja, os aspectos comportamentais, para depois começarmos a pensar as identidades envolvidas e os possíveis significados simbólicos de artefatos, gestos e contextos, bem como discutir a estrutura social.

E como a Arqueologia não é neutra, mas sim um discurso socialmente colocado e que atende a interesses específicos, e que envolve, além dos arqueólogos, outros grupos de pessoas, não poderíamos deixar de lado a questão da ética no estudo dos contextos funerários. Essa é uma problemática complexa e controversa, que jamais poderíamos dar conta apenas em uma dissertação de mestrado. Porém, tampouco deveríamos nos privar de tratar desse assunto.

\subsection{Uma Arqueologia dos Vivos Através da Morte}

Como nos traz Pearson (2002), e também é dito por Monteiro da Silva (2005), é um paradoxo que os remanescentes físicos dos mortos, como os ossos, cabelos, pele, etc., revelem muito mais sobre a vida desses indivíduos e das populações às quais eles pertenciam do que sobre a morte em si. Ossos e tecidos são testemunhos de vidas, revelando quanto tempo essas pessoas viveram, qual seu sexo biológico, que doenças tiveram, qual sua altura, sua ancestralidade genética, como se alimentavam (que tipos de comidas), se realizavam esforços físicos pesados (e quais), o quão saudáveis eram, se sofreram deformações, se foram amarrados ou sacrificados.

O modo como o sepultamento é encontrado pode trazer informações sobre os ritos pelos quais o morto passou, ou mesmo se de fato passou por ritos funerários ou se foi apenas depositado naquele local. Os arqueólogos (as) não só procuram documentar os ritos através das evidências de práticas funerárias passadas, como também buscam entender essas práticas dentro de seus contextos históricos, tentando explicar porque elas ocorriam daquela forma (Pearson, 2002). 


\subsubsection{Síntese histórica dos estudos sobre contextos funerários}

Como nos traz Rapp Py-Daniel (2015), os contextos funerários sempre estiveram presentes na Arqueologia. Porém, o interesse principal não era o indivíduo sepultado. Desde o século XIX os sepultamentos são reconhecidos como locais que contêm objetos mais íntegros, ou seja, menos fragmentados, e a intencionalidade de sua deposição seria clara. No período pré-científico da Arqueologia, os antiquaristas e os viajantes já tinham contato com mounds e outras formas de sepultamento monumentais desde tempos remotos na Europa e nas Américas. Acreditava-se que tais mounds continham ancestrais diretos das populações locais, e alguns eram importantes em disputas por fronteiras nacionais. Uma preocupação central era a identidade dos construtores. No final do século XVIII e início do XIX, os sepultamentos tornaram-se objeto das primeiras escavações sistemáticas. Os pioneiros escavaram centenas de mounds funerários (Chapman \& Randsborg, 1981).

Em meados do século XIX, o dinamarquês Worsaae elabora e organiza técnicas de estratigrafia e conceitos para a análise arqueológica, sendo considerado por alguns o primeiro arqueólogo profissional. Em 1840, ele recomendava o desenho e descrição dos artefatos com referências espaciais e localização estratigráfica dentro do sítio, assim como a conservação de ossos humanos e de animais. Porém, suas considerações não eram levadas muito em conta pelos primeiros arqueólogos, e durante muito tempo a observação e registro do contexto em que os remanescentes humanos eram encontrados foi deixada de lado. Worsaae elaborou também o que foi posteriormente chamado de Lei de Worsaae: os artefatos encontrados juntos provavelmente foram também utilizados juntos (Ribeiro, 2007).

Hoje sabemos que os objetos encontrados juntos não são necessariamente contemporâneos, inclusive aqueles provenientes de contextos funerários, tanto porque sua deposição pode não ter se dado no momento do sepultamento, quanto porque sua fabricação pode não ter se dado num momento próximo à sua deposição junto ao sepultamento (Ribeiro, 2007).

A formação dos antiquários e museus no século XIX se deu em grande parte com artefatos provenientes de sepultamentos escavados. Para o Neolítico, Idade do Bronze e Idade do Ferro, evidências de contextos funerários são o maior corpo de dados coletado 
durante aquele século, embora estruturas não monumentais fossem pouco conhecidas. Os primórdios da Arqueologia foram desenhados sobre esses materiais (Chapman \& Randsborg, 1981).

No século XIX, e durante muito tempo, os sepultamentos eram considerados como uma cápsula do tempo, nos quais os objetos utilizados pelas pessoas de uma mesma época podiam ser encontrados, e assim usados para a construção de cronologias regionais (Ribeiro, 2007). Nesse sentido, os contextos funerários eram considerados como "contextos fechados" (Rapp Py-Daniel, 2015). Esses contextos se opunham aos depósitos de assentamento, pois estes eram considerados ocasionais ou acumulativos, e geralmente remexidos, portanto, cronologicamente imprecisos, ao contrário dos sepultamentos. Dentro das premissas do que chamamos de Histórico-Culturalismo, os contextos fechados que representavam os sepultamentos eram procurados com o objetivo de estruturar tipologias e seriações a partir dos artefatos contidos dentro desses contextos (Rapp Py-Daniel, 2015).

Hoje temos consciência de que os contextos funerários não são fechados, muitas ações ocorreram durante longo tempo, funerárias ou não, bem como processos naturais. Mesmo que pareçam não estarem remexidos, e mesmo que o grau de alterações nesses locais seja menor do que no restante do sítio, a sua pouca alteração não deve ser considerada a priori, e sim comprovada.

Juntamente com a construção de tipologias, o Histórico-Culturalismo se baseava na premissa de que as diferenças encontradas entre os objetos presentes nos contextos funerários, os tipos e diferentes locais de sepultamento, etc., deveriam ser explicados pela chegada de novos habitantes ou pela importação de cultura. A etnologia, quando mencionada, servia apenas para exemplificar o comportamento das populações e o exotismo das religiões. No século XIX, o Evolucionismo na Antropologia influenciava também a Arqueologia.

Após a invenção e desenvolvimento do conceito de Cultura Arqueológica, no final do século XIX, ele passou a ser utilizado também na arqueologia das práticas mortuárias, definindo-se uma cultura típica de uma região a partir de padrões e mobiliário funerário. Através dos elementos constitutivos de uma cultura funerária, 
observava-se o que poderia ser considerado parte da cultura e o que era estranho a ela, sendo os elementos "não típicos" interpretados como fruto de contato e hibridez (Ribeiro, 2007). Nos anos 1920, Gordon Childe considera o conceito de cultura arqueológica como fundamental para a Arqueologia, sendo os traços culturais (como por exemplo as práticas de sepultamento) resistentes a mudanças (Ribeiro, 2007). Childe colocava as práticas funerárias no campo da ideologia e da religião, apesar de elas serem um elemento importante na sua definição de cultura arqueológica (Chapman \& Randsborg, 1981).

Raramente os sepultamentos eram analisados em sua totalidade, incluindo contextos, acompanhamentos funerários, indivíduo (ou indivíduos) sepultado (s), gestos e processos tafonômicos (Rapp Py-Daniel, 2015). Embora já no século XIX tivessem sido apresentadas novas perspectivas de abordagem dos contextos funerários, elas não foram amplamente utilizadas pois esse período se caracterizava pela busca das origens, pela construção de datações através de tipologias e das estratigrafias, com o objetivo de fornecer subsídios para a construção de modelos de evolução humana (Ribeiro, 2007).

Como nos traz Ribeiro (2007), as primeiras elaborações teóricas relacionadas aos mortos foram feitas não pela Arqueologia, mas pela Antropologia. No século XIX, o Evolucionismo colocava as sociedades em estágios e, dentro das premissas evolucionistas, Tylor, em 1871, elaborou a existência da crença na dicotomia entre corpo e espírito, esse último sobrevivendo após a decadência do primeiro. $\mathrm{O}$ autor divide a religião em estágios, do mais primitivo ao mais elaborado: animismo, politeísmo e monoteísmo. Também no final do século XIX, Frazer apresenta outra interpretação: os rituais mortuários são fruto do medo do espírito dos mortos e, por isso, seriam usados como meios de controle dos vivos sobre os mortos.

Ainda no início do século XX, a Escola Sociológica Francesa traz um novo rumo para as pesquisas sobre as práticas mortuárias. Indo de acordo com as premissas lançadas por Durkheim, as práticas mortuárias passam a ser consideradas como parte do todo social, estando ligada a outras instituições da sociedade, de modo que as variações nos ritos estão ligadas a variações na estrutura social. Durkheim não fala especificamente de práticas mortuárias, mas fala de ritos. As obras de Hertz e Van Gennep sobre os rituais acrescentam à de Durkheim. Hertz considerava que as práticas que envolvem a morte são ritos de passagem para o mundo sobrenatural, sendo que tais ritos mudam conforme 
o "status" do morto na comunidade, sua idade e o tipo da morte. A crença em um mundo sobrenatural, para Hertz, seria fruto da contradição entre a continuidade do sistema social e a natureza transitória dos membros da sociedade. A essa perspectiva soma-se à de Van Gennep, de que os ritos de passagem apresentam três momentos: separação, transição e incorporação (Monteiro da Silva, 2005; Ribeiro, 2007). Apesar da influência fundamental da Escola Sociológica Francesa na Antropologia, ela só vai passar a influenciar de fato e entrar para as discussões teóricas na Arqueologia a partir da década de 1970 (Ribeiro, 2007).

Kroeber (1927) propõe o oposto de Childe, afirmando que as práticas de sepultamento não são resistentes a mudanças, mas sim modismos que se alterariam constantemente, modificáveis a partir do contato entre grupos, ou que, por serem muito diversificadas, não estariam ligadas a um sistema religioso ou social, e que por causa disso não poderiam servir como base para se conhecer as populações do passado (Rapp Py-Daniel, 2015; Ribeiro, 2007). O trabalho de Kroeber vem se opor à visão da Escola Sociológica Francesa de que as práticas mortuárias estão dentro de um contexto social mais amplo (Ribeiro, 2007). Entretanto, a perspectiva de Kroeber não ganhou muita adesão na arqueologia norte americana, e a natureza conservativa das práticas mortuárias continuou como fundamento teórico.

Os arqueólogos sempre utilizaram as características culturais para estabelecer os rastros de contato entre grupos e assim reconstituir a sua história. No HistóricoCulturalismo, dentre os traços culturais dos sepultamentos, eram analisados a presença de mounds, a posição do corpo, presença ou ausência de pintura nos ossos e as decorações nas cerâmicas de acompanhamento funerário. A presença de traços diferentes do "grupo de origem" (aquele em que o traço é considerado uma característica cultural original) era interpretada como simples contato entre grupos e/ou movimentação no território, com um grupo influenciando e o outro sendo influenciado (Ribeiro, 2007). Hoje está claro que os grupos se influenciam mutuamente, diferente dessa perspectiva de aculturação.

Outra grande influência para a Arqueologia das práticas funerárias, também a partir dos anos 1970, foi a Antropologia Social Inglesa, o chamado Funcionalismo. O papel social dos indivíduos, elaborado por Radcliffe-Brown, e os diversos papéis por eles acumulados durante a vida, são empregados nas teorizações sobre as práticas funerárias. Os papéis sociais e o conjunto de papéis de um indivíduo, selecionados pela sociedade 
para caracterizá-lo (pessoa social ou social persona, para Binford) condicionam as práticas envolvidas no ritual funerário e no enterro, pois o grupo social reage contra a destruição dos laços de solidariedade que o unem à pessoa que morreu (Ribeiro, 2007). Já segundo Malinowski - outro expoente da Antropologia Social Inglesa - os participantes do ritual funerário ficam fisiologicamente abalados pelo evento, pois a morte de um indivíduo gera um sentimento de autopreservação por parte de outros, e revela emoções associadas a distúrbios fisiológicos nos corpos dos participantes. A morte é vista, segundo ele, como fonte de medo e ansiedade para a sociedade, e as cerimônias relacionadas a ela servem para contrapor esse medo, providenciando a reintegração do grupo abalado pela perda. Os seguidores de Malinowski relacionavam diretamente a grandiosidade das manifestações de um grupo diante da morte de um indivíduo com a intensidade das emoções que essa morte provocou devido ao sentimento que nasce da quebra da solidariedade social (Ribeiro, 2007).

A partir da década de 1960, o Processualismo, a chamada Nova Arqueologia, passou a criticar os pressupostos teóricos e metodológicos do Histórico-Culturalismo, e não foi diferente na arqueologia das práticas mortuárias. Tanto na Europa quanto nos Estados Unidos uma parte da Arqueologia se volta para o mundo funerário (Rapp PyDaniel, 2015). Com o Processualismo, os contextos funerários passam a ser valorizados como objetos de pesquisa arqueológica per se, diferentemente de como eram considerados no Histórico-Culturalismo (Souza, 2011).

Ucko, em 1969, foi quem pela primeira vez sistematizou a possibilidade de se utilizar analogias etnográficas para a construção de hipóteses para reconstituir os comportamentos humanos que deram origem ao que veio a ser chamado de registro arqueológico funerário. Ele também sugere que os arqueólogos deveriam refinar mais seus métodos de análise de material funerário, pois na Etnografia há vários registros de casos de práticas mortuárias que desafiariam as leituras do arqueólogo. Como exemplo, está a ausência de tratamento dado ao morto, o que não significaria uma ausência de crenças em um mundo dos mortos. Ucko também observava nas diferentes práticas funerárias dentro de uma sociedade a diferenciação entre pessoas, mas isso não estaria necessariamente ligado ao status social. Ele também afirmava que cada sociedade é um caso, e que umas são mais rigorosas e outras mais flexíveis em relação às práticas funerárias (Rapp Py-Daniel, 2015). Essas considerações dificultam as generalizações desejadas pelo Processualismo. 
No início dos anos 1970, Binford e Saxe se colocam contra a caracterização normativa que o histórico-culturalismo fazia, que colocava os comportamentos funerários como normas e como modelos mentais. Binford também critica bastante as perspectivas de Kroeber, em especial, ressaltando a importância dos contextos funerários para se entender a sociedade (Binford, 1971). Esses autores processualistas trazem a perspectiva da análise social para os contextos funerários, propondo uma relação direta entre a organização social de uma comunidade e suas práticas funerárias. Estas representariam muito mais a estrutura social do que as crenças daquela sociedade. As crenças e sistemas religiosos teriam menor importância, pois as variações nos sepultamentos estariam principalmente ligadas a diferenciações na sociedade dos vivos (Chapman \& Randsborg, 1981; Rapp Py-Daniel, 2015). Ou seja, a análise da variabilidade das práticas mortuárias teria como objetivo reconstruir a estrutura social (Pearson, 2002). Desse modo, a variação nos tratamentos mortuários se daria não por causa do contato entre culturas (como pregam o Difusionismo e o Migracionismo), mas sim devido às diferenças na estrutura social e entre as sociedades (Ribeiro, 2007). Saxe sugeria que, ao sepultar os mortos, as decisões dos vivos para caracterizar a identidade social daquela pessoa eram determinadas por direitos e dívidas provenientes de sua relação com eles, em seus vários papéis sociais (Pearson, 2002).

A maior parte dos estudos realizados nos países de língua inglesa, nas décadas de 1970 e 1980, seguindo as propostas de Binford e Saxe, interpretaram os contextos funerários como um espelho das sociedades dos vivos, criando regras para ligar o mundo dos mortos ao dos vivos, fazendo analogias diretas do contexto funerário com a estrutura social e elementos do grupo enquanto vivo (Rapp Py-Daniel, 2015). Os processualistas passam a utilizar como estrutura conceitual as noções de identidade social, relações de identidade e pessoa social (social persona) do morto. Esses conceitos proporcionam a leitura dos diferentes tipos de vestígios mortuários como consequências de diferenças sociais baseadas em sexo, idade, status e filiações nas unidades sociais. A manifestação do status social do morto é vista pelos arqueólogos nas variáveis associadas ao momento da deposição, como o tratamento dado ao corpo, o local de deposição do mesmo e os acompanhamentos funerários. Nesse sentido, os mortos seriam um reflexo do que eram enquanto vivos, gerando a possibilidade de se reconstituir a organização social a partir dos status sociais deduzidos dos mortos dos contextos funerários (Ribeiro, 2007; Rapp Py-Daniel, 2015). 
Tainter, ícone da antropologia cultural americana, também trabalha com a premissa da relação direta entre os contextos funerários e a estrutura social. Ele propõe, por um lado, que quanto mais complexa a sociedade, mais complexo será o tratamento dado aos mortos; e por outro, que quanto maior o status do morto, mais complexo será o tratamento dado a ele. Os artefatos presentes nos sepultamentos, o tratamento dado ao corpo (inumação ou cremação), a duração dos rituais funerários e os tipos de sepulturas construídas para os mortos são medidos em termos do gasto de energia que as atividades requereram. Quanto maior a quantidade de energia despendida, maior o status social e econômico do morto (Souza, 2011). Quanto mais abrangentes fossem as relações sociais (que, segundo autores processualistas, caracterizariam pessoas de alto status social), maior o envolvimento da sociedade no tratamento dado ao corpo, e maior o grau de ruptura nas atividades cotidianas do grupo para viabilizar tal tratamento mortuário (Ribeiro, 2007). Tainter argumenta que os casos de cremação, mesmo quando o sepultamento não apresenta acompanhamentos funerários, são o tipo de sepultamento que dispenderia maior gasto de energia, e, portanto, seriam indicativos de um elevado status social (Souza, 2011).

A arqueologia processual dos anos 1970 possuía uma abordagem das dimensões sociais das práticas mortuárias baseada no conceito de estágios evolutivos da sociedade. $\mathrm{O}$ caldo que a influenciou era constituído: pelos conceitos elaborados no século XIX de selvageria, barbarismo e civilização; pelo esquema, criado em meados do século XX, de bando, tribo, cacicado e estado; pela evolução multilinear; e pelo esquema de sociedades igualitárias, hierarquizadas, estratificadas e estatais. O modelo utilizado pelos processualistas nos anos 1960 e 1970 era de uma evolução social em que as sociedades iriam de simples a complexas de acordo com a sobrevivência do mais adaptado. Grande parte dos arqueólogos que se baseavam nessas teorias se preocupava em utilizar as práticas mortuárias para identificar em que estágio estariam as sociedades analisadas, se seriam bandos ou tribos igualitárias, ou cacicados com hierarquia social, ou estados incipientes com estratificação social. Isso traz implícito não apenas uma noção de que complexidade e adaptação estão associadas com desigualdade social, como também de que os grupos sociais podem ser facilmente classificados em poucas categorias (Pearson, 2002).

Binford (1971), também defende que diferentes práticas funerárias (como cremação, inumação, sepultamento em urna, etc.) poderiam ter tido diferentes significados em diferentes sociedades (Chapman \& Randsborg, 1981). Isso contraria as considerações feitas 
simplesmente a partir da morfologia dos artefatos, bastante predominantes no HistóricoCulturalismo, que utilizava morfologias para dizer que um grupo se difundiu por uma região ou migrou.

No Processualismo, o ambiente passa a ser determinante para os sistemas sociais, sendo a cultura vista como um meio extra somático de adaptação a ele. Por isso, as reconstruções de paleoambientes começaram a ser uma tônica, e trouxeram para a arqueologia das práticas mortuárias a possibilidade de se rastrear remanescentes orgânicos associados aos sepultamentos (microvestígios de plantas e animais) e, juntamente com a análise dos remanescentes humanos, fazer a reconstrução de dietas e paleopatologias/ paleoepidemias (Ribeiro, 2007).

Um pouco apartados das arqueologias de língua inglesa, os arqueólogos franceses desenvolveram de maneira mais sistemática ainda a pesquisa em contextos funerários. Eles se debruçaram no desenvolvimento e aperfeiçoamento de técnicas de campo voltadas para esse tipo de contexto, chamando a atenção para elementos muitas vezes ignorados, como a intencionalidade do sepultamento: a intenção de se sepultar um ou mais indivíduos não deveria ser assumida pela simples presença de ossos humanos em um contexto, mas sim comprovada através de métodos de análise específicos. A disciplina, inicialmente chamada por eles de Archéothanatologie (Arqueotanatologia), preocupa-se em buscar os gestos materializados nos contextos funerários, voltando a ênfase da pesquisa para o indivíduo (ou indivíduos) sepultado, e se preocupando menos com os objetos sepultados junto dele, considerados apenas acessórios. Assim, o indivíduo passa por uma análise detalhada, em que seus ossos, a posição dos mesmos no contexto, os sedimentos em que se encontram, etc., são os elementos centrais de um contexto funerário. Essa ênfase não nos objetos de acompanhamento mas no indivíduo sepultado veio como uma crítica às pesquisas que focavam apenas nos acompanhamentos e na sepultura (Rapp Py-Daniel, 2015). Através dos estudos de tafonomia - que é o conjunto de processos pelo qual um corpo passa depois de ser sepultado ou descartado - a Arqueotanatologia se preocupava em diferenciar os processos culturais e naturais do contexto funerário, formando um arcabouço metodológico para a análise de estruturas funerárias que possibilita recuperar as intencionalidades humanas contidas no sepultamento, possíveis de serem reconhecidas nas sutilezas do registro arqueológico (Ribeiro, 2007). 
Por mais que sejam verdadeiras as considerações da Arqueotanatologia sobre a importância dos remanescentes humanos em seu contexto e a arquitetura da sepultura, hoje em dia é reconhecido que os acompanhamentos funerários não têm um papel secundário ou desprezível, e sim possuem uma agência que vai muito além da função de simples acompanhamento. Eles são repletos de "poderes", que podem ser reconhecidos através das leituras de rituais funerários de grupos indígenas da América do Sul, e o seu papel como seres capazes de fazer coisas que os humanos não são capazes, como conter e "controlar" as almas dos mortos, é fundamental (Barreto, 2008).

A Arqueologia Comportamental, que se volta para o comportamento humano e sua relação com os artefatos e o registro arqueológico, para as relações entre o contexto arqueológico e o contexto sistêmico e para as transformações naturais e culturais do registro arqueológico, também trouxe diversas contribuições para o estudo dos contextos funerários (Ribeiro, 2007).

A partir dos anos 1980, certos autores começaram a criticar vários pressupostos da Arqueologia Processual, não apenas em relação ao estudo das práticas mortuárias mas também na Arqueologia de uma maneira geral, com destaque para Hodder, um dos primeiros a propor novas abordagens para os contextos funerários (Souza, 2011). Várias hipóteses de Binford e Saxe começam a ser questionadas. Como podemos hierarquizar diferentes graus de formalidade dos sepultamentos para dizer quais deles seriam de hierarquias superiores ou inferiores, ou para dizer quais seriam diagnósticos de sociedades mais hierarquizadas ou não? Como podemos definir quais recursos são mais valiosos ou menos para certo grupo? Há inúmeros casos em que a complexidade social não está relacionada diretamente com as práticas mortuárias. Devemos também levar em conta se a ausência de sepultamentos em um período ou região é real ou apenas resultado de pouco conhecimento arqueológico (Chapman \& Randsborg, 1981).

Mais recentemente, também os estudos antropológicos sobre práticas funerárias discordam, em sua maior parte, das premissas funcionalistas, desenvolvendo noções mais sofisticadas sobre as relações entre ritual funerário e estrutura social, entre as quais, de maneira geral, o teatro dos ritos funerários constitui uma arena de conflitos, reafirmações e disputas de poder. Desse modo, observam-se contradições entre o sepultamento e o status social do falecido e seu grupo, não havendo uma relação direta e confiável entre ambas as coisas (Pearson, 2002). 
As chamadas arqueologias pós-processuais, devido ao seu caráter de estudo, grosso modo, contextual, do simbólico, das agências dos objetos, das representações, etc., viram no estudo das práticas mortuárias uma ótima oportunidade para se analisar simbologias e representações. Assim, as primeiras contribuições dos pós-processualistas voltam-se para o caráter ritual do funeral (já sistematizado por Hertz e Van Gennep no início do século $\mathrm{XX}$ ) e para as possibilidades de seu uso para a manutenção e reestruturação do poder. O reconhecimento da natureza ritual do funeral já está presente no Processualismo, mas os estudos se voltam para o reconhecimento da pessoa social do morto através do tipo e quantidade de acompanhamentos funerários. Para os pósprocessualistas, os acompanhamentos funerários, a orientação do corpo, o tratamento dado ao mesmo, além de outros elementos, são analisados não com o objetivo de se reconstituir as pessoas sociais e a estrutura social, mas sim os gestos funerários e seus possíveis significados (Ribeiro, 2007).

No Pós-Processualismo, os mortos não são um espelho do mundo dos vivos, mas sim os vivos é que se representam através dos mortos. Eles representam e simbolizam a si mesmos, o seu grupo social, grupo familiar ou o próprio morto, através das práticas e rituais funerários dedicados aos mortos. Ou seja, as práticas mortuárias (não apenas funerárias) são uma construção dos vivos sobre os mortos para o seu próprio benefício. Não são mais vistas como um microcosmo da organização social, e sim como a expressão material das relações idealizadas que são formuladas sobre os mortos pelos diferentes indivíduos e grupos dentro de uma sociedade. Abordagens de base marxista ainda colocam que o sepultamento é um momento de propaganda, no qual a manutenção da dominação ou as mudanças na mesma são retratadas por grupos sociais através das práticas mortuárias (Ribeiro, 2007).

Isso não significa que tenha havido, na Arqueologia, uma ruptura com os pressupostos que relacionam a estrutura social com as práticas mortuárias. Muitos arqueólogos ainda fazem uma relação direta entre o tratamento do corpo e os acompanhamentos funerários presentes no sepultamento com a estrutura social, colocando elementos como a raridade e durabilidade de certos acompanhamentos como importantes para se entender relações simbólicas de poder.

Autores pós-processualistas afirmam que o determinismo comportamental do processualismo não deixava espaço para se encontrar as ideologias. Desse modo, ao invés 
de buscarem leis gerais do comportamento humano, dão ênfase à contextualização dos estudos. A ideologia e o simbólico não são mais menosprezados, sendo avaliado o papel dos mortos no mundo dos vivos. O positivismo que marca a Arqueologia Processual cede lugar para abordagens menos generalizantes do comportamento humano e mais preocupadas com os diferentes contextos, buscando entender momentos e regiões (Rapp Py-Daniel, 2015).

Para alguns autores pós-processualistas, como Pearson, por mais paradoxal que pareça, os funerais são vivos, e neles papeis sociais são manipulados, adquiridos e descartados, práticas sociais moldam normas e instituições, e relações sociais são ativamente modificadas, revistas, transformadas ou atualizadas. Assim, para o autor, identidades forjadas através de ritos funerários são compostas não por papéis sociais, mas por práticas culturais (Pearson, 2002). Desse ponto de vista, a cultura material recuperada como remanescentes de ritos funerários pelos arqueólogos não é o resultado passivo e estático de comportamentos do passado, ou de papéis sociais que os mortos necessariamente possuíam, e sim é parte ativa de uma manipulação das percepções, crenças e fidelidades de pessoas. Identidades simbolizadas na morte são resultado de muitas forças diferentes agindo sobre os enlutados, o grupo e o falecido, e não simplesmente um status social inerente ao morto.

Papéis sociais são vistos como rígidos e inescapáveis, pré-ordenados pela sociedade e assim seguidos fielmente. Já a ênfase de arqueólogos pós-processualistas se dá não na pré-existência dos papéis em si, mas nas práticas sociais que os criam, tornando-os fluidos e amorfos, abertos a manipulações de várias maneiras. Papéis institucionais podem determinar e limitar ações e comportamentos, mas a adesão das pessoas a eles é bastante variável. Na Arqueologia Pós-Processual, a sociedade passa a ser vista como constituída não por papéis sociais, mas por agência, que cria, reitera, manipula ou omite esses papéis na hora do sepultamento, de acordo com interesses (Pearson, 2002).

A utilização dos conceitos de bandos, tribos, cacicados e estados também é alvo de críticas. Pearson (2002) aponta alguns problemas dessa abordagem processualista, que são:

- As sociedades são muito mais heterogêneas do que categorias como cacicado, por exemplo, poderiam englobar e explicar; 
- Para se fazer tais classificações é preciso reunir um conjunto de traços que caracterizariam cada estágio social, e os traços variam muito entre as sociedades, a ponto de haverem sempre nuances dentro de cada categoria (por exemplo, chamar certas sociedades de cacicado simples e outras de cacicado complexo), enfraquecendo a ideia inicial.

Concordamos com a crítica pós-processualista e não pretendemos utilizar nenhuma dessas classificações para os grupos Tupi.

Abordagens pós-processualistas passam a valorizar o particular e o contextual, criticando a busca por leis gerais do comportamento humano. O particular é importante para se acessar as pessoas, suas crenças e sua agência como objeto de estudo. Esta última é entendida como as ações das pessoas como atores conscientes e suas intenções por trás dessas ações. Nas práticas funerárias, como em todos os aspectos da experiência humana, pensamento e ação formam uma dualidade entrelaçada, que deve ser entendida em termos de crenças e agência dos grupos analisados, não apenas sob os moldes de nossa própria racionalização externa enquanto arqueólogos. O campo das práticas funerárias deve ser entendido, da melhor forma possível, de uma maneira êmica. A simples correlação entre práticas funerárias e crenças, a supervalorização de regularidades transculturais relacionadas à morte e a concepção de que rituais funerários são essencialmente conservativos (seguindo sempre as mesmas tradições) são coisas que foram tomadas como pressupostos mas que, segundo Pearson, não foram devidamente comprovadas. É preciso utilizar uma perspectiva contextual que analise o contexto em que as práticas se desenvolveram, e não assumir regularidades e generalizações a priori (Pearson, 2002).

\subsubsection{Definindo conceitos}

Como vimos, o estudo dos contextos funerários existe desde o início da Arqueologia. Nos diferentes lugares em que se desenvolveu, muitas vezes com abordagens diferentes, ele adquiriu vários nomes.

Os britânicos, desde a década de 1970, chamavam de Bioarqueologia os estudos com material faunístico e, posteriormente, todo o material biológico proveniente de contextos arqueológicos, incluindo o faunístico, o vegetal e o humano. Além disso, o termo também era empregado para nomear a reconstrução da atividade humana e processos de saúde e doença. Já os americanos começaram a chamar de Bioarqueologia 
uma série de temas que tinham a ver com remanescentes humanos: programas funerários e organização social; atividades cotidianas e divisão do trabalho; paleodemografia (estimativas de tamanho e densidade populacional); movimentos populacionais e relações genéticas; dieta e doença. Essa perspectiva, desenvolvida por Jane Buikstra e outros autores, foi fortemente influenciada pela New Archaeology e estudos populacionais e ecológicos, mas também enfatizava a abordagem antropológica, no sentido de a pesquisa ir para além da mera descrição de dados. $O$ foco era diferente do britânico porque procurava fazer uma integração entre a antropologia e os dados arqueológicos, e se preocupava com a reconstrução de histórias humanas (Buikstra \& Beck, 2006). Hoje em dia, britânicos e americanos utilizam o termo com uma conotação muito parecida: o estudo dos remanescentes humanos em seu contexto, também incluindo restos animais e vegetais. Trata-se de uma perspectiva multidisciplinar que integra os dados biológicos dos esqueletos humanos com outros dados arqueológicos, com o objetivo de entender as vidas de pessoas do passado (Roberts, 2009).

Paralelamente, o termo Arqueologia da Morte (Archaeology of Death) surge e se difunde a partir da década de 1970. Esse termo apresenta um sentido semelhante ao termo Bioarqueologia no que se refere ao estudo dos remanescentes ósseos provenientes de contextos funerários e não funerários, entretanto, difere ao não englobar necessariamente todos os estudos arqueológicos que utilizam conceitos das ciências biológicas. Ribeiro (2007) utiliza o termo Arqueologia das Práticas Mortuárias, para enfatizar de maneira mais ampla os estudos arqueológicos das práticas relacionadas à morte (evitando termos mais específicos como 'archéologie des cemitières' ou 'archéologie funéraire') e, ao mesmo tempo, evitar dizer que a arqueologia estuda a morte, como o termo sugere. Segundo a autora, embora o termo Arqueologia da Morte esteja bastante difundido, seu uso não é correto porque a Arqueologia não estuda a morte em si (embora as causas e circunstâncias da morte também façam parte do objeto de estudo), já que sua principal preocupação é recuperar, através de vestígios materiais, os atos que foram praticados em relação ao morto, as escolhas sociais diante da morte, a simbologia que deu lógica às práticas mortuárias, e a vida dos indivíduos sepultados. Segundo Monteiro da Silva (2005), o termo Arqueologia das Práticas Mortuárias

[...] indica e define a linha de pesquisa adotada para analisar e interpretar dados mortuários, informações encontradas no contexto arqueológico que remetem às práticas mortuárias [...], as respostas diante do fenômeno da morte. 
Há ainda outros termos, como Arqueotanatologia, utilizado por Henri Duday, e mencionado anteriormente. Os arqueólogos devem estar treinados para aplicar em campo uma estratégia que não se limita à mera coleta de ossos para serem levados ao laboratório, e sim o estudo desses ossos em contexto. Afinal, o morto é muitas vezes deixado de lado, apesar de ele ser o centro da cena funerária. Isso não significa não realizar estudos dos acompanhamentos funerários, mas sim integrá-los aos estudos do falecido em si, não ignorando o mesmo, como muitas vezes é o caso (Duday, 2009, p. 6).

$\mathrm{Na}$ arqueologia de grupos Tupi os relatos de que foram achados esqueletos são numerosos, porém esses esqueletos não são facilmente encontrados para análise. Um fator determinante para o baixo número de esqueletos de grupos indígenas em geral é a sua preservação precária em solos brasileiros, sendo que muitas vezes os esqueletos de grupos Tupi-Guarani são encontrados já num estágio em que se tornaram completamente mineralizados, portanto já transformados em pó.

No Brasil, o termo Bioarqueologia normalmente é utilizado mais em estudos sobre paleopatologia, paleodemografia, dieta, entre outros que apresentam uma relação muito forte com as Ciências Biológicas. Isso provavelmente tem a ver com a história dessa disciplina aqui, que vem se desenvolvendo de maneira muito ligada a essa área. Os estudos preocupados com as práticas em relação à morte e ritos funerários têm utilizado mais o conceito de Arqueologia das Práticas Mortuárias ou Arqueologia da Morte.

Para esta pesquisa, todos esses conceitos são importantes, pois estamos analisando contextos funerários de grupos Tupi-Guarani com o objetivo de entender sua variabilidade e recuperar práticas mortuárias desses grupos. Portanto, pretendemos fazer uma análise contextual que leve em consideração remanescentes humanos, objetos cerâmicos e outros, e como eles estão dispostos no registro arqueológico. Para isso, essas disciplinas são fundamentais como base teórica e metodológica.

Para fins dessa pesquisa, utilizaremos os termos Arqueologia das Práticas Mortuárias e Arqueologia das Práticas Funerárias. Quando se fala em práticas mortuárias estamos denominando, de um modo geral, qualquer tratamento dado ao corpo morto, inclusive deposições em valas coletivas sem qualquer cuidado no sentido de dar um bom fim àquela pessoa (como as valas em que se jogavam os judeus nos 
campos de concentração, por exemplo). Já as práticas funerárias são aquelas feitas com finalidades de funeral, ou seja, para dar o tratamento necessário ao corpo e um destino adequado àquela pessoa morta.

De acordo com Monteiro da Silva (2005), na Arqueologia das Práticas Mortuárias, os esqueletos humanos e os restos materiais de natureza cultural também passam a ser objeto de reflexão arqueológica e dados como sexo, idade e determinadas modificações ósseas e dentárias também passam a fazer parte dos dados arqueológicos. Hábitos culturais, doenças degenerativas e determinados traços de práticas mortuárias são aspectos de interesse arqueológico e podem ser recuperados no registro. A partir dos remanescentes humanos e seus acompanhamentos funerários, bem como da forma de deposição dos mesmos, podemos entender as características técnicas e operacionais do comportamento funerário intra e inter sítios. Os atributos simbólicos ou rituais das práticas funerárias, embora não possam ser completamente recuperados, podem ser inferidos pelo arqueólogo com base em descrições etnográficas e etnohistóricas.

Os vestígios das práticas funerárias constituem traços de um funeral maior, ou de um ritual funerário, e este um traço dos sistemas sociais. Por isso, características de grupos, em especial suas respostas em relação ao fenômeno morte e iminência de desagregação e extinção do grupo, podem ser trazidas pelos arqueólogos como inferências sobre práticas rituais, obtidas de descrições etnográficas. Os rituais funerários são feitos de ações vinculadas a pensamentos voltados ao sobrenatural, ao mundo alémtúmulo. Uma vez em contexto arqueológico, o ritual resulta em uma cultura material funerária com carga simbólica e potencialidades de interpretação. As ações de caráter simbólico traduzidas em atividades rituais - ou seja, as práticas funerárias - atuando no corpo do morto resultam em produtos observáveis no contexto arqueológico (Monteiro da Silva, 2005).

Ainda de acordo com este autor, o estudo das práticas mortuárias consiste na reconstrução de variáveis biológicas (sexo, idade e traços herdados) e de variáveis culturais (localização e morfologia da cova, a forma de processamento do corpo e os acompanhamentos funerários). A identificação dessas duas variáveis, biológica e cultural, define padrões de sepultamento ou programas funerários de uma determinada sociedade em um período de tempo de longa duração (Monteiro da Silva, 2005). 


\subsubsection{A Gestos funerários}

A arqueologia das práticas funerárias tem como objeto de pesquisa os gestos funerários. Como diz Rapp Py-Daniel (2015), isso nos permite acessar contextos simbólicos repletos de escolhas culturais, mesmo não sendo possível acessar nem a maior parte dos significados por trás dos gestos.

Os gestos funerários são as ações realizadas pelos vivos para o morto, em contextos de funeral, ou seja, quando há a intenção de dar àquele morto um destino adequado, em que crenças, cosmologias e simbologias estão intimamente relacionadas. Os gestos, quando repetidos, padronizados e socialmente aceitos, tornam-se práticas e comportamentos funerários.

Os franceses que desenvolveram a Anthropologie du terrain preocupavam-se em buscar gestos materializados sobre os corpos e estruturas funerárias, separando-os dos processos naturais e pós-deposicionais pelos quais eles passavam. Eles buscavam entender o que a repetição das ações poderia indicar sobre as práticas funerárias socialmente estabelecidas (Duday, 2009; Rapp Py-Daniel, 2015).

É muito frequente que algo inesperado e pouco usual encontrado em um contexto funerário seja considerado um gesto. Mas antes de se considerar algum elemento como um gesto funerário, é preciso saber se aquilo foi intencional na deposição inicial. Muitas vezes, a avaliação sobre se algo é intencional ou se é natural só é possível se observarmos elementos de fora do sepultamento. A repetição de um certo elemento, ou seja, um padrão, pode indicar que se trata de um gesto, e sua exclusividade em um único contexto pode indicar que aquilo é uma alteração não intencional (Duday, 2009).

Duday faz uma distinção entre uma arqueologia dos ritos funerários e dos comportamentos funerários. O autor afirma que uma arqueologia baseada somente na observação do contexto arqueológico, sem a análise de outras fontes que possibilitem inferências a respeito dos rituais - ou seja, da simbologia envolvida nas ações funerárias e pensamentos em relação aos mortos - é uma arqueologia dos gestos funerários e não do ritual funerário. Essa é a arqueologia mais possível de ser feita na maior parte dos casos, a dos gestos e práticas funerárias.

Mendonça de Souza \& Rodrigues-Carvalho (2013) falam da necessidade de um olhar mais refinado para os contextos funerários, que busque não apenas os remanescentes 
humanos mas também os gestos funerários. Para que haja esse olhar refinado, é de extrema importância analisar o que está além dos ossos no chão, pois o contexto funerário não é constituído apenas de materiais palpáveis e com morfologia definida, mas também por diversos outros elementos que só podem ser observados em campo, alguns muito sutis. A escavação e registro corretos são cruciais, pois sem eles muitas informações são perdidas. O contexto deve ser considerado como o testemunho de cenas e gestos funerários, e não apenas como o lugar onde estão os ossos. Pensar nessa variedade de evidências que apontam para gestos funerários dá a oportunidade para realizar inferências através da documentação de elementos que se perderão após o desmonte da estrutura. Pequenos gestos, que resultam em sequências construtivas, quando notados podem nos levar a perceber diferenças culturais locais e entre sítios, bem como podem ajudar a pensar sobre o tempo, energia e recursos econômicos gastos para preparar e homenagear os mortos.

Como nos traz Rapp Py-Daniel (2015), os contextos funerários arqueológicos não são simplesmente locais de deposição dos mortos, mas sim locais plenos de vida, onde uma série de gestos socialmente aceitos e muitas vezes simbolicamente significativos permitem ao arqueólogo conhecer várias informações sobre grupos do passado e do presente. No entanto, ao falarmos de práticas funerárias, partimos da Arqueologia e dos dados que ela pode nos trazer, que vão muito aquém de todas as práticas rituais envolvidas e que são tão importantes quanto o próprio sepultamento. As informações que podem ser obtidas resumem-se ao que está materializado junto ou próximo aos sepultamentos. Nos casos em que há relatos do ritual funerário pode-se ir mais longe, mas esses casos são raros.

No início do século XX, como já foi visto, os arqueólogos buscavam observar como materiais funerários, oriundos de gestos, se difundiam pelo espaço, de uma cultura para outra, ou migravam de uma região para outra. Hoje sabemos que não existe significado universal para nenhuma prática, seja funerária ou não. Somente o contexto e as mudanças sociais através do tempo permitem que alguma inferência possa ser feita sobre significados. Portanto, falar em uma difusão dos gestos funerários, sem levar em conta o contexto histórico em que estão inseridos, não traz nenhuma informação plausível. Os gestos funerários podem ser, às vezes, parecidos entre grupos diferentes, mas são únicos na sua concepção e execução (Rapp Py-Daniel, 2015). 
De acordo com Nilsson Stutz (2010), as práticas funerárias também são fundamentais no processo de construção de identidades que, como se sabe, são dinâmicas, constantemente reproduzidas na interação com outros. As práticas são importantes porque a maneira como se dão criam marcadores de diferença e similaridade entre grupos. No encontro com o outro, as práticas são racionalizadas e sistematizadas, e então fronteiras sociais, diferenças de status ou categorias étnicas são produzidas e reproduzidas.

\subsubsection{B Acompanhamentos funerários}

Chamamos de acompanhamentos funerários os artefatos presentes no contexto funerário juntamente com os remanescentes humanos dos mortos. Como já foi dito, uma parte considerável da arqueologia de contextos funerários consistiu no estudo dos acompanhamentos isoladamente, sem as devidas correlações com os remanescentes dos indivíduos sepultados. Em nosso ponto de vista, seguindo vários autores, os acompanhamentos devem ser analisados em seu contexto e num estudo integrado com o dos remanescentes humanos, quando possível.

De acordo com Pearson, os arqueólogos devem levar em consideração que os acompanhamentos funerários são selecionados cuidadosamente e podem ter muitos significados diferentes. Eles podem ser artefatos cotidianos ou feitos especialmente para o sepultamento. Podem ser destruídos ou consumidos durante os ritos funerários, ou apenas colocados no sepultamento. Eles podem ter sido selecionados por servirem como lembranças, ou algo similar, da pessoa sepultada. Vasilhas de acompanhamento podem conter comida ou água, ou estarem lá apenas simbolicamente. Os acompanhamentos podem estar próximos ou distantes do sepultamento, e no segundo caso passam quase que invisíveis pelos arqueólogos. O estudo dos acompanhamentos funerários e sua variação nos contextos é sempre um quebra-cabeças com muitas peças faltando (Pearson, 2002).

Monteiro da Silva (2005) afirma que no estudo dos acompanhamentos funerários interessa ao arqueólogo não somente o modo como os artefatos são confeccionados e do que são feitos, mas as comparações entre esses materiais provenientes de sítios diferentes de uma mesma região, o que possibilitaria a identificação de mudanças em tradições de oferendas e de organização dos sepultamentos. 
A cultura material específica do contexto funerário apresenta-se no corpo (adornos, vestimentas), são do corpo (postura) ou estão fora dele (utensílios, armamentos, etc...). O potencial analítico e interpretativo de estruturas funerárias é sempre calibrado por fatores tafonômicos (Pearson, 2002; Monteiro da Silva, 2005).

Uma compreensão do quanto os objetos podem, ou não, ser significativos em um contexto funerário passa pelo conhecimento do que existia em contextos residenciais e áreas de descarte, daí a necessidade de integrar dados da arqueologia como um todo e não fazer fragmentações do conhecimento (Rapp Py-Daniel, 2015).

Como já vimos, diversas pesquisas relacionam a presença de muitos acompanhamentos funerários e de objetos "raros" com sepultamentos de pessoas de alto status social. Essas pessoas sepultadas com muitos acompanhamentos, ou com acompanhamentos "raros", eram vistas como portadoras de muitas social personae e, portanto, em vida mantiveram relações com um grande número de pessoas que, na sua morte, lhe deviam um grande número de honras. Nesse entender, a presença de muitos acompanhamentos e alguns deles elaborados, feitos com materiais difíceis de encontrar na região, é um atestado de alto prestígio social e, consequentemente, de setores dominantes na sociedade.

Mas na perspectiva de outros autores, como Pearson (2002), papéis sociais não são rígidos na hora da morte e sim construídos, retificados e contestados; portanto os acompanhamentos funerários não são apenas parte de um "kit de identidade" do indivíduo morto. A identidade nas práticas funerárias é mais complexa do que os processualistas supunham, pois o processo de identidade promovido pelos vivos passa por uma série de outras questões, que vão além da simples posição do morto na estrutura social. Os acompanhamentos funerários são parte de uma série de ações dos enlutados para expressar algo de suas relações com o morto, portanto não podem ser considerados como simples enfeites, mas sim itens dados ou deixados com o morto na complexa relação dos vivos com ele. Alguns podem ser pertences do próprio morto, outros podem ser de fato presentes. Seu valor e riqueza também podem mudar com o tempo, sendo também elementos contextuais. 


\subsubsection{O corpo como artefato}

O corpo é uma metáfora da sociedade, um meio para a experiência da vida, uma superfície para inscrições (Joyce, 2005). De acordo com Pearson (2002), o corpo de uma maneira geral, tanto dos mortos como dos vivos, não é apenas uma entidade biológica, mas sim um artefato cuidadosamente produzido, e transformado após o momento da morte. Mais do que ser um reflexo no espelho do indivíduo enquanto vivo, ele traz representações sobre a morte e a vida após, sobre a natureza da humanidade dentro de certa concepção e sobre a ordenação do mundo social. Assim, o tratamento dado ao corpo do morto traz complexos conceitos a respeito do corpo vivo, da sociedade à qual pertence $\mathrm{e}$ da natureza da sua morte, que não podem ser resumidos em uma simples imagem ou desenho de como era a estrutura social. De acordo com Nilsson-Stutz (2010), esses conceitos são culturalmente fundamentais e têm um papel central na produção de identidades. Portanto, os contextos funerários são importantes marcadores de identificações de grupos, sendo um objeto privilegiado para o estudo das continuidades e descontinuidades que marcam as relações entre grupos de pessoas diferentes.

Não há interpretações universais sobre como os corpos eram tratados e considerados em diferentes sociedades. Cada caso deve ser analisado de maneira contextual, observando-se as especificidades e tentando entendê-las em comparação com outros casos (Pearson, 2002).

Como traz Barreto (2008), a morte não é apenas a cessação da vida física, antes de tudo é uma transformação na qual o morto é instrumento e objeto, uma transmutação do sujeito através do corpo. Os momentos de funeral (e momentos pósfuneral) são quando essa transformação acontece, quando um novo tipo de identidade é conferido ao morto, seja para ser lembrado como ancestral, seja para ser separado do mundo dos vivos e esquecido (Barreto, 2008), ou mesmo para não ser lembrado como ancestral, mas mesmo assim não ser totalmente separado dos vivos, como no caso Tupi-Guarani (Viveiros de Castro, 1986).

O grande problema para qualquer consideração sobre o corpo em contextos Tupi-Guarani é que os remanescentes das pessoas sepultadas não se preservam muito bem, seja por causa da acidez dos solos e do descuido com o qual os ossos são tratados pelas pessoas que os encontram (geralmente pessoas da comunidade local, como fazendeiros), seja por causa de práticas funerárias que destroem os ossos 
intencionalmente. Mas a ausência ou má preservação dos remanescentes humanos não significa que não houve ali um corpo (ou mais de um) que foi o ator central da ação, um artefato tratado e ritualizado.

A leitura de etnografias sobre rituais funerários de grupos indígenas, como os Bororo (Viertler, 2006) ou os Wari (Vilaça, 1992), nos faz perceber a existência desses elementos citados anteriormente: o corpo como um artefato cuidadosamente produzido, embora não preservado devido às práticas, trazendo representações sobre a vida e a morte, sobre a natureza da humanidade e sobre a ordenação do mundo social. Isso nos faz pensar que, mesmo sem um corpo preservado, quaisquer considerações sobre o sepultamento devem ser feitas levando isso em conta, e deve-se tentar recuperar o máximo de informações possível sobre aquele corpo.

\subsubsection{Gestos pós-funerários}

Além desses gestos ligados ao funeral, a preparação do morto para ter um destino adequado, há outros gestos (além dos processos naturais) que ocorrem no sepultamento, mas que não necessariamente são funerários.

Como já foi mencionado, conforme Weiss-Krejci (2011), gestos pós-funerários, extra funerários e não funerários também podem ocorrer sobre a sepultura, alterando-a, às vezes bastante. Quando os gestos são pós-funerários, eles estão relacionados ao morto, são ações intencionais e conscientes com relação àquele morto com outros objetivos diversos que não estão necessariamente ligados ao funeral, como ações de outros rituais que não o funerário. Gestos extra funerários são aqueles que também não são fruto do ritual funerário, mas são obra do acaso, sem intenções específicas com relação àquele morto, como a perturbação dos ossos devido à abertura de outra cova posterior ou devido à escavação de um buraco para se fixar uma estaca de fundação de cabana, por exemplo. E gestos não funerários seriam aqueles em que não houve funeral e o corpo foi simplesmente descartado, como no caso de perseguidos políticos de governos ditatoriais que são mortos e depositados em valas clandestinas com o objetivo de ocultação dos corpos. O reconhecimento de cada um desses tipos de deposições mortuárias não é tão simples, e muitas vezes requer o conhecimento de gestos através de fontes históricas e etnohistóricas. 
Como nos trazem Mendonça de Souza e Rodrigues-Carvalho (2013) os cemitérios são locais dinâmicos que passam por diversas intervenções durante o seu período de utilização. Além dessa dinâmica de utilização de uma ou mais áreas funerárias pelo grupo em questão durante certo período, temos que pensar também na dinâmica de utilização após o abandono dessas áreas, ou após certas modificações sócio-políticas. Outros grupos poderiam utilizar a área funerária ou o mesmo grupo poderia voltar a utilizá-la posteriormente, de outras maneiras (Mendonça de Souza, 2001).

Além disso, nem todas as ações que se deram em uma área mortuária estão diretamente relacionadas ao ritual funerário. Não há nenhuma razão para acreditar que tudo o que há nos contextos funerários está diretamente relacionado às práticas mortuárias ou à morte (Charles, 2005). Portanto, outras ações poderiam ter ocorrido sobre os contextos funerários, intencionalmente ou não, que contribuíram para sua alteração enquanto registro arqueológico.

Os processos de formação de depósitos mortuários - naturais e culturais - são muito complexos, muito variáveis, e identificar os processos que estão ligados ao ciclo funerário e os que não estão não é assim tão simples. Igualmente, entender a variabilidade dos contextos funerários e sua relação com a organização social de um grupo pode, por essa razão, ser mais difícil do que aparente. Identificar um ciclo funerário específico como um sepultamento secundário ou primário - também pode ser bastante difícil, especialmente quando os remanescentes humanos não se preservam muito bem, como no nosso caso. Quando os remanescentes humanos estão incompletos ou desarticulados, é difícil avaliar como era o sepultamento original. Talvez seja por isso que muitos arqueólogos normalmente se referem a esses tipos de contextos como sepultamentos secundários, sem discutir sobre a sua natureza potencialmente complexa (Andrews \& Bello, 2009; Weiss-Krejci, 2005, 2011). Isso é bastante comum com os contextos mortuários de grupos Tupi.

Mas o termo "sepultamento secundário se refere a muitos tipos de práticas e programas funerários diferentes. A formação desse tipo (ou seriam vários tipos) de sepultamento pode estar ligada a muitos tipos de gestos diferentes, rituais ou não, acidentais ou intencionais (Weiss-Krejci, 2005). 
No nosso caso, para essa dissertação, trabalhamos também com os gestos pósfunerários - aqueles realizados não com objetivo de funeral, mas com outros objetivos devido a sua presença nos contextos de grupos Tupi. Algumas fontes (que serão trabalhadas no capítulo IV) fazem menção a eles, mostrando como os mortos tinham uma presença e importância no mundo dos vivos. Porém, essa importância não significa que haja rememoração dos ancestrais, como é comumente interpretado para os contextos funerários em geral. No caso dos Tupi, em especial dos Tupi-Guarani, as pesquisas da Antropologia há tempos postulam uma pouca rememoração dos mortos, e uma ausência de culto aos ancestrais (Viveiros de Castro, 1986, entre outras). Trata-se de outros tipos de presença e importância dos mortos.

Isso significa que, em nosso ponto de vista, seguindo as pesquisas antropológicas, os gestos pós-funerários dos grupos Tupi-Guarani não são marcas de um culto aos ancestrais, e sim gestos ligados a outros rituais nos quais certos mortos também podem estar envolvidos, mas que não são rituais de funeral, nem de uma lembrança dos ancestrais. Parece haver relações com os mortos que não pode ser explicada simplesmente como culto aos ancestrais, portanto, os gestos pós-funerários não deveriam ser interpretados nesse sentido. Claro que essa questão ainda precisa ser extensamente trabalhada.

De qualquer maneira, a possibilidade de gestos pós-funerários em contextos Tupi traz consequências para a interpretação dos mesmos e sua variabilidade, que são as questões centrais dessa dissertação. Quando foram realizados gestos pós-funerários em certo contexto, ossos podem ter sido removidos, remexidos, quebrados, queimados, etc., partes do corpo podem ter sido selecionadas, outras descartadas, perdidas, o corpo pode ser transportado e colocado em outro lugar.

\subsubsection{Os processos do sepultamento}

O conjunto das transformações que ocorrem nos sepultamentos, naturais e culturais, é analisado pela Tafonomia, que é um dos elementos mais fundamentais da arqueologia funerária. Ela é o estudo do que ocorre com os remanescentes humanos após a morte e como os processos relacionados a ela afetam a interpretação arqueológica e zoológica. De uma maneira geral, duas categorias de variáveis são importantes nos estudos de Tafonomia: variáveis ligadas ao indivíduo, suas características físicas, e variáveis ambientais. Quando o objeto da análise são os remanescentes humanos, uma 
terceira e fundamental categoria é acrescentada a essas: influências e ações culturais e sociais, tais como preparação do morto e práticas de sepultamento. A complexidade das variáveis ligadas a esse tipo de remanescentes justifica que eles sejam separados em um campo de estudos a parte, chamado Tafonomia Humana (Nawrocki, 1991). A decomposição do corpo no caso de inumação, a degradação e consequente desaparecimento dos materiais perecíveis da estrutura, a ação de animais, plantas, pessoas (inclusive o próprio arqueólogo), o tipo de solo, a química e mecânica do mesmo, o seu manejo, todos são fatores que alteram a estrutura funerária e não são causados por um ritual.

Duday (2009) chama a atenção para o fato de que a primeira coisa que o arqueólogo deve ter em mente é que todo o esqueleto um dia foi um corpo. O processo de decomposição se inicia no momento da morte, ou até mesmo um pouco antes (quando há necrose dos tecidos mal irrigados de sangue), e acontece devido a dois grupos de fatores: endógenos e exógenos. Os fatores endógenos acontecem a partir de dentro do corpo e são, primeiramente, a ação de bactérias e fungos que estão presentes no sistema digestivo e que, após a morte, se proliferam muito, já que o corpo não oferece mais impedimentos para isso. $\mathrm{O}$ aumento rápido dessas bactérias e fungos ataca o corpo falecido, e as primeiras consequências imediatas são o aumento da temperatura e a produção de gás. O gás faz o corpo inchar e algumas partes ficam cinza e marrom. Em um espaço aberto, o abdômen pode até estourar se a temperatura estiver alta o bastante. Isso não acontece se o corpo estiver enterrado no solo ou com solo preenchendo o espaço. Roupas geralmente se decompõem junto com o corpo, assim como outros materiais orgânicos. Fatores exógenos vêm do ambiente e da sepultura, e variam muito de acordo com o tipo de sepultamento. Por exemplo, se o corpo está exposto partes do mesmo são levadas por animais. A detecção desses animais pode ajudar a fazer inferências sobre a arquitetura da tumba e sobre a proteção (se houver) do corpo (Duday, 2009). Se o corpo é sepultado em urna e tampado, ele sofre a ação de animais pequenos que conseguem entrar, como roedores, vermes, formigas, etc., como pudemos detectar em mais de um dos sepultamentos que analisamos.

Devido a todos esses processos tafonômicos, a posição dos ossos é sempre diferente, ao menos um pouco, da sua posição quando havia um corpo. E a arquitetura do sepultamento, bem como o tipo do mesmo (se primário, secundário, cremação, etc.) 
são determinantes para saber como esses ossos estarão no final do processo de decomposição. Após este, há outros processos que afetam os ossos, tais como a ação de solos ácidos que decompõem a parte orgânica dos ossos, os mineralizando e transformado em pó (Duday, 2009), como é muito comum em sepultamentos em terras tropicais, e absolutamente frequente em sepultamentos Tupi. Todos os ritos que afetam o corpo após a morte são também processos tafonômicos. O grande desafio, característico da Arqueologia, é separar os processos naturais dos gestos.

A arqueologia funerária se preocupa em reconstruir o depósito funerário inicial, começando pelo final dos processos tafonômicos, que é quando o sepultamento é encontrado e escavado, trabalhando como que para retroceder no tempo em que ocorreram. Mas também é preciso analisar, antes disso, quais os possíveis tratamentos dados ao corpo no pré-sepultamento e, se possível, as causas da morte também (Duday, 2009).

Os vestígios arqueológicos do sepultamento (artefatos e estruturas) são os resquícios de ritos que separam os vivos dos mortos, transportando aquele morto para uma outra dimensão de compreensão. Esses ritos podem ter atingido o seu final ou terem cessado antes disso (Pearson, 2002). Um sepultamento não é um fato, mas sim uma série de processos que ocorreram por certo período de tempo, por vezes longo. Mendonça de Souza e Rodrigues-Carvalho (2013) fazem considerações sobre o assunto:

É recorrente, no nosso imaginário sobre o funeral, um ato pontual, o que certamente não corresponde ao que sabemos para diferentes grupos humanos. A fraca motivação etnográfica e a formação antropológica, quando insuficiente, contribuem para isso. Por outro lado, nossa própria postura cultural hegemônica, de crescente distanciamento em relação à morte, talvez favoreça uma visão dos funerais como um 'quase descarte', pouco contribuindo para pensar sobre a morte cerimonializada. (Mendonça de Souza \& Rodrigues-Carvalho, 2013)

O funeral não deve ser encarado como um ato pontual, mas sim como um evento que pode ser prolongado, em etapas sucessivas, que modificaram e afetaram a cena funerária. Essa consideração amplia as possibilidades de busca e identificação do impacto humano nos lugares dos mortos (Mendonça de Souza \& Rodrigues-Carvalho, 2013).

Chapman \& Randsborg (1981) falam sobre a possível presença de diferentes fases do ritual funerário entre os sepultamentos de um sítio. O que alguns arqueólogos poderiam considerar como sendo várias pessoas sociais daquele grupo, poderia ser nada 
mais do que diferentes partes do ritual funerário representadas. Mesmo quando há um bom controle cronológico de todos os sepultamentos (o que não é o nosso caso, de forma alguma), como saber se realmente são diferentes pessoas sociais ou similares em diferentes estágios do ritual funerário?

Dependendo do estágio do ritual, o registro arqueológico pode desaparecer por completo, como é o caso do sepultamento primário diretamente na terra entre os grupos Tupi, que etnograficamente sabemos que havia, mas que não se preserva na maioria dos contextos. Uma das formas de resolver, ao menos em parte, esse problema é a análise de fontes etnohistóricas sobre sepultamentos.

A preservação de certos materiais, como ossos, tecidos, acompanhamentos funerários orgânicos, etc., é bastante ruim ou nula, dependendo do tipo de material, de solo e das condições do contexto. Isso dificulta muito a recuperação de informações sobre muitos contextos, fazendo muitas vezes parecer que o que ocorreu naquela deposição foi bem mais simplório do que realmente aconteceu. Além disso, nem todas as práticas funerárias deixam um registro arqueológico. Os diferentes métodos de sepultamento não possuem igual chance de deixar um registro arqueológico e muitos, inclusive, destroem as evidências (Chapman e Randsborg, 1981). Um caso típico é o das urnas funerárias: elas, assim como seu conteúdo, muitas vezes estão bem melhor preservadas do que os outros sepultamentos do mesmo sítio, gerando uma falsa ilusão de que é a forma de sepultamento predominante, como nos lembra Rapp Py-Daniel (2015).

A essa altura já percebemos que, como nos mostram Mendonça de Souza e Rodrigues-Carvalho (2013), os ossos não são testemunhos absolutos no contexto funerário mas sim relativos, e quando tirados de seu contexto uma parte grande da informação é perdida se não analisada com cuidado. A posição dos remanescentes ósseos, espaços vazios e preenchidos, tonalidades, movimentos, processos de colapso, quebras, compactações, etc., constituem uma semiologia das estruturas funerárias.

A variabilidade dos contextos funerários é fruto em muito de ações humanas, mas também em grande parte de processos naturais, que vão depender da natureza do solo, do tipo de sepultamento, ação de animais, pressão de rochas e sedimentos, perturbação por outros humanos posteriormente. Por um lado, algumas práticas funerárias podem 
proteger o corpo de animais e outros agentes naturais. Porém, outras podem causar a destruição e perda de partes do corpo ou dele inteiro (Andrews \& Bello, 2009).

Para os grupos Tupi, sabemos através de etnografias que há diversos ritos funerários antes, durante e depois do sepultamento, e que o mesmo pode se dar em mais de uma etapa. Um dos objetivos dessa dissertação é recuperar gestos funerários desses grupos, com a finalidade de propor interpretações para os contextos encontrados na região analisada e em outras.

Em nosso caso, não pudemos realizar trabalhos de campo pois os sítios pesquisados foram escavados há tempos. Então, perdemos muito do contexto e suas sutilezas, tendo que contar com o olhar dos arqueólogos que pesquisaram os sítios nas diferentes épocas.

\subsubsection{A mudança diacrônica nas práticas mortuárias}

A mudança diacrônica das práticas funerárias é outro fator fundamental a ser considerado em uma análise de variabilidade mortuária. Não se pode pensar na espacialidade e na variabilidade dos sepultamentos sem considerar, juntamente, suas diferenças e semelhanças temporais.

O estudo de O'Shea (1984) sobre remanescentes arqueológicos de dois grupos norte-americanos, os Pawnee e os Arikara, datados entre 1740 e 1845, trata da importância das mudanças diacrônicas nos conjuntos de sepultamentos de um mesmo grupo. Segundo o autor, as práticas mortuárias se alteram com o tempo, mas a maneira como isso ocorre não é igual para todas as práticas. Para os grupos analisados, ele constatou que as diferenciações verticais como status e posição social não se alteraram muito com o tempo, mas as horizontais, como diferenças entre gêneros e idades, variaram mais. Características como orientação da cova, tipos de acompanhamentos funerários e cobertura da cova variaram com o tempo também. Entretanto, considerando-se que o período em questão foi de intensas mudanças para esses grupos, os métodos de sepultamento mais básicos permaneceram os mesmos: sepultamentos simples, fletidos e primários (Strauss, 2010).

As mudanças nas práticas mortuárias ao longo do tempo não ocorrem aleatoriamente, mas sim por causa de mudanças nas condições ou percepções da sociedade dos vivos, mudanças estas que são coerentes com as alterações estruturais e, 
muitas vezes, na estrutura social. Porém, as mudanças nas práticas funerárias não ocorrem apenas por causa de mudanças na estrutura social, mas também devido a contingências históricas (Strauss, 2010).

Esse é um tema totalmente em aberto na arqueologia brasileira. Não temos muita ideia exatamente de como se deram as mudanças diacrônicas nas práticas funerárias de grupos Tupi. Sabemos que os Guarani não sepultam mais em urnas há bastante tempo, pois etnografias do início do século XX já trazem a informação de que não há memória entre vários grupos Guarani de sepultamento em urna de cerâmica.

\subsubsection{Análise espacial de contextos funerários}

A análise espacial é outro elemento fundamental para a arqueologia de contextos funerários. Para essa pesquisa, consideramos que a análise da espacialidade funerária é uma boa oportunidade para entendermos esse aspecto pouco conhecido no Brasil, que é a relação espacial que envolve vasilhas cerâmicas, indivíduos e contextos funerários de grupos de línguas Tupi-Guarani. Devido ao grande número de contextos funerários destruídos e vasilhas descontextualizadas, a espacialidade acaba se perdendo na maioria dos estudos, o que deixa inúmeras questões obscuras. Como já foi dito antes, a má preservação dos esqueletos compromete os estudos sobre a espacialidade, mas não o impossibilita, como demonstraremos, sendo que muitas informações ainda podem ser obtidas.

A bibliografia sobre arqueologia espacial é extensa e não há espaço para discuti-la aqui. Discutiremos sobre arqueologia espacial aplicada a contextos funerários.

Goldstein (1981) defende a análise do componente espacial do sistema funerário para que se possa entender (1) o grau de separação espacial e de ordenamento da área funerária e (2) a relação espacial entre os indivíduos. Segundo a autora, tomando-se o devido cuidado com a temporalidade dos sepultamentos e a mudança diacrônica nas práticas funerárias, pode-se notar na espacialidade funerária um reflexo de princípios organizacionais da sociedade e diferenças de status social entre os indivíduos, bem como grupos familiares, grupos de descendência e classes sociais especiais. Sítios funerários trazem uma diferenciação de atividades realizadas naquele espaço, além de uma diferenciação de unidades sociais que realizaram aquelas atividades, sendo esses sítios complexas composições espaciais. A organização espacial se dá com base em elementos 
culturais, não sendo aleatória. A autora também afirma que o componente espacial das práticas mortuárias, tal como o estudo dos contextos funerários, é multidimensional por si só. A utilização do espaço se dá a nível da associação entre acompanhamentos funerários e destes com o indivíduo sepultado, da associação entre indivíduos, entre grupos de indivíduos e no contexto geral da área (Goldstein, 1981). Essa espacialidade também deve ser analisada de uma perspectiva regional (Ashmore \& Geller, 2005).

Como seguidora da escola processualista, Goldstein (1981) é fortemente influenciada por Saxe e Binford, tendo revisado e expandido a hipótese 8 do primeiro ${ }^{1}$. Então, para ela, a análise da espacialidade funerária era utilizada para se buscar grupos de afinidade e diferenças sociais, e para relacioná-los a outros aspectos, como o acesso a recursos. Porém, outras autoras, como Ashmore \& Geller (2005), realizam um estudo da espacialidade funerária de alguns sítios Maia que relaciona a localização dos sepultamentos na paisagem e a orientação do corpo com aspectos simbólicos. As autoras, assim como Goldstein, também realizam uma análise de grupos sociais e de como e onde são sepultados, mas o enfoque é diferente: elas não se restringem a encontrar grupos sociais e fazer uma classificação da sociedade, mas também fazem relações entre grupos e indivíduos e aspectos simbólicos ligados a concepções de mundo e do cosmos Maia. Os aspectos da organização social representados em contexto funerário são vistos em sua relação com aspectos simbólicos e objetivos políticos dos vivos.

O estudo da espacialidade funerária está ligado intimamente ao estudo das mudanças diacrônicas nas práticas funerárias, pois espacialidade e temporalidade não

\footnotetext{
${ }^{1}$ Hipótese de Saxe-Goldstein: nos anos 1970, A. Saxe publica seu grande e importante estudo que combina arqueologia e etnografia na análise de contextos funerários. Suas análises o levaram à formulação de 8 hipóteses, sendo a mais utilizada e conhecida a oitava. Ela indica que a emergência e presença de cemitérios formais é uma consequência da competição crescente por recursos naturais restritos e da formação de linhagens, que tentam reivindicar e se apossar de tais recursos justificando essa reivindicação através de uma descendência com os mortos. Assim, a manutenção de áreas formais específicas para sepultar os mortos indicaria que aquele grupo possuía essas linhagens de descendência para legitimar seu acesso aos recursos. L. Goldstein, também na década de 1970, revisitou os dados de Saxe, e testou as hipóteses em 30 outras sociedades. Sua critica principal é uma reformulação da hipótese 8 , para a qual ela faz 3 sub-hipóteses correlacionadas. 1) Na medida em que os direitos de um grupo corporativo de controlar recursos cruciais e restritos são alcançados e/ou legitimados por meios de descendência linear com os mortos, tais grupos irão ritualizar e reafirmar regularmente esses direitos, por meio da manutenção de uma área permanente e exclusiva para a deposição dos mortos. 2) Se existe uma área permanente, especializada e cercada para a deposição dos mortos, é possível que ela represente um grupo corporativo que que tem direitos sobre o controle de recursos. A descendência com os mortos torna esse controle sobre os recursos mais provável de ser alcançado e/ou legitimado, tanto em termos da existência de uma linhagem real quanto de uma tradição de transmissão dos recursos de geração para geração. 3) Quanto mais formal e estruturada a área de deposição, menor a quantidade de explicações alternativas a essa a respeito da organização social, e vice-versa (Souza, 2011).
} 
podem ser separadas. Sem o controle cronológico, uma análise pode juntar práticas que ocorreram em períodos muito distantes entre si e separar práticas muito distintas que ocorriam no mesmo período (Strauss, 2010).

No entanto, não dispomos de datas para cada sepultamento nos sítios analisados nesta pesquisa. $\mathrm{Na}$ realidade, as datas que possuímos foram consideradas pelos autores para cada sítio como um todo, como é convencional na arqueologia brasileira de uma maneira geral, e não encontramos detalhes sobre essas datações, como a área de onde a amostra foi tirada, etc. Por causa disso, como já foi dito antes, decidimos não analisar a organização social e nem tentar relacioná-la aos contextos funerários.

Porém, a espacialidade funerária pode trazer outras informações sobre grupos Tupi, além da sua organização social. No âmbito do contexto funerário em si, a espacialidade entre artefatos cerâmicos e outros (tembetás, conchas, etc.), e entre estes e remanescentes humanos, pode trazer muitas informações sobre práticas funerárias características de grupos que ocuparam aquele local. A espacialidade entre os contextos de cada sítio e entre estes contextos e as estruturas de habitação pode trazer informações sobre aspectos da relação entre os vivos e os mortos, bem como outras práticas funerárias. Como dizem Ashmore \& Geller (2005), a distância entre áreas de sepultamento e de habitação é carregada por aspectos simbólicos referentes a essa relação. Por fim, no âmbito regional a análise da espacialidade pode trazer muitas informações sobre programas funerários e sua variabilidade.

Buarque (2009) traz uma interessante análise espacial de contextos funerários Tupinambá de sítios do Rio de Janeiro, na qual relaciona as vasilhas cerâmicas não apenas entre si, mas também com fogueiras, buracos de estacas e outras estruturas, o que permite à autora recuperar uma série de práticas funerárias dos grupos daquela região, e delimitar possíveis áreas cerimoniais ligadas a certos contextos funerários.

A distribuição espacial das cerâmicas funerárias sempre foi um elemento fundamental nos estudos sobre expansão de grupos Tupi, pois muitas das cerâmicas analisadas eram provenientes de contextos funerários. Desse modo, é inevitável uma análise da associação entre cerâmicas e contextos, verificando como elas se distribuem geograficamente pela região considerada.

\subsection{As cerâmicas funerárias}


Ao analisarmos os contextos funerários de grupos Tupi-Guarani das regiões do Paranapanema e Alto Paraná, o que mais chama a atenção são as diversas vasilhas presentes neles, entre elas as grandes urnas funerárias. Assim, uma das primeiras questões que vêm à mente é: qual seria a variabilidade das cerâmicas funerárias? Outras questões são: que tipo de vasilhas eram aquelas, eram utilizadas apenas nos contextos funerários ou não? Quais os possíveis gestos e escolhas que levaram à sua utilização como parte de rituais funerários?

Visando responder, ao menos parcialmente, algumas dessas perguntas, escolhemos analisar a variabilidade e as marcas de uso dos artefatos funerários.

A variabilidade cerâmica, baseada em tipologias, sempre foi utilizada na arqueologia de grupos Tupi no Brasil. No entanto, a análise de variabilidade que fizemos se preocupa mais com a observação de quais materiais estão espacialmente contextualmente e regionalmente - associados do que com a construção de tipologias. Essa análise nos possibilita a reconstrução de padrões regionais, que são compostos por continuidades e descontinuidades entre as diversas regiões.

Muitas referências sobre contextos funerários de grupos Tupi revelam que as urnas funerárias são "reutilizadas", ou seja, antes de serem usadas para sepultar os mortos eram utilizadas como vasilhas para outros fins, como preparar, servir e estocar alimentos. Para testar essa hipótese com as vasilhas da região pesquisada, resolvemos fazer uma análise de marcas de uso.

\subsubsection{A variabilidade dos artefatos funerários}

A variabilidade artefatual possui 4 dimensões: formal, quantitativa, espacial e relacional. Cada uma delas é resultante de diferentes processos de formação que só podem ser identificados através da análise de toda a sequência de atividades e acontecimentos em que eles foram envolvidos (Silva, 2000).

Segundo Schiffer \& Skibo (1997), a variabilidade formal dos artefatos se dá não por causa de ideias e tradições, mas sim por causa das diferentes escolhas tecnológicas envolvidas na confecção deles. Escolhas tecnológicas são aquelas feitas desde o início da cadeia operatória do artefato para que este tenha a performance desejada. Assim, desse ponto de vista, as escolhas são feitas para afetar a forma, estrutura e decoração dos artefatos para que eles desempenhem a função que o artesão e o grupo envolvido 
desejam. Essas escolhas são pautadas pela experiência do artesão e por fatores situacionais, que são fatores (ambientais, sociais) externos à produção do artefato em si, mas que influenciam na mesma. Mas as escolhas tecnológicas também estão relacionadas a fatores de ordem social e simbólica, por isso a necessidade de se considerar a organização social e as representações simbólicas como inter-relacionadas com essas escolhas (Silva, 2007).

De acordo com Silva (2007, 2009), o significado da variabilidade formal dos artefatos é múltiplo, sendo fruto de escolhas relacionadas a fatores socioculturais ou de decisões individuais, com motivações tanto pragmáticas quanto simbólicas. $\mathrm{Na}$ cerâmica dos Asurini do Xingu, a variabilidade se dá por causa de diferentes fatores, como a funcionalidade das vasilhas, estrutura de ensino-aprendizagem, organização social, cosmologia e contingências históricas. Ela possui diferentes significados de ordem prática, social e simbólica. A organização social e a estrutura de ensino-aprendizagem são responsáveis por variações internas na cerâmica, mesmo que um padrão rigoroso seja seguido. A criatividade no emprego da pintura faz com que haja variações nesse aspecto, e contingências históricas que geram relações interculturais são responsáveis por outras variações formais. Já no caso dos Kayapó-Xikrin, a variabilidade artefatual dos tipos de braçadeiras está intimamente ligada a categorias sociais como gênero, idade, status social, e relações de parentesco.

Assim, certos atributos permitem uma maior ou menor variação nos conjuntos artefatuais. E a variabilidade artefatual pode ser um índice de fronteiras e relações sociais, usada para representar e construir identidades (Silva, 2007).

Para Dias (2007), as técnicas são produções sociais que expressam e definem identidades, reafirmando, representando e dando sentido a um mundo socialmente construído de possibilidades e limites. Sistemas tecnológicos são um recurso e um produto de criação e manutenção de um ambiente natural e social, simbolicamente construído. A tecnologia pode ser definida como o corpus de artefatos, comportamentos e conhecimentos transmitidos de geração a geração e utilizados nos processos de transformação e uso do mundo material. Ela é um produto social e as escolhas tecnológicas são estratégias dinâmicas, relacionadas frequentemente com diferenciação e identidade social. Tecnologia, função e estilo são aspectos inter-relacionados do comportamento, e sinalizam fronteiras sociais e afiliação cultural, que podem ser 
reconhecidos na cultura material. Grupos vizinhos em geral têm plena consciência de suas escolhas técnicas mútuas, e a ausência de algum traço tecnológico em um dos sistemas pode representar uma estratégia consciente de demarcação de diferenciações sociais. Contudo, esses fenômenos são altamente contextualizados em termos históricos, podendo ter relação com interesses pessoais ou grupais.

A autora faz uma crítica de como os conceitos de fase e tradição foram utilizados por certos representantes do PRONAPA (Programa Nacional de Pesquisas Arqueológicas). Segundo ela, o uso que foi feito não permite explicar como a variabilidade artefatual se relaciona a comportamentos culturais do passado (Dias, 2007).

Segundo Robrahn-González (1996), não é mais possível se fazer a classificação de sítios, considerando como grupos (étnicos ou categorias culturais mais gerais), apenas com base nas características gerais de sua indústria cerâmica, sem levar em conta os padrões de assentamento dos sítios, áreas de implantação, e características específicas de cada conjunto cerâmico. Análises gerais somente da cerâmica juntam ocupações marcadamente diferentes na mesma tradição arqueológica. Os sítios das tradições Aratu e Uru do centro-oeste, de acordo com os dados trazidos pela autora, não formam grupos culturais únicos como as tradições supunham, apresentando variações entre os materiais cerâmicos dos sítios, tanto espacialmente quanto cronologicamente.

\subsubsection{Análise das marcas de uso das vasilhas funerárias Tupi-Guarani}

Como sabemos, a história de vida de um artefato engloba sua cadeia operatória de produção, os diversos usos que ele adquire enquanto circula pelo grupo que o produziu, sua deposição e transformação em registro arqueológico, seu resgate pelos arqueólogos e sua transformação em objeto de museu, entre outras coisas (Holtorf, 2002). Com relação aos usos que ele adquire no grupo em que foi produzido, ou em outros grupos (caso tenha sido trocado, vendido, comprado, roubado ou dado), uma forma de se estudar se havia e quais poderiam ser alguns desses usos é através das marcas de uso.

De acordo com Skibo (1992), o estudo das marcas de uso faz parte da análise das alterações na cerâmica, resultantes de processos físicos ou químicos que podem causar adição, exclusão ou modificação do material na superfície ou na subsuperfície do objeto (no caso, a cerâmica). Mas a alteração pode ocorrer em qualquer momento desde a manufatura do artefato até sua recuperação pelo arqueólogo e também depois 
disso. As marcas podem ser feitas por processos de uso ou não do artefato, e por agentes humanos ou não humanos (Skibo, 1992, p. 42-43). O que interessa para a nossa pesquisa são as marcas provenientes do uso por agentes humanos, consideradas sinais da interação intencional de pessoas com aqueles artefatos.

A alteração das propriedades físicas e químicas da cerâmica pode ser chamada de traço (Skibo, 1992, p. 46). As marcas são o resultado de fatores ligados à natureza da vasilha (características ligadas à confecção, queima, forma, densidade, porosidade, tratamento de superfície, resistência, etc.) e às atividades realizadas pelas pessoas (Skibo, p. 46-47). Isso significa que a presença de certas marcas em algumas vasilhas e ausência em outras não significa necessariamente que o seu uso tenha sido diferenciado, pois é preciso levar em consideração esses fatores ligados à natureza da cerâmica. Os fatores ligados às atividades realizadas dependem de uma série de variáveis também: características de quem usou, modo de usar, os conteúdos da vasilha (o tipo de material que foi armazenado), o tempo e a frequência do uso e o contexto de uso.

A detecção de marcas de uso (ou traços, de acordo com Skibo) se dá ao se levar em consideração o máximo desses fatores que se possa ter acesso. Após a exclusão de marcas recentes (provenientes da escavação e manuseio pelos arqueólogos e outros pessoas que tiveram acesso à urna ou vasilha) e marcas que podem estar ligadas a fatores pós deposicionais (como a descoloração ou completo apagamento da pintura), é possível inferir marcas relacionadas ao uso.

Nos estudos das marcas de uso na cerâmica, o objetivo é inferir o uso a partir de 3 tipos de traços: abrasão, depósitos de carbono e resíduos orgânicos (Skibo, 1992, p. 48). Escolhemos analisar apenas as marcas de abrasão, pois são mais claras e simples de diagnosticar em peças que não sabemos ao certo como foram manuseadas após sua escavação e que provavelmente passaram por diversas intervenções, como remontagens, etc.

\section{3. Ética no estudo de contextos funerários}

Problemas surgem quando há um conflito entre o que geralmente consideramos como objeto de estudo e os interesses dos grupos que fariam parte desse "objeto de estudo", pois esses grupos, longe de serem objeto, são sujeitos. Materiais arqueológicos que para nós são simples objeto de análise, para outros grupos humanos possuem 
diferentes significados, que às vezes entram em conflito com nossas abordagens e métodos. Como dizem Smith \& Wobst (2005), a Arqueologia em geral é colonialista porque traz uma abordagem ocidental que, na maioria das vezes, ignora os grupos humanos mesmo quando trabalha com remanescentes associados a eles, e tenta contar histórias do passado desses grupos como se eles não pudessem falar por si próprios.

Muitos grupos indígenas, com diferentes visões de temporalidade, consideram que a sua história pertence a eles próprios, e que não precisam de pessoas de fora para lhes contar, muito menos usar os mortos para isso. Em muitas partes do mundo, a reivindicação do repatriamento e não perturbação de sepulturas acaba diminuindo ou paralisando as pesquisas arqueológicas em contextos funerários, o que gera embates e conflitos entre comunidades indígenas e arqueólogos, e entre os próprios arqueólogos, conflitos esses muito difíceis de se lidar (Pearson, 2002).

Certos remanescentes, paisagens, etc., não são simples objetos de estudo, mas sim um patrimônio vivo sob o qual os grupos envolvidos têm direitos e responsabilidades. Esses grupos indígenas às vezes têm concepções e interesses que são conflitantes com os dos arqueólogos, o que pode gerar uma situação bastante complexa (Smith \& Wobst, 2005). Em se tratando de remanescentes humanos e artefatos ligados a sepultamentos essa situação pode ficar ainda mais complicada, como demonstram os diversos movimentos para a não profanação de sepulturas e pelo repatriamento de remanescentes humanos que aconteceram e ainda ocorrem em certos países.

$\mathrm{Na}$ Arqueologia das Práticas Mortuárias nós buscamos entender a vida através da morte, e isso às vezes nos coloca em uma situação difícil: como estudar uma vida que, muitas vezes, na verdade estamos ignorando? Ao analisarmos a vida de indivíduos sepultados em sítios arqueológicos, nos preocupamos com aquela existência que o indivíduo e sua comunidade tinham no passado, mas esquecemos de nos preocupar com a vida que aqueles indivíduos representam para algumas pessoas e grupos no presente.

Pois mesmo os mortos mais antigos podem estar ligados aos vivos através de laços políticos, religiosos, econômicos, sociais e ancestrais e ao pesquisarmos os mortos acabamos, sem querer, interferindo nesses laços. Por isso, os arqueólogos (as) devem trazer em seu trabalho o respeito pelas tradições dos grupos indígenas, bem como pelas profundas crenças religiosas e pelas sensibilidades de comunidades locais (Pearson, 2002). 
No Brasil, um país em que interesses conflitantes de diversos setores sociais acabam tornando o cenário da Arqueologia muitas vezes um palco de conflitos, isso é ainda mais importante, e por isso mais difícil. Estamos em um país multiétnico em que, até hoje, apenas uma das etnias - os descendentes de europeus - é de fato reconhecida pelo governo. Isso gera uma série de conflitos, em que por vezes (ainda raras nesse país, mas que já existem) os contextos funerários são alvo de debates. Os arqueólogos aqui se veem, algumas vezes, no olho da tempestade, pois estão envolvidos em um cenário de contradições que são anteriores a eles próprios, mas nas quais, mesmo assim, eles acabam se tornando a linha de frente, sem ter muitos recursos para lidar com elas.

Em 2013, um caso que ficou famoso - e que tornou a se repetir em 2017 - ocorreu na área da Cachoeira das Sete Quedas, no Rio Teles Pires, entre os estados de Mato Grosso e Pará, local onde estava sendo construída a Usina Hidrelétrica Teles Pires. Lideranças Munduruku descobriram que estavam sendo escavadas urnas funerárias de sua etnia, e reivindicaram junto ao IPHAN (Instituto do Patrimônio Histórico e Artístico Nacional) e ao Ministério Público Federal a interrupção das obras e também a paralisação das intervenções arqueológicas na área. Trechos da carta da Associação Indígena PUSURU e do Conselho Indígena Munduruku do Alto Tapajós (CIMAT) ${ }^{2}$ estão reproduzidos abaixo:

Nós, caciques e lideranças do povo Munduruku, reunidos na aldeia Sai Cinza, município de Jacareacanga, Pará, entre os dias 23, 24 e 25 de abril do ano 2013, tivemos conhecimento de fatos transcorridos na cachoeira das Sete Quedas [...] lugar sagrado para os Munduruku, para onde vão as almas dos nossos mortos, onde vive a Mãe dos Peixes e onde um dos nossos grandes guerreiros Muraycoko, pai da escrita, deixou registrada sua história para as gerações futuras do povo Munduruku. [...]

Situação esta agravada por não ter havido comunicação nem autorização de nosso povo para isto, que consideramos uma violação de nosso território sagrado e ancestral. [...]

Assim, exigimos ao Ministério Público Federal do Mato Grosso e Pará, que é o nosso advogado e arbitra em nossa causa, que tome as providências cabíveis urgentemente, pois sabemos que nosso maior lugar sagrado já se encontra sendo destruído pelas obras da Usina Hidrelétrica Teles Pires, e com isso já estamos perdendo parte importante de nossa história de origem ancestral. Além disso, a violação de nosso cemitério sagrado representa um grande risco espiritual, cultural, social e ecológico, não só para

\footnotetext{
${ }^{2}$ A carta pode ser lida no site: http://acervo.racismoambiental.net.br/2013/05/17/mundurukudenunciam-roubo-de-urnas-funerarias-e-violacao-de-lugar-sagrado-no-teles-pires-e-pedem-ao-mpfparalisacao-dos-trabalhos-e-investigacao-imediata/
} 
os Munduruku, mas também para os parentes Apiaká e Kayabi, que semelhantemente consideram as Sete Quedas um lugar sagrado para eles, bem como, relevante para o patrimônio cultural e histórico da sociedade brasileira como um todo.

Assinam este documento caciques, lideranças, guerreiros e povo Munduruku.

A história das relações entre ocidentais e grupos indígenas na Antropologia Biológica, na Arqueologia das Práticas Mortuárias e na formação dos museus mostra, em grande parte, até que extremos esse problema da ciência colonizadora chegou. A civilização ocidental, com sua história de colonização, cometeu atrocidades terríveis contra as populações indígenas em todo o mundo, criando zoológicos humanos, sequestrando indígenas para serem expostos em galerias e museus, tirando remanescentes humanos de seus lugares de origem e mandando-os para outros países sem nenhum critério e respeito. Já faz tempo que esse quadro vem mudando, e diversas coisas comumente aceitas no início do século XX são hoje inaceitáveis.

Mesmo assim, alguns museus ao redor do mundo estão repletos de peças retiradas de vários lugares - em geral de países que foram colônias - por antiquaristas, aventureiros, arqueólogos e caçadores de tesouros. Comunidades locais e países reivindicam a devolução de muitas dessas peças. A Arqueologia surgiu e cresceu com o colonialismo europeu durante o século XIX e primeira metade do XX, sendo muitas vezes apenas um braço do controle colonial, retirando sem restrições artefatos das comunidades e países de origem. Com o fim dos sistemas coloniais entre as décadas de 1940 e 1970, o respeito pelos interesses e vozes das comunidades locais ou nacionais não veio automaticamente, e até os dias atuais ainda é pauta de reivindicações (Pearson, 2002). No entanto, mesmo tendo surgido em meio ao colonialismo, isso não significa que a Arqueologia tenha que estar parada no tempo.

Aqui estamos falando especificamente dos remanescentes humanos retirados de sítios arqueológicos. Os maiores conflitos com relação à escavação e ao tratamento destes geralmente têm ocorrido em antigas colônias europeias, em especial nos Estados Unidos, Austrália e África do Sul. Desde os anos 1960, grupos indígenas destes países vêm realizando grandes campanhas pela compensação de injúrias estatais fruto da colonização. Entre elas estão a restituição de sua propriedade cultural, a não perturbação de sepulturas e o reenterramento de seus mortos (Pearson, 2002). 
A filosofia positivista da ciência que regulou os estudos arqueológicos até o final do século XX fez com que as pesquisas tenham sido construídas com o propósito de traçar objetivamente o que aconteceu no passado. Assim, os remanescentes culturais e humanos de culturas indígenas tornaram-se objetos de pesquisa legítimos, utilizados para se entender processos e mudanças culturais. A história oral dessas populações, suas mitologias e até mesmo os textos escritos por e sobre elas muitas vezes foram considerados representações "êmicas", carregadas com a subjetividade do observador e dos interlocutores e, por isso, inferiores ao ponto de vista científico que a Arqueologia poderia trazer. Grupos indígenas poderiam dizer que seus ancestrais vieram do céu, mas a Arqueologia vai dizer que eles chegaram em levas migratórias de outros continentes há milhares de anos (Pearson, 2002). A Arqueologia até meados do século XX estava imersa na visão de progresso inevitável, típica de uma ciência positivista, ao mesmo tempo em que possuía um saudosismo romântico pelo passado, que se manifestou num desejo de preservar culturas. Esse desejo estava impregnado por uma concepção de que grupos indígenas eram coisa do passado, ou estavam prestes a deixar de existir. Com a justificativa de preservar culturas que estavam prestes a serem extintas, a Arqueologia e os museus colecionavam objetos, corpos, ossos, etc. Por causa disso, ela é vista até hoje com desconfiança por grupos que sofreram expropriação e massacres por parte dos ocidentais (Nilsson Stutz, 2007).

De acordo com Pearson (2002), nos Estados Unidos, a repatriação, reenterramento e não perturbação dos sepultamentos se tornou uma questão central a partir dos anos 1960, quando grupos indígenas iniciaram movimentos de reivindicação dos remanescentes de seus ancestrais expostos em vitrines de museus e lojas. Até os anos 1970, arqueólogos escavavam contextos funerários sem ter nenhuma referência sobre as comunidades indígenas próximas.

Em 1971, um grupo de arqueólogos escavou, em Iowa, um cemitério de colonos brancos do século XIX. Um dos sepultamentos continha acompanhamentos funerários que os fizeram crer ser o sepultamento de um indígena. Os remanescentes dos colonos brancos foram removidos para serem reenterrados em outro lugar, enquanto o esqueleto do indígena foi deixado para que os arqueólogos o levassem para ser guardado em um museu. Indígenas da região consideraram um ultraje essa diferença racista de tratamento. Outros eventos similares ocorreram, como o caso de outro sítio em que soldados norte- 
americanos foram exumados em uma escavação arqueológica e depois reenterrados, enquanto remanescentes de guerreiros Lakota não foram reenterrados.

Com uma história de genocídio por parte dos brancos, os indígenas americanos sofriam com o tratamento dado aos remanescentes de seus mortos, mais uma forma de discriminação, sendo tratados como cidadãos de segunda classe, sem direitos sobre seus mortos. Seu passado era exposto em museus de história natural dos Estados Unidos como se eles fossem parte da flora e da fauna do período antes da colonização, enquanto os europeus vindos de fora realizavam seu "destino manifesto". Por causa desse quadro, alguns movimentos indígenas foram criados para protestar contra essa situação, como o AIM (American Indian Movement) e o AIAD (American Indian Against Desecration), que levaram o caso para a conferência da Society for American Archaeology (SAA) na cidade de Minneapolis, em 1982 (Pearson, 2002).

Durante os anos 1980, a grande maioria dos arqueólogos americanos se opôs ao repatriamento ou ao reenterramento dos remanescentes humanos, alegando que a Arqueologia deveria proteger seus dados de pesquisa contra esses pedidos, que incluíam a devolução de meio milhão (estimado) de esqueletos presentes em coleções arqueológicas no país. Também defendiam que, para solicitar o repatriamento, deveria ser necessário que a pessoa que o reivindicasse oferecesse provas de que descendia do grupo étnico ao qual pertenciam os mortos. Esse tipo de coisa era bastante difícil de comprovar já que, devido ao processo de colonização, a grande maioria dos grupos indígenas sobreviventes foi deslocada das terras de seus antepassados e os remanescentes humanos encontrados dificilmente pertenciam ao mesmo grupo dos indígenas que atualmente viviam nas cercanias do sítio. Porém, o AIAD reivindicava que todos os remanescentes indígenas fossem repatriados, não importando o grupo ou sua relação com outros indígenas próximos (Pearson, 2002).

Poucos arqueólogos defendiam o repatriamento. Ao longo dos anos 1980 os debates foram intensos na comunidade arqueológica, mas algumas mudanças na lei, que os afetaram profundamente, não vieram por suas mãos, mas sim pela criação do National Museum of the American Indian Act, em 1989, e do Native American Graves Protection and Repatriation Act (NAGPRA), em 1990. Por determinação do NAGPRA, museus do país inteiro tiveram que devolver todos os remanescentes humanos indígenas aos seus grupos étnicos de origem, mas essa devolução teria que ser 
analisada caso a caso. Os debates não se esgotaram, e a controvérsia sobre o NAGPRA ainda é forte porque, entre outras coisas, até mesmo remanescentes muito antigos, os paleoíndios, são reivindicados para repatriação. Alterações na lei foram solicitadas pelos arqueólogos, como a da possibilidade de estudos caso a filiação cultural não seja possível de ser comprovada (Pearson, 2002).

Assim como nos Estados Unidos, na Austrália indígenas também eram caçados, massacrados, mutilados, torturados e escravizados até poucas gerações atrás. A exemplo desse país, movimentos pela repatriação de remanescentes humanos também ocorriam nessa outra ex-colônia britânica. As mais diversas atrocidades ocorriam lá, como a preservação de corpos de aborígenes mortos atestados como "os últimos sem mistura genética de sua etnia", para estudos dentro e fora da Austrália - evidentemente contra a vontade dos indivíduos, famílias e comunidades. Solicitações pela devolução desses remanescentes humanos foram feitas várias vezes (Pearson, 2002).

Em 1989, o World Archaeological Congress (Congresso Mundial de Arqueologia) propôs o Acordo de Vermillion, que buscava conciliar o respeito às crenças dos povos indígenas com a pesquisa científica. Embora seja criticado devido a certas ambiguidades, ele se tornou uma base para negociações entre arqueólogos e indígenas (Pearson, 2002).

Muitos arqueólogos vêm revendo sua postura em relação ao estudo dos contextos funerários. Desde a década de 1960, alguns deles, juntamente com antropólogos, começaram a questionar a ética de sua disciplina (Pearson, 2002). De 30 anos para cá algumas teorias arqueológicas têm enfatizado a subjetividade do processo de interpretação, o que resultou em arqueologias preocupadas com a multivocalidade. Há um desejo de se dar voz a grupos até então marginalizados (Nilsson Stutz, 2007). Desde o início dos anos 1980, um grupo minoritário clama por uma abordagem mais política e ética em relação aos remanescentes humanos. Hoje em dia, é cada vez mais forte a percepção de que uma arqueologia puramente positivista, que logra "descobrir" sobre culturas passadas, é questionável, pois como ciência humana a Arqueologia não é neutra, nem apartada de questões que envolvam o restante da sociedade, e muito menos livre. Ela está dentro de uma rede de relações sociais e econômicas em que conhecimento intelectual é poder (Pearson, 2002). 
Casos como estes mostram quais consequências podem haver quando não há um cuidado e uma ética para se lidar com contextos funerários. Como lidar com essas questões? Como conciliar o nosso direito de conhecer o passado e o presente com os direitos de comunidades indígenas envolvidas?

Além dessas dificuldades, que não são pequenas, as pesquisas arqueológicas muitas vezes esbarram em problemas relacionados a outros agentes envolvidos na Arqueologia, além dos grupos indígenas. Por exemplo, no Brasil, o conflito entre fazendeiros, latifundiários e grupos indígenas é central nas pesquisas arqueológicas, pois os primeiros na maioria das vezes não oferecem empecilhos para que a pesquisa (prospecções, escavações, etc.) ocorra em suas terras, mas não aceitam sequer a ideia de indígenas se aproximando delas. Como fazer então uma arqueologia junto com indígenas em um caso assim? Muitas vezes os arqueólogos estão no centro de conflitos muito maiores que sua possibilidade de ação a curto prazo, e nesse quadro a conciliação de interesses de todos os agentes envolvidos na pesquisa é extremamente difícil. E a possibilidade de ação do arqueólogo (a) é limitada, então, qual deveria ser nosso papel? Essa é uma discussão extremamente atual, e longe de estar resolvida.

Mas a dificuldade extrema não é motivo para se deixar de ter senso crítico e reflexão. Por mais complexa que seja a situação, acredito que o respeito à ética no trabalho arqueológico e um certo senso de autocrítica sejam um bom começo. Um caminho de autocrítica e conciliação, se é que isso é possível no Brasil, talvez pudesse fazer com que não haja em nosso país a necessidade de algo tão extremo como o NAGPRA, que impossibilita muitas pesquisas arqueológicas. A reflexão sobre o modo tradicional de se fazer arqueologia e pontos de vista cada vez menos colonizadores talvez sejam úteis para evitar que conflitos acirrados como os que citamos acima ocorram aqui. 


\section{Capítulo III MÉTODOS}

Para esta pesquisa procuramos formular um método que possibilitasse o estudo dos contextos funerários englobando tanto o material cerâmico (as urnas e vasilhas) quanto o material ósseo, além de contemplar parcialmente outros materiais que poderiam estar presentes (como conchas e tembetás), e a espacialidade dos artefatos dentro do contexto. Seguindo as considerações dos autores da Arqueotanatologia, como Duday (2009), acreditamos que uma análise que não integrasse todos esses elementos não seria suficiente para termos uma compreensão dos contextos funerários.

Juntamente com a observação do material e contexto arqueológico, foi realizada a análise de fontes etnohistóricas e etnográficas sobre sepultamentos de grupos Tupinambá e Guarani. Com isso, pretendemos aliar Arqueologia, Antropologia e História para uma abordagem mais completa dos contextos e práticas funerárias desses grupos.

\subsection{Entendendo a variabilidade: análise multidimensional dos sepultamentos}

Os primeiros pesquisadores a pensarem em uma análise das práticas funerárias Guarani e suas evidências arqueológicas, e a proporem um método para isso, foram Montardo \& Noelli (1995-96). Os autores trazem analogias etnográficas a partir de fontes etnohistóricas, e propõem um método para a abordagem de contextos funerários baseado no trabalho de O'Shea (1984). A partir do trabalho do autor, eles elencam seis categorias para a análise: aspectos biológicos (sexo, idade aproximada da morte, dieta, entre outros), tratamento do corpo, características da sepultura (se há a presença de cova, de construções sobre ela, etc.), material associado (acompanhamentos funerários), aspectos locacionais do sepultamento (se dentro da casa, no pátio, na periferia da aldeia, etc.) e aspectos ambientais da região (análise de pólens, amidos, etc.). Dentro da categoria tratamento do corpo, os autores propõem que se analise a conexão anatômica dos ossos (se é um sepultamento primário ou secundário), a integridade (se o esqueleto está completo ou incompleto), a posição dos ossos, a orientação do corpo (a direção da linha tomada do centro da pélvis até o crânio em direção a pontos cardeais ou a acidentes geográficos) e dos acompanhamentos, e a destinação do corpo (se dentro de vasilha cerâmica, rede ou cestaria, ou se enterramento diretamente na terra). 
Esse método é interessante, pois engloba várias dimensões de análise, configurando uma análise multidimensional. Como nos traz Pearson (2002), o estudo de contextos funerários necessariamente deve ser multidimensional para que possamos recuperar os gestos e processos envolvidos com a formação deles.

Nosso método de pesquisa se baseou no que foi proposto pelos autores, porém fizemos algumas alterações. Primeiramente, não seguimos integralmente a proposta devido às limitações de pesquisa intrínsecas ao nosso trabalho. Como não escavamos o material, tivemos que depender de relatórios e publicações sobre os sepultamentos, e isso limita bastante qualquer análise sobre remanescentes humanos ou contextos funerários. Desse modo, algumas das categorias de análise propostas não puderam ser muito bem exploradas. A integridade do esqueleto não é possível de ser analisada, pois não temos como saber se todos os ossos do sepultamento se encontravam no contexto ou não, e os remanescentes que encontramos nas reservas técnicas de museus e instituições museais são quase sempre incompletos devido ao manuseio ruim e perda de ossos, provavelmente não sendo, em sua maior parte, representativos da totalidade do esqueleto que originalmente existia. Além disso, a acidez do solo também é responsável pela não integridade do esqueleto. A posição dos ossos também não pode ser recuperada na maioria dos casos em que se analisou a documentação sobre os contextos, assim como a orientação do corpo e dos acompanhamentos. Em poucos casos essas variáveis foram descritas. A conexão anatômica do esqueleto (se era um sepultamento primário ou secundário) é descrita pelos pesquisadores que o escavaram às vezes. Os aspectos biológicos, dos quais escolhemos apenas o sexo e idade aproximada da morte para analisar, foram comprometidos também pela má conservação dos remanescentes humanos aos quais tivemos acesso. As características ambientais da região à época do sepultamento não serão exploradas por nós, pois fogem ao propósito dessa pesquisa. Porém, na análise das características gerais dos sítios, traremos alguns aspectos do ambiente, como relevo, etc.

Feitas essas ressalvas, buscamos empregar o método e ampliamos o número de dimensões de análise. A categoria 'material associado' foi expandida para uma análise da variabilidade e marcas de uso dos acompanhamentos funerários, em especial para aquele que mais aparece: a cerâmica.

O que tentamos fazer foi montar um método que pudesse unir esses três objetivos: 
- Recuperar os possíveis gestos funerários que foram empregados no sepultamento e como eles variam espacial e temporalmente;

- Verificar a variabilidade formal e tecnológica das cerâmicas funerárias, para conhecer as características das mesmas e analisar sua variabilidade de uma perspectiva regional;

- Verificar a presença de marcas de uso nas cerâmicas, inferir se tiveram outros usos além do funerário ou não.

É preciso analisar cada sepultamento individualmente, o conjunto dos sepultamentos de cada sítio e depois o conjunto dos sítios em uma perspectiva regional. A análise de cada sepultamento individualmente visa recuperar alguns gestos funerários utilizados neles, assim como as particularidades de cada um. Já a observação do conjunto de sepultamentos no sítio nos possibilita perceber quais gestos poderiam ter sido utilizados naquele local durante o período em que o sítio foi utilizado e, através da análise do conjunto desses gestos, podemos chegar a algumas práticas funerárias características de cada sítio. E a observação da variabilidade entre os sítios nos permite ter um panorama da região, vendo como padrões funerários se distribuem.

Unir a análise de contextos funerários para recuperar práticas com uma análise da cerâmica pode nos trazer a variabilidade dos contextos e práticas em conjunto com a variabilidade da cerâmica. Isso nos permite:

- Comparar a morfologia cerâmica, tão importante para as pesquisas com grupos Tupi-Guarani, com as práticas funerárias;

- Perceber arranjos espaciais de vasilhas, tanto no contexto individual, quanto no sítio, quanto na região;

- Perceber diferenças e semelhanças no emprego de vasilhas para fins funerários;

- Verificar o que a literatura já afirma há tempos, que é a "reutilização" de vasilhas para fins funerários, e traçar parcialmente algumas histórias de vida de artefatos funerários.

A variabilidade morfológica e tecnológica das cerâmicas de cada sítio entra em outra dimensão de análise: a da variabilidade artefatual nos contextos funerários. A observação de tipos, morfologias e outros aspectos dos materiais associados ao sepultamento, também chamada de análise dos acompanhamentos funerários, é algo 
que sempre foi feito desde o início da Arqueologia, como já foi visto. No entanto, como salientam vários autores, o elemento principal de um sepultamento é o morto. Então a análise dos remanescentes humanos que forem encontrados deve ser feita conjuntamente com a análise dos artefatos que compõem o sepultamento. Entretanto, a análise das cerâmicas funerárias é de extrema importância para percebermos práticas locais e regionais, assim como variações dentro dessas práticas, fatores que se alteram e fatores que permanecem, continuidades e descontinuidades (tanto no espaço quanto no tempo) que podem caracterizar parte de processos de construção de identidades.

De acordo com Silva (2000), a variabilidade artefatual possui 4 dimensões: formal, quantitativa, espacial e relacional. A análise formal se refere aos aspectos morfológicos dos artefatos; a quantitativa à quantidade de cada tipo no conjunto; a espacial à distribuição desses artefatos (no contexto, no sítio e entre os sítios); e a relacional se refere a como eles se relacionam entre si e com outros artefatos e estruturas do sítio. No caso dos sítios analisados por nós, a grande maioria dos artefatos presentes nos contextos funerários é composta por cerâmicas. A variabilidade das cerâmicas funerárias está sendo considerada nessas 4 dimensões.

A categoria 'aspectos locacionais' foi expandida para uma análise da espacialidade dos contextos funerários. Essa análise se dá, primeiramente, no nível contextual, em que é observada a distribuição e posição dos artefatos juntamente com os remanescentes humanos; depois ela se dá entre os sepultamentos no sítio, observando-se como eles se relacionam com outras estruturas. Por fim, podemos até mesmo comparar sítios diferentes, para ver se há padrões espaciais similares ou distintos no espaço.

Além de sentirmos a necessidade de expandir categorias, notamos que as categorias selecionadas por Montardo \& Noelli (1995-96), apesar de seguirem a proposta de O'Shea, não consideram os processos pelos quais o sepultamento passa, os ritos funerários e diversos gestos em relação ao morto, os processos tafonômicos naturais e culturais, os gestos pós funerários e extra funerários. A análise desses processos é parte integrante da análise dos contextos funerários, pois eles interferem diretamente na sua variabilidade. 
Portanto, com base nas categorias, ou dimensões, de análise elencadas por Montardo \& Noelli, expandimos, repensamos e acrescentamos coisas. Isso nos fez chegar em um conjunto de dimensões, apresentadas no diagrama.

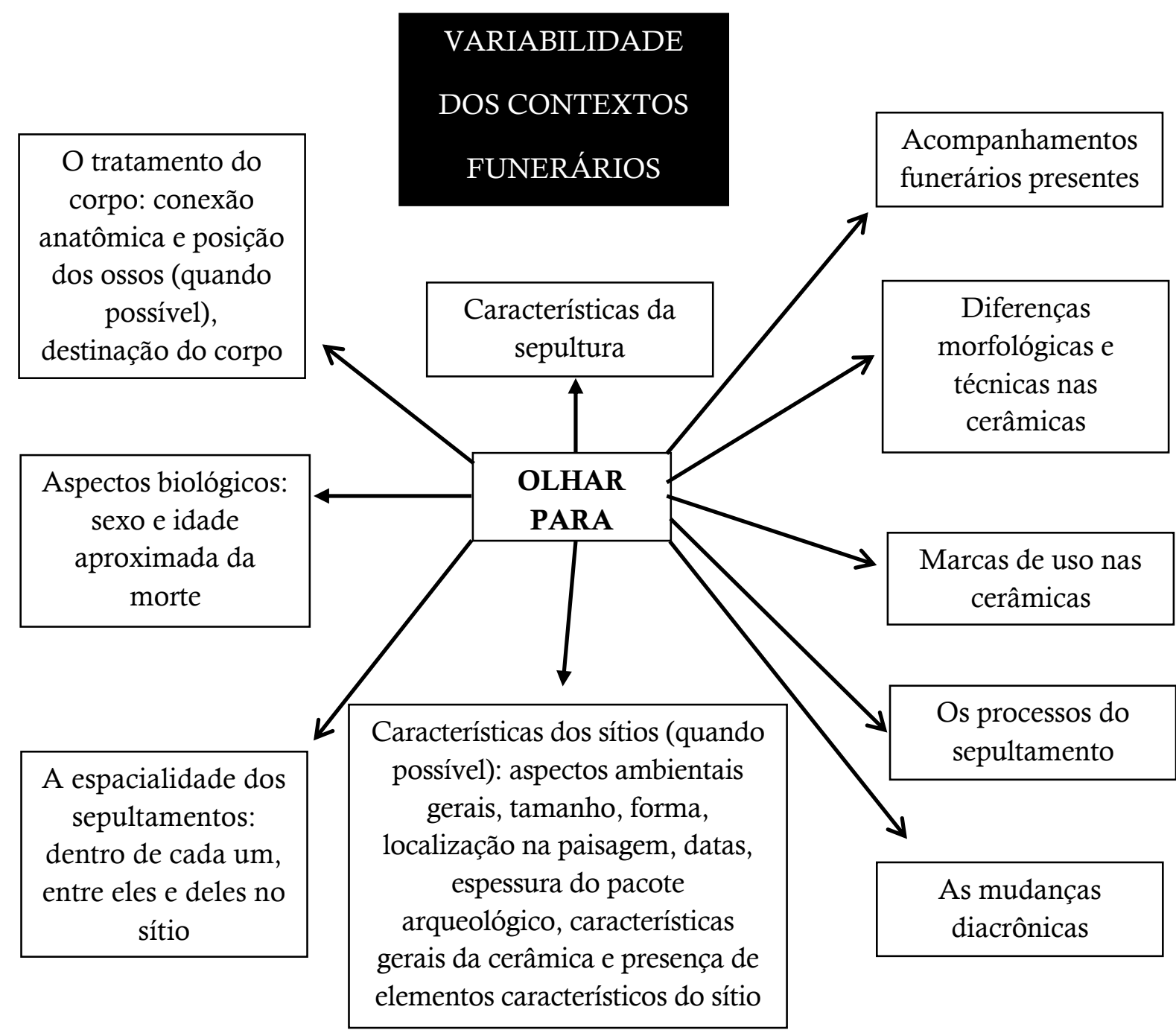

Como nos traz Pearson (2002), Duday (2009) e vários outros autores, os contextos funerários não podem ser entendidos de maneira isolada quando se busca por padrões. Elementos do contexto não funerário também devem ser considerados, pois as práticas funerárias acontecem dentro de um grupo e são realizadas pelos vivos, não são algo a parte (Rapp Py-Daniel, 2015). Ao mesmo tempo, sepultamentos não são atos pontuais, mas sim processos longos e, por isso, devem ser entendidos como tal. 


\subsection{Análise do material cerâmico}

A análise do material cerâmico teve os seguintes objetivos:

- Verificar a variabilidade morfológica e tecnológica das cerâmicas funerárias dos sítios escolhidos;

- Verificar a classificação funcional de acordo com a forma que cada vasilha assume no contexto não funerário, baseado nos estudos já realizados para os grupos Guarani e Tupinambá;

- Verificar se há a presença de marcas de uso, em especial marcas de abrasão, nas vasilhas.

A história de vida dos artefatos funerários também pode ser, em parte, elucidada através da análise de fontes etnográficas. Mas algo importante a respeito dela pode ser recuperado pela arqueologia, que é o uso. A análise de marcas de uso pode trazer a informação sobre se a vasilha era usada durante um certo tempo para outros fins ou não. Quais eram esses usos, se eram ligados a outros rituais ou se eram cotidianos, já é outra questão. Não obstante, o fato de as vasilhas funerárias terem sido utilizadas em outros contextos antes do funerário faz toda a diferença em termos de gestos funerários.

O protocolo de análise da cerâmica foi baseado no trabalho de Moraes (2007) e seguiu os seguintes critérios:

- Instituição de guarda;

- Número de acervo;

- Proveniência: sítio, município, estado;

- Espessuras mínima e máxima da borda;

- Tipo de lábio: se é plano, arredondado, apontado ou biselado;

- Tratamentos de superfície da face interna e externa: se há banho, barbotina, brunidura, engobo, pintura ou decorações plásticas;

- Forma da borda: se é direta, infletida, cambada, contraída ou carenada

- Diâmetro da borda;

- Maior diâmetro;

- Altura;

- Forma da base: se é convexa, côncava, plana ou pedestal. 
Esses critérios abordam aspectos formais e técnicos das peças. A classificação da vasilha, segundo a forma, foi feita de acordo com La Salvia \& Brochado (1989). E a presença ou ausência de marcas de uso nas vasilhas, realizada de acordo com o proposto por Skibo (1992). Dentre as diversas marcas de uso possíveis, escolhemos analisar principalmente as de abrasão porque, devido ao estado de conservação, grande parte das vasilhas analisadas apresenta diversas marcas modernas, como arranhões de pá feitos na hora da escavação, desgaste e substâncias na superfície cerâmica - características de uma conservação não muito boa - que confundiam a análise, podendo levar a falsas interpretações. Por isso, escolhemos analisar aquelas marcas que mais facilmente poderiam indicar uso. Além das marcas de abrasão, também analisamos outras marcas de uso recorrentes em vasilhas associadas a grupos Guarani, que são os furos paralelos acompanhando as rachaduras.

Como instrumentos de análise, utilizamos uma lanterna de luz branca, outra de luz ultravioleta, uma fita métrica, um paquímetro digital, uma lupa ocular de ampliação 5x, e uma máquina fotográfica digital.

A ficha de análise que utilizamos se encontra no Apêndice A.

\subsection{Análise dos remanescentes humanos}

A análise dos remanescentes humanos, no âmbito desta pesquisa, teve os seguintes objetivos:

- Fazer um inventário dos esqueletos, ou um registro simples quando estiverem muito fragmentados;

- Diagnosticar sexo e idade aproximada da morte dos indivíduos, desde que isso seja possível, a fim de tentar recuperar elementos do ritual funerário.

Para tal, montamos uma ficha de análise do material ósseo composta por vários itens (Anexo B). A elaboração de cada uma dessas partes foi baseada na leitura de bibliografia especializada. Os diagramas dos ossos e do inventário ósseo foram retirados da tese de Monteiro da Silva (2005), sendo que os mesmos foram adaptados de Buikstra \& Ubelaker (1994). O inventário dos dentes e os critérios para o diagnóstico de sexo e idade foram retirados diretamente desta última publicação. 
Os arqueólogos encontram dificuldades para lidar com os remanescentes humanos de grupos Tupi encontrados em campo, pois, entre outros motivos, devido à acidez de grande parte do solo em território brasileiro, os remanescentes humanos se mineralizaram, apresentando uma consistência pulverulenta, se desfazendo ao menor toque. Por causa disso, grande parte deles não pode ser levada para o laboratório, tendo que se fazer o registro em campo.

A ficha que utilizamos não foi testada em campo por nós da maneira como a montamos, pois não escavamos o material. Ela foi utilizada em laboratório e se mostrou útil para o registro das informações que queríamos. Independente da ficha que for usada, o que importa é o registro correto e o mais completo possível dos remanescentes humanos encontrados, pois essa informação é crucial na hora de se recuperar gestos funerários.

A ficha é dividida em 6 partes:

- Ficha de análise preliminar

- Diagrama de partes anatômicas

- Inventário de partes anatômicas

- Inventário dental (diagrama)

- Ficha de diagnóstico de sexo

- Ficha de diagnóstico de idade aproximada da morte

Acreditamos que o levantamento dessas características seja importante para sabermos sobre o indivíduo sepultado, embora isso muitas vezes não seja possível por causa da má preservação (e má escavação) dos remanescentes humanos.

Consideramos os diagramas de inventário importantes porque trazem uma visão geral do esqueleto e das partes que restaram. No caso dos dentes, podemos ter uma noção de quais deles havia e em qual estado de fragmentação, bem como se havia lesões como cáries e abcessos. Também realizamos o registro do desgaste dos dentes, bem como se há desgastes especiais, mais ou menos acentuadas em um ou outro dente. Não fizemos uma análise específica dos desgastes nos dentes, nem das cáries, pois fugia ao objetivo inicial da nossa pesquisa.

O inventário das partes anatômicas presentes possibilita dizer qual o estado de preservação de cada uma, que é identificado por números, da seguinte maneira: 
1. Presente e completa;

2. Presente e fragmentada;

3. Ausente post mortem

4. Perda ante mortem

5. Dente não erupcionado

6. Ossos congenitamente misturados

As fichas de identificação do sexo biológico e da idade aproximada da morte do indivíduo são idênticas àquelas propostas por Buikstra \& Ubelaker (1994), e a metodologia para a identificação foi retirada dessa bibliografia, que é bastante utilizada no Brasil. A morfologia dos ossos se altera conforme o sexo biológico, sendo que estruturas específicas, quando comparadas, podem trazer um diagnóstico do sexo do indivíduo. As variações entre os sexos são baseadas de acordo com populações, sendo os parâmetros populacionais fundamentais (Buikstra \& Ubelaker, 1994). Para os grupos Tupi, ou qualquer outro grupo indígena brasileiro, não há parâmetros populacionais baseados em medidas de séries de esqueletos; então o diagnóstico de sexo deve ser tomado como uma possiblidade, não como algo certo.

Para o diagnóstico do sexo, utiliza-se a análise de estruturas presentes nos ossos do quadril e no crânio. $\mathrm{Na}$ análise dos ossos do quadril, os autores utilizam as seguintes estruturas:

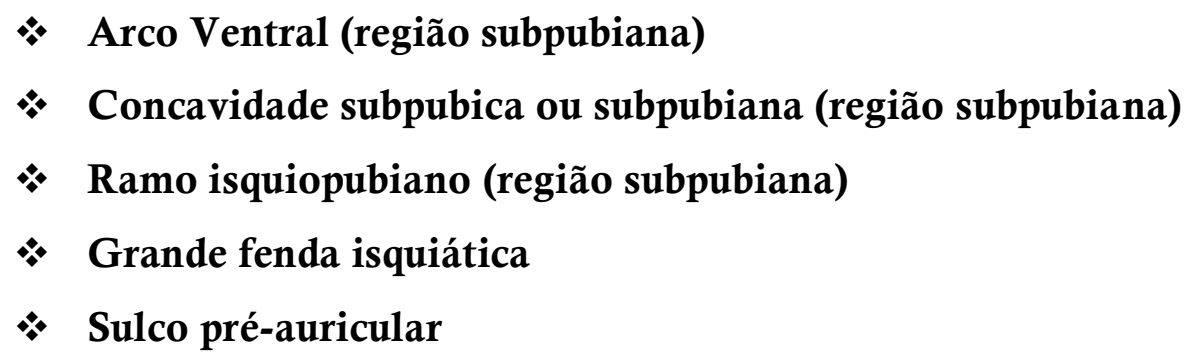

A cada uma dessas estruturas é dado um número que representa se o esqueleto é feminino, indeterminado ou masculino. No caso das estruturas da região subpubiana, esses números são de $\mathbf{1}$ a $\mathbf{3}$, sendo: $\mathbf{1}=$ feminino; 2 = indeterminado e $\mathbf{3}=$ masculino.

A grande fenda isquiática tende a ser mais larga em mulheres e mais estreita em homens, entretanto, sua morfologia não é tão confiável para o diagnóstico do sexo quanto a das estruturas subpubianas. Seus números de classificação são de $\mathbf{1}$ a $\mathbf{5}$, sendo: 
$1=$ feminino; $2=$ pouco feminino; 3 =indeterminado; $4=$ pouco masculino e $5=$ masculino. No caso do sulco pré-auricular, os números da classificação são de $\mathbf{0}$ a 4 , sendo: $\mathbf{0}=$ ausência de sulco; $1=$ sulco largo e profundo; $2=$ sulco largo e raso; $3=$ sulco bem definido, porém mais estreito e $4=$ sulco estreito, raso e na forma de uma depressão lisa.

Já para o diagnóstico através da análise das estruturas presentes no crânio, são utilizados os seguintes marcadores de sexo:

\section{* Crista nucal \\ * Processo mastoide \\ * Margem supraorbital \\ * Proeminência da glabela \\ * Eminência mental}

O diagnóstico através das estruturas do crânio é menos confiável se comparado ao das estruturas da pélvis, pois as do crânio podem variar muito de população para população. Cada uma dessas estruturas do crânio recebe uma classificação de 1 a 5 , sendo: 1= feminino; 2=pouco feminino; 3=indeterminado; $4=$ pouco masculino e $5=$ masculino.

Ao final, com base em todas as características da pélvis e do crânio que puderem ser diagnosticadas, atribui-se uma classificação geral para cada parte, da seguinte forma: 0 =sexo indeterminado; 1 =feminino; 2 =provável feminino; 3 =sexo ambíguo; $4=$ provável masculino e $5=$ masculino.

O diagnóstico da idade aproximada da morte, proposto pelos autores, utiliza a análise das seguintes estruturas:

\section{* Sínfise púbica (ou pubiana) \\ * Superfície auricular \\ * Suturas do crânio}

Para o diagnóstico, é observada a superfície dessas estruturas, a qual é correlacionada com alguma das diversas fases descritas pelos autores. 
No caso das suturas do crânio observa-se o grau de fechamento, sendo a presença de suturas mais fechadas indicativo de indivíduos mais velhos, e as mais abertas de indivíduos mais jovens. Porém, há uma grande variação no grau do fechamento. As suturas do crânio podem ser ectocraniais (10 suturas), palatais (4) e endocraniais (3). Cada sutura possui um nome específico. O grau de fechamento é analisado pela numeração de 0 a 3: 0=sutura aberta; 1=fechamento mínimo; 2= fechamento significativo e $3=$ completamente fechada.

Após a análise de todos os marcadores possíveis, as informações de idade de cada um devem ser cruzadas em um diagrama, conforme é demostrado em Buikstra \& Ubelaker (1994, pp. 37-38). Então, é dada uma classificação para a idade, conforme abaixo:

* Adulto jovem (20-34 anos)

- Adulto médio (35-49 anos)

* Adulto velho (50 ou mais anos)

Através da análise de cada um dos marcadores, quantificada através de diagramas, é possível estreitar a estimativa de idade, atribuindo um intervalo menor.

Para o diagnóstico da idade em esqueletos infantis há outra metodologia, mas como não encontramos nenhum remanescente infantil não a abordaremos aqui. $\mathrm{O}$ diagnóstico de idade em adultos é sempre muito mais impreciso do que em crianças, havendo sempre intervalos grandes (Buikstra \& Ubelaker, 1994).

O diagnóstico de sexo e idade nos remanescentes humanos que encontramos nas reservas técnicas de museus e instituições museais foi um verdadeiro desafio. Estavam muito fragmentados, por isso apenas poucos esqueletos possibilitaram algum diagnóstico. E mesmo assim, não conseguimos fazer a classificação para muitos marcadores, pois as estruturas estavam ausentes. 


\section{Capítulo IV \\ OS TUPI-GUARANI E A MORTE}

Neste capítulo mostraremos questões referentes à arqueologia de grupos TupiGuarani, à morte e práticas funerárias. Não iremos nos aprofundar nos complexos conceitos sobre a morte que grupos Tupi-Guarani possuem, pois isso iria requerer a leitura de uma bibliografia muito extensa - apenas sobre os Guarani ela já é muito grande -, cuja análise não seria tão adequada à proposta desta dissertação. Em contrapartida, realizamos um levantamento de práticas funerárias de grupos TupiGuarani mais meridionais, excluindo grupos Amazônicos porque levantamentos das práticas de tais grupos já foram feitos (ver César, 1966, 1975; Monteiro da Silva, 2008; Rapp Py-Daniel, 2015).

Ao falarmos em "Tupi-Guarani”, estamos nos referindo à família dentro do tronco linguístico. Como o foco dessa pesquisa é Tupinambá e Guarani, não iremos generalizar nossas considerações para outros grupos do Tronco Tupi. A documentação sobre a qual nos focamos é sobre essas duas línguas, e as considerações que estamos buscando traçar se restringem mais a elas.

\subsection{A arqueologia de grupos Tupi-Guarani: questões pertinentes}

Os pesquisadores do PRONAPA (Programa Nacional de Pesquisas Arqueológicas), pioneiros da arqueologia no Brasil, definiram a Tradição Tupiguarani, mas não a associaram a grupos humanos, nem sequer aos grupos falantes das línguas Tupi-Guarani. Ela se referia apenas ao registro arqueológico que continha machados líticos polidos, tembetás, cerâmicas (pintadas, lisas e corrugadas) e sepultamentos em vasilhas usadas secundariamente como urna funerária (Silva \& Noelli, 2017). O conceito de tradição utilizado pelo PRONAPA era relacionado a um grupo de elementos ou técnicas com persistência temporal, e sua contribuição fundamental foi comprovar a extensão da distribuição dos vestígios arqueológicos. A Tradição Tupiguarani foi subdividida em 3 subtradições: pintada, corrugada e escovada, considerando o predomínio de um tratamento de superfície sobre os outros.

Foi com o livro de Donald Lathrap, de 1970 - "The Upper Amazon" - que se iniciaram as bases para se associar definitivamente o registro arqueológico a grupos humanos falantes de línguas do Tronco Tupi (Silva \& Noelli, 2017), embora essa 
associação já tivesse sido feita por alguns autores no século XIX e início do XX, que associavam materiais cerâmicos a grupos "tupi" - sendo que esse tupi não estava bem definido ainda (Corrêa, 2014). Lathrap propunha o abandono da mera descrição do registro arqueológico, sua ordenação tipológica em conjuntos regionais e sequências cronológicas, para se buscar, além disso, sua relação com dados linguísticos e antropológicos. Assim, começou a ser desconstruído o conceito de Tradição Tupiguarani. Brochado, seguindo essa linha de interpretação dos dados arqueológicos através de uma articulação entre Linguística, Etnologia, História e Arqueologia, se aproximou da perspectiva de Aryon Rodrigues, que considerava as línguas da família Tupi-Guarani como manifestações diferenciadas da mesma língua original. A Linguística nos anos 1960 já havia feito muito mais formulações em relação aos grupos Tupi do que a Arqueologia, sendo a obra de Rodrigues um marco que vigora até hoje. Brochado (1984) aplicou o modelo histórico-linguístico para os conjuntos arqueológicos, e a partir da década de 1980 passa a desmembrar o que fora agrupado dentro do conceito de Tupiguarani pelo PRONAPA, dividindo-o em subtradições, uma localizada nas regiões mais a leste da América do Sul, através da costa atlântica, a Subtradição Tupinambá, e outra no sul, chamada de Subtradição Guarani. Essa separação inaugurou uma metodologia de se buscar nas cerâmicas dos falantes de línguas do Tronco Tupi características tecnológicas comuns e funções homólogas, como também distinções (variabilidade e variação) entre elas (Noelli, 1993; Silva \& Noelli, 2017).

Para Noelli (1993), o estabelecimento da tradição Tupiguarani seria problemático, pois teria consequências negativas na interpretação arqueológica posterior, confundindo os pesquisadores, que uniformizaram sob esse nome culturas com diferenciações importantes tanto do ponto de vista da arqueologia quanto da etnologia. O pensamento de Métraux teria tido uma influência marcante nessa construção.

Acompanhando essa ideia, Corrêa (2014) trabalha com a expansão dos grupos Tupi pela América do Sul, mapeando a distribuição das morfologias de vasilhas cerâmicas, e propõe uma distribuição espacial para as mesmas que vai além das propostas Tradição Tupiguarani e Subtradições Tupinambá e Guarani. Segundo Corrêa, há 5 grandes conjuntos cerâmicos Tupi, que ocupam grandes áreas do Brasil: Tupi NorteOcidental, Tupi Norte-Oriental, Proto-Tupinambá, Tupinambá e Guarani. Esses conjuntos não correspondem a populações, nem sequer necessariamente a línguas dentro 
do tronco linguístico. Eles podem estar historicamente associados a línguas (como no caso do conjunto associados aos falantes de língua Guarani) ou podem ter sido produzidos por falantes de diversas línguas Tupi diferentes. Já Almeida (2013) propõe o subgrupo Tupinambá Amazônico, identificando os grupos Tupi que teriam semelhança, em termos de estilo cerâmico, com os Tupinambá e habitaram áreas da Amazônia longe das calhas dos grandes rios, se deslocando por terra.

Se alguns autores possuem a preocupação de destrinchar o Tupiguarani, buscando entender suas particularidades regionais, outros procuram entender quais seriam suas semelhanças a nível continental, para poder relacioná-lo com outras tradições cerâmicas. Para Neves (2012), a etnologia das terras baixas da América do Sul identificou, assim como a Arqueologia, um nível geral de abstração entre os diferentes grupos TupiGuarani, conforme o que foi proposto em Viveiros de Castro (1986). Este autor defende que há algo em comum ou geral entre os diferentes grupos Tupi-Guarani, para além da identidade linguística, e por trás de uma aparente diversidade morfo-sociológica.

Viveiros de Castro (1986) formula que há uma suplementaridade, um excesso do discurso cosmológico em relação à organização social em sociedades Tupi-Guarani. A organização social seria "frouxamente estruturada" (nas palavras do autor), com um número restrito de categorias sociais, ausência de segmentos e divisões globais, fraca institucionalização ou formalização das relações interpessoais, relativa indistinção das esferas pública e doméstica, e poucos mecanismos integrativos. Em contrapartida, há uma extensa taxonomia do mundo sobrenatural - mas de difícil redução a princípios homogêneos - e uma ativa presença desse mundo na vida cotidiana, com os mortos exercendo um papel fundamental. Entre os Araweté, não é possível fazer uma relação entre morfologia da sociedade e cosmologia, entre a instituição e a representação.

Agora, as relações entre a cultura material e a cosmologia em grupos Tupi, e mesmo as relações entre a primeira e os aspectos sociais, são um campo de estudos muito pouco explorado na Arqueologia.

Tal similaridade entre cosmologias poderia ter também manifestações materiais que constituem padrões, segundo Neves (2012). Na arqueologia relacionada a grupos Tupi\, a padronização da produção cerâmica e a preferência padronizada por assentamentos em áreas de mata se contrasta com a ausência de um claro padrão na 
morfologia das aldeias e no tempo de duração na ocupação desses assentamentos. Tratase de um caso em que o padrão arqueológico é constituído pela recorrência de alguns elementos (o ecológico e a produção material) e variação de outros (a morfologia e padrões de assentamentos). Isso, segundo o autor, contrasta com a simetria e o rigor das ocupações Manacapuru e Paredão na Amazônia Central, ou com as aldeias circulares Aratu (Neves, 2012).

Entretanto, o padrão (ou ausência de) na morfologia das aldeias e no tempo de duração dos assentamentos são tópicos que possuem muito poucos estudos, então não se conhece muito sobre esses temas no Brasil.

Discussão relacionada a esta é sobre o uso dos termos. O termo Tupi, de início, foi utilizado para designar as populações que habitavam a região de São Vicente, e depois para se referir aos grupos aliados dos portugueses que falavam uma língua diferente dos Guarani. Essa diferenciação também veio como uma necessidade de diferentes designações para os indígenas aliados dos portugueses e dos espanhóis. Desde o século XVI os termos tupi, tupinambá e guarani foram utilizados de diversas maneiras, sendo que foi nos anos 1950 e 1960, com a obra de Aryon Rodrigues - "A classificação linguística do tronco Tupí”, entre outras - que o termo Tupi foi definido de maneira cientificamente clara e generalizada, passando a se referir a todas as populações falantes das línguas do Tronco Tupi, e não apenas aos grupos que habitavam o litoral das regiões Nordeste e Sudeste do Brasil (Corrêa, 2014).

Igualmente, o termo Tupinambá também foi definido por Rodrigues na Linguística, e também com a obra de Florestan Fernandes nos anos 1950 e 1960 - "A Organização Social dos Tupinambá" e "A Função Social da Guerra na Sociedade Tupinambá". Rodrigues denominou como Tupinambá a língua comum falada entre diversos grupos descritos nas fontes que habitavam uma ampla região da costa brasileira do Pará até São Paulo, e regiões do interior. Já Florestan, baseado na unidade cultural dos grupos "Tupi” proposta por Métraux, designa como Tupinambá os vários grupos descritos sob este nome nas fontes etnohistóricas, aqueles que entraram em contato com os europeus na vasta área do litoral e na Ilha de Tupinambarana (Fernandes, 1963). Na Arqueologia, Brochado se utiliza da definição de Rodrigues para caracterizar conjuntos cerâmicos. 
Neves (2012) problematiza o termo "Tupinambá", colocando que é muito genérico pois inclui uma série de grupos falantes de línguas Tupi-Guarani que não são Guarani, grupos esses que ocupavam o litoral das regiões nordeste e sudeste do Brasil, partes da Zona da Mata mineira, das planícies do São Francisco e outras regiões da Mata Atlântica e do interior, e eram distintos e inimigos entre si, como os Tamoio, Tupiniquim, Tememinó, Caeté, Tupinambá, Aimorés, etc.

De igual maneira, o termo Guarani passou a ser utilizado, desde o século XVI, para todos os grupos que falavam a mesma língua. Mas os Guarani também são distintos entre si, o que é atestado pelas autodenominações Kaiowá, Mbyá e Ñandéva, e talvez também o fossem no passado. Há inúmeras denominações para os Guarani nas fontes etnohistóricas, e a relação entre essas diferentes denominações e diferentes grupos Guarani é complexa (Schaden, 1962). Segundo Cadogan (1968): Chiripá e Apapokuva são outras nomenclaturas utilizadas para os Ñandéva, mas os Chiripá não se localizavam em território brasileiro. De acordo com Schaden, os Apapokuva estão dentro do subgrupo Nandéva, sendo eles chamados pelos Mbyá de Txiripá í (Chiripá í). Os outros dois subgrupos são: Mbyá (ou Mbüá), autodenominação mais utilizada pelos grupos conhecidos na bibliografia como Kainguá ou Kaiuá; e Kayowá, também conhecido como Teüi ou Tembekuá. No Paraguai, Bolívia e Argentina haveria outros grupos Guarani além desses (Schaden, 1962).

Tupinambá e Guarani são, portanto, línguas associadas tanto a diversos grupos com denominações e autodenominações diferentes, quanto a vários sítios arqueológicos das regiões do Paranapanema e Alto Paraná. Mas a questão que fica é: se há algo em comum que possa fazer com que haja uma relação entre falantes do mesmo tronco linguístico e cerâmicas/sítios, ou entre cerâmicas/sítios e línguas específicas - no caso do Tupinambá e Guarani - quais são as diferenças dentro desses grandes agrupamentos? Esse problema começou a ser explorado apenas recentemente. O Tupinambá e Guarani arqueológicos são fenômenos bastante intrigantes, pois se estendem por áreas imensas, mas pouco se conhece sobre suas particularidades regionais.

Silva e Noelli (2017), entre outros textos que podem ser citados, defendem que as similaridades entre os conjuntos cerâmicos dos grupos de línguas Tupi-Guarani propostas por Brochado ocorrem como resultado da prática social de transmissão de conhecimentos, na qual as línguas são elementos fundamentais na promoção desse 
processo de ensino-aprendizagem. A padronização dos conjuntos artefatuais se daria por causa da transmissão das técnicas nas quais estão envolvidos os processos de seleção de materiais, de instrumentos, os procedimentos e as sequências técnicas. Percepções socialmente apreendidas de como as coisas devem ou não serem feitas, resultado de transmissões desse conhecimento, poderiam explicar a padronização na cerâmica entre grupos Tupinambá e Guarani.

Mas como seriam as relações entre essas bases comuns e os diversos grupos regionais? Acreditamos ser bastante útil a busca pelas regionalidades Tupi, que pode trazer mais informações sobre comportamentos, simbologias, relações e percepções de grupos humanos falantes dessas línguas. Entender as regionalidades pode ajudar inclusive a explorar as continuidades - a morfologia cerâmica, certos padrões de assentamento, cosmologias com muitos elementos em comum - pois pode ajudar a compreendermos como se davam as relações que possibilitaram essas continuidades e levaram a variações.

Especificamente, para essa pesquisa, nos perguntamos se havia diferenças, e como se dariam, entre as práticas funerárias de grupos Guarani e Tupinambá de regiões do Paranapanema, Alto Paraná e outras dos estados de Mato Grosso do Sul, Paraná, São Paulo e Rio de Janeiro.

Mas primeiro, precisávamos saber quais práticas funerárias havia, e fizemos um levantamento das mesmas, que será apresentado mais adiante.

\subsection{Pesquisas e abordagens teóricas sobre a morte Tupi-Guarani e as urnas}

\section{funerárias}

Desde a última década do século XIX, Ambrosetti já escavava sepultamentos atribuídos aos Guarani na fronteira entre o Brasil, o Paraguai e a Argentina. Na região de Misiones (Argentina), ao longo do rio Paraná, ele relata ter encontrado artefatos cerâmicos e líticos. Ele fala de vários pontos ao longo do rio Paraná onde moradores locais encontraram vasilhas com vasilhas dentro, vasilhas com tembetás e contas. Também relata que, na região de Misiones, encontraram uma grande vasilha com 4 crânios humanos. Em uma área próxima à foz do Iguaçu, próximo à margem do rio Paraná, na área da colônia do exército brasileiro (ao menos na época), o autor relata o encontro de vasilhas com e sem ossos dentro, umas próximas às outras, outras distantes mil ou mil e duzentos metros entre 
si (Ambrosetti, 1895). Na primeira metade do século XX, na foz do Rio da Prata, Samuel Lothrop, um arqueólogo americano que era espião dos Estados Unidos em países da América Central e do Sul, escavou sítios arqueológicos e diversos materiais cerâmicos, entre eles vasilhas provenientes de contextos funerários que posteriormente vieram a ser classificados como Guarani (Bonomo, 2013).

O primeiro a explorar sistematicamente os dados dos cronistas quinhentistas sobre os Tupinambá e Guarani foi Alfred Métraux. Seu método era de comparação dos traços culturais em termos de sua difusão, e desse modo o autor considerava ser possível estabelecer quais elementos da cultura material são próprios dos Tupi-Guarani, e identificar a partir disso quais povos Tupi-Guarani são "autênticos" ou "aculturados". Ele define os Tupi-Guarani como antes difusores do que inventores de cultura material, ao contrário dos Arawak. Foi ele o primeiro a apontar relações entre sociedades Tupi-Guarani estudadas por etnólogos no início do século XX e a imagem dos Tupinambá deixada pelos cronistas (Viveiros de Castro, 1986).

De acordo com Métraux (2012 [1928]), o sepultamento primário em urna "do mesmo tipo" era característico de grupos Guarani do Paraguai, devido ao grande número de urnas. Mas não é característico de todos os grupos Tupi-Guarani, apenas de grupos Tupinambá, Guarani do Paraguai, Chiriguano e Guarayu.

O sepultamento secundário em urnas, de acordo com o que traz o autor, era praticado por grupos Tupi Amazônicos, como os Cocama, Omágua e Oyampi (Wayampi). Os Cocama sepultavam em uma vasilha de cerâmica até que as partes moles se soltassem completamente dos ossos, e depois sepultavam o esqueleto em outra vasilha menor, que era deixada na residência. Os Omágua desenterravam os ossos dos mortos após três meses, os lavavam e pintavam, e colocavam em uma vasilha cerâmica, que era despachada em um córrego, ou então enterravam os mortos em uma canoa na margem dos rios. Outros grupos Tupi Amazônicos praticavam outros tipos de sepultamento: os Yuruna (Juruna) e Apiaká realizavam o sepultamento primário na residência, em cova rasa, depois desenterravam os ossos e os penduravam em redes ou cestos no teto da casa. Os Mauhé (Maué) sepultavam uma pessoa importante em uma esteira, sendo que o corpo era exposto ao fogo até ficar queimado, e este era sepultado de cócoras. E os Auetó enterravam, cercando a sepultura com uma pequena barreira de madeira (Métraux, 2012 [1928]). 
Ele sugere que a ausência do sepultamento secundário em urnas tenha sido um elemento incorporado mais recentemente, quando esses grupos Tupi já haviam saído da Amazônia. Portanto, segundo ele, o sepultamento primário em vasilhas cerâmicas seria característico de grupos das regiões meridionais (Métraux, 2012 [1928]).

$\mathrm{O}$ autor via uma lógica comum para as práticas funerárias de sepultamento em "câmara funerária" e em urna, que é proteger o corpo e cobrir a cabeça, ou somente cobrir a cabeça. Seja em urnas cerâmicas, câmaras funerárias ou cestos, a lógica se repete para grupos Guarani e Tupinambá. A presença de uma cobertura para a sepultura, seja uma pequena cabana, seja a própria habitação, também se repete entre os dois grupos linguísticos, e o autor considera que ela era indispensável, pois segundo Léry, quando os Tupinambá abandonavam alguma aldeia destruíam as habitações, mas depositavam folhas de palmeira pindó sobre os sepultamentos, não apenas para reconhecer o local como também para evitar que o solo da sepultura ficasse descoberto (Métraux, 2012 [1928]). De fato, as descrições para os sepultamentos de grupos Guarani e Tupinambá dos séculos XVI e XVII são muito semelhantes, sendo que os gestos presentes nas descrições são parecidos.

Métraux (2012 [1928]) sugere que os sepultamentos em urna e fora de urna não se excluíam um ao outro, ou seja, havia a presença dos dois. Ele também afirma que o mais importante era evitar a pressão direta da terra sobre o corpo, e por isso o sepultamento em câmara funerária ou urna era a mesma coisa. Mas ele atribuía às vasilhas cerâmicas maior facilidade e comodidade no sepultamento, pois

Devia ser muito mais rápido e mais fácil para os índios pôr os restos mortais de seus parentes em uma grande cuba para chicha do que acomodá-los em uma pequena habitação subterrânea. (Métraux, 2012)

Essa questão do peso da terra sobre o corpo, e a simplicidade com a qual Métraux atribui funções para vasilhas cerâmicas (urnas e tampas) funerárias, ignorando os possíveis significados e simbologias envolvidas no emprego dessas vasilhas, foram alvo de críticas. Carvalho (1983) e Mano (2009) sublinham que apenas proteger o corpo da terra não pode ter sido a única função das vasilhas cerâmicas, e que as mesmas possuíam uma simbologia. Isso certamente é válido, mas mesmo assim o peso da terra sobre o corpo pode ter sido uma questão real e importante entre os Tupinambá e Guarani. 
Viveiros de Castro $(1986,2013)$ descreve que, entre os Araweté, havia a preocupação de o peso da terra e da sepultura ser muito grande para as crianças pequenas filhas de pais mortos. Os pais sepultados não eram enterrados, e sim era feita uma espécie de jirau com varas entrelaçadas, para que o peso da terra no corpo da mãe/pai não fosse muito grande sobre o peito da criança. De maneira semelhante, os Tupinambá preferiam a morte pelo ritual antropofágico do que a morte natural na qual eram enterrados, pois

Até os cativos julgam que lhes sucede nisso coisa nobre e digna, deparando-se lhes morte tão gloriosa, como eles julgam, pois dizem que é próprio de ânimo tímido e impróprio para a guerra morrer de maneira que tenham de suportar na sepultura o peso da terra, que julgam ser muito grande [...]. (Anchieta, $1554^{3}$ apud Viveiros de Castro, 2013)

Foi com Florestan Fernandes que o vasto material deixado pelos cronistas é utilizado de maneira exaustiva e sistemática. Para o autor, todos os elementos da sociedade Tupinambá estão subordinados à sua religião, sendo que esta era fundada sobre o complexo da guerra e da vingança, e sobre o culto dos antepassados (Viveiros de Castro, 1986). O autor formula que o complexo da guerra de vingança e ritual antropofágico seria um instrumento da religião Tupinambá, um mecanismo para a restauração da integridade do corpo social ameaçado pela morte de um dos membros, religando o grupo aos ancestrais através do sacrifício de uma vítima (Viveiros de Castro, 2013).

Florestan foi o primeiro a notar a importância e centralidade da morte para os Tupinambá, e propõe que as relações dos vivos com seus parentes mortos eram muito íntimas, tendo esses influência em várias esferas da vida, mas em especial na genealogia e determinação do status de um indivíduo. Os parentes do lado paterno influenciariam na determinação do status de um indivíduo na sociedade Tupinambá, sendo os ancestrais mortos, por isso, cultuados. No entanto, o próprio autor nota a falta de descrições concisas, por parte dos cronistas dos séculos XVI e XVII, desse culto aos ancestrais. Os ritos funerários entre os Tupinambá teriam uma finalidade bem clara: restabelecer o equilíbrio do sistema de relações sociais por meio da exclusão do membro falecido e da atribuição de um novo status ao morto, na sociedade dos ancestrais. Se isso não fosse feito, o morto representava um perigo para a comunidade.

\footnotetext{
${ }^{3}$ Anchieta, José de. Cartas, informaç̧ões fragmentos históricos e sermões (1554-1594). Rio de Janeiro: Civilização Brasileira, 1933.
} 
$\mathrm{Na}$ interpretação do autor, como a ligação da alma com os restos mortais não era totalmente suprimida, os vivos tinham uma série de obrigações com os mortos, como os prantos rituais e outras ações (Fernandes, 1963).

Após a morte a alma viajava para o Guajupiá, voando para além das montanhas, onde se encontravam os antepassados. O desfecho da viagem consistia na integração do falecido na sociedade dos antepassados. O autor afirma que isso era a coisa mais ambicionada pelos Tupinambá, sendo o ideal básico da cultura. Uma boa parte da vida dos Tupinambá estava polarizada na direção de seus parentes e amigos mortos (Fernandes, 1963).

Viveiros de Castro $(1985,1986,2013)$ critica essa visão de Florestan Fernandes sobre a guerra de vingança Tupinambá. Essa crítica se dá especialmente sobre dois pontos: o sentido e a temporalidade da vingança, e o papel dos mortos. Florestan coloca a vingança como um mecanismo restaurativo, de recuperação de uma ordem anterior, pretérita, que foi abalada pela morte prévia de um membro do grupo, e para restaurar a ordem praticava-se a vingança. Em Florestan a vingança olha para o passado, e os mortos do grupo possuem o status de ancestral. Em Viveiros de Castro, a vingança e a morte eram um motor para se produzir o futuro. Não se praticava vingança porque havia ocorrido o assassinato de um dos membros do grupo, se praticava para que o grupo inimigo continuasse a matar, e assim se poderia continuar a praticar a vingança. $\mathrm{O}$ objetivo da vingança era mais vingança, pois era nessa relação que estava baseada a sociedade Tupinambá.

A guerra não fazia algo voltar a ser o que era antes, pois a característica dos Tupinambá era o devir, então não se almejava um retorno, e sim um constante avanço. A sociedade Tupinambá se fundava na vingança, mas não como um retorno ao passado, e sim como um impulso adiante. Desse modo, ela não era uma religação dos vivos com seus mortos para uma recuperação de substância, pois não se buscava recuperar nada (Carneiro da Cunha \& Viveiros de Castro, 1985; Viveiros de Castro, 1986).

[...] não se tratava de haver vingança porque as pessoas morrem e precisam ser resgatadas do fluxo destruidor do devir; tratava-se de morrer (em mãos inimigas de preferência) para haver vingança e assim haver futuro. [...] A vingança não era um retorno, e sim um impulso adiante; a memória das mortes passadas, próprias e alheias, servia à produção do devir. (Viveiros de Castro, 2013) 
A consumação pelos inimigos estava certamente associada a um tema comum em cosmologias Tupi-Guarani, que é o horror ao enterramento e à putrefação do cadáver. Suportar na sepultura o peso da terra era indesejável, da mesma forma que suas carnes apodrecerem e eles serem comidos pelos bichos. O exocanibalismo dos Tupinambá era um sistema funerário, embora não fosse motivado por sentimentos como piedade, e sim por vingança e honra (Viveiros de Castro, 2013).

A morte aos inimigos e a morte pelas mãos dos inimigos, portanto, eram o motor da perpetuação da vingança. Os antepassados, os mortos do grupo, não tinham o status de ancestral, porque eles não eram uma referência do passado, e sim um objetivo futuro. Além disso, o complexo papel dos mortos não se resumia a serem referências ancestrais. Pode-se dizer que eles eram passado, presente e futuro (Viveiros de Castro, 1986).

Viveiros de Castro critica a noção de culto aos antepassados proposta por Florestan. Este último a utiliza num esforço de caracterizar os Tupinambá como uma sociedade de descendência patrilinear que, por isso, praticava o culto dos antepassados da linha paterna. Porém, não há evidências de que os Tupinambá ou outros grupos TupiGuarani tivessem direitos de descendência ligados a alguma linhagem. E como traz Carneiro da Cunha (1978), nos grupos Jê, em que há a oposição fundamental entre vivos e mortos, não há linhagens, nem culto aos ancestrais. Viveiros de Castro traz que os Araweté não rompem totalmente com os mortos (apesar de eles serem inimigos), pois a morte é o destino e motor da vida. Porém, entre eles tampouco há culto aos ancestrais. A noção de culto aos ancestrais é problemática, pois além de o próprio Florestan notar que não havia muitas descrições desses cultos, há outras formas de relação com os mortos, diferentes de um culto. Entre os Araweté e os Tupinambá não havia nem culto, nem ancestrais, e sim uma presença global dos mortos no pensamento e nas concepções. Não se cultuava linhagens de ancestrais, mas nem por isso os mortos tinham uma importância e centralidade pequena nas cosmologias de grupos Tupi-Guarani (Viveiros de Castro, 1986). Desse modo, a morte para os Tupinambá não era algo que precisasse ser negado ou transcendido para que pudesse haver a continuidade da sociedade, pois essa continuidade não se interrompia com a morte. Justamente o contrário, era a morte que mantinha a continuidade (Carneiro da Cunha \& Viveiros de Castro, 1985).

A morte pelas mãos do inimigo era desejável pois podia ser vingada, ao contrário da morte por doença, velhice ou feitiçaria. Os antepassados deixavam sim uma herança, 
que era a memória da vingança, mas essa era uma memória para o futuro, não para o passado. E essa memória era guardada pelo inimigo, pois dependia da ação dele. Nesse sentido, o centro da sociedade Tupinambá não estava dentro dela mesma, mas fora. Os inimigos eram quem lhe garantiam a continuidade. Pensar na vingança, ou seja, pensar no inimigo, era o seu mecanismo de manter-se no fluxo do tempo. O que era transmitido de geração em geração entre os Tupinambá não eram nomes e nem posições cerimoniais, apenas a memória da vingança. E não uma memória que é o resgate de uma origem ou de uma identidade, e sim a construção constante de uma identidade. Não é uma busca pelo início dos tempos, mas pelo seu fim (o término no paraíso, ou na terra sem males) (Carneiro da Cunha \& Viveiros de Castro, 1985; Viveiros de Castro, 1986, 2013).

Portanto, nos Tupi-Guarani não haveria culto aos ancestrais porque para eles não interessa o passado, e sim o futuro: a morte e a memória dos mortos estão a serviço da vida para constituir o futuro, e é o futuro de toda a vida. Não há um retorno a algo anterior, e sim um constante avanço (Carneiro da Cunha e Viveiros de Castro, 1985). Entretanto, isso não significa que a morte o os mortos não tenham uma presença e importância fundamental entre os vivos. Sua importância é grande e permeia muitas esferas da vida, conforme já notava Florestan Fernandes. A crítica de Viveiros de Castro (1986) se concentra mais em dizer que os termos "culto" e "ancestrais" são inadequados.

Mesmo porque, o que seriam as formas de "culto aos ossos"? Se, como escreve Viveiros de Castro, as relações dos grupos Tupi-Guarani com seus mortos vão muito além do que foi descrito por Florestan, há outros mecanismos e outras formas de relação. Para nós, o mais importante neste momento é notar que essas outras e diversas formas de relação, que não são exatamente culto, nem necessariamente funerais, alteram o registro arqueológico funerário - como mostram, inclusive, as fontes etnohistóricas - e por isso também é importante considera-las como gestos, embora não necessariamente funerários, envolvidos na formação do contexto.

José Vicente César $(1966,1975)$ foi o segundo, depois de Métraux, a fazer uma síntese das práticas funerárias (em especial o sepultamento em urnas) dos grupos Tupi, e o último até agora a reunir práticas de todos ou quase todos os grupos do Tronco Tupi. Ele faz um levantamento maior do que o de Métraux, agregando muitos dados. Faz uma análise de materiais provenientes de museus, bem como uma análise de etnografias. Um de seus focos está em romper com a antiga ideia, ainda corrente na época, de que os 
sepultamentos em urna são exclusivos ou característicos de grupos falantes de línguas do Tronco Tupi. De acordo com ele, além de não serem exclusivos, sequer são característicos, pois não são praticados nem pela maioria dos grupos. Registros de sepultamento primário em urna há somente para Caiuá (Guarani), Carijó (Guarani), Chané, Chriguano (Guarani), Cocama, Cocamilla, Guaianá, Guarani, Guarayu, Omágua, Pauserna, Tupiniquim e Wayoro. Já sepultamento secundário em urna havia entre os Aicauá, Arupaí, Cocama, Curuaia, Guarani arqueológicos, Juruna, Munduruku, Wayampi, Omágua, Tucuniapé e Xipaia.

No entanto, de acordo com o autor, para os grupos Guarani e Tupinambá, o sepultamento dentro de urna cerâmica seria típico sim, embora não seja a única forma de sepultamento existente. Mais ao sul do Brasil e países próximos dessa região as vasilhas empregadas como urnas são, em média, mas não exclusivamente, maiores que as mais ao norte, de grupos amazônicos ou do centro-oeste. Ele fala em 4 grupos morfológicos de urnas: em forma de bacia, dois cones unidos pela base, em forma de panela e semi-ovais. Fala também em diferentes formas de tampas: alta e arredondada, forma de bacia pequena, forma de tigela (Cesar, 1966).

Carvalho (1983) propõe que o ato de sepultar alguém em vasilhas cerâmicas confeccionadas para se depositar cauim possui a simbologia de transformar o guerreiro que não morria em batalha em cauim e alimento. Segundo a autora, poucos indivíduos eram sepultados em urnas, e esses indivíduos eram guerreiros que fizeram cativos para o ritual antropofágico, vingando-se de vários inimigos. Eles seriam sepultados nas vasilhas e cobertos por outras vasilhas - que já contiveram partes do corpo dos inimigos. Essa reutilização de vasilhas explicaria o porquê das urnas não serem padronizadas, nem feitas "sob medida" para o morto.

Mano (2009), seguindo parcialmente o pensamento de Métraux, afirma que os Tupinambá e Guarani compartilhavam o mesmo tipo de sepultamento, o que deve ter implicações lógicas para uma determinada visão de mundo em comum. Porém, critica esse autor quando ele diz que as urnas tinham a função simplesmente de proteger o corpo da terra. Ele concorda com Carvalho no que se refere ao caráter esporádico do sepultamento em urnas, sendo ele reservado a poucos indivíduos. A confecção demorada das grandes vasilhas cerâmicas as tornaria mais raras e em menor número, por isso os indivíduos sepultados deveriam ter uma importância social maior, sendo 
certamente homens adultos. As urnas e outras vasilhas utilizadas no sepultamento seriam "reutilizadas" de usos cotidianos, não tendo sido confeccionadas somente para o uso funerário.

Também da mesma forma que Carvalho, Mano defende que o sepultamento em urnas tem implicações rituais que se relacionam com o universo mágico-religiosoguerreiro dos Tupi-Guarani. O chefe ou guerreiro que não terminasse seus dias sacrificado pelos inimigos era inumado em um grande vaso de cauim ou chicha, para que ele mesmo fosse devorado pelos deuses canibais no céu, tornando-se assim um imortal. As urnas/panelas seriam um meio de transposição para a consumação canibal pelos deuses, para que o morto se tornasse imortal. Assim, o sepultamento em urnas teria relação com concepções a respeito de deuses canibais e com o universo simbólico da antropofagia (Mano, 2009).

Concordamos com algumas das ideias de Carvalho e Mano, mas discordamos de outras. Certamente o sepultamento em urnas não possuía simplesmente um caráter utilitário, carregando consigo uma carga simbólica fundamental. As marcas de uso nas vasilhas funerárias, de uma maneira geral, sugerem mesmo outros usos além do funerário, tendo a história de vida das vasilhas abrangido mais do que um tipo de uso. $\mathrm{E}$ a proposta da existência de uma relação com o universo da antropofagia também parece plausível, embora essa relação não tenha sido satisfatoriamente provada até agora.

Mas o caráter esporádico ou raro do sepultamento em urnas ainda é uma questão que, a nosso ver, precisa ser melhor trabalhada. Não há dados estatísticos que demonstrem claramente se esses sepultamentos eram esporádicos ou não. Sabemos que sepultamentos dentro e fora de urna conviviam nesses grupos, mas nada sabemos sobre o quanto um era mais ou menos frequente em número que o outro. Além disso, há sempre a questão da amostragem no registro arqueológico: há poucas escavações intensivas de sítios Guarani ou Tupinambá, e mesmo essas não conseguem abranger áreas tão grandes quanto provavelmente seriam as áreas de distribuição desses contextos funerários. A ausência de cemitérios - locais específicos de sepultamentos entre os Tupi faz com que seja difícil realizar análises estatísticas do número de mortos, então não temos como saber ao certo se realmente havia poucos sepultados em urnas ou se eles ocorriam de maneira tão dispersa - e distante das áreas residenciais com concentrações de vestígios arqueológicos - que simplesmente não foram encontrados. 
Alguns elementos sugerem que os sepultamentos eram dispersos, como a etnografia dos Araweté que relata que os adultos mortos eram sepultados em trilhas de caça, pelo menos 500 metros longe da aldeia (Viveiros de Castro, 1986).

Além dessas questões, há outra, fundamental a nosso ver, que influenciaria no número de sepultamentos em um sítio: a mobilidade desses grupos. Sabemos que os Guarani atuais possuem alta mobilidade, se deslocando pelo espaço. Mesmo quando há aldeias constituídas, indivíduos viajam bastante. Antes alguns grupos, dependendo da conjuntura histórica, sepultavam os mortos dentro da habitação e depois deixavam as aldeias. Mesmo quando não faziam isso, os locais dos mortos comumente eram esparsos, embora alguns grupos utilizem cemitérios, inclusive cemitérios municipais. Supondo que o hábito de deslocarem-se pelo território também estivesse presente entre grupos Guarani e Tupinambá do passado, mesmo que as conjunturas históricas dos grupos antes do contato fossem totalmente diferentes dos grupos atuais, essa mobilidade de indivíduos não poderia fazer com que os sepultamentos ocorressem em vários pontos do território, o que diminuiria o grau de sua concentração? Mesmo quando não havia uma mobilidade constante do grupo inteiro, o que poderia ser atestado pela presença das manchas de terra preta em vários sítios - que demoram para se formar, demandando uma ocupação constante - a mobilidade de certos indivíduos por diferentes aldeias não poderia contribuir para uma dispersão dos mortos?

Finalmente, a última proposta dos autores da qual discordamos é a de os sepultados em urnas serem guerreiros matadores. A ideia de Carvalho (1983) é anterior à tese de Viveiros de Castro, e Mano seguiu a ideia original da autora de que os poucos sepultados em urnas seriam guerreiros. Mas Viveiros de Castro $(1986,2013)$ afirma que, para os Araweté, os Maï não devoravam os matadores de gente (de inimigos), pois eles já haviam passado pela morte e já eram imortais. Quando iam para o céu, eles não passavam pelo canibalismo divino e iam direto para o banho rejuvenescedor, pois não havia neles mais humanidade que precisasse ser digerida pelos Maï. Segundo o autor, os devorados pelos deuses eram por excelência mulheres adultas, embora fosse difícil que todos ou mesmo a maioria dos homens fossem matadores, mesmo em tempos antigos, então homens também eram devorados pelos deuses. Crianças pequenas também não eram devoradas (Viveiros de Castro, 1986). Esse argumento, somado às evidências arqueológicas dos remanescentes humanos (que representam diferentes sexos e idades entre os sepultados em urnas), enfraquece a hipótese de que os sepultados em urnas entre os Tupinambá eram apenas 
guerreiros matadores. Não que mulheres não pudessem ser matadoras também, e não conhecemos evidências ou discussões sobre isso na bibliografia. Mas se aceitarmos a hipótese de que os guerreiros dos Tupinambá eram similares aos dos Araweté, o argumento de que aqueles que não pereciam em batalha eram oferecidos em "panelas" para serem devorados pelos deuses não se sustenta, pois, de qualquer modo, guerreiros não precisavam mais ser devorados.

Noelli (1993) utiliza o termo urna funerária para nomear o recipiente onde foram depositados remanescentes humanos. Ele considera o termo igaçaba impróprio, pois tratase de um neologismo utilizado na Língua Geral para designar certos recipientes, pois significa pote em que fazem os vinhos. Entre os Guarani, a cova era chamada de tibi, não havendo um nome para a vasilha funerária enquanto esquife.

O autor divide as estruturas funerárias da seguinte forma:

Enterramento primário: Dentro da estrutura de habitação

Fora da estrutura de habitação

Enterramento secundário: Dentro da estrutura de habitação

Fora da estrutura de habitação

Para ele, os sepultamentos secundários são aqueles realizados dentro de recipientes cerâmicos, enquanto os primários seriam os realizados diretamente na terra (talvez em redes ou esteiras) ou aqueles em que um crânio está coberto por um recipiente cerâmico (Noelli, 1993).

Entretanto, a única referência que encontramos nas fontes pesquisadas que demonstrasse claramente que os Tupinambá, especificamente, praticassem sepultamento secundário foi sobre o sepultamento secundário de partes do corpo e/ou cabeças. Vimos inúmeras referências para vários outros grupos do tronco Tupi, inclusive os Guarani, que praticavam sepultamento secundário além do primário, bem como outras diversas formas de sepultamento. De acordo com César (1975), vários grupos Tupi praticavam sepultamento secundário em urnas, mas para os Tupinambá e Tupiniquim o autor não traz essa informação, apenas a do sepultamento primário. Há diversos relatos de práticas secundárias para grupos amazônicos, e sepultamentos secundários em urnas - e, de fato, muitas das urnas, inclusive as antropomorfas e zoomorfas, encontradas em vários pontos 
da Amazônia possuem sepultamentos secundários dentro. Mas para grupos Tupinambá, encontramos poucos relatos de gestos que sugiram sepultamento secundário. Não há dados estatísticos que possam responder se os sepultamentos em urna eram em sua maioria secundários ou não, e a má preservação dos remanescentes humanos dificulta o diagnóstico do tipo de sepultamento na esmagadora maioria dos casos. Além do mais, há sempre o problema da descrição das fontes, que pode estar incompleta, ocultando outras etapas do funeral ou outros gestos envolvidos com o sepultamento. Os relatos sugerem principalmente sepultamentos primários em urnas entre os Tupinambá, embora haja esses relatos de sepultamentos secundários de crânios de pessoas que morreram longe de casa, que eram enterrados provisoriamente, e depois definitivamente em suas residências.

Noelli (1993) traz a escavação de um sepultamento fora de urna com vasilhas cobrindo, encontrado por Nordenskiöld na região dos Guarani-Chiriguano, Bolívia:

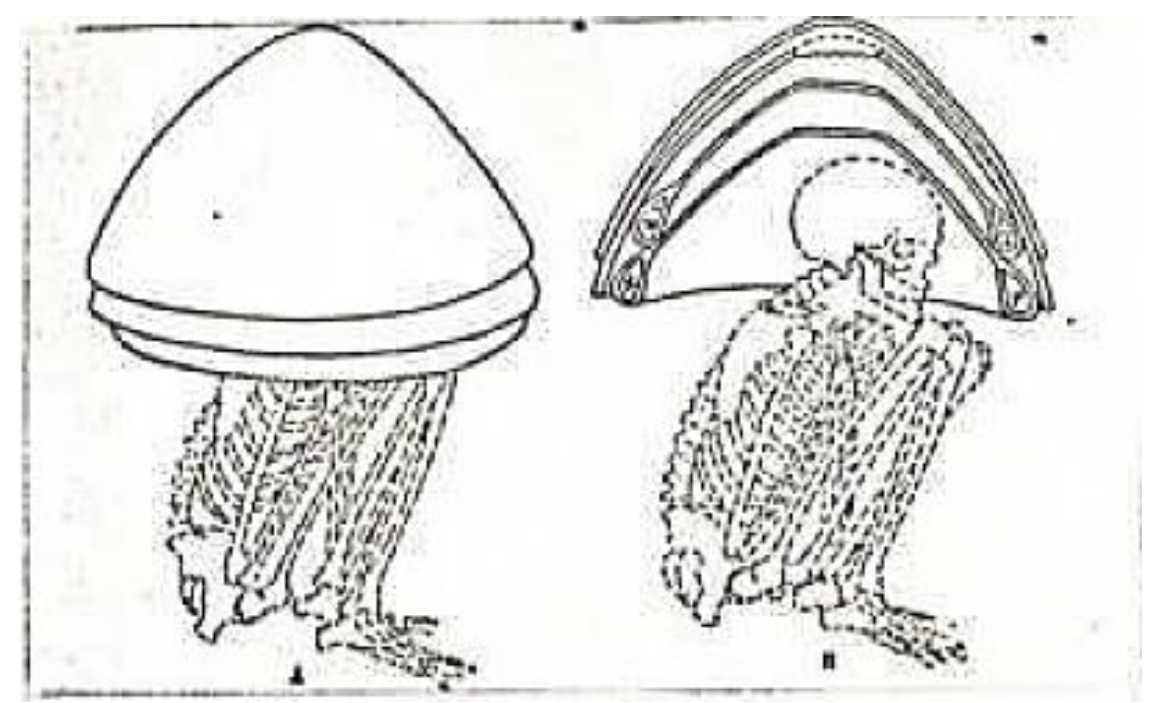

Figura 4: Desenho esquemático de sepultamento na Bolívia, feito por Nordenskiöld em 1913. Fonte: Noelli, 1993.

Aparentemente, apenas dois contextos funerários até agora foram encontrados dentro de manchas de terra preta, e ambos foram escavados por Igor Chmyz (1971 e 1983). Todos os outros contextos foram encontrados fora delas (Noelli, 1993).

De acordo com o autor, das 10 classes de vasilhas identificadas por Brochado, Monticelli e Neumann (1990), 9 já foram encontradas em contextos funerários (tabela 3), sendo que apenas o ñamôpyu (tostador de farinhas) não foi encontrado. 
Quadro 1: Vasilhas Guarani já encontradas em contexto funerário e suas respectivas funções básicas.

\begin{tabular}{|c|c|c|}
\hline \multicolumn{3}{|c|}{ Vasilhas encontradas em contexto funerário Guarani } \\
\hline $\begin{array}{l}\text { Classe da vasilha segundo a } \\
\text { relação função-forma }\end{array}$ & $\begin{array}{l}\text { Descrição de funções não } \\
\text { funerárias }\end{array}$ & Função funerária \\
\hline Yapepó & $\begin{array}{l}\text { Panela para cozinhar } \\
\text { alimentos }\end{array}$ & $\begin{array}{l}\text { Urna (abrigar o sepultamento } \\
\text { em seu interior) }\end{array}$ \\
\hline Cambuchí i açá & Talha para fermentar bebidas & $\begin{array}{l}\text { Urna (abrigar o sepultamento } \\
\text { em seu interior) }\end{array}$ \\
\hline Cambuchí irirú & Vasilha para armazenar água & $\begin{array}{l}\text { Urna (abrigar o sepultamento } \\
\text { em seu interior) }\end{array}$ \\
\hline Ñaetá/ñaeá & $\begin{array}{l}\text { Caçarola para cozinhar } \\
\text { alimentos }\end{array}$ & $\begin{array}{l}\text { Tampa (cobrir o sepultamento, } \\
\text { em especial a cabeça) }\end{array}$ \\
\hline Ñae apoá & Escudela & $\begin{array}{l}\text { Tampa (cobrir o sepultamento, } \\
\text { em especial a cabeça) }\end{array}$ \\
\hline Yapepó & $\begin{array}{l}\text { Panela para cozinhar } \\
\text { alimentos }\end{array}$ & $\begin{array}{l}\text { Tampa (cobrir o sepultamento, } \\
\text { em especial a cabeça) - menos } \\
\text { comum }\end{array}$ \\
\hline Cambuchi & Talha para fermentar bebidas & $\begin{array}{l}\text { Tampa (cobrir o sepultamento, } \\
\text { em especial a cabeça) - menos } \\
\text { comum }\end{array}$ \\
\hline Cacos de Ñaetá/ñaeá e Ñae apoá & & $\begin{array}{l}\text { Tampa (cobrir o sepultamento, } \\
\text { em especial a cabeça) }\end{array}$ \\
\hline$\tilde{N} a e ́$ & Prato para servir & $\begin{array}{l}\text { Vasilha anexa (conter } \\
\text { oferendas e/ou estar ali por } \\
\text { outros motivos rituais que não } \\
\text { este) }\end{array}$ \\
\hline Naembé & Prato para servir & $\begin{array}{l}\text { Vasilha anexa (conter } \\
\text { oferendas e/ou estar ali por } \\
\text { outros motivos rituais que não } \\
\text { este) }\end{array}$ \\
\hline Cambuchí caguabá & Recipiente para beber & $\begin{array}{l}\text { Vasilha anexa (conter } \\
\text { oferendas e/ou estar ali por } \\
\text { outros motivos rituais que não } \\
\text { este) }\end{array}$ \\
\hline Cambuchí mîni igôaba & Recipiente para beber & $\begin{array}{l}\text { Vasilha anexa (conter } \\
\text { oferendas e/ou estar ali por } \\
\text { outros motivos rituais que não } \\
\text { este) }\end{array}$ \\
\hline Cambuchí yarucuaí & Recipiente para beber & $\begin{array}{l}\text { Vasilha anexa (conter } \\
\text { oferendas e/ou estar ali por } \\
\text { outros motivos rituais que não } \\
\text { este) }\end{array}$ \\
\hline
\end{tabular}


Segundo o autor, os primeiros planos topográficos de sítios com os locais de sepultamento contextualizados foram publicados por Pallestrini no final dos anos 1960 . Nos anos 1970 e 1980, Chmyz, e Morais e Perasso (1984) publicaram os primeiros planos topográficos para sítios Guarani. De acordo com Noelli, há dificuldade em se determinar arqueologicamente qual a ligação entre a estrutura funerária externa à área de habitação e a própria área, atribuindo essa dificuldade à ausência de trabalhos que tenham ido além do mapeamento e medição de distâncias entre as estruturas funerárias e as de habitação. Entretanto, o próprio autor propõe que a análise de fontes etnohistóricas e etnoarqueológicas poderia trazer contribuições para a interpretação dessas relações entre estruturas de habitação e funerárias, e para se inferir possíveis motivos simbólicos para o enterramento dentro ou fora da habitação.

Outra autora que trabalha com a morte Tupi é Rapp Py-Daniel (2015). De acordo com ela, os grupos Tupi da Amazônia apresentam a maior variabilidade de formas de sepultamento e práticas funerárias: sepultamento primário direto, indireto (em rede, cestaria ou urna), sepultamento secundário direto na terra, exocanibalismo, cremação, mumificação, moqueação, distribuição de ossos, guarda de ossos em residência, exposição em rede ou plataforma. De todas as práticas levantadas pela autora, apenas o endocanibalismo e o sepultamento secundário múltiplo não apareceram. Um padrão funerário Tupi não existiria. Ela sugere que essa diversidade de tipos de sepultamento pode ser explicada pela variedade de formas organizacionais que os diferentes grupos Tupi possuem, indo de nômades, pequenos núcleos familiares a sistemas clânicos (Rapp Py-Daniel, 2015).

\subsection{Práticas funerárias de grupos Tupi de regiões ao sul do Brasil: o que dizem as fontes etnohistóricas}

Realizamos um levantamento de fontes etnohistóricas que contêm informações sobre práticas funerárias de grupos de línguas Tupi-Guarani que habitaram ou habitam áreas das regiões Sul, Sudeste, Nordeste e Centro-Oeste do Brasil, além de certas áreas do Paraguai e Argentina. Nós nos restringimos principalmente aos Guarani (em suas diversas denominações e autodenominações) e aos Tupinambá (para os quais encontramos, nas fontes pesquisadas, praticamente apenas essa denominação genérica, "Tupinambá", por mais que haja diversas outras). Não tivemos a intenção de esgotar as fontes que tratam de práticas funerárias de grupos Tupi, e várias fontes não foram 
contempladas em nossa lista. Na realidade, essa lista tende a aumentar conforme outras pesquisas forem trazendo mais informações. Nos preocupamos em pesquisar principalmente grupos Tupi de regiões mais meridionais, então muitos grupos da região Nordeste, Minas Gerais, Espírito Santo, etc. não são mencionados.

Essas informações etnohistóricas recolhidas passaram por uma análise crítica que procurou perceber as diferenças entre as práticas no espaço e no tempo. Além de enumerar práticas funerárias, procuramos tentar entender como essas práticas descritas variavam ou não no tempo e no espaço. Claro que a subjetividade de cada descrição, bem como a não especificação, em várias dessas fontes, das regiões onde estão os grupos que estão sendo descritos, limitou essa delimitação espaço-temporal das práticas. Mas mesmo assim foi possível fazer essa delimitação em certa medida.

Com essas informações, fizemos analogias etnográficas diretas, mas não tentando associar contextos a práticas diretamente, e sim tomando as descrições de práticas como hipóteses para possíveis interpretações dos contextos funerários analisados. Claro que essas interpretações são apenas uma possibilidade entre muitas.

\subsubsection{Analogias etnográficas}

O que estamos fazendo é uma arqueologia etnográfica, ou seja, estamos usando a analogia etnográfica - feita a partir de fontes documentais primárias e, sobretudo, etnografias realizadas por outros -, como uma ferramenta para o estudo do passado, subordinada à Arqueologia, segundo a definição de Castañeda (2008).

O uso de analogias etnográficas no estudo dos contextos funerários é proposto desde a década de 1960, com os estudos de Peter Ucko. Pearson (2002), por exemplo, as considera como ferramentas importantes na análise dos contextos funerários. Com uso desse tipo de documentação é possível fazer inferências acerca dos ritos funerários. Monteiro da Silva $(2005,2008)$ também defende o uso dessas fontes como uma forma de trazer à tona possibilidades de interpretação para o registro arqueológico funerário. Para o autor, as informações etnohistóricas e a arqueologia são intercomplementares, pois a Etnografia pode ajudar na criação de modelos gerais para ajudar nessa interpretação, e a Arqueologia pode ajudar a calibrar e desmentir certas descrições que, devido à subjetividade dos autores, podem estar imprecisas ou equivocadas. Noelli (1993) acredita que o estudo de fontes etnohistóricas e descrições etnográficas poderia trazer uma melhor 
compreensão sobre as práticas funerárias de grupos Guarani. Segundo ele, uma comparação entre mapas topográficos de escavações - contendo estruturas de habitação e funerárias - e a localização dos sepultamentos na iconografia e nos relatos da crônica quinhentista poderia trazer a possibilidade de se propor um padrão comportamental para os Guarani, através de analogias.

Os arqueólogos processualistas usavam analogias etnográficas para traçar regularidades e leis gerais do comportamento humano em relação aos mortos. Arqueólogos pós-processualistas criticam a analogia direta feita por muitos arqueólogos processualistas. Pearson (2002) escreve que os processualistas fazem um uso acrítico dos dados etnográficos, o que levou a generalizações forçadas. A crítica do autor se concentra no fato de muitos autores processualistas terem tratado o registro etnográfico como um eterno presente, uma descrição desprovida de tempo, espaço, conflitos, objetivos. Assim, se perde a dimensão histórica que possuem. Frequentemente, relatos históricos foram feitos em períodos de grandes mudanças para certos grupos, sendo relatos de alterações radicais e desastrosas para eles. Esses relatos, ao invés de serem vistos como representativos das mudanças, são muitas vezes vistos como atemporais. A analogia etnográfica empregada no estudo de práticas e contextos funerários deve ter uma perspectiva dinâmica e diacrônica do grupo, e não considerar apenas um momento estático de ação. Ela deve levar em conta o filme, e não a foto do grupo. Para isso, requer uma abordagem regional, em que as dimensões espacial e temporal devem ser combinadas. O papel da analogia, para o autor, não é encher o passado com informações provenientes do presente de outros grupos, ou trazer o uso de certos artefatos e aspectos da atividade humana, mas sim nos trazer ideias e possibilidades de ação humana em relação a mortos e vivos.

\subsubsection{Análise de fontes primárias e secundárias}

Fizemos a análise de fontes primárias (textos de cronistas, relatos etnográficos) e secundárias (leituras etnográficas). Com o objetivo de organizarmos as práticas funerárias de uma maneira que pudéssemos entender os gestos envolvidos em cada prática diferente e em cada etapa dessas práticas, separamos conjuntos de gestos funerários. Dentro dessa separação, colocamos os relatos que temos para cada grupo. 
A totalidade dos gestos, bem como a sua especificidade e todos os significados envolvidos, não podem ser recuperados, como é ressaltado várias vezes na bibliografia.

Os cronistas e os autores que realizaram as descrições etnográficas, as regiões visitadas por eles e as épocas em que fizeram a observação encontram-se na tabela abaixo. Para que possamos recuperar a historicidade das práticas, tentamos colocar os autores das descrições em perspectiva histórica, ressaltando sua época e o contexto em que se encontravam Mas muitos dos cronistas e etnógrafos circularam por diversos lugares, não especificando exatamente de onde era a descrição, o que tornou a detecção da espacialidade da distribuição dos gestos funerários difícil.

Quadro 2: Autores das fontes primárias sobre práticas funerárias, suas respectivas regiões visitadas e épocas de observação

\begin{tabular}{|l|l|l|}
\hline Autor & Regiões que visitou/viveu & Época \\
\hline Gabriel Soares de Souza & Bahia & Século XVI \\
\hline Fernão Cardim & $\begin{array}{l}\text { Pernambuco, Bahia, Espírito Santo, } \\
\text { Rio de Janeiro, São Paulo }\end{array}$ & Século XVI \\
\hline Jean de Léry & Rio de Janeiro (Bahia de Guanabara) & Século XVI \\
\hline André Thevet & Rio de Janeiro (Bahia de Guanabara) & Século XVI \\
\hline Manoel da Nóbrega & Bahia, Rio de Janeiro, São Paulo & Século XVI \\
\hline Yves d'Évreux & Maranhão & Século XVII \\
\hline Claude D'Abbeville & Maranhão & Século XVII \\
\hline Simão de Vasconcelos & Bahia & Século XVII \\
\hline Antonio Ruiz de Montoya & Paraguai, Paraná, Argentina, Uruguai & Século XVII \\
\hline Edmundo Krug & São Paulo (vale do Paranapanema $)^{4}$ & Início do século XX \\
\hline Wanda Hanke & $\begin{array}{l}\text { Região do Chaco, Paraguai, Uruguai, } \\
\text { Argentina, Brasil }\end{array}$ & Meados do século XX \\
\hline Egon Schaden & $\begin{array}{l}\text { Litoral paulista, sul do Mato Grosso } \\
\text { do Sul, região sul do Brasil }\end{array}$ & Meados do século XX \\
\hline León Cadogan & Argentina, Paraguai & Meados do século XX \\
\hline Jose Antonio Perasso & Paraguai oriental & $\begin{array}{l}\text { Segunda metade do } \\
\text { século XX }\end{array}$ \\
\hline
\end{tabular}

Os períodos históricos em que viveram são bem distintos. Isso influencia muito a acurácia das descrições das práticas funerárias, guiada pelos objetivos e interesses de cada autor.

\footnotetext{
${ }^{4}$ Ele fala de grupos de Cayuás (Guarani) que habitavam até além da margem esquerda do rio Tibagi e próximo à Serra do Diabo, no estado de São Paulo. Fala que vieram do Jataí, no estado do Paraná, e antes vieram do Paraguai, onde habitavam o vale do rio Paraná.
} 
Em um primeiro grupo, encontramos os cronistas dos séculos XVI e XVII (Soares de Souza, Cardim, Léry, Thevet, Yves d'Évreux, Claude D'Abbeville, Simão de Vasconcelos, Manoel da Nóbrega), todos abordados por Métraux e César em suas obras. Esses autores são colonos ou padres que vieram para o Brasil colonizar a terra ou cristianizar os indígenas, então suas descrições, grosso modo, tratam as práticas dos indígenas como pitorescas, estranhas e coisas do demônio. Soares de Souza e Léry eram colonos, Cardim, Nóbrega e Simão de Vasconcelos eram da Companhia de Jesus, Thevet, d'Évreux e D'Abbeville eram padres franceses de outras congregações. Seus relatos, que abrangem a costa brasileira do Maranhão até São Paulo, são interpretados por Métraux para compor sua compilação de diversas práticas dos grupos indígenas de línguas Tupi-Guarani. Este autor reúne os relatos de maneira que um complemente o outro, formando um quadro, como uma pintura das práticas mortuárias, na qual os contextos regionais e locais são pouco considerados, tornando-se imprecisos (Métraux, 1947, 1979, 2012 [1928]). Para tentar recuperá-los, fomos buscar as regiões visitadas por cada cronista, mas alguns visitaram regiões extensas, algumas muito extensas. Por isso, algumas das descrições podem ser provenientes de um grupo Tupi ou de vários, e certamente foram observadas em regiões diferentes e distantes entre si.

Os períodos em que esses cronistas viram e relataram as práticas certamente são bastante turbulentos por causa das consequências de colonização (guerras, epidemias, etc.). O grau de mudança pelo qual os grupos indígenas descritos estavam passando é muito difícil de medir, mas provavelmente era bastante alto no período desses cronistas, que foi meados e a segunda metade do século XVI e primeira metade do século XVII. Montoya presenciou a jornada de indígenas do Guairá que fugiam dos bandeirantes paulistas, ele mesmo dando-lhes armas para que se defendessem. Portanto, muito provavelmente as descrições dos cronistas foram feitas em épocas de mudanças nos grupos indígenas observados, mudanças estas que não temos como precisar aqui, mas que certamente envolviam alterações no modo de vida dos indígenas e na sua estrutura social.

Um segundo grupo que poderíamos formar é o dos viajantes e etnógrafos do século XX: Krug, Hanke, Cadogan, Schaden, Perasso e Métraux. Eles observaram diversos grupos Guarani com objetivos de fazer etnografias, embora nem todos fossem antropólogos de formação. Seu interesse era registrar aspectos dos grupos indígenas, alguns autores partindo do pressuposto de que estavam desaparecendo ou sendo aculturados pelos 
brancos - isso é bem claro em Schaden (1962) -, embora esses aspectos registrados também variem de acordo com os interesses de cada autor. Mas o caráter de sua descrição é diferente do dos cronistas, não somente pelo fato de os dois grupos estarem em contextos históricos totalmente diferentes, mas também, entre outras coisas, porque há uma certa preocupação com as particularidades regionais e dos diferentes grupos na maioria deles. Sendo Métraux um dos antropólogos da primeira metade do século XX, a leitura dos cronistas feita por ele possui um viés muito similar à leitura feita dos indígenas por esses autores, como se ele fizesse uma etnografia das fontes, embora não se preocupe em contextualizar os relatos. Esse método inclusive influenciou os outros.

Ao longo do século XX, muitas mudanças também ocorreram para os grupos Guarani de regiões meridionais como o sul do Brasil, sudeste, centro-oeste, Argentina e Paraguai. A ocupação de áreas que antes eram pouco habitadas, a expansão da agropecuária ao longo desse século, são fatores que influenciam de maneira decisiva os grupos indígenas, sendo que a situação de guerra (declarada ou não) e genocídio nunca foi interrompida. Talvez isso tenha gerado mudanças diacrônicas nas práticas funerárias ao longo do século XX também, pois com a necessidade de, muitas vezes, mudar de lugar (causada por questões políticas, não somente por fatores culturais dos Guarani), os grupos não podiam permanecer no mesmo lugar que morria uma pessoa mesmo que quisessem, $\mathrm{e}$ também não podiam realizar integralmente os seus rituais com relação aos mortos.

Evidentemente esta é uma análise rápida e grosseira, e claro que cada cronista deve ser analisado individualmente e com mais cuidado, bem como os etnógrafos. Mas nosso objetivo aqui não é fazer uma análise historiográfica detalhada dos cronistas dos séculos XVI e XVII e dos etnógrafos da primeira metade do século XX.

As descrições sobre os Tupinambá selecionadas por Métraux só remetem até o século XVII, enquanto as etnografias sobre os Guarani remetem principalmente a diferentes momentos do século XX, sendo apenas a descrição de Montoya do século XVII. Mas não encontramos, por exemplo, descrições de práticas funerárias dos Carijó do litoral sul. Essa característica das fontes analisadas por nós faz com que as práticas cotejadas para os Guarani sejam em sua maioria muito mais recentes do que aquelas cotejadas para os Tupinambá. Montoya é o principal elo que liga as práticas dos dois grupos linguísticos, na medida em que relata sobre os Guarani mais antigos e suas práticas funerárias similares às dos Tupinambá. 
Descrições para o final do século XVII, séculos XVIII e XIX não foram encontradas por nós. Desse modo, há um hiato temporal de mais de dois séculos entre os Tupinambá e os Guarani de Montoya e os diversos grupos Guarani observados pelos etnólogos. Nesse período de 5 séculos, evidentemente houve mudanças radicais nas sociedades e modos de vida de Guaranis e Tupinambás, que se refletiram nas práticas funerárias. O exemplo mais óbvio é o abandono da prática do sepultamento em urnas de cerâmica pelos Guarani. Entre estes, houve aqueles que entraram no sistema colonial e tiveram que abandonar diversas práticas tradicionais, por exemplo, deixando de beber cauim, o que pode ter contribuído para o abandono da confecção de vasilhas cerâmicas e da prática do sepultamento em vasilhas. Houve também aqueles que não entraram no sistema colonial, mas que também deixaram de construir vasilhas por diversos motivos.

Tentamos rastrear e considerar essas mudanças diacrônicas nas práticas funerárias, mesmo com a fragmentação e imprecisão das informações etnográficas. A tabela abaixo traz os gestos funerários de cada grupo da maneira como foram descritos por Métraux, com base nos cronistas, e pelos etnógrafos do século XX.

Quadro 3: Resumo das práticas funerárias e pós-funerárias

\begin{tabular}{|c|c|c|c|c|}
\hline $\begin{array}{l}\text { Grupo/ } \\
\text { População }\end{array}$ & $\begin{array}{l}\text { Localização } \\
\text { da } \\
\text { descrição }\end{array}$ & $\begin{array}{l}\text { Época da } \\
\text { descrição }\end{array}$ & Práticas funerárias descritas & Fontes \\
\hline $\begin{array}{l}\text { Tupinambá } \\
\text { genéricos }\end{array}$ & $\begin{array}{l}\text { Litoral do } \\
\text { Maranhão } \\
\text { até São } \\
\text { Paulo }\end{array}$ & $\begin{array}{l}\text { Séculos } \\
\text { XVI e } \\
\text { XVII }\end{array}$ & $\begin{array}{l}\text { - Pintura do corpo, ato de passar mel no } \\
\text { corpo, cobertura com penas, amarração } \\
\text { dos membros junto ao corpo, corpo } \\
\text { enrolado em redes } \\
\text { - Cova redonda e profunda, escavada pelo } \\
\text { parente masculino mais próximo do } \\
\text { morto, que era também que carregava o } \\
\text { corpo } \\
\text { - Sepultamento em redes suspensas, } \\
\text { dentro de "câmaras funerárias", nas quais } \\
\text { as paredes da cova são cobertas por } \\
\text { madeiras, assim como o corpo do morto } \\
\text { - Colocação de alguns pertences do morto } \\
\text { na sepultura } \\
\text { - Colocação de vasilhas com água e }\end{array}$ & $\begin{array}{l}\text { Métraux } \\
(1947, \\
1979,2012 \\
[1928])\end{array}$ \\
\hline
\end{tabular}




\begin{tabular}{|c|c|c|c|c|}
\hline & & & $\begin{array}{l}\text { comida na sepultura } \\
\text { - Presença de uma fogueira na sepultura } \\
\text { - Sepultamento de adultos e crianças em } \\
\text { vasilhas cerâmicas, enrolados em redes } \\
\text { - Exocanibalismo } \\
\text { - Sepultamento tanto dentro da habitação } \\
\text { quanto fora; quando fora erguia-se uma } \\
\text { pequena cabana sobre o sepultamento }\end{array}$ & \\
\hline $\begin{array}{l}\text { Tupinambá } \\
\text { genéricos }\end{array}$ & $\begin{array}{l}\text { Estado de } \\
\text { São Paulo }\end{array}$ & $\begin{array}{l}\text { Séculos } \\
\text { XVI e } \\
\text { XVII }\end{array}$ & $\begin{array}{l}\text { - Sepultamento secundário de partes do } \\
\text { corpo e/ou cabeças }\end{array}$ & $\begin{array}{l}\text { Monteiro } \\
\text { da Silva } \\
\text { (2008) }\end{array}$ \\
\hline $\begin{array}{l}\text { Guarani } \\
\text { genéricos }\end{array}$ & $\begin{array}{l}\text { Região do } \\
\text { Guairá }\end{array}$ & $\begin{array}{l}\text { Séculos } \\
\text { XVI e } \\
\text { XVII }\end{array}$ & $\begin{array}{l}\text { - Sepultamento em vasilhas cerâmicas, } \\
\text { fechadas com uma ampla tampa que as } \\
\text { cobre parcialmente } \\
\text { - Construção de uma pequena cabana } \\
\text { sobre o sepultamento, e limpeza dos } \\
\text { matos e ervas daninhas que crescem sobre } \\
\text { o mesmo } \\
\text { - Índios cristianizados sepultavam } \\
\text { diretamente na terra } \\
\text { - Exocanibalismo } \\
\text { - Conservavam os ossos do xamã ou } \\
\text { cacique morto dentro de uma cabana, em } \\
\text { uma maca coberta com mantos, } \\
\text { enfeitados com penas, e em volta eram } \\
\text { colocados cestos com oferendas de } \\
\text { colheitas }\end{array}$ & $\begin{array}{l}\text { Métraux } \\
(2012 \\
[1928]) \\
\text { Montoya } \\
(1639) \\
\text { Piedade \& } \\
\text { Soares } \\
(2000)\end{array}$ \\
\hline Guarayú & Bolívia & - & $\begin{array}{l}\text { - Colagem de penas no corpo do morto } \\
\text { - Sepultamento em vasilhas cerâmicas } \\
\text { - Sepultamento em redes suspensas dentro } \\
\text { de "câmaras funerárias", com madeiras } \\
\text { nas paredes da cova e sobre o morto }\end{array}$ & $\begin{array}{l}\text { Métraux } \\
(1947)\end{array}$ \\
\hline Cayuá & $\begin{array}{l}\text { Vale do } \\
\text { Paranapane } \\
\text { ma }\end{array}$ & $\begin{array}{l}\text { Início do } \\
\text { século XX }\end{array}$ & $\begin{array}{l}\text { - Sepultamento em redes suspensas dentro } \\
\text { de covas profundas, em "câmaras } \\
\text { funerárias" } \\
\text { - Pertences do morto sobre a sepultura } \\
\text { - Colocação de vasilhas com alimentos e } \\
\text { cauim, este renovado diariamente até que } \\
\text { cresçam ervas sobre a sepultura }\end{array}$ & Krug (1924) \\
\hline
\end{tabular}




\begin{tabular}{|c|c|c|c|c|}
\hline Mbyá & $\begin{array}{l}\text { Região do } \\
\text { Chaco }\end{array}$ & $\begin{array}{l}\text { Meados } \\
\text { do século } \\
\text { XX }\end{array}$ & $\begin{array}{l}\text { - Abertura de cova, fumando-se no } \\
\text { processo para afugentar maus espíritos, } \\
\text { depois varria-se a cova } \\
\text { - Todos os pertences do morto eram } \\
\text { colocados dentro da cova } \\
\text { - Colocação de um copo de água, mate ou } \\
\text { leite na cova } \\
\text { - Sepultamento dentro da residência } \\
\text { seguido de abandono da aldeia }\end{array}$ & $\begin{array}{l}\text { Hanke } \\
(\mathrm{S} / \mathrm{D}), \\
\text { Cadogan } \\
(1968)\end{array}$ \\
\hline Mbyá & $\begin{array}{l}\text { Várias } \\
\text { regiões }\end{array}$ & $\begin{array}{l}\text { Meados } \\
\text { do século } \\
\text { XX }\end{array}$ & $\begin{array}{l}\text { - Sepultamento fora da residência, } \\
\text { sepulturas distantes umas das outras, } \\
\text { sobre elas "pequeno monte de terra, uma } \\
\text { choça de guaricanga e uma cruz de } \\
\text { madeira fincada aos pés do defunto" } \\
\text { - Cerimônias funerárias acontecem por } \\
\text { vários dias junto à sepultura } \\
\text { - Acendiam sobre a sepultura uma } \\
\text { pequena fogueira, principalmente na noite } \\
\text { do enterro, logo após o sepultamento } \\
\text { - Pertences do morto na sepultura } \\
\text { - Os mortos eram enterrados deitados } \\
\text { (estendidos) com os pés voltados para o } \\
\text { sol nascente. }\end{array}$ & $\begin{array}{l}\text { Schaden } \\
\text { (1962) }\end{array}$ \\
\hline Mbyá & $\begin{array}{l}\text { Região do } \\
\text { Guairá }\end{array}$ & $\begin{array}{l}\text { Início a } \\
\text { meados } \\
\text { do século } \\
\mathrm{XX}\end{array}$ & $\begin{array}{l}\text { - Colocação de crianças pequenas em } \\
\text { caixas de madeira de cedro, que eram } \\
\text { mantidas nas casas de reza }\end{array}$ & $\begin{array}{l}\text { Cadogan } \\
(1968)\end{array}$ \\
\hline Cainguá & - & - & $\begin{array}{l}\text { - Colocavam uma vasilha de boca para } \\
\text { baixo sobre a cabeça do morto } \\
\text { - Antes os sepultamentos eram realizados } \\
\text { dentro da habitação, depois passaram a } \\
\text { ser realizados a certa distância da aldeia, e } \\
\text { erguia-se uma pequena cabana sobre eles }\end{array}$ & $\begin{array}{l}\text { Métraux } \\
(1947,2012 \\
[1928])\end{array}$ \\
\hline Ñandéva & $\begin{array}{l}\text { Litoral } \\
\text { Paulista }\end{array}$ & $\begin{array}{l}\text { Meados } \\
\text { do século } \\
\text { XX }\end{array}$ & $\begin{array}{l}\text { - Levam seus mortos para os cemitérios } \\
\text { públicos de Peruíbe e Itanhaém, e } \\
\text { enterram o morto em um caixão de } \\
\text { madeira revestido de panos e com um } \\
\text { adorno religioso, e sobre a sepultura } \\
\text { fincam uma cruz } \\
\text { - Acendiam sobre a sepultura uma } \\
\text { pequena fogueira, principalmente na noite }\end{array}$ & $\begin{array}{l}\text { Schaden } \\
\text { (1962) }\end{array}$ \\
\hline
\end{tabular}




\begin{tabular}{|c|c|c|c|c|}
\hline & & & $\begin{array}{l}\text { do enterro, logo após o sepultamento } \\
\text { - Pertences do morto na sepultura } \\
\text { - Os mortos eram enterrados deitados } \\
\text { (estendidos) com os pés voltados para o } \\
\text { sol nascente. }\end{array}$ & \\
\hline Chiripá & Paraguai & $\begin{array}{l}\text { Meados } \\
\text { do século } \\
\text { XX }\end{array}$ & $\begin{array}{l}\text { - Sepultamento sob pequenas cabanas } \\
\text { - Colocação de uma cruz de madeira, uma } \\
\text { cabaça com água ou mel, raízes e os } \\
\text { pertences do morto. O autor relata que em } \\
\text { períodos anteriores o morto era sepultado } \\
\text { dentro da própria casa e depois esta era } \\
\text { abandonada. }\end{array}$ & $\begin{array}{l}\text { Perasso } \\
(1986)\end{array}$ \\
\hline Kayová & - & $\begin{array}{l}\text { Meados } \\
\text { do século } \\
\text { XX }\end{array}$ & $\begin{array}{l}\text { - Sepulturas bem próximas umas das } \\
\text { outras } \\
\text { - Enterro em redes, tendo a cova } \\
\text { profundidade de "sete palmos" } \\
\text { - Era costume deixar sobre a sepultura a } \\
\text { vara utilizada para carregar a rede com o } \\
\text { morto } \\
\text { - Acendiam sobre a sepultura uma } \\
\text { pequena fogueira, principalmente na noite } \\
\text { do enterro, logo após o sepultamento } \\
\text { - Pertences do morto na sepultura } \\
\text { - Os mortos eram enterrados deitados } \\
\text { (estendidos) com os pés voltados para o } \\
\text { sol nascente. }\end{array}$ & $\begin{array}{l}\text { Schaden } \\
\text { (1962) }\end{array}$ \\
\hline Guayakí & $\begin{array}{l}\text { Rios } \\
\text { Paraguai e } \\
\text { Paraná }\end{array}$ & Século XX & $\begin{array}{l}\text { - Sepultamento em posição sentada, sobre } \\
\text { esteiras de palmeira pindó os braços são } \\
\text { amarrados contra o peito, os pés são } \\
\text { presos juntos com uma corda, e as costas } \\
\text { são encostadas em estacas, o rosto virado } \\
\text { para oeste; fazem uma cobertura sobre o } \\
\text { corpo } \\
\text { - Os pertences do morto são destruídos } \\
\text { - Abandono do acampamento após essas } \\
\text { ações } \\
\text { - Fogueira deixada acesa na sepultura por } \\
\text { vários dias após o enterro } \\
\text { - Sobre a sepultura era erguida uma } \\
\text { pequena cabana }\end{array}$ & $\begin{array}{l}\text { Monteiro } \\
\text { da Silva } \\
(2008) \\
\text { Susnik } \\
(1983)\end{array}$ \\
\hline
\end{tabular}




\begin{tabular}{|c|c|c|c|c|}
\hline & & & $\begin{array}{l}\text { - Pessoas que sofriam morte violenta eram } \\
\text { cremadas } \\
\text { - Abandonavam, ou queimavam os } \\
\text { anciãos, mas não gostavam da morte dos } \\
\text { mais jovens } \\
\text { - Inumação seguida de cremação dos } \\
\text { ossos } \\
\text { - Consumação do corpo do morto }\end{array}$ & \\
\hline $\begin{array}{l}\text { Guarani } \\
\text { genéricos }\end{array}$ & $\begin{array}{l}\text { Rio Grande } \\
\text { do Sul }\end{array}$ & & $\begin{array}{l}\text { - Sepultamento do corpo ou dos ossos } \\
\text { descarnados em vasilhas cerâmicas com } \\
\text { tampas } \\
\text { - Pequenas vasilhas com alimentos } \\
\text { acompanhavam o morto } \\
\text { - Sepultamento em área próxima à aldeia }\end{array}$ & $\begin{array}{l}\text { Monteiro } \\
\text { da Silva } \\
(2008)\end{array}$ \\
\hline $\begin{array}{l}\text { Guarani } \\
\text { genéricos }\end{array}$ & São Paulo & - & $\begin{array}{l}\text { - deposição direta do corpo dos mortos em } \\
\text { urna funerária, sentados } \\
\text { - Sepultamento secundário de partes do } \\
\text { corpo e/ou cabeças }\end{array}$ & $\begin{array}{l}\text { Monteiro } \\
\text { da Silva } \\
(2008)\end{array}$ \\
\hline $\begin{array}{l}\text { Guarani } \\
\text { genéricos }\end{array}$ & $\begin{array}{l}\text { Região do } \\
\text { Guairá }\end{array}$ & $\begin{array}{l}\text { Início a } \\
\text { meados } \\
\text { do século } \\
\text { XX }\end{array}$ & $\begin{array}{l}\text { - Trituração de ossos e dispersão na terra } \\
\text { para garantir colheitas }\end{array}$ & $\begin{array}{l}\text { Cadogan } \\
(1968)\end{array}$ \\
\hline Chiriguano & Bolívia & - & $\begin{array}{l}\text { - Sepultamento em vasilhas cerâmicas, } \\
\text { fechadas com uma ampla tampa que as } \\
\text { cobre parcialmente } \\
\text { - Vasilhas para chicha usadas para } \\
\text { sepultamento } \\
\text { - Sepultamento de pessoas de "prestígio" } \\
\text { em vasilhas cerâmicas permaneceu ate fins } \\
\text { do século XVIII }\end{array}$ & $\begin{array}{l}\text { Métraux } \\
(2012 \\
[1928]) \\
\text { Susnik } \\
(1983)\end{array}$ \\
\hline Guajajára & Maranhão & - & $\begin{array}{l}\text { - fecham os mortos em um cesto, } \\
\text { colocando sobre a sua cabeça um cestinho }\end{array}$ & $\begin{array}{l}\text { Métraux } \\
(2012 \\
[1928])\end{array}$ \\
\hline
\end{tabular}


Quadro 4: Gestos funerários e grupos descritos

\begin{abstract}
Gestos funerários
Gestos de Preparação do Corpo

Os Tupinambá primeiramente untam o corpo todo do morto com mel, e por cima do mel empenam com penas de pássaros de cores. Colocam nele também uma carapuça de penas na cabeça e outros enfeites usuais "nas festas". Segundo Soares de Souza (Bahia), Cardim (Pernambuco, Bahia, Espírito Santo, Rio de Janeiro, São Paulo), Léry (Rio de Janeiro), Thevet (Rio de Janeiro), Yves d'Évreux (Maranhão) e Claude D'Abbeville (Maranhão), os membros eram amarrados com fibras de algodão, que às vezes eram tantas que o corpo ficava totalmente coberto. Era acomodado na cova em posição de cócoras. Segundo Soares de Souza (Bahia), eles também eram enrolados em suas redes (Métraux, 1947, 1979, 2012 [1928]).
\end{abstract}

Segundo Métraux (1947), os Guarayú (grupo Guarani da Bolívia, segundo o mapa de Nimuendajú) colavam penas no cadáver.

\section{Gestos de Escavação da Cova}

Entre os Tupinambá, a cova é escavada pelo parente masculino mais próximo, que também carrega o corpo (Métraux,1947). A cova era redonda e profunda, parecida com um grande tonel de vinho (Métraux, 2012 [1928]).

\section{Gestos de sepultamento Primário Fora de Urna}

Métraux (1947) chama de sepultamento em "câmara funerária" o seguinte tipo de sepultamento: os Tupinambá fazem na casa em que vivia o morto uma cova funda e grande, com uma estacada nas paredes para que a terra não caia sobre o morto, e amarram a sua rede debaixo para que o corpo não toque o chão. Colocam-no enfeitado assim na rede, colocando junto da rede seu arco e flechas, sua espada e seu maracá. Fazem-lhe fogo próximo à rede para o morto se esquentar. Dão comida em um alguidar e água em um cabaço, e colocam seu instrumento de fumo na sua mão. Cobrem o conjunto com madeira, de maneira que esta não toque o corpo. Enterram. $\mathrm{E}$, na casa, a mulher e a família continuam vivendo como antes (Soares de Souza [Bahia)] [apud Métraux, 1979]). Ele afirma que entre os Tupinambá, que geralmente praticam o sepultamento direto em urna, às vezes há o sepultamento em covas cujas paredes são recobertas com gravetos. Sobre a cabeça do morto colocavam um pote ou uma cabaça, segundo Cardim (Pernambuco, Bahia, Espírito Santo, Rio de Janeiro, São Paulo) e Thevet (Rio de Janeiro) (Métraux, 2012 [1928]).

Entre os Guarayú (Guarani), sepultamento similar e fazia-se uma espécie de plataforma sobre sua cabeça para que a terra não caísse sobre ele.

Krug (1924) (São Paulo) relata também um sepultamento semelhante entre os Cayuá do vale do Paranapanema. Sobre o morto, a certa distância, é feito um verdadeiro estrado com paus roliços, sobre o qual vão atirando terra até encher a cova. Sobre a sepultura eram colocados os adornos e armas do morto e algumas vasilhas com alimentos e cauim. Este último é renovado diariamente, até que cresçam ervas sobre o chão.

Hanke (S/D) (Região do Chaco, Paraguai, Uruguai, Argentina, Brasil), fez descrições para os Mbyá. Escreve que eles cavavam uma cova para os mortos, e
Grupos descritos

Tupinambá

genéricos,

Guarayú

(Guarani)

Tupinambá

genéricos

Tupinambá

genéricos,

Guarayu

(Guarani),

Cayuá (Guarani),

Mbyá (Guarani),

Ñandéva

(Guarani),

Kayová (Guarani),

Guayakí (Guarani) 
enquanto isso fumavam muito, para afugentar os maus espíritos. Ao ser aberta ela deveria ser varrida, e todos os objetos que pertenciam ao morto deveriam ser colocados dentro dela, além de um copo de água ou mate. Se era um bebê morto, deveria ser colocado um copo com leite da mãe.

Cadogan (1968) (Argentina, Paraguai, Brasil), ao conviver com os Guarani em meados do século XX, faz uma diferenciação entre algumas práticas mortuárias dos diferentes subgrupos Guarani. Escreve que os Mbyá tem muito medo do mboguá dos mortos, e por isso após sepultar alguém dentro de sua própria casa abandonam a aldeia (o que também é relatado por Hanke [S/D]). Segundo sua interpretação, era por isso que as casas dos Mbyá são mais simples (segundo ele) e menores que as dos Kaiová, porque as residências são abandonadas após o sepultamento.

Schaden (1962) (Litoral paulista, sul do Mato Grosso do Sul, região sul do Brasil) fala de sepulturas dos Mbyá fora de residência, relata que as sepulturas são distantes umas das outras, havendo sobre elas "pequeno monte de terra, uma choça de guaricanga e uma cruz de madeira fincada aos pés do defunto". O enterro é feito no dia imediato ao falecimento, no qual o ñanderú planta a cruz e dirige as cerimônias, que se repetem por vários dias junto à sepultura. As mesmas cerimônias são feitas na morte de crianças.

Já os Ñandéva do litoral paulista, segundo o autor, levam seus mortos para os cemitérios públicos de Peruíbe e Itanhaém, e enterram o morto em um caixão de madeira revestido de panos e com um adorno religioso, e sobre a sepultura fincam uma cruz. Schaden considera que o distanciamento do sepultamento em relação à aldeia denota o medo do anguêry (a alma que não vai para o paraíso).

As sepulturas dos Kayová observados pelo autor ficavam bem próximas umas das outras. O enterro se faz em redes, tendo a cova profundidade de "sete palmos". Era costume deixar sobre a sepultura a vara utilizada para carregar a rede com o morto.

Segundo Schaden, Mbyá, Ñandéva e Kayowá acendiam sobre a sepultura uma pequena fogueira, principalmente na noite do enterro, que é acendida logo após o sepultamento. Colocavam, também todos os objetos do morto na sepultura, ou enterrados junto, ou por cima dela, onde ficavam por tempo ilimitado. Entre os Mbyá, os bens materiais do morto continuam sendo propriedade do seu mboguá, e este viria buscar a quem deles se apropriasse.

Os mortos eram enterrados deitados (estendidos ou fletidos) com os pés voltados para o sol nascente.

Já entre os Guayakí dos rios Paraguai e Paraná, havia o sepultamento em posição sentada, os braços são amarrados contra o peito, os pés são presos juntos com uma corda, e as costas são encostadas em estacas. Um fogo é deixado aceso na sepultura por vários dias após o enterro, até que algum filho ou irmão menor o pisoteie. Sobre a sepultura era erguida uma pequena cabana (Monteiro da Silva, 2008).

\section{Gestos de Sepultamento Primário em Urna}

Métraux (2012) afirma que os sepultamentos fora de urna e em urna não excluíam um ao outro, ou seja, havia a presença dos dois.

Thevet (Rio de Janeiro), Cardim (Pernambuco, Bahia, Espírito Santo, Rio de Janeiro, São Paulo) e Vasconcelos (Bahia) relataram que os corpos dos Tupinambá

\section{Tupinambá} genéricos

Guarani genéricos, Cainguá (Guarani), 
eram acomodados em grandes vasilhas de barro, que em seguida eram enterradas. Já Soares de Souza (Bahia) afirmou que somente as crianças eram colocadas em uma vasilha, os adultos eram "enterrados sozinhos no solo" (Métraux, 2012 [1928]). Métraux afirma que os dois modos de sepultamento eram feitos. Não é possível entender ao certo se Soares de Souza dizia que os adultos eram sepultados na "câmara funerária". Talvez na região em que ele colheu as práticas os adultos fossem sepultados apenas fora de urna. Talvez houvesse uma variabilidade, alguns grupos Tupinambá sepultassem só crianças em urnas, outros sepultassem também adultos em urnas. Ou talvez o cronista tenha presenciado/ouvido falar em apenas sepultamento de criança em urna e de adulto fora.

O sepultamento "imediato" em urnas era praticado igualmente pelos Guarani, Chiriguano e Cocama (grupo amazônico). As urnas são geralmente fechadas com uma ampla tampa que as cobre parcialmente. Montoya observa que elas não eram enterradas completamente, mas só até o gargalo. Ambrosetti (1895) afirmava que nas proximidades das sepulturas eram frequentemente encontrados vasos fechados com outros dentro, geralmente decorados, talvez antes destinados a receber alimentos para o morto. Entre os Chiriguano, as vasilhas para chicha serviam para sepultar os mortos (Métraux, 2012 [1928]).

Thevet (Rio de Janeiro) (apud Métraux, 1979) assim descreve as práticas funerárias dos Tupinambá: quando morre o marido, ou esposa, pais, mães, tios ou irmãos (diversos tipos sociais passam por esse tratamento funerário) os parentes curvam-no dentro da própria rede em que falece, dando-lhe a forma de um bloco "à semelhança da criança no ventre materno". Ele é envolvido e amarrado com cordas de algodão, e colocado em um grande vaso de barro, coberto com "a gamela onde o defunto costumava lavar-se".

Cardim (apud Métraux, 1979) observa que entre os Tupinambá havia o receio de que o morto ressuscite se não está bem amarrado. Já Yves d'Évreux (Maranhão) observa que os ligamentos não devem estar muito apertados, para que o morto não se sinta preso dentro da tumba.

A urna, entre os Tupinambá, é colocada dentro de uma cova redonda como um poço, mais ou menos da altura de um homem, "pondo-lhe junto fogo e farinha" para evitar a aproximação dos espíritos malignos e para que não falte comida se a alma tiver fome. Em seguida, cobrem com terra tirada do fosso. Além disso, junto ao morto enterravam-se suas armas e utensílios, assim como todos os objetos que lhe pertenceram em vida. Objetos emprestados do morto aos outros também eram enterrados com ele, para que sua alma não viesse molestar as pessoas por causa dos objetos. Já os objetos recebidos pelo morto de outras pessoas voltam para elas. Entre os Tupinambá, os pertences do morto (ou ao menos de alguns mortos) eram depois dados ao cativo a ser sacrificado que havia limpado sua sepultura, sendo que este retirava a sua corrupção, permitindo que outras pessoas pudessem usá-los depois 5 (Métraux, 1979).

Montoya (1639) (Paraguai, Paraná, Argentina, Uruguai) relata para os Guarani que

50 prisioneiro capturado, logo ao entrar na aldeia, era levado para limpar a sepultura de um antepassado do seu captor, renovando-a. Depois disso, era levado para a cabana na qual morara esse morto, e eram-lhe trazidos o arco, flechas, colares, penas, redes, frutos e outras coisas que haviam pertencido à pessoa agora morta. 0 prisioneiro podia utilizar esses objetos à vontade. Ele deveria limpar o arco e flechas, por isso ninguém podia usar algum objeto da pessoa falecida sem antes o prisioneiro ter usado, pois ele os "limpava de qualquer corrupção" (Métraux, 1979). 
diante da morte do marido, as mulheres dão fortes gritos e choros. Sugere que eles não consideram a morte como algo natural, e sim como um acaso. Eles creem que a alma (seria a alma que permanece na Terra) permanecia junto com o corpo em sua sepultura, por isso sepultavam seus mortos em grandes vasilhas, colocando outra vasilha na boca, para que naquela concavidade estivesse mais acomodada a alma. Os índios cristianizados enterravam seus mortos na terra, mas ele relata ter visto a cena de uma velha que, disfarçadamente, movia uma pequena peneira pela sepultura, como se estivesse pegando algo ("....] acudia al dissimulo uma vieja com un cedazo muy curioso, y pequeño, y muy al dissimulo traía el cedazo por la sepultura, como que sacava algo [...]'). Os índios diziam que na peneira retiravam a alma do morto, para que não ficasse enterrada com seu corpo.

Os Cainguá colocavam uma vasilha de cabeça para baixo sobre a cabeça do morto. Os Guajajára (grupo amazônico, do Maranhão) fecham os mortos em um cesto, colocando sobre a sua cabeça um cestinho (Métraux, 2012 [1928]).

\section{Exocanibalismo}

Guarani genéricos,

Montoya (1639) (Paraguai, Paraná, Argentina, Uruguai) relata que os Guarani engordam e matam os inimigos presos, com muita solenidade, na qual todos tocam no cativo e este é morto com uma pancada. O corpo é repartido, e cada pedaço é cozido em muita água, sendo feito com eles uma sopa. Todos comem um pouco dessa sopa, inclusive as mulheres dão a seus filhos bebês, e com esse gesto lhes põem um nome.

Os Tupinambá também praticavam o ritual antropofágico e o exocanibalismo, como já é bem conhecido (Métraux, 1979).

\section{Sepultamento secundário de partes do corpo e/ou cabeças}

Segundo Monteiro da Silva (2008), se um guerreiro morre longe de sua aldeia, o enterram provisoriamente, e depois transportam os ossos ou apenas o crânio para sua cabana, onde ele era enterrado definitivamente.

\section{Gestos de cremação/ inumação seguida de cremação}

Tupinambá

ganéricos

Guarani genéricos,

Tupinambá

genéricos

(ambos do estado de São Paulo)

Entre os Guayakí dos rios Paraguai e Paraná, aqueles que sofriam uma morte violenta eram cremados (Monteiro da Silva, 2008).

De acordo com Susnik (1983), os Guayakí (Aché) do Paraguai entravam em um verdadeiro estado de angústia pela presença dos mortos, ou melhor, do ianwé, a alma terrena dos mortos, que não quer se separar dos vivos e causa doenças e morte. Abandonam ou queimam os anciãos, mas a morte de uma pessoa jovem não é aceita facilmente. Para acabar com a angústia, precisam romper os vínculos entre a alma do morto e os vivos. Desconheciam intervenções xamânicas.

Dois grupos Guayakí culturalmente iguais, no entanto, possuem práticas funerárias muito diferentes. Um deles realiza uma inumação seguida de cremação dos ossos. Quando alguém do grupo morre, o corpo é colocado em posição fetal e fortemente amarrado. Em uma cova pouco profunda e ovalada se coloca o corpo em posição sentada, com o rosto virado para o oeste, sobre duas esteiras trançadas de folhas de palmeira pindó. Algumas estacas são fincadas dentro da cova. Sobre a cova colocam 
uma pequena cobertura, que impede o morto de sair daquele lugar. $\mathrm{O}$ acampamento é abandonado logo em seguida, para que o ianwé do morto não encontre os vivos. Os pertences do morto são destruídos, também para que o ianwé não os busque. A segunda etapa do funeral é ainda mais importante. Após algumas semanas, quando já houve a putrefação do cadáver, voltam ao local da inumação, retiram os ossos da cova, sem tocá-los. Um homem parente do morto remove o crânio e o despedaça com golpes de arco, queimando-o em seguida. Desse modo, o ianwé é definitivamente expulso e abolido. (Susnik, 1983).

Gestos de consumação do corpo do morto

De acordo com Susnik (1983), outro grupo Guayakí do Paraguai, com os mesmos aspectos culturais, tem práticas funerárias bastante distintas. A cabeça do morto é retirada, os braços e as pernas são removidos do tronco e as vísceras são extraídas. Todos os homens e mulheres do grupo, e pessoas de outros grupos vizinhos, comem da carne ou levam um pedaço assado, exceto os parentes mais próximos do morto (mãe, irmãos, filhos). O crânio se destrói no processo, e juntamente com outros ossos se queima. Essas práticas são uma luta contra os ianwé, e um meio para acabar com a angústia.

A autora ressalta que $\mathrm{H}$. Clastres não atribui a essa prática um caráter de endocanibalismo, pois não há o consumo dos ossos pulverizados, e a associa com a antropofagia Guarani. Porém, não deixa de ser uma prática de consumo do corpo de um dos mortos do grupo.

\section{Gestos funerários após o sepultamento}

De acordo com Métraux (1947), entre os Tupari, uma fogueira era deixada próxima à sepultura do morto por muitos dias ou semanas.

Alimentos e bebidas eram regularmente depositados na tumba do morto até que o corpo estivesse totalmente "corrompido". Os Tupinambá explicavam esse costume dizendo que "se Anhan não encontrasse outras carnes perto da sepultura, desenterraria o morto para o fim de devorá-lo". Yves d'Évreux relatou sobre uma índia cristianizada que, certo dia, espalhava milho na sepultura do marido, para que o morto o tomasse e fosse embora (Métraux, 1979).

"Quando muere alguno dellos entierralo assentado y pónence de comer com uma rede em que ellos duermen, y dizen que sus ánimas andam por los montes y que vienen allí comer [...] esto porque creen, según, dizen, que después que muren tornam a comer y descansar sobre su sepultura. Hechanlos em cuevas redondas, y si son principales hâzenles uma choça de palma[...]" (Serafim Leite, a respeito dos tupi do litoral, apud Piedade \& Soares, 2000)

"[...] enterran sus difuntos em el campo o hacenda, sobre la sepultura unas choçuelas y de quando em quando van a limpiar la yerba que nace em ella porque así dicen que descansa el difunto [...] (Cortesão, a respeito dos Guarani do Guairá, apud Piedade \& Soares, 2000) 
Quadro 5: Gestos pós-funerários

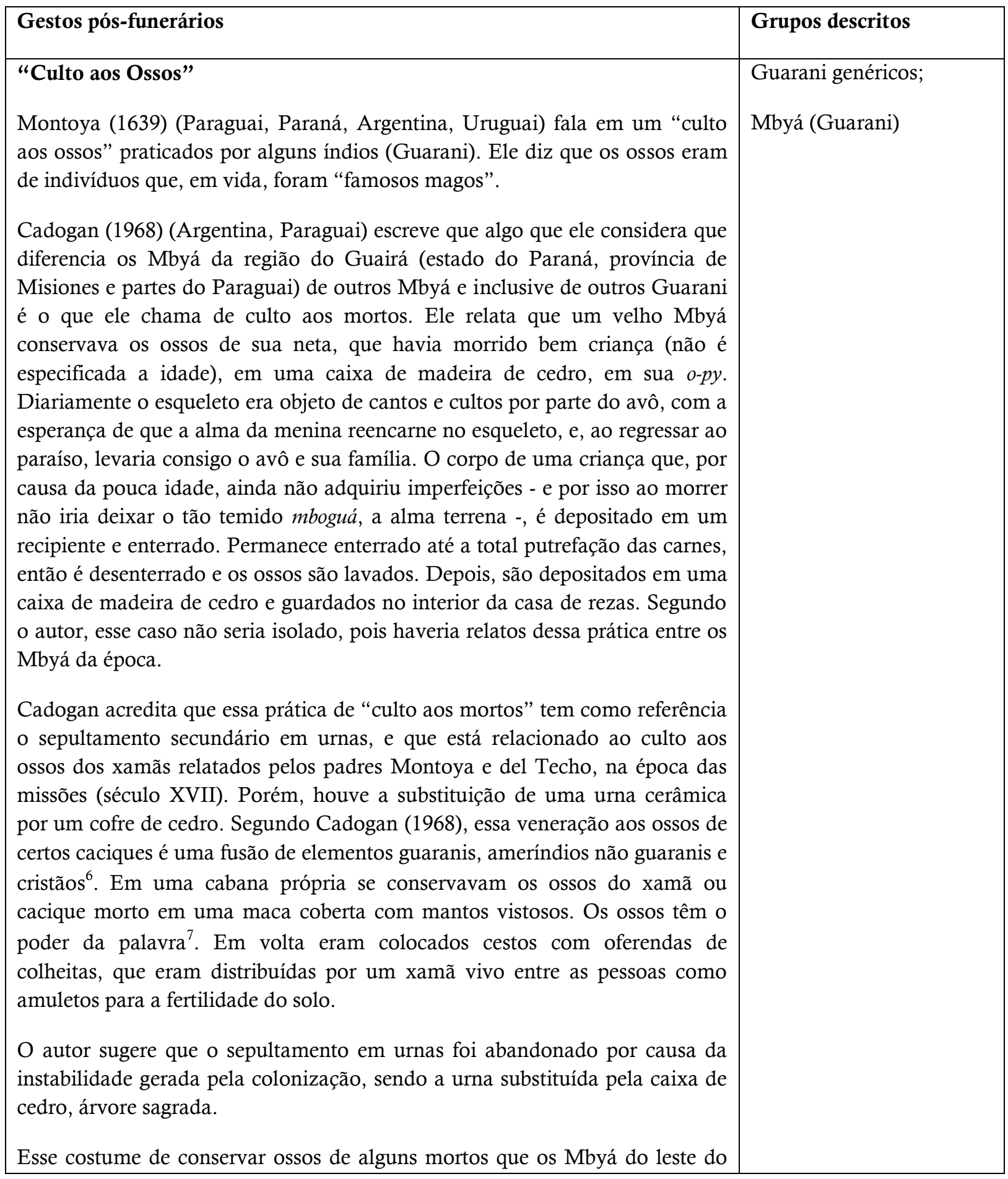

\footnotetext{
${ }^{6}$ Esse assunto com certeza mereceria mais atenção, e certamente está em aberto, mas não o discutiremos aqui, pois não pretendemos discutir as concepções dos Guarani em relação à morte.

7 Segundo Perasso (1986), "La concepción de hueso-palabra refiere explicitamente al "Ñe'eng" de los shamanes falecidos, a través de los cuales se interpretaba una reafirmación de los elementos shamánicos parlentes y obrantes; evidentemente la presencia de aspectos religioso-cristianos, no se hallaba disociada a este culto, puesto que ella significaba de hecho el motivo de "reacción", así la adoración de los huesos de tres hechiceros em lugar de la "Santíssima Trinidad" y los "huesos que se volvieron a cobrir de carne" en asociación con el "Verbo Encarnado", sustituciones de conceptualización de reencarnación de almas [...]”
} 
Paraguai da época possuíam não acontecia entre os Ñandéva (Chiripá), para os quais a alma terrena estava estreitamente ligada com os ossos do indivíduo (Cadogan, 1968). Perasso (1986) confirma que os Chiripá do Paraguai oriental não praticam o culto aos ossos.

\section{Trituração de ossos}

Guarani

Perasso (1986) (Paraguai oriental) traz outros tipos de ações em relação aos ossos dos mortos praticados na região do Guairá: eram triturados e jogados na terra junto com as sementes para assegurar o crescimento de colheitas. Mas ele não especifica quais mortos são esses, e nem dá maiores detalhes sobre esse ritual.

\section{Abertura de sepulturas para quebra de crânios}

De acordo com Carneiro da Cunha \& Viveiros de Castro (1985), na vingança $\mathrm{o}$ ato de quebrar o crânio era até mais importante que o ritual antropofágico, tendo o segundo sido abandonado antes do primeiro costume. A quebra da cabeça era o que garantia a morte do inimigo, mesmo que ele tenha sofrido outros golpes mortais. Esse ato era muito praticado pelos Guarani e Tupinambá, e havia a prática de se desenterrar os inimigos mortos para lhes quebrar o crânio e assim realizar a vingança e conseguir um novo nome. Ela era uma condição fundamental para se chegar ao paraíso. Era preciso vingar e ser vingado, quebrar o crânio inimigo e ter o seu quebrado. A morte gloriosa se dava no sistema de vinganças, quando ela despertava uma memória de vingança, ligando o passado e o futuro, fazendo com que o tempo corresse.

\section{Abertura de sepultamentos e retirada de ossos}

Segundo Piedade \& Soares (2000), alguns sepultamentos, especialmente de xamãs e caciques, eram abertos e mexidos para serem retirados ossos. Essas práticas são tratadas pelas descrições de maneira genérica e preconceituosa, como "bruxaria" ou "feitiçaria", ações que tem como objetivo quebrar "feitiços" realizados por xamãs ou outras pessoas. Pegavam-se ossos para "castigar" o autor do feitiço, ou para anular um feitiço previamente realizado. Pessoas que faziam feitiços ruins eram castigadas com vários golpes no antebraço, entre ostras ações. Pode-se levantar a possibilidade de que ações com essas eram realizadas em pessoas já sepultadas também.

Para os Guarani, segundo Schaden (1962), as doenças são consideradas fruto de práticas mágicas, e epidemias podem causar desagregação do grupo porque há o receio de que um dos membros tenha lançado feitiçaria para causar as doenças e mortes. Para se vingar a vítima de uma morte por feitiço, usa-se um contrafeitiço. Uma das práticas de contrafeitiço consistia em cortar o corpo do morto por feitiço antes de ser enterrado, pois assim o autor do feitiço também morrerá.

Segundo Schaden (1962), entre os Kayová o autor de um feitiço que matou uma pessoa, para se livrar do contrafeitiço que lhe foi lançado no ato do sepultamento, deve desenterrar o corpo da vítima e jogá-lo na água. Pessoas vistas ou supostamente vistas remexendo sepultamentos eram acusadas de causadores das mortes por meio de feitiço. 
De acordo com Piedade \& Soares (2000), há descrições de que os padres do século XVII queimavam, em fogueiras, em praça pública, os ossos que os Guarani "cultuavam", com o objetivo de promover a cristianização.

Quadro 6: Locais de sepultamento

\begin{tabular}{|c|c|}
\hline Locais de Sepultamento & Grupos descritos \\
\hline 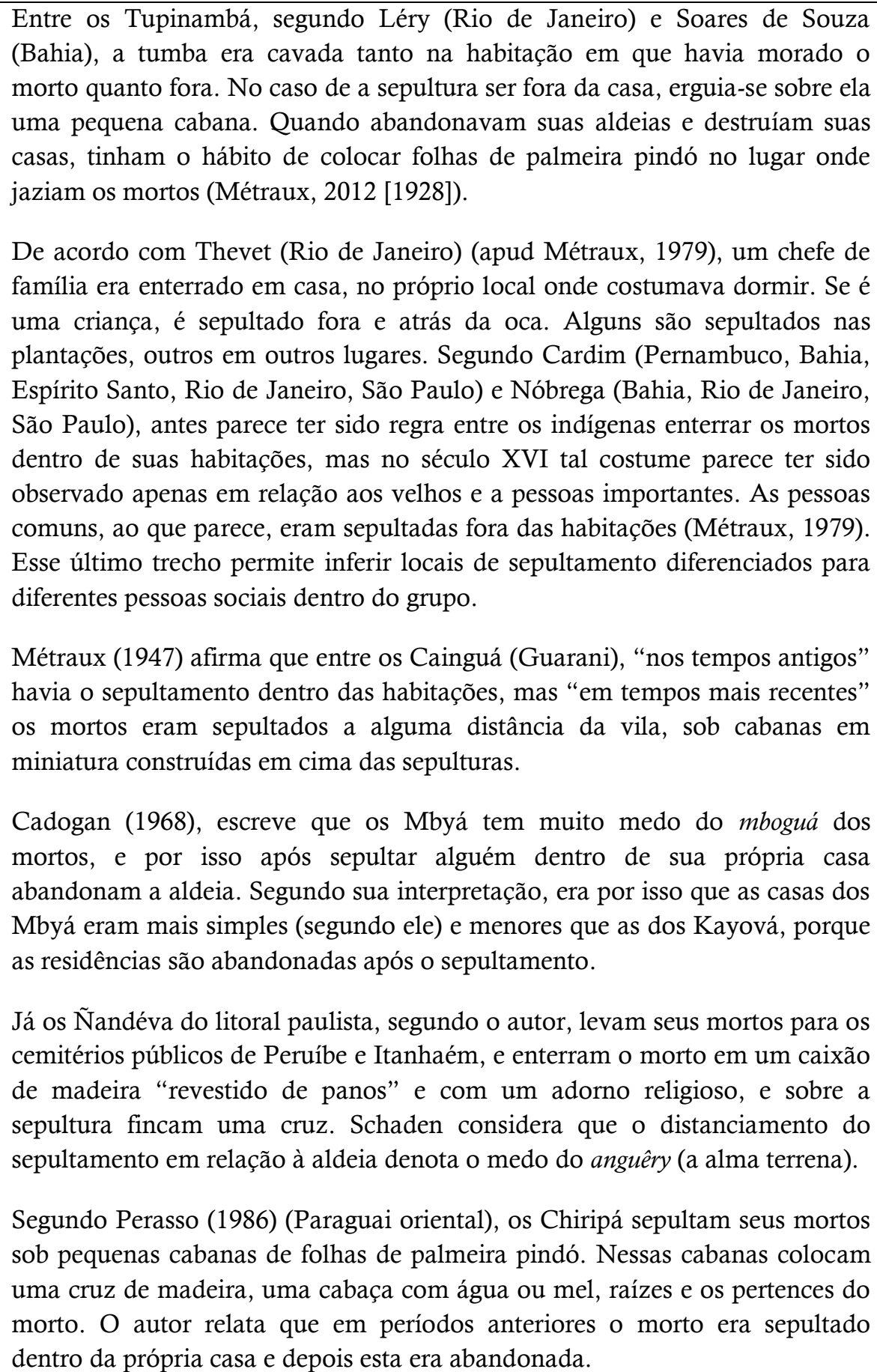 & $\begin{array}{l}\text { Cainguá (Guarani), } \\
\text { Tupinambá genéricos, } \\
\text { Chiripá/Ñandéva } \\
\text { (Guarani), } \\
\text { Mbyá (Guarani), } \\
\text { Kayová (Guarani), } \\
\text { Guarani genéricos }\end{array}$ \\
\hline
\end{tabular}


Já Schaden (1962) (Litoral paulista, sul do Mato Grosso do Sul, região sul do Brasil) relata que não viu a prática do sepultamento no interior das casas entre os Guarani. Os Mbyá têm a memória de que praticavam isso, assim como os Ñandéva do sul do Mato Grosso do Sul - que também abandonavam a casa após o sepultamento. Para os Kayová ele não tem a informação, mas relata que muitos abandonavam ou queimavam a casa em que algum membro da família tinha morrido. As sepulturas dos Mbyá descritas pelo autor estavam localizadas no mato, a alguns quilômetros da aldeia.

Segundo Monteiro da Silva (2008) os Guarani do Rio Grande do Sul sepultavam seus mortos em "cemitério" próximo à aldeia, e os mortos eram enterrados da mesma maneira, independentemente do seu status social. Sobre a sepultura dos caciques era feita uma cabana e uma praça muito bem varrida ao redor. Mas fontes antigas registram o sepultamento em suas casas.

As imagens dos sepultamentos de grupos Tupi-Guarani que aparecem na literatura são variadas, sendo desenhos feitos pelos cronistas do século XVI ou desenhos esquemáticos de sepultamentos escavados no século XX. Abaixo, temos alguns exemplos que pudemos encontrar.

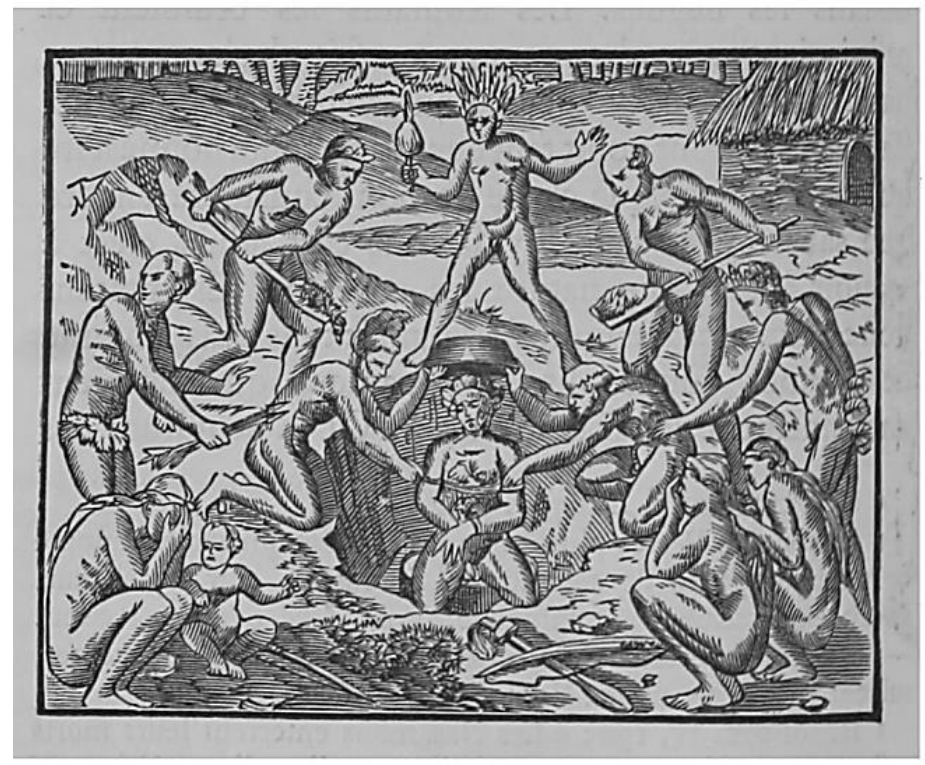

Figura 5: Sepultamento de um "pai de família" Tupinambá, segundo Thevet. Fonte: Thevet, 1878. 

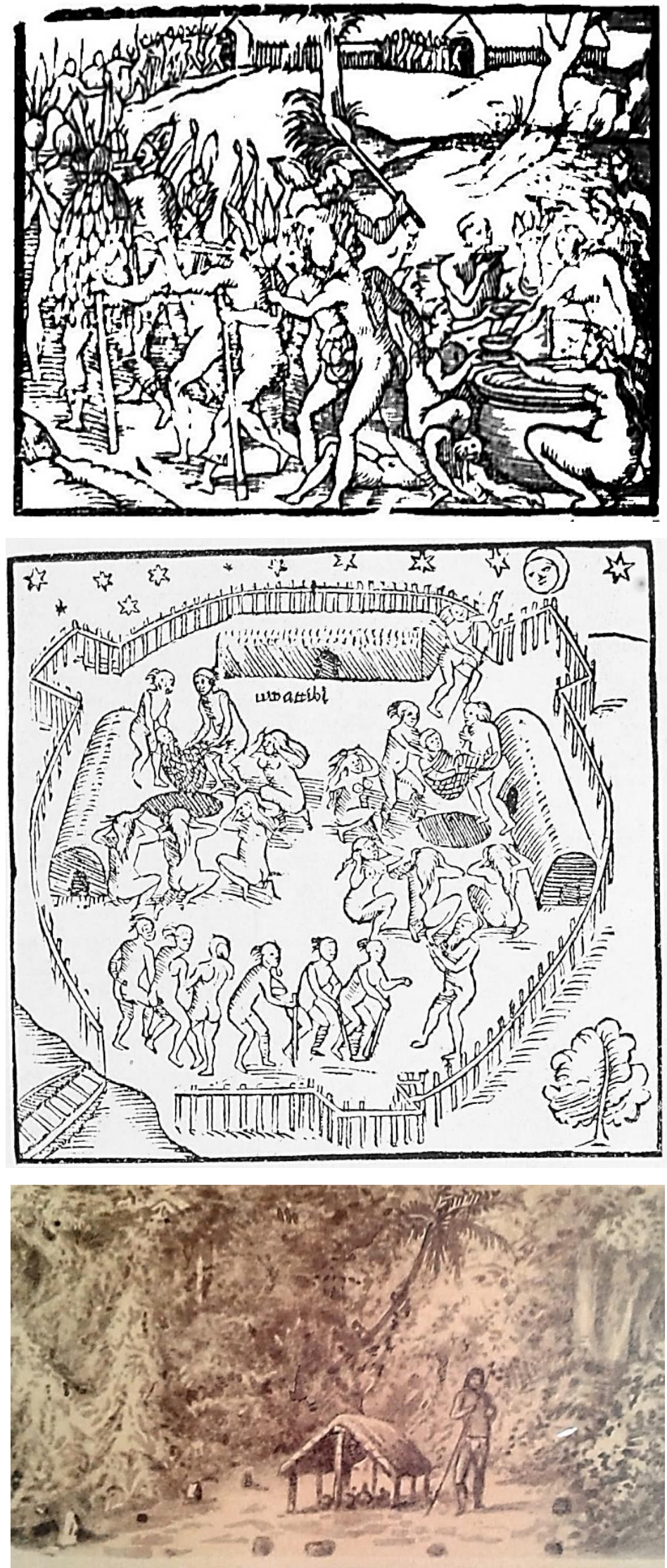

Figura 6: Beberagens e danças

funerárias dos Tupinambá, segundo Thevet. Fonte: Thevet, 1558.

Figura 7: Sepultamento de Tupinambás mortos por doença, região do litoral, entre São Vicente e o Rio de Janeiro, segundo Hans Staden. Fonte: Staden, 1900.

Figura 8: Sepultamento Guarani no Paraguai, final do século XIX.

Fonte: Noelli, 1993. 
Embora a precisão das descrições varie bastante, o que dificulta a compreensão de quais gestos se repetiam entre vários grupos e quais variavam entre eles, é possível notar que há práticas funerárias que se repetem e se perpetuam no tempo, outras que foram abandonadas, e outras que variam entre grupos diferentes. Entre as práticas funerárias há continuidades e descontinuidades.

Entre as continuidades, há duas dimensões em que elas ocorrem. A primeira é a continuidade nas descrições dos cronistas dos séculos XVI e XVII. Os gestos que mais se repetem entre as descrições dos cronistas, que falam dos Tupinambá e Guarani de uma maneira genérica, são:

- Amarração dos membros junto ao tronco da pessoa morta com fibras de algodão (que foi notado desde o Maranhão ao Rio de Janeiro para os Tupinambá)

- Corpo enrolado em redes (Tupinambá e Guarani)

- Cova redonda e profunda (para os Tupinambá)

- Covas com paredes cobertas por gravetos e madeiras sobre o corpo do morto (notado no Rio de Janeiro, Bahia e possivelmente outros lugares, para os Tupinambá)

- Sepultamento em vasilhas enterradas, com outra vasilha cobrindo (para os Tupinambá e Guarani)

- Exocanibalismo (para os Tupinambá e Guarani)

- Presença de uma vasilha cobrindo a cabeça (Tupinambá e Guarani)

- Existência de ritos com danças coletivas para os funerais (Tupinambá e Guarani)

Já a segunda continuidade é a continuidade temporal, as práticas que, apesar de pequenas mudanças diacrônicas, continuaram existindo. Elas variam entre diferentes grupos, não sendo empregadas de maneira homogênea. Cada grupo, de acordo com sua história, foi abandonando certos gestos e adquirindo outros. Além disso, os detalhes das práticas mudam (por exemplo, os pertences do morto em 1550 não são os mesmos que hoje em dia). No entanto, há uma permanência das práticas, mesmo que elas não se deem da mesma maneira entre diferentes grupos e tenham se modificado com o tempo. Esses gestos que permanecem desde os séculos XVI e XVII até o XX são:

- Presença de cova - enterramento 
- Presença de cova com estacas nas paredes e madeiras sobre o corpo, formando uma câmara (Tupinambá, Guarayu)

- Corpo pendurado em rede para que não toque o chão (Tupinambá-Bahia, Guarayú, Cayuá-Paranapanema)

- Pertences do morto na sepultura (Tupinambá, Cayuá-Paranapanema, MbyáChaco, Mbyá, Kayowá, Ñandéva)

- Vasilhas com alimentos e bebidas (Tupinambá-Bahia, CayuáParanapanema, Mbyá-Chaco, Guarani-Rio Grande do Sul)

- Presença de fogueira acesa sobre a sepultura (Tupinambá-Bahia, Mbyá, Kayowá, Ñandéva, Guaiakí-rios Paraná e Paraguai)

- Existência de sepultamentos dentro e fora da residência (Tupinambá, Guarani, Mbyá-Chaco, Ñandéva)

Em especial o uso de cova, a deposição de pertences do morto na sepultura, a presença de alimentos e bebidas para o morto e a presença de uma fogueira acesa sobre a sepultura são práticas que se repetem para todos os grupos analisados, desde o século XVI até parte do XX. Mesmo com todas as mudanças que ocorreram nesse longo período de tempo, esses gestos continuaram a ser praticados. Eles parecem ser uma "base", práticas menos susceptíveis a mudanças, mais fixas, embora estejam sujeitas a pequenas variações. A recorrência dessas diversas práticas entre diversos grupos Tupinambá e Guarani nos leva a supor que elas façam parte do pensamento comum a esses grupos, alguns dos "aspectos cosmológicos" que unem os Tupi-Guarani, como escreve Viveiros de Castro (1986).

Paralelamente, há as descontinuidades nas práticas funerárias. Elas são pouco aparentes entre Tupinambá e Guarani nas fontes consultadas, pois esses dois são tratados como um único bloco. Porém, os relatos de "culto aos ossos" só foram encontrados para os Guarani, não para os Tupinambá. Já entre os grupos Guarani do século $\mathrm{XX}$, os etnógrafos notaram algumas diferenças em relação às práticas funerárias.

Os Mbyá continuaram praticando uma forma de "culto aos ossos" até o século XX, enquanto para outros grupos Guarani não foi encontrada a descrição. Há também a prática de cremação para pessoas que sofriam morte violenta entre os Guayakí dos rios Paraná e Paraguai, o que não é visto em mais nenhum grupo analisado. 
Entre as descrições dos cronistas há muitas descontinuidades, e também contradições, mas elas são inerentes a esse tipo de fonte. É difícil saber se uma prática não havia ou se apenas não foi observada.

De uma maneira geral, houve grandes modificações nas práticas funerárias dos Guarani entre os séculos XVI e XX. Porém, essa mudança não é total, há elementos que se mantiveram. Como já mencionamos esses elementos, passaremos agora para aqueles que se modificaram.

No século XX ou antes, várias práticas foram abandonadas pelos Guarani. O sepultamento em urnas provavelmente foi sendo deixado de lado desde o século XVII, pois há relatos de que os Guarani cristianizados não sepultavam mais em vasilhas cerâmicas. A presença de uma cobertura sobre o sepultamento também foi sendo abandonada, e há relatos para o século XX de grupos Guarani que faziam essa cobertura sobre os sepultamentos e de outros que não faziam. Outra prática que foi abandonada foi o sepultamento dentro da residência. Ele parece ter sido praticado por vários grupos Guarani, mas foi abandonado. Aparentemente, os Mbyá do Paraguai o abandonaram por último.

Para alguns grupos Guarani do século XX os relatos falam da mudança de casa ou da aldeia após o sepultamento dentro da residência. Já para os Tupinambá do século XVI, não se mudava da residência após o sepultamento. Mas, ao longo do século XX, os Guarani também abandonaram essa prática de se mudar da aldeia após uma morte. No entanto, os Pai Tavyterã (Ñandéva) do Paraguai contemporâneo, após a morte de alguém, abandonam e queimam a casa onde morava o morto, e os parentes que moravam perto dele deixam suas casas por um tempo, devido ao temor do angue, a alma que permanece na terra (Meliá et al, 2008).

As descrições de sepultamentos primários fora de urna para os Guarani do século XX falam em enterramentos em posição estendida, diferente dos sepultamentos sentados dos Guayakí e dos Tupinambá. Esses sepultamentos eram feitos em contextos em que o sepultamento em urna não é mais praticado há tempos. Mbyá, Ñandéva e Kayová praticavam sepultamentos primários em covas, fora de urnas, estendidos e com os pés voltados para o sol nascente no século $\mathrm{XX}$, mas os gestos de sepultamento eram ligeiramente diferentes entre os três subgrupos. 
Os Guayakí do Paraguai tinham duas práticas funerárias bastante distintas, mesmo sendo grupos com os mesmos traços culturais: inumação seguida de cremação, e consumo do corpo do morto. É também um dos poucos relatos de canibalismo de um membro de dentro do grupo entre os Tupi de uma maneira geral.

A questão dos locais de sepultamento é uma das mais notadas pelos autores, e os relatos apontam para mudanças diacrônicas. Todos falam da existência de sepultamentos dentro e fora das habitações, entre Guarani e Tupinambá. Mas todos também afirmam que o sepultamento dentro da habitação era mais comum no passado do que no presente das observações, tendo sido este já abolido pelos Guarani na época das observações de Schaden, então talvez a mudança diacrônica tenha sido a perda da prática do sepultamento dentro da habitação, ou a sua redução (até a época dos Tupinambá observados, de acordo com Métraux). É possível também notar diferenças sociais nas práticas funerárias em alguns casos, que são os locais de sepultamento diferenciados para os velhos e chefes e as crianças entre os Tupinambá, e a construção de uma estrutura diferenciada para os caciques entre os Guarani do Rio Grande do Sul. No caso dos Guarani do século XX, os diferentes subgrupos, em diferentes regiões, apresentam variações nos locais de sepultamento e, provavelmente, na espacialidade entre os sepultamentos também, embora o tipo de sepultamento seja o mesmo.

Esses relatos foram feitos desde a década de 1920 até a de 1960, e não há descrições suficientes para se acompanhar detalhadamente a mudança diacrônica nas práticas funerárias dentro desse período mais curto. E como elas são de regiões diferentes e foram vistas por observadores diferentes, não fica claro o quanto as práticas são regionais ou não. Os grupos do Paraguai e do Chaco contam com mais descrições, mas não sabemos se podemos generalizar para todos os lugares. O que parece é que, entre Mbyá, Ñandéva e Kayová Guarani há diferenças sutis nos gestos envolvidos no sepultamento primário fora de urna.

Essas informações nos fazem pensar que, por mais que o tipo de sepultamento seja o mesmo - primário fora de urna cerâmica - há uma certa variação dos gestos entre diferentes subgrupos Guarani, sendo que alguns sepultam em redes, outros em caixões; alguns fazem os sepultamentos próximos, outros distantes uns dos outros. $\mathrm{Ou}$ seja, há semelhanças - o tipo de sepultamento, de posição do corpo, a presença de cruzes e dos pertences do morto na sepultura -, mas os gestos envolvidos na formação 
desses sepultamentos são ligeiramente distintos, gerando uma variabilidade dentro da categoria "sepultamento primário fora de urna" que está ligada, no caso, a subgrupos linguísticos e identitários dentro de uma mesma língua, o Guarani. Mas não somente, pois gestos diferentes também podem haver dentro do mesmo subgrupo. A variabilidade parece ter mais a ver com a história própria de cada subgrupo em cada região (ou em mais de uma região).

Além desses gestos, que podem deixar algum registro arqueológico, há outros gestos antemortem, durante e depois dos funerais. Métraux (1947) traz que há relatos de assassinato do doente considerado terminal entre os Chiriguano. Quando não há mais esperança de que viva, algumas poucas mulheres velhas "pronunciam uivos assustadores até que ele dê seu último suspiro". Já um Apapokuva-Guarani (Ñandéva Guarani ou Chiripa, segundo Cadogan, 1968) que sentia que seu fim estava próximo começou a cantar canções "mágicas" enquanto as mulheres lamentavam e os xamãs sacudiam seus chocalhos "para se despedir dessa alma que partia". Segundo Soares de Souza (apud Métraux, 1979), todo indivíduo cuja doença era considerada incurável era deixado por si só. Ninguém o alimentava mais nem cuidava dele se a morte era considerada inevitável. Porém, quando estava prestes a morrer, seus parentes precipitavam-se sobre ele. Segundo Cardim, os que não podiam se aproximar do moribundo atiravam-se no chão com força (aqui ele está falando dos Guarani). De acordo com Yves d'Évreux, nos últimos instantes do doente, os parentes cercam-lhe o leito, olhando-o atentamente, derramando lágrimas contínuas. O pranto ritual era entoado principalmente pelas mulheres, em especial as mais velhas. Todos os vizinhos e parentes eram convidados a tomar parte nas manifestações de dor e lamentos. Aos que não choravam eram lançadas pragas, dizendo que eles não hão de serem chorados. Na morte de um chefe, o luto torna-se geral em toda a aldeia. Depois que o corpo é chorado, o principal da maloca ou da aldeia fazia um discurso em homenagem ao morto, "batendo muitas vezes no peito e nas coxas e contando as façanhas e proezas do morto". Entre os Tupinambá do Rio de Janeiro, o elogio do morto era feito pelas mulheres. Thevet descreve que, quando morre algum chefe de família, seja na guerra, seja de velhice ou por acidente, suas mulheres cortam o cabelo bem rente, depois de arrancarlhe parte com choros e lamentos, que perduram por metade de um ano. Já o luto pesado dura apenas por 4 ou 5 dias após a morte (Métraux, 1979). 
Só após esses choros é que o morto vai para a cova. Entretanto, em geral os Tupinambá tinham pressa extrema para enterrar o morto, acontecendo até de amortalharem pessoas que ainda não estavam mortas (Métraux, 1979).

Os enlutados Guarani, Tupinambá, Chiriguano, Tupi-Kawahib e Munduruku cortam o cabelo. Mulheres Chiriguano colocam o cabelo cortado na sepultura de seus maridos. As mulheres Tupinambá cortam o cabelo bem rente, e os homens o deixam crescer. Tupinambá e Munduruku pintavam seus rostos e corpos com jenipapo em diferentes momentos dos ritos funerários. Enlutados Guarani jogavam-se de uma altura quando um ente querido morre, machucando-se e, às vezes, até matando-se (Métraux, 1947). O luto durava no mínimo uma semana. Entre os Tupinambá, o período de luto se encerra com uma festa, durante o sexto mês após o sepultamento. É realizada uma grande bebedeira, na qual os enlutados comparecem pintados de jenipapo. Durante a festa todos lançam elogios ao morto e ao organizador da festa. Próximo ao final, as mulheres enlutadas cortam novamente os cabelos. Só se livram de todas as obrigações do luto quando os cabelos voltam a crescer até cobrirem os olhos. Os homens podiam sair do luto quando quisessem (Métraux, 1947, 2012 [1928], 1979).

Hanke (S/D) faz alguns relatos de costumes funerários de comunidades indígenas da região do Chaco, que ela visitou na primeira metade a meados do século XX. Ao relatar práticas funerárias dos Mbyá, escreve que eles fumam muito durante a escavação da cova, para afugentar os espíritos malignos. Se um bebê morre nos braços da mãe, esta deve coloca-lo sobre o solo por algum tempo.

\subsection{Discussão}

Os dados apresentados chamam a atenção para a variedade de práticas funerárias que havia entre os grupos Guarani e Tupinambá, e ajudam a trazer subsídios para a interpretação de contextos arqueológicos.

Observando as vasilhas utilizadas em contextos funerários Guarani (Noelli, 1993), podemos notar que trata-se de todo um aparato para cozinhar alimentos, preparar e armazenar bebidas, e servir alimentos e bebidas. Quase todas as vasilhas que eram utilizadas para isso eram também utilizadas em contexto funerário. Não há um nome específico para nenhuma vasilha utilizada em práticas funerárias, o que sugere que, como já se afirma, são as mesmas vasilhas do cotidiano. Outra coisa que sugere isso são as 
marcas de uso, analisadas no próximo capítulo. Vasilhas para se cozinhar alimentos, fermentar bebidas, armazenar água e servir alimentos/bebidas são utilizadas como urnas e tampas, enquanto que como vasilhas anexas - aquelas que provavelmente continham alimentos e bebidas para o sepultamento - aparecem geralmente recipientes para servir alimentos e bebidas e para se beber (serem utilizados como copo).

Conforme traz Rapp-Py Daniel (2015), os grupos Tupi da Amazônia são, em comparação com grupos Arawak, Karib e Jê, os que possuem a maior variedade de práticas funerárias. As fontes etnohistóricas que analisamos sugerem que essa variedade diminui em regiões mais meridionais, sendo que os Tupinambá e Guarani aparentemente praticavam principalmente o sepultamento primário - conforme aponta Métraux - dentro e fora de vasilhas cerâmicas. O sepultamento secundário, em grupos mais meridionais também era praticado, embora as práticas de sepultamento secundário não estejam muito claras nas fontes que consultamos. Mas é possível questionar se era um sepultamento muito comum para um grande número de pessoas ou se era mais restrito. Entre os Tupinambá, há o relato dos sepultamentos secundários de crânios, mas daqueles indivíduos que morriam longe da aldeia em que moravam. É possível questionar o quanto esse sepultamento secundário era comum ou não, mas como não há dados estatísticos fica difícil saber. Na Amazônia, por outro lado, havia muito mais tipos de sepultamentos distintos.

Müller \& Mendonça de Souza (2011) fazem algumas reflexões importantes sobre os sepultamentos Guarani. Normalmente, de um modo geral, as interpretações dos sepultamentos em urnas funerárias costumam associá-las a práticas secundárias, um pressuposto que frequentemente resulta de observações incompletas das estruturas, já muito modificadas pelos processos tafonômicos. O tamanho de algumas vasilhas também leva a interpretações de que eram sepultamentos secundários. No entanto, além da possibilidade de alguns serem sepultamentos infantis, poderiam ser sepultamentos de adultos pequenos muito bem amarrados, de maneira a caberem pelo menos parcialmente dentro de uma vasilha não muito grande. A perda das partes moles faria com que o volume da pessoa dentro da vasilha diminuísse muito mais após a decomposição.

Portanto, com base em todas essas evidências, nos perguntamos se muitos dos sepultamentos interpretados como secundários poderiam ser, na verdade, primários que sofreram tanto com os processos tafonômicos que o diagnóstico fica muito difícil. 
A análise da distribuição espacial e das mudanças diacrônicas nas práticas funerárias, mesmo com todas as suas dificuldades, nos possibilitou compor um quadro que nos permitiu notar continuidades e descontinuidades nessas práticas.

Várias práticas são comuns entre grupos Guarani e Tupinambá, e perduram por um período de 4 séculos, como o uso de cova, a deposição de pertences do morto na sepultura, a presença de alimentos e bebidas para o morto e a presença de uma fogueira acesa sobre a sepultura. Essa "base" comum pode estar ligada às semelhanças em termos cosmológicos que há entre os grupos Tupi-Guarani. Claro que esses elementos comuns apresentam variações no tempo e no espaço, os detalhes de cada um mudam (por exemplo, o formato da cova, os tipos de pertences do morto, a duração da fogueira, as vasilhas para alimentos e bebidas). Mas mesmo variando eles perduram, o que mostra que são práticas menos suscetíveis a mudanças.

Além disso, os 4 séculos de mudanças intensas alteraram bastante as práticas funerárias dos Guarani de uma maneira geral. No entanto, mesmo assim houve elementos que permaneceram, a mudança não foi total, mesmo com a cristianização. As mudanças também não foram adotadas pelos grupos Guarani de maneira homogênea. Grupos diferentes em regiões diferentes tinham práticas funerárias ligeiramente distintas entre si, mas seguindo uma base comum. Alguns grupos demoraram mais a abandonar certas práticas - como o sepultamento dentro da residência e posterior mudança de aldeia, ou a confecção de uma pequena cabana sobre a sepultura -, outros as abandonaram mais cedo.

Mbyá, Ñandéva e Kayová praticavam sepultamentos primários em covas, fora de urnas, estendidos e com os pés voltados para o sol nascente no século $\mathrm{XX}$, mas alguns gestos de sepultamento - como configuração da sepultura, uso de caixões ou redes, e locais de sepultamento - eram diferentes entre os três subgrupos. Esses subgrupos possuem histórias diferentes e próprias que levaram a essas identidades distintas (Schaden, 1962). Então, podemos inferir que, no caso dos Guarani, a variabilidade das práticas funerárias se deu de maneira que certos princípios comuns (mas não necessariamente práticas idênticas) tiveram interpretações diferentes e foram se modificando de acordo com a história distinta de cada subgrupo. Então, nesse caso, a variabilidade das práticas funerárias se dá através de certos elementos comuns presentes em grupos que tiveram contingências históricas distintas. Ao observarmos, além do tipo de sepultamento, também os detalhes, os gestos 
que o compõem, pudemos notar diferenças - já percebidas por Schaden (1962) e Cadogan (1968) - que podem se relacionar com diferentes subgrupos.

Outro tópico que queremos ressaltar é o chamado "culto aos ossos". Esse termo é tão terrível quanto "culto aos ancestrais". A expressão já era usada por Montoya, e Cadogan utilizava "culto de los muertos". Ambas as expressões parecem se referir a uma série de práticas em que os ossos de ao menos alguns mortos estavam envolvidos. Essas práticas pareciam englobar tanto o sepultamento secundário - ou manutenção dos ossos em um local especial - de alguns indivíduos (caciques, xamãs e crianças), quanto outras ações não necessariamente funerárias - gestos pós-funerários, que não estão relacionados com as práticas de sepultamento, como a manutenção dos ossos de xamãs em cabanas especiais, o desenterramento de alguns indivíduos para que fossem "castigados". Outras práticas encontradas na bibliografia eram a trituração de ossos de mortos para serem espalhados na terra, a fim de garantir colheitas - e não está claro se é uma prática funerária ou não -, e o desenterramento de inimigos mortos para lhes quebrar o crânio, assim podendo ser realizada a vingança e a aquisição de novos nomes.

Portanto, os ossos dos mortos estão associados a outras práticas além do sepultamento, práticas pós-funerárias. Embora os sepultamentos e remanescentes humanos estivessem envolvidos, eram práticas que não faziam parte do funeral, e sim eram fruto de outros objetivos. Isso demonstra a importância e presença dos mortos entre os vivos, que vai muito além das práticas funerárias. Com base nesses dados, pode-se dizer que, entre os Guarani e também entre os Tupinambá, uma série de gestos não necessariamente funerários se dão no contexto funerário, e são relacionados aos mortos também. Esses gestos são fruto de cosmologias nas quais os mortos possuem uma presença e importância fundamentais entre os vivos de várias formas e em várias instâncias - seja no sistema de vinganças, seja em rezas, seja como "feiticeiros" a se castigar, seja como meios para se conseguir melhores colheitas. Desse modo, os contextos funerários de grupos Tupinambá e Guarani devem ser analisados se levando também isso em consideração, ou seja, a possível presença de gestos não funerários, porém com os quais os mortos também estavam envolvidos, e que demonstram a sua agência fundamental no mundo dos vivos. 


\section{Capítulo V}

\section{AS ANÁLISES}

Nesse capítulo trazemos a análise da variabilidade entre materiais arqueológicos e contextos funerários para certas regiões meridionais do Brasil (dentro das regiões Sudeste, Sul e Centro-Oeste do país).

Os dados que utilizamos para compor a dissertação são constituídos por etnografias sobre grupos Tupi, relatos de cronistas, descrições feitas por arqueólogos a respeito de contextos funerários, e materiais arqueológicos, principalmente cerâmico e ósseo. Buscamos, em 4 instituições ${ }^{8}$, por esse material escavado dos contextos funerários que consta nas descrições existentes para contextos do Paranapanema. Encontramos a maior parte dele, porém, muitas peças não. Uma parte pequena do material ósseo descrito foi encontrado e, como esperado, suas condições de preservação não estão boas.

Nossa análise se deu da seguinte forma:

1- Análise das descrições e fotos de contextos funerários já escavados, a fim de reunir informações contextuais que nos possibilitassem inferir algumas práticas funerárias;

2- Análise do material cerâmico juntamente com o material ósseo que encontramos, com o objetivo de verificar a variabilidade morfológica, de tratamentos de superfície e de marcas de uso presentes na cerâmica, bem como de averiguar o potencial informativo dos remanescentes humanos, fazer um inventário ósseo e diagnosticar sexo e idade aproximada da morte do indivíduo (quando isso fosse possível).

Analisamos publicações e teses a procura de descrições de contextos funerários, tentando apreender o maior número possível de detalhes sobre os mesmos. No entanto, nem sempre foi possível obter muitos detalhes do contexto e de sua escavação.

Tendo em mente que vasilhas funerárias são encontradas em muitos museus, mas que a maioria não possui contexto, e muitas vezes nem sequer a informação de que

\footnotetext{
${ }^{8}$ Museu de Arqueologia e Etnologia da USP - São Paulo (SP); Centro Regional de Arqueologia Ambiental - Piraju (SP), pertencente ao MAE-USP; Centro de Museologia, Antropologia e Arqueologia da UNESP Presidente Prudente (SP); e Museu de Arqueologia de Iepê - Iepê (SP).
} 
possuíam remanescentes humanos dentro ou não, o nosso critério para escolher os materiais arqueológicos que analisamos nessa dissertação seguiu alguns fatores. Primeiramente, a existência de contextos funerários descritos, cujo material pudesse ser analisado por nós. Então, partimos das publicações referentes à região da bacia do Paranapanema que continham descrições de contextos funerários para escolher o material, e fomos às instituições onde este se encontrava. Nessas visitas, nos deparamos também com peças sem contexto, que possuíam apenas o município ou, no máximo, o bairro onde o sítio foi encontrado, mas que eram interessantes mesmo assim, pois traziam informações mesmo sem o contexto, ou serviam como elementos para a construção de um padrão em uma análise comparativa inter sítios. Procuramos nos concentrar nas peças que possuíam contexto, então analisamos bem poucas que não as possuíam.

Houve também o problema dos sítios que lemos as descrições dos contextos funerários, mas que não conseguimos ter acesso ao material para analisar. Nesses casos, mesmo sem analisar as vasilhas cerâmicas e os eventuais remanescentes humanos, mantivemos as descrições que coletamos a respeito dos contextos pelo mesmo motivo que analisamos algumas vasilhas sem contexto: essas descrições agregavam dados para compor um quadro de práticas funerárias para as regiões que escolhemos analisar.

Desse modo, lidamos com 4 tipos de situações: sítios com contextos funerários bem descritos e material que pudemos analisar; sítios com contextos mal descritos, e que pudemos analisar o material; sítios com contextos descritos (ora bem, ora mal), mas cujo material não conseguimos analisar; e material sem nenhuma descrição de contexto, apenas a referência do sítio e município de onde vieram. Isso era inevitável, pois são diversas pesquisas, realizadas em épocas e locais diferentes, por diferentes pessoas, então consequentemente as informações são muito fragmentárias. Nosso esforço foi juntar e sistematizar tudo isso, para buscar por padrões e diferenças - ou seja, fazer uma análise de variabilidade -, para, através disso, construir um quadro de práticas funerárias.

Dessa forma, temos:

1- Sítios com informações gerais e contextuais e material que analisamos: Fonseca, Prassévichus, Lagoa São Paulo 2, Alves, Aguinha, Pernilongo 
2- Sítios e ocorrências com (ora poucas) informações gerais e poucas informações do contexto funerário, e material que analisamos: Salto Grande do Paranapanema, Nunes, Jango Luiz, Itaguá, Panema

3- Sítios e ocorrências sem informações gerais nem dos contextos funerários, e material que analisamos: Silveira, Lopes, Romanini e Canuto, e ocorrências de Piraju e de Rosana

4- Sítios e ocorrências com informações gerais e contextuais, mas que não conseguimos analisar o material: MT-IV-1, PR-FO-24 (Ilha do Alemão 1), Rio Ivinhema 1, Itororó, PR-NL-7 (Pesqueiro Barragem de Rosana), SP-SG-9 (Hotel Uselpa 2), PR-SE-3 (Vitorino 3), PR-NA-1 (Fazenda Água da Fartura), SP-IP-8 (Cemitério do Renato), SP-IP-9 (Cemitério do Espanhol), Morro Grande, Serrano, São José, Bananeiras, Franco de Godoy, Alto Paraná 8 e PR-FI-148 (Caranguejeiras), e ocorrência da cidade de Salto, além dos materiais de coleções do noroeste de São Paulo

Portanto, reunimos neste capítulo informações de contextos funerários e/ou material cerâmico funerário de pelo menos 35 sítios e ocorrências.

\subsection{Os sítios principais e secundários}

Analisamos material de contextos funerários de 15 sítios e 2 ocorrências arqueológicas das regiões do Paranapanema e Alto Paraná, e um do litoral do estado de São Paulo (sítios dos itens 1, 2 e 3 logo acima). Foram analisadas 49 vasilhas cerâmicas e também remanescentes humanos de 9 indivíduos, buscando inventariar os ossos e diagnosticar sexo e idade.

Para 6 desses sítios (sítios principais - item 1 acima) conseguimos mais informações, e para os outros 11 (sítios secundários - itens 2 e 3 acima) não. A seguir mostraremos as análises para esses 14 sítios e 2 ocorrências. Mais adiante no capítulo, colocamos as descrições dos outros sítios cujos materiais cerâmicos não pudemos analisar (item 4), mas que trazem informações importantes a serem consideradas sobre os contextos funerários.

\subsubsection{Aspectos gerais: sítios Tupinambá e Guarani}

As tabelas adiante trazem os sítios com descrições de contextos funerários cujo material analisamos. 
A análise das cerâmicas e da espacialidade funerária dos sítios ao longo do Paranapanema confirma o que já vem sendo dito sobre os sítios dessa região há tempos (Noelli, 1993; Corrêa, 2014): no alto e médio Paranapanema, os sítios escavados por Luciana Pallestrini podem ser associados aos Tupinambá; enquanto no médio e baixo curso desse rio os sítios podem ser associados aos Guarani. Assim, os sítios Fonseca, Prassévichus, Salto Grande do Paranapanema, Jango Luiz, Panema, Itaguá e a ocorrência do município de Piraju trazem materiais cerâmicos que podem ser associados aos Tupinambá, enquanto os sítios Alves, Aguinha, Pernilongo, Lagoa São Paulo 2, Nunes, Romanini, Lopes, Canuto e a ocorrência no município de Rosana podem ser associados aos Guarani.

Com base nessa divisão regional que apareceu para os materiais cerâmicos, começamos então a analisar quais diferenças havia entre as cerâmicas funerárias de sítios Tupinambá e Guarani, e quais as diferenças na espacialidade funerária dos contextos. Percebemos que havia padrões que caracterizavam os sítios Tupinambá e outros que caracterizavam os sítios Guarani dessa região. 
Quadro 7: Sítios principais analisados.

\begin{tabular}{|c|c|c|c|c|c|c|c|c|c|}
\hline \multicolumn{10}{|c|}{ Sítios com contextos funerários bem descritos e cujo material analisamos } \\
\hline Prassévichus & $\begin{array}{l}\text { UTM } \\
\text { Zona: } 22 \mathrm{~F} \\
\text { Longitude } \\
\text { (E): } 0.692 .800 \\
\text { Latitude }(\mathrm{N}) \text { : } \\
7.383 .000\end{array}$ & Itaí- SP & $\begin{array}{l}\text { Luciana } \\
\text { Pallestrini e } \\
\text { José Luiz de } \\
\text { Morais }\end{array}$ & $\begin{array}{l}\text { Década } \\
\text { de } 1980\end{array}$ & - & $\begin{array}{l}8 \text { urnas funerárias. } \\
\text { Uma delas continha } \\
\text { vasilhas em seu } \\
\text { interior. Urnas pelo } \\
\text { menos } 25 \text { metros } \\
\text { distantes de alguma } \\
\text { mancha de terra preta. }\end{array}$ & $\begin{array}{l}\text { Sítio a céu aberto, } \\
\text { localizado em topo } \\
\text { de colina, a aprox. } \\
125 \text { metros do } \\
\text { Ribeirão do } \\
\text { Caçador. }\end{array}$ & $\begin{array}{l}80.000 \mathrm{~m}^{2} \\
\text { ou } 8 \\
\text { hectares }\end{array}$ & $\begin{array}{l}\text { Pallestrini, } \\
\text { 1975; Correa, } \\
\text { 2014; Morais, } \\
2001\end{array}$ \\
\hline Fonseca & $\begin{array}{l}\text { UTM } \\
\text { Zona:22K } \\
\text { Longitude } \\
\text { (E): } 0711688 \\
\text { Latitude (N): } \\
7373916\end{array}$ & $\begin{array}{l}\text { Itapeva - } \\
\text { SP }\end{array}$ & L. Pallestrini & $\begin{array}{l}\text { Final da } \\
\text { década } \\
\text { de } 1960\end{array}$ & $\begin{array}{l}899 \mathrm{AD}, \\
1190 \pm 120 \\
\mathrm{AP}, \\
1110 \pm 110 \\
\mathrm{AP}, \\
1100 \pm 100 \\
\mathrm{AP}, \\
1100 \pm 110 \\
\mathrm{AP}, \\
1076 \mathrm{AP}, \\
1010 \pm 100 \\
\mathrm{AP}, 970 \pm 100 \\
\mathrm{AP}\end{array}$ & $\begin{array}{l}6 \text { urnas funerárias (5 } \\
\text { contextos), esparsas } \\
\text { em relação à área das } \\
\text { manchas pretas, } 3 \\
\text { delas bastante } \\
\text { afastadas das mesmas. }\end{array}$ & $\begin{array}{l}\text { Sítio a céu aberto, a } \\
40 \text { metros de } \\
\text { altitude do córrego } \\
\text { Agrião. Localizado } \\
\text { em planalto, em } \\
\text { meia encosta. }\end{array}$ & $\begin{array}{l}40.000 \mathrm{~m}^{2} \\
\text { ou } 4 \\
\text { hectares }\end{array}$ & $\begin{array}{l}\text { Pallestrini, } \\
1969\end{array}$ \\
\hline
\end{tabular}




\begin{tabular}{|c|c|c|c|c|c|c|c|c|c|}
\hline Alves & $\begin{array}{l}\text { UTM } \\
\text { Longitude } \\
\text { (E): } 673000 ; \\
\text { Latitude (N): } \\
7426000 \\
\text { Graus, } \\
\text { minutos e } \\
\text { segundos: } 23^{\circ} \\
15^{\prime} 57^{\circ} \mathrm{S} 49^{\circ} \\
18^{\prime} 30^{\prime \prime} \mathrm{W}\end{array}$ & Piraju - SP & $\begin{array}{l}\text { Luciana } \\
\text { Pallestrini }\end{array}$ & $\begin{array}{l}\text { Década } \\
\text { de } 1970\end{array}$ & $\begin{array}{l}1150 \pm 100 \\
\mathrm{AP}, \\
1021 \pm 100 \mathrm{AP}, \\
1020 \mathrm{AP}, \\
955 \pm 100 \mathrm{AP}\end{array}$ & $\begin{array}{l}5 \text { urnas funerárias } \\
\text { dispostas todas dentro } \\
\text { da área compreendida } \\
\text { entre as manchas. } \\
\text { Dentro das urnas } 2 \text { e } 4 \\
\text { foram encontrados } \\
\text { recipientes. }\end{array}$ & $\begin{array}{l}\text { Sítio a céu aberto, } \\
\text { localizado em } \\
\text { planalto. Aprox. } \\
110 \text { metros do curso } \\
\text { d'água, em meia } \\
\text { encosta de uma } \\
\text { colina. Presença de } \\
\text { afloramento de } \\
\text { basalto e arenito } \\
\text { silicificado no } \\
\text { entorno. Materiais } \\
\text { arqueológicos em } \\
\text { superfície e em } \\
\text { profundidade. }\end{array}$ & $\begin{array}{l}40.000 \\
\mathrm{~m}^{2} \\
\text { ou } 4 \\
\text { hectares }\end{array}$ & $\begin{array}{l}\text { Pallestrini, } \\
1975\end{array}$ \\
\hline Aguinha & - & Iepê - SP & $\begin{array}{l}\text { Neide } \\
\text { Barrocá } \\
\text { Faccio }\end{array}$ & $\begin{array}{l}1999- \\
2010\end{array}$ & $700 \pm 160 \mathrm{AP}$ & $\begin{array}{l}6 \text { urnas funerárias no } \\
\text { total, algumas sem um } \\
\text { contexto bem descrito. } \\
\text { Presença de } 2 \\
\text { contextos funerários } \\
\text { no mínimo. Presença } \\
\text { de vasilhas dentro e } \\
\text { próximo de algumas } \\
\text { urnas. }\end{array}$ & $\begin{array}{l}\text { Deposição em } \\
\text { superfície e } \\
\text { profundidade. Sítio } \\
\text { a céu aberto } \\
\text { localizado em } \\
\text { planície de } \\
\text { inundação, em } \\
\text { baixa vertente. }\end{array}$ & & Faccio, 2011 \\
\hline
\end{tabular}




\begin{tabular}{|c|c|c|c|c|c|c|c|c|}
\hline Pernilongo & - & Iepê - SP & $\begin{array}{l}\text { Neide } \\
\text { Barrocá } \\
\text { Faccio }\end{array}$ & $\begin{array}{l}1999, \\
2000 \\
2002 \\
2007 \\
2010\end{array}$ & $700 \pm 160 \mathrm{AP}$ & $\begin{array}{l}\text { Presença de urnas } \\
\text { funerárias e possíveis } \\
\text { urnas, tendo sido } \\
\text { algumas escavadas pela } \\
\text { pesquisadora. Dois } \\
\text { contextos funerários no } \\
\text { mínimo. Uma urna foi } \\
\text { encontrada contendo } \\
\text { vasilhas dentro e } \\
\text { vasilhas ao lado, bem } \\
\text { como restos ósseos } \\
\text { dentro. Esta "urna" } \\
\text { trata-se de vasilha } \\
\text { caracterizada como } \\
\text { cambuchi caguaba, ou } \\
\text { tigela para beber. A } \\
\text { outra é de pequenas } \\
\text { dimensões, tendo sido } \\
\text { encontrada junto à } \\
\text { tampa. }\end{array}$ & $\begin{array}{l}\text { Deposição em } \\
\text { superfície e } \\
\text { profundidade. Sítio } \\
\text { a céu aberto } \\
\text { localizado em } \\
\text { planície de } \\
\text { inundação, em } \\
\text { baixa vertente. }\end{array}$ & $\begin{array}{l}\text { Faccio, 2011; } \\
\text { Baco, } 2012\end{array}$ \\
\hline $\begin{array}{l}\text { Lagoa São } \\
\text { Paulo } 2\end{array}$ & - & $\begin{array}{l}\text { Presidente } \\
\text { Epitácio - } \\
\text { SP }\end{array}$ & $\begin{array}{l}\text { Ruth Kunzli } \\
\text { e equipe }\end{array}$ & 2010 & & $\begin{array}{l}5 \text { áreas com } \\
\text { enterramentos } \\
\text { associados a vasilhames } \\
\text { de variados tamanhos, } \\
\text { totalizando parte de } 7 \\
\text { esqueletos humanos } \\
\text { (nos PS } 09,23,28,38, \\
50 \text { e } 64 \text { ). Alguns estão } \\
\text { enterrados em urnas e } \\
\text { outros próximos a elas } \\
\text { ou próximos a vasilhas } \\
\text { menores. Associados } \\
\text { aos ossos também há } \\
\text { vasilhas menores nas } \\
\text { urnas maiores }\end{array}$ & $\begin{array}{l}\text { Encontra-se na } \\
\text { margem esquerda } \\
\text { do rio Paraná, em } \\
\text { um terraço fluvial. } \\
\text { Nele foram } \\
\text { encontradas } 22 \\
\text { manchas de terra } \\
\text { preta. }\end{array}$ & Cabrera, 2015 \\
\hline
\end{tabular}


Quadro 8: Sítios secundários.

\begin{tabular}{|c|c|c|c|c|c|c|c|c|c|}
\hline \multicolumn{10}{|c|}{ Sítios com contextos funerários com menos ou nenhuma descrição e que analisamos material } \\
\hline Nome do sítio & Coordenadas & $\begin{array}{l}\text { Local do } \\
\text { sítio }\end{array}$ & $\begin{array}{l}\text { Primeiro } \\
\text { pesquisador } \\
\text { (a) }\end{array}$ & $\begin{array}{l}\text { Época } \\
\text { da } \\
\text { pesquisa }\end{array}$ & $\begin{array}{l}\text { Datações } \\
\text { do sítio }\end{array}$ & $\begin{array}{l}\text { Caracterização } \\
\text { básica dos } \\
\text { contextos } \\
\text { funerários }\end{array}$ & $\begin{array}{l}\text { Caracterização geral do } \\
\text { sítio }\end{array}$ & $\begin{array}{l}\text { Área do } \\
\text { sítio }\end{array}$ & $\begin{array}{l}\text { Referências } \\
\text { Bibliográficas } \\
\text { para o sítio }\end{array}$ \\
\hline $\begin{array}{l}\text { Salto Grande } \\
\text { do } \\
\text { Paranapanema }\end{array}$ & $\begin{array}{l}\text { UTM } \\
\text { Zona: } 22 \mathrm{~F} \\
\text { Longitude (E): } \\
0.603 .097 \\
\text { Latitude (N): } \\
7.465 .620\end{array}$ & $\begin{array}{l}\text { Salto } \\
\text { Grande - } \\
\text { SP }\end{array}$ & $\begin{array}{l}\text { José Luiz de } \\
\text { Morais }\end{array}$ & $\begin{array}{l}\text { Décadas } \\
\text { de } 1980 \\
\text { e } 1990\end{array}$ & - & $\begin{array}{l}\text { Foram } \\
\text { encontrados } \\
\text { remanescentes } \\
\text { humanos por } \\
\text { moradores } \\
\text { locais, que } \\
\text { foram } \\
\text { descontextualiz } \\
\text { ados. Foi } \\
\text { encontrada } \\
\text { também uma } \\
\text { urna com } \\
\text { remanescentes } \\
\text { humanos, in } \\
\text { situ. }\end{array}$ & $\begin{array}{l}\text { O sítio está em terraço } \\
\text { fluvial elevado. }\end{array}$ & & $\begin{array}{l}\text { Morais, 1999; } \\
\text { Morais, } 2001\end{array}$ \\
\hline
\end{tabular}




\begin{tabular}{|c|c|c|c|c|c|c|c|c|c|}
\hline Jango Luiz & $\begin{array}{l}\text { UTM } \\
\text { Zona: } 22 \mathrm{~F} \\
\text { Longitude (E): } \\
0.755 .800 \\
\text { Latitude (N): } \\
7.392 .850\end{array}$ & $\begin{array}{l}\text { Angatuba } \\
\text { - SP }\end{array}$ & $\begin{array}{l}\text { Luciana } \\
\text { Pallestrini }\end{array}$ & $\begin{array}{l}\text { Década } \\
\text { de } 1960\end{array}$ & $\begin{array}{l}1260 \mathrm{AP}, \\
980 \pm 100 \\
\mathrm{AP} \\
1540 \pm 150 \\
\mathrm{AP}(765 \\
\mathrm{AD}) \\
\text { e1076 AP }\end{array}$ & - & $\begin{array}{l}\text { Possuía várias manchas de } \\
\text { terra preta, com tamanho } \\
\text { aproximado médio de } 10 \mathrm{~m} \\
\text { X } 10 \mathrm{~m} \text {, formando } \\
\text { aproximadamente um } \\
\text { semicírculo assim como no } \\
\text { caso do Fonseca. Os } \\
\text { vestígios arqueológicos } \\
\text { formavam uma camada de, } \\
\text { no máximo, } 40 \mathrm{~cm} \text { de } \\
\text { espessura. O sítio } \\
\text { apresentava outras } \\
\text { características, tais como: } \\
\text { manchas de ocre agrupadas } \\
\text { ou esparsas, manchas e areia } \\
\text { clara,agrupamentos de } \\
\text { partículas de carvão em toda } \\
\text { a extensão do setor e em } \\
\text { profundidade. }\end{array}$ & $\begin{array}{l}38.000 \mathrm{~m}^{2} \\
\text { ou } 3,8 \\
\text { hectares }\end{array}$ & $\begin{array}{l}\text { Pallestrini, } \\
1975\end{array}$ \\
\hline Panema & $\begin{array}{l}\text { UTM } \\
\text { Zona:22K } \\
755.715 \mathrm{e} \\
7387.730\end{array}$ & $\begin{array}{l}\text { Campina } \\
\text { do Monte } \\
\text { Alegre - } \\
\text { SP }\end{array}$ & $\begin{array}{l}\text { Marisa } \\
\text { Coutinho } \\
\text { Afonso e } \\
\text { equipe }\end{array}$ & $\begin{array}{l}\text { Final } \\
\text { dos anos } \\
1990\end{array}$ & $\begin{array}{l}290 \pm 40 \\
\mathrm{BP}(\text { Beta } \\
\mathrm{n}^{\circ} \\
144862) \\
\text { para o } \\
\text { esqueleto; } \\
2030 \mathrm{AP} \\
\text { para a } \\
\text { cerâmica }\end{array}$ & $\begin{array}{l}1 \text { sepultamento } \\
\text { dentro de urna }\end{array}$ & $\begin{array}{l}\text { Estava em topo e encosta de } \\
\text { colina suave, e apresentava } \\
\text { manchas de solo } \\
\text { antropogênico }\end{array}$ & - & $\begin{array}{l}\text { Piedade } \& \\
\text { Soares, } 2000\end{array}$ \\
\hline
\end{tabular}




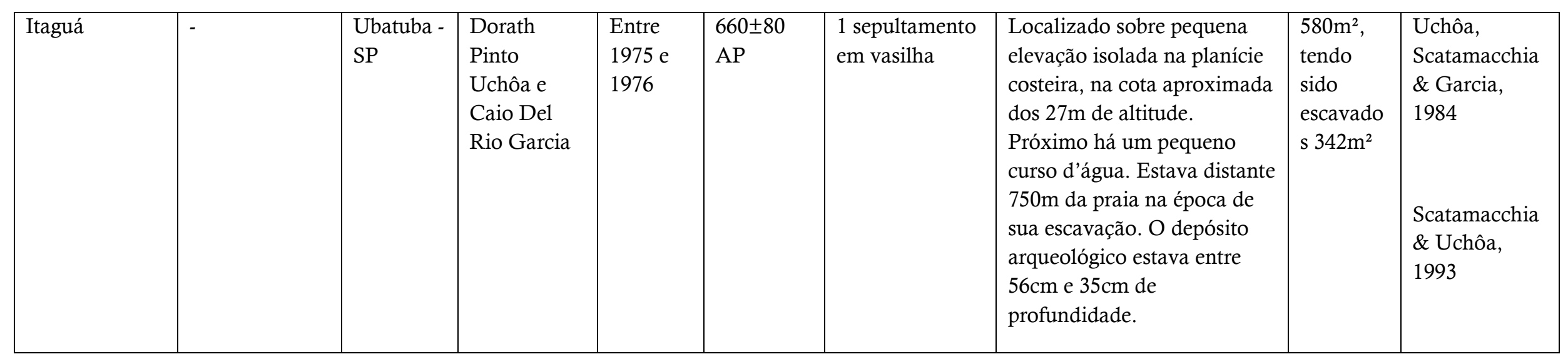


Mapa 2: Municípios onde estão os sítios que analisamos material cerâmico e/ou ósseo. Rosa=Tupinambá; castanho= Guarani; verde=Tupinambá e Guarani. Elaboração: Glauco Constantino Perez.
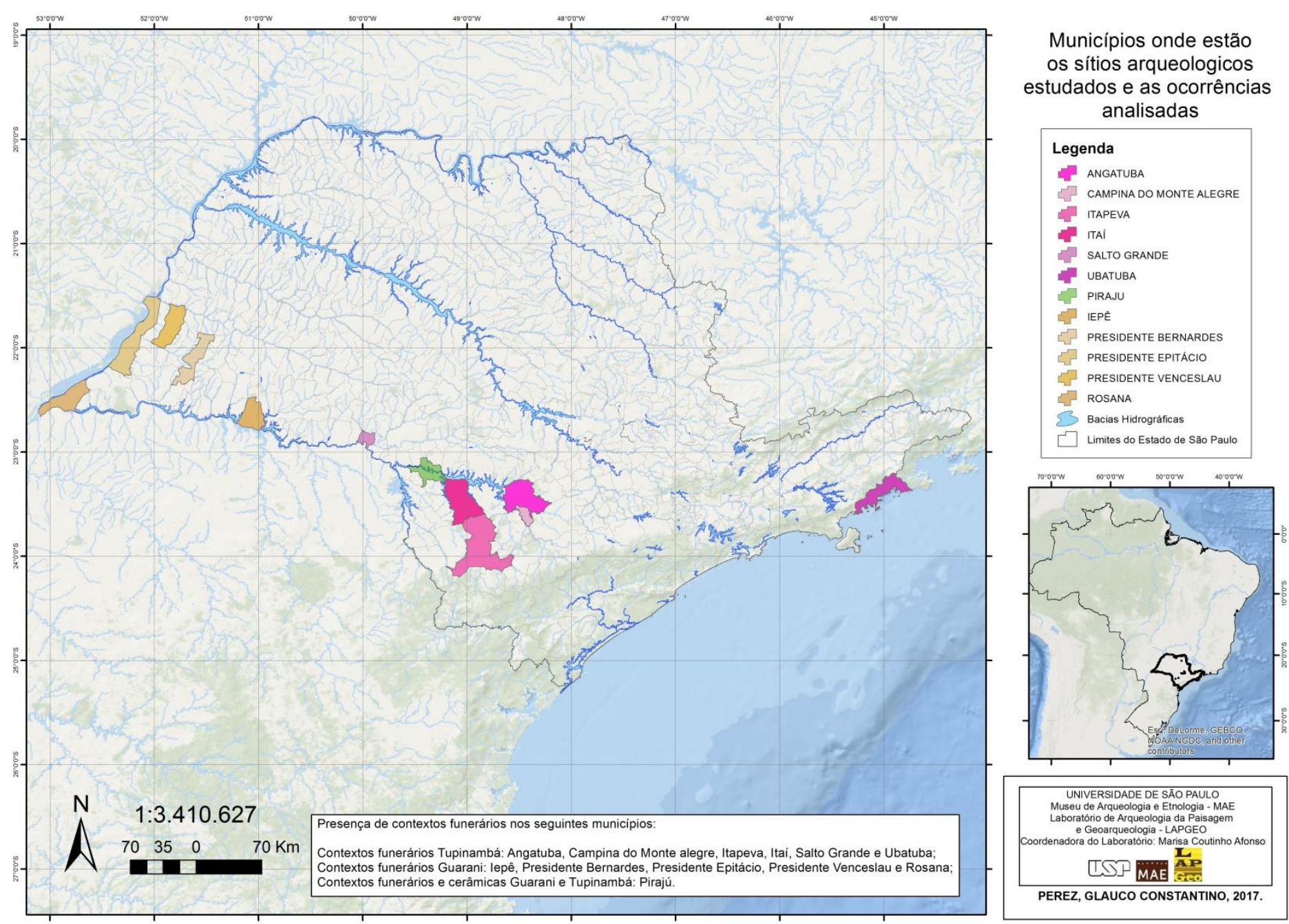


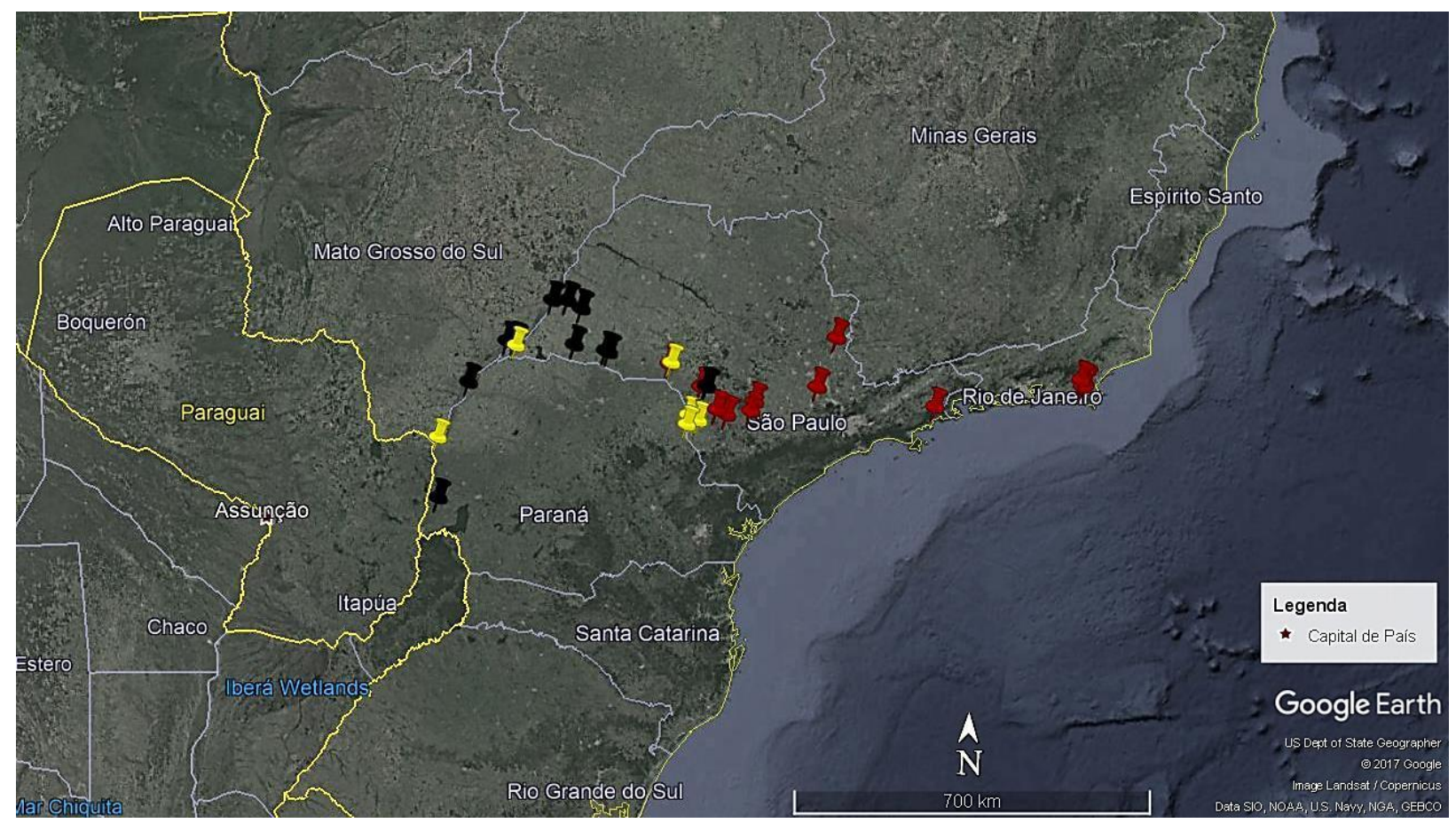

Figura 9: Croqui com a localização dos municípios dos sítios descritos nessa dissertação que possuíam informação para tal. Legenda das cores: vermelho = sítios com material cerâmico funerário Tupinambá; preto = sítios com material cerâmico funerário Guarani; amarelo = sítios sem classificação do seu material funerário.

\section{Sítio Fonseca}

Localizava-se no município de Itapeva (SP), em terras da Fazenda Fonseca. Por ocasião do plantio de milho na fazenda, em 1967, depois de ser passado o arado, agricultores encontraram fragmentos cerâmicos esparsos e potes inteiros cujas tampas, arrancadas pelo disco do arado, deixaram à mostra ossos. Alguns desses potes foram retirados do solo e enviados ao ginásio estadual de Itapeva, tendo sido guardados algumas mandíbulas reconhecidas como humanas. Ao se inteirar da notícia, o vice prefeito da cidade entrou em contato com a Universidade de São Paulo, requisitando o envio de especialistas à região. A equipe coordenada pela arqueóloga Dra. Luciana Pallestrini deu então início a uma série de trabalhos de campo e laboratório na área (Pallestrini, 1969).

O sítio se localiza em uma colina de pequena elevação, a 40m de altitude em relação ao rio mais próximo, sendo que a colina era ladeada por dois rios de pequeno porte. Era a céu aberto, a 40 metros de altitude do córrego Agrião. Localizado em topo de colina, tinha uma área de $40 \mathrm{mil} \mathrm{m}^{2}$ ou 4 hectares. Apresentava manchas de terra preta, que estavam dispostas no topo da colina. Essas manchas, que eram um total de 8, tinham, segundo a autora, diâmetros de $10 \mathrm{~m} \times 8 \mathrm{~m}, 7 \mathrm{~m} \times 5 \mathrm{~m}, 6 \mathrm{~m} \times 5 \mathrm{~m}$ e $7 \mathrm{~m} \times 6 \mathrm{~m}$. O material arqueológico, com exceção 
dos sepultamentos, era encontrado sempre dentro das manchas. As datações para esse sítio são 1076 AP, $1100 \pm 110$ AP, $1010 \pm 100$ AP, $1190 \pm 120$ AP,970 \pm 100 AP, $1100 \pm 100$ AP, $1110 \pm 110$ AP e 899 AD, realizadas através do método Termoluminescência.

\section{Sítio Prassévichus}

Foi escavado primeiramente entre 1981 e 1982. Em 1998 e 1999, os trabalhos no sítio foram reiniciados, foram descobertas novas manchas de terra preta, e o sítio foi renomeado para Caçador.

Sítio a céu aberto, localizado em topo de colina, próximo da confluência do Ribeirão do Caçador com o rio Taquari (afluente do Paranapanema pela margem esquerda), município de Itaberá - SP. Sua área era de $80 \mathrm{mil} \mathrm{m}^{2}$ ou 8 hectares, tendo sido escavado em 1981 e 1982. Era constituído por 9 manchas de terra preta de diâmetros que variavam entre 8 e 10m (Pallestrini, 1983/4). Segundo a autora, as manchas de terra preta se apresentavam em dois grupos, um de seis manchas formando quase um semicírculo aberto para o leste, e o outro com três, dispostas em linha reta. As urnas 1, 7 e 8 estariam mais relacionadas com este último grupo de manchas, enquanto as urnas 2, 3, 4, 5 e 6 com o outro. A planta do sítio feita pela autora mostra isso.

\section{Sitio Salto Grande do Paranapanema}

Este sítio depois foi renomeado para Jequitibá (Morais, 1999), mas também optamos por manter o nome original.

Localiza-se no município de Salto Grande, e foi interpretado como os remanescentes de uma aldeia de horticultores da Tradição Tupiguarani. O sítio está em terraço fluvial elevado, e localizava-se próximo ao antigo Salto Grande dos Dourados, o maior acidente do leito do Paranapanema - hoje em dia destruído por causa da construção da usina hidrelétrica de Salto Grande, nos anos 1950 - a jusante (na parte de baixo), a $500 \mathrm{~m}$ da cachoeira. Foi pesquisado primeiro em 1985 e depois nos anos 1990. Tratava-se de uma área que se estendia por várias chácaras de recreio, tendo sido possível a escavação apenas em uma, a chácara 7. Foram encontrados remanescentes humanos por moradores locais, que foram descontextualizados e analisados por Piedade (Morais \& Piedade,1994). Foi encontrada também uma urna com remanescentes humanos, in situ (Morais, 1997). 


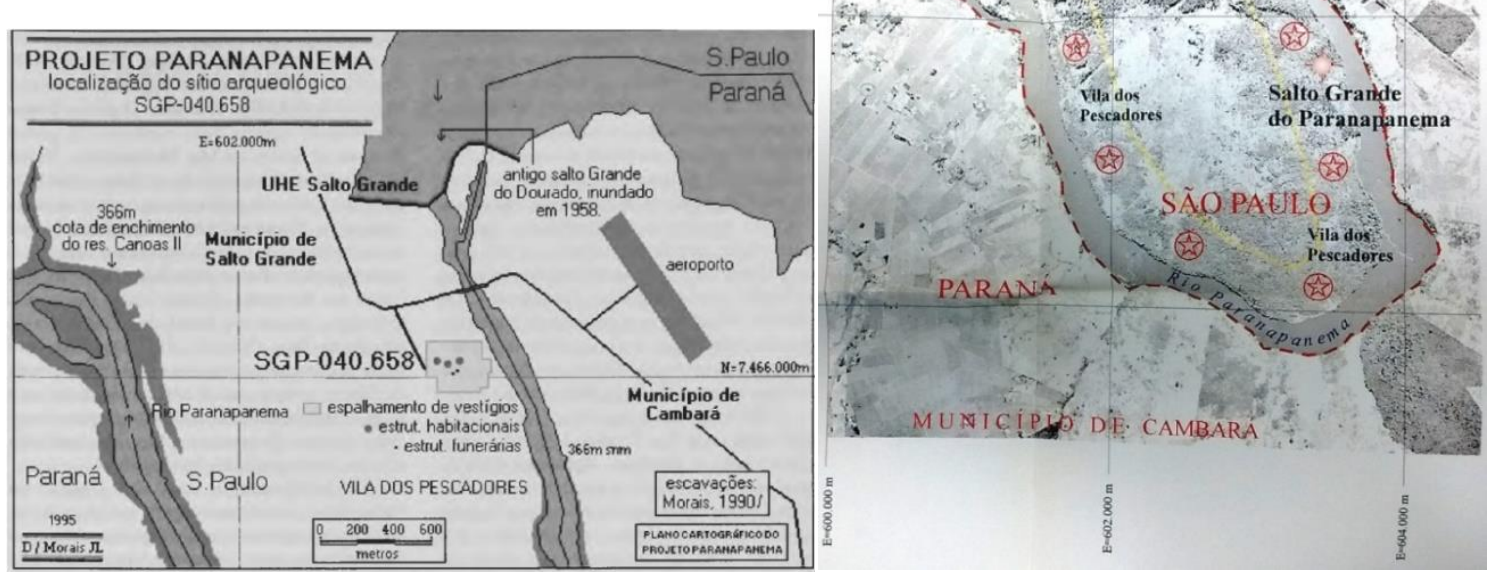

Figuras 10 e 11: Localização do sítio Salto Grande do Paranapanema. Fonte: Morais \& Piedade, 1994; Morais, 1999.

\section{Sítio Jango Luiz}

Do material cerâmico descrito para esse sítio encontramos apenas uma vasilha fragmentada. Mas a descrição de Luciana Pallestrini é similar ao do Fonseca.

Localizado no município de Angatuba (SP), em topo de pequena elevação, com um rio na base, e teve sua escavação realizada em 1969. A escavação desse sítio tinha como objetivo, entre outras coisas, fazer uma correlação com o que foi encontrado no Fonseca. Estava situado em topo de colina e tinha uma área de $38.000 \mathrm{~m}^{2}$ ou 3,8 hectares. Possuía várias manchas de terra preta, com tamanho aproximado médio de $10 \mathrm{~m}$ X $10 \mathrm{~m}$, formando aproximadamente um semicírculo assim como no caso do Fonseca. Os vestígios arqueológicos formavam uma camada de, no máximo, $40 \mathrm{~cm}$ de espessura. O sítio apresentava outras características, tais como: manchas de ocre agrupadas ou esparsas, manchas e areia clara com cerca de $2 \mathrm{~cm}$ de comprimento de eixo maior, mais frequentes nos primeiros $10 \mathrm{~cm}$ de decapagem, agrupamentos de partículas de carvão em toda a

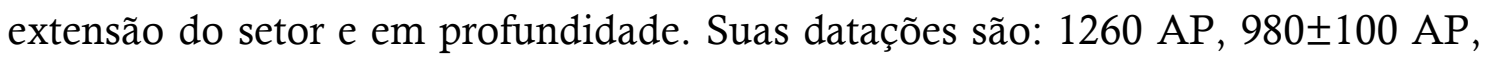
$1540 \pm 150$ AP (765 AD) e1076 AP.

A região constitui parte da depressão paleozoica, com relevo constituído por colinas de topo plano e vertentes côncavas, cujas altitudes variam entre $660 \mathrm{~m}$ 
e 750m (Pallestrini, 1975). A planta do sítio, feita pela autora, mostra a distribuição das manchas de terra preta e das urnas que foram descritas por ela.

Pallestrini (1968-1969) traz informações sobre o sítio Jango Luiz, que apresentava manchas de terra preta e diversas estruturas funerárias, no entanto apenas 3 foram encontradas pelos arqueólogos e somente uma vasilha foi encontrada por nós. Segundo a autora, as urnas funerárias do sítio Jango Luiz eram muito similares às do Fonseca e Prassévichus.

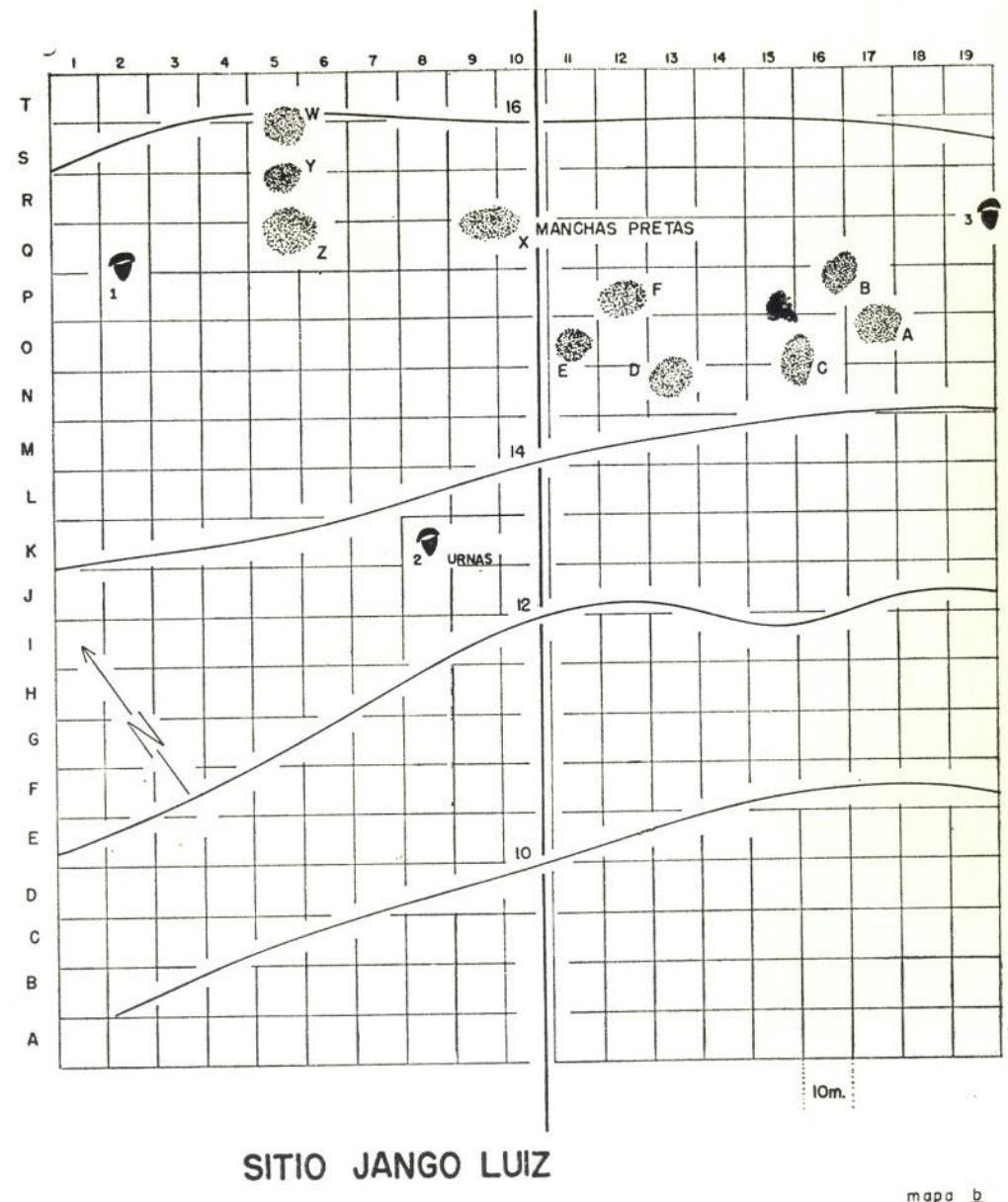

Figura 12: Planta do sítio Jango Luiz. Fonte: Pallestrini, 1975.

As figuras a seguir são a vasilha do sítio Jango Luiz fotografada por nós e os desenhos das vasilhas encontradas por Pallestrini: 


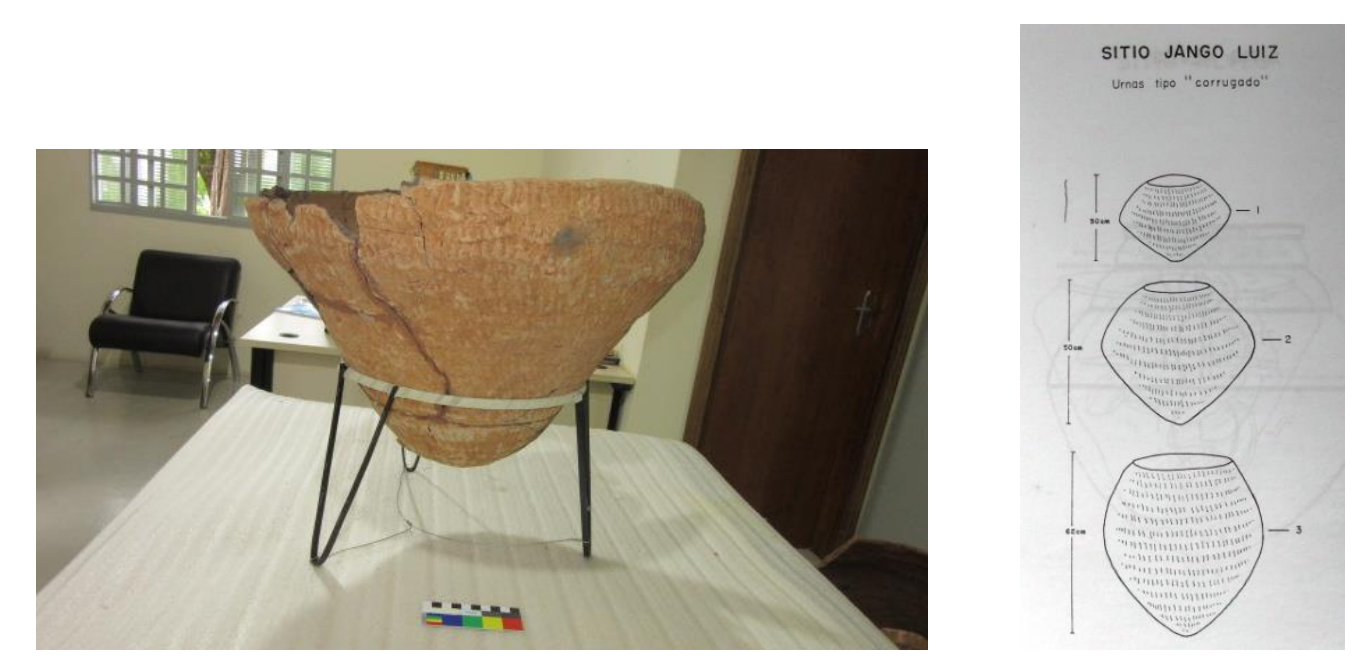

Figuras 13 e 14: Vasilha do sítio Jango Luiz com a borda quebrada. Foto: Mariana Cristante. E desenho das vasilhas encontradas por Pallestrini no sítio. Fonte: Pallestrini, 1975.

\section{Sitio Panema}

Esse sítio se localizava em Campina do Monte Alegre (SP), e possuía coordenadas UTM 22K755.715 e 7387.730. Estava em topo e encosta de colina suave, e apresentava manchas de solo antropogênico. A datação do esqueleto

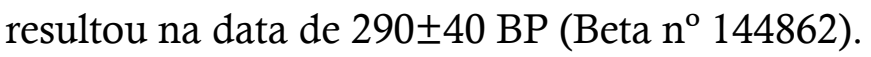

Nele foi encontrado um sepultamento em vasilha cerâmica por moradores locais, que será analisado mais adiante nesse capítulo. O conjunto funerário possuía urna e tampa, ambas corrugadas. O sítio foi classificado no artigo de Piedade \& Soares (2000) como Guarani, mas a morfologias das vasilhas cerâmicas sugere que na verdade seja Tupinambá, o que traz questões intrigantes devido ao tipo de sepultamento que havia, que serão detalhadas mais adiante. As figuras abaixo são fotos das vasilhas. Não conseguimos encontrar a urna, apenas a tampa, que estava no Centro Regional de Piraju.

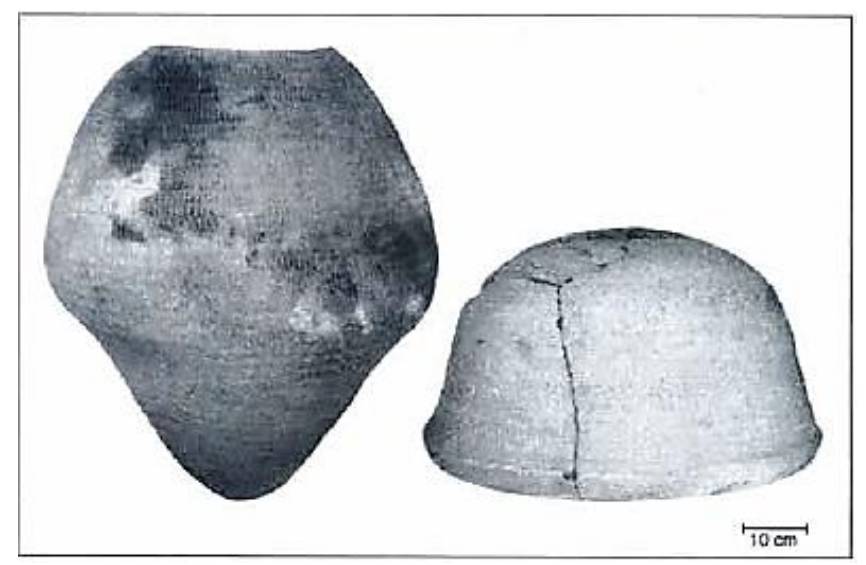

Figura 15: Vasilhas funerárias do sítio Panema. Fonte: Piedade \& Soares, 2000. 


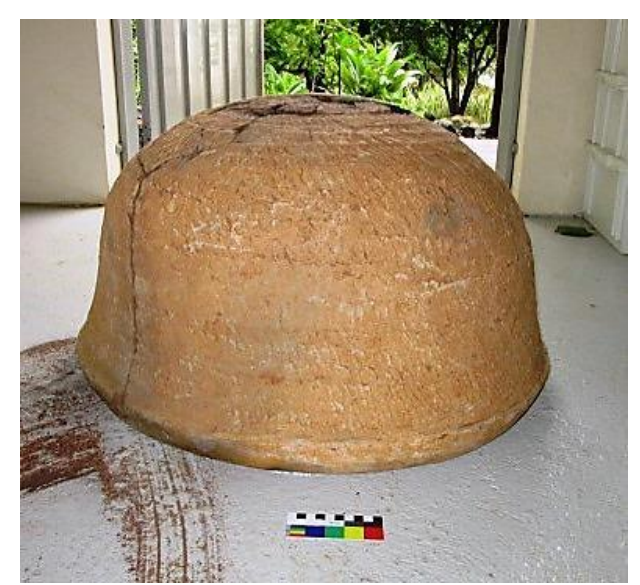

Figura 16: Vasilha que servia como tampa no conjunto funerário do sítio Panema. Foto: Mariana Cristante.

\section{Sítio Itaguá}

O sítio foi escavado em uma pesquisa de salvamento realizada pelos arqueólogos do antigo Instituto de Pré-História da Universidade de São Paulo (que agora é parte do Museu de Arqueologia e Etnologia) Dra. Dorath Pinto Uchôa e Dr. Caio Del Rio Garcia, entre 1975 e 1976. O material cerâmico foi analisado no início da década de 1980 pela arqueóloga Prof. Dra. Maria Cristina Mineiro Scatamacchia. Segundo Uchôa, Scatamacchia e Garcia (1984), foi enquadrado na chamada Tradição Tupiguarani, e foi considerado como sendo uma ocupação relativamente recente, da época do contato com os europeus. Isso devido à presença de 4 contas azuis de vidro, um disco de cobre (de diâmetro $13,5 \mathrm{~cm}$ e espessura $1,8 \mathrm{~mm}$ ), e um prato cerâmico com características formais e de tratamento de superfície que lembram a forma e decoração de uma louça europeia típica do século XVI. A datação para o sítio, proveniente de uma amostra de carvão, resultou em 660 180 AP ou aproximadamente $1290 \mathrm{AD}$, porém foi rejeitada pelos pesquisadores por ser muito anterior à época da chegada dos europeus nas Américas.

O sítio Itaguá estava localizado sobre pequena elevação isolada na planície costeira, na cota aproximada dos $27 \mathrm{~m}$ de altitude. Próximo à elevação há um pequeno curso d'água conhecido como Rio da Lagoa. Estava distante $750 \mathrm{~m}$ da praia na época de sua escavação. A área do sítio foi calculada em aproximadamente $580 \mathrm{~m}^{2}$, tendo sido escavados $342 \mathrm{~m}^{2}$. De acordo com os autores, o depósito arqueológico estava entre $56 \mathrm{~cm}$ e $35 \mathrm{~cm}$ de profundidade. O material é composto, além dos itens descritos acima, por mais de 3000 fragmentos de cerâmica, vasilhas inteiras e líticos. 


\section{Sitio Alves}

Localizava-se no município de Piraju, à beira da rodovia que ligava Piraju a São Paulo, a uma distância de mais ou menos $7 \mathrm{~km}$ daquela cidade. Foi escavado em 1970 por Luciana Pallestrini. Sítio a céu aberto, localizado em planalto, a aprox. 110 metros do curso d'água mais próximo, o ribeirão Alves, no topo de uma colina de mais ou menos $17 \mathrm{~m}$. Presença de afloramento de basalto e arenito silicificado no entorno. Área de $40 \mathrm{mil} \mathrm{m}^{2}$ ou 4 hectares. As datações para o sítio

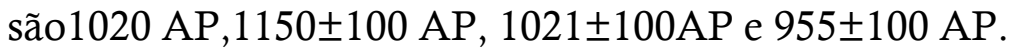

O sítio possuía manchas de terra preta, tal como os outros, e contextos funerários externos às manchas, como os outros. As manchas apresentam um eixo máximo de 10m e um mínimo de 5m (PALLESTRINI, 1975).

\section{Sítio Nunes}

O sítio Nunes localiza-se na contravertente do rio em relação ao Alves, bastante próximo, então devido a essa característica e ao material cerâmico, Morais (1999) considera esses dois sítios como um mesmo complexo. O sítio Alves começou a ser escavado em 1969 por Luciana Pallestrini, e o Nunes só foi escavado em 1986.

\section{Sítio Aguinha}

Foi diagnosticado em 1999, quando a família do proprietário da fazenda percebeu duas bordas de vasilhas cerâmicas aflorando na superfície do solo, próximo ao lago da UHE Capivara, município de Iepê. Logo foi constatado que se tratava de um sítio Guarani, e iniciaram-se pesquisas arqueológicas. A datação foi

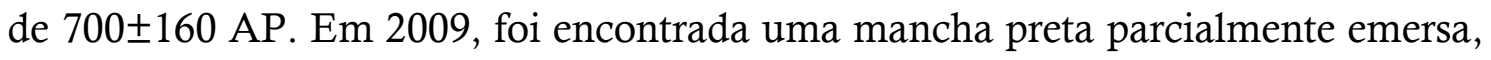
onde foram encontrados 306 fragmentos cerâmicos. Por toda a área havia fragmentos cerâmicos em superfície, totalizando mais de 4 mil, e líticos lascados e polidos. A cerâmica do sítio é 77,21\% de tipo liso, 7,63\% corrugado, 3,22\% pintado e 9,33\% com engobo, entalhado, inciso, ungulado serrungulado, escovado ou mamilar (Faccio, 2011).

Além dos contextos funerários descritos mais adiante no capítulo, foram encontradas outras vasilhas inteiras, algumas delas consideradas urnas pelos arqueólogos que as escavaram (Faccio, 2011). Tratam-se das urnas 4, 5 e 6. 


\section{Sítio Pernilongo}

O sítio foi descoberto pelo dono da fazenda onde se encontra em 1999, durante um período de seca em que as águas da represa da UHE Capivara

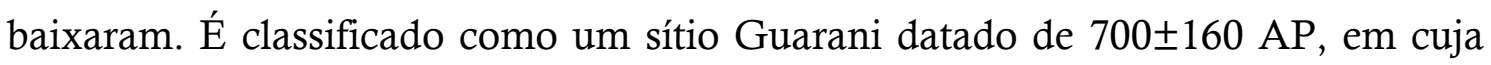
área pareciam ter havido casas indígenas e urnas enterradas fora das mesmas. Nele foram encontrados muitos fragmentos, vasilhas, urnas, fragmento de um cachimbo, fundos de casas, líticos lascados e polidos, e adornos em resina de jatobá (tembetá e adornos auriculares). Esses adornos foram analisados por Faria et al (2004). O tratamento de superfície dos fragmentos cerâmicos encontrados no sítio é $91,71 \%$ alisamento interno e externo, 4,09\% enegrecimento interno, 0,78\% enegrecimento interno e externo, $0,47 \%$ alisamento externo, 0,78\% alisamento interno, 5,66\% pintura e 5,51\% engobo (Faccio, 2011).

Além dos contextos funerários I e II descritos mais adiante no capítulo, outras vasilhas consideradas urnas também foram encontradas. Trata-se da urna 3. A urna 2 é um cambuchí que foi encontrado dentro da água, com uma vasilha menor dentro., sem remanescentes humanos (que poderiam ter desaparecido devido à ação das águas da represa).

\section{Sítio Lagoa São Paulo 2}

Localizado no município de Presidente Epitácio - SP, o sítio encontra-se na margem esquerda do rio Paraná, em um terraço fluvial, em uma área onde em 1993 foram encontradas duas urnas de cerâmica durante a retirada de sedimentos de um barranco por uma empresa ceramista. A área antes da construção do lago da UHE Engenheiro Sérgio Motta era ocupada por um complexo lacustre (CABRERA, 2015, p. 64).

Em 1982, uma equipe da Universidade de São Paulo, coordenada por Luciana Pallestrini, escavou no distrito de Campinal, relativamente próximo, outro sítio, que foi denominado Lagoa São Paulo. O nome do sítio em questão - Lagoa São Paulo 2 - veio daí.

O sítio passava por processos erosivos devido à ação das águas do lago, que estavam solapando a encosta onde se encontra o sítio. Além disso, havia no terreno construções ilegais (um chiqueiro de porcos, um galinheiro e uma horta) (CABRERA, 2015, p. 53). 
O material arqueológico foi encontrado a uma média de $40 \mathrm{~cm}$ de profundidade, e supõe-se que os sítios tenham em torno de 1000 anos (CABRERA, 2015 , p. 66), embora não haja datas específicas para este sítio. O método de escavação utilizado foi o de superfícies amplas (CABRERA, 2015, p. 67). Os trabalhos de campo nele se realizaram em 1995, 1998, 2005 e 2010.

Foram encontradas 22 manchas de terra preta no sítio, sendo que duas delas estavam em um barranco que estava sendo retirado para a obtenção de argila, uma estava junto ao leito do lago, e as outras estavam em locais acima do nível da água.

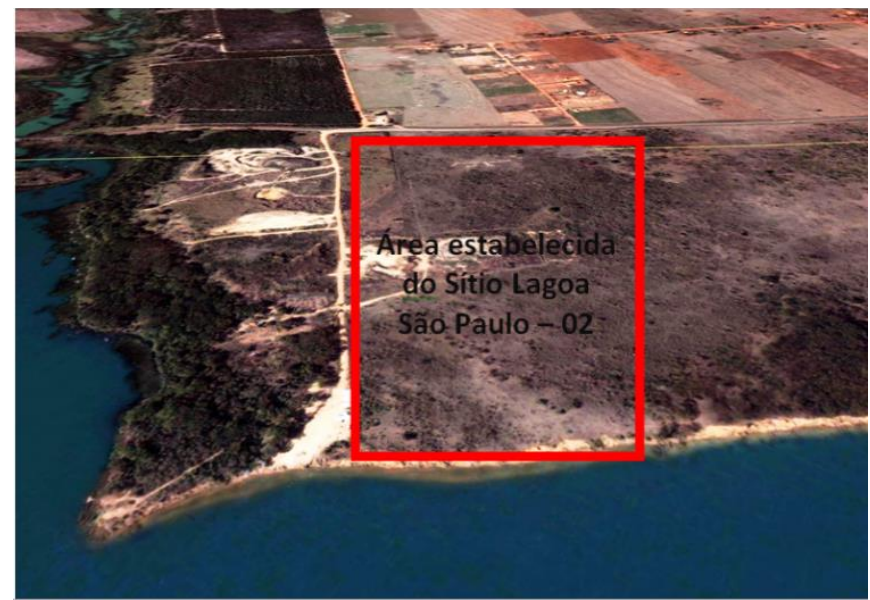

Figura 17: Área do sítio Lagoa São Paulo 2. Fonte: Kunzli et al, 2010.

Para os sítios Silveira, Lopes, Romanini e Canuto não encontramos mais informações e descrições dos contextos funerários, assim como para as ocorrências dos municípios de Piraju e Rosana.

\subsection{2 - Características e áreas de implantação dos sítios}

Os sítios Fonseca, Prassévichus, Jango Luiz e Panema são a céu aberto, e estão localizados em topo de colina, próximos a córregos, o segundo próximo à confluência com o rio Taquari. Eles possuem 8 e 9 manchas de terra preta, respectivamente, interpretadas como vestígios de habitações. Já o Salto Grande do Paranapanema se encontra em um terraço fluvial elevado, a jusante da cachoeira que era o maior acidente do leito do rio. $\mathrm{O}$ padrão de assentamento desse último sítio difere dos demais, pois os primeiros seguem o padrão topo de morro com um pequeno rio na base, longe de rios de grande porte, enquanto o último se localiza na calha de um rio de grande porte, em terraço fluvial elevado e em uma área bastante peculiar, a 500m da antiga maior cachoeira do Paranapanema. 
E o sítio Itaguá possui um padrão de assentamento totalmente diferente, pois encontrava-se no litoral, próximo à praia, porém igualmente em topo de morro com um pequeno rio próximo, assim como o Fonseca e Prassévichus.

O sítio Alves também é a céu aberto, localizado no topo de uma colina, próximo a um ribeirão, o que torna seu padrão de implantação semelhante ao do Fonseca e Prassévichus. Apresentava 7 manchas de terra preta. O sítio Nunes encontra-se próximo ao Alves, e é considerado como sendo o mesmo complexo (Morais, 1999). Já os sítios Aguinha e Pernilongo foram encontrados bem próximos ao lago da UHE Capivara, ficando à mostra somente no período das secas. Provavelmente se encontravam em baixa/média vertente, na calha do Paranapanema. Já o Lagoa São Paulo 2, que possui 22 manchas de terra preta, encontra-se também na calha de rio de grande porte, em terraço fluvial, num padrão de assentamento semelhante aos outros 2 e também diferenciado do Alves.

Entre os sítios analisados, a maior parte daqueles com cerâmica Tupinambá encontram-se em topos de colinas e próximos a rios de menor porte - exceto o Salto Grande -, enquanto a maioria dos sítios Guarani encontra-se na calha de um grande rio - exceto o Alves/Nunes. Como já salientava Morais (1999), os sítios do alto e médio Paranapanema se encontram em áreas de assentamento diferentes dos do baixo curso. Isso mostra padrões de assentamento diferenciados entre os sítios Tupinambá e Guarani, mas também desvios dentro desse padrão - os seja, sítios estabelecidos em locais diferentes -, demonstrando que grupos Guarani e Tupinambá podiam ocupar tanto as proximidades de rios de menor porte quanto de maior, em ocupações longas. Porém, não é possível saber se a ocupação do Salto Grande foi longa ou não, porque estava muito impactado e não foram encontradas manchas de terra preta.

De qualquer modo, o padrão já notado por Morais na região do Paranapanema ocorre, demonstrando que havia uma diferença bem marcada entre os padrões de assentamento do alto/médio e do baixo Paranapanema, ao menos entre os sítios analisados. Esse padrão de assentamento diferenciado coincide, em sua maior parte, com as diferenças nas cerâmicas funerárias: Tupinambá em partes altas de morros com um rio de menor porte próximo, Guarani na calha do Paranapanema ou Alto Paraná. Mas há exceções, que são os sítios Alves - que 
segue o padrão Tupinambá apesar de a cerâmica ser Guarani -, e Salto Grande do Paranapanema, que segue o padrão Guarani.

Não há datações para cada mancha ou sepultamento individual, então não há como saber se todas as manchas e os sepultamentos são simultâneos. Mas a formação das manchas de terra preta já é um indicativo de uma ocupação pelo menos um pouco longa.

\subsubsection{Cronologia}

Levantamos e observamos as datações para os sítios, que estão no quadro 9.

De uma maneira geral, pode-se dizer que a região do alto Paranapanema analisada parece ter sido ocupada por grupos Tupinambá (sítios Fonseca, Prassévichus, Jango Luiz) pelo menos desde o século oitavo, e perdurou pelo menos até um século depois do ano mil nos sítios Fonseca e Jango Luiz de uma maneira mais ou menos contínua. A ocupação por grupos Guarani nessa região (sítio Alves) parece ter se iniciado um pouco depois, pouco antes do ano mil. Já a ocupação dos sítios do baixo Paranapanema analisados é posterior, mas não estamos considerando aqui todas as datas Guarani do baixo Paranapanema. Há datas mais antigas, como o sítio Ragil, com 1660 AP (Morais, 2000).

As datações disponíveis para os sítios sugerem que o Fonseca e o Alves possuem uma certa contemporaneidade, ao menos por algum tempo. Por possuírem datações muito próximas e estarem em regiões também próximas, é muito provável que tenha havido contatos entre as pessoas do Alves e as do Fonseca, o que pode ter gerado influências mútuas. As datações do sítio Jango Luiz também apontam para um período similar de contato, sugerindo que na região do alto e médio Paranapanema, em torno do ano mil, grupos Guarani e Tupinambá habitavam e muito provavelmente tinham contatos entre si, conforme já propunha Brochado (1984). As manchas de terra preta sugerem que essas ocupações eram duradouras. Não encontramos datações para o Salto Grande, que fica mais a jusante do rio. Mas ele mostra que a ocupação Tupinambá pode ter chegado pelo menos até esse ponto, o local da antiga maior cachoeira do Paranapanema. E a

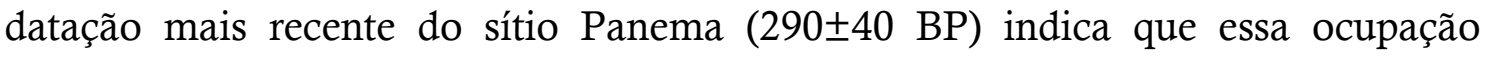
Tupinambá provavelmente perdurou até depois do contato com o europeu. 
Quadro 9: Cronologia para os sítios principais e secundários que possuem datas.

\begin{tabular}{|c|c|c|c|c|c|}
\hline $\begin{array}{l}\text { Nome do } \\
\text { sítio }\end{array}$ & $\begin{array}{c}\text { Local do } \\
\text { sítio }\end{array}$ & $\begin{array}{c}\text { Datações para o } \\
\text { sítio }\end{array}$ & Método de datação & $\begin{array}{l}\text { Área do } \\
\text { sítio }\end{array}$ & $\begin{array}{c}\text { Classificação } \\
\text { do material } \\
\text { cerâmico } \\
\text { funerário }\end{array}$ \\
\hline Fonseca & $\begin{array}{l}\text { Itapeva - } \\
\text { SP }\end{array}$ & $\begin{array}{c}899 \mathrm{AD} \\
1190 \pm 120 \mathrm{AP} \\
1110 \pm 110 \mathrm{AP} \\
1100 \pm 100 \mathrm{AP} \\
1100 \pm 110 \mathrm{AP} \\
1076 \mathrm{AP} \\
1010 \pm 100 \mathrm{AP} \\
970 \pm 100 \mathrm{AP} \\
\end{array}$ & Termoluminescência & $\begin{array}{c}40.000 \mathrm{~m}^{2} \\
\text { ou } 4 \\
\text { hectares }\end{array}$ & Tupinambá \\
\hline Jango Luiz & $\begin{array}{l}\text { Angatuba } \\
\text { - SP }\end{array}$ & $\begin{array}{c}1540 \pm 150 \mathrm{AP} \\
(765 \mathrm{AD}), 1260 \\
\mathrm{AP}, 1076 \mathrm{AP} \\
980 \pm 100 \mathrm{AP}\end{array}$ & Termoluminescência & $\begin{array}{c}38.000 \mathrm{~m}^{2} \\
\text { ou } 3,8 \\
\text { hectares }\end{array}$ & Tupinambá \\
\hline Panema & $\begin{array}{l}\text { Campina } \\
\text { do Monte } \\
\text { Alegre - } \\
\text { SP }\end{array}$ & $\begin{array}{l}290 \pm 40 \text { BP (Beta } \\
\left.\mathrm{n}^{\circ} 144862\right) \text { para o } \\
\text { esqueleto; } 2030 \\
\text { AP para a } \\
\text { cerâmica }\end{array}$ & $\begin{array}{l}\text { Carbono } 14 \text { - } \\
\text { datação do esqueleto; } \\
\text { Termoluminescência - } \\
\text { datação da cerâmica }\end{array}$ & - & Tupinambá \\
\hline Itaguá & $\begin{array}{l}\text { Ubatuba - } \\
\text { SP }\end{array}$ & $660 \pm 80 \mathrm{AP}$ & Carbono 14 & $\begin{array}{l}580 \mathrm{~m}^{2} \\
\text { tendo sido } \\
\text { escavados } \\
342 \mathrm{~m}^{2}\end{array}$ & Tupinambá \\
\hline Alves & Piraju - SP & $\begin{array}{l}1150 \pm 100 \mathrm{AP} \\
1021 \pm 100 \mathrm{AP} \\
1020 \mathrm{AP} \\
955 \pm 100 \mathrm{AP}\end{array}$ & Termoluminescência & $\begin{array}{l}40.000 \mathrm{~m}^{2} \\
\text { ou } 4 \\
\text { hectares }\end{array}$ & Guarani \\
\hline Aguinha & Iepê - SP & $700 \pm 160 \mathrm{AP}$ & Termoluminescência & - & Guarani \\
\hline Pernilongo & Iepê - SP & $700 \pm 160 \mathrm{AP}$ & Termoluminescência & - & Guarani \\
\hline
\end{tabular}

Os sítios Panema e Itaguá possuem datações e materiais que sugerem um período posterior à chegada dos europeus às Américas, pelo menos em certo período da ocupação dos sítios. O sepultamento bastante peculiar do sítio Panema foi datado em um período pós-contato, enquanto no sítio Itaguá havia materiais trazidos pelo europeu, embora sua data seja anterior.

Já os sítios Aguinha e Pernilongo também possuem uma datação semelhante, embora seja uma única data para cada um. E ambos são muito próximos, um ao lado do outro na margem da represa da Capivara. Isso sugere que também pode ter havido relações e contatos entre os Guarani que habitaram cada sítio.

Portanto, de uma maneira geral, os dados analisados sugerem que temos ocupações longas e mais ou menos contínuas para os Tupinambá e Guarani no alto e médio Paranapanema, de mais ou menos duzentos a trezentos anos. Embora não haja datas para o sítio Lagoa São Paulo 2, a grande quantidade de manchas de terra preta sugere que também seja uma ocupação longa, então os Guarani no alto 
Paraná e provavelmente também baixo Paranapanema também possuíam ocupações duradouras.

Os contextos funerários dos sítios principais podem ter grandes variações diacrônicas, sendo um bem mais antigo ou mais recente que o outro dentro do mesmo sítio, e não há controle cronológico deles. Mas, é bastante provável que as práticas funerárias do Fonseca e do Alves tenham convivido, assim como as do Aguinha e Pernilongo. Isso sugere um cenário em que grupos que ocupavam, em um período próximo, locais diferentes da mesma região (o alto e médio Paranapanema, e o baixo curso desse rio), e sendo que alguns provavelmente falavam línguas diferentes - embora semelhantes - (Tupinambá e Guarani), possuíam práticas funerárias que talvez tenham convivido, e que apresentam continuidades e descontinuidades, como será discutido durante o capítulo e resumido ao final.

No caso dos sítios Aguinha e Pernilongo, devido à sua proximidade, podemos até pensar em uma ocupação contínua da mesma área. Nessa mesma área, cerâmicas Guarani constituem parte de práticas funerárias que poderiam ter sido parte integrante de um mesmo sistema, as mesmas pessoas utilizando aquelas diferentes vasilhas em diferentes locais.

As duas datações do sítio Panema, uma para a cerâmica (2030 AP) e outra

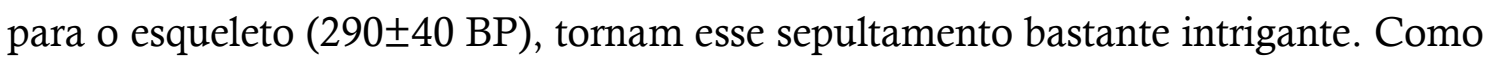
não há muitas datações comparando cerâmicas com esqueletos, a compreensão disso é mais difícil ainda, pois não sabemos se isso poderia ocorrer em outros contextos. Mesmo com o erro da TL, são datas muito distantes. Poderia ser uma urna mais antiga e um esqueleto muito mais recente? Teriam desenterrado uma urna antiga e colocado o esqueleto dentro?

\subsubsection{Análise do material cerâmico e marcas de uso}

\subsubsection{A Variabilidade morfológica}

Fizemos a análise da variabilidade morfológica entre as vasilhas dos diversos sítios. Comparamos cada uma das variáveis escolhidas para cada um dos sítios, chegando a alguns padrões morfológicos. Os sítios principais, sobre os quais possuíamos mais informações e mais material cerâmico (Fonseca, Prassévichus, 
Alves, Aguinha e Pernilongo), foram a base para nossas considerações ${ }^{9}$. Nesses sítios principais, apenas alguns contextos foram bem documentados e descritos: os contextos funerários que chamamos de I e II do sítio Aguinha; I e II do sítio Pernilongo; os contextos I, II, III, IV e V do sítio Fonseca; II, III, IV e V do sítio Alves; e alguns do Prassévichus. Os contextos I e II do Aguinha e II do Pernilongo também foram encontrados sem ossos dentro, mas isso pode ser atribuído à ação das águas do lago da represa ${ }^{10}$. Algumas das vasilhas chamadas de urnas desses contextos foram encontradas por moradores da comunidade local, tendo perdido o seu contexto original. Todas as vasilhas que estamos chamando de urnas foram consideradas urnas funerárias pelos arqueólogos que as escavaram, sem que o critério que os levou a julgarem como urnas seja sempre claro. Faccio (comunicação pessoal) uma vez nos disse que o contexto em que se encontravam era o que a fazia crer que eram urnas, pois o sedimento no entorno onde estavam era menos compactado, atestando solo escavado.

As vasilhas que constituem os contextos funerários dessa região podem ser classificadas em três tipos: urnas, tampas e vasilhas anexas. O que estamos chamando de urnas são as vasilhas maiores (já descritas como urnas por quem as escavou), muitas vezes encontradas com vasilhas dentro, às vezes cobertas por outras vasilhas (tampas), em que poderia haver ossos humanos dentro ou que há a confirmação de ossos, não importando a origem dos mesmos - i. e., se é um sepultamento primário ou secundário. As tampas são as coberturas dos sepultamentos, sendo que nem todas as vasilhas emborcadas são necessariamente tampas. $\mathrm{E}$ as vasilhas anexas são todas as outras que constituem o contexto funerário, que podem estar dentro ou fora de vasilhas maiores (urnas). Essa classificação já havia sido proposta por Noelli (1993). Devemos ressaltar que tratase de uma classificação grosseira feita por nós, e que possui um caráter apenas instrumental, com o intuito de facilitar o processamento dos dados. Essas classes não devem ser consideradas como guias para se compreender as práticas funerárias,

\footnotetext{
${ }^{9} \mathrm{O}$ sítio Lagoa São Paulo 2 possui grande parte de seus contextos apenas parcialmente escavados, portanto, tivemos acesso a apenas uma única vasilha cerâmica, descrita para nós como urna funerária. Assim, em termos de análise cerâmica, o sítio nos forneceu poucas informações, tendo sido mais útil nas análises das práticas funerárias e da espacialidade funerária.

${ }^{10}$ As águas do lago da UHE Capivara sobem e descem, agindo sobre o sítio de maneira a arrastar materiais arqueológicos mais leves, o que dispersa fragmentos cerâmicos e pode ter carregado ossos. Os próprios sítios Aguinha e Pernilongo só puderam ser escavados em um período de seca, pois ficam a maior parte do tempo submersos (Faccio, 2011).
} 
pois são fruto de funcionalidades pré-concebidas atribuídas às vasilhas, sendo uma classificação nada êmica.

É possível notar algumas funcionalidades para as urnas e tampas, que são conter os ossos e cobrir o sepultamento, respectivamente (Noelli, 1993). Essas funcionalidades se repetem, sendo que todos os sepultamentos analisados são compostos, no mínimo, por esses dois elementos, ou seja, urna e tampa. Entretanto, os sepultamentos não são constituídos apenas e simplesmente por urnas e tampas. Dos elementos preservados nos contextos, há os ossos - quase sempre menosprezados e deixados de lado nas análises -, e também podem ser encontradas outras vasilhas e também conchas, tembetás, contas e líticos.

Embora possa ser vista uma funcionalidade para urnas e tampas, as funcionalidades das vasilhas anexas não são muito claras. A própria categoria "vasilhas anexas" é problemática, pois engloba vasilhas com as mais diversas morfologias, encontradas nas mais diversas posições, e que certamente não constituem um conjunto funcional único. Além disso, o termo "anexas" as coloca em uma posição secundária em relação às urnas, o que não se justifica. As fontes etnohistóricas falam em vasilhas deixadas no sepultamento que continham água e alimentos para o morto e os espíritos que rondam a sepultura. Poderia ser essa a funcionalidade dessas vasilhas, ou uma das.

Claro que a funcionalidade das vasilhas é uma categoria completamente nossa, que não leva em conta os significados e agências diversas que esses artefatos possuíam. É apenas a observação de padrões comportamentais que podem ser notados no registro arqueológico, e não tentaremos relacioná-los diretamente a algum significado, pois não é nosso objetivo.

Além disso, embora possamos notar padrões funcionais para as vasilhas, não queremos logo de cara atribuir-lhes funções ou significados fechados e definidos. Como nos traz Holtorf (2002), os significados e a própria identidade material de um artefato não são características intrínsecas, inerentes, fixas e imutáveis dele. São negociados em diferentes circunstâncias sociais, podendo um objeto ter múltiplas identidades materiais diferentes. Essas identidades não são as mesmas em todas as épocas, mas mudam ao longo da história de vida do artefato, pois são o resultado das diferentes relações entre pessoas e coisas. Isso não quer 
dizer que os significados e características atribuídos a um objeto sejam arbitrários, mas sim que esses significados e características são determinados por vários fatores existentes no presente. Portanto, nossas considerações sobre as vasilhas funerárias são fruto de nosso presente e de nossas limitações teórico-metodológicas, e servem para atender a nossas necessidades de conhecer as práticas funerárias, não podendo ser tomadas como a única interpretação possível e imutável.

Feitas essas ressalvas, seguiremos em nossa tentativa de compreensão dos contextos funerários. De início, acreditávamos que todo o material fosse Guarani, porém, as vasilhas encontradas em contexto funerário apresentaram diferenças morfológicas muito significativas, que formam padrões para cada sítio. Os sítios Tupinambá apresentam urnas funerárias com formato piriforme, com base cônica e bordas diretas sem extroversão. O tratamento de superfície delas é corrugado - o que não é um diferencial, estando presente esse tratamento em vasilhas de todos os sítios analisados. Já os contextos Guarani possuem urnas com bordas extrovertidas, não havendo a forma da borda direta sem extroversão.

A figura a seguir é um esquema que traz a espacialidade regional das formas das vasilhas que analisamos. 
Figura 18: Espacialidade regional das formas. Elaboração: Mariana Cristante, Glauco Perez e Gabriele Santos.

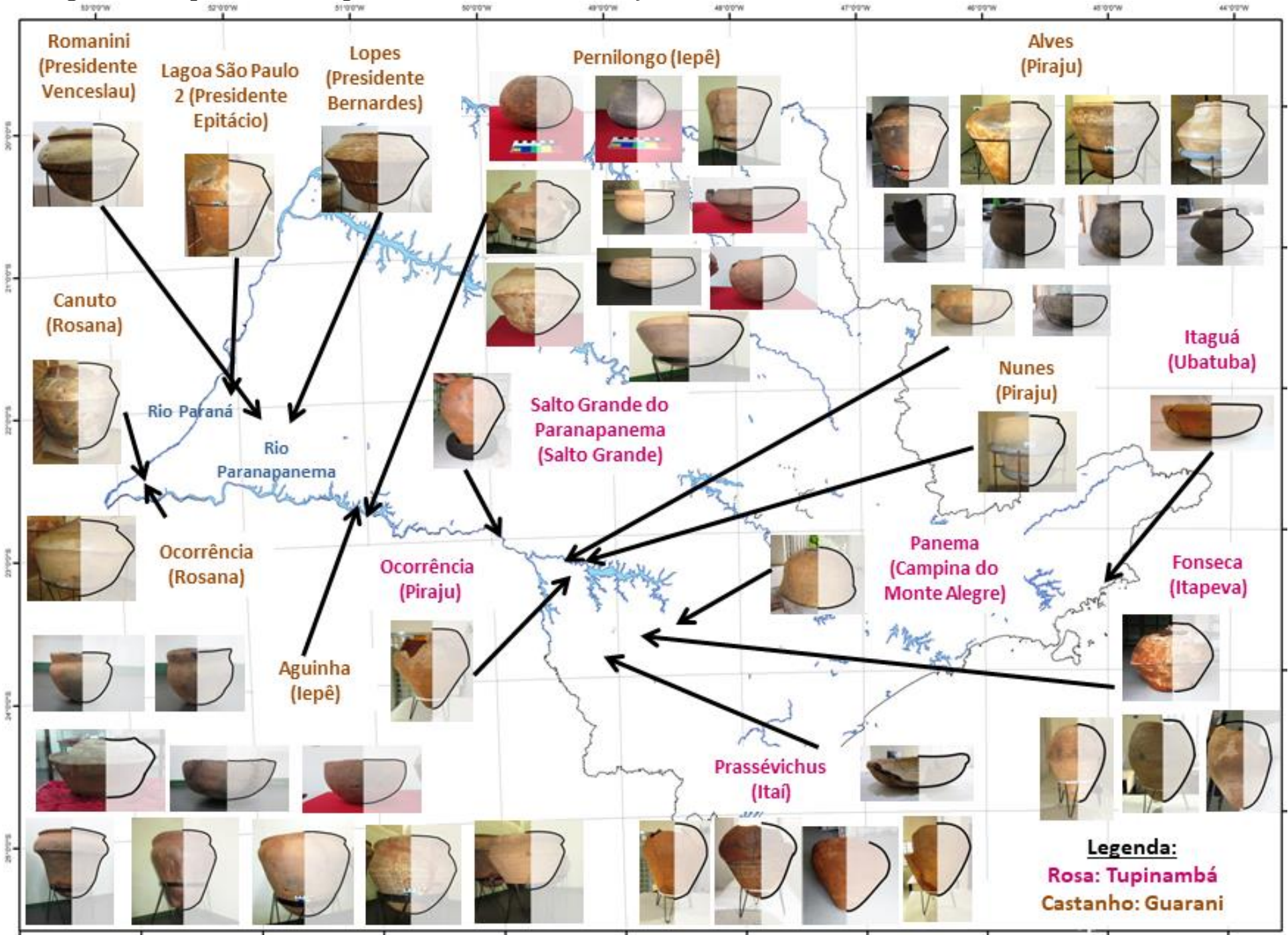


Além dessa característica marcante na cerâmica - que é a existência dessas urnas piriformes com bordas diretas sem extroversão em alguns sítios e em outros não -, há outras características relacionadas à morfologia cerâmica que formam padrões entre os sítios. Esses padrões morfológicos apresentam semelhanças e diferenças.

Em todos os sítios, a estrutura funerária mínima encontrada (ou ao menos as que pudemos achar informação suficiente) constitui-se por urna e tampa. Nas classes urna, tampa e vasilhas anexas, encontram-se diversas das formas descritas por La Salvia \& Brochado (1989). Das urnas, quase todas pertencem às classes yapepó guaçu (ou nhaempepó, que é o nome Tupinambá) e cambuchí (ou camuci), tanto em sítios Tupinambá quanto Guarani. Uma das urnas pertence à classe cambuchí caguaba e outra à classe yapepó myri (ambos contextos encontrados no sítio Pernilongo, baixo Paranapanema). Em quase todos os sítios principais, com exceção do sítio Pernilongo, há muito mais urnas yapepó do que cambuchí. A figura abaixo é a camuci do sítio Prassévichus, não encontrada por nós.

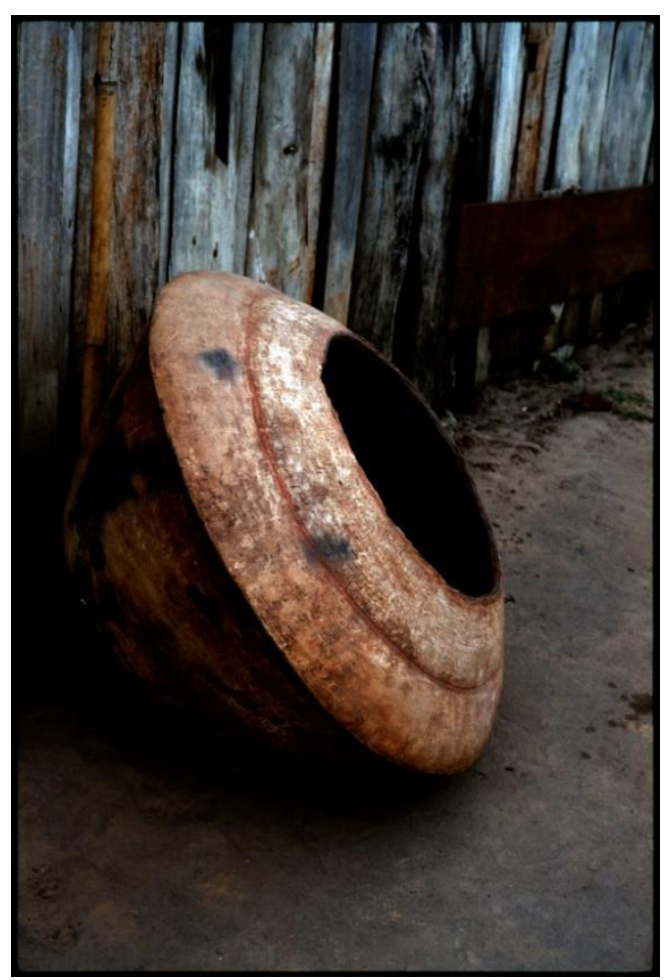

Figura 19: Camuci do sítio Prassévichus. Acervo documental do MAE/USP. 


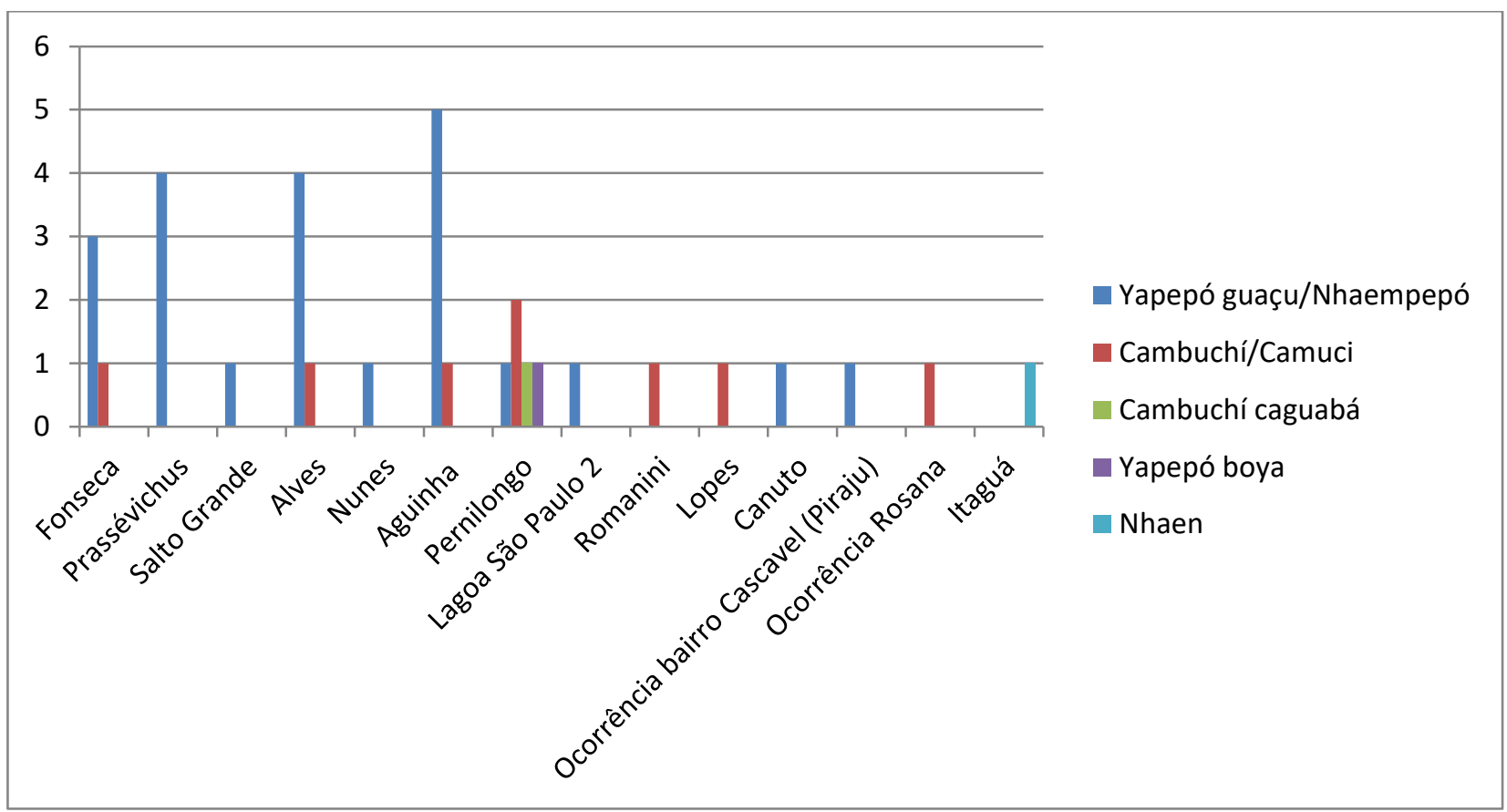

Gráfico 1: Tipos e número de vasilhas usadas como urnas por sítio.

O sítio Pernilongo foi o que mais apresentou variedade nas morfologias e classes de vasilhas usadas como urnas funerárias, sendo que nenhum outro apresentou, nem entre o material analisado nem entre os relatos de material, vasilhas cambuchí caguabá e yapepó boya.

Portanto, um padrão entre os sítios Guarani e Tupinambá do Paranapanema é a presença de urnas yapepó guaçu/ nhaempepó e cambuchí/ camuci em todos os sítios principais, sendo que o número de yapepó/ nhaempepó é, em quase todos os casos, muito superior ao de cambuchí. Mesmo nos sítios e ocorrências dos quais só pudemos encontrar uma urna cada, a maioria das mesmas é também yapepó. A exceção é o sítio Pernilongo, que apresenta diversas morfologias diferentes de urnas.

Ao observar as características morfológicas do material cerâmico, notamos que os sítios Tupinambá (Fonseca, Prassévichus, Salto Grande e a ocorrência de Piraju) e o sítio Alves apresentam uma padronização intra-sítio de suas vasilhas funerárias muito maior em termos de formas, tratamentos de superfícies e bordas (morfologias e espessuras) do que os sítios Aguinha e Pernilongo. No mesmo sítio as vasilhas seguem um padrão, sendo as nhaempepó/ yapepó muito parecidas entre si. Entre os sítios também há um padrão, sendo que as urnas do Fonseca, Prassévichus, Salto Grande e do bairro Cascavel também são parecidas entre si. Já as urnas do Alves são muito diferentes na forma e tratamentos de superfície quando 
comparados às desses outros. Nos sítios Tupinambá, as urnas são na sua maioria corrugadas, e as do sítio Guarani apresentam alisado e engobo, além das espessuras das bordas serem muito maiores.

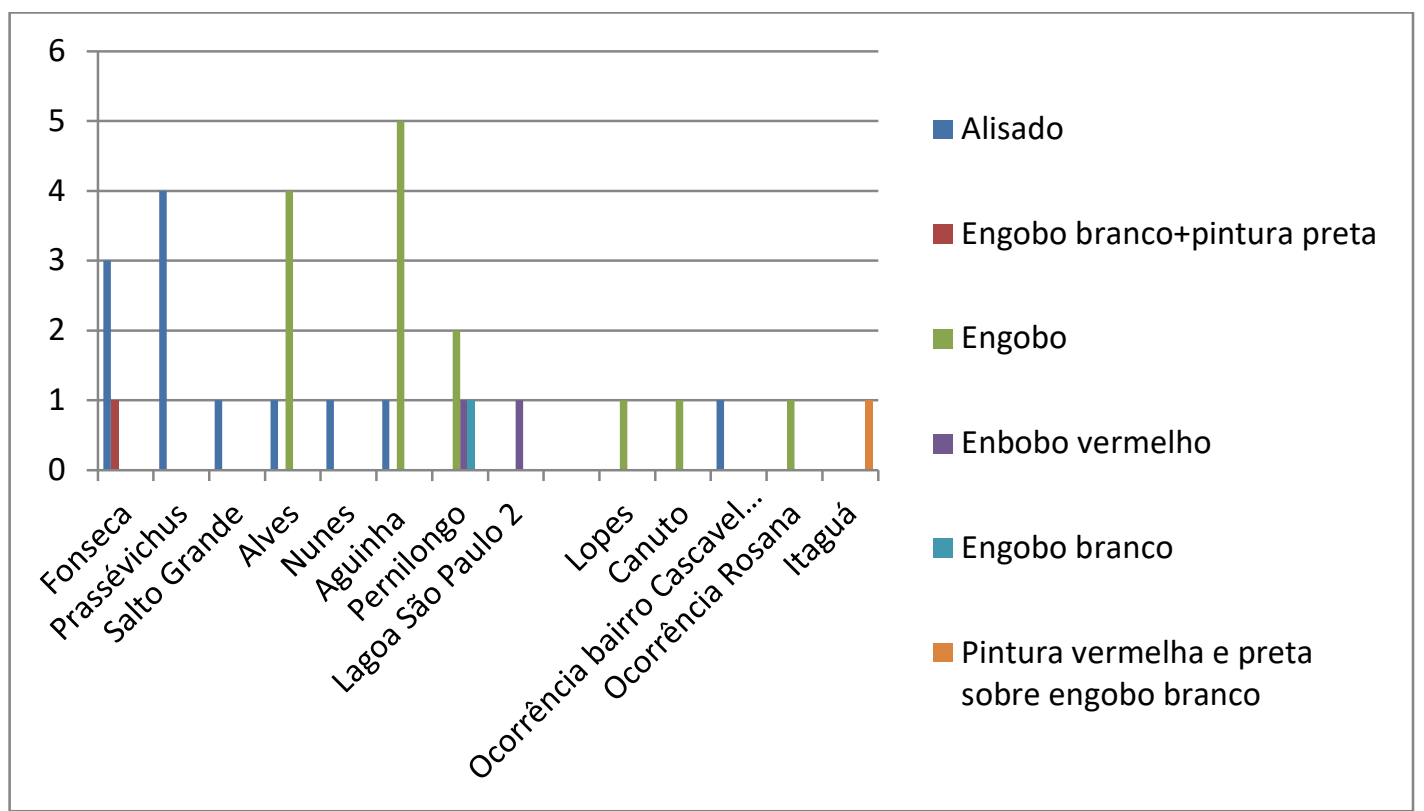

Gráfico 2: Tratamentos de superfícies internas das urnas de cada sítio.

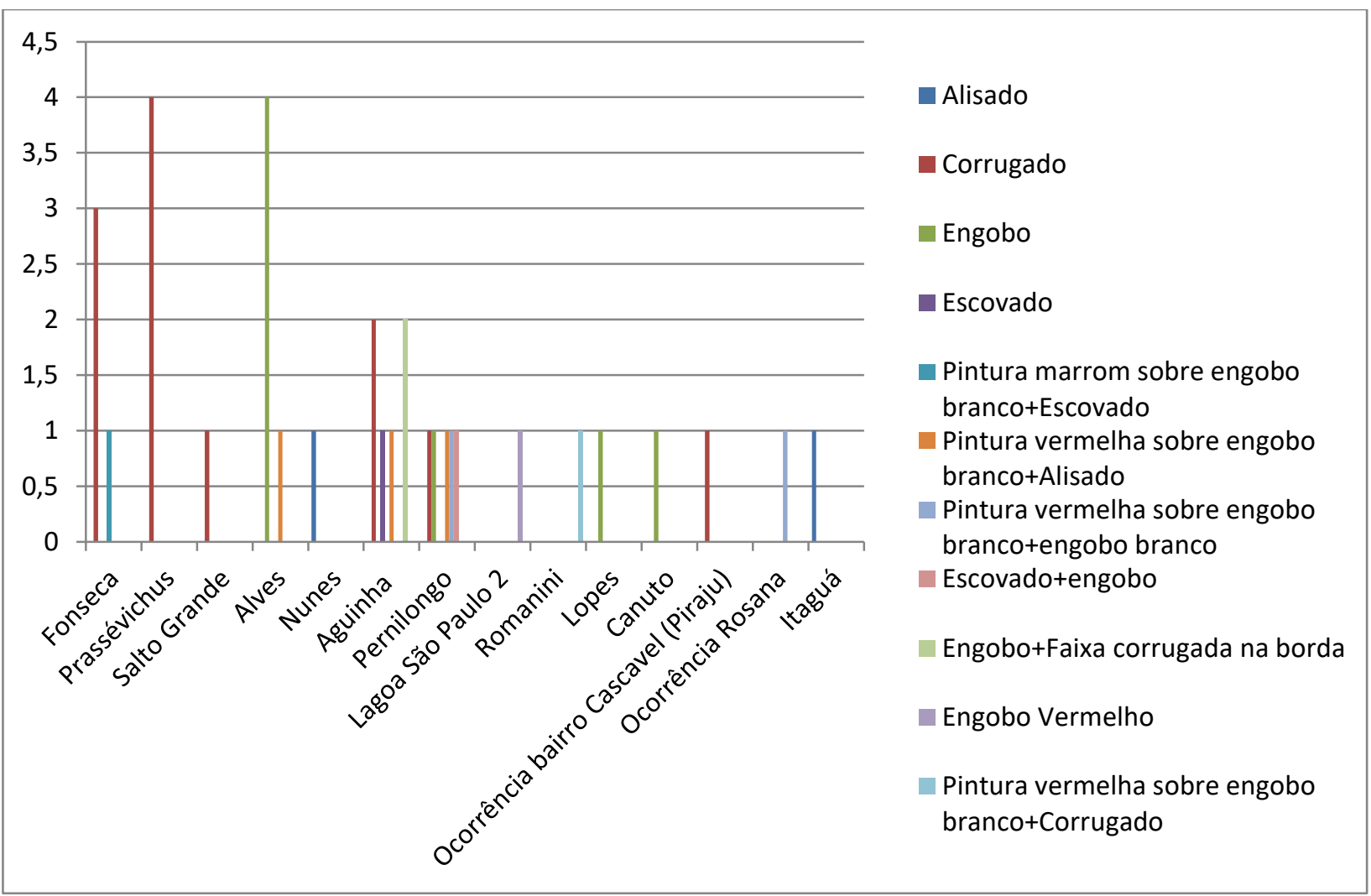

Gráfico 3: Tratamentos de superfícies externas das urnas de cada sítio. 
As espessuras máxima e mínima das bordas das urnas dos sítios Fonseca, Prassévichus e Salto Grande são mais padronizadas variando pouco entre as vasilhas do mesmo sítio e entre aquelas desses diferentes sítios. Embora haja variações, elas são menores se comparadas às dos sítios Guarani. Do mesmo modo, as formas da borda e do lábio das nhaempepó são iguais (diretas sem inflexão, lábio arredondado) nos sítios Tupinambá, e os diâmetros das bocas das vasilhas também são mais ou menos constantes, entre 20 e $30 \mathrm{~cm}$, mesmo com os diferentes tamanhos de urnas. As larguras máximas das vasilhas variam mais dentro do mesmo sítio e entre os diferentes sítios Tupinambá, mesmo entre as urnas nhaempepó. Já as alturas máximas variam dentro de um mesmo sítio, mas seguem um padrão entre sítios diferentes (de 53 a $64 \mathrm{~cm}$ tanto no Fonseca, Prassévichus e ocorrência de Piraju), embora a nhaempepó do Salto Grande seja bem mais alta que as outras, $\operatorname{com} 86 \mathrm{~cm}$.

Já no sitio Itaguá, outro sítio Tupinambá, a urna encontrada possui uma morfologia totalmente diferente, não sendo uma nhaempepó, e sim nhaen, além de ser pequena demais para se caber uma pessoa inteira dentro, em sepultamento primário. A vasilha apresentava pintura vermelha e preta sobre engobo branco. Em seu interior foram encontrados alguns dentes e ossos do crânio muito decompostos.

As urnas do Alves possuem as espessuras mínimas e máximas da borda maiores que as dos sítios Tupinambá (mínimas de $1,4 \mathrm{~cm}$ a $1,8 \mathrm{~cm}$, e máximas de $1,8 \mathrm{~cm}$ a $3,7 \mathrm{~cm})$, variando entre si, sendo que a borda do cambuchí é de longe a mais larga. As formas da borda seguem aparentemente o mesmo padrão entre as yapepó (infletidas), só diferindo na cambuchí (infletida e carenada). Os diâmetros da boca também são parecidos entre as urnas inteiras $(56 \mathrm{~cm}$ e $57 \mathrm{~cm})$, sendo que apenas uma possui o diâmetro bem maior $(69 \mathrm{~cm})$. A largura máxima também é padronizada entre as yapepó inteiras $(84 \mathrm{~cm}$ a $87 \mathrm{~cm})$, e bem maior na cambuchí $(102 \mathrm{~cm})$. E a altura entre as urnas inteiras varia entre $64 \mathrm{~cm}$ e $79 \mathrm{~cm}$. A vasilha inteira analisada do sítio Nunes segue os padrões do Alves em quase todas essas dimensões, exceto no diâmetro da boca - a do Nunes é ligeiramente maior que a maioria das do Alves $(63 \mathrm{~cm})$-, e na largura máxima - que é $74 \mathrm{~cm}$, menor que a média do Alves. 
Prancha 1: Urna do contexto funerário do sítio Itaguá.

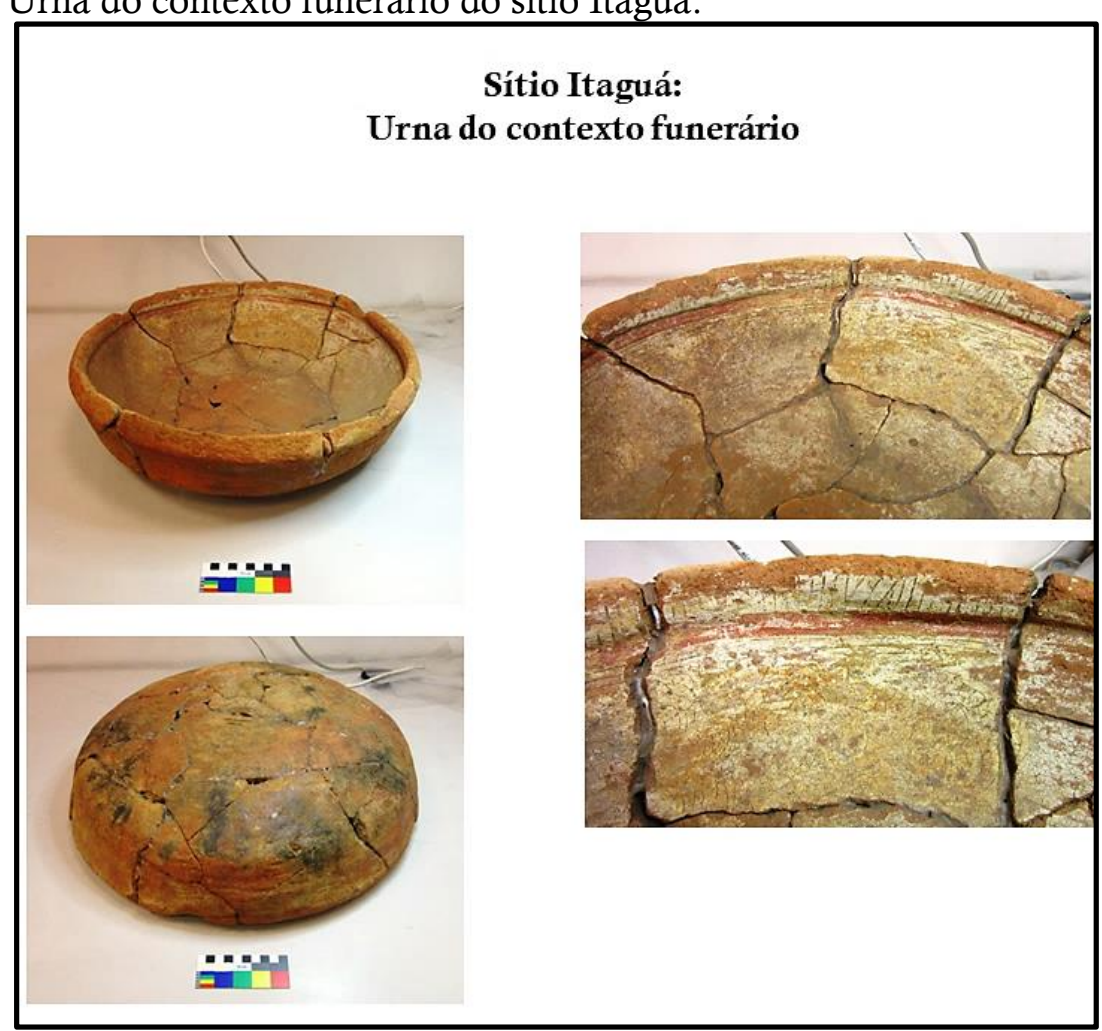

Pranchas 2-4: Vasilhas dos contextos funerários do sítio Fonseca. A urna do contexto III apresenta algo que parece uma pintura preta sobre o engobo branco, como uma camada até a parte mesial da vasilha, mas que poderia também ser resquício de algo que tenha sido preparado ou armazenado na vasilha. Fotos: Mariana Cristante.

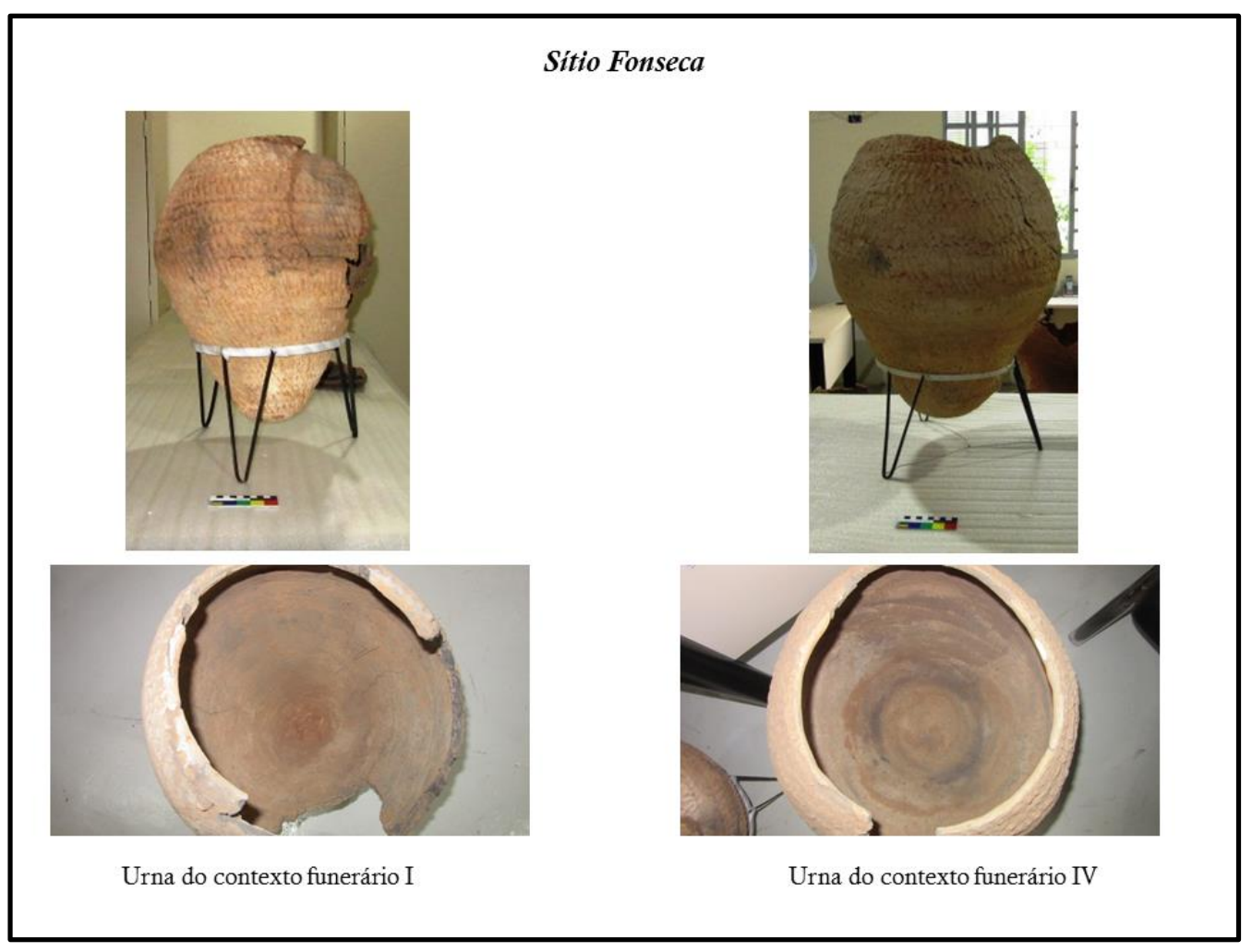



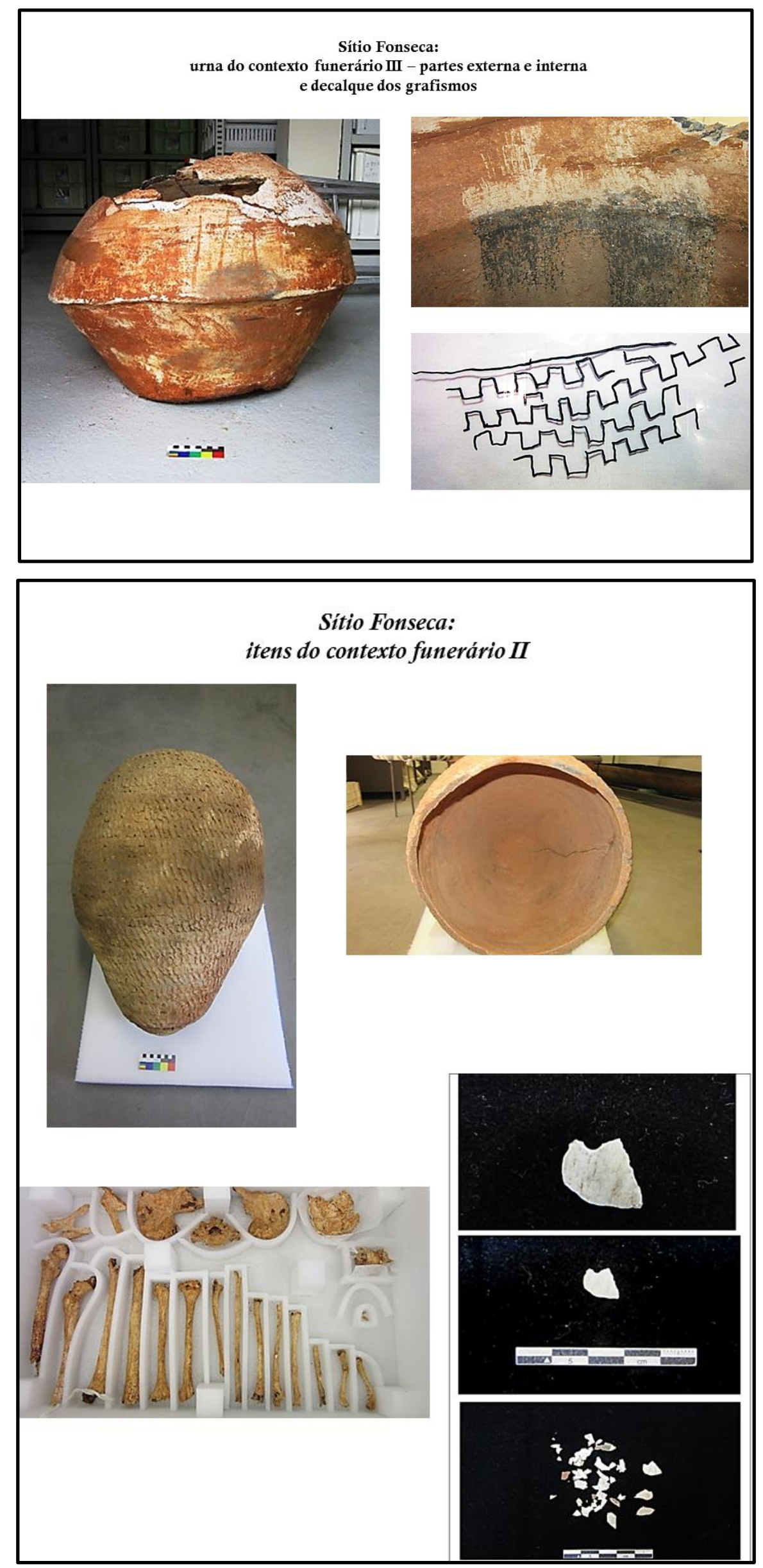
Pranchas 5-7: Vasilhas dos contextos funerários do sítio Prassévichus. Fotos: Mariana Cristante.

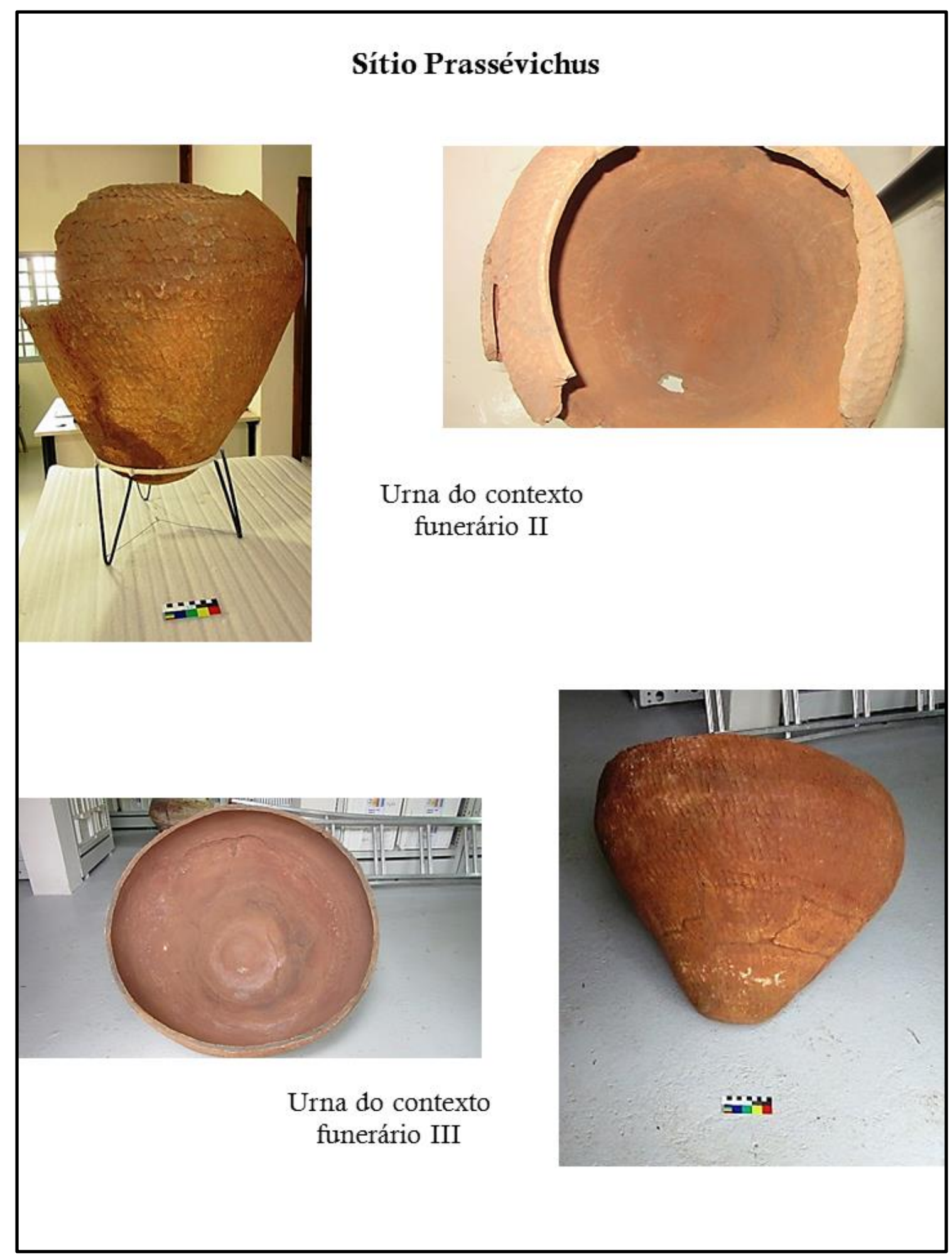




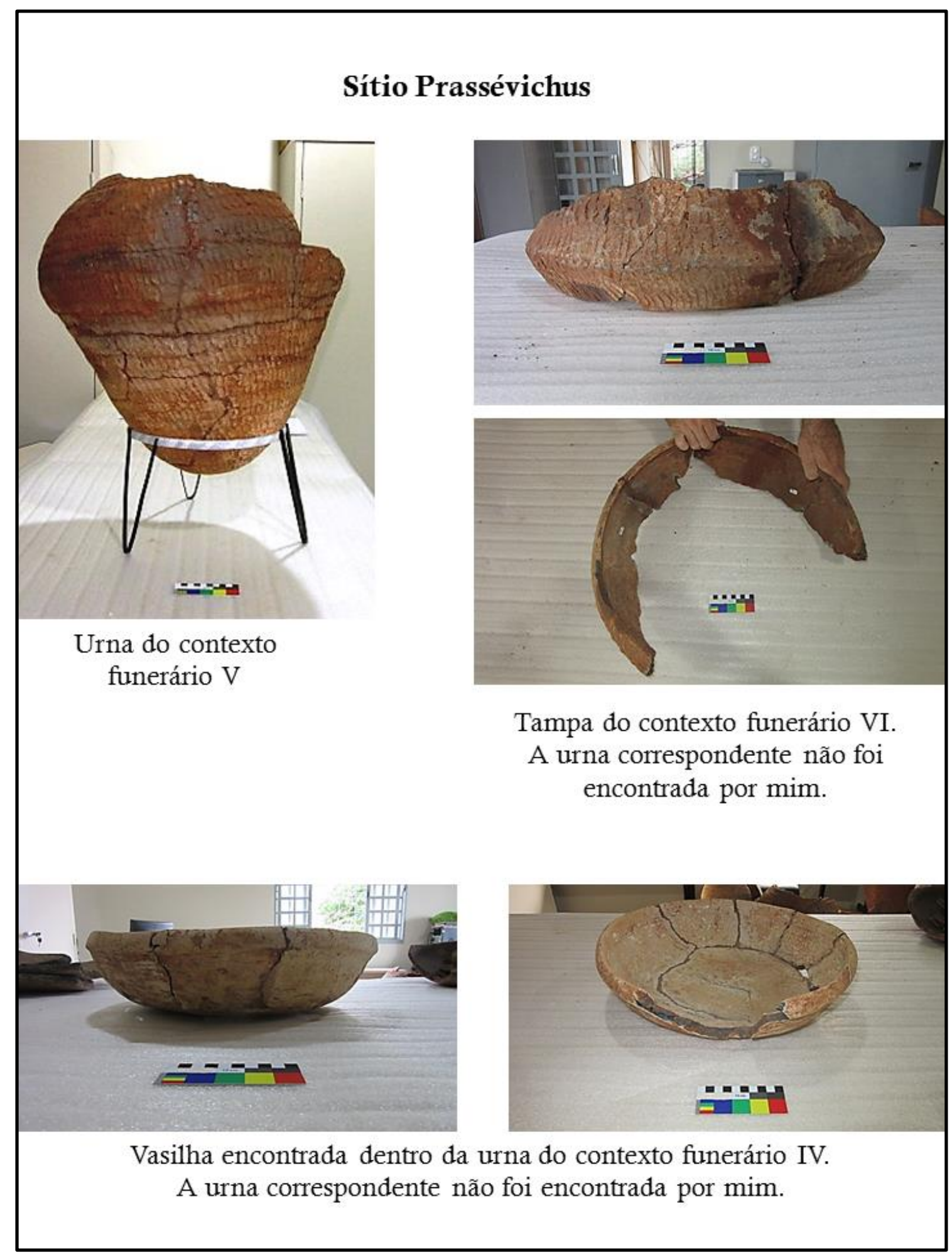



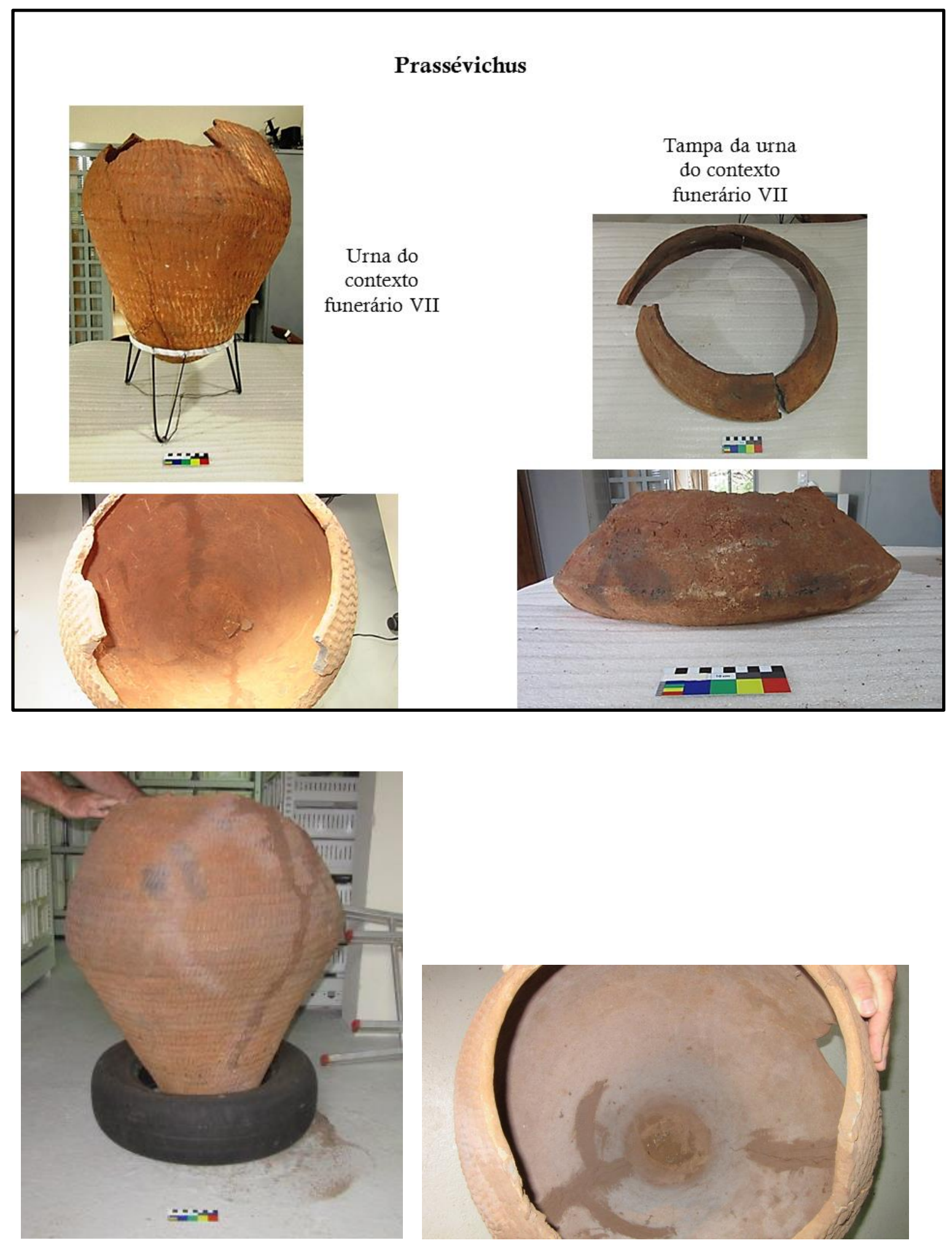

Figuras 20 e 21: Urna do sítio Salto Grande do Paranapanema. Fotos: Mariana Cristante. 
Pranchas 8-12: Vasilhas dos contextos funerários do sítio Alves. Fotos: Mariana Cristante.

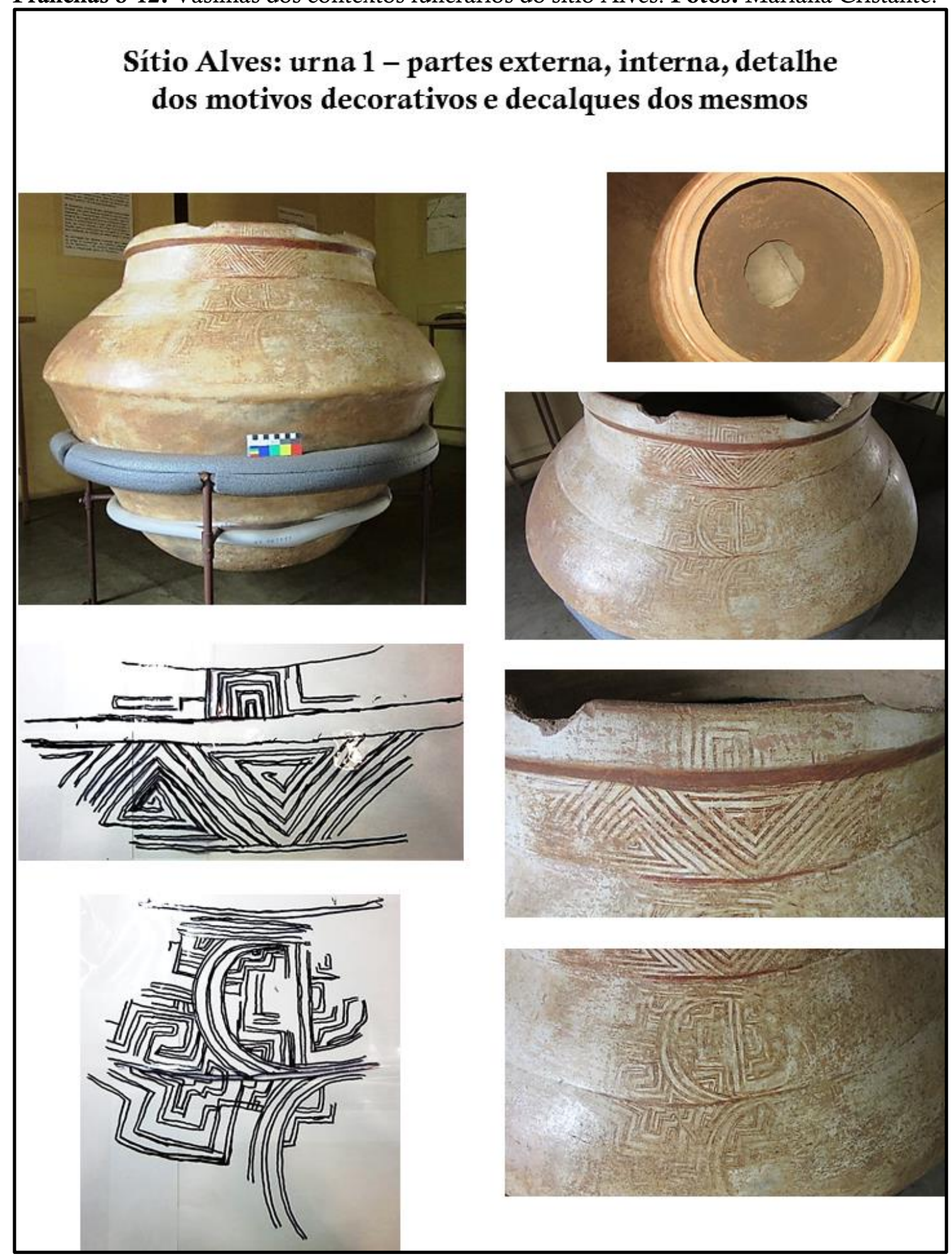




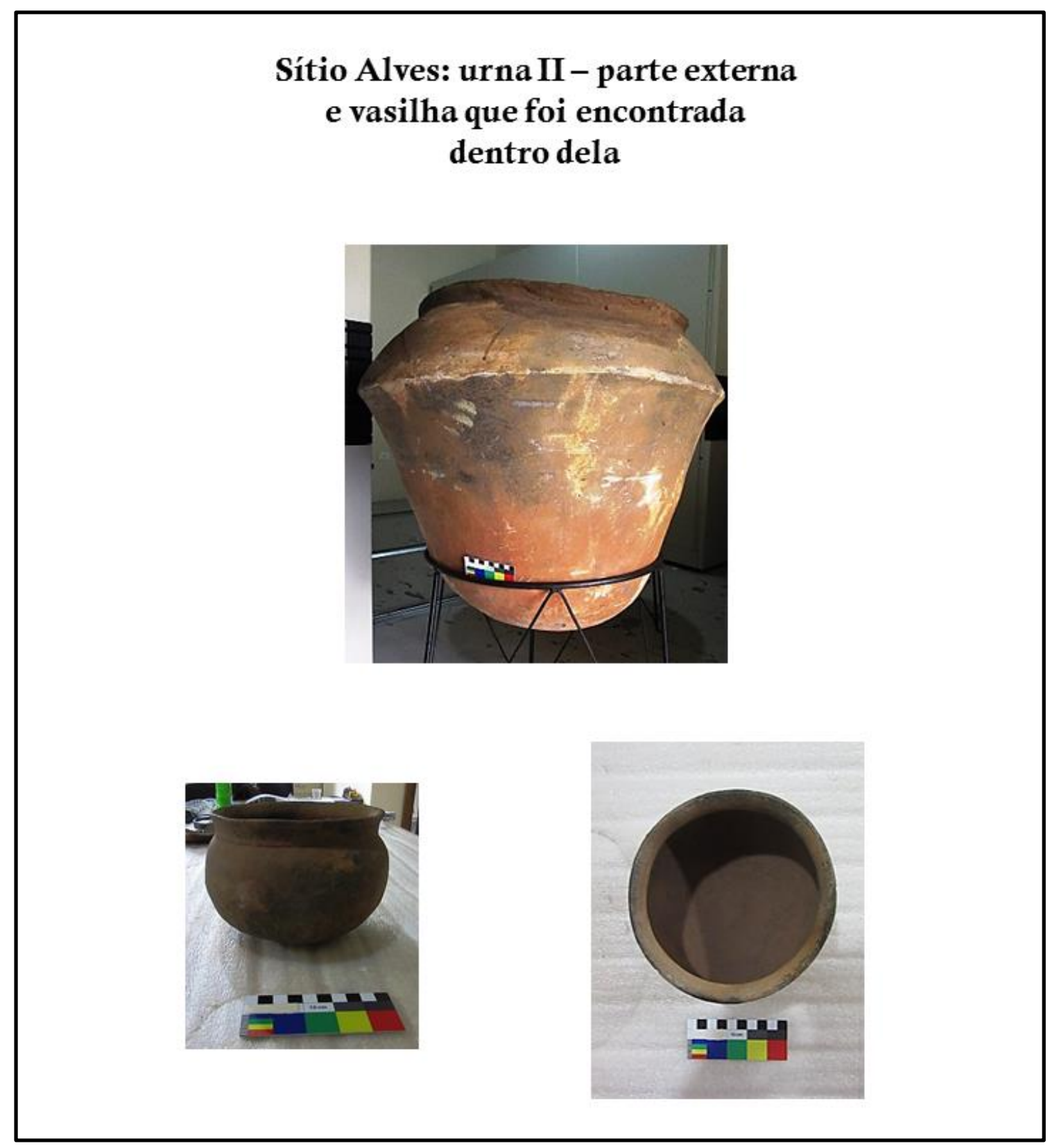




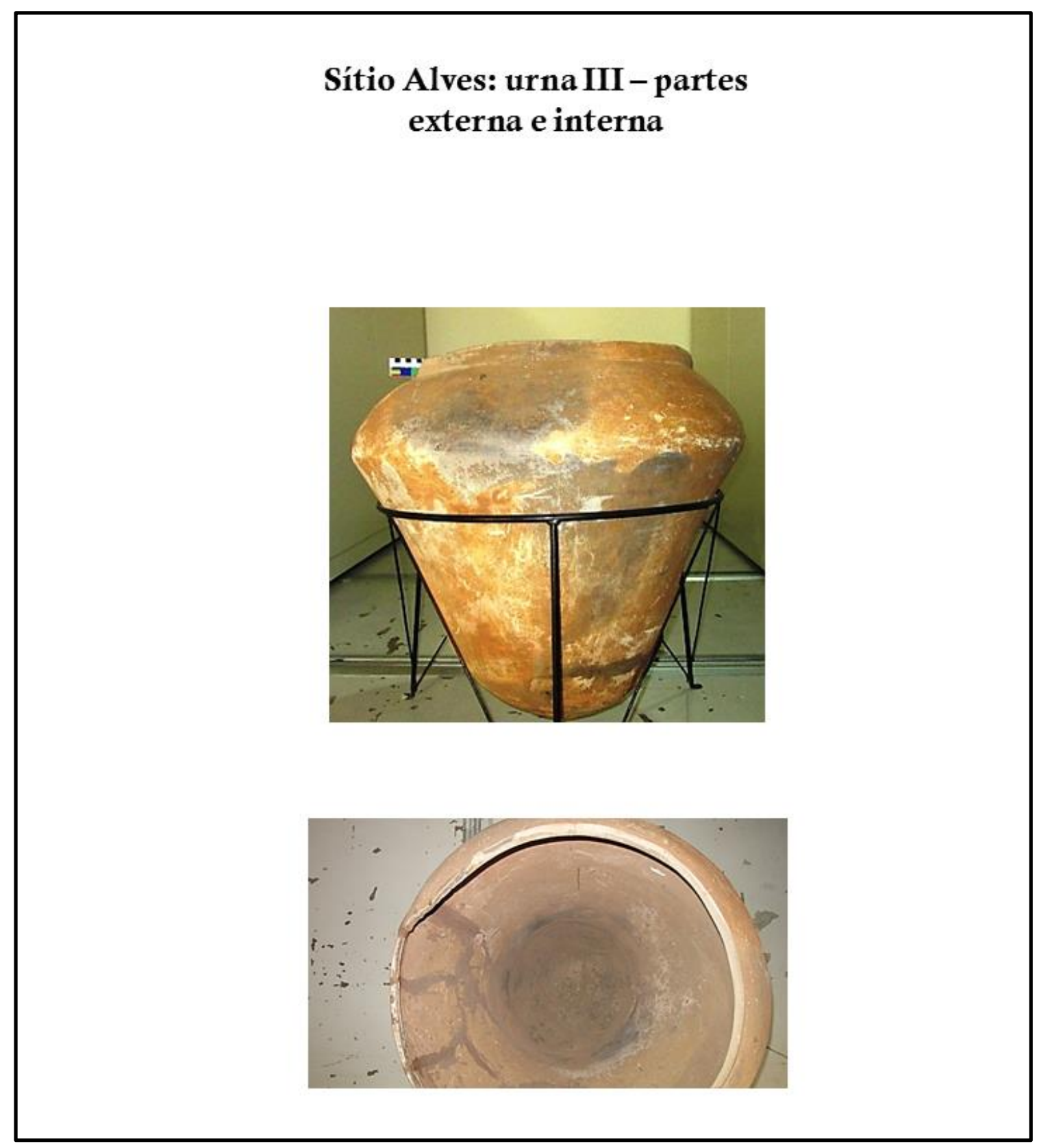


Sítio Alves: urna e vasilhas do contexto funerário IV. Bloco A - urna, partes externa e interna; bloco B - vasilha pintada (partes externa $\mathrm{e}$ interna), detalhe dos motivos pintados e decalque dos mesmos; blocos $C, D$ e E - outras vasilhas que estavam dentro da urna

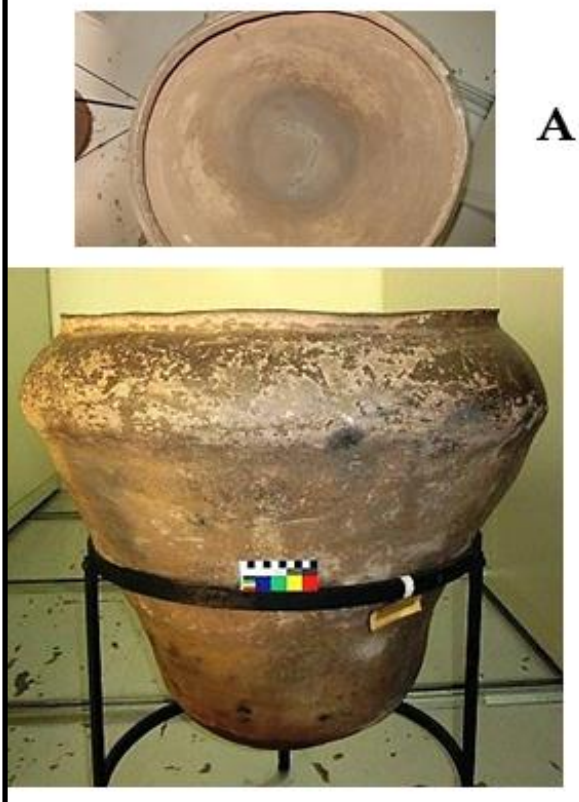

B
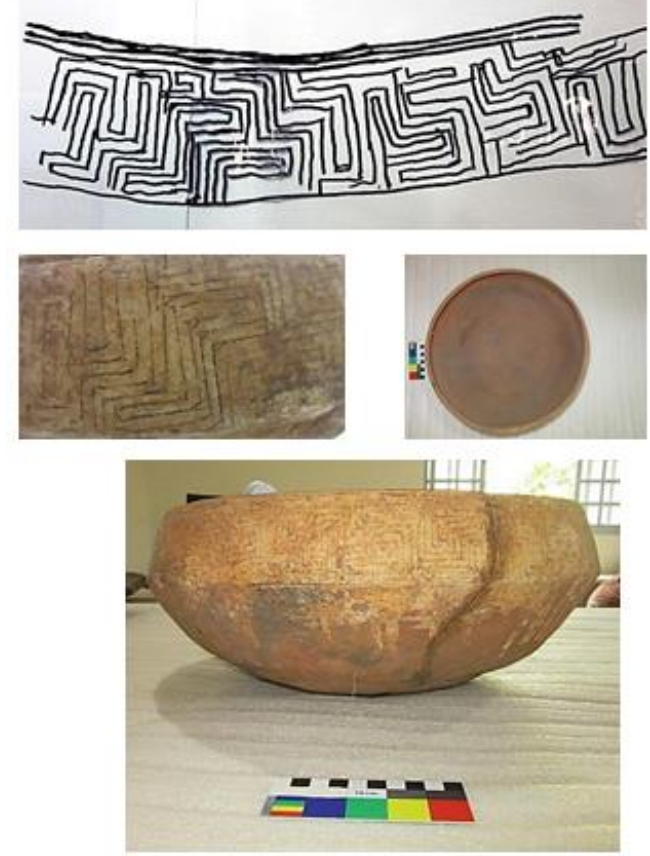

C

D
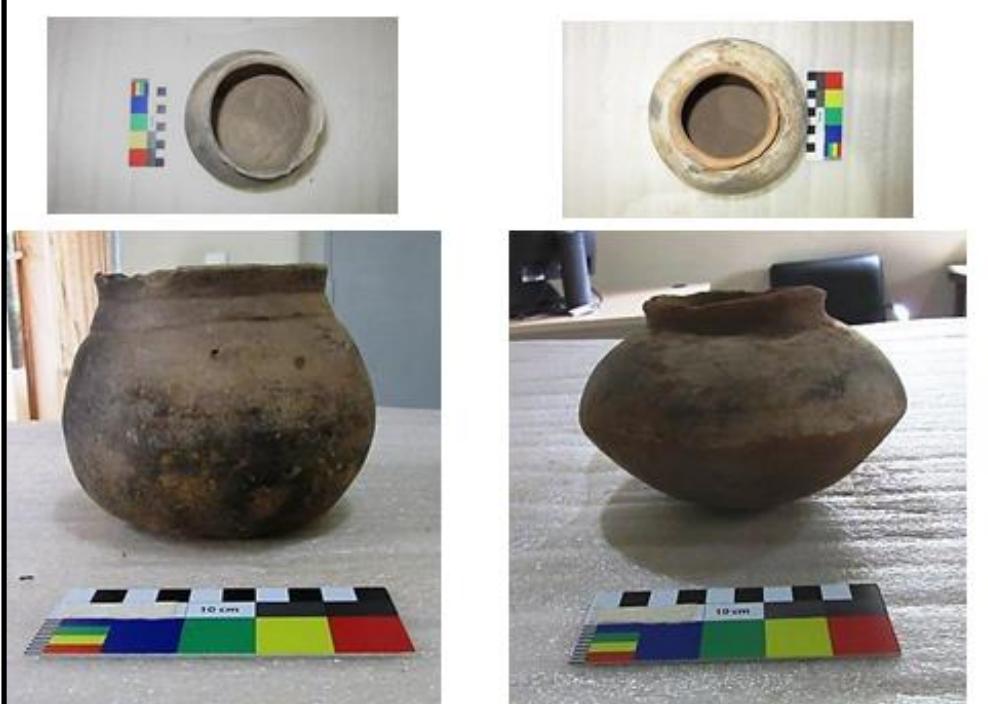

$\mathbf{E}$

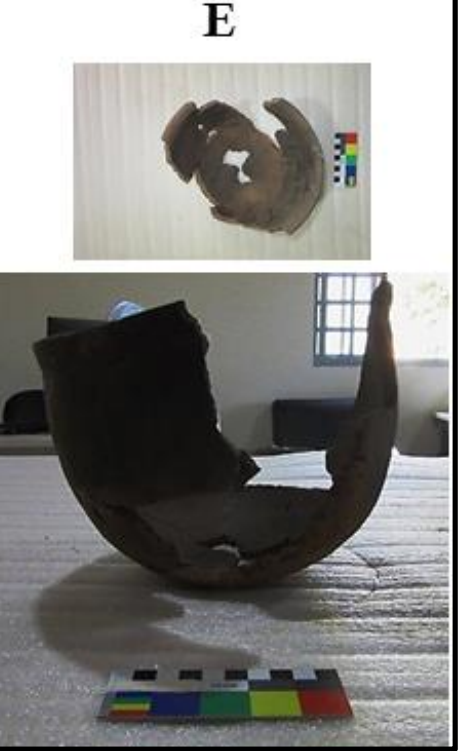




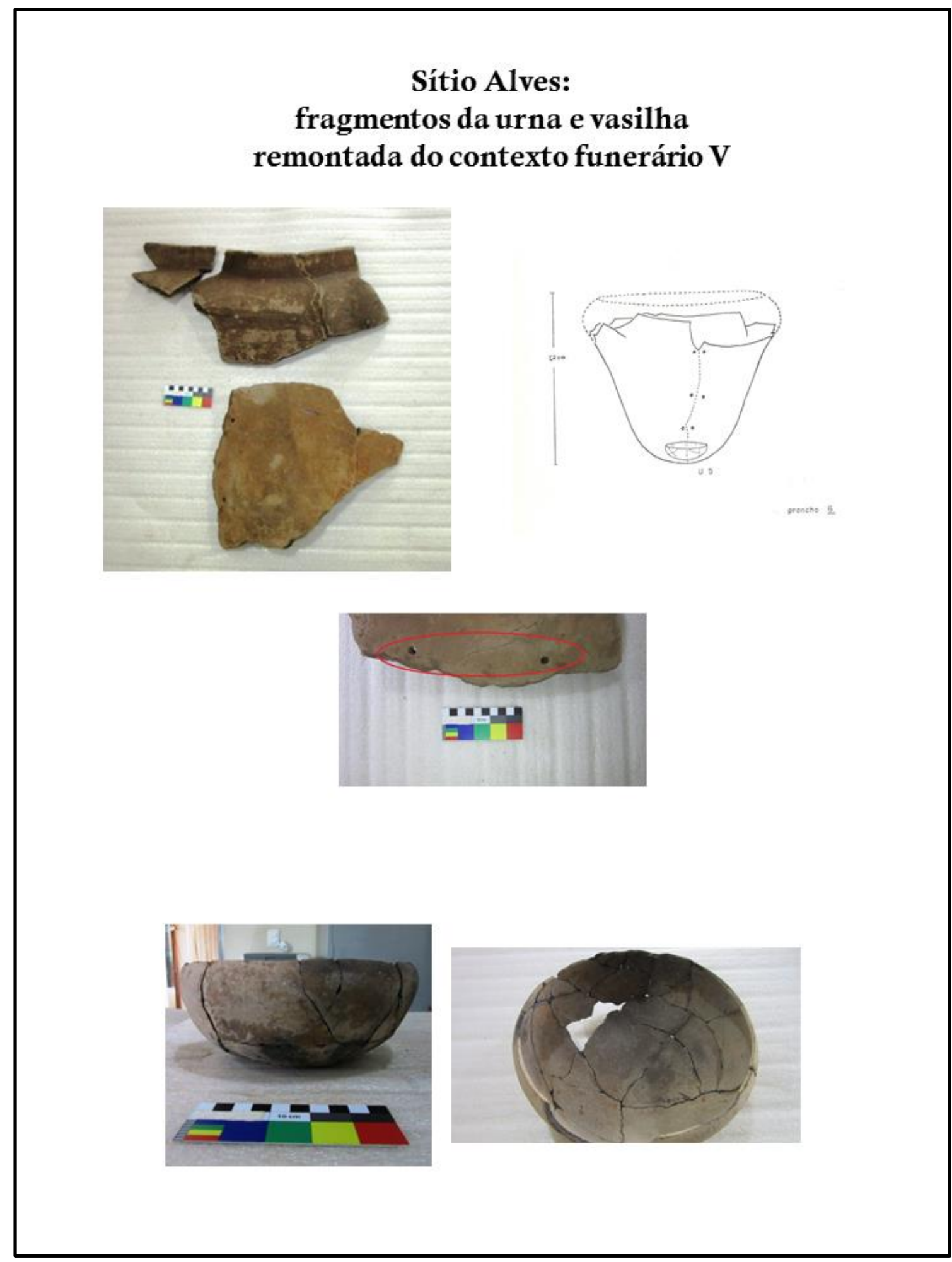


Já as urnas do Aguinha e Pernilongo não são muito padronizadas, em especial as do Pernilongo, que além de serem formas bastante diferentes, possuem espessuras de borda e tratamentos de superfície bem variadas.

As espessuras máxima e mínima da borda das vasilhas do sítio Aguinha (exceto a da urna maior) são mais padronizadas que as do Pernilongo, e a da vasilha analisada do sítio Lagoa São Paulo 2 segue mais ou menos essas medidas das do Aguinha. As formas das bordas de quase todas as urnas do Aguinha e da do Lagoa São Paulo 2 são infletidas, e os lábios arredondados; já as bordas do Pernilongo são bem variadas (direta inclinada interna, direta inclinada externa e carenada). Os diâmetros das bocas das urnas do Aguinha também são bem mais padronizados que no Pernilongo, variando entre $40 \mathrm{~cm}$ a $51 \mathrm{~cm}$ no primeiro, e entre $21 \mathrm{~cm}$ a $58 \mathrm{~cm}$ no segundo. As larguras máximas no Pernilongo também variam bem mais que no Aguinha, pois nesse primeiro sítio variam mais as classes de vasilhas empregadas como urnas; no Aguinha, assim como no Alves, a cambuchí é a vasilha mais larga. E as alturas das vasilhas tanto no Aguinha quanto no Pernilongo variam bastante entre si.

Portanto, ao contrário dos outros 3 sítios principais, esses dois não apresentam uma padronização muito grande de suas vasilhas, nem no mesmo sítio, nem com algum outro. A semelhança mais marcante entre eles é a ausência de vasilhas piriformes com bordas diretas sem extroversão. O Aguinha, apesar de apresentar uma grande variedade de formas e tratamentos de superfície de yapepó, apresenta uma certa padronização entre as espessuras, formas e diâmetros de borda de suas urnas, bem como das classes formais. Isso mostra que esse sítio é mais padronizado que o Pernilongo, embora não possua conjuntos cerâmicos funerários parecidos a nenhum dos anteriores. Já o Pernilongo é de longe o mais variado tanto em termos de classes de vasilhas empregadas como urnas, como de tratamentos de superfície, espessuras, formas e diâmetros de borda. 
Pranchas 13-15: Vasilhas dos contextos funerários do sítio Aguinha. Fotos: Mariana Cristante.

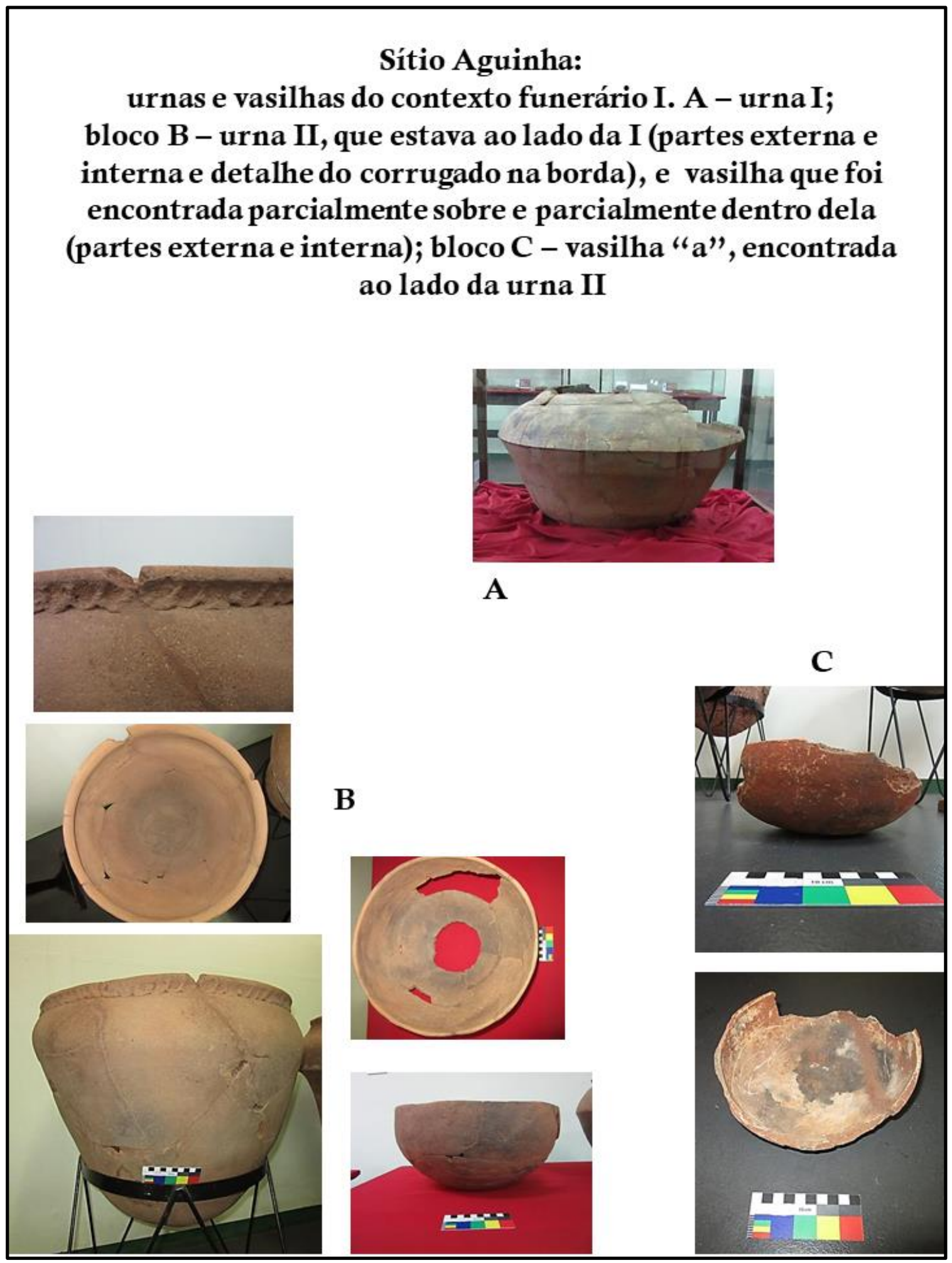




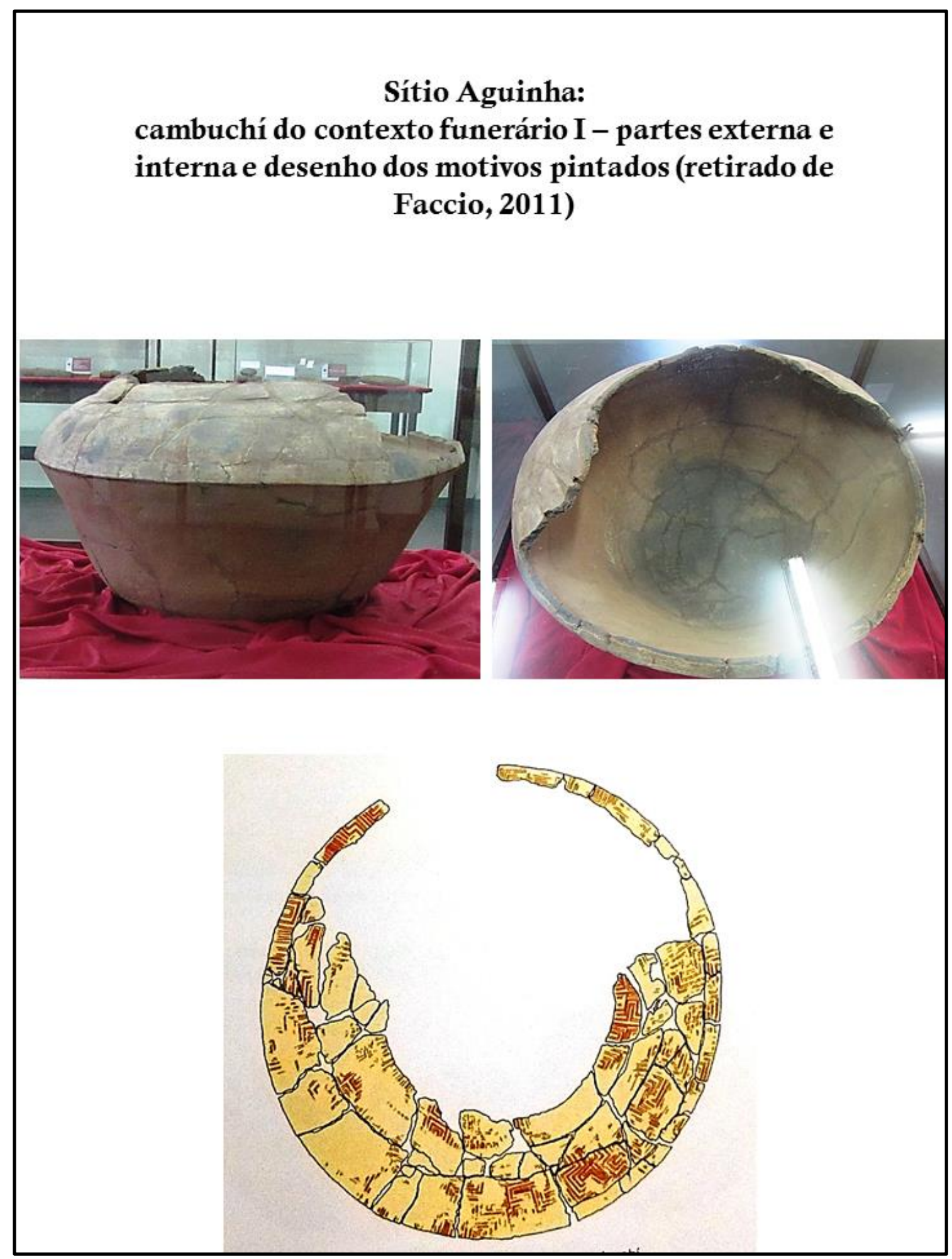




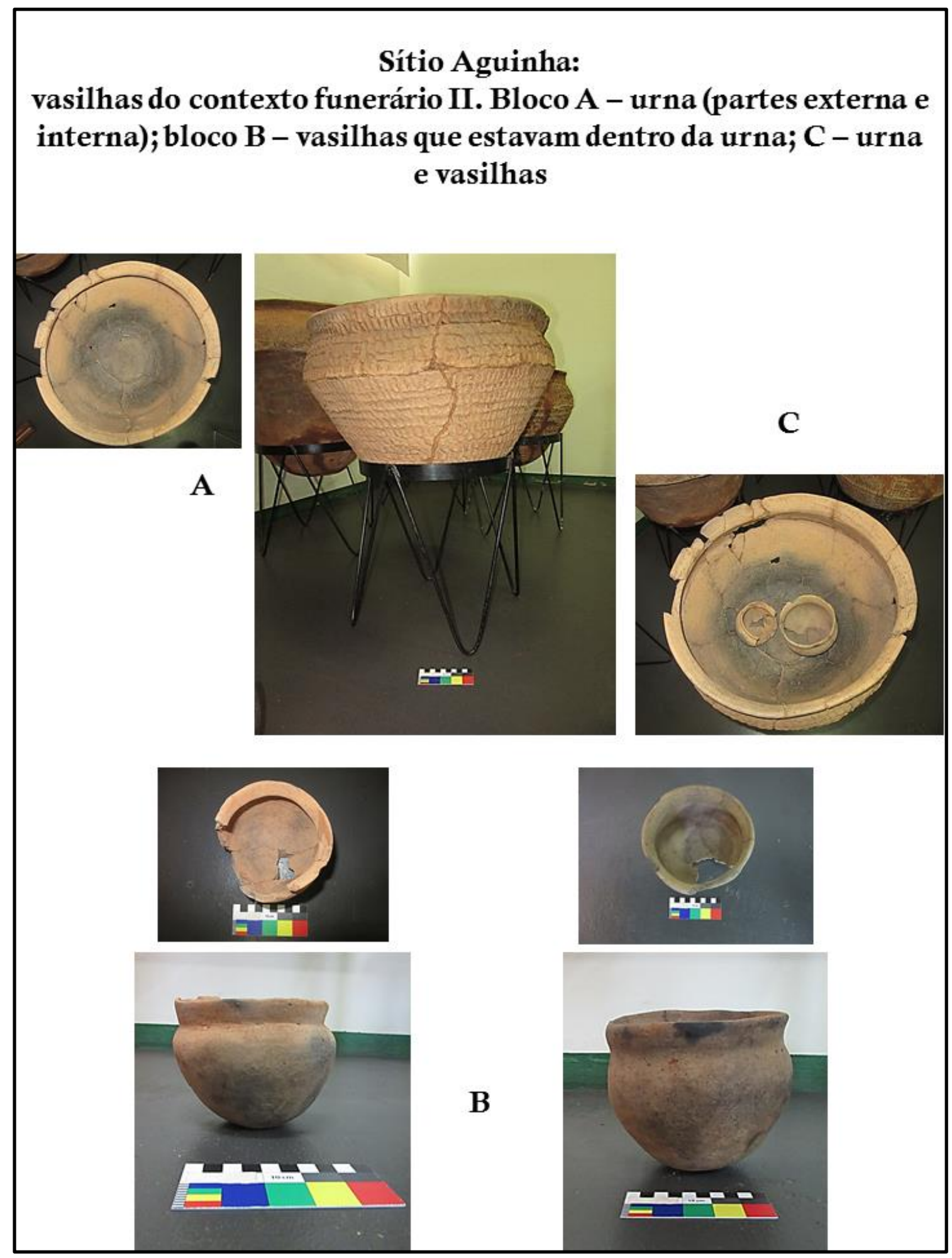


Pranchas 16-19: Vasilhas dos contextos funerários do sítio Pernilongo. Fotos: Mariana Cristante.

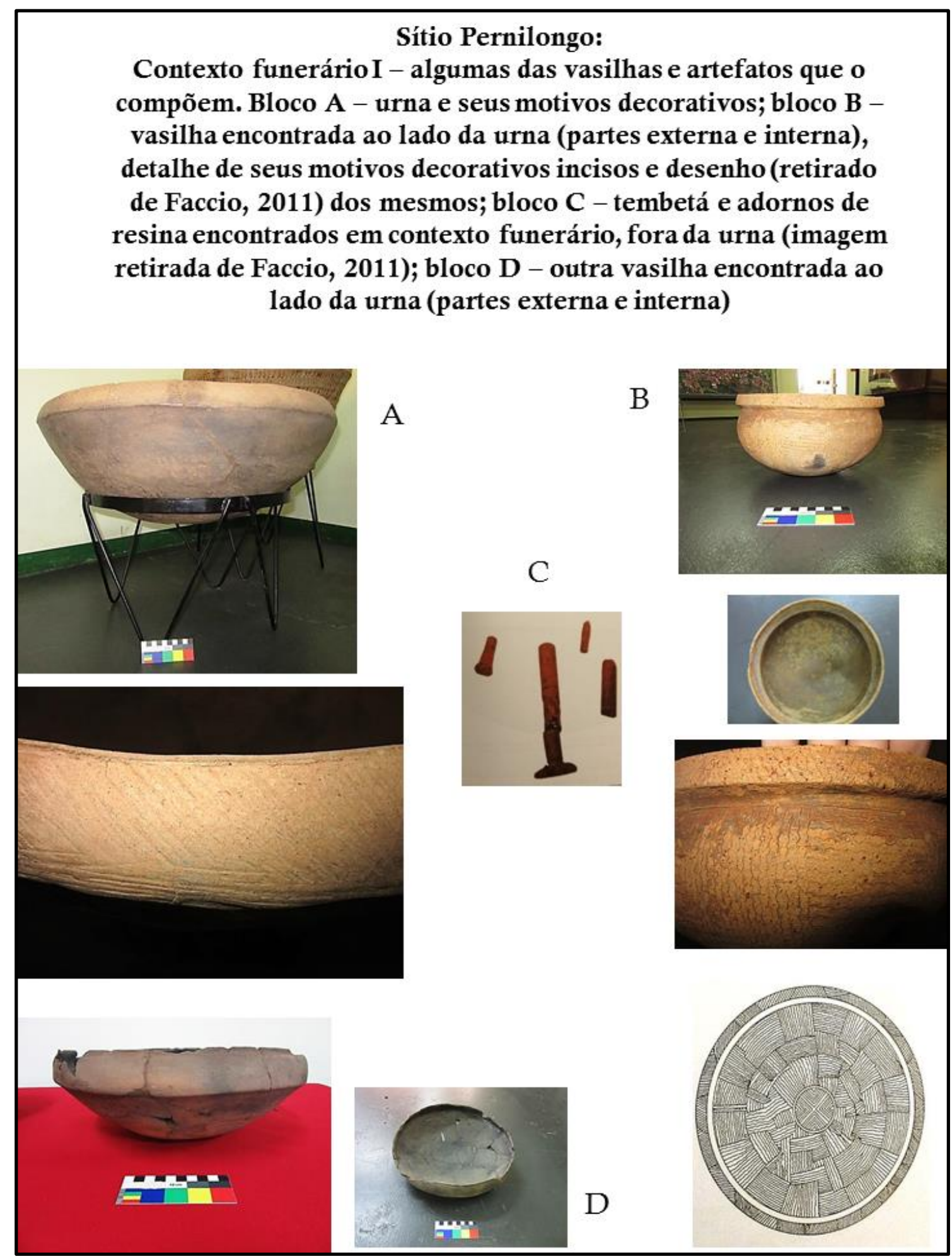




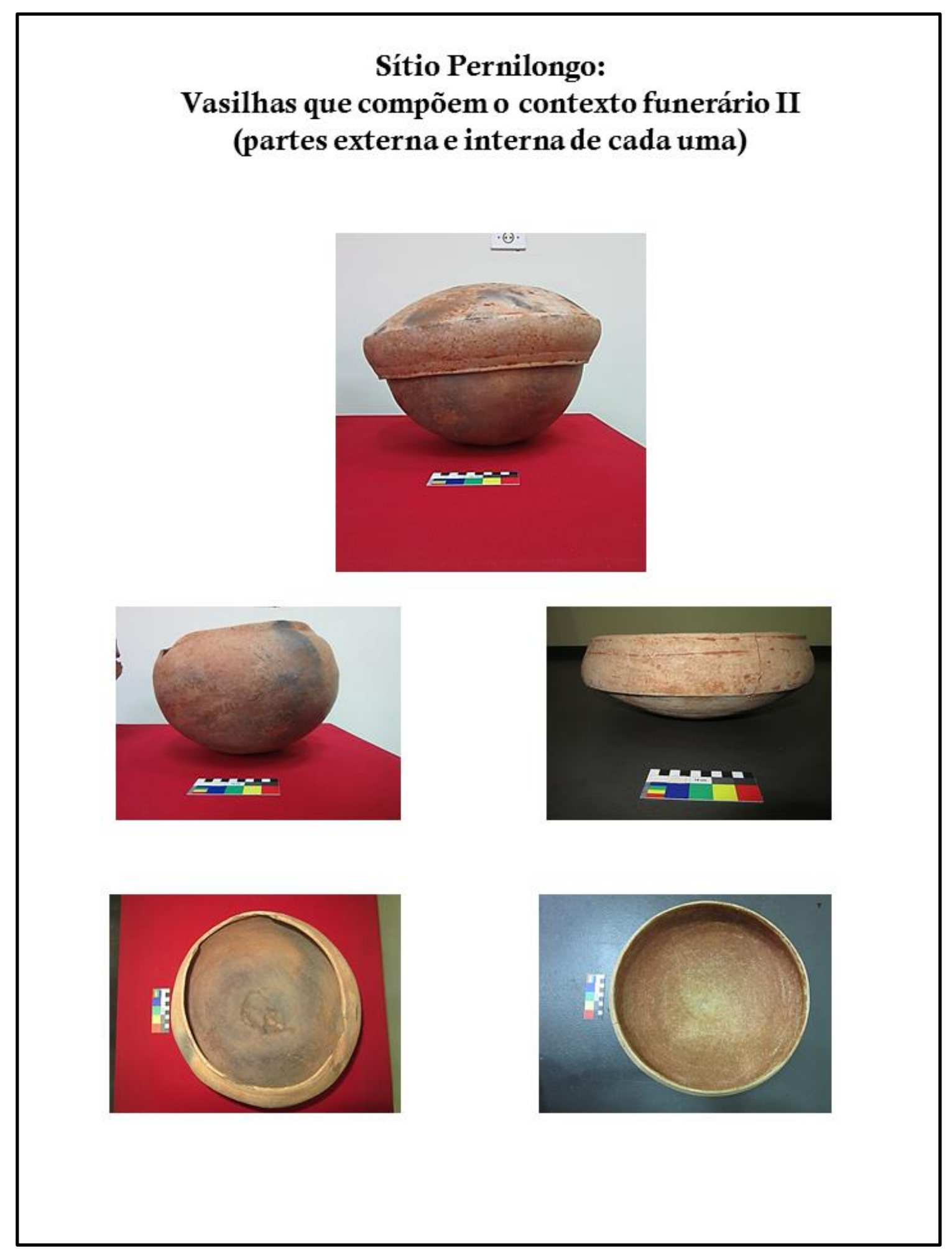




\section{Sítio Pernilongo:}

cambuchí encontrada dentro do lago do reservatório, parcialmente soterrada no sedimento vermelho. Partes externa e interna, pintura e desenho da mesma retirado de Faccio, 2011
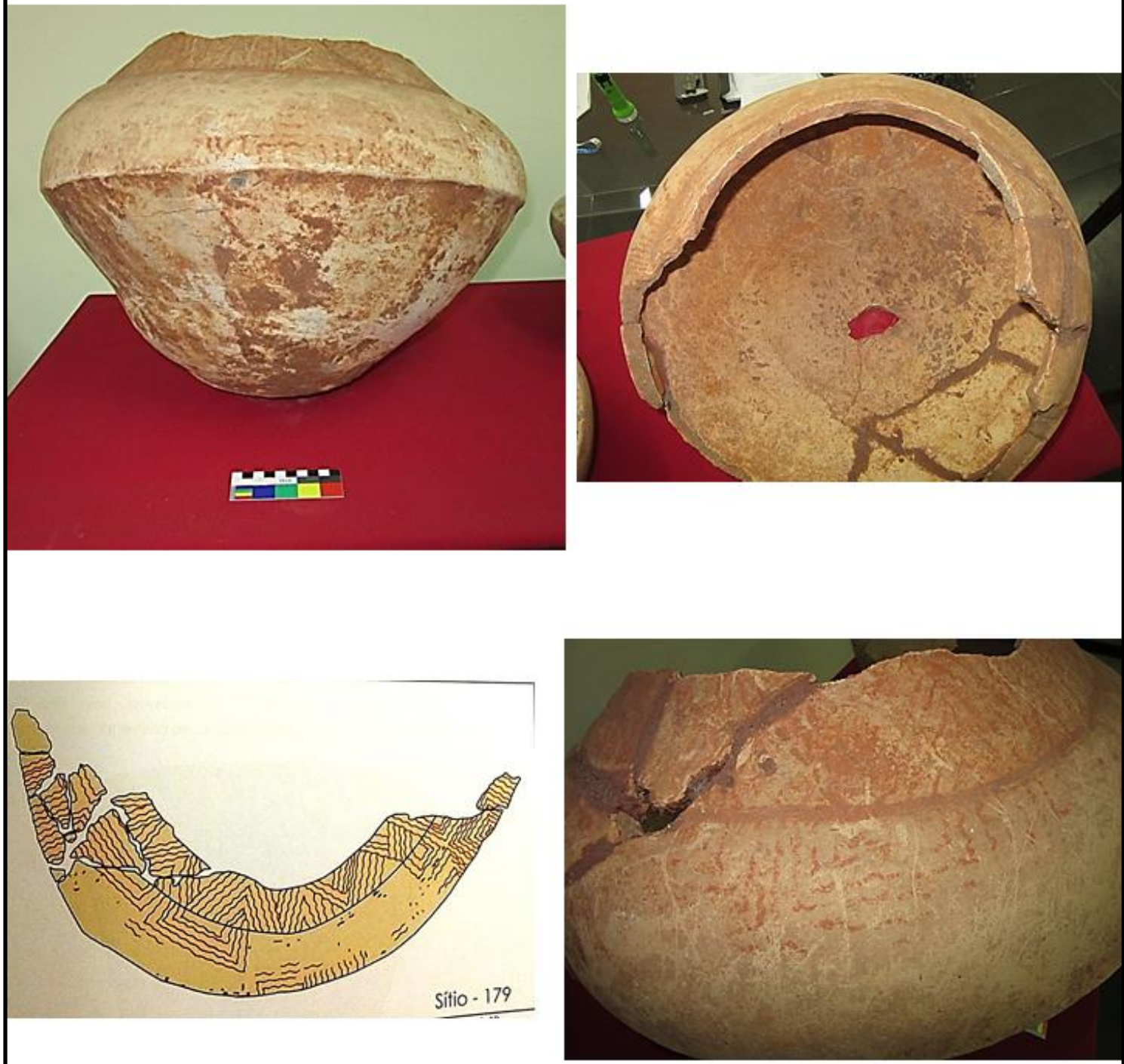


\section{Sítio Pernilongo:}

Urnas encontradas no sítio sem um contexto bem preservado. Bloco A - cambuchí encontrada pelos proprietários da fazenda (partes externa e interna) com seus motivos decorativos pintados;

B - yapepó considerada como urna funerária (partes externa e interna)

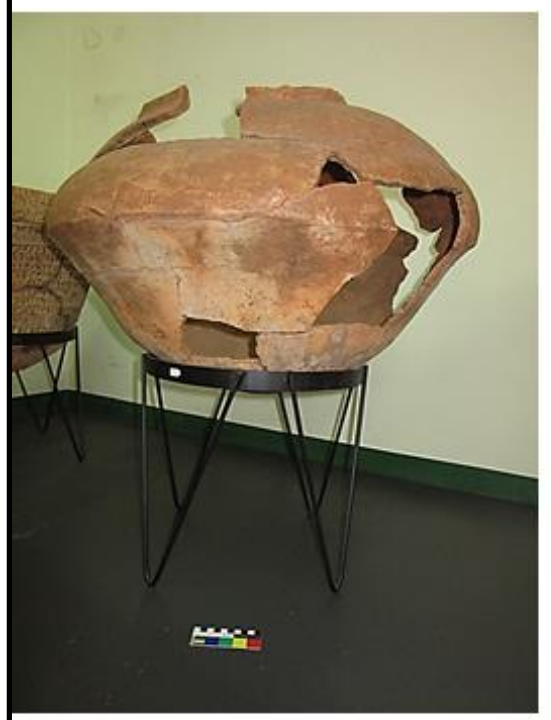

A
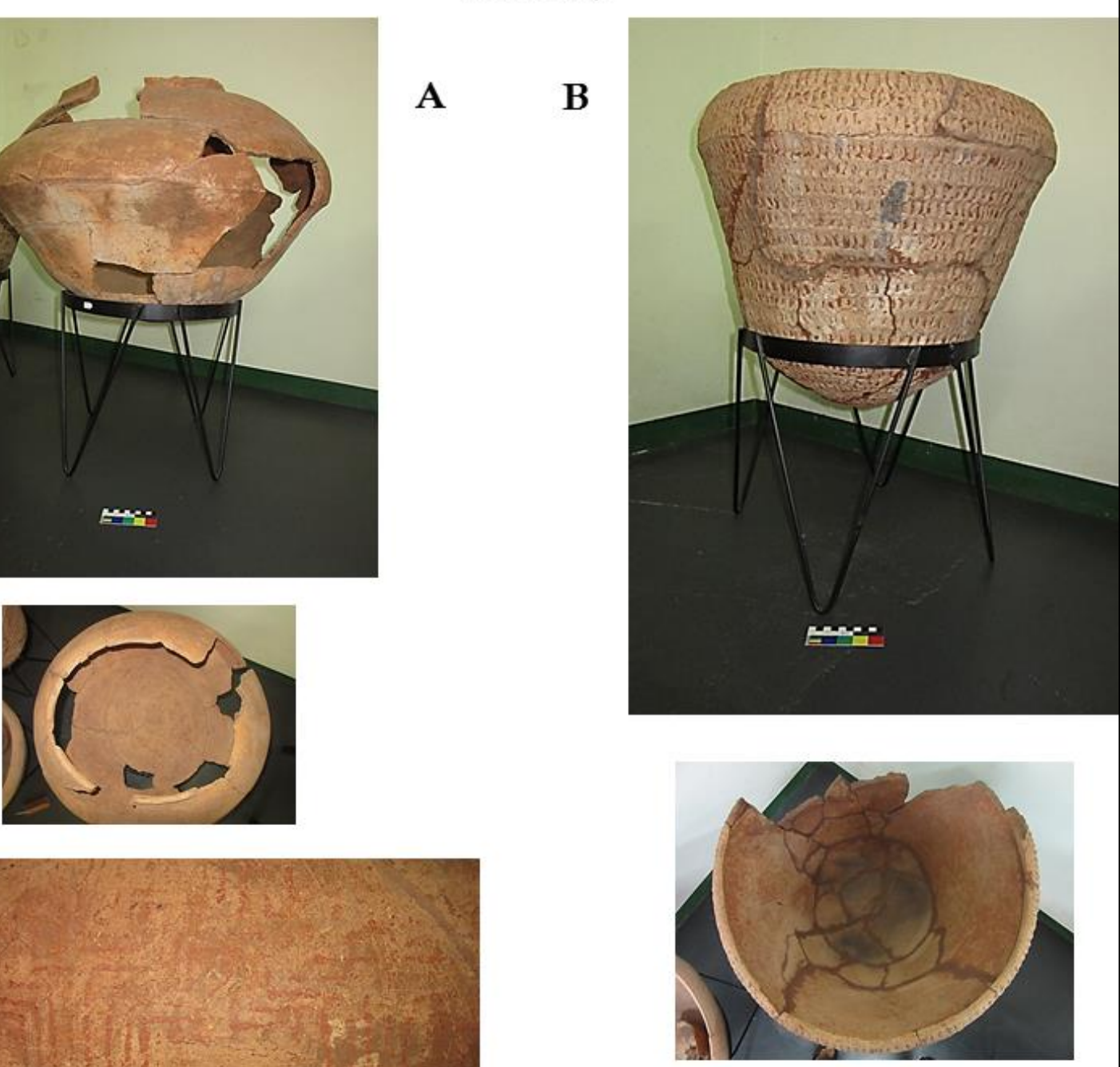
Prancha 20: Vasilhas de contextos funerários do sítio Pernilongo. Fotos: Mariana Cristante.

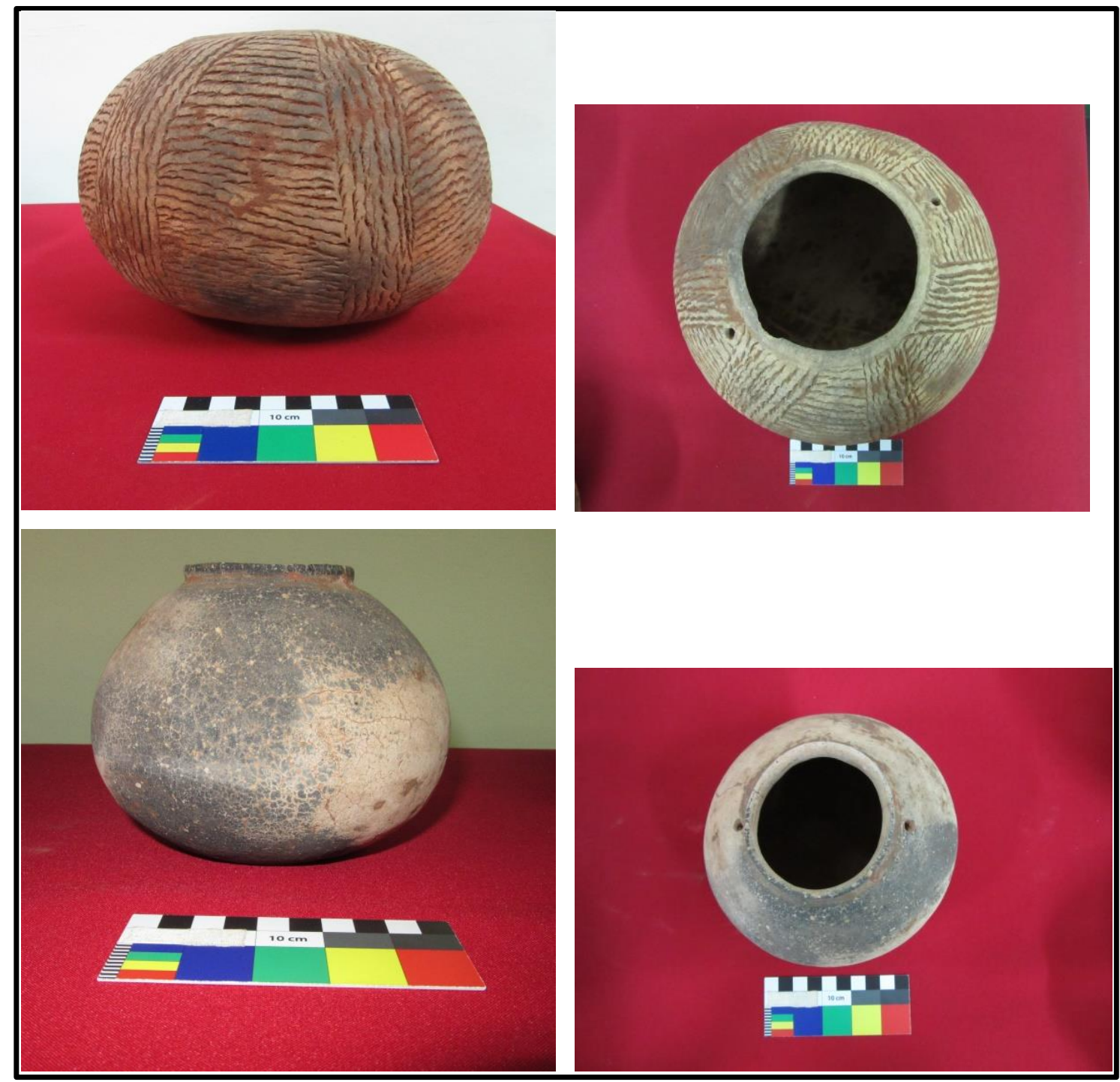

Os sítios os quais analisamos apenas uma vasilha não possibilitam a identificação de padrões intra-sítio, apenas comparações com os outros. A vasilha do sítio Nunes é muito similar às do Alves, como já sugeria Morais (1999). A vasilha do sítio Salto Grande e a do bairro Cascavel são muito similares às do Fonseca e Prassévichus, sendo todas essas de morfologia Tupinambá. A cambuchí do sítio Lopes e do achado fortuito de Rosana também se parecem um poco, assim como a vasilha do sítio Lagoa São Paulo e a do sítio Canuto. 


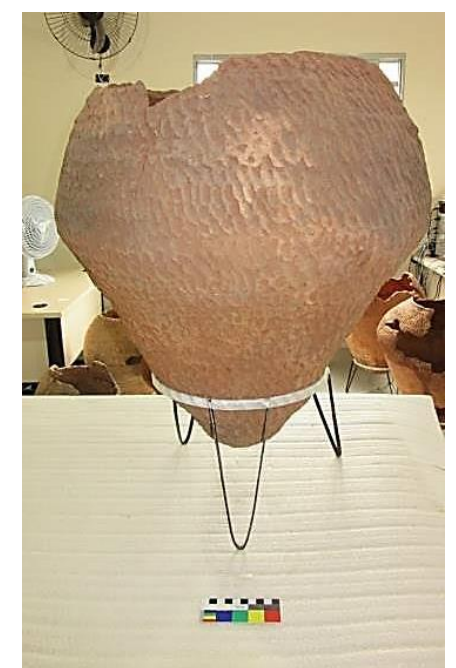

Figura 22: Urna encontrada no bairro Cascavel, Piraju. Acervo Centro Regional de Piraju. Foto: Mariana Cristante.
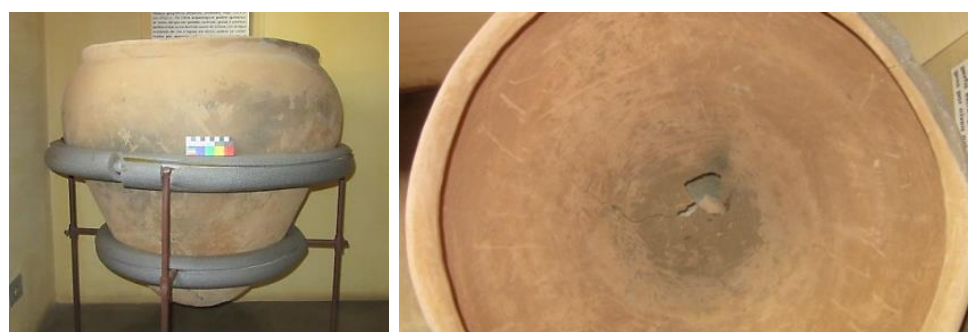

Figuras 23-24: Urna retirada de contexto, proveniente do sítio Nunes. Exposição Centro Regional de Piraju. Fotos: Mariana Cristante.
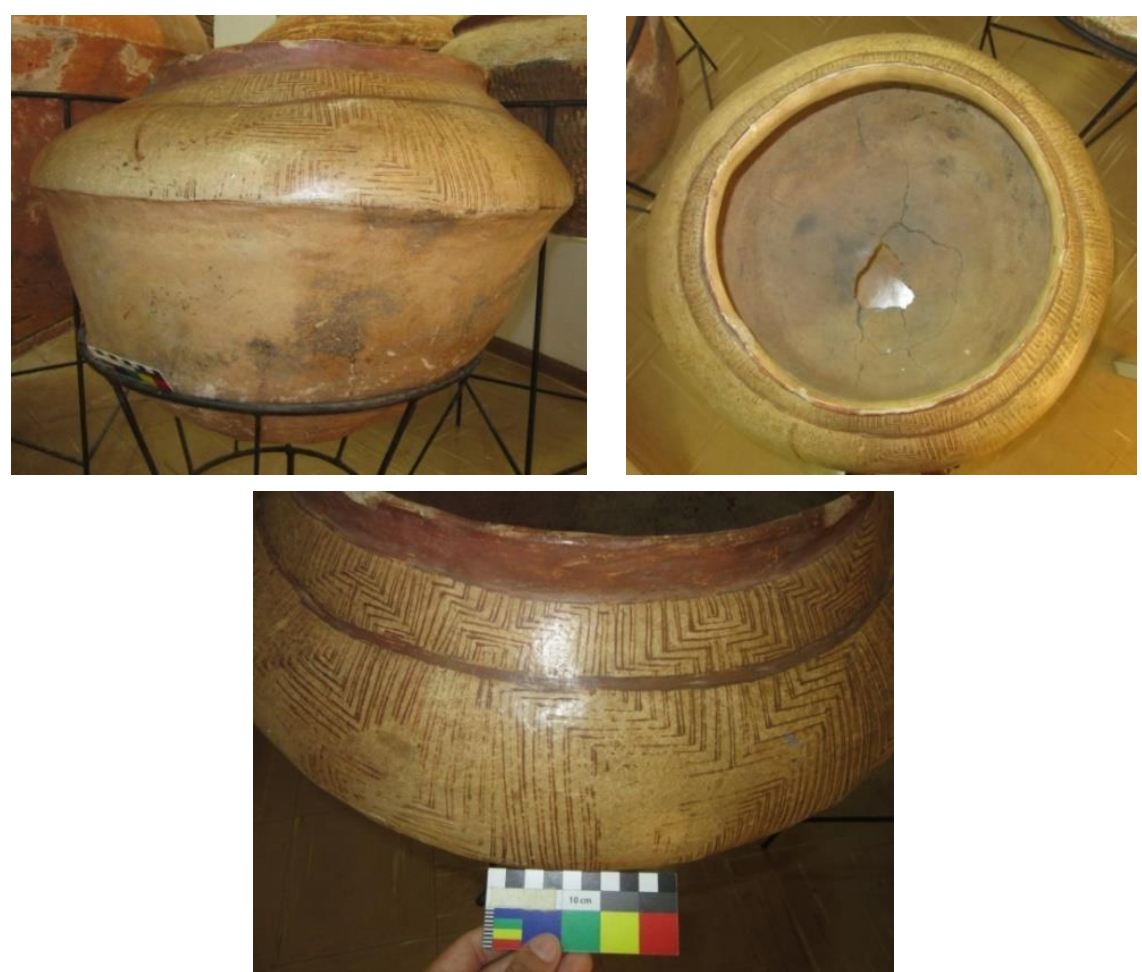

Figuras 25-27: Vasilha encontrada em ocorrência no município de Rosana. Exposição CEMAARQ. Fotos: Mariana Cristante. 

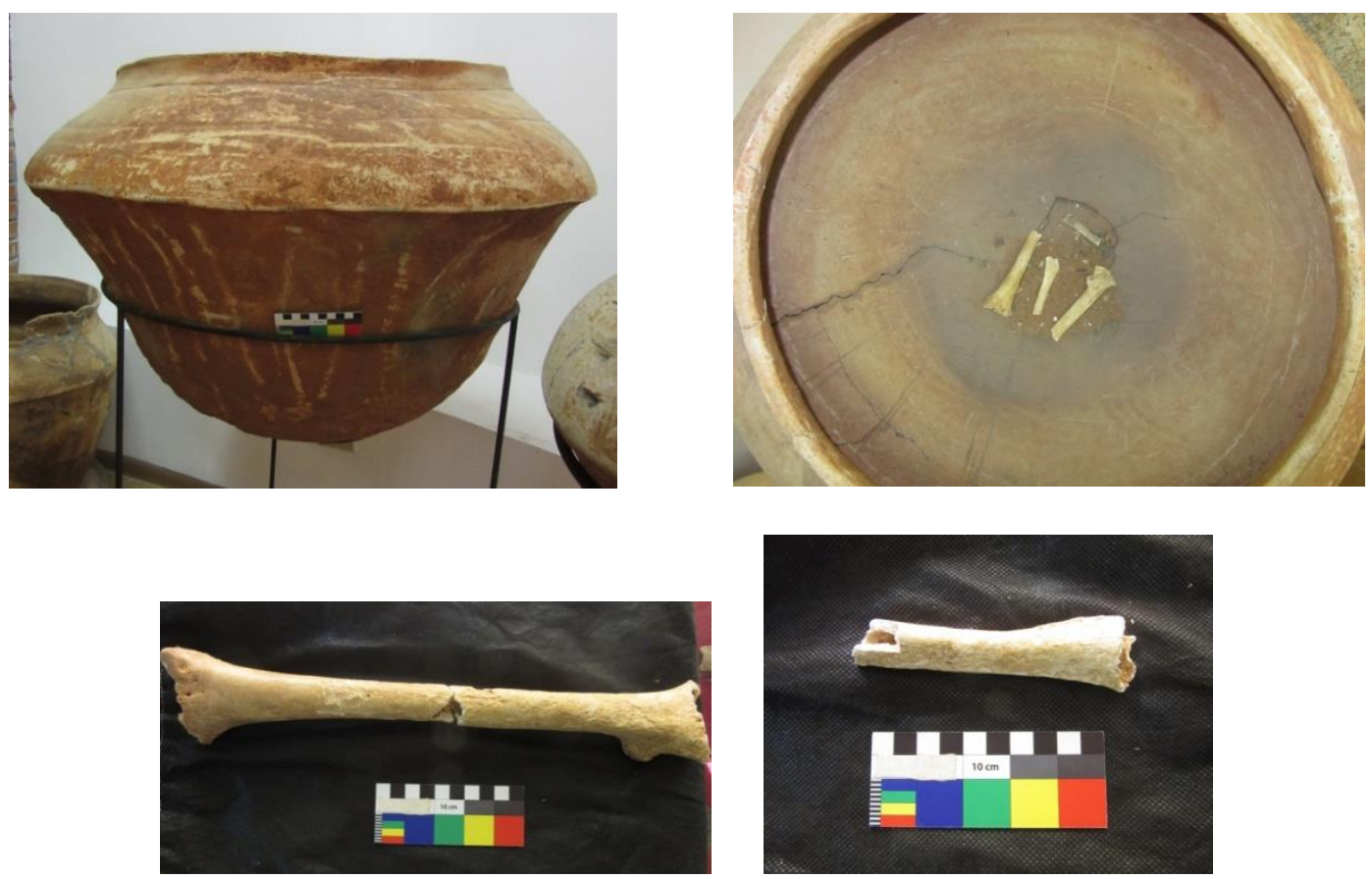

Figuras 28-31: Vasilha do sítio Lopes, com fragmentos de ossos humanos dentro. Exposição do CEMAARQ. Fotos: Mariana Cristante.
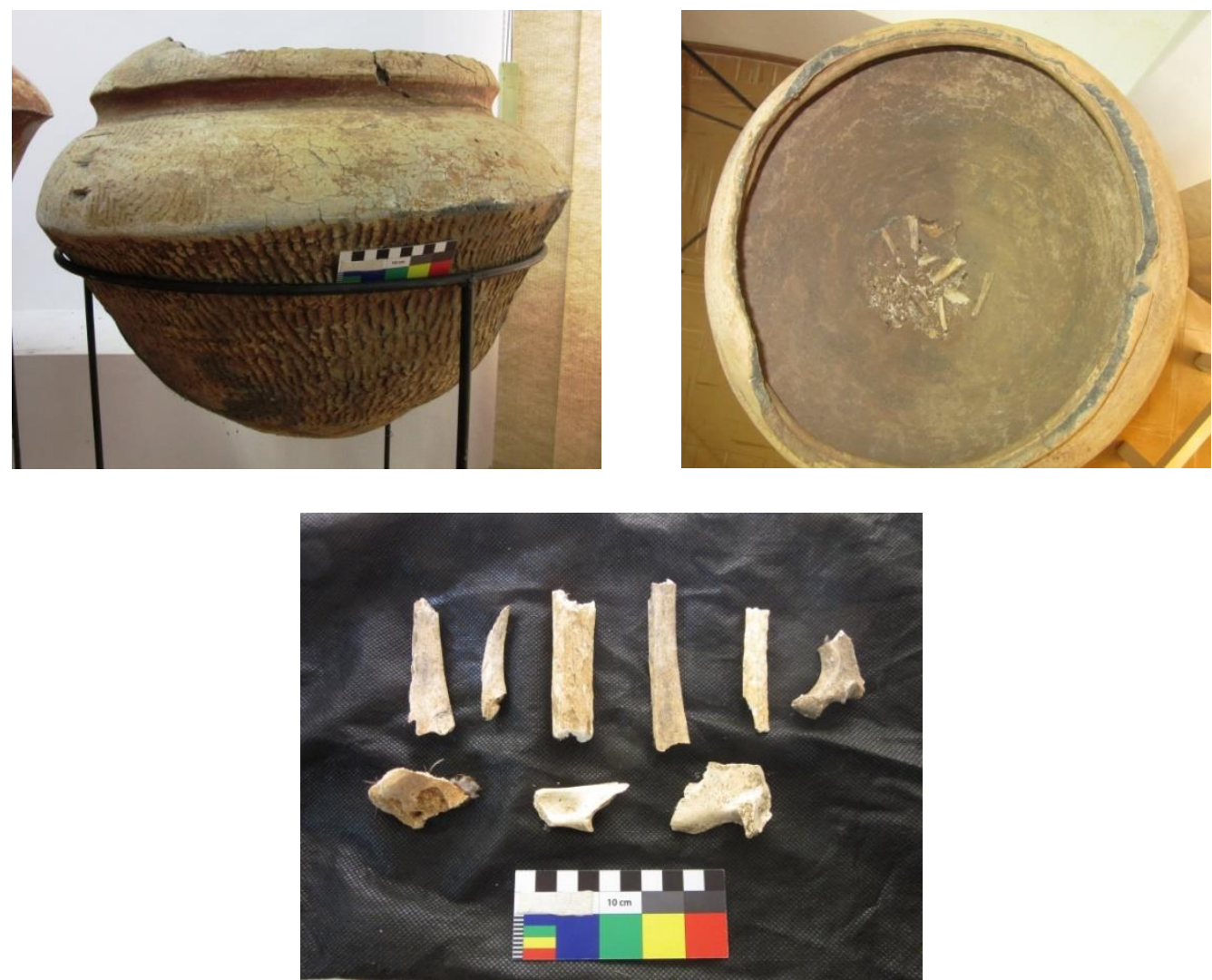

Figuras 32-34: Vasilha do sítio Romanini, com fragmentos de ossos dentro. Exposição CEMAARQ. Fotos: Mariana Cristante. 
Prancha 21: Vasilha do sítio Canuto (1 ou 2). Exposição CEMAARQ. Fotos: Mariana Cristante.

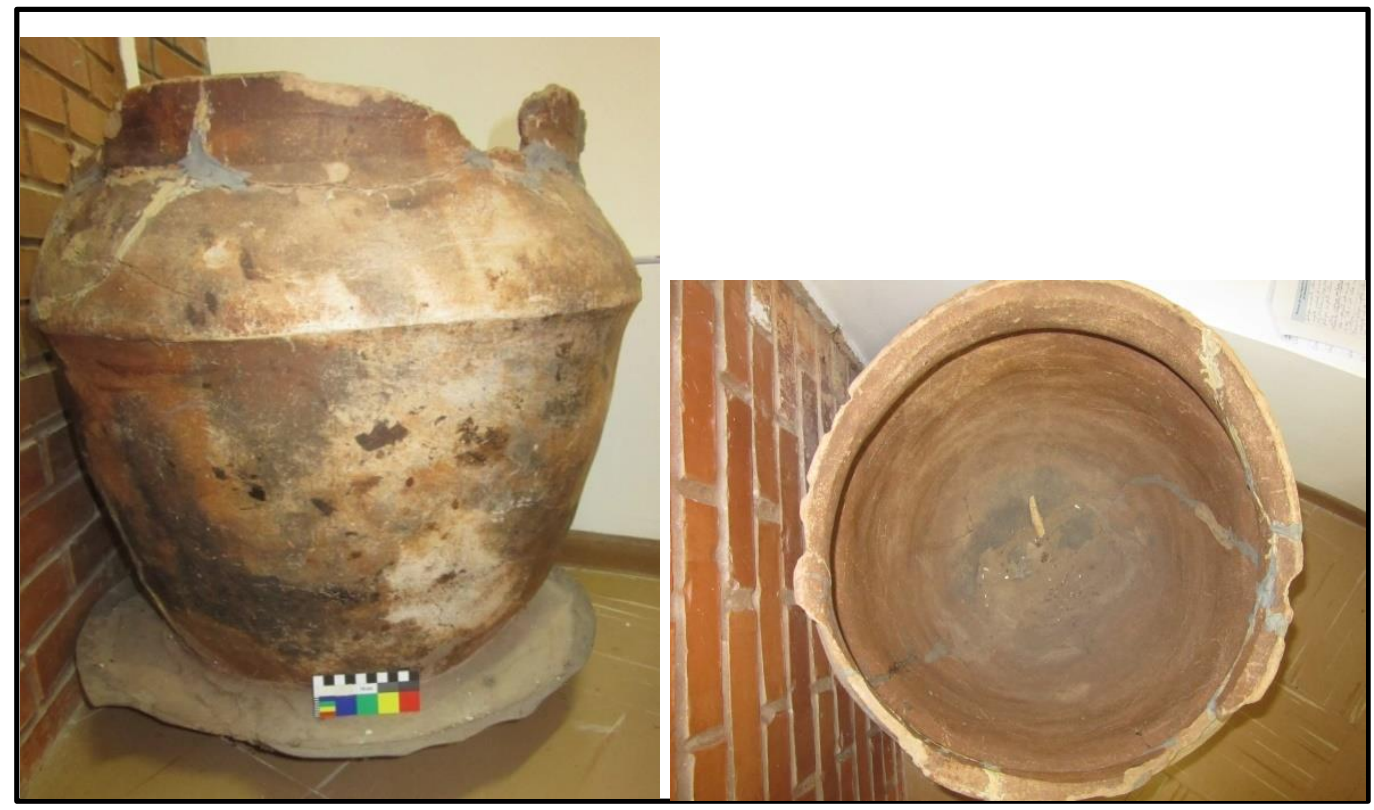

Prancha 22: Urna do sítio Lagoa São Paulo 2. Exposição CEMAARQ. Fotos: Mariana Cristante.

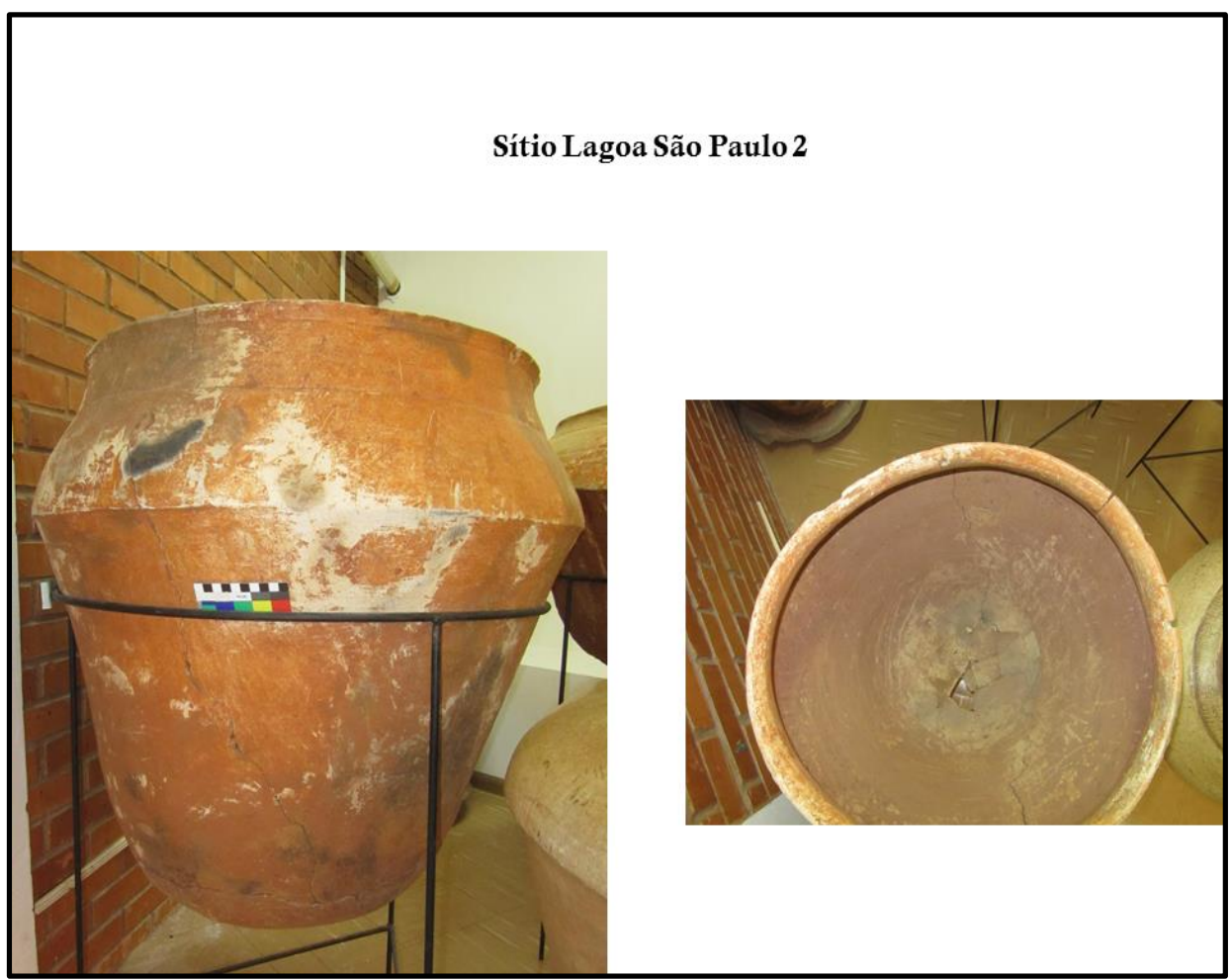

Os dados demonstram que as urnas Tupinambá do Paranapanema são bem padronizadas, mesmo entre sítios diferentes, enquanto as Guarani são bem variadas, tanto inter quanto intra-sítios. O único sítio Guarani analisado com 
material não muito variado no âmbito do sítio é o Alves, aquele que é contemporâneo a sítios Tupinambá mais ou menos próximos.

Ao observar a altura e maior diâmetro das urnas, e fazendo um cálculo aproximado de volume, podemos ver que as do Prassévichus são maiores e com bem maior capacidade que as do Fonseca. A do Salto Grande é maior do que qualquer urna desses dois primeiros sítios (sendo a maior nhaempepó corrugada), e a do bairro Cascavel possui o tamanho semelhante a uma das do Fonseca. As urnas do Alves são, juntas, maiores e com muito maior capacidade que os conjuntos dos outros sítios, embora haja outras urnas que possuam capacidade similar a cada urna individual do Alves (como a cambuchí do sítio Aguinha). A urna do Nunes é de um tamanho similar às do Alves, e as do Pernilongo e Aguinha são, em geral, menores, com exceção da cambuchí do Aguinha, que possui um tamanho e capacidade bastante maior que as outras urnas do sítio e que qualquer vasilha do Pernilongo. Tanto no sítio Fonseca quanto no Alves, Aguinha e Pernilongo, as cambuchí possuem um volume maior que as yapepó. Os sítios Alves e Aguinha apresentam as maiores cambuchí.

As tampas encontradas foram poucas, e várias estavam quebradas, pois em muitos casos o contexto foi encontrado após a passagem de maquinário agrícola sobre ele, e no processo a tampa se quebrou, não sendo possível a observação de seu padrão morfológico. Das poucas que pudemos analisar, quase todas possuem no mínimo $50 \mathrm{~cm}$ de diâmetro máximo, sendo que apenas a tampa do contexto funerário II do Pernilongo possui $35 \mathrm{~cm}$. As que puderam ter sua forma reconstituída são ñaembé guaçu (prato grande) e cambuchí caguabá. Os tratamentos de superfície também variam, sendo alisado, engobo, corrugado e pintura vermelha.

As vasilhas anexas que encontramos para analisar não são tantas quanto as que possivelmente havia nos contextos. No caso do sítio Prassévichus, só tivemos certeza de uma das vasilhas que foram encontradas dentro da urna, sendo que provavelmente havia outras. No sítio Alves, encontramos quase todas as vasilhas descritas por Pallestrini (1975) como integrantes dos contextos funerários. Já no caso dos sítios Aguinha e Pernilongo, sabemos que havia diversas outras vasilhas nos contextos funerários, mas não obtivemos informação de quais são as outras, além daquelas que analisamos. 
O conjunto de vasilhas anexas dos sítios apresenta formas bastante variadas, pertencentes às classes: ñaetá/nhaem, yapepó myri, cambuchí myri e cambuchí caguabá. O Alves é o que possui a maior variedade classes de vasilhas anexas, encontradas dentro de urnas, no entanto é o sítio que mais encontramos vasilhas anexas para analisar. O Aguinha provavelmente também possui outras formas que não encontramos. Quanto aos tratamentos de superfície interna e externa, são bastante variados em todos os sítios, em especial o tratamento externo, havendo Alisado, Engobo, Engobo Vermelho, Engobo preto, Ungulado, Incisos, Pintura preta sobre engobo branco + Engobo Vermelho, Alisado + Engobo branco, Alisado + Engobo, Engobo + Pintura vermelha no lábio. Embora as formas das vasilhas anexas sejam mais variadas que as das urnas, os tipos de tratamentos de superfície são um pouco menos variados nas vasilhas anexas do que nas urnas.

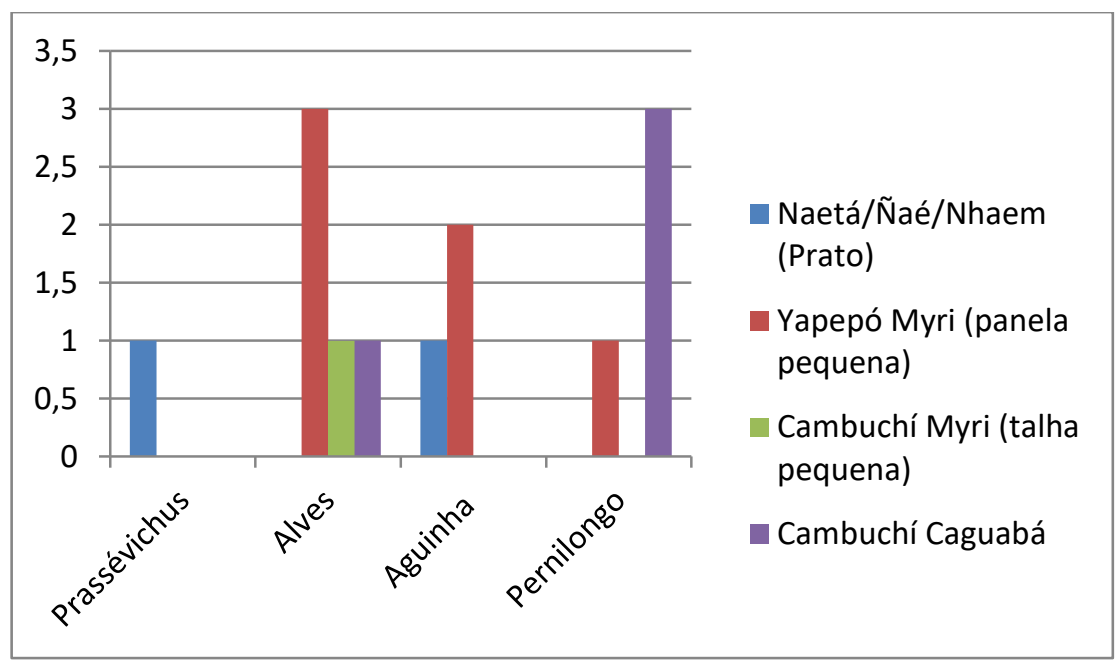

Gráfico 4: Classes de vasilhas anexas por sítio.

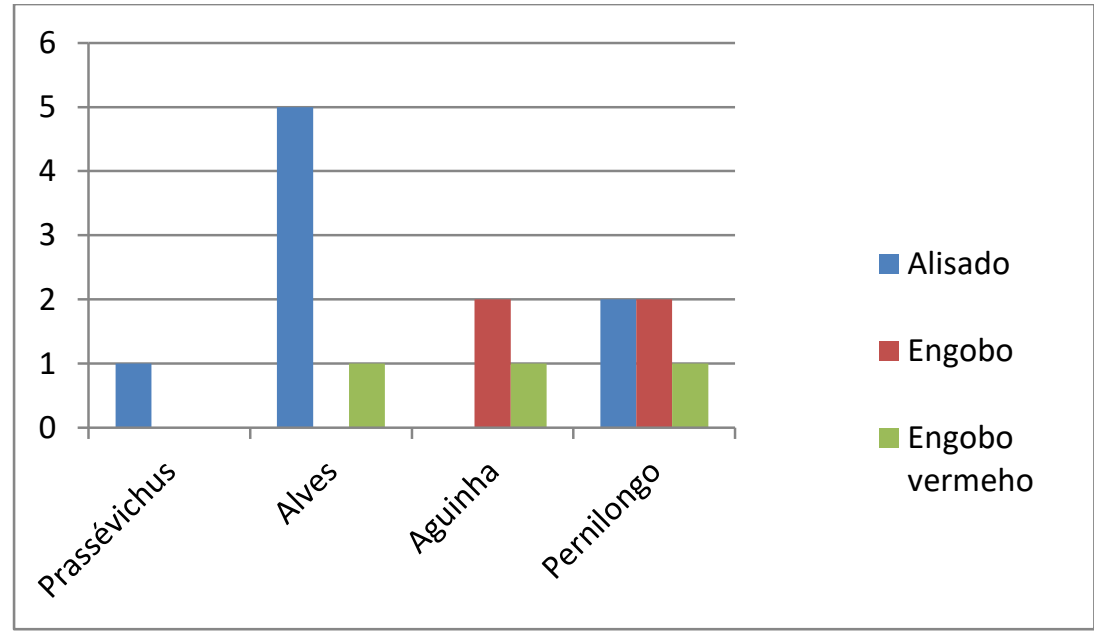

Gráfico 5: Tratamentos de superfície interna das vasilhas anexas. 


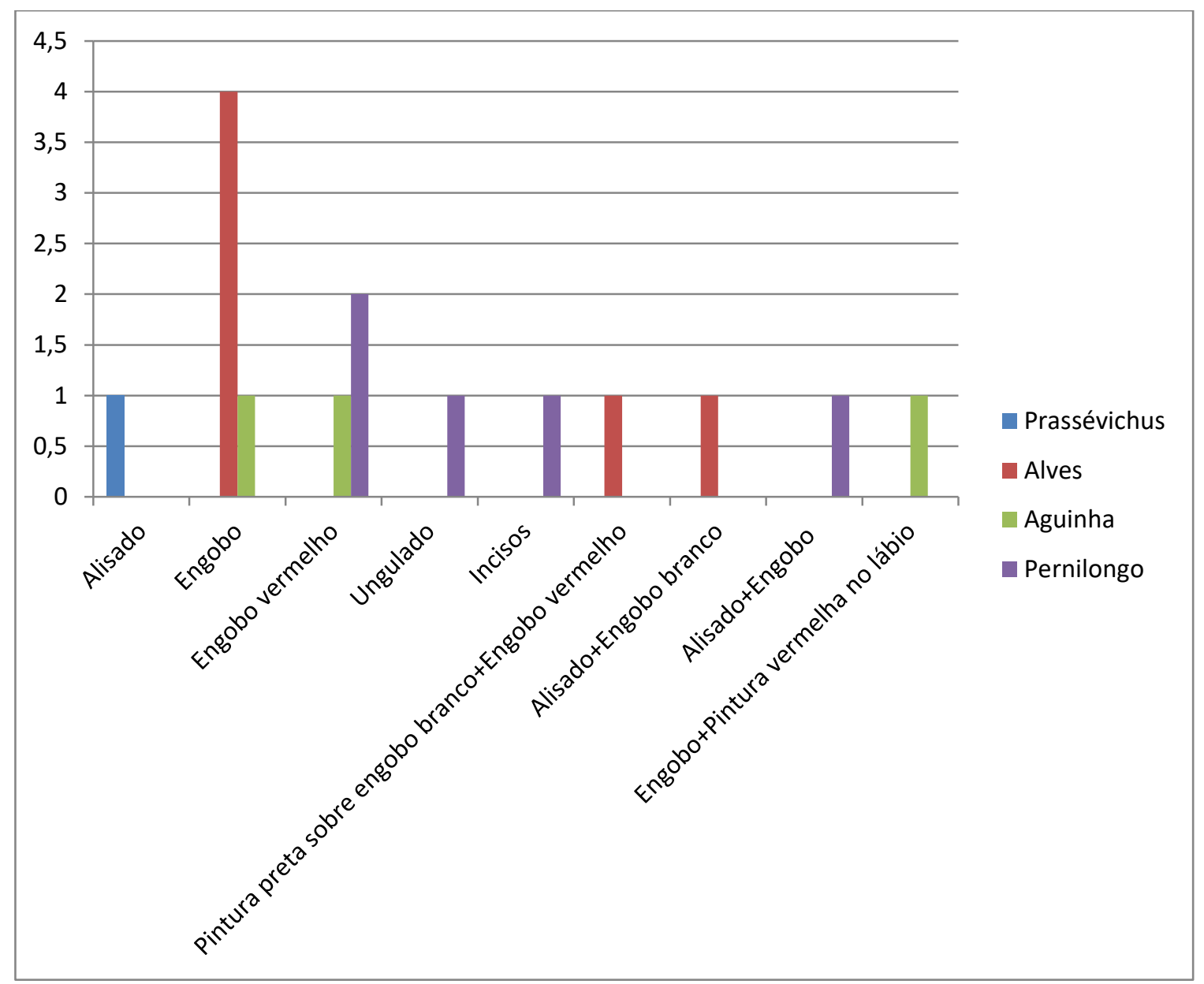

Gráfico 6: Tratamentos de superfície externa das vasilhas anexas.

\subsubsection{B - Marcas de uso}

A análise da existência de marcas de uso nas urnas e vasilhas ligadas aos contextos funerários é interessante porque pode trazer mais informações sobre as práticas relacionadas aos mortos. $\mathrm{O}$ estudo do uso de vasilhas cerâmicas, dentro de uma perspectiva de história de vida dos objetos, pode trazer mais informações sobre aspectos simbólicos das práticas funerárias Guarani.

A observação de marcas de uso nas cerâmicas funerárias não é algo novo na arqueologia de grupos Tupi. Vários arqueólogos mencionam que as vasilhas são "reaproveitadas". Na etnografia também há observações de grupos Tupi que usavam vasilhas para chicha ou cauim como urnas funerárias.

Porém, até agora não foi muito trabalhada essa relação entre o uso cotidiano ou em outros rituais, como o antropofágico, e o uso funerário. Há uma diferença significativa se uma vasilha cerâmica é utilizada exclusivamente para o funeral, construída apenas para aquele fim, ou se ela é primeiro utilizada em outras 
situações e depois no funeral. Essa diferença está ligada a distintos gestos funerários empregados, provenientes de simbologias diferentes em relação aos mortos. No caso de vasilhas fabricadas exclusivamente para o funeral, houve o trabalho de confecção das mesmas para a ocasião, e no caso de vasilhas provenientes de outros contextos, de outras situações (optamos por não utilizar o termo reutilizadas), a confecção se deu em outro momento e com outras finalidades para além do funeral.

De acordo com Silva \& Noelli (2017), entre os Asurini do Xingu as vasilhas utilizadas em contextos rituais são quase as mesmas utilizadas em contextos cotidianos, com a diferença de que as de uso ritual são, em geral, maiores. Apenas uma vasilha é utilizada apenas em contexto ritual, pois ela é o receptáculo do sobrenatural tauva, do ciclo ritual turé. Similares parecem ser também as vasilhas funerárias dos Tupinambá e Guarani, confeccionadas para outros usos, sendo a deposição em contexto funerário apenas uma parte de sua história de vida.

A análise de marcas de uso demanda a observação atenta e exclusão daquelas marcas que foram feitas por outros fatores que não uso cotidiano ou ritual, tais como a escavação da vasilha, a conservação (ou ausência de) na instituição de guarda, etc. Eu muitos casos, a detecção correta de marcas de uso torna-se muito difícil.

Em se tratando de uso, as relações, as atividades realizadas pelas pessoas, englobam ações ligadas ao cozimento, armazenamento e limpeza das vasilhas (idem, p. 47). No caso de vasilhas encontradas em contexto ritual (caso tenham sido utilizadas também em outras situações além do ritual), acrescentam-se ações próprias do mesmo, que são provenientes de histórias de vida diferenciadas daqueles objetos rituais em relação aos cotidianos (Walker, 2001).

Um estudo aprofundado desses traços em vasilhas cerâmicas Guarani é muito desejável, porém não é o objetivo primeiro de nossa pesquisa. Por isso, iremos nos focar apenas na análise de algumas marcas que podem indicar abrasão, através das quais podemos inferir uso com alguma segurança. A análise que fizemos foi a olho nu e com lupa de aumento $5 \mathrm{x}$, sendo que não recorremos a análises mais detalhadas, utilizando métodos arqueométricos, por exemplo.

As marcas de abrasão na cerâmica são definidas como a remoção ou deformação de partes da superfície da mesma. Isso pode ocorrer através de processos 
mecânicos de abrasão, tais como raspagem, arranhões ou choques causados por objetos, ou processos não ligados à raspagem, como a erosão por sal ou acidez (Skibo, 1992, p. 106).

Além das marcas causadas por abrasão, identificamos um tipo de marca bastante interessante: furos que ladeiam rachaduras em vasilhas ou quebras de fragmentos que compõem vasilhas. A única referência que encontramos que explique o que são está em Faccio (2011), que interpreta esses furos como feitos ao lado de uma rachadura da vasilha com o objetivo de servirem para se passar cordas que amarram a rachadura, impedindo seu progresso e a consequente quebra da vasilha. A rachadura poderia atrapalhar o armazenamento ou cozimento de líquidos, mas ainda poderia ser possível utilizar a vasilha para o armazenamento de outras coisas, ou simplesmente para fins funerários.

Nosso objetivo era inferir se houve outros usos das urnas e vasilhas encontradas em contextos funerários além do de sepultar os mortos e servir como agentes no ritual funerário, a fim de testar a hipótese já bastante corrente na arqueologia de que as urnas são recipientes primeiramente utilizados em outros contextos, e depois no funerário. Nossa análise tem indicado que sim. Várias urnas e vasilhas apresentam marcas de uso que levam a crer que tiveram outros usos antes de serem utilizadas para fins funerários. As marcas que pudemos observar são todas relativas à abrasão causada por raspagens e/ou pancadas de outros objetos, talvez mexedores ou mesmo outras vasilhas utilizadas em conjunto com a vasilha em questão. Essas marcas indicam o uso dessas vasilhas para outras atividades antes de serem empregadas como recipientes no ritual funerário, tendo sido este o uso final desses objetos, mas não o único.

Durante a análise das urnas e vasilhas, notamos que algumas delas possuíam certas marcas que em alguns casos se repetem, formando certos padrões, que descrevemos abaixo.

1- Abrasão em formato de anel próximo à base, causada provavelmente por raspagem através da movimentação em sentido circular de objeto na superfície interna da vasilha, talvez um mexedor utilizado durante o preparo de alimentos, gerando o desgaste do tratamento de superfície e a exposição da queima interna da cerâmica, preta. Contextos em que isso é encontrado: Fonseca, Prassévichus, Alves e no achado fortuito na cidade de Salto Grande. 
Pranchas 23 e 24: Abrasão em forma circular próxima à base.

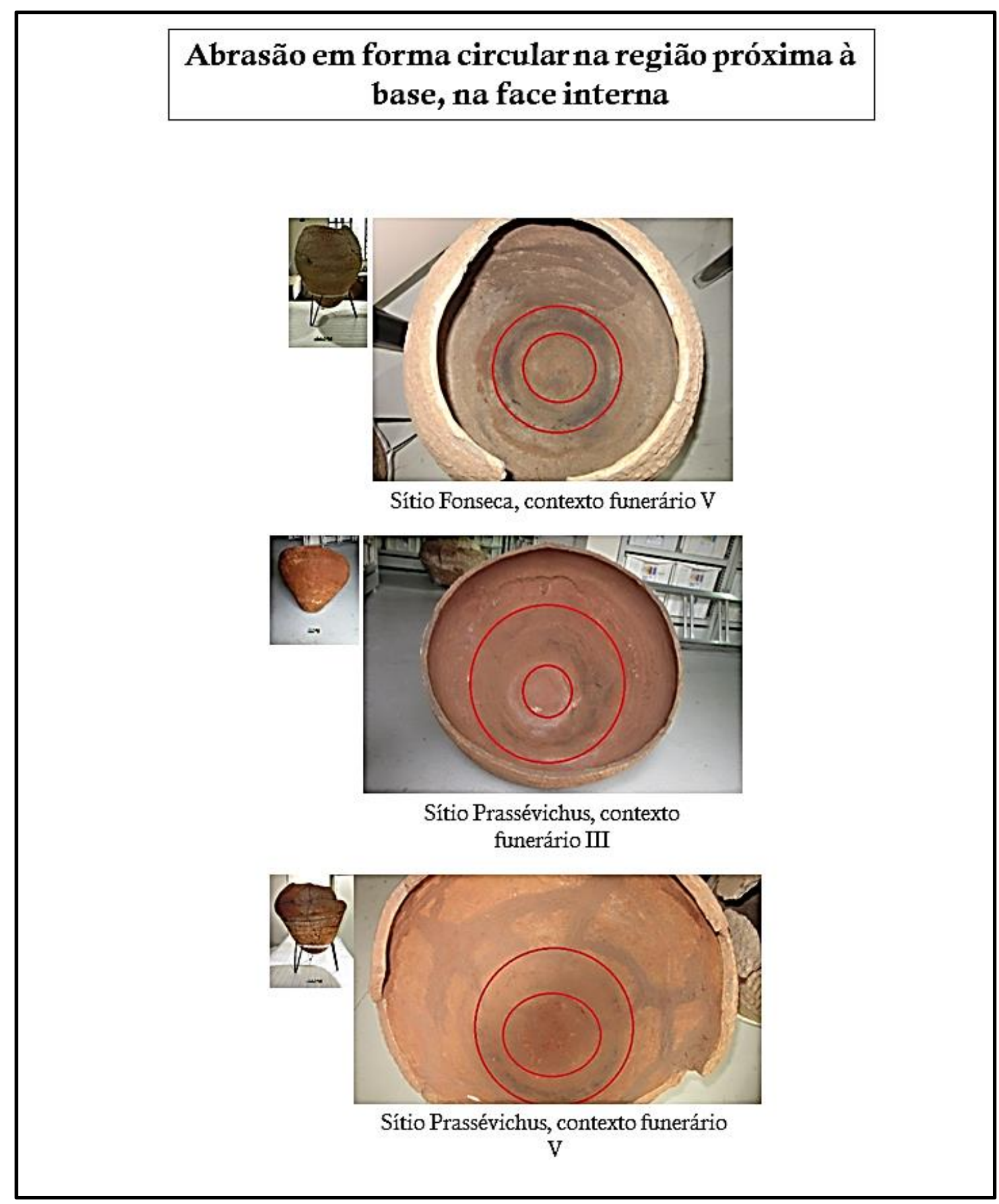




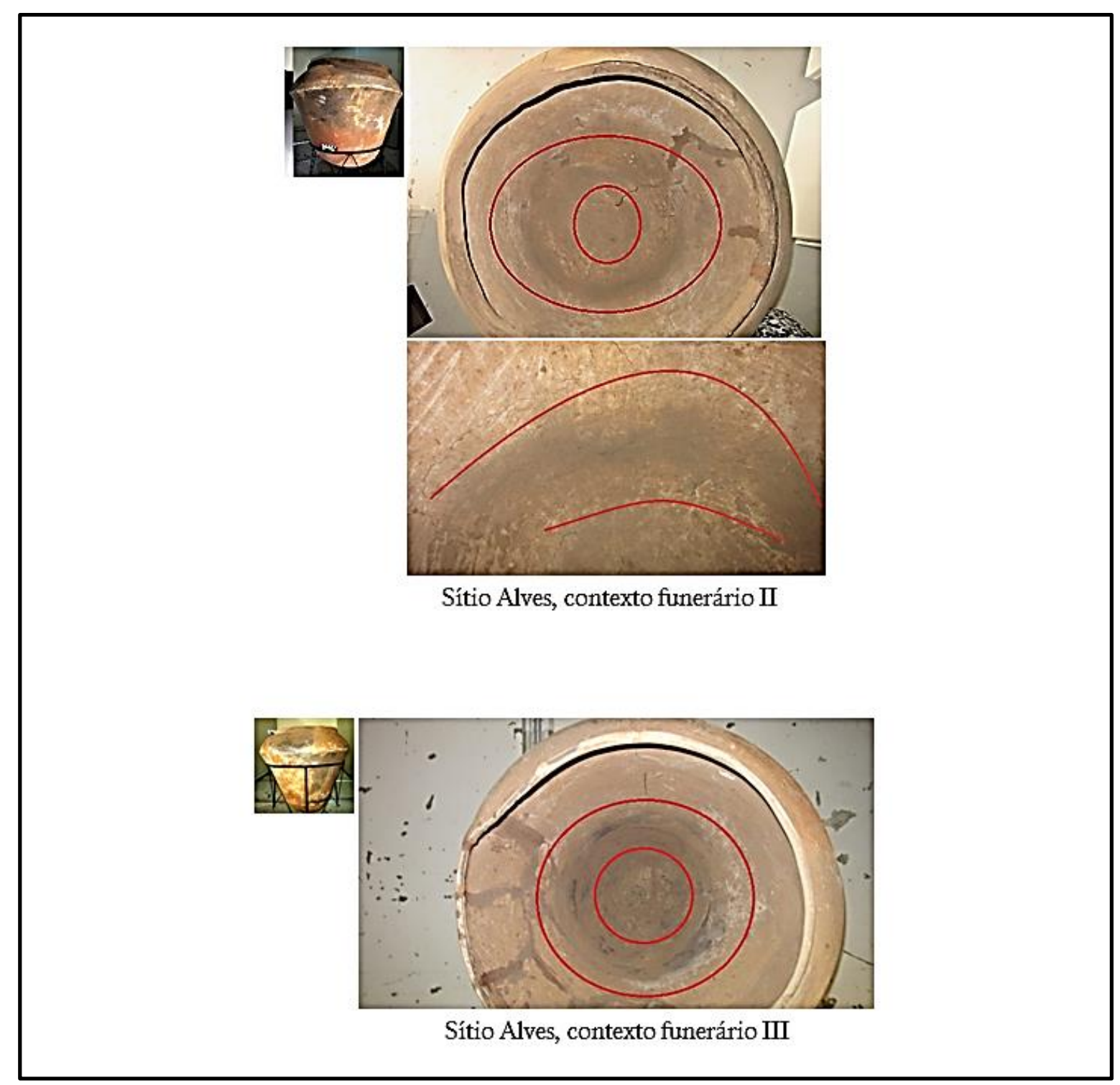


2- Abrasão por raspagem cobrindo uma área relativamente extensa da base na face externa, provavelmente causada por movimentação da vasilha sobre uma superfície abrasiva, levando ao desgaste do tratamento de superfície e consequente exposição da queima da cerâmica (no caso da vasilha do sítio Prassévichus), ou da superfície sem o engobo (no caso da vasilha do sítio Pernilongo). Contextos em que isso acontece: Prassévichus e Pernilongo.

Prancha 25: Abrasão na face externa da base.

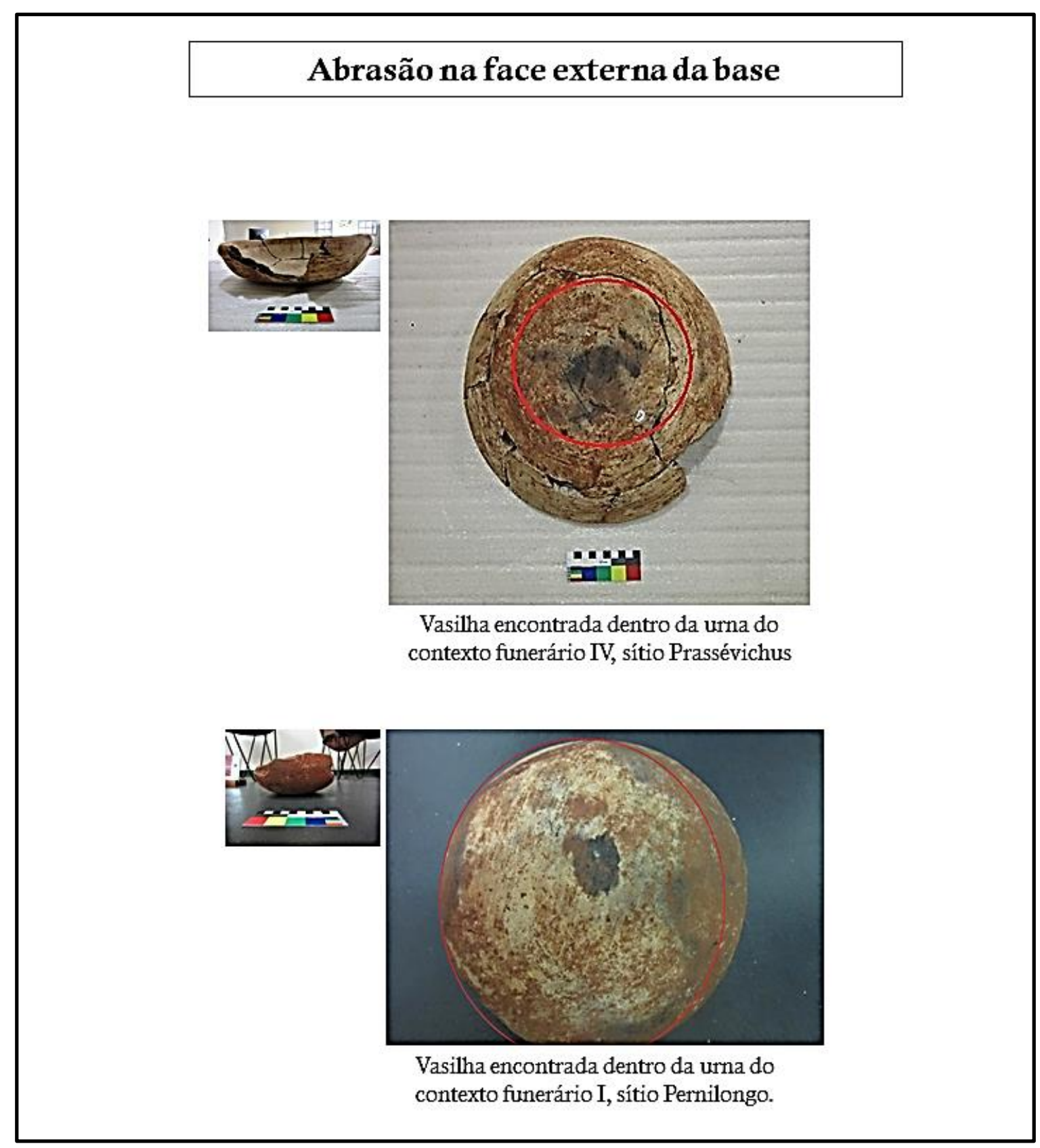


3- Abrasão em forma de buracos, localizados em apenas um lado da base, na face interna, em que houve a remoção de partes do engobo até chegar à queima do interior da cerâmica. Provavelmente causados por golpes repetitivos de algum objeto. Contextos em que isso ocorre: Pernilongo.

Prancha 26: Marcas de uso na parte interna de um dos lados da base.

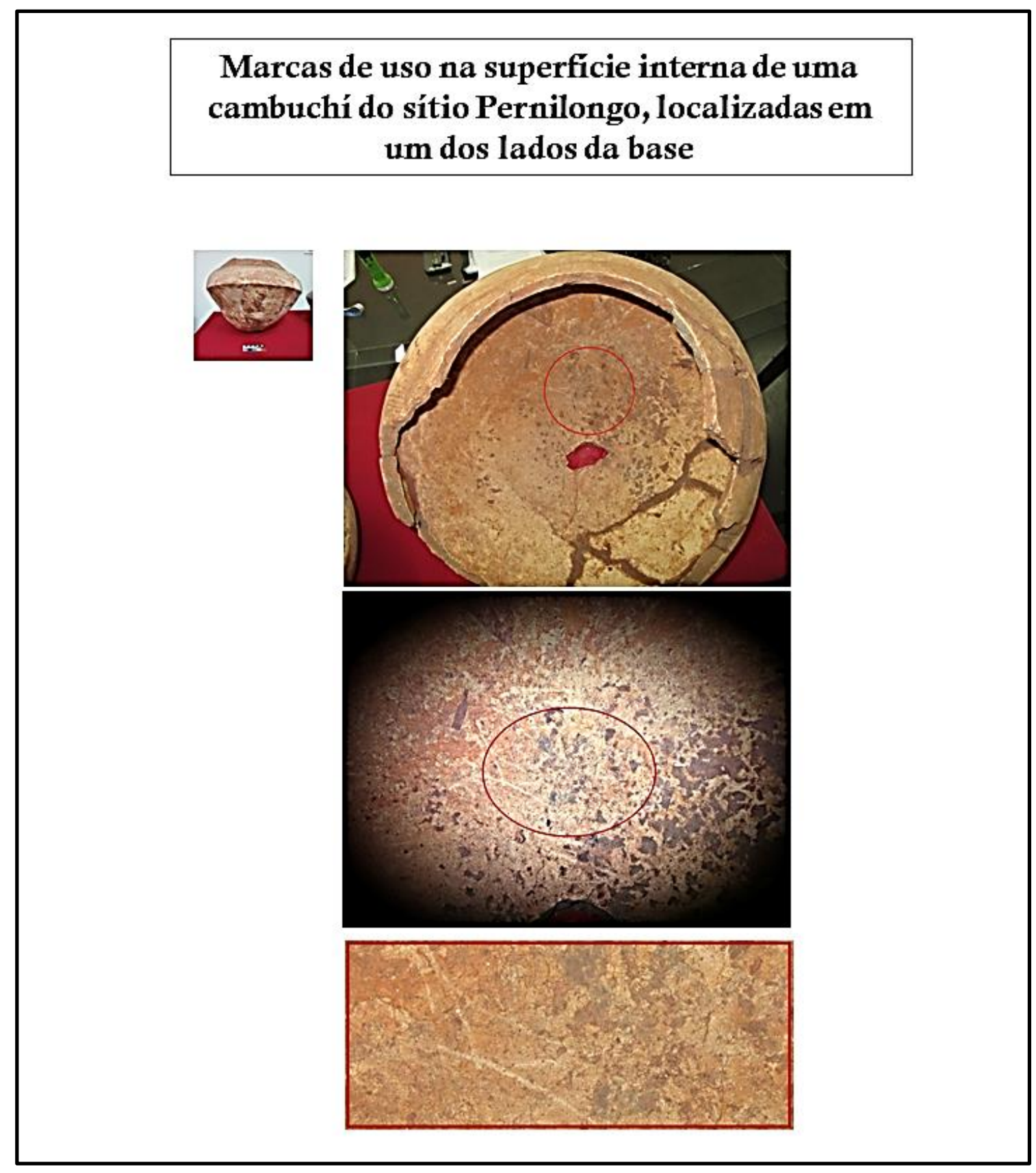


4 - Abrasão extensa por toda a região da base, na face interna. Diferentemente de raspagens causadas por escavação da vasilha, essas marcas são concentradas em um única região e a queima mais escura do interior da cerâmica aparece, sugerindo abrasão causada por objetos devido ao uso prolongado da vasilha para alguma atividade, talvez culinária. Sítio em que isso acontece: Aguinha.

Prancha 27: Abrasão na parte interna da base.

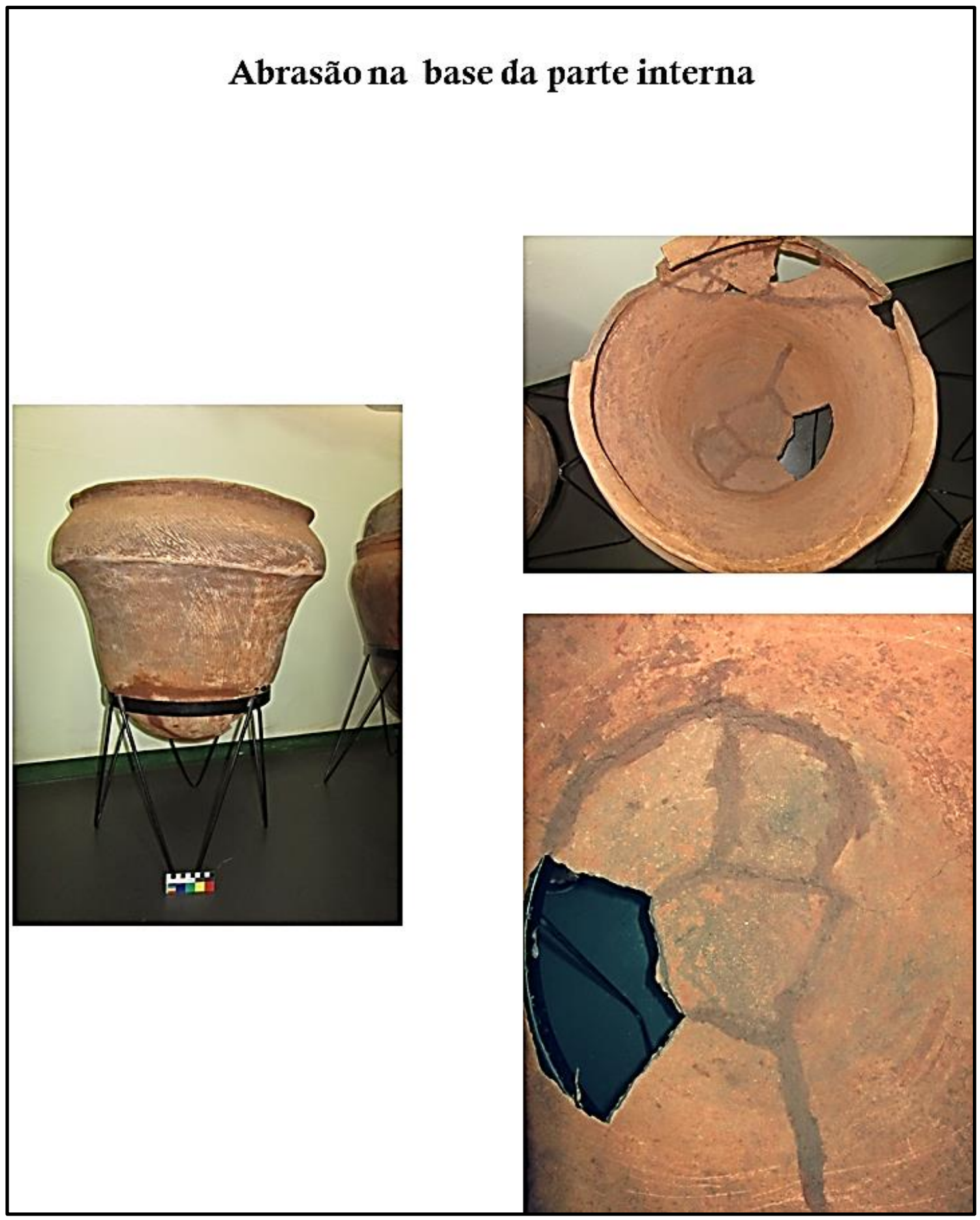


5 - Furos para a passagem de cordas que impeçam o quebramento da vasilha. Sítios em que isso acontece: Nunes.

Prancha 28: Furos ladeando rachaduras.

\section{Furos ladeando rachaduras}

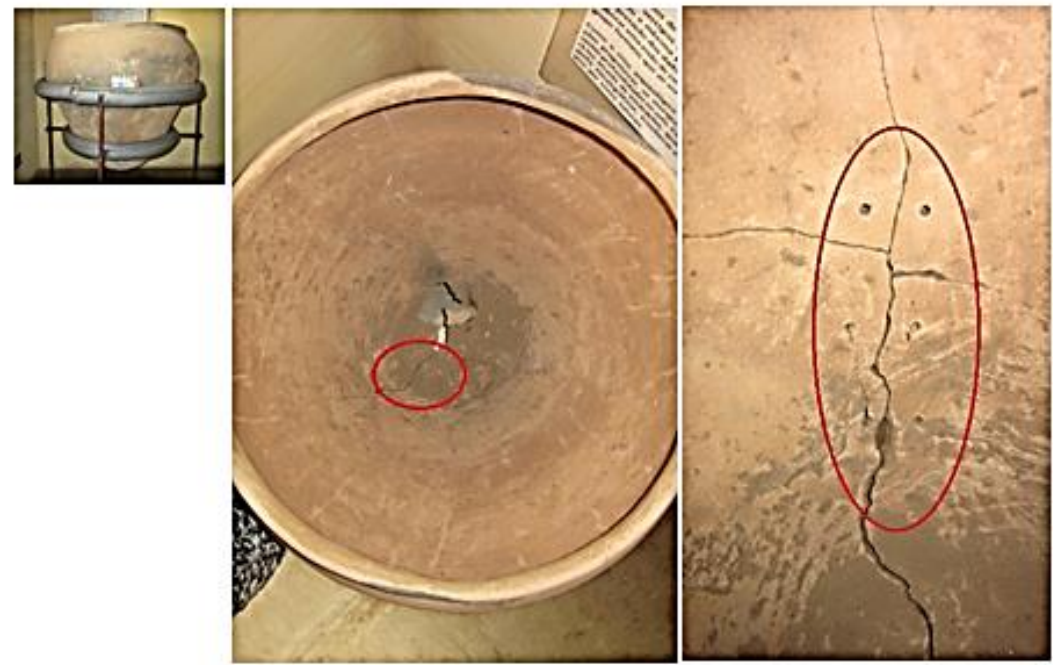

Urna encontrada na área do sítio Nunes, sem contexto
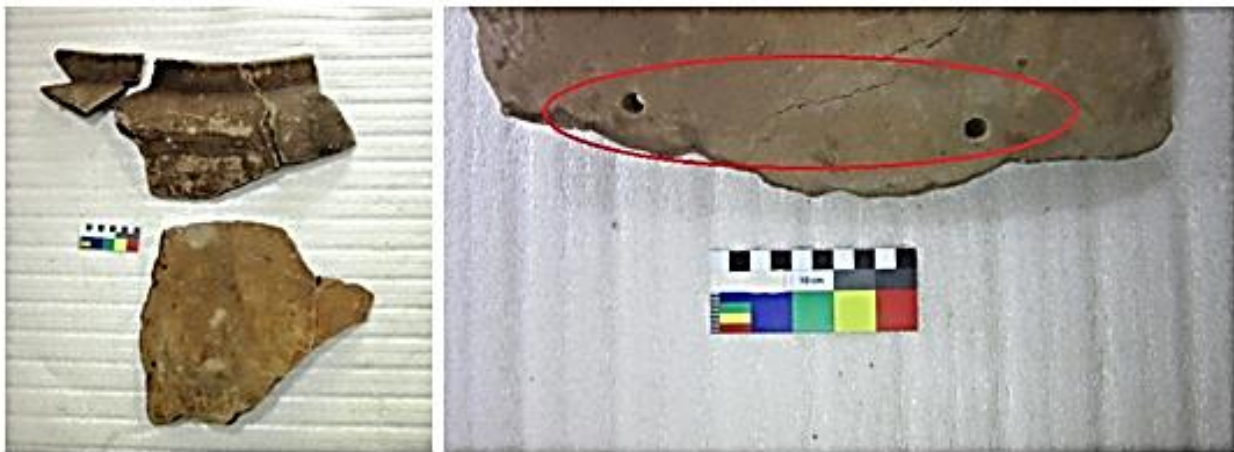

Fragmentos da borda e parede da urna do contexto funerário V, sítio Alves 
As marcas foram observadas tanto em urnas e possíveis urnas quanto em vasilhas anexas, sugerindo que de fato as vasilhas funerárias eram utilizadas em outros contextos antes do funerário tanto em grupos Guarani quanto Tupinambá, do alto, médio e baixo Paranapanema. Embora as marcas não sejam claras em todas as vasilhas encontradas, é possível propor que pelo menos algum tempo de uso não funerário elas tiveram.

Outra demonstração dessa utilização de cerâmicas feitas anteriormente para outros fins é a presença de cacos de cerâmica utilizados como tampa, ou a cobertura de "buracos" na parte de baixo ou de cima das urnas com outras vasilhas. Por vezes, quando uma vasilha não dava conta de cobrir devidamente a pessoa sepultada, eram utilizadas duas, o que demonstra a importância do gesto de cobrir com cerâmicas.

Assim, a análise das marcas de uso das cerâmicas funerárias traz a tona uma questão fundamental das mesmas: sua história de vida diferenciada quando comparada às vasilhas de uso cotidiano. Walker (2001) propõe que os artefatos de contextos rituais possuem uma história de vida diferenciada daqueles de contextos cotidianos, pois sua deposição final ocorreu por ações integrantes desses rituais.

A história de vida dos objetos engloba 4 estágios básicos: produção e distribuição, uso, reutilização e descarte (Skibo, 1999). As vasilhas funerárias dos Tupinambá e Guarani, portanto, possuem uma história de vida com pelo menos 4 estágios: seleção das matérias primas, confecção, uso cotidiano ou em outros rituais, uso funerário.

\subsection{5 - Análise da espacialidade funerária entre os sítios Tupinambá e Guarani}

\subsubsection{A - Os contextos funerários}

A análise da espacialidade funerária se deu de uma maneira multidimensional: na busca por gestos funerários (tentando distinguir o que são processos naturais de gestos) em cada contexto; e na observação da existência ou não de padrões em cada sítio, e se esses padrões se repetem entre os sítios. Foram observadas a posição de cada vasilha no contexto, a posição dos ossos (quando há), a posição das vasilhas em relação aos ossos, a posição das vasilhas e dos ossos em relação a outros elementos presentes no contexto (como pedras, tembetá), o espaçamento dos contextos no sítio e sua relação com outras estruturas (como as 
manchas de terra preta e fogueiras), e a distribuição desses padrões de cada sítio na região do Paranapanema e Alto Paraná. Evidentemente, todas essas observações não puderam ser feitas para todos os sítios.

No âmbito de cada contexto, de uma maneira geral, a espacialidade funerária varia bastante, indo muito além do tradicional "Urnas cobertas por tampas". Há contextos compostos por urnas com ou sem vasilhas dentro, contextos compostos por vasilhas ao lado de urnas, urnas uma ao lado da outra, uma sobre a outra, ou simplesmente a urna coberta por tampa.

A observação dos padrões que puderam ser percebidos dos 35 sítios nos levou a separar esses padrões em tipos distintos de sepultamentos em urna, que serão mostrados mais adiante no capítulo. Agora iremos mostrar os padrões para os sítios principais do Paranapanema.

Os contextos dos sítios Fonseca e Prassévichus são muito mais homogêneos mas não totalmente -, sendo, na sua maioria, uma única urna com tampa sobre ela. Já os contextos dos sítios Alves, Aguinha, Pernilongo e também Lagoa São Paulo 2, são mais diversificados dentro de cada sítio, havendo sepultamentos com vasilhas próximas, vasilhas dentro de urnas, vasilhas e ossos dentro de urnas, ossos diretamente na terra com vasilhas ao redor.

Portanto, os sítios Guarani possuem contextos funerários com a espacialidade intra-contexto mais diversificada. Houve a deposição final de muitas vasilhas em cada contexto, dentro e fora de outras vasilhas maiores, e também houve a deposição de grandes vasilhas próximas umas das outras. Como no caso dos sítios Tupinambá, isso não é uma regra, havendo também contextos compostos apenas por uma urna e tampa. O que estamos observando são apenas padrões que se repetem.

Já nos sítios Tupinambá do alto Paranapanema os contextos funerários são mais parecidos uns com os outros, sua espacialidade intra-contexto é mais homogênea. Houve o menor emprego de vasilhas menores dentro das grandes, não foram encontradas vasilhas menores fora, e o único caso de duas vasilhas grandes próximas - no qual uma está sobre a outra - não foi visto igual nos outros sítios.

Esse padrão, é claro, é desses sítios do alto Paranapanema. Se formos observar outros sítios Tupinambá, há a presença de vasilhas menores fora, como iremos mostrar adiante. 
Há uma diferença, no entanto, entre o sítio Alves e os demais sítios Guarani: Nesse sítio não há vasilhas fora e ao redor de urnas, apenas dentro, e não há grandes vasilhas muito próximas. Isso o torna, a princípio, o sítio Guarani mais parecido com os Tupinambá, parecido com o Fonseca e Prassévichus. Como mostramos acima, os sítios dessa região podem ter sido habitados por grupos Tupinambá e Guarani que conviveram entre si. Seria apenas coincidência a espacialidade intra-contexto nas estruturas funerárias ser mais parecida entre o Alves e o Fonseca/Prassévichus do que entre o Alves e o Aguinha/Pernilongo? O sítio Alves encontra-se em uma área repleta de sítios e ocorrências de cerâmicas Tupinambá, mesmo ele apresentando, em suas cerâmicas, contextos funerários e espacialidade funerária, diferenças marcantes com os sítios Tupinambá próximos.

\section{Sítios Tupinambá}

\section{Prassévichus}

Foram encontrados 8 contextos funerários. Os contextos funerários I e VIII foram destruídos por moradores locais, tendo sido encontrados apenas fragmentos cerâmicos e ossos nos locais. Não encontramos esses fragmentos e ossos, e por isso não puderam ser analisados. O contexto IV, cuja foto tirada na época da escavação está abaixo, continha duas vasilhas cerâmicas dentro, uma simples, de forma discoide, e a outra com pintura em seu interior. Não encontramos esta urna também. Segundo Pallestrini, ela possuía $70 \mathrm{~cm}$ de altura e $40 \mathrm{~cm}$ de diâmetro da boca (Pallestrini, 1983/4).

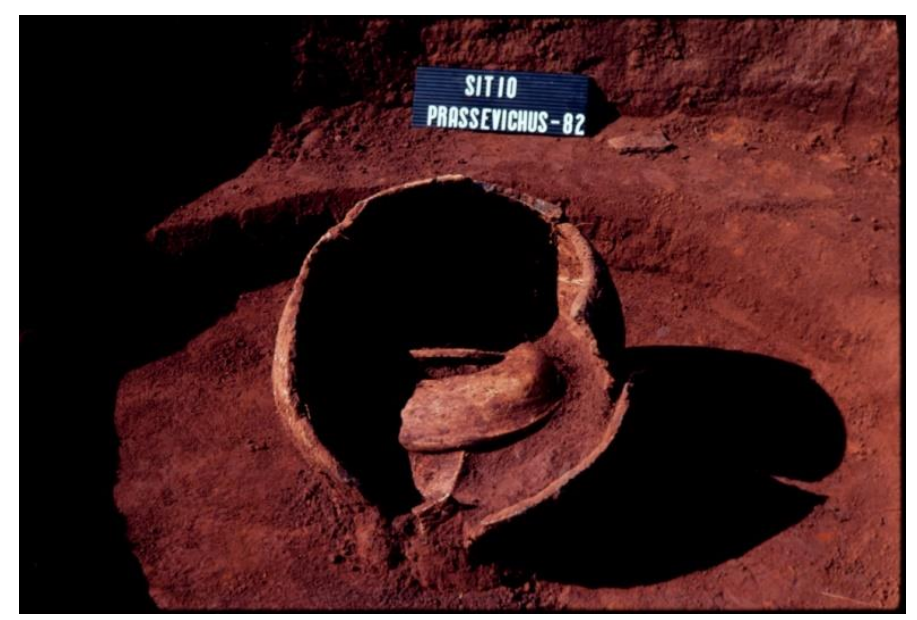

Figura 35: Contexto funerário IV do sítio Prassévichus. Foto do acervo documental do MAE/USP. 


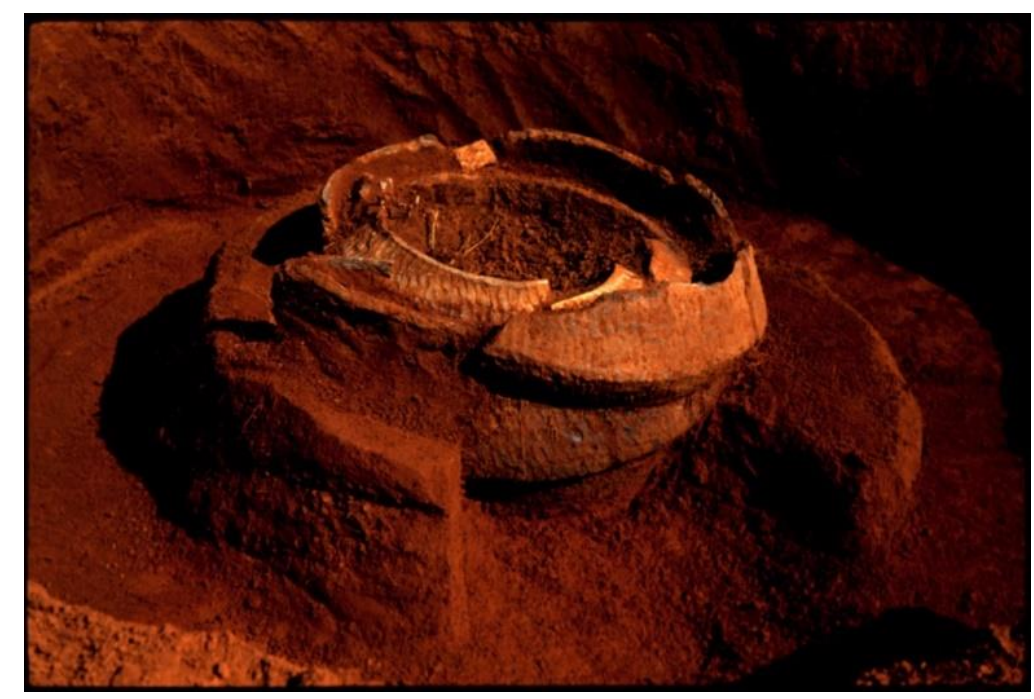

Figura 36: Contexto indeterminado do sítio Prassévichus, com ausência de vasilhas ao redor ou próximas à urna e à tampa. Foto do acervo documental do MAE/USP.

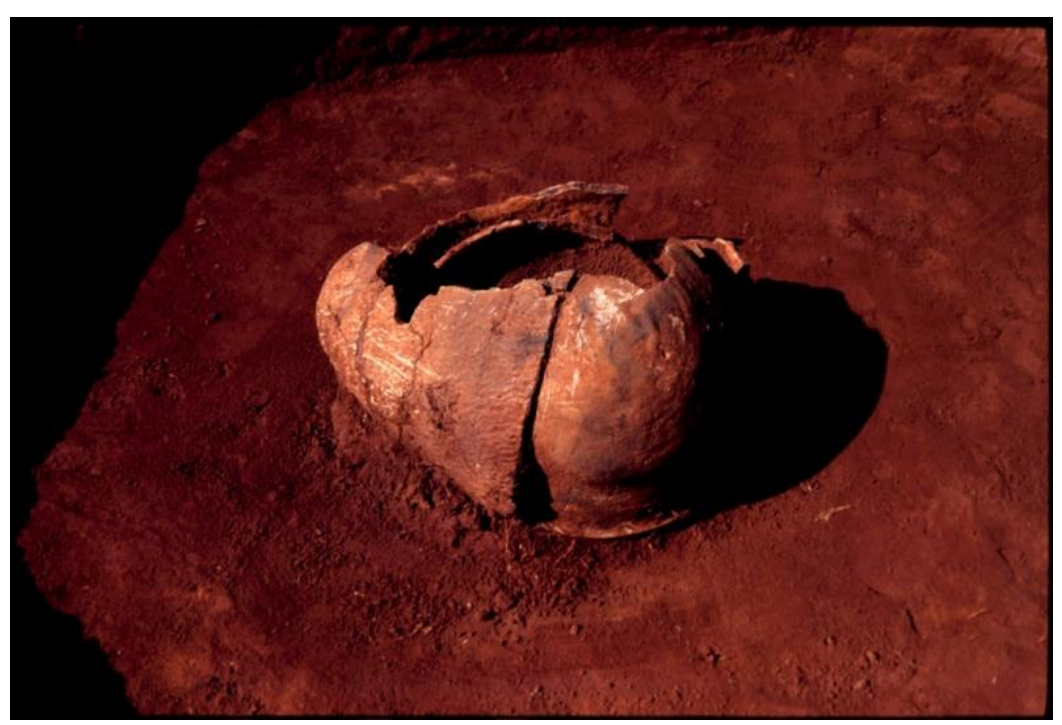

Figura 37: Contexto indeterminado do sítio Prassévichus, com duas tampas. Foto do acervo documental do MAE/USP.

A urna do contexto funerário VI, antes mesmo de ser escavada, fora retirada pelos moradores locais, sendo que a tampa e o esqueleto que afirmavam haver em seu interior foram perdidos (Pallestrini, 1983/4). Segundo a autora, ela era carenada e com pintura, e possuía $110 \mathrm{~cm}$ de altura e $60 \mathrm{~cm}$ de diâmetro da boca.

Todos os contextos são compostos por urnas com tampas, uma das urnas sendo camuci e as outras nhaempepó. Uma das nhaempepó, o contexto IV, possuía vasilhas dentro, tendo sido apenas um nhaem (prato) analisado por nós (Pallestrini, 1983/4). 
Prancha 29: Contexto funerário IV do sítio Prassévichus. Fonte: Pallestrini, 1983/4. Elaboração: Mariana Cristante.

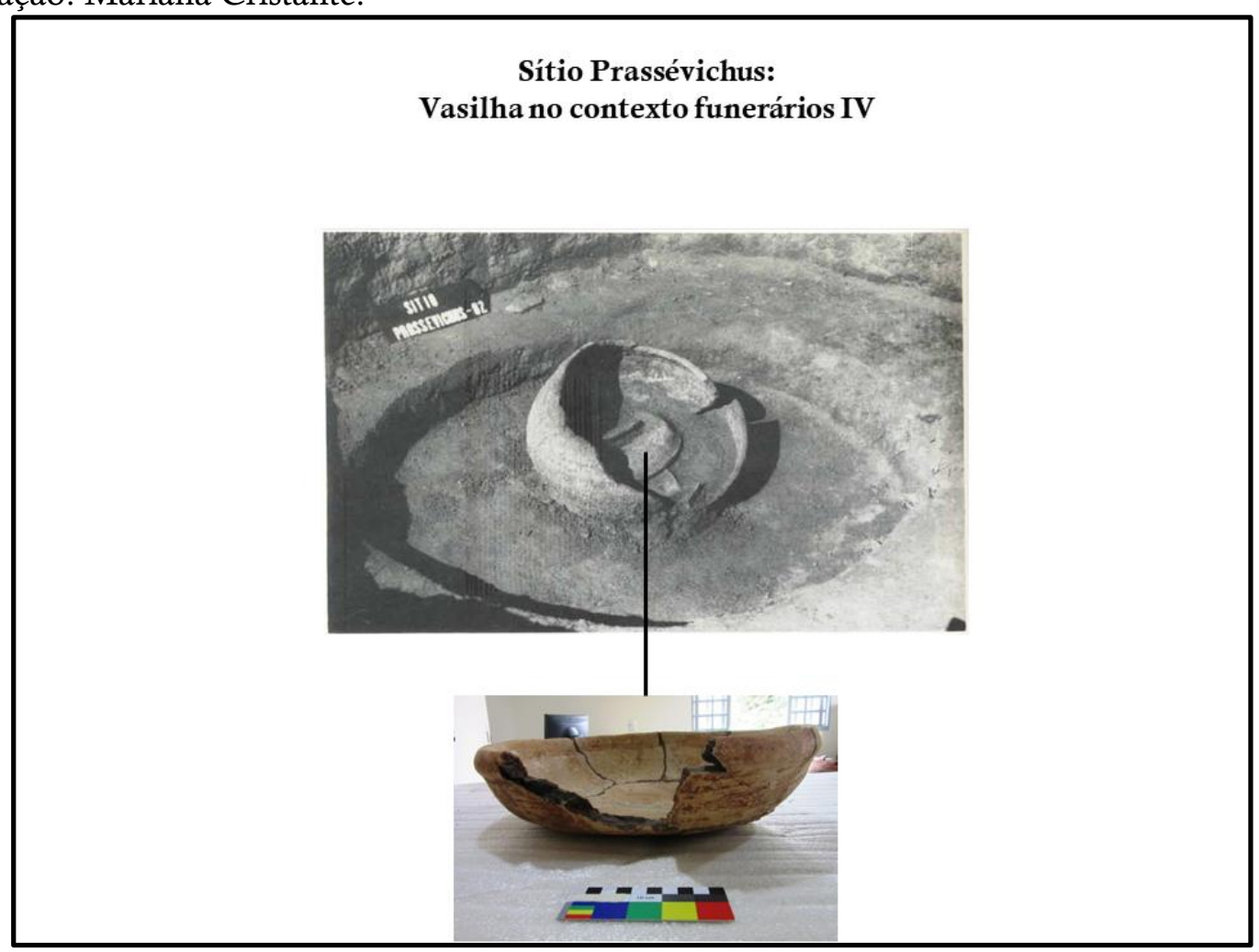

\section{Fonseca}

Foram encontradas 6 urnas, em 5 contextos funerários. Os contextos funerários estão localizados ora próximos a uma mancha, ora um pouco mais distantes, ora muitos distantes das manchas. Pode-se dizer que eles podiam estar tanto dentro do espaço da aldeia, em áreas que tinham uma razoável circulação de pessoas, quanto fora, em áreas com menor circulação.

Os sepultamentos I e II foram encontrados pelos agricultores. O primeiro era composto por urna e tampa, sendo que esta havia sido parcialmente quebrada pelo trator. A parte superior da tampa havia sido encontrada a aproximadamente $25 \mathrm{~cm}$ da superfície atual do solo, em terra vermelha, não havendo nenhum outro vestígio arqueológico ao redor num perímetro de $1,5 \mathrm{~m}$ por $1,5 \mathrm{~m}$. Foi realizada a decapagem no contexto funerário, tendo sido evidenciados o restante da tampa e depois o corpo da urna. Após a retirada dos fragmentos da tampa que haviam se soltado, começou-se o pincelamento na parte interna da urna. O sedimento foi todo retirado com pincel, e na parte do fundo da urna foram encontrados 11 dentes humanos. O sedimento no interior da urna era mais escuro que a terra vermelha que a circundava (Pallestrini, 1969). 
Abaixo, fotos da escavação do sepultamento I, tiradas pela arqueóloga na época. É possível notar a tampa quebrada e o sedimento dentro da urna, e que tanto a tampa quanto a urna eram corrugadas.
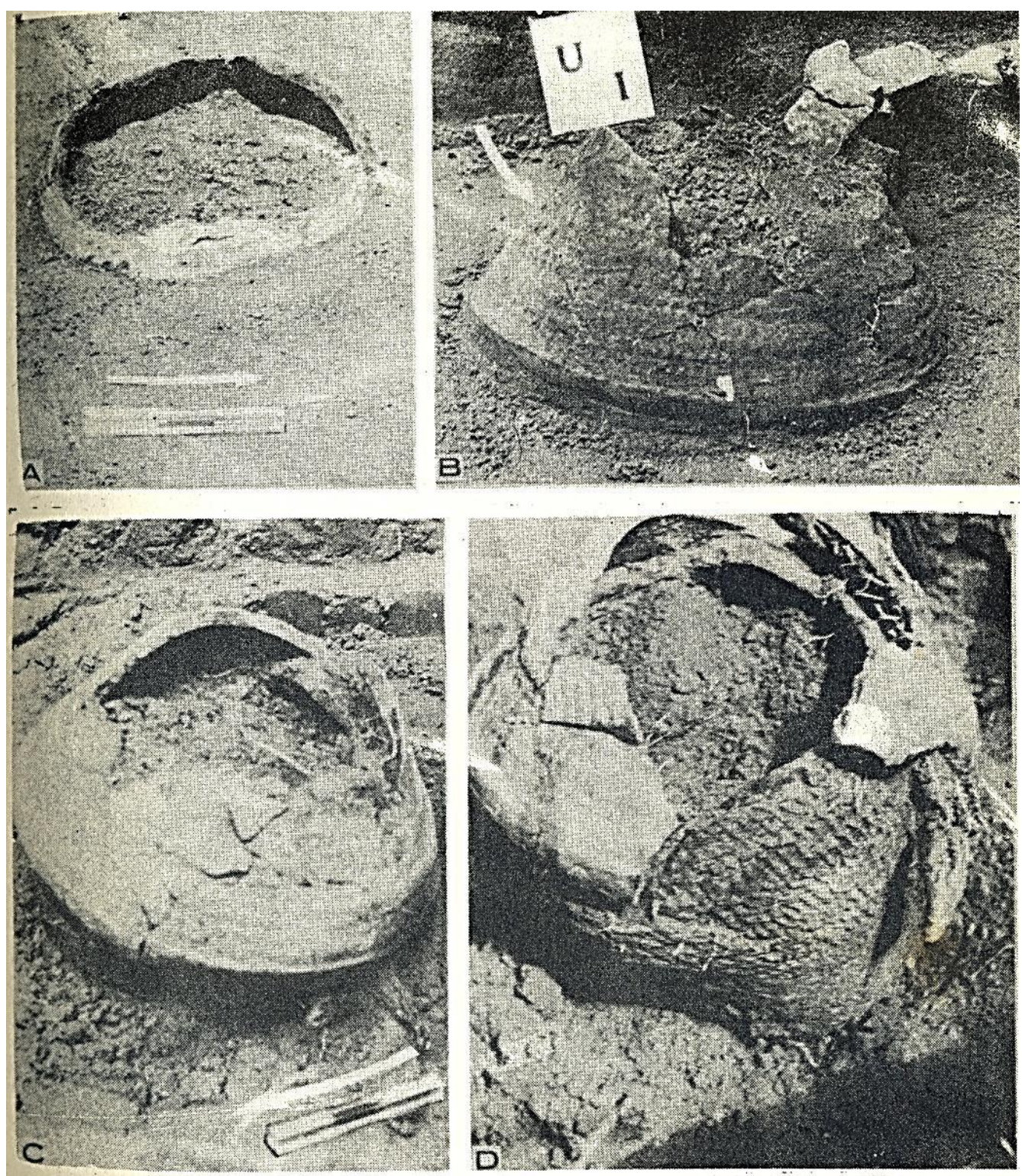

PRANCHA 9: Urna 1

$$
\begin{aligned}
& \text { A - Início da evidenciação } \\
& \text { B - Evidenciação da tampa (corrugada), com os fragmentos } \\
& \text { arrastados pelo disco do trator } \\
& \text { C - Tampa completamente evidenciada } \\
& \text { D - Tampa e corpo evidenciados: ambos de estilo corrugado }
\end{aligned}
$$

Figura 38: Escavação do sepultamento I - sítio Fonseca. Fonte: Pallestrini, 1969.

O sepultamento II também teve sua tampa parcialmente quebrada pela ação do arado. A tampa começou a aparecer aproximadamente a $20 \mathrm{~cm}$ da superfície do solo. O contexto encontrava-se em terra vermelha, também sem nenhum vestígio arqueológico ao redor num perímetro de $1,5 \mathrm{~m}$ por $1,5 \mathrm{~m}$. Sua escavação foi 
realizada através de decapagem, tendo sido evidenciada a tampa e seus fragmentos que se soltaram devido à quebra. O pincelamento na parte interna revelou a presença de ossos humanos. A urna era corrugada, mas a tampa era lisa.

Logo no início do pincelamento, surgiram as duas primeiras vértebras (Atlas e Axis) de um esqueleto humano, seguidas das partes restantes, em perfeita conexão. A cintura escapular e os ossos dos membros superiores estavam ligeiramente distorcidos sobre a caixa torácica; o crânio havia rolado e se encontrava perfeito em frente ao externo; a cintura pélvica em posição, apresentava os fêmures inseridos na cavidade glenóide, bem levantados, com a rótula na altura das vértebras cervicais; tíbias e perônios dos dois membros inferiores, quase paralelos aos fêmures correspondentes; em conexão também os pés. O rolamento do crânio devia ter sido posterior ao enterramento. (Pallestrini, 1969)

Através da posição relativa da coluna vertebral, das cinturas, dos membros e do crânio, em regular conexão anatômica, a autora concluiu tratar-se de um sepultamento primário. Ela coloca que essa posição só seria possível como cadáver bem amarrado (possivelmente com materiais perecíveis). O sedimento no interior da urna também apresentava uma tonalidade marrom-escuro diferente do solo vermelho do exterior.

$\mathrm{Na}$ figura 39 colocamos fotografias da escavação do sepultamento II, tiradas na época. Essas fotos foram analisadas por mim e pela professora Verônica Wesolowski de Aguiar e Santos, em conversas e numa aula, ao longo de uma disciplina ministrada pela mesma em 2015.

É possível ver que, de fato, trata-se de um sepultamento primário, cuja cabeça devia estar inclinada para frente (até mesmo devido ao formato da urna), e por isso tombou com o processo de decomposição antes do desprendimento da mandíbula, depositando-se na altura da virilha do indivíduo. A presença de vértebras alinhadas do lado esquerdo da coluna vertebral indica que houve uma queda para este lado, sugerindo que a parte superior do corpo pendeu e tombou para a esquerda durante a decomposição. As costelas caíram em sentido vertical, indicando que pelo menos boa parte do tórax ainda encontrava-se nesta posição quando houve este processo. A queda da cabeça, das vértebras e das costelas desse modo atesta que todos esses processos ocorreram num espaço vazio, que é o espaço do interior da urna. Apenas após esses processos terem ocorrido foi que 
houve a entrada do sedimento que manteve os ossos na posição em que foram encontrados pelos arqueólogos.

Apesar de as fotografias de Pallestrini, retiradas da publicação de 1969, não estarem muito bem nítidas, podemos perceber algumas discrepâncias entre as mesmas e a descrição que a autora faz da evidenciação do esqueleto, transcrita acima. As primeiras vértebras que aparecem não parecem ser cervicais, e sim torácicas. Três vértebras aparecem uma ao lado da outra na região próxima ao ombro esquerdo do indivíduo. As costelas não se encontram em perfeita conexão anatômica, e sim caídas umas sobre as outras, como se tivessem tombado no sentido vertical após a decomposição dos tecidos moles. O crânio aparece inteiro, tendo caído antes da desarticulação da mandíbula, só que na região ventral do indivíduo, próximo à virilha, e não na região torácica. Membros inferiores parecem estar como autora descreve. Vértebras torácicas e lombares encontram-se articuladas. Essas últimas evidências confirmam ser um sepultamento primário. $\mathrm{O}$ modo como o crânio se encontrava caído, com a mandíbula articulada e os dentes em oclusão, sugere que a posição do esqueleto era mesmo ao menos similar a uma posição fetal (até mesmo devido ao próprio formato da urna), em que a cabeça ficava curvada para frente.

Essa discrepância entre a descrição feita pela autora e as fotos pode ter se dado por causa dos momentos em que as fotos foram tiradas. Se tiradas no meio do processo de decapagem, é provável que ossos estivessem já fora do seu lugar de origem no momento da foto. Entretanto, alguns elementos, como as três vértebras lado a lado na região que seria abaixo do ombro esquerdo do indivíduo, de fato não foram mencionados. 

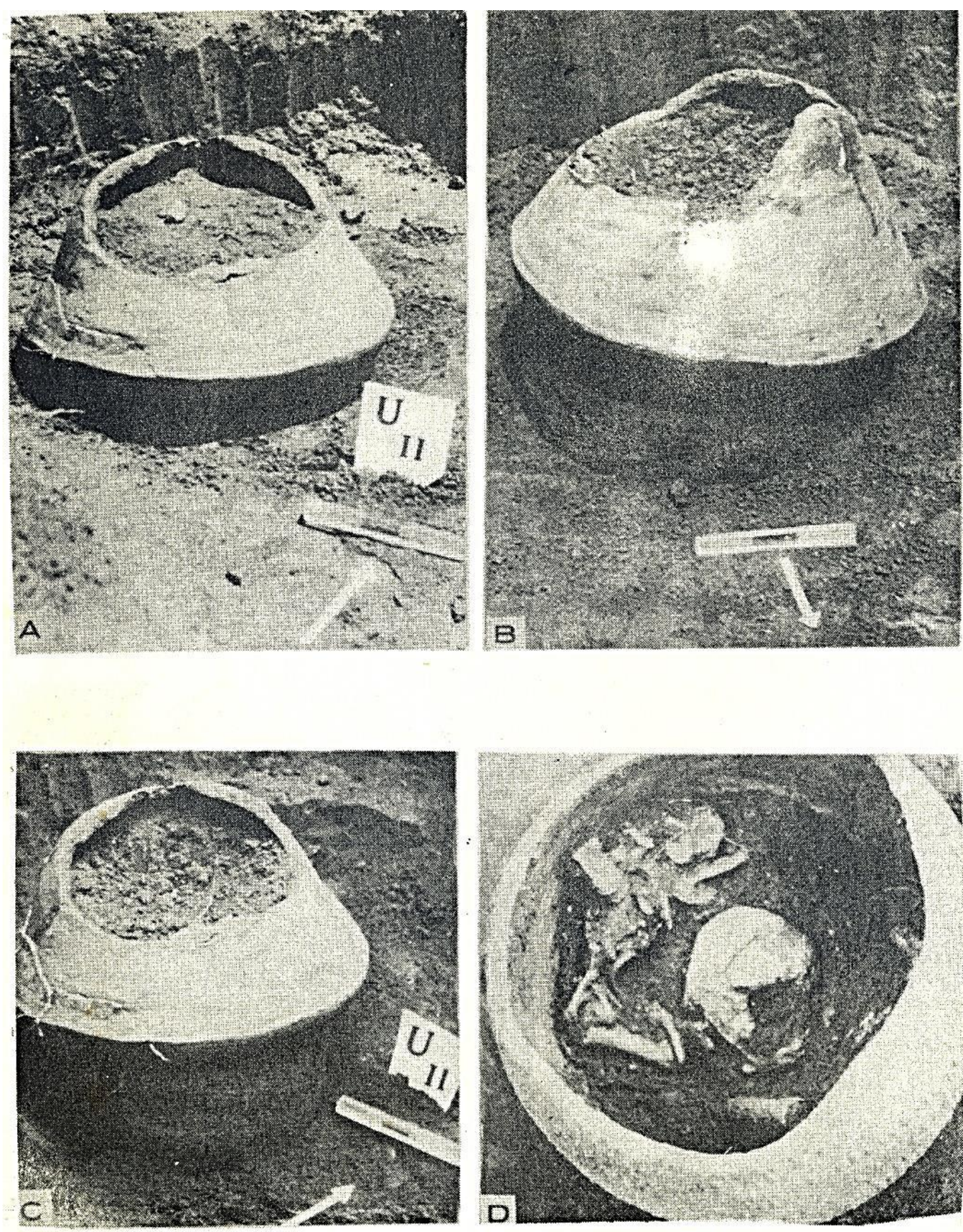

PRANCHA 10: UrnaIT

A - Início da decapagem: evidenciação da tampa (lisa).

B - Evidenciação ao corpo da urna (corrugado)

C - Evidenciaçäo final

D - Urna sem tampa: esqueleto no interior

Figura 39: Escavação do sepultamento II - Sítio Fonseca. Fonte: Pallestrini, 1969. 


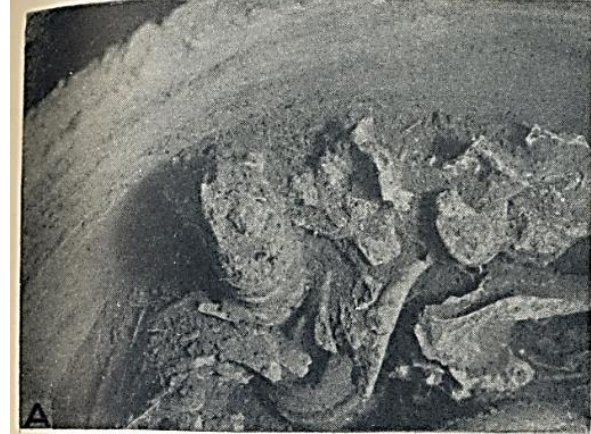

Praschs 11: Esque leto cont ido na Urna II

A - Prime iras vértebras cervicais

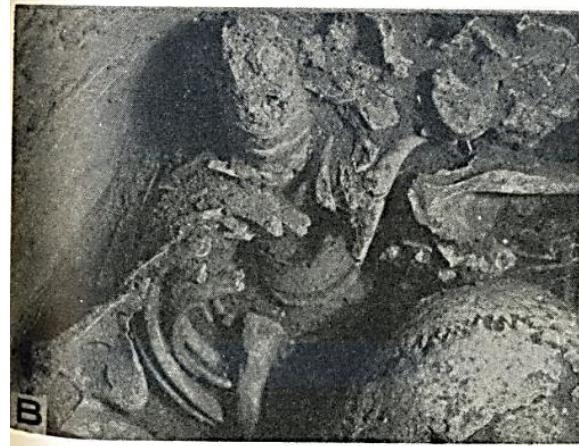

B - Vértebras cervicais e dorsais; cintura escapular

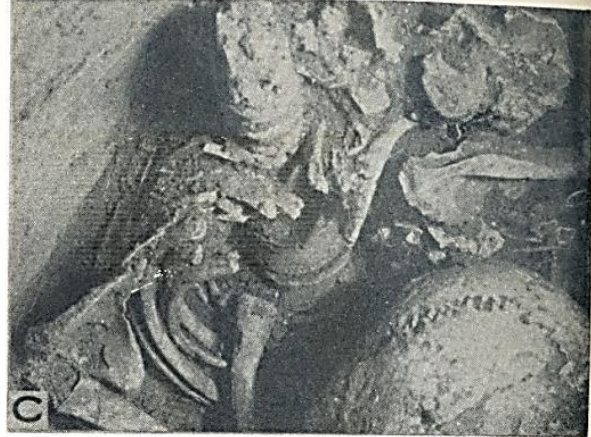

C- Omoplatas, en conexão con a coluna vertebral

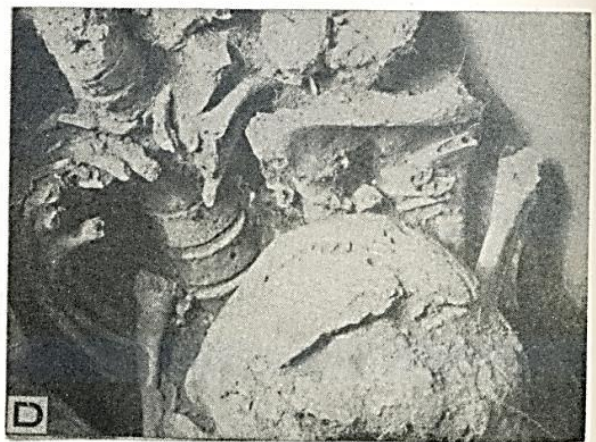

D - Vértebras torácicas, clavicula, mator evidenciação do
crañio.

Figura 40: Escavação do interior da urna II - Sítio Fonseca. Fonte: Pallestrini, 1969.

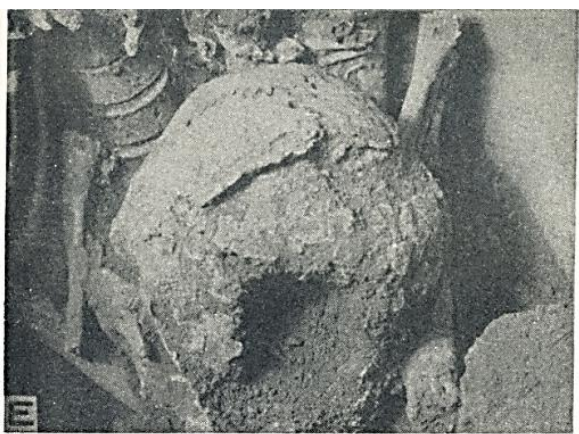

E - Evidenciaçào tota1 do crânío

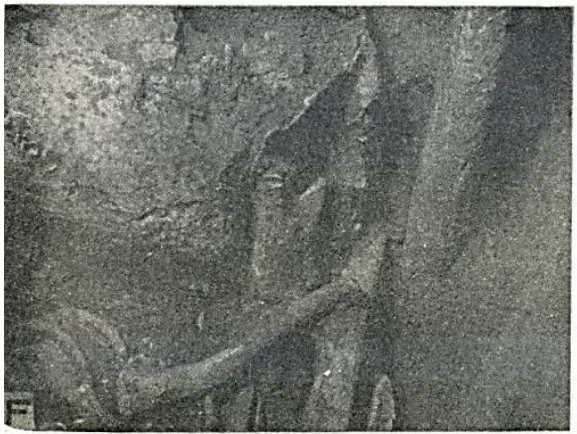

G, H - Vista tateral do crinio: maxilares e insercóes
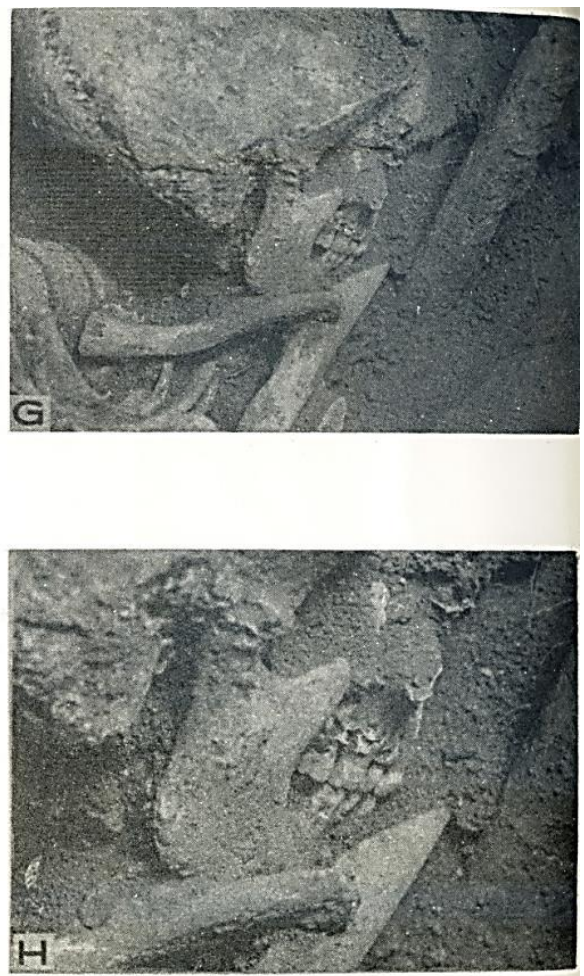

Figura 41: Escavação do interior da urna II - Sítio Fonseca (continuação). Fonte: Pallestrini, 1969. 
O sepultamento III foi encontrado, da mesma forma que os dois primeiros, nos trabalhos preliminares do sítio. A existência da urna foi inferida através da presença de grandes fragmentos cerâmicos esparsos numa superfície de $1 \mathrm{~m} \times 1 \mathrm{~m}$, cacos esses que pertenciam a uma tampa também quebrada pelo trator. Fragmentos enterrados da tampa foram encontrados a aproximadamente $20 \mathrm{~cm}$ de profundidade em relação à superfície do solo atual. Eles mostravam uma tampa lisa e muito menor em relação ao tamanho da urna. Da mesma forma que os outros, o contexto foi encontrado em terra vermelha, sem vestígios ao redor, e o sedimento da parte interna da urna apresentava uma coloração marrom escuro, diferente do sedimento do lado exterior (Pallestrini, 1969).

Foi realizada a decapagem que revelou restos da tampa ainda presos ao corpo da urna. Esses cacos da tampa foram retirados para se dar prosseguimento à decapagem. A escavação do sedimento da parte interna da urna foi realizada concomitantemente com a do da parte externa, ainda quando o corpo da urna apenas havia começado a se evidenciar. O pincelamento da parte interna revelou evidências ósseas muito fragmentadas, sem a estrutura anatômica encontrada no sepultamento II. Havia, segundo a autora, fragmentos de ossos diversos: costelas, vértebras, fragmentos de crânio. Nenhum se encontrava em posição anatômica. A decapagem começou a revelar fragmentos ósseos também na parte de fora da urna. Isso se deveu à quebra do corpo da urna em sua parte inferior. Essa quebradura formava, de acordo com Pallestrini, uma abertura de $20 \mathrm{~cm}$ entre as duas partes da urna. A parte superior foi retirada para que fosse feita a evidenciação da parte inferior. Nessa parte foram encontrados, em posição, ossos longos das pernas e braços de um esqueleto humano.

A autora acredita que a urna pode ter se inclinado pela ação das chuvas e enxurradas em data posterior ao sepultamento. O peso do solo teria provocado a ruptura da região basal da urna, e os esqueleto teria se movido em parte para fora. A base da urna, logo abaixo da quebra, teria se mantido na posição original. Fornecendo assim evidência da posição provável do corpo ao ser enterrado. Baseando-se na disposição relativa dos ossos dos braços e das pernas, Pallestrini sugere que a posição desse corpo tivesse sido fletida, com braços e pernas encolhidos. 
Abaixo, fotos de época do sepultamento III. É possível notar que o corpo da urna encontra-se deslocado do fundo, devido à quebra, com os ossos no fundo.
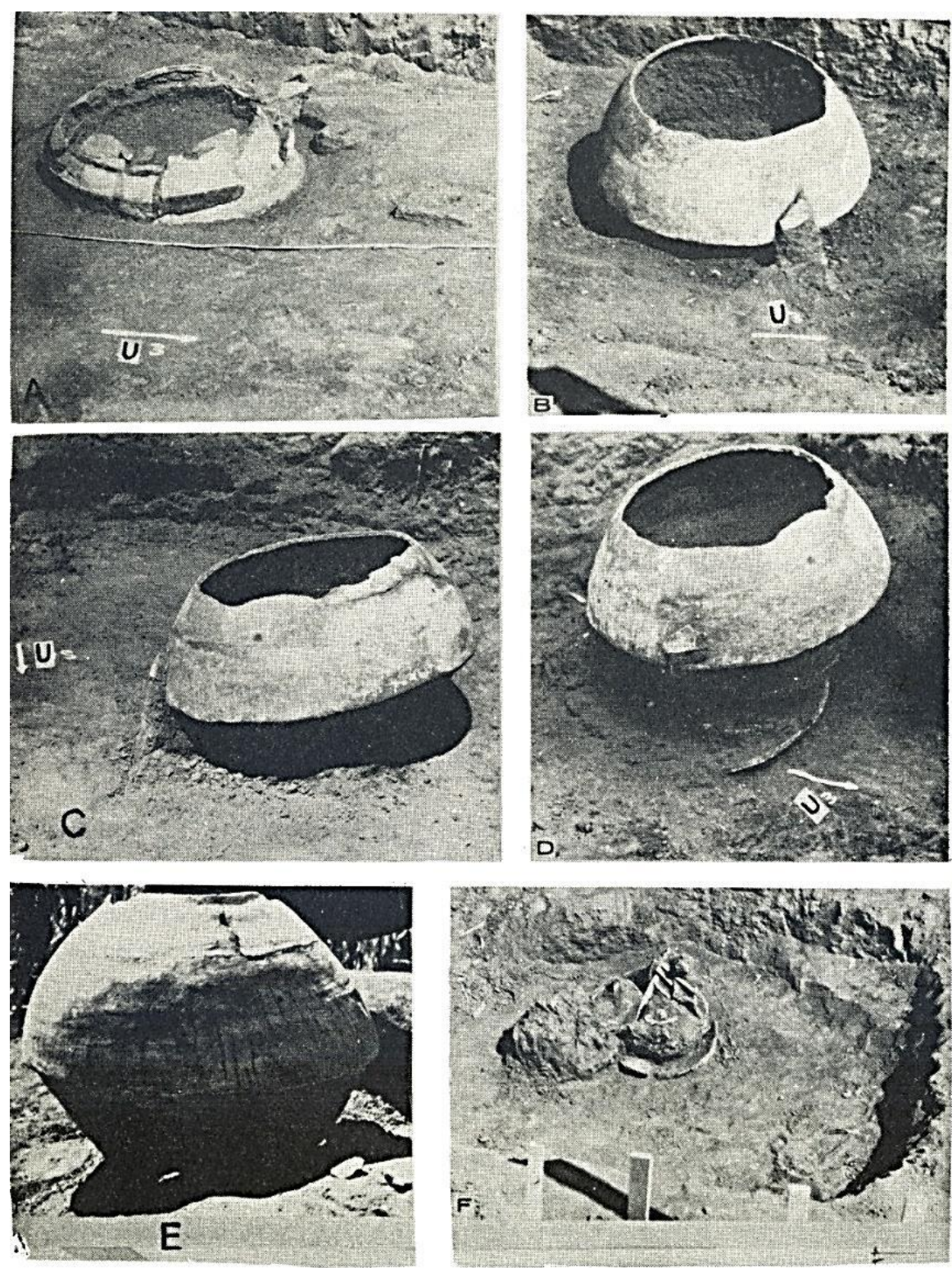

PRANCHA 12: Urna III

$$
\begin{aligned}
& \text { A - Início da evidenciação: restos de tampa (lisa). ainda } \\
& \text { presos ao corpo } \\
& \text { B, C - Evidenciação do corpo da urna, sem tampa } \\
& \text { D - Quebradura basal, separando a urna em duas porções, } \\
& \quad \text { uma superior e outra inferior } \\
& \text { E - Porção superior da urna, anterior à quebradura basal } \\
& \text { F - Porção inferior da urna, com restos ósseos, posterior } \\
& \text { à quebradura basal }
\end{aligned}
$$

Figura 42: Escavação do sepultamento III - Sítio Fonseca. Fonte, Pallestrini, 1969.

O sepultamento IV foi evidenciado em uma trincheira de verificação traçada com o intuito de verificar a estratigrafia geral do sítio. Havia uma tampa que estava quebrada, sendo tanto esta quanto a urna corrugadas. Os restos da tampa estavam a 
$20 \mathrm{~cm}$ de profundidade da superfície do solo na época. Foi iniciada uma decapagem, mas com o cair da noite os trabalhos foram deixados para o dia seguinte. Durante a noite, vândalos que certamente esperavam encontrar ouro, destruíram o contexto, retirando a urna do lugar e espalhando seus cacos e o seu conteúdo pelo chão, que incluía ossos humanos. Foi possível somente tirar a informação sobre a localização da urna, que era fora de mancha de terra preta, em solo vermelho como as outras. Nem a urna nem a tampa foram encontradas por nós.

A urna $\mathrm{V}$ foi evidenciada do outro lado da estrada, longe das manchas de terra preta, como sempre, com a parte superior da tampa destruída pelo trator. A tampa e a urna eram corrugadas. Curiosos já haviam arrancado quase todo o conteúdo da urna, deixando apenas alguns ossos. A decapagem da parte externa da urna revelou que ela encontrava-se inclinada para o lado, deitada numa posição quase horizontal, e não em pé como as outras. Além disso, estava imediatamente sobre outra urna, a VI. Esta última estava em posição vertical, sem tampa própria: a tampa era uma só para o conjunto, tendo sido depositada sobre a urna de cima que se encontrava deitada. Pallestrini não diz na publicação se havia ossos também na urna VI. Esse conjunto estava fora de mancha de terra preta, sem nenhum vestígio arqueológico ao redor num perímetro de 1,5m por 1,5m (PALLESTRINI, 1969). Devido à falta da informação fundamental sobre a presença de ossos na urna VI, não sabemos se era um sepultamento duplo ou não. Devido à proximidade e posição das duas urnas, consideramos como um único contexto funerário, envolvendo duas urnas e uma tampa. As fotos tiradas pela autora que conseguimos encontrar estão reproduzidas abaixo. Conseguimos encontrar a urna 5 e analisar, já a 6 não.

No sítio Fonseca, quase todos os contextos funerários são formados apenas por urnas e tampas, sem nenhuma vasilha ao redor ou dentro. Até mesmo a cambuchí recebeu uma tampa (uma vasilha lisa, segundo a descrição). No entanto, o contexto funerário $\mathrm{V}$ é composto pela urna $\mathrm{V}$ em posição horizontal, posicionada sobre a urna VI, e o conjunto todo recebia uma tampa, posicionada emborcada sobre a urna V (Pallestrini, 1969), um padrão de sepultamento em urna que não se repete em nenhum outro contexto. 

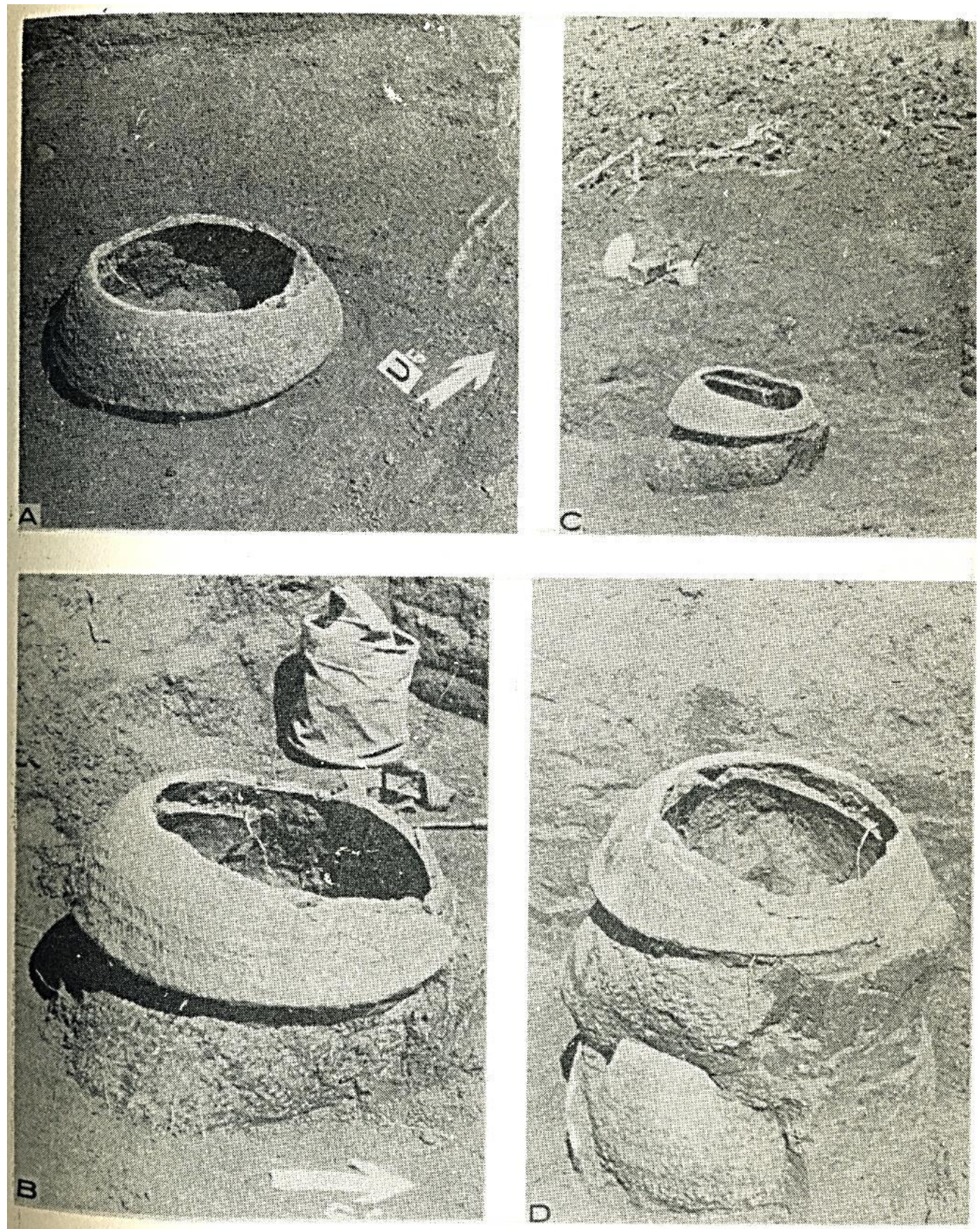

PRANCHA 21: Urnas V e VI

A - Decapagem da tampa da urna $V$ (corrugada)

B, C - Tampa e corpo (corrugado)

D - Evidenciação da urna VI sob a urna V

Figura 43: Evidenciação das urnas V e VI, sítio Fonseca. Observa-se que a urna V, em posição horizontal, está imediatamente sobre a VI, em posição vertical, e a tampa recobre o conjunto todo. 


\section{Salto Grande do Paranapanema}

Nesse sítio, foi encontrada uma urna para a qual há relatos de que havia remanescentes humanos dentro, mas não os encontramos. 2 esqueletos foram encontrados por moradores locais, portanto estavam descontextualizados, e não há a informação de estarem dentro ou fora de urna e qual urna. No sedimento em que foram encontrados os esqueletos foram também encontrados um fragmento de concha, um dente de porco do mato e uma ponta de osso. A concha é de um molusco marinho, o que sugere contato com regiões litorâneas (Morais \& Piedade, 1994).

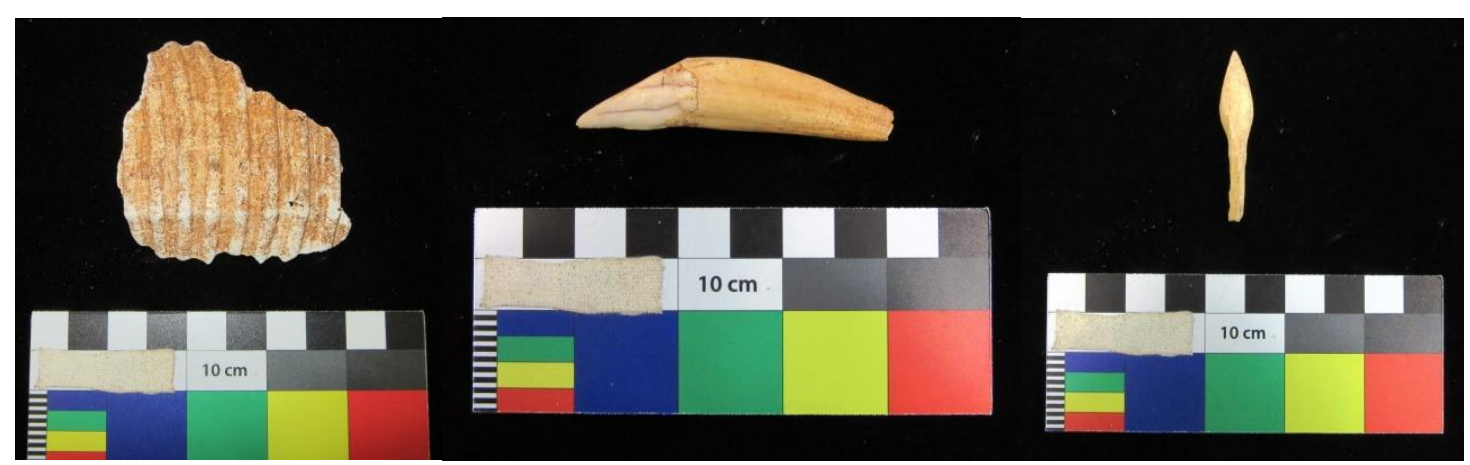

Figuras 44-46: Fragmento de concha (família Tonnidae), dente de porco do mato e ponta de osso com pedúnculo, encontrados no sedimento próximo aos sepultamentos 1 e 2 .

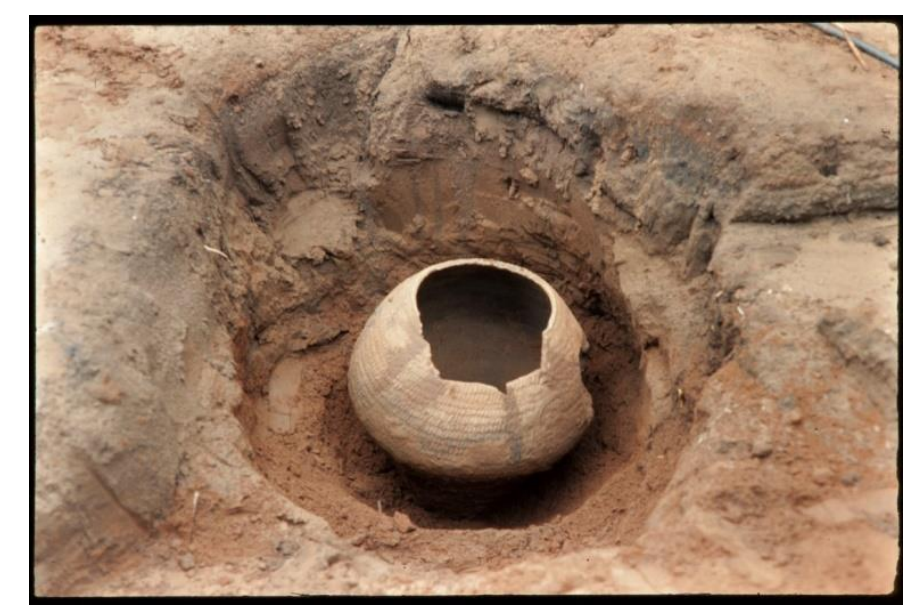

Figura 47: Local onde foi encontrada a urna do Salto Grande analisada por nós. Foto do acervo documental do $\mathrm{MAE} / \mathrm{USP}$

Com relação ao esqueleto 1 (chamado de sepultamento 1), na caixa em que está guardado o mesmo havia alguns fragmentos cerâmicos, e constava que estavam associados ao sepultamento. Não há nenhuma informação contextual que 
permita saber qual era a relação entre os ossos e as cerâmicas, se é que havia associação de fato.

Realizamos uma análise dos fragmentos cerâmicos, levando em conta o tratamento de superfícies, tipo de fragmento (parede, borda, base) e espessura média de cada fragmento. Como nosso objetivo inicial era analisar vasilhas inteiras, e também nem há como ter certeza da associação entre esses fragmentos e algum sepultamento, não demos tanto destaque para eles. Mas não podíamos simplesmente ignorá-los.

Esses fragmentos cerâmicos são em número de 19, dos quais 3 são bordas e os outros são paredes. Das 3 bordas, todas apresentam tratamento de superfícies interna e externa alisado. Suas espessuras vão de $1,3 \mathrm{~cm}$ a $1,6 \mathrm{~cm}$. Apenas uma das bordas possibilitou a visualização da circunferência com o ábaco, e a medição leva a crer que a vasilha possuía entre $46 \mathrm{~cm}$ e $48 \mathrm{~cm}$ de diâmetro da boca, se for redonda.

Já os fragmentos de parede, 3 apresentam corrugado na parte externa e alisado na interna, e espessuras médias entre $1,4 \mathrm{~cm}$ e $1,6 \mathrm{~cm}$.

Outros dois fragmentos de parede possuem ungulado na face externa e engobo na interna, a espessura média de um deles é $0,7 \mathrm{~cm}$ e do outro $1 \mathrm{~cm}$ (o que indica que podem ter sido de vasilhas pequenas a médias). $\mathrm{O}$ fragmento de maior espessura apresenta depósito de carbono na parte interna, mais ou menos paralelo à região de inflexão do caco, provavelmente sendo uma marca que indica o uso para preparação de alimentos.

Outro fragmento de parede possui engobo na face externa, e a face interna está desgastada demais para se ver o tratamento. A espessura média é $1,8 \mathrm{~cm}$.

Outro fragmento de parede possui tratamento externo pintado, uma pintura vermelha, aparentemente em linha duplas, sobre engobo branco, e tratamento interno engobo. $\mathrm{O}$ fragmento possui carena, na qual a espessura é $2,8 \mathrm{~cm}$. A pintura só vai até a parte do ângulo de inflexão, e a partir daí está muito desgastado. Poderia trata-se de um fragmento de camuci, pois parece ser uma grande vasilha com pintura até a carena. 
Há outros 6 fragmentos, cobertos com engobo em ambas as faces, que possuem espessuras menores (entre $0,6 \mathrm{~cm}$ e $1,3 \mathrm{~cm}$ ), e sugerem vasilhas pequenas, médias e grandes. Há também outros 3 fragmentos, desgastados demais para nossa análise.

Prancha 30: Fragmentos cerâmicos associados a sepultamento do sítio Salto Grande do Paranapanema.

Sítio Salto Grande do Paranapanema:

fragmentos cerâmicos associados ao sepultamento 1

$A$ - face externa de fragmento com carena; $B$ - face interna do mesmo

frag.; C - pintura da face externa; $D$ - frag. ungulados; $E$ - face interna dos mesmos frag.; $\mathrm{F}$ - frag. corrugados; $\mathrm{G}$ - bordas; $\mathrm{H}$ - frag. de parede; I - face interna dos frag. corrugados;

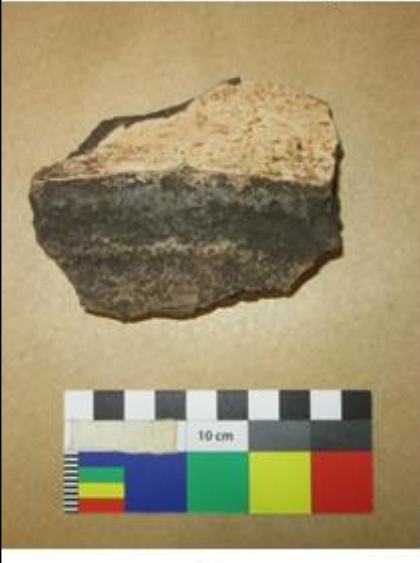

A

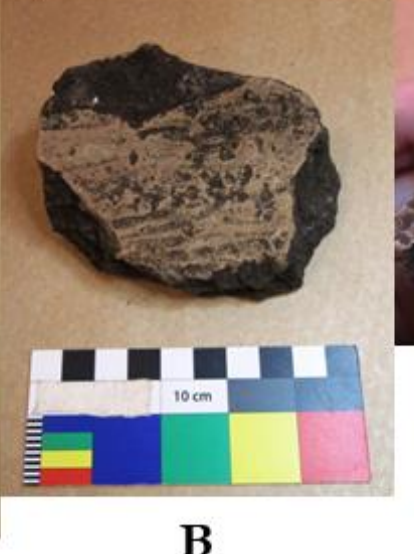

B

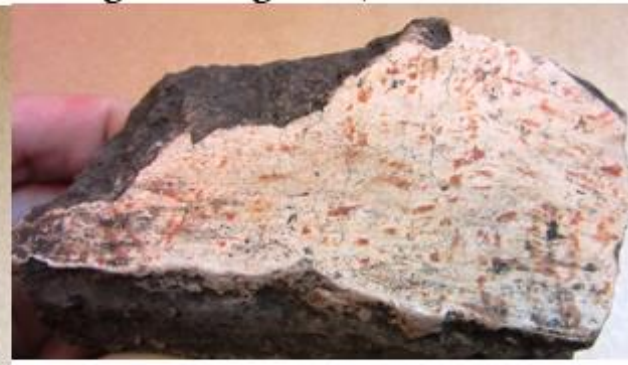

C

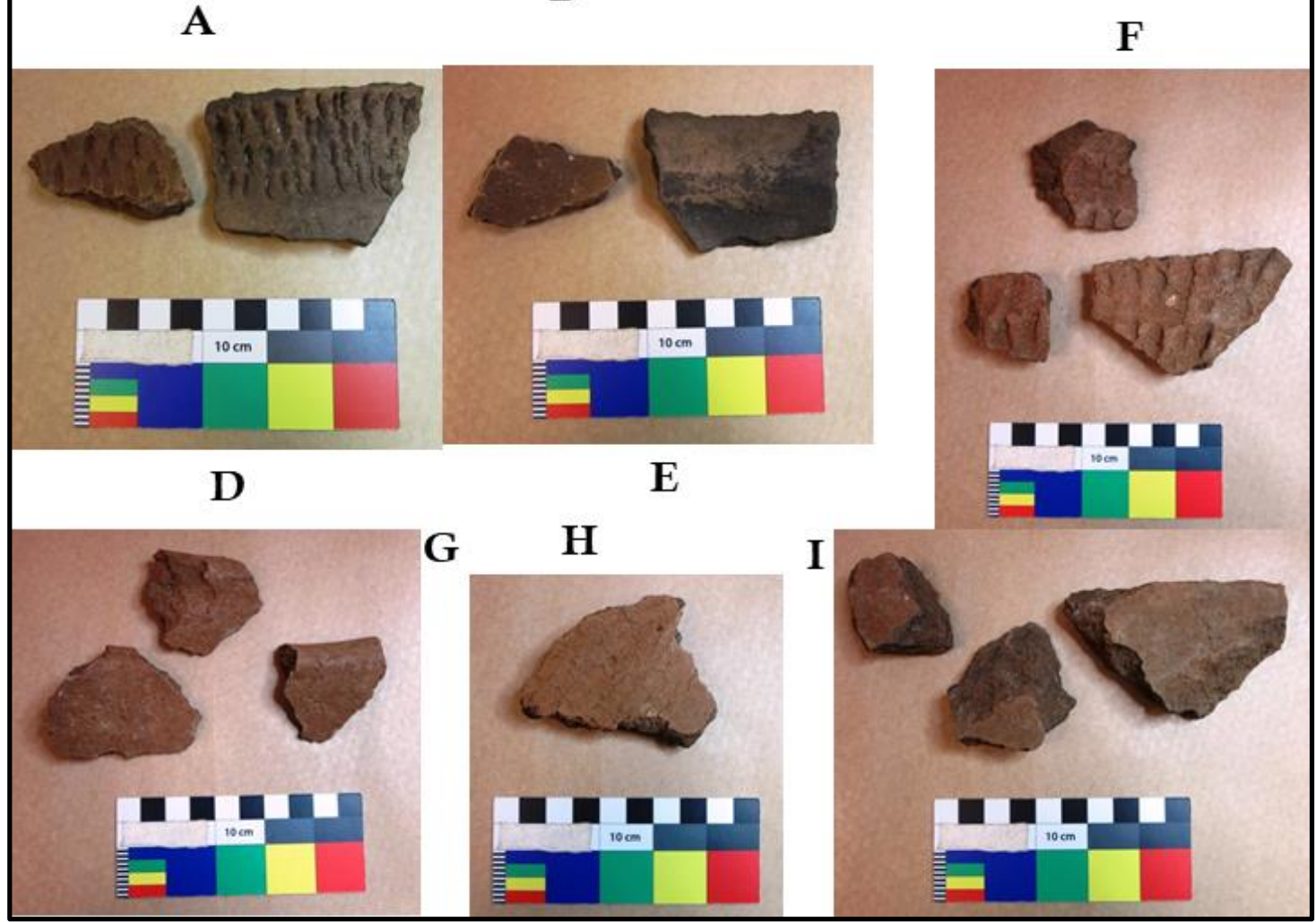




\section{Itaguá}

Nesse sítio foi encontrado um único sepultamento, e não foram dados maiores detalhes sobre o contexto funerário. Scatamacchia (comunicação pessoal), indicou qual era a vasilha que continha o sepultamento, e trata-se de uma vasilha aberta do tipo nhaem, pequena demais para se caber um adulto inteiro. Entretanto, dentro da mesma foram encontrados remanescentes ósseos e dentes que sugeriam adulto. Dos dentes restava apenas o esmalte. Como trata-se de muito pouco material, colocamos as fotos abaixo. A vasilha do sepultamento será analisada mais adiante.

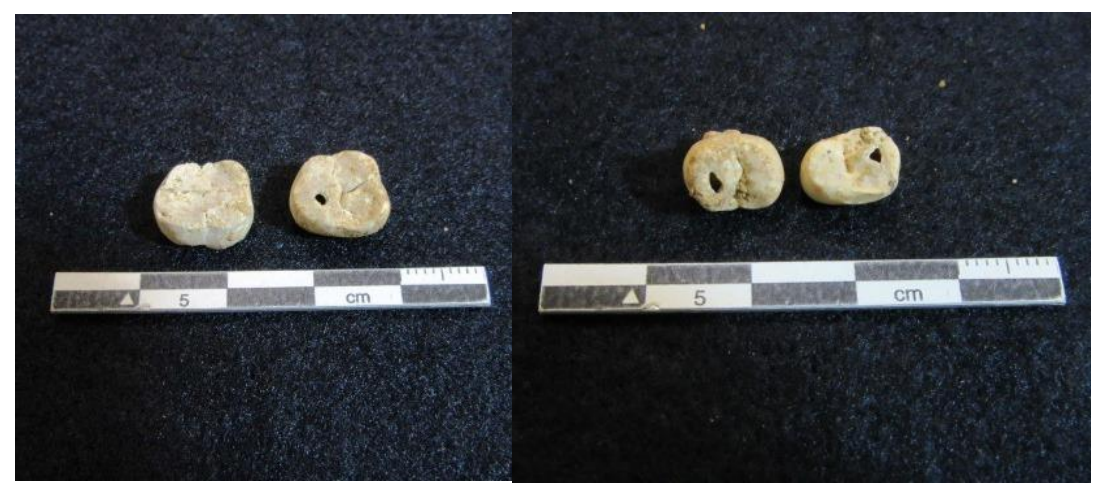

Figuras 48 e 49: Dentes encontrados dentro de vasilha aberta do sítio Itaguá. Fotos: Mariana Cristante.

\section{$\underline{\text { Sitios Guarani }}$}

Alves

No sítio foram encontradas 5 vasilhas que foram chamadas de urnas funerárias (Pallestrini, 1975). A urna I, a única com pinturas, havia sido descontextualizada antes das escavações.

A urna 2 continha quatro recipientes em seu interior, porém não consegui encontrar todos. Um deles tinha o formato de uma gamela, com fundo quebrado, e que estava em posição emborcada, de boca para baixo, cobrindo as outras vasilhas como uma tampa, segundo Pallestrini (1975). Analisei uma vasilha desse tipo, mas que estava sem maiores identificações, e por isso não foi possível saber se era a vasilha desse formato encontrada na urna 2 ou na urna 4. Abaixo dessa vasilha emborcada havia outro recipiente, o qual não conseguimos encontrar, mas que segundo a descrição da autora encontrava-se em posição também emborcada, e apresentava pintura preta sobre engobo branco, altura de $18 \mathrm{~cm}$ e diâmetro da boca 
de $32 \mathrm{~cm}$. Outro recipiente estava depositado no fundo da urna, com a boca para cima, sendo este encontrado por nós e analisado. A quarta vasilha pertencente a esse conjunto funerário estava posicionada acima da boca da urna, aparentemente em posição também emborcada. A autora atribui essa posição um tanto quanto fora da urna a uma movimentação da vasilha para cima devido à ação de raízes, mas não temos como confirmar essa hipótese. Ela descreve que raízes entravam na urna. O croqui abaixo, feito pela autora na época da escavação, mostra isso.

A urna 3 foi encontrada sem vasilhas dentro segundo o texto de descrição, mas, segundo o croqui abaixo, havia fragmentos cerâmicos em seu interior. Havia ossos humanos, descritos pela autora simplesmente como "Restos de longos ossos apareceram no fundo da urna." (Pallestrini, 1975, p. 51). Não encontrei nenhuma vasilha associada a essa urna, muito menos ossos.

SITIO ALVES

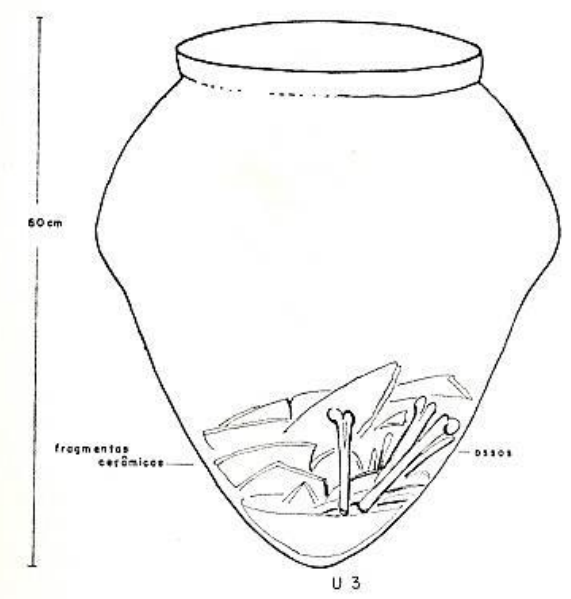

pronche 4 .

Figura 50: Esquema do contexto funerário 3 do sítio Alves. Fonte: Pallestrini, 1975.

A urna 4 foi encontrada com 6 recipientes em seu interior, dos quais conseguimos encontrar e analisar 4 . O recipiente 1 seria uma vasilha com formato de gamela, muito semelhante à do sepultamento 2, e que talvez tenhamos analisado, mas não sabemos se se trata desta mesma ou não. De qualquer modo, a descrição de Pallestrini nos diz que essa estava em posição emborcada, com o 
fundo parcialmente quebrado, dentro da urna, cobrindo as outras vasilhas como uma tampa, de modo muito parecido com o que foi encontrado na urna 2. Abaixo desta vasilha, as outras 5 estavam posicionadas "[...]quase numa mesma linha horizontal [...]" (Pallestrini, 1975, p. 51). O croqui feito pela autora e a foto tirada no momento da decapagem mostram isso. A vasilha número 2 é uma tigela com pinturas pretas sobre engobo branco, analisada por nós. A vasilha 3 tinha a forma de um vaso pequeno, que provavelmente trata-se da mesma vasilha analisada por nós. A vasilha 4 estava bem ao lado da 3 e era, segundo a autora, um vaso de colo estreito, liso. Entretanto, a vasilha que analisamos com este formato possuía resquícios de engobo branco. A vasilha 5 era um vaso que estava dentro da número 3. O recipiente 6 é descrito como um vaso de paredes retas, fundo chato, e liso, e encontrava-se "[...] parcialmente esmagado, ao lado da tigela decorada número 2 [...]" (Pallestrini, 1975, p. 52). Após a retirada de todas as vasilhas, a autora descreve que "[...] começaram a aparecer longos ossos, bastante estragados" (ibidem).

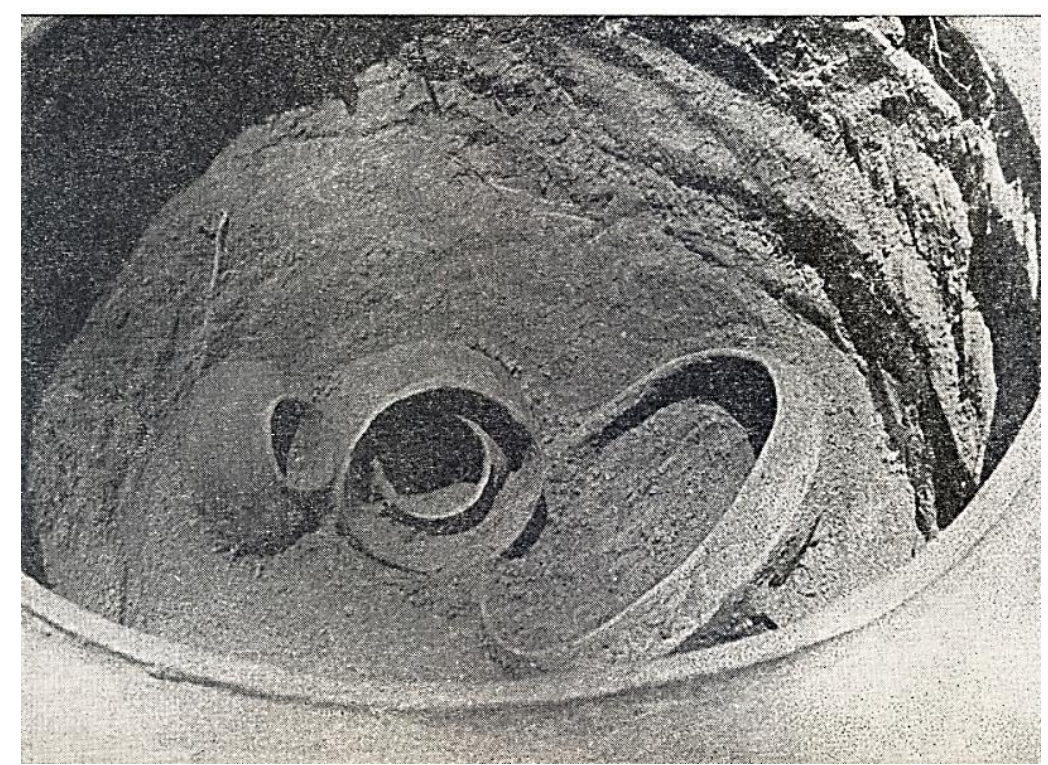

Figuras 51: Esquema do contexto funerários 4 escavação da urna 4 do sítio Alves, com evidenciação de vasilhas. Fonte: Pallestrini, 1975.

A urna 5 estava bastante fragmentada já em campo, e quando a encontramos seus fragmentos estavam em uma caixa, não tendo sido possível remonta-la. Por isso, analisamos apenas alguns de seus grandes e pesados fragmentos. Ela apresenta orifícios que acompanham a quebra do fragmento, e aparecem num dos fragmentos selecionados por mim, e que são tradicionalmente explicados como furos feitos para se passarem cordas para unir a rachadura e 
impedir que ela progrida e a vasilha se quebre. Em seu fundo foi encontrada, no campo ainda, somente uma vasilha do tipo tigela rasa, que acreditamos ter encontrado e, por isso, analisamos. Pallestrini dá como medidas da urna 5 a altura de $72 \mathrm{~cm}$ e diâmetro da boca de $60 \mathrm{~cm}$.

Como a própria Pallestrini (1975) já nota, as urnas desse sítio possuem dimensões muito maiores que as dos outros, bem como a espessura. Urnas semelhantes às do Alves foram encontradas entre o material do sítio Nunes, também escavado por Pallestrini, cujas urnas estavam já todas descontextualizadas.

A urna 5 apresenta perfurações na parede da cerâmica que ladeiam uma rachadura. Se realmente forem com o propósito de se amarrar cordas que impeçam a quebra da vasilha, isso pode demonstrar um interesse em preservá-la. Ela provavelmente não era mais tão eficiente para armazenar alimentos ou bebidas, pois possuía uma grande rachadura.

As urnas 2, 4 e 5 apresentaram vasilhas dentro. Cada contexto era único, com um arranjo, quantidade e formas de vasilhas diferentes. Havia vasilhas pintadas e não pintadas, mas as urnas 2 e 4 apresentavam uma vasilha que poderia ser uma tampa, mas não ficou claro se era de fato.

As vasilhas dessas três urnas foram escavadas por decapagem, o que revelou sua posição quando foram encontradas. Na urna 2 a vasilha menor e mais fechada encontrava-se próximo à base, de boca para cima; uma vasilha mais aberta foi encontrada próximo à borda; emborcada; outra vasilha estava acima da borda. Não há como a vasilha mais fechada estar onde está (no fundo da urna) sem ter ou sido colocada lá ou ter se deslocado de cima de algo que se decompôs, parando junto ao fundo. Já a vasilha aberta que se encontrava na altura da borda só pode ter se mantido lá devido à presença de sedimento que a segurou naquela posição. Devido à posição da vasilha fechada, mais abaixo, parece que foi colocada primeiro, e as vasilhas emborcadas depois.

Na urna 4 havia várias vasilhas, sendo que uma grande vasilha aberta cobria as outras, estando emborcada. A análise da descrição, do croqui e da foto antiga nos indica que as outras vasilhas estavam colocadas de boca para cima, uma ao lado da outra, porém, deslocadas de seu eixo vertical por causa do formato da urna, com o fundo estreito e cônico. Isso dá a entender que elas foram depositadas 
quando havia nenhum ou pouco sedimento dentro da urna, tendo tombado seguindo o formato da mesma. Uma das vasilhas estava totalmente dentro da outra, o que sugere que tenha sido depositada desse modo, e que no momento da deposição a vasilha maior se encontrava ou vazia, ou com materiais perecíveis dentro (caso contrário, não seria possível a vasilha menor estar nessa posição, exatamente dentro de outra). Pallestrini relata que encontrou ossos longos abaixo das vasilhas.

A urna 5 também continha uma vasilha aberta, mas bem no fundo, de boca para cima. O fato de não terem sido encontrados ossos tanto na urna 2 quanto na urna 5 pode significar várias coisas: que tiveram uma tafonomia diferente dos esqueletos das urnas 3 e 4; ou que os ossos foram retirados em um momento anterior; ou mesmo que não havia ossos humanos dentro. Não há mais como comprovar nenhuma dessas hipóteses, mas a última, a de que não era um sepultamento, foi descartada por nós devido à semelhança desses contextos com os outros do sítio, que continham ossos humanos bastante fragmentados.

Prancha 31: Croquis dos contextos funerários do sítio Alves, com as respectivas vasilhas. Fonte: Pallestrini, 1975. Elaboração: Mariana Cristante.

\section{Sepultamentos com vasilhas}

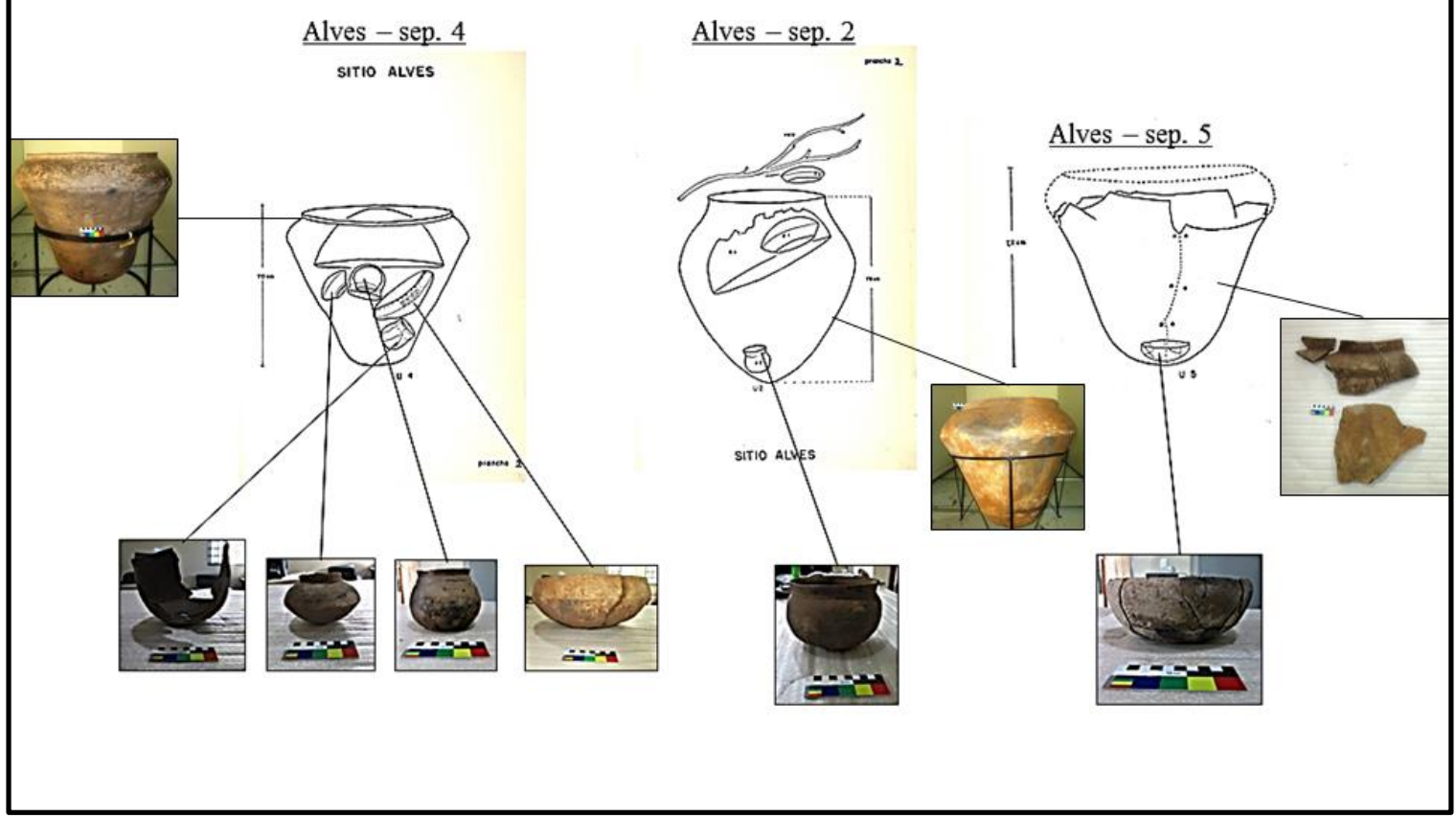




\section{Lagoa São Paulo 2}

Durante as escavações no sítio, foram evidenciados 7 esqueletos humanos, em 3 tipos de sepultamentos. Esses sepultamentos estão dentro e fora de urna. Em duas áreas de decapagem foi encontrada 1 urna com tampa em cada uma, e em outras duas foram encontrados esqueletos fora de urna associados a vasilhas cerâmicas, enterradas no entrono e ao lado deles.

Em relatório sobre esse sítio, os contextos funerários são descritos da seguinte maneira:

Foram encontrados 5 pontos com enterramentos associados a vasilhames de variados tamanhos, totalizando parte de 7 esqueletos humanos (nos PS 09, 23, 28, 38, 50 e 64) [...] sendo que alguns estão enterrados em urnas e outros próximos a elas ou próximos a vasilhames menores (utensílios de oferenda). Também é interessante ressaltar que associados aos ossos estão vasilhames menores nas urnas maiores (decoradas com engobo branco com riscos vermelhos em formato de losango) no PS 38. (Kunzli et al, 2010)

Os primeiros sepultamentos e conjuntos de vasilhas encontrados estão melhor descritos. Em etapas de campo posteriores foram identificadas novas vasilhas que poderiam ser urnas e ossos que poderiam pertencer a sepultamentos humanos, mas não foram escavados. O que é possível supor, de acordo com o relatório de Kunzli et al (2010), é que se tratava de uma aldeia que possuía muitos sepultamentos.

Não há datas para o sítio e nem um controle cronológico dos sepultamentos.

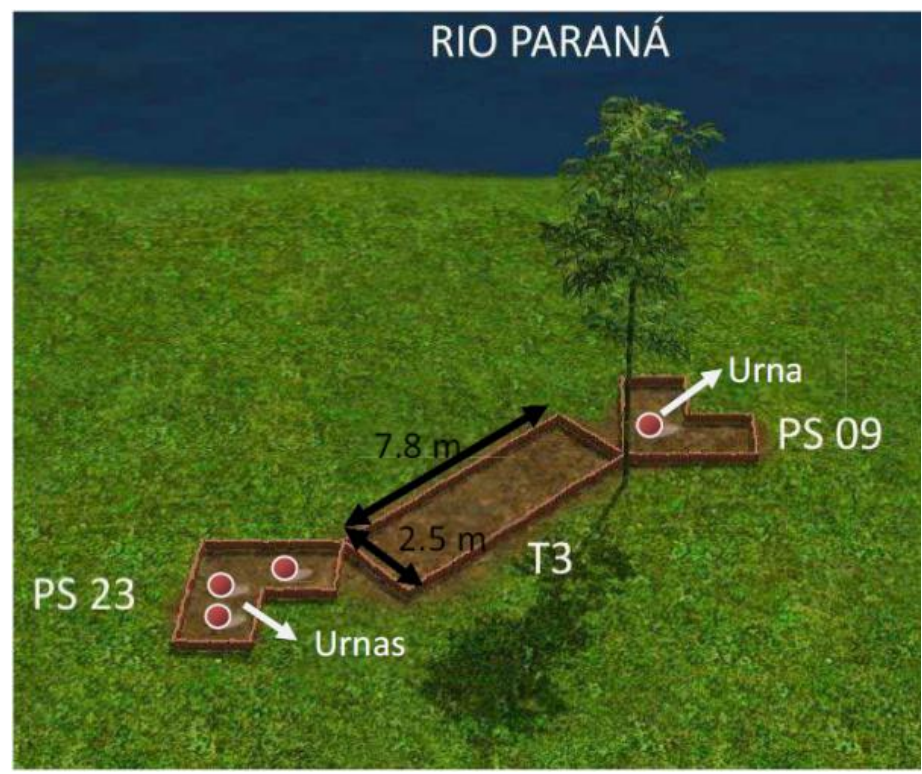

Figura 52: Croqui da abertura de unidades de escavação onde se evidenciaram contextos funerários no sítio Lagoa São Paulo 2. Fonte: Cabrera, 2015, p. 78. 


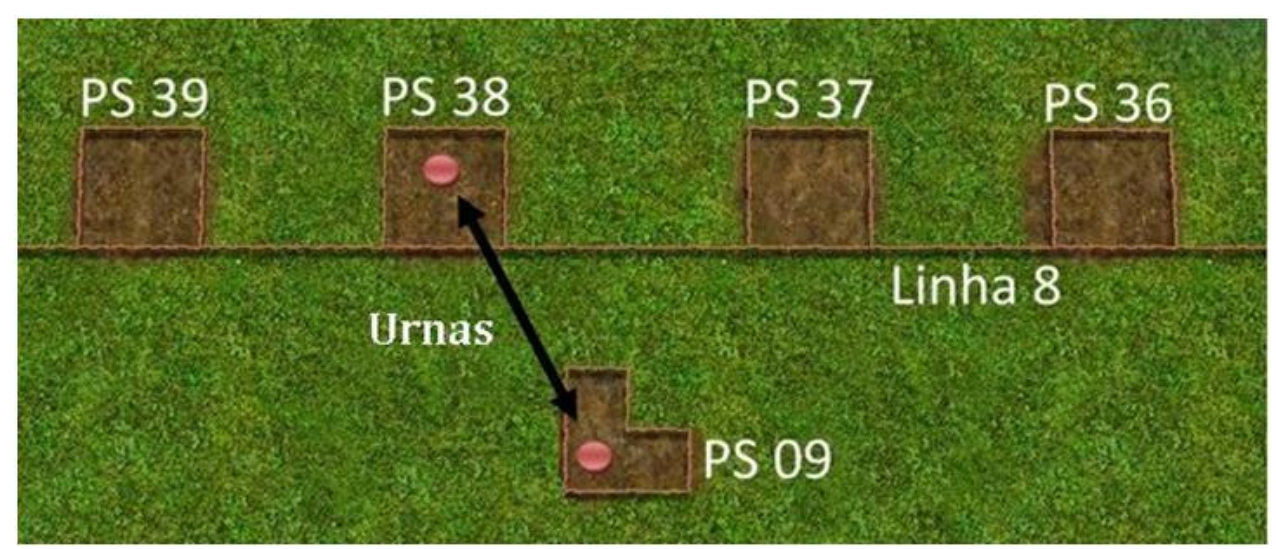

Figura 53: Croqui de unidades de escavação que contêm contextos funerários. Fonte: Kunzli et al, 2010.

O quadro 10 traz os contextos funerários do sítio: 
Quadro 10: Contextos funerários do sítio Lagoa São Paulo 2. Fotos: Kunzli et al, 2010.

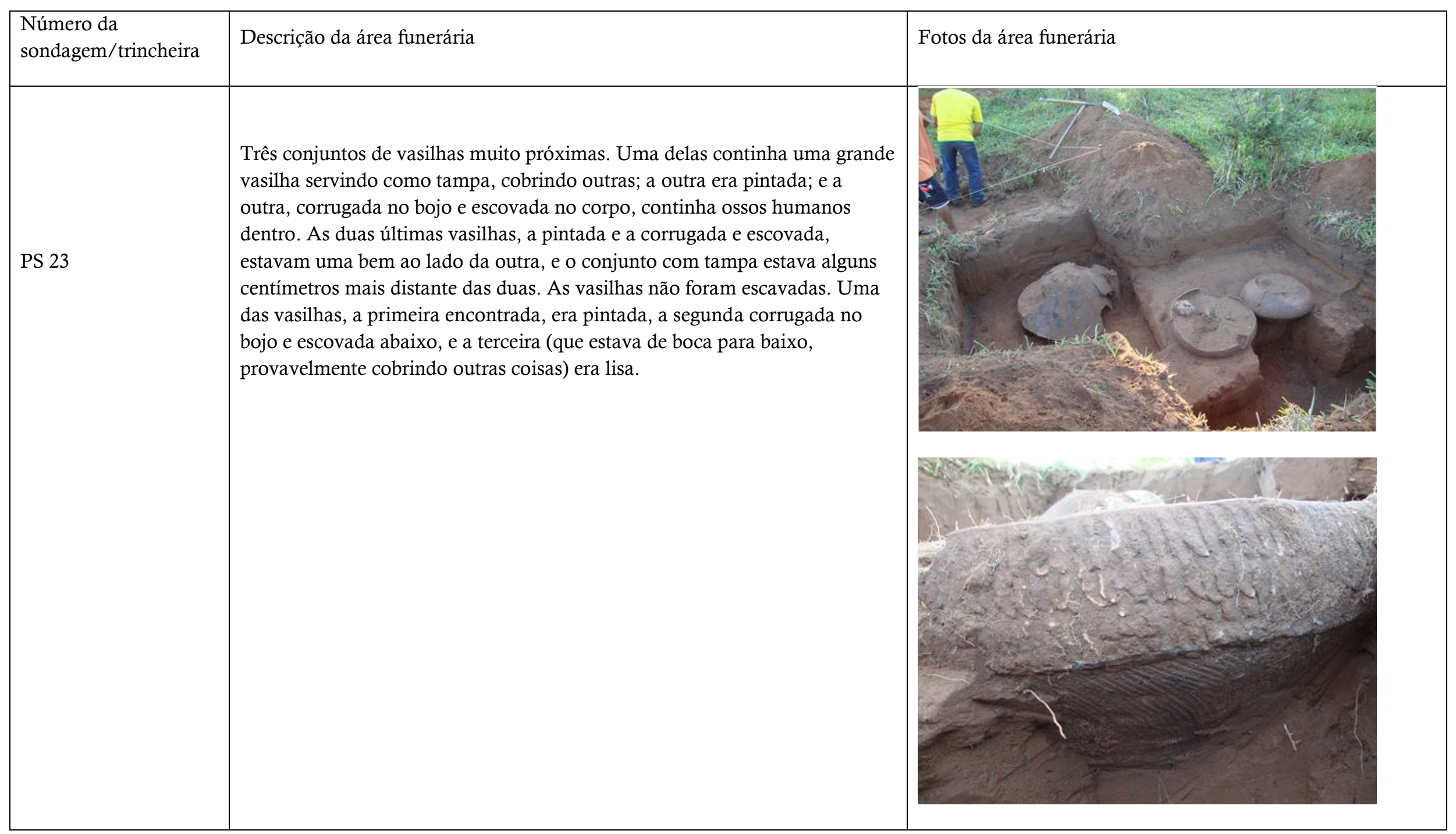




\begin{tabular}{|c|c|}
\hline PS 28 & Remanescentes humanos fora de urna, próximos a vasilhas cerâmicas. \\
\hline PS 50 & $\begin{array}{l}\text { Vasilhas de vários tamanhos, em diversas posições, próximas a esqueletos } \\
\text { humanos. }\end{array}$ \\
\hline
\end{tabular}




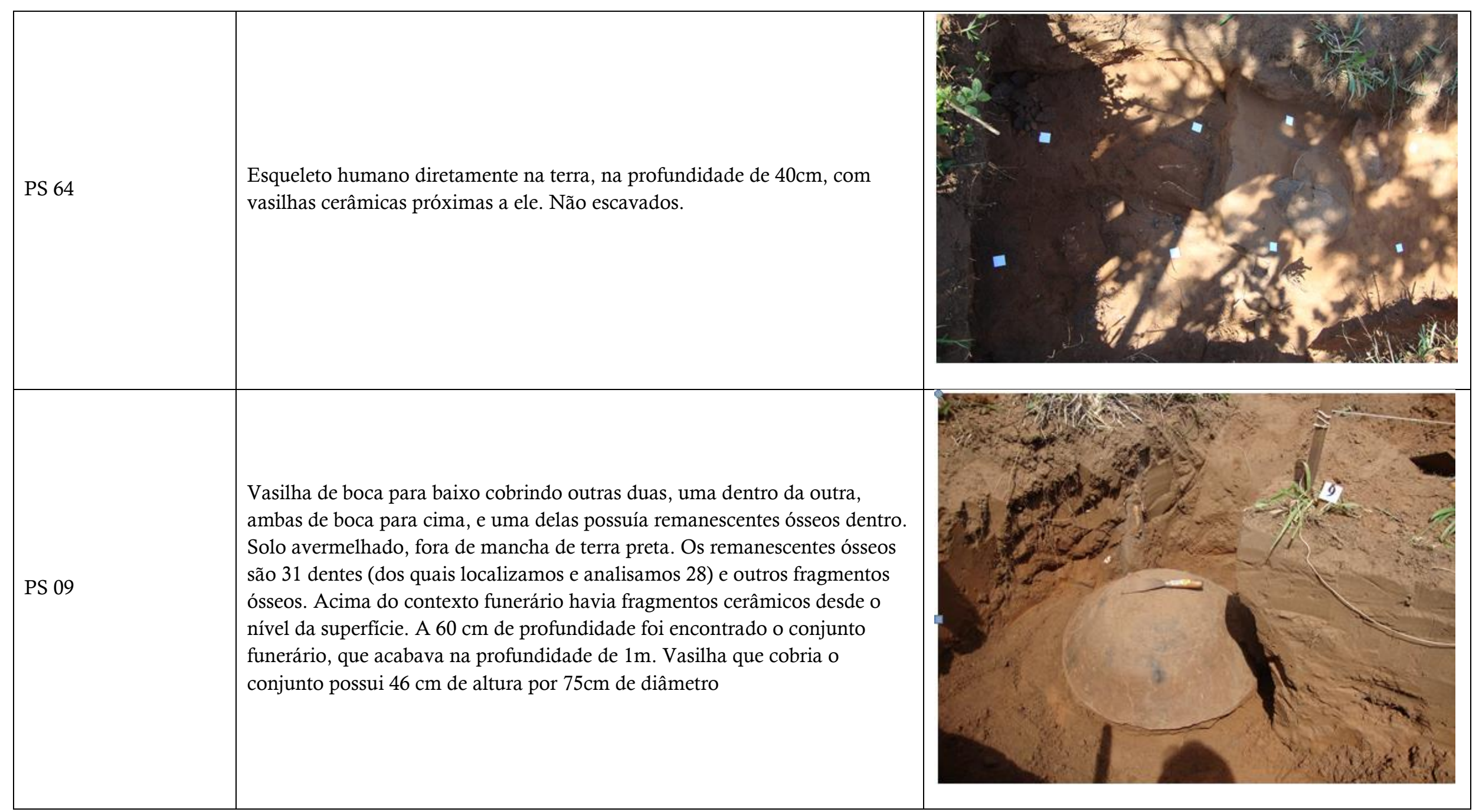




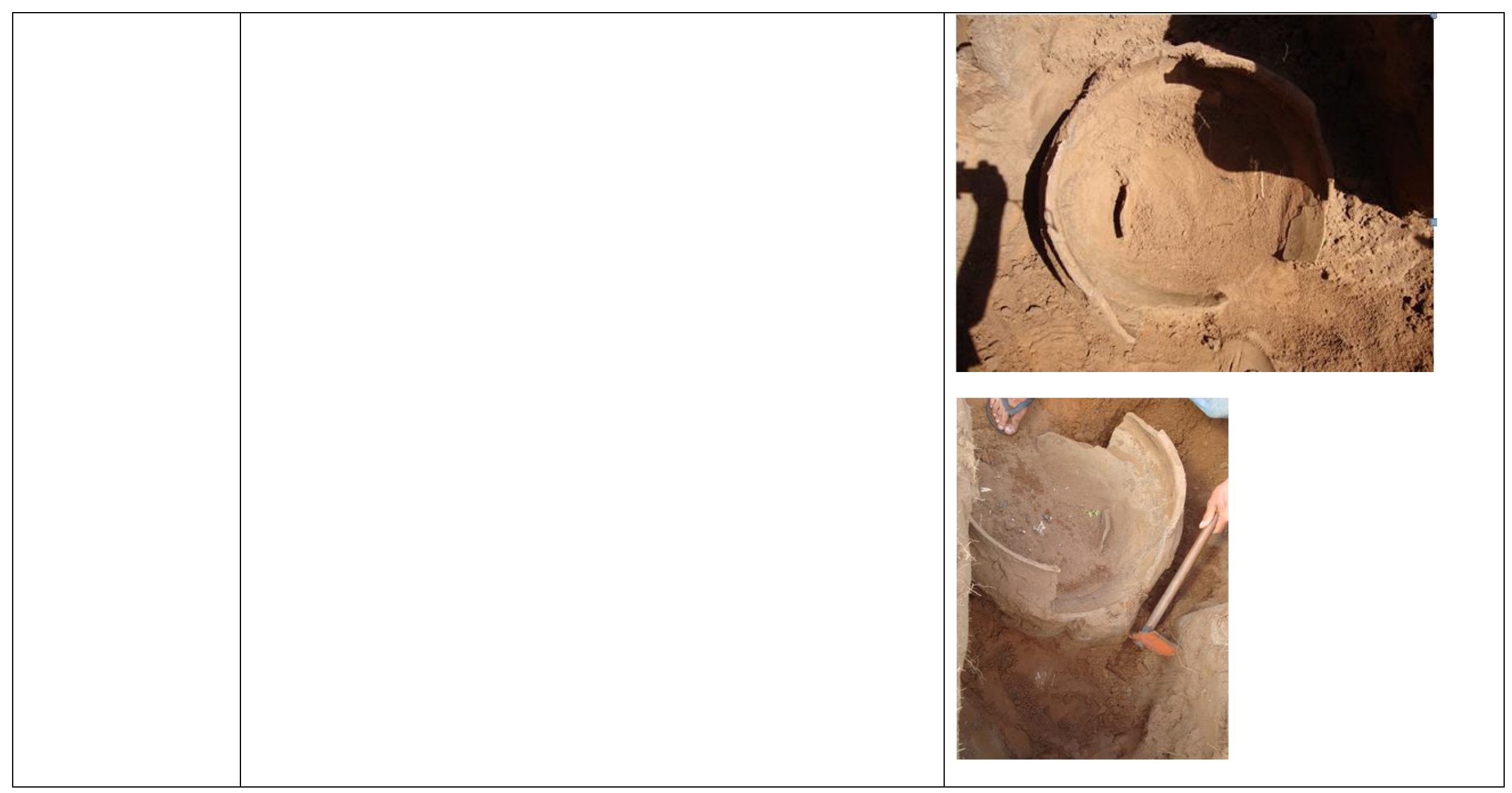




\section{Aguinha}

Foi aberta uma área de decapagem no entorno do local onde afloravam bordas de vasilhas, e assim foi evidenciada a vasilha que era parte do conjunto funerário. Faccio (2011), que realizou a pesquisa arqueológica, assim descreve o contexto:

Verificamos, então, a presença de três vasilhas dispostas no sentido norte-sul, de tamanhos e formas diferentes. Foram denominadas respectivamente urnas 1 e 2 e vasilha ' $a$ '.

A urna 1 apresentou contorno carenado, com pintura vermelha sobre engobo branco e tampa lisa. Dentro da urna evidenciamos vasilhas carenadas e de contorno direto. A urna 2 apresentou contorno infletido, corpo liso e borda corrugada. A vasilha não apresentou borda, sendo do tipo liso.

As três vasilhas evidenciadas nesta área de decapagem apresentaram sedimento em seu interior. No caso da urna 1 , isso ocorreu porque a tampa se quebrou. Nos casos da urna 2 e da vasilha 'a', provavelmente a tampa e a borda, respectivamente, foram levadas pela ação das águas do lago da UHE da Capivara (Faccio, 2011).

A autora também coloca que a urna 1 foi classificada como cambuchí, e partes de sua tampa também foram levadas pelas águas do lago. O sedimento no interior da urna era da mesma cor que o do entorno. A peça possui $64 \mathrm{~cm}$ de altura e diâmetro máximo de $1,40 \mathrm{~m}$. Nessa urna foram encontradas vasilhas, uma delas classificada como ñaetá, que estava parte dentro da urna e parte sobre a borda. Foi encontrada uma fogueira próxima às urnas.

A urna 2 foi encontrada com os fragmentos separados, mas após o restauro apresentou a forma de yapepó, lisa e com corrugado na borda. Uma borda de uma vasilha foi encontrada sobre a parede da urna, em posição vertical, de boca para cima (foto abaixo). O restante da vasilha estava dentro da urna, o que levou a autora a inferir que essa peça estava no interior da mesma, tendo sido quebrada pela ação das águas.

Abaixo, temos as urnas I e II do sítio Aguinha. Como não foram encontrados ossos dentro de nenhuma das vasilhas, a inferência de que sejam de fato urnas, feita pela autora, se dá basicamente por causa do seu formato e do padrão que o contexto segue, que é o de vasilhas grandes com outras menores dentro. Devido à semelhança de vasilhas como essas com outras encontradas em outros contextos funerários, mesmo com a ausência de ossos poder-se-ia dizer que é funerário. Outro fator que contribui para a inferência de contexto funerário é o 
relato, realizado pela autora diretamente para mim, de que esse contexto foi encontrado em solo vermelho, fora de qualquer macha de terra preta, o que está de acordo com o padrão encontrado por Pallestrini $(1969,1975)$ para os contextos funerários dos sítios Fonseca, Alves e Prassévichus.

Por essas duas urnas mais a vasilha (que aparece bem no canto da foto) estarem muito próximas e em um mesmo nível estratigráfico, consideramos que se trata de um mesmo contexto funerário, que chamamos de contexto funerário 1. As fotos das pranchas 32 e 33, tiradas na época da escavação e copiadas de uma publicação da autora, mostram esse contexto.

Foi encontrada uma outra vasilha, a oeste (urna 3), muito próxima das outras, corrugada, com tampa lisa e dois potes dentro dela. A chamamos de contexto funerário 2, que apresentava apenas uma urna com vasilhas dentro. Suas fotos estão abaixo.

Fragmentos da tampa contornavam a borda do vaso, de forma bastante fragmentada. O restante da tampa foi levado, certamente, pelo avanço e recuo das águas do lago da UHE da Capivara.[...] A urna 3, depois de restaurada, apresentou a forma de um yapepó, do tipo corrugado, com dois potes do tipo liso em seu interior, também na forma de yapepó (Faccio, 2011).

Através das fotos, podemos ver que pelo menos um dos potes foi depositado virado para baixo. Este parecia estar mais ou menos entre a região mesial e a borda da urna, com sedimento embaixo, que o segurou nessa posição. A inferência de que se trata de um contexto funerário provem dos mesmos argumentos que corroboraram para o contexto funerário 1.

A autora coloca que foi evidenciada uma fogueira próxima a essas urnas funerárias e uma lagoa no entorno da área do sítio (a oeste), próximo da qual não foi encontrado nenhum vestígio arqueológico.

No mapa apresentado pela pesquisadora (2011), reproduzido na prancha 39, aparecem outras 3 vasilhas. Através da escala, podemos deduzir que os contextos funerários foram encontrados a mais de 200 metros da mancha de terra preta. Entretanto, provavelmente havia outras manchas que não se preservaram. No mapa podemos perceber que os contextos funerários estão mais ou menos próximos uns dos outros, sendo que as urnas 4 e 5 encontram-se mais afastadas, e a urna 6 mais afastada ainda (mais do dobro da distância que as urnas 4 e 5 estão afastadas 
das urnas 1, 2 e 3). Claro que nada impede que houvesse outras urnas, que não foram encontradas.

Os outros contextos do sítio não possuem informações, ou então as vasilhas foram descontextualizadas antes de serem escavadas.

Pranchas 32 e 33: Contextos funerários I e II do sitio Aguinha. Fonte: Faccio, 2011. Elaboração: Mariana Cristante.
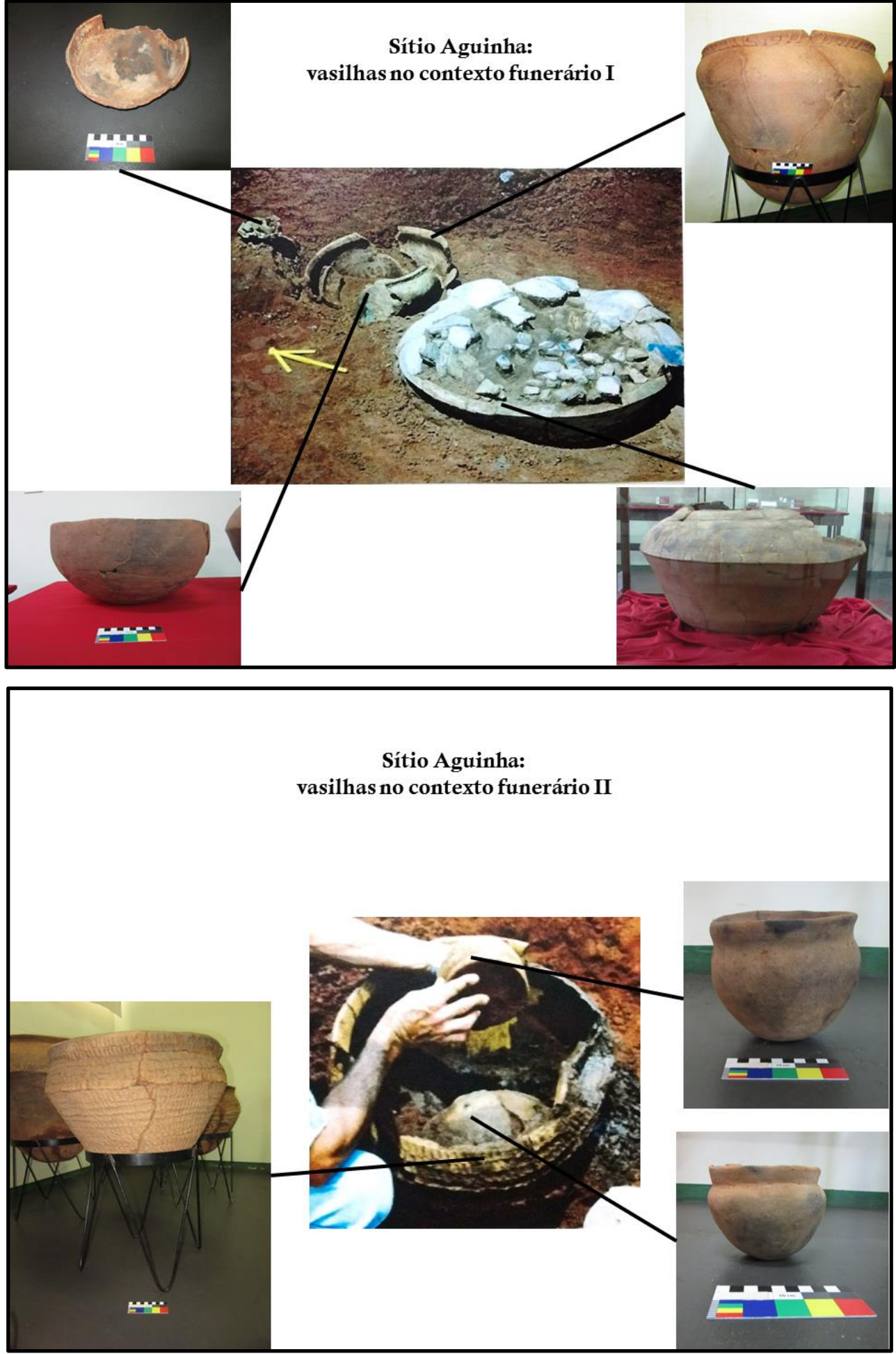


\section{Pernilongo}

Em 1999, o proprietário da fazenda onde está o sítio encontrou uma urna fragmentada e uma vasilha ao lado desta.

Após o início das pesquisas arqueológicas, Faccio e equipe encontraram mais uma urna, mas esta possuía um formato aberto. Segundo a autora, dentro havia um osso em decomposição juntamente com outras vasilhas menores. Ao lado dessa urna, foram evidenciadas duas outras vasilhas, dois blocos de basalto e adornos em resina de jatobá, que estavam bem ao lado de um dos blocos. Os vestígios ósseos estavam bastante decompostos, formando um arranjo circular que a arqueóloga acredita ser uma cabeça que, devido ação da entrada de terra e água na urna, tornou-se uma concentração de ossos, se desfazendo e misturando-se a terra. Após a coleta, a bola de terra se desfez, e os vestígios ósseos não foram identificados.

Abaixo há fotos das vasilhas encontradas na área de decapagem 1 do sítio Pernilongo. Denominamos este como contexto funerário 1, devido à associação estratigráfica e espacial entre as vasilhas, os blocos de basalto e os adornos em resina. Todos esses elementos provavelmente faziam parte do contexto funerário, sendo o que restou de um ritual para esse morto (ou mortos, não é possível saber ao certo) cujos poucos ossos que se preservaram foram encontrados. Através da foto que está abaixo podemos ver que as vasilhas ao lado da urna parecem ter sido depositadas de boca para cima. Já as vasilhas dentro da urna parecem ter ido depositadas de boca para cima e para baixo umas sobre as outras, e junto com os ossos. Elas podem ter sido deslocadas de suas posições originais pela ação das águas do lago da hidrelétrica.

As fotos a seguir, tiradas na época da escavação e retiradas de uma publicação, mostram esse contexto. 


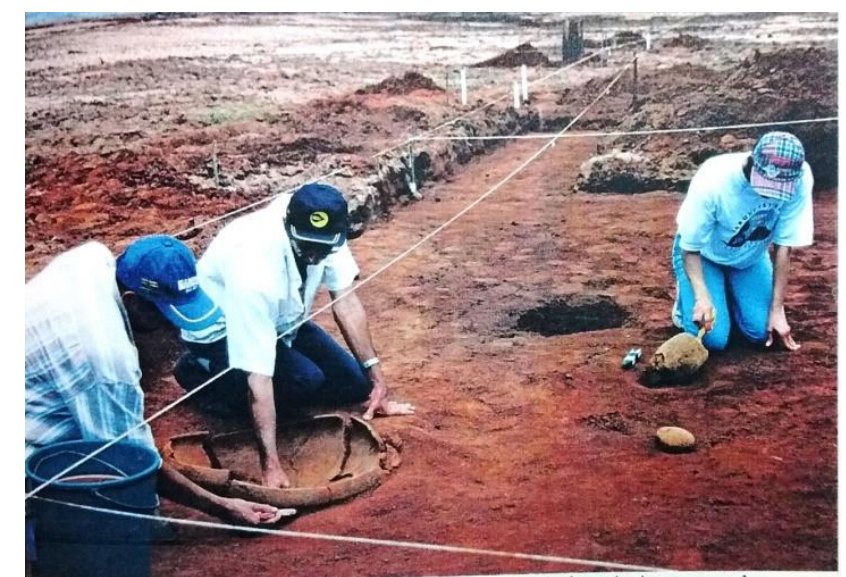

Figura 54: Escavação do contexto funerário 1, sítio Pernilongo. Fonte: Faccio, 2011.

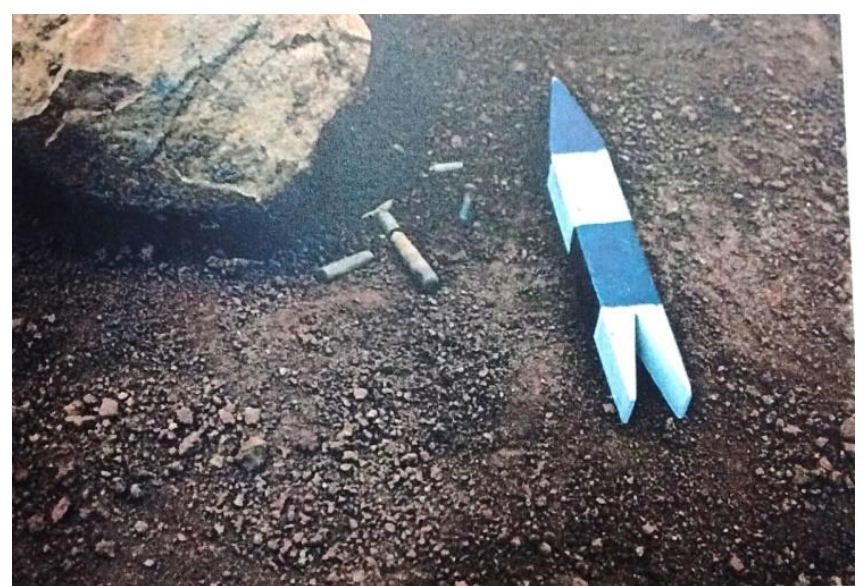

Figura 55: Tembetá e adornos em resina encontrados ao lado de bloco de basalto, próximos ao contexto funerário 1, sítio Pernilongo. Fonte: Faccio, 2011.

Uma outra vasilha foi encontrada no sítio, que a autora sugere ser uma urna funerária pequena com tampa. Dentro não havia nenhum outro vestígio arqueológico. Denominamos este de contexto funerário 2, embora, novamente, a inferência de que seja funerário se justifica sobretudo pelo fato de ser uma vasilha tampada, em solo vermelho segundo Faccio, como até agora parece ser um padrão funerário para esses grupos. Abaixo, temos uma foto tirada na época da escavação.

Ambos os contextos que estamos descrevendo para esse sítio diferem bastante dos contextos dos sítios escavados por Pallestrini décadas atrás (sítios Fonseca, Prassévichus e Alves). A forma e o tamanho das urnas funerárias é muito diferente, pois a urna do contexto 1 é uma vasilha aberta, com outras vasilhas ao lado e dentro, e a do contexto 2 é muito pequena quando comparada a outros sepultamentos dos outros sítios. 
Outra vasilha do tipo cambuchí foi retirada de dentro da água, sendo que seu fundo estava parcialmente enterrado. A autora sugere que poderia também ser uma urna.

Pranchas 34 e 35: Contextos funerários I e II do sítio Pernilongo. Fonte: Faccio, 2011. Elaboração: Mariana Cristante.

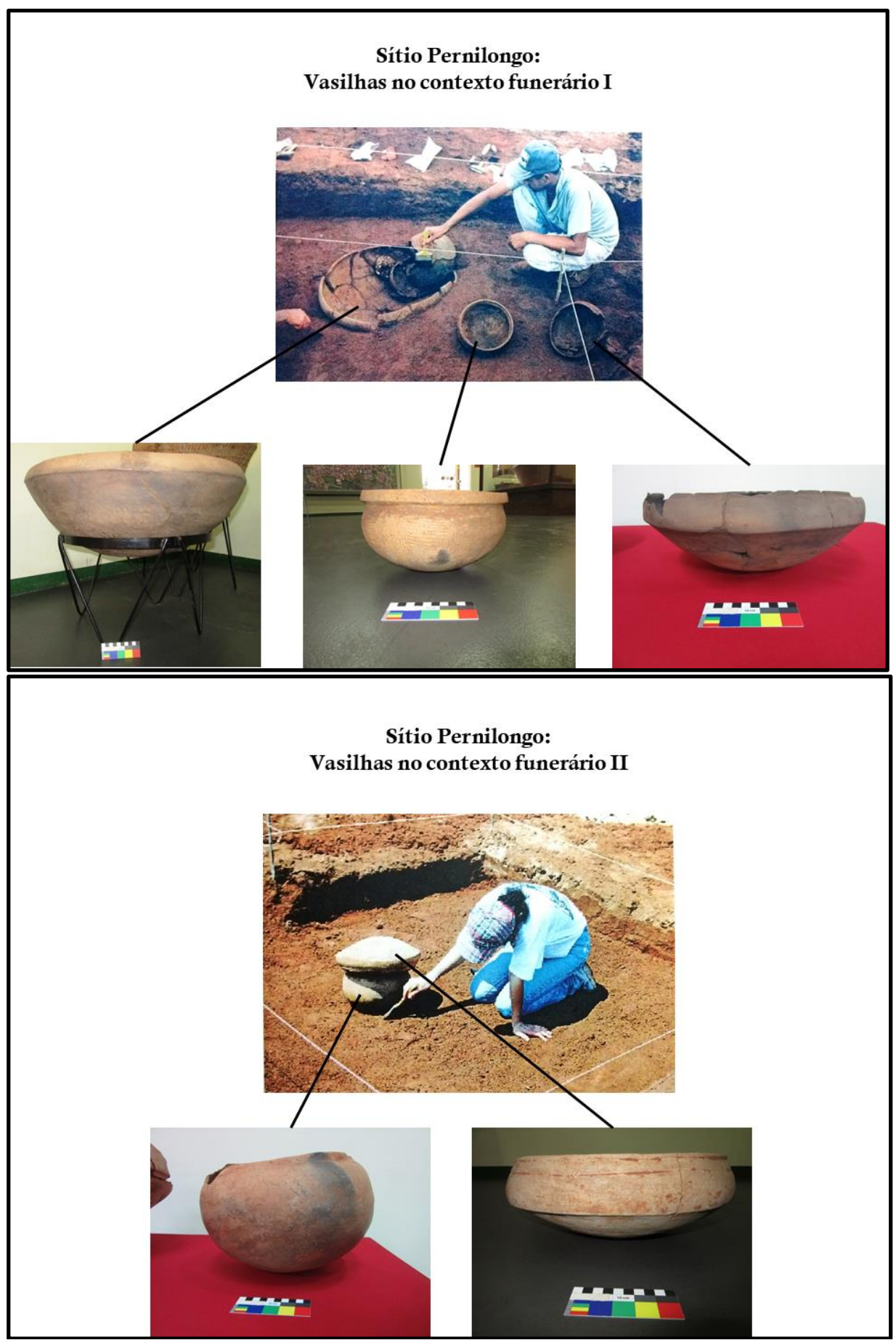




\subsubsection{B - A espacialidade entre os contextos no sitio}

Quando observamos a espacialidade dos contextos funerários dentro de cada sítio, podemos ver que, em alguns sítios, os contextos são mais esparsos, bastante distantes uns dos outros, e em outros eles são mais próximos. Essa diferença na espacialidade coincide, novamente, com a diferença entre as cerâmicas. Nos sítios com cerâmicas Tupinambá (Fonseca e Prassévichus) os contextos são distantes uns dos outros, alguns próximos a manchas de terra preta, outros muito distantes das mesmas, e, em geral, bastante esparsos pela área do sítio. Quando observamos os sítios Guarani, vemos contextos mais próximos uns dos outros. Nos sítios Alves e Aguinha, os sepultamentos estão todos em uma área mais concentrada do sítio, enquanto no sítio Pernilongo há contextos mais dispersos, no entanto, ainda assim havendo alguns próximos entre si.

Todos os contextos, de todos os sítios em que foram encontradas manchas de terra preta, são exteriores a elas, nenhum dentro.

Pranchas 36-40: Vasilhas funerárias na planta do sítio. Fonte: Pallestrini, 1975; Faccio, 2011.

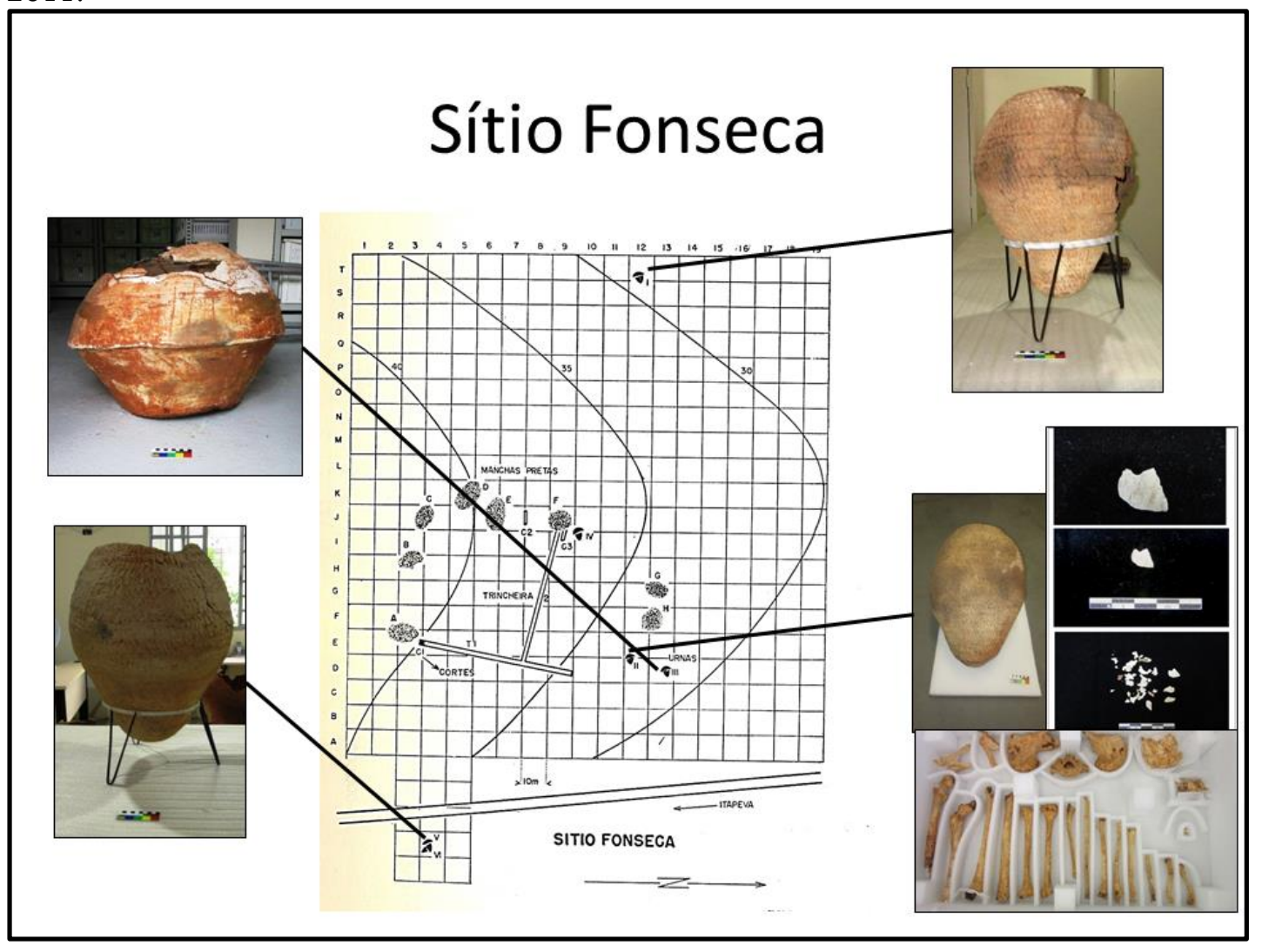



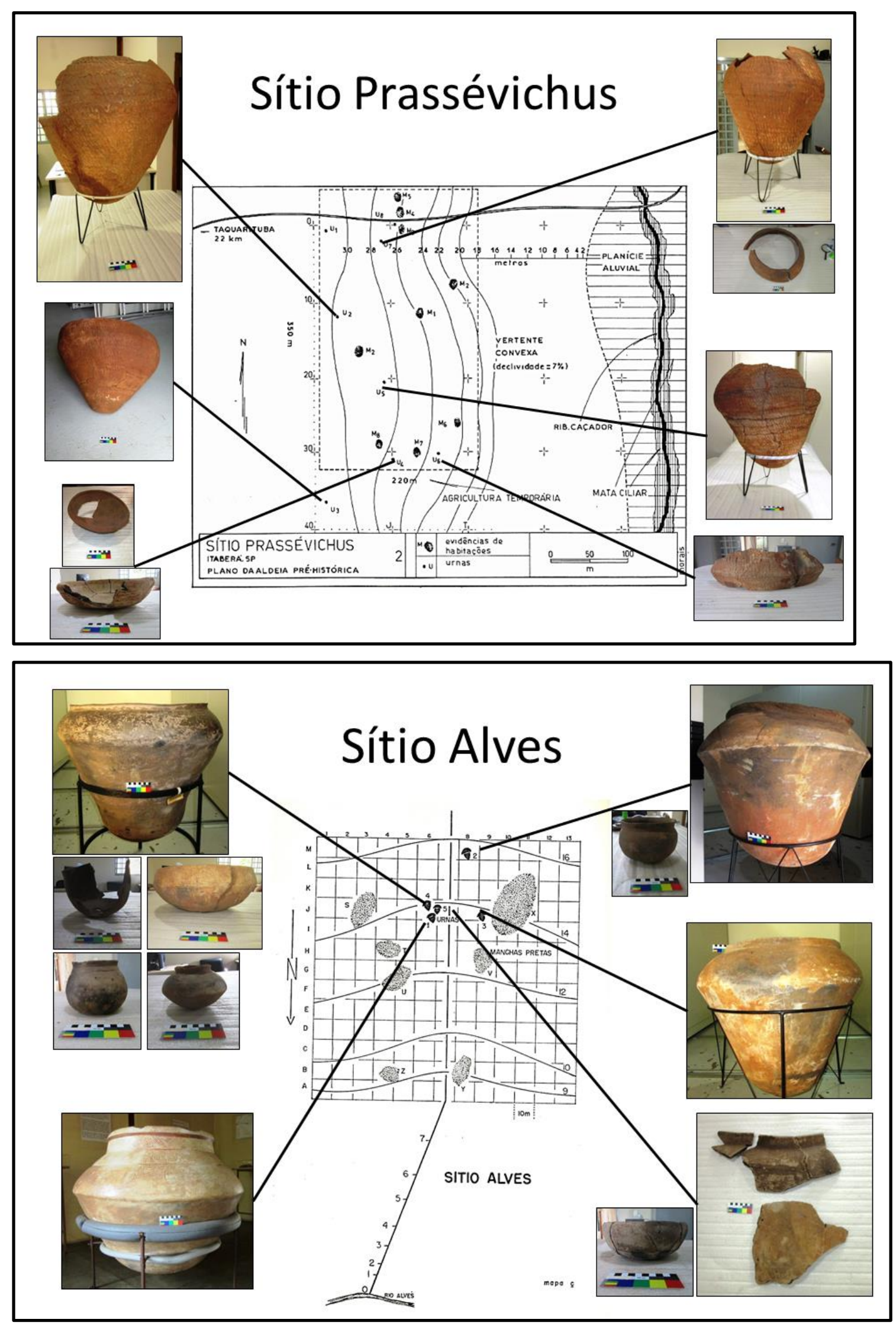


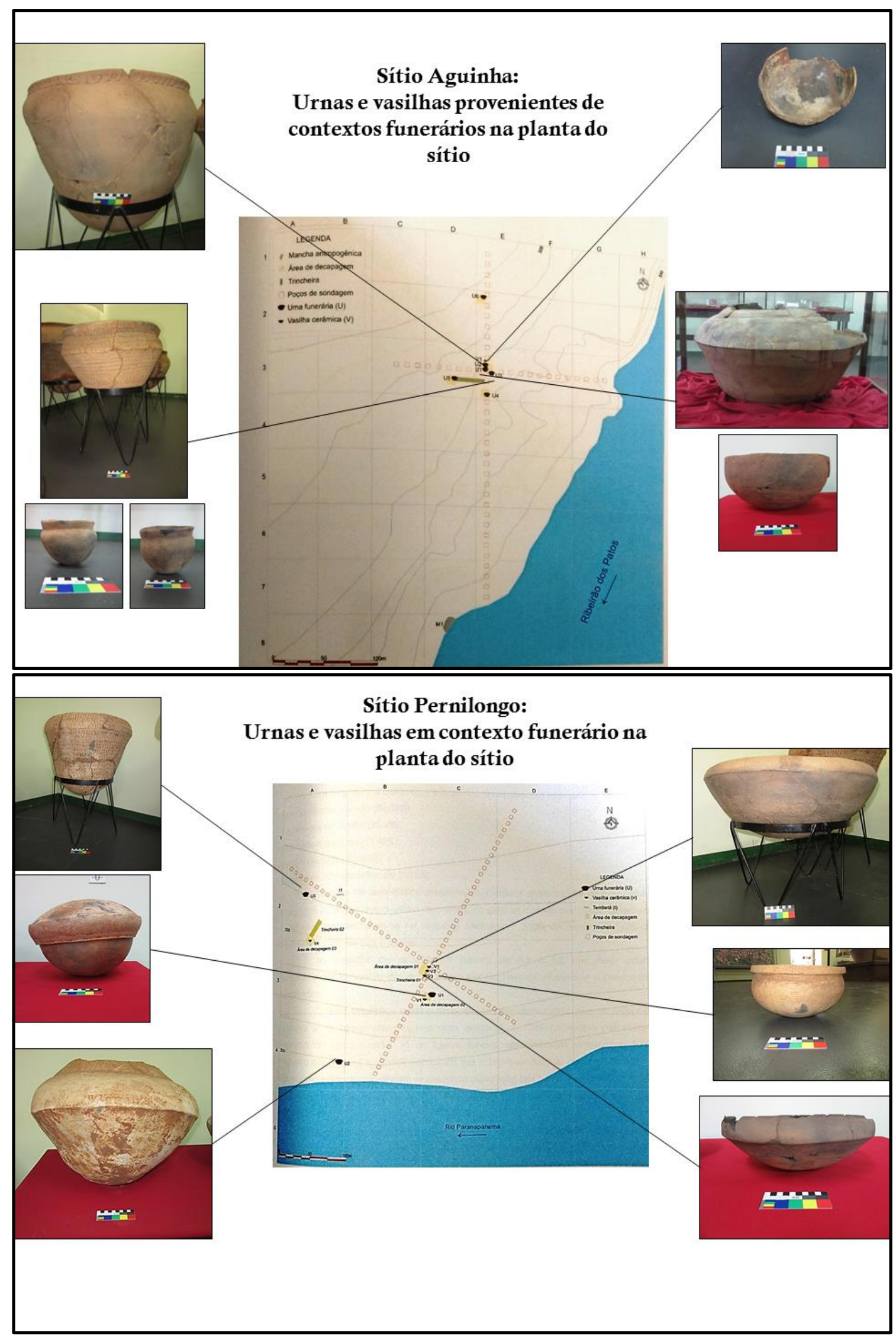


Essa análise espacial experimental nos mostra que há diferenças na espacialidade funerária entre sítios Guarani e Tupinambá dessa região. As cerâmicas distintas, os diferentes padrões de assentamento, e a localização dos sítios ao longo do Paranapanema, nos mostram dois blocos distintos, os sítios Guarani e Tupinambá apresentando diferenças bem marcadas entre si. Isso acrescenta uma informação nova às fontes etnohistóricas, pois a leitura das mesmas faz parecer que as práticas de sepultamento em urna de grupos Guarani e Tupinambá seriam idênticas, mas não o são.

As relações dessas diferenças na espacialidade e na presença de vasilhas anexas ou não com comportamentos funerários e com aspectos da cosmologia são difíceis de serem feitas. O que procuramos fazer aqui foi um esboço, um início de compreensão dos comportamentos funerários dos grupos Tupinambá e Guarani.

Os dados que trouxemos apontam para continuidades e descontinuidades nos contextos funerários desses sítios.

\subsection{6 - Análise dos remanescentes humanos}

Como a preservação dos remanescentes humanos em sítios Tupi é, em geral, bastante ruim, não há como obter quase nenhuma informação do componente biológico do contexto. A descontextualizarão de vasilhas e a falta de informações sobre a escavação das mesmas quando esta é realizada por arqueólogos são outros fatores que limitam em muito qualquer interpretação. É por isso que a análise das vasilhas dos sítios Lagoa São Paulo 2, Salto Grande, Nunes, Romanini, Lopes, Canuto, das ocorrências em Piraju e em Rosana - todas sem descrição de seus contextos -, e dos contextos sem descrição dos sítios principais, veio como um complemento e um reforço para as informações que obtivemos com os contextos mais bem descritos, mas não foram a fonte principal de nossas considerações.

As fichas preenchidas de inventário ósseo e dentário e de diagnóstico de sexo e idade dos indivíduos estão no apêndice B. O quadro abaixo mostra quais contextos de cada sítio possuem relatos claros de ossos humanos, embora não tenhamos encontrado muitos desses indivíduos. Os outros contextos foram considerados funerários pelos arqueólogos que os escavaram também, mas não há a informação clara de ossos humanos. 
Quadro 11: Informações sobre a presença de ossos humanos nos contextos analisados.

\begin{tabular}{|c|c|}
\hline \multicolumn{2}{|c|}{ Contextos funerários com informações claras da presença de ossos humanos } \\
\hline Sítio & $\begin{array}{c}\text { Contexto funerário } \\
\text { I, II, III, IV, V } \\
\text { (todos os contextos) }\end{array}$ \\
\hline Fonseca & I, VIII \\
\hline Prassévichus & I \\
\hline $\begin{array}{c}\text { Salto Grande do } \\
\text { Paranapanema }\end{array}$ & III e IV \\
\hline Alves & Não há informações \\
\hline Aguinha & I \\
\hline Pernilongo & 5áreas com 7 esqueletos dentro e fora de urnas, sem especificação do contexto \\
\hline $\begin{array}{c}\text { Lagoa São } \\
\text { Paulo 2 }\end{array}$ & $\begin{array}{c}\text { Na urna da exposição do CEMAARQ }{ }^{11} \text { há um fêmur humano e outro fragmento } \\
\text { ósseo, e um osso de fauna. Se são realmente daquela urna ou não, não há como } \\
\text { saber. }\end{array}$ \\
\hline Lopes & $\begin{array}{c}\text { Na urna da exposição do CEMAARQ há alguns fragmentos ósseos dentro, um } \\
\text { deles sendo de uma costela humana. Também não é possível saber se pertencem } \\
\text { àquele contexto de fato ou não. }\end{array}$ \\
\hline Romanini & \multicolumn{2}{c}{} \\
\hline
\end{tabular}

Os remanescentes humanos que encontramos para análise estavam, em sua grande maioria, descontextualizados. Alguns puderam ser associados a certos contextos cujo material cerâmico também analisamos, mas não foram a maioria dos casos. Isso fez com que a associação entre cerâmicas e indivíduos fosse problemática.

\section{Sítio Alves}

Foram encontrados poucos fragmentos ósseos de um dos sepultamentos do sítio Alves, que não possibilitam diagnóstico de sexo e idade por métodos visuais. O tamanho dos ossos sugere ser um adulto. Os ossos apresentam marcas de ataque de formigas, entre outros agentes tafonômicos. Não há marcas aparentes nem de queima, nem de corte, embora as superfícies ósseas estejam muito desgastadas.

${ }^{11}$ Centro de Museologia, Antropologia e Arqueologia, Universidade Estadual Paulista, Presidente Prudente-SP. 
Prancha 41: Ossos humanos provenientes do sítio Alves. Fotos: Mariana Cristante.

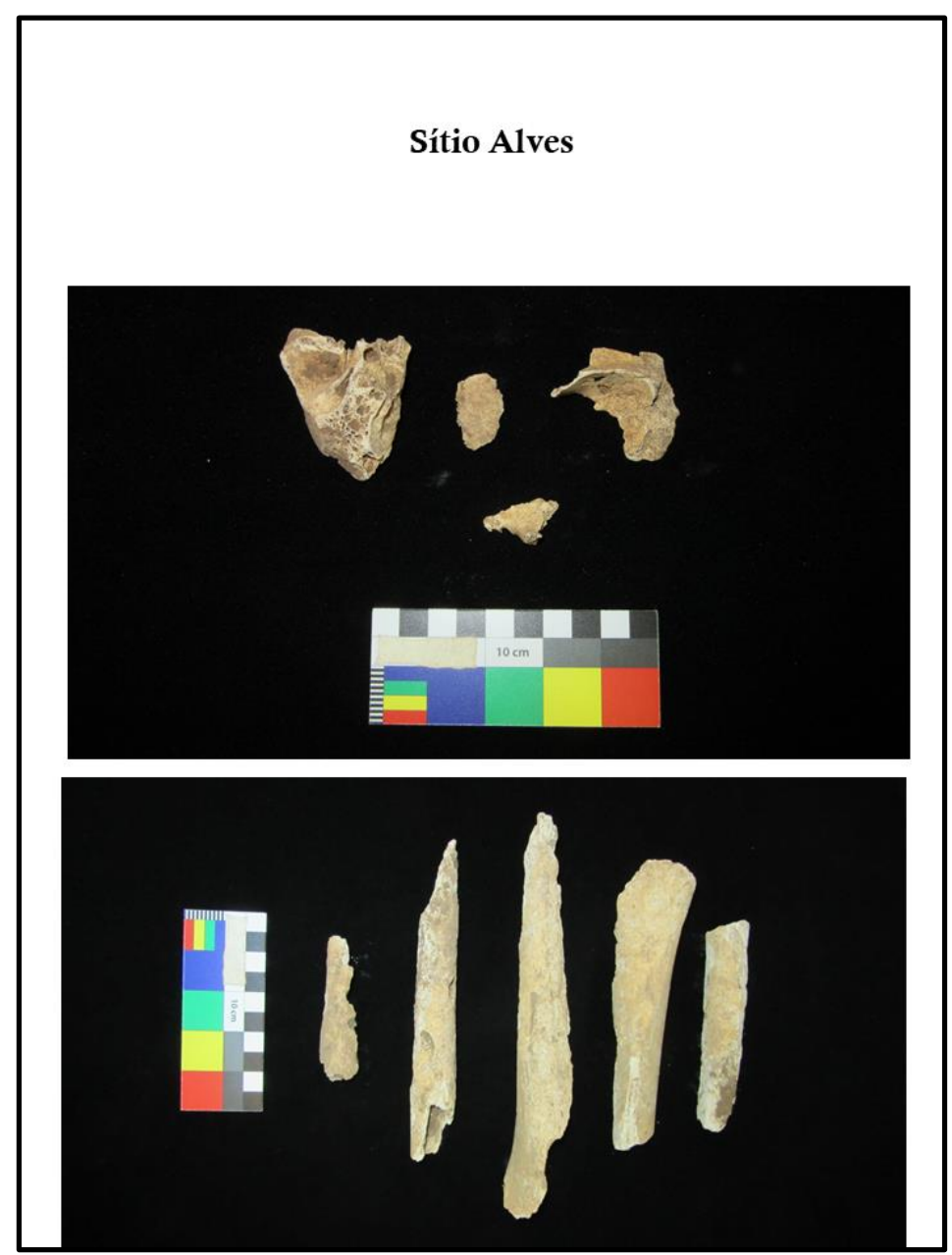

\section{Sítio Lagoa São Paulo 2}

Este sítio apresenta uma grande quantidade de material osteodontomalacológico, sobretudo fauna, bastante interessante para futuras pesquisas sobre dieta e outros temas, dada a raridade de material faunístico, e também humano, recuperado de sítios Guarani ou Tupi. Não analisamos o material faunístico, mas notamos que há diversas espécies de conchas (tanto bivalves quanto univalves), ossos de peixes e mamíferos.

Os remanescentes humanos que foram escavados até agora são poucos e muito fragmentados, não permitindo o diagnóstico de sexo e idade aproximada da morte dos indivíduos. Dos diversos sepultamentos encontrados nesse sítio, apenas três puderam ser analisados por nós, já que os outros não foram escavados, com o objetivo de preservá-los melhor in situ. 
$\mathrm{O}$ primeiro sepultamento encontrado consiste em um fundo de urna corrugada e alguns poucos remanescentes humanos. De acordo com o que nos foi informado, a máquina da olaria que funcionava na área do sítio quebrou uma urna funerária, expondo seus ossos. Dessa urna fragmentada restaram apenas esse fundo e esses ossos. As figuras abaixo são desse sepultamento.

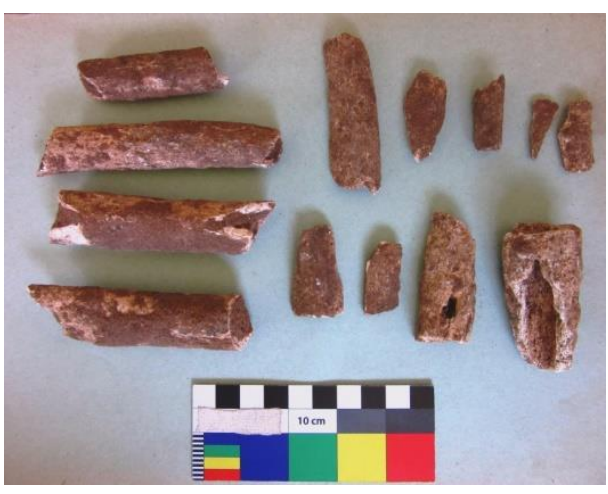

Figura 56: Fragmentos diversos do primeiro sepultamento encontrado no sítio Lagoa São Paulo 2.

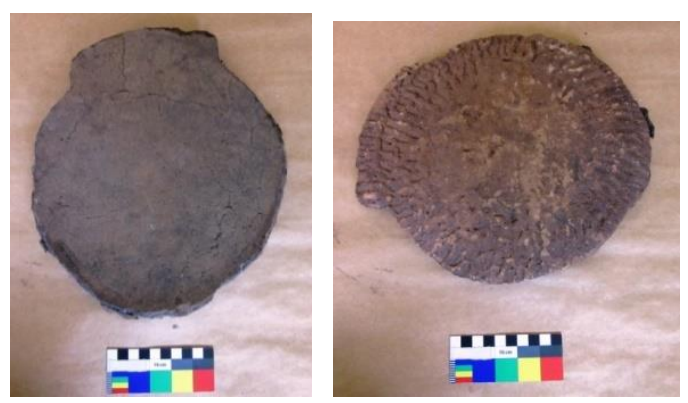

Figuras 57 e 58: Fundo da urna onde se encontrava o sepultamento (vistas da face interna e externa, respectivamente. O restante foi arrancado por máquina da olaria.

O segundo sepultamento encontrado pelos arqueólogos nos trabalhos de campo também foi escavado. Os remanescentes humanos são dentes provenientes da urna funerária do $\boldsymbol{P S}$ 09. O relatório descreve que foram encontrados 31 dentes, mas só encontramos 28, permanentes. Aparentemente, são dentes de um único indivíduo, pois formam quase toda a arcada dentária, sem repetições.

Desses dentes, estavam presentes apenas as coroas, contendo parte das dentinas e os esmaltes. $\mathrm{O}$ inventário segue mais abaixo. Há 2 terceiros molares, provavelmente um superior e o outro inferior. Como não estavam articulados, não é possível saber se os mesmos estavam inclusos ou erupcionados, ou ter certeza se os dois eram superiores ou inferiores e sua lateralidade, mas sua presença nos leva a crer que muito provavelmente se trata de um indivíduo adulto. O grau de desgaste dos dentes corrobora essa hipótese. Os incisivos laterais superiores estão faltando, e não podemos dizer se foi uma perda antemortem ou post-mortem. Porém, são os únicos dentes faltantes, além dos outros dois terceiros molares. Os dentes apresentam um desgaste diferenciado, pois um dos incisivos laterais encontra-se 
mais desgastado que o outro. Os primeiros molares, tanto superiores quanto inferiores, também apresentam elevado grau de desgaste. $\mathrm{O}$ primeiro molar inferior esquerdo apresenta um desgaste severo, bastante diferenciado dos outros dentes, mesmo dos outros molares. O primeiro molar superior direito apresenta um desgaste muito menor, apenas em uma das cúspides, enquanto o inferior direito apresenta desgaste na mesma região, porém, bem menos acentuado. Os segundos molares e os terceiros molares presentes não apresentam um desgaste significativo. Um dos incisivos laterais inferiores também apresenta maior desgaste que o outro, assim como um dos incisivos centrais inferiores. Provavelmente, esse desgaste diferenciado entre os incisivos se dê devido ao uso maior de um dos lados da boca para a mastigação ou para alguma outra atividade que envolvesse esses dentes.

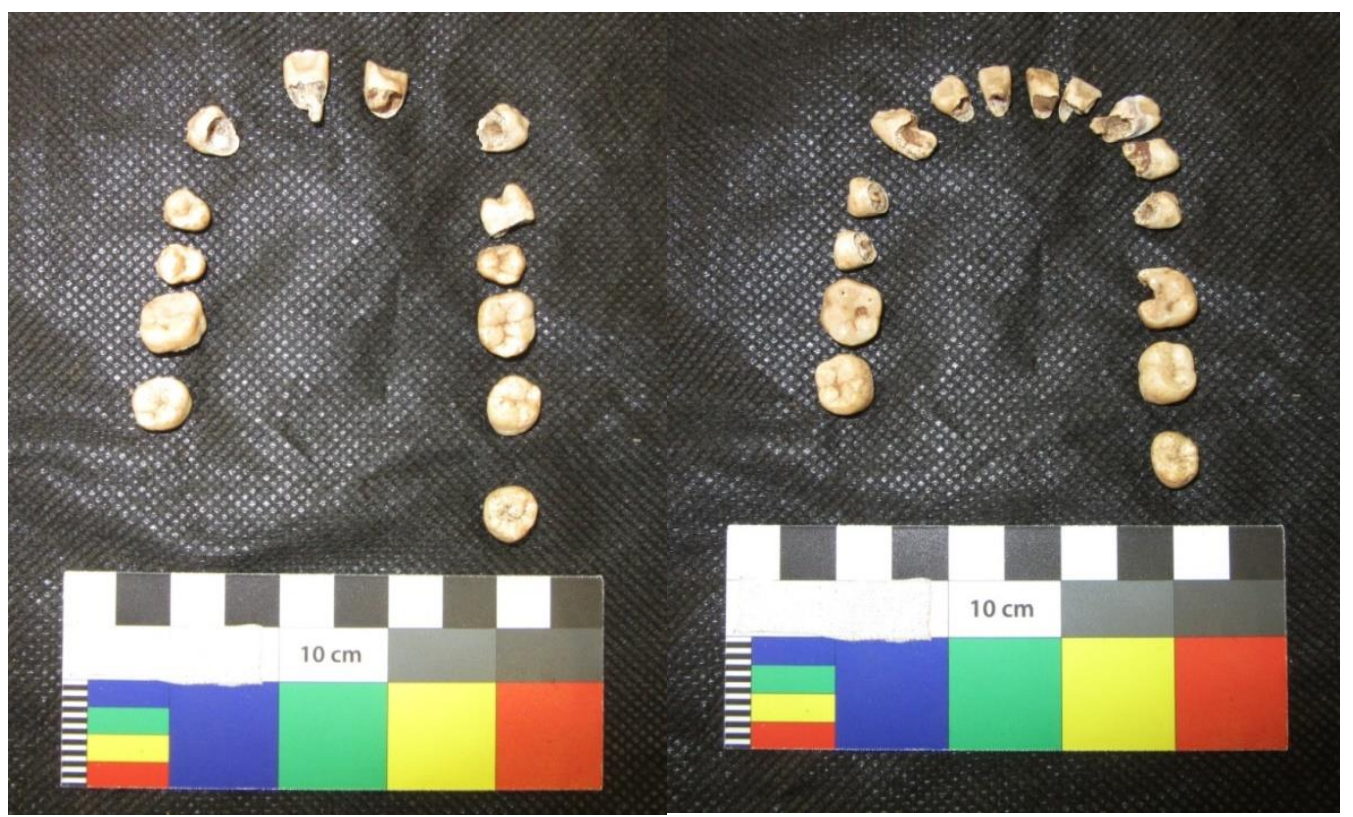

Figuras 59 e 60: Fragmentos dos dentes do PS - 09. Primeira foto: superiores, ausência dos incisivos laterais; segunda foto: inferiores.

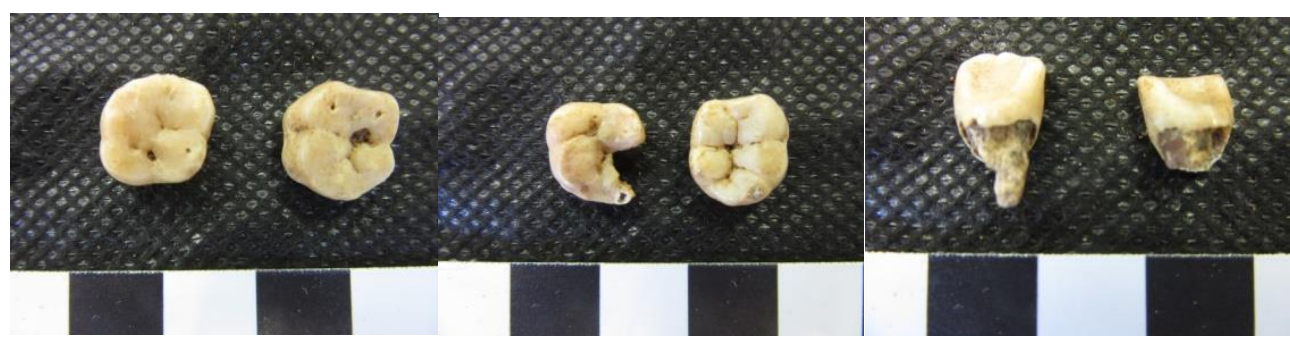

Figuras 61-63: PS - 09. Primeiros molares superior e inferior esquerdos, primeiros molares superior e inferior direitos, incisivos frontais superiores. Os molares apresentam desgaste acentuado, e os incisivos desgaste diferente entre si. 
O outro sepultamento escavado no sítio foi o do PS-28. Estava em uma caixa em que havia muitos ossos de fauna, separados em sacos. Há uma clara diferença na coloração do sedimento aderido aos ossos humanos em relação àquele aderido aos ossos de fauna, sendo aquele avermelhado e este preto. Os remanescentes humanos estão muito fragmentados, não permitindo nem mesmo a remontagem do esqueleto, pois a lateralidade dos ossos era dúbia. Entretanto, observando o tamanho dos ossos, podemos supor que se trata de um indivíduo adulto.

Foram identificados 2 fragmentos do frontal, 2 fragmentos de fêmur, 3 fragmentos de fíbula, e outros fragmentos de ossos longos que não podemos identificar com certeza. Apesar do sedimento avermelhado que recobre os ossos, é possível notar que estão cobertos por manchas escuras, tais como as do sepultamento II do sítio Fonseca.

O fragmento maior do frontal apresenta uma perfuração bastante bem delineada, que não sabemos dizer com certeza qual teria sido a causa. Os dois fragmentos apresentam também outros orifícios.

Prancha 42: Remanescentes humanos encontrados no segundo sepultamento exumado do sítio Lagoa São Paulo 2. Fragmentos do frontal. Primeira foto: vista dos fragmentos ósseos arrumados em sua posição vertical; segunda: fragmento que se encontra perfurado; terceira: detalhe da perfuração. Trata-se de perfuração de origem incerta, podendo estar relacionada a algum fator tafonômico natural. Fotos seguintes: fragmentos de ossos longos.

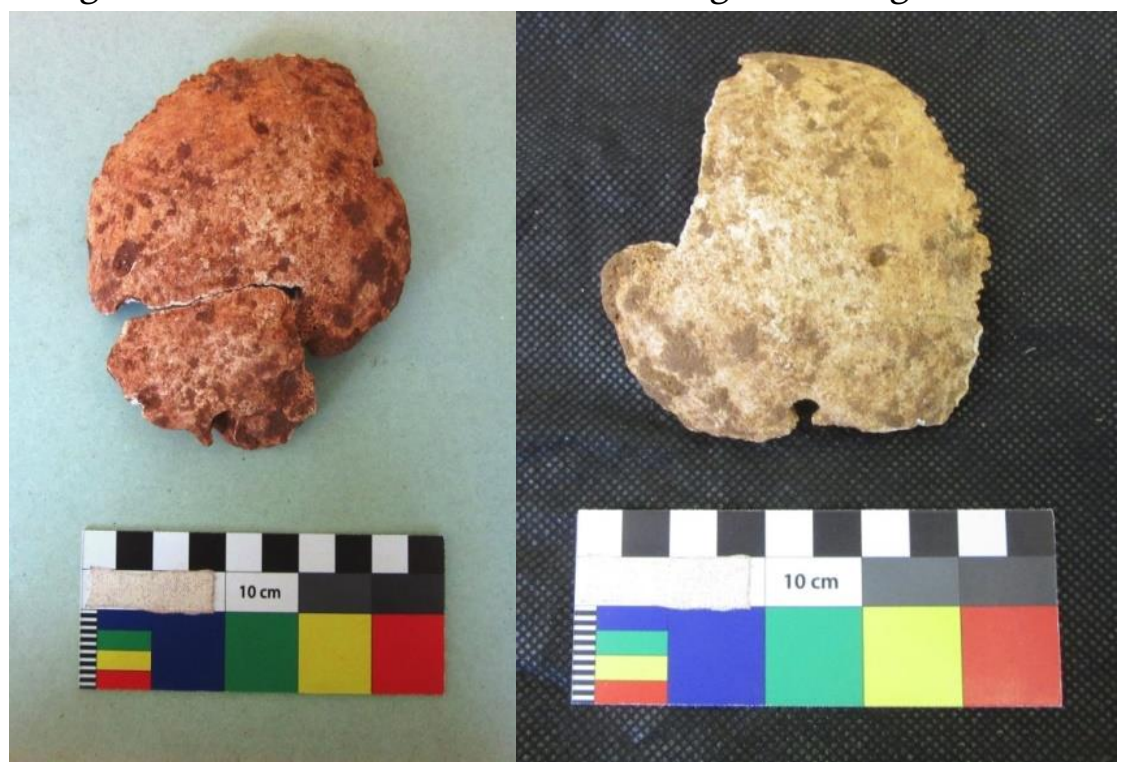




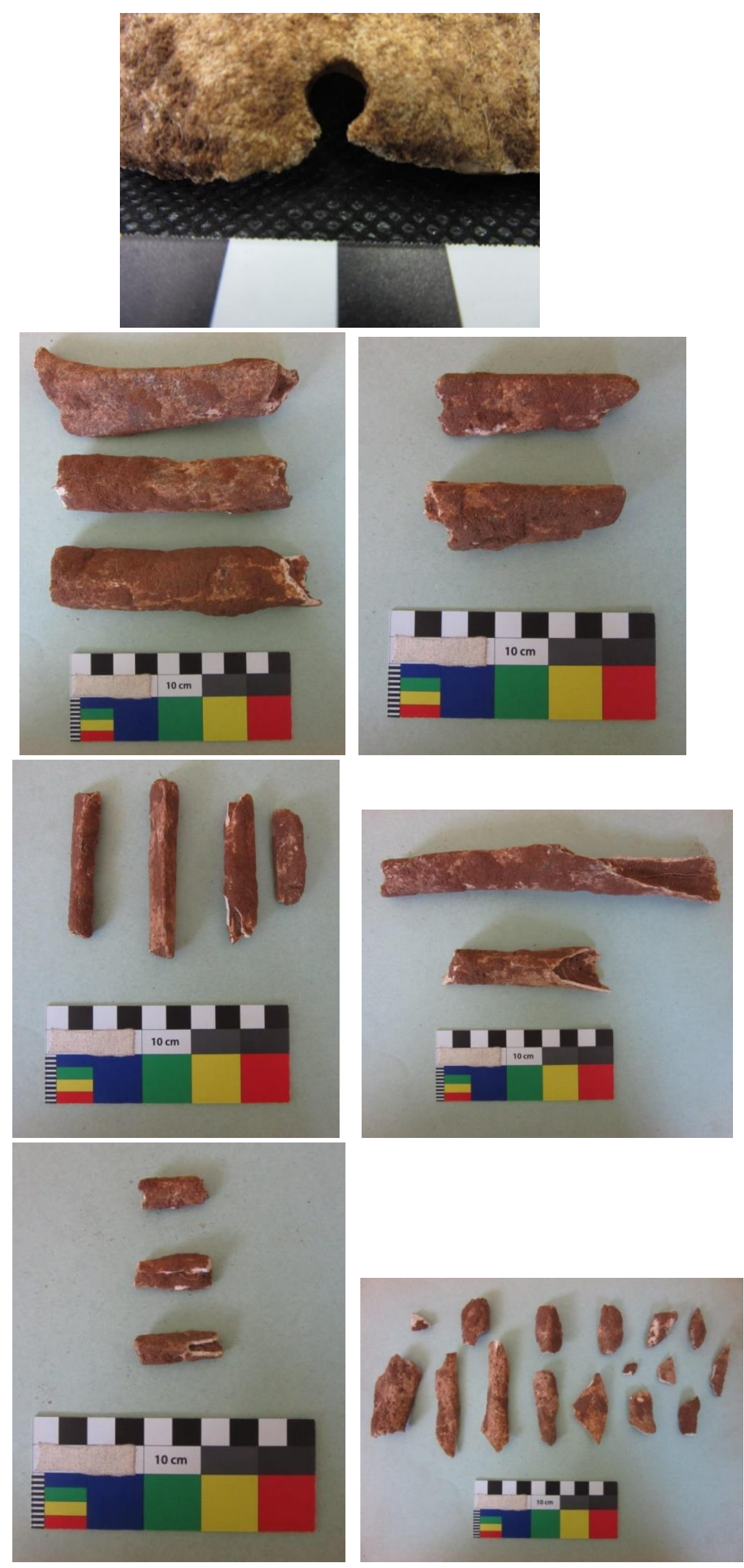




\section{Sítio Fonseca}

\section{Sepultamento II}

Tipo de sepultamento: primário e simples

O esqueleto está bastante fragmentado, entretanto, foi possível observar as características dimórficas para sexo e idade, mesmo não sendo possível visualizar muitos marcadores. No entanto, a incisura isquiática mais larga e pouco profunda, de grau 1 ou 2, indica o sexo feminino, em conjunto com outros caracteres no púbis, ísquio e ílio. Isto associado aos marcadores identificados no crânio, ou seja, o desenvolvimento dos processos mastoides e da crista occipital externa (crista nucal), aponta para um indivíduo de sexo feminino. Uma ficha com as classificações dos marcadores de sexo encontra-se nos apêndices.

Devido ao estado de preservação dos ossos, nem todos os marcadores de idade da morte puderam ser observados. Mas as suturas do crânio que pudemos observar não apresentam sinais de sinostose, o que indica tratar-se de um adulto jovem (20-35 anos). A análise da superfície auricular indica que se trata de um adulto entre 20 e 24 anos. Outros elementos do esqueleto indicam que não se trata de uma criança, mas também não é um adulto médio ou idoso: presença de um $3^{\circ}$ molar erupcionado, anel vertebral presente e fusionado (mas não completamente), presença de linhas de fusionamento ainda aparentes no ílio esquerdo e no esterno.

Foi realizado um inventário ósseo e dentário através de diagramas, que se encontram abaixo. O esqueleto está bastante frágil, os ossos muito friáveis, cobertos com sedimento vermelho que provavelmente estava na urna onde foram encontrados. Porém, várias partes anatômicas estão preservadas, possibilitando uma boa reconstituição e a determinação de sexo e idade aproximada da morte. Os ossos não apresentam sinais de queima, porém vários deles apresentam manchas cinza-escuras cuja composição química é desconhecida. Uma das costelas (provavelmente a $7^{\mathrm{a}}$ ou algo próximo) apresenta um sinal de fratura na parte posterior, estando esta fratura cicatrizada e consolidada antemortem. Outras costelas apresentam marcas que perecem ter sido feitas por roedor. Alguns ossos também apresentam marcas deixadas por formigas. 
Nenhum osso apresenta sinais claros e aparentes de patologia diagnosticáveis através dos fragmentos presentes. Entretanto, há sinal de cribra orbitália em estágio inicial.

Os dentes presentes no momento da análise eram apenas os superiores e os incisivos centrais inferiores, quase todos articulados. Todos apresentam desgaste na superfície oclusal, sendo que nos incisivos centrais (superiores e inferiores), o nível do desgaste é 4 , nos caninos e nos pré-molares o nível é 2, e nos molares 3 (Buikstra e Ubelaker, 1994). Presença de cáries na face oclusal do primeiro prémolar direito e na face labial do $2^{\circ}$ incisivo esquerdo. Presença também de indício de abscesso acima do primeiro pré-molar esquerdo.

Junto com o esqueleto, foram encontrados alguns pequenos fragmentos de conchas, sendo que um deles apresenta sinal de perfuração, o que nos leva a crer que talvez os fragmentos fossem uma única concha com uma perfuração, que poderia ter sido usada como pingente em algum momento. 
Pranchas 43 e 44: Ossos do sepultamento 2 do sítio Fonseca. Fotos: Mariana Cristante.

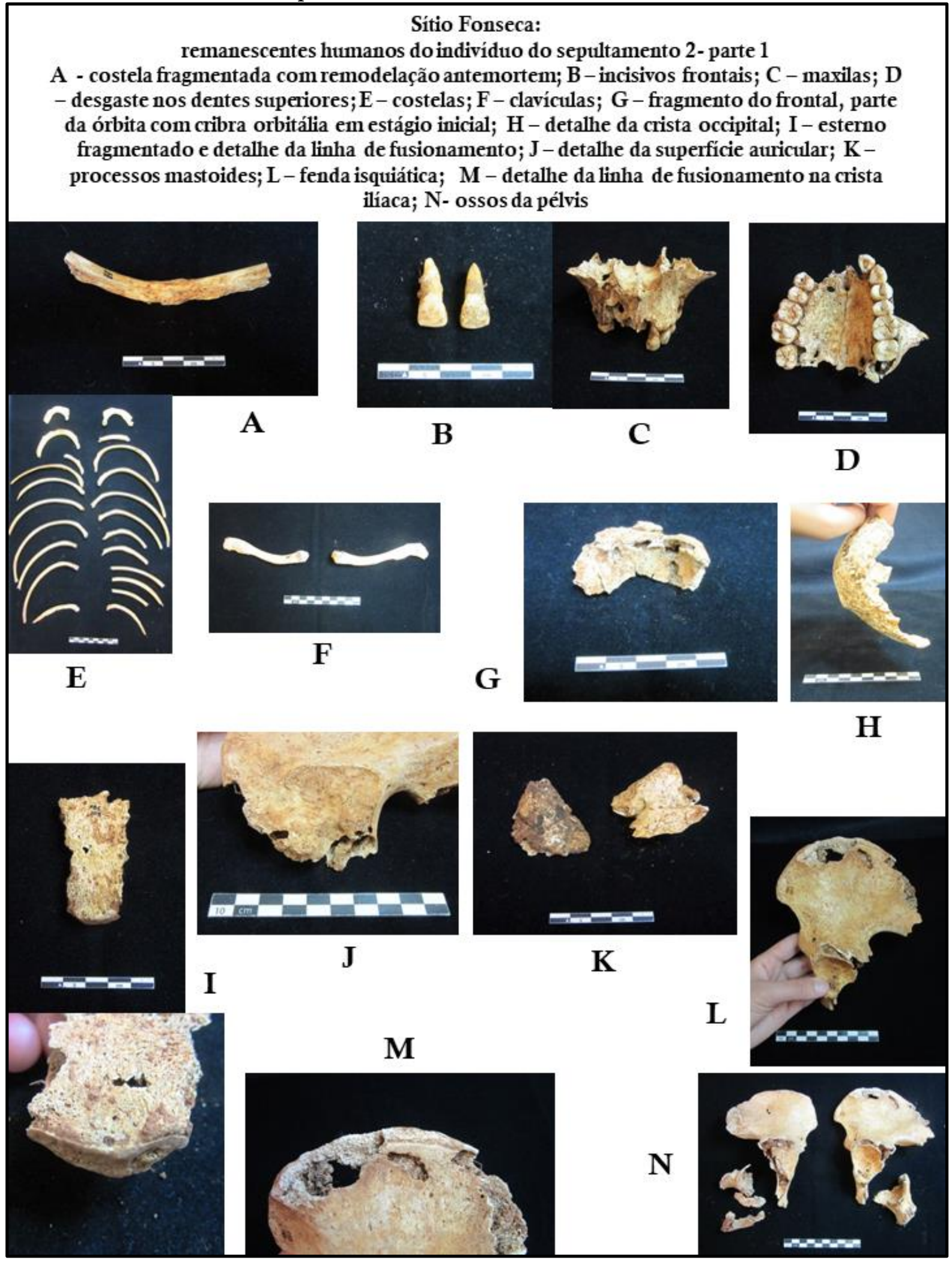




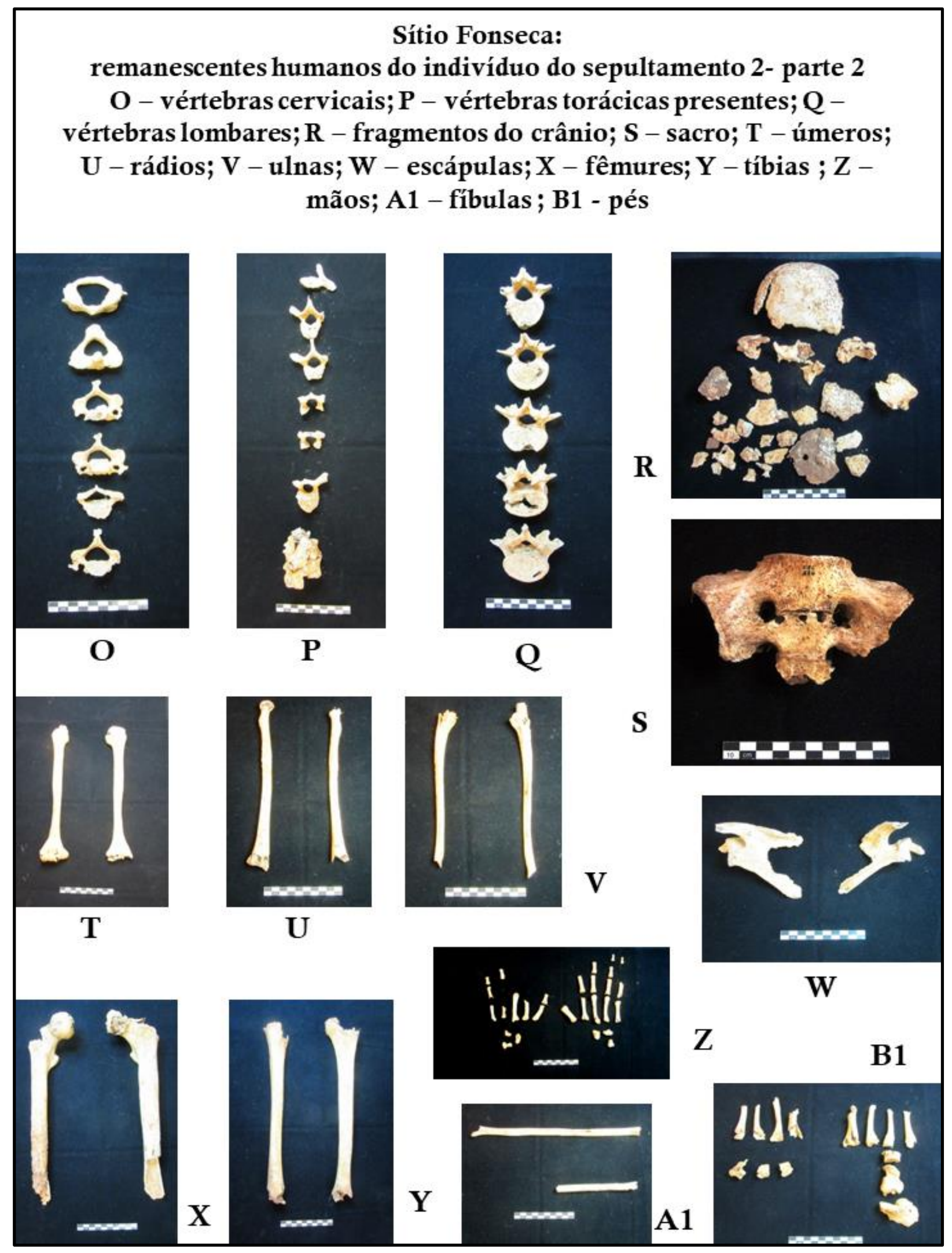




\section{Sítio Silveira}

\section{Sepultamento 2}

O sítio Silveira se localiza no município de Itapeva, São Paulo. Não encontramos mais informações sobre o sítio ou o sepultamento.

Na caixa, o sepultamento está identificado como 2, mas não encontramos o 1. O esqueleto apresenta diversos ossos, bastante completo quando comparado à maioria dos outros analisados, permitindo inferência de sexo e idade aproximada da morte. Há a presença de diversos fragmentos de costela, mas não foi possível identificar a lateralidade. As vértebras estavam muito decompostas, dificultando a identificação. Não havia rótulas reconhecíveis, nem escápulas, nem mandíbula, e apenas 1 fragmento de clavícula. Os ossos dos pulsos estavam quase todos ausentes, assim como metacarpos e falanges distais das mãos. Falanges distais e médias dos pés quase todas ausentes. Ossos tarsianos ausentes, exceto os talus e calcâneos. Há fragmentos de fíbula que não permitem saber a lateralidade. Não foram encontrados os demais ossos do crânio. Os dentes superiores estão quase todos presentes.

Havia a presença de poucos marcadores de sexo, tornando sua identificação difícil. Os marcadores presentes me indicaram provável masculino. A Prof. Verônica Wesolowski (comunicação pessoal) sugere também que seja um indivíduo masculino. Já o diagnóstico da idade também foi difícil devido ao grau de fragmentação do esqueleto, que não possuía suturas do crânio ou superfície auricular. $\mathrm{O}$ indivíduo era claramente adulto, com mais de 18 anos devido ao $3^{\circ}$ molar eclodido. Não havia sinais de linhas de fusionamento em nenhum osso presente. A observação visual dos ossos sugere ser um adulto médio, entre 35 e 50 anos (Verônica Wesolowski, comunicação pessoal). 
Pranchas 45 e 46: Ossos do sepultamento 2 do sítio Silveira. Fotos: Mariana Cristante.

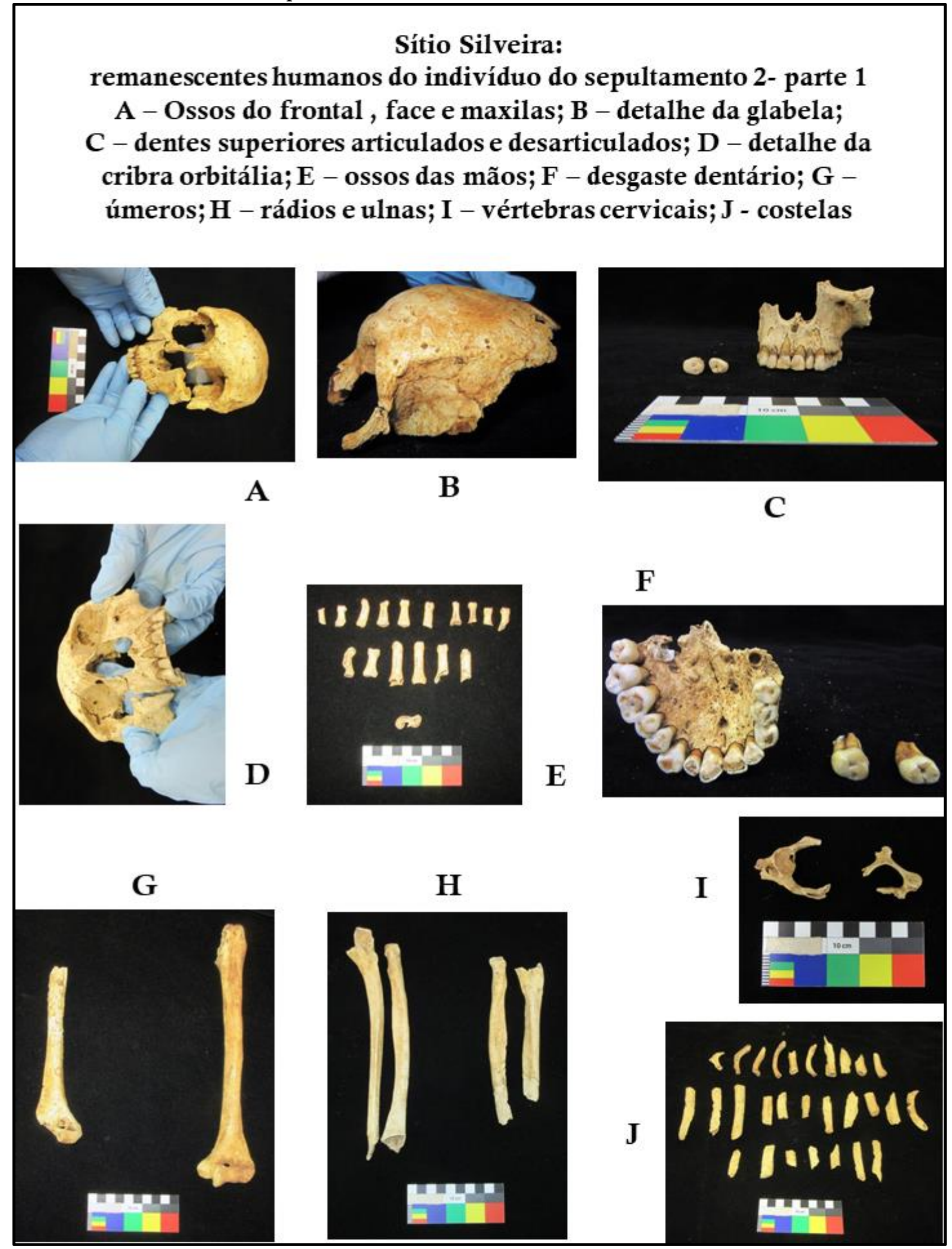




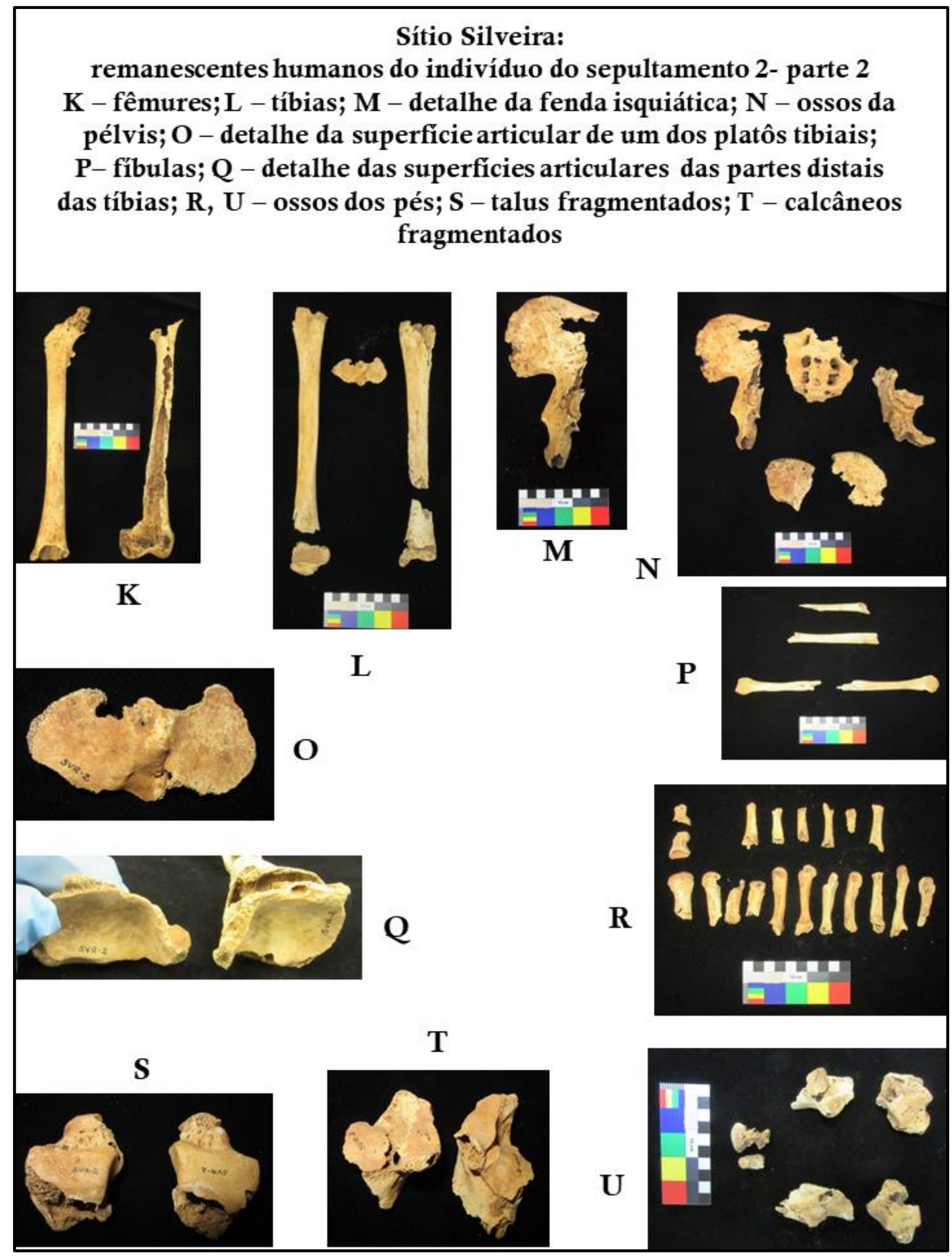




\section{Sítio Salto Grande do Paranapanema}

\section{Sepultamento 1}

Há a presença dos ossos de um indivíduo, todos cobertos por sedimento marrom-avermelhado, alguns apresentando marcas de ataque de fungos, formigas e cupins. As costelas estão muito fragmentadas, o crânio e a mandíbula estão ausentes. Há a presença de diversos ossos fragmentados demais para serem identificados. Nas mãos, há a presença de 4 metacarpos fragmentados, ossos dos pulsos, 6 falanges proximais, 5 médias e 2 distais. Dos pés há 6 metatarsos fragmentados e 1 falange proximal fragmentada, além de ossos tarsais dos 2 pés.

Como o crânio e mandíbula estavam ausentes, não foi possível ver os marcadores de sexo dessas regiões. Na região pélvica, só foi possível ver 1. A análise visual dos ossos levou a crer que se tratava de um indivíduo provavelmente masculino (Verônica Wesolowski, comunicação pessoal). Os marcadores de idade também estavam quase todos ausentes devido à falta do crânio, mas a análise da superfície auricular e dos ossos presentes leva a crer que se trate de um indivíduo velho, entre 50 e 55 anos ou mais velho (Verônica Wesolowski, comunicação pessoal).

Em Morais \& Piedade (1994), há a informação de que o crânio havia sido quase totalmente reconstituído, mas não o encontramos na caixa do esqueleto. Os autores também afirmam que havia perda de dentes antemortem, com reabsorção dos processos alveolares em todos. O indivíduo apresenta patologia nas vértebras e em algumas articulações e o talus indica que costumava ficar na posição de cócoras. Os autores diagnosticam a idade do indivíduo entre 50 e 55 anos. 
Pranchas 47 e 48: Ossos do sepultamento 1 do Salto Grande. Fotos: Mariana Cristante.

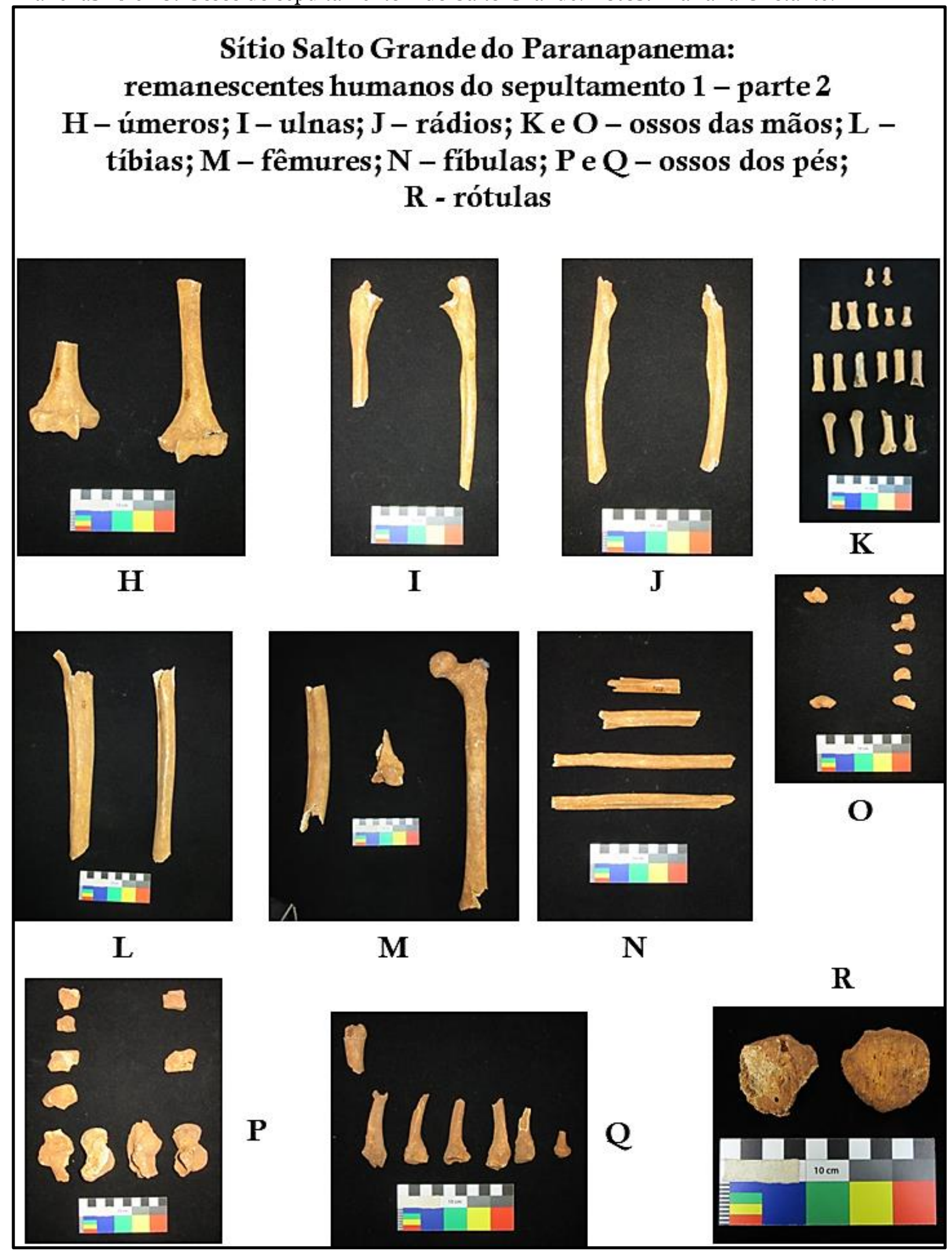




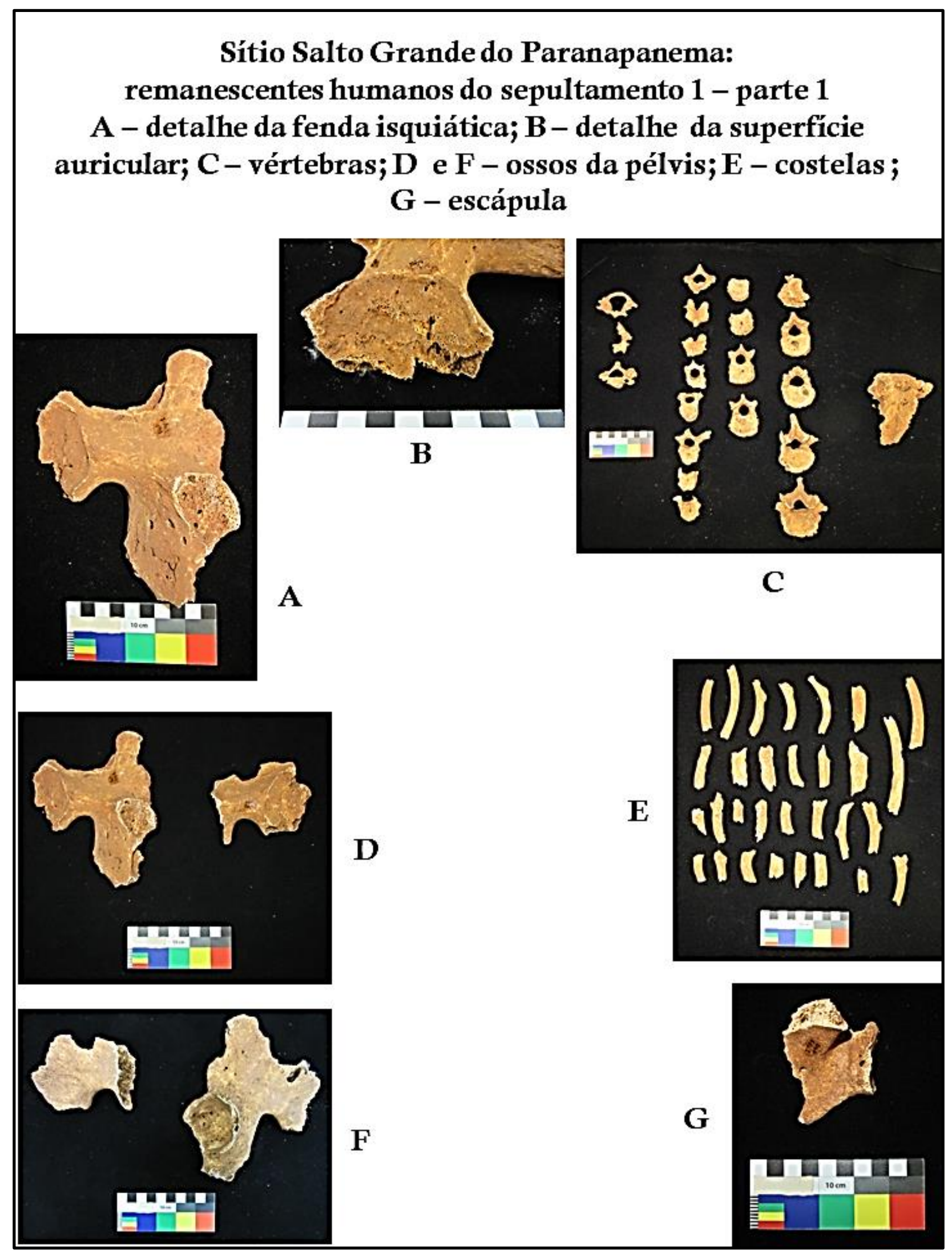




\section{Sepultamento 2}

$\mathrm{O}$ indivíduo 2 do sítio Salto Grande estava bem mais incompleto, com a presença de poucos ossos. Não foi possível fazer a identificação visual de sexo e idade. Há a presença de 11 dentes permanentes. Dois dentes não parecem pertencer a esse indivíduo, pois estão muito mais desgastados que os outros, sendo que quase toda a coroa foi perdida. Provavelmente são dentes de algum outro indivíduo do sítio, misturados e esse por causa da descontextualização feitas pelos moradores locais.

Prancha 49: Ossos do indivíduo 2 do sítio Salto Grande. Fotos: Mariana Cristante.

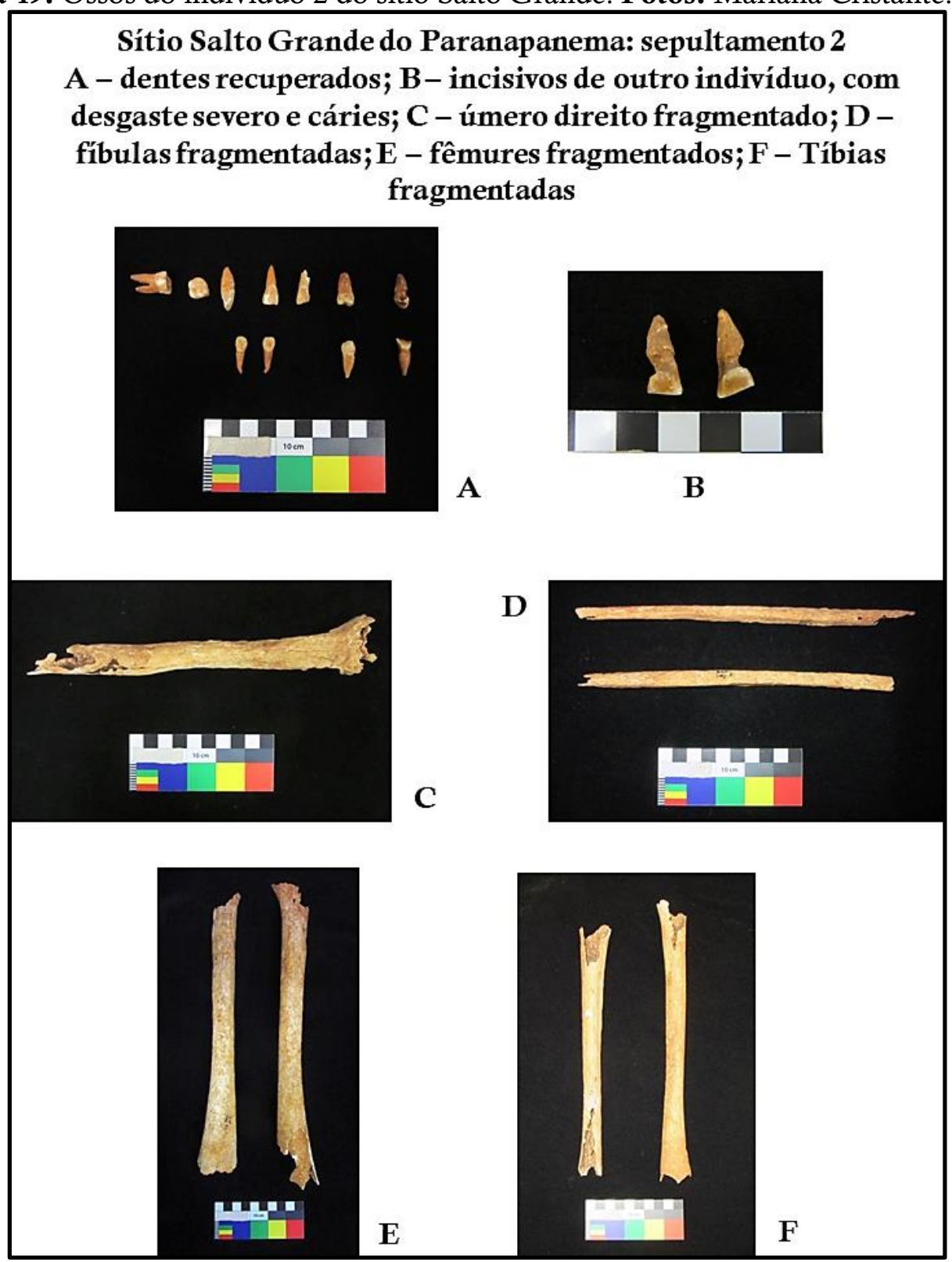




\section{Sítio Panema}

\section{Sepultamento I}

O sepultamento encontrado no sítio Panema é o mais particular de todos os que analisamos. Os ossos apresentam uma série de alterações que não foram encontradas em nenhum outro, embora muitos estivessem mal conservados demais para uma observação mais acurada. As alterações analisadas levam a crer que uma série de gestos funerários e não funerários podem ter ocorrido envolvendo esses ossos.

O esqueleto apresenta dentes muito fragmentados, com alguns reconhecíveis, e presença de diversos ossos de mãos e pés fragmentados e inteiros.

O indivíduo sepultado em urna foi datado em $290 \pm 40$ BP, ou seja, período histórico. Já a vasilha cerâmica em que estava foi datada em 2030 AP. A análise de DNA mostrou ser um indivíduo de sexo masculino. Em Piedade \& Soares (2000) temos uma análise desse indivíduo, que iremos transcrever agora. Em seguida, colocaremos nosso próprio inventário dos ossos.

A análise das fraturas dos ossos levou os autores a descartar que foram causadas por ritual antropofágico ou por ataque de animais carnívoros. Diversos ossos fragmentados não apresentavam complemento, e essas perdas poderiam ser atribuídas ao manuseio na época do sepultamento em urna ou após a escavação da mesma. A análise das queimas nos ossos sugeriu queimas com temperaturas entre $185^{\circ} \mathrm{C}$ e $525^{\circ} \mathrm{C}$, tendo sido detectadas marcas de queima em menor temperatura e marcas de maior temperatura nos ossos. A queima parece ter ocorrido nos ossos já desidratados, diretamente nas chamas, em fogueira simples.

Além da queima, os autores também detectaram outros 3 tipos de alterações: sulcos, faixas raspadas e depressões. Os sulcos se assemelham a cortes, e são predominantes, ocorrendo em fragmentos do crânio, mandíbula, escápula esquerda, clavícula esquerda, úmero direito e esquerdo, ulna esquerda, rádio direito e fêmur direito. Nos ossos longos, estão localizados principalmente nas diáfises. Os sulcos às vezes estão próximos à parte fragmentada do osso, mas às vezes não parecem ter causado a fragmentação. Os formatos dos sulcos variam, bem como suas direções em relação ao eixo principal do osso. 
As faixas raspadas parecem ser facetas resultantes da possível retirada de fatias longitudinais do osso, estão principalmente localizadas nas diáfises dos ossos longos, acompanhando o eixo principal do osso. Estão presentes nos úmeros direito e esquerdo, no rádio esquerdo, ulna esquerda, fêmur direito, tíbia direita, em fragmento de mandíbula e de costela. Os autores propõem que as faixas raspadas tenham sido causadas por lasca lítica com o intuito de raspar pequenas porções do tecido ósseo compacto, sem a intenção de atingir o tecido ósseo esponjoso.

Há também, em um menor número de ossos, a presença de depressões, que parecem ter sido causadas por vários sulcos juntos, em uma repetição de movimentos. Estão localizadas na clavícula esquerda, ulna esquerda e em um fragmento de costela.

Os autores acreditam que pelo menos a maioria dos sulcos, faixas raspadas e depressões foram feitos com os ossos já desidratados, e posteriormente à queima. Porém, algumas das marcas se parecem com as de descarnamento, que sugerem que foi realizado, em um momento anterior, o descarnamento do indivíduo. Portanto, as alterações teriam ocorrido em pelo menos dois momentos: antes da queima, com os ossos ainda frescos, e posteriormente, com os ossos já desidratados. Em alguns ossos os sulcos não ultrapassam as quebras, o que sugere que foram feitos após o osso já ter se quebrado. Os fragmentos teriam sido recolhidos e depositados na vasilha, o que seriam uma ação antrópica.

Como hipóteses etnohistóricas para esse sepultamento, os autores propõem que a sequência dos acontecimentos pelos quais os ossos passaram são: $1^{\circ}$ - o indivíduo foi descarnado para o sepultamento; $2^{\circ}$ - foi recolhido para a queima; $3^{\circ}$ alterações tafonômicas e antrópicas ocorreram, como ação de carnívoros e a realização de raspagens por pessoas; $4^{\circ}$ - sepultamento em urna. Teria havido uma queima intencional com posterior retirada de pó ou fragmentos pequenos de ossos, com os ossos já secos.

A descrição desses gestos aparentemente não existe claramente nas fontes como prática funerária. Isso leva os autores a levantarem a hipótese de que a queima nesses ossos tenha sido realizada por padres ou outros europeus, com o objetivo de dar um fim a práticas não cristãs entre os Guarani. Essa práticas estariam ligadas à cosmologia Guarani, chamadas pelos cronistas grosseiramente 
de "feitiços" ou "bruxaria". Algumas dessas práticas envolviam ações de "castigo" no indivíduo sepultado, com o objetivo de romper com algum feitiço. Elas levariam às marcas feitas nos ossos já secos. Essas práticas são chamadas na literatura de "culto aos ossos".

Assim, a sequência hipotética das ações em relação aos ossos proposta pelos autores é: enterramento primário em urna ou cova; exumação; descarnamento; enterramento secundário em urna ou cova; nova exumação; queima; alterações que levaram aos sulcos e depressões; alterações antrópicas sugeridas pelas raspagens; recolhimento e depósito dos ossos e fragmentos na urna; novo enterramento da urna.

Portanto, em nosso linguajar arqueológico, ações funerárias e não funerárias estariam ocorrendo nesse sepultamento, com objetivos não apenas de funeral, mas também outros ligados à cosmologia Guarani. Isso demonstra a existência de práticas não funerárias que podem ocorrer nos sepultamentos Guarani, como tratamos no capítulo IV. 
Pranchas 50 e 51: Ossos do sepultamento do sítio Panema. Fotos: Mariana Cristante.

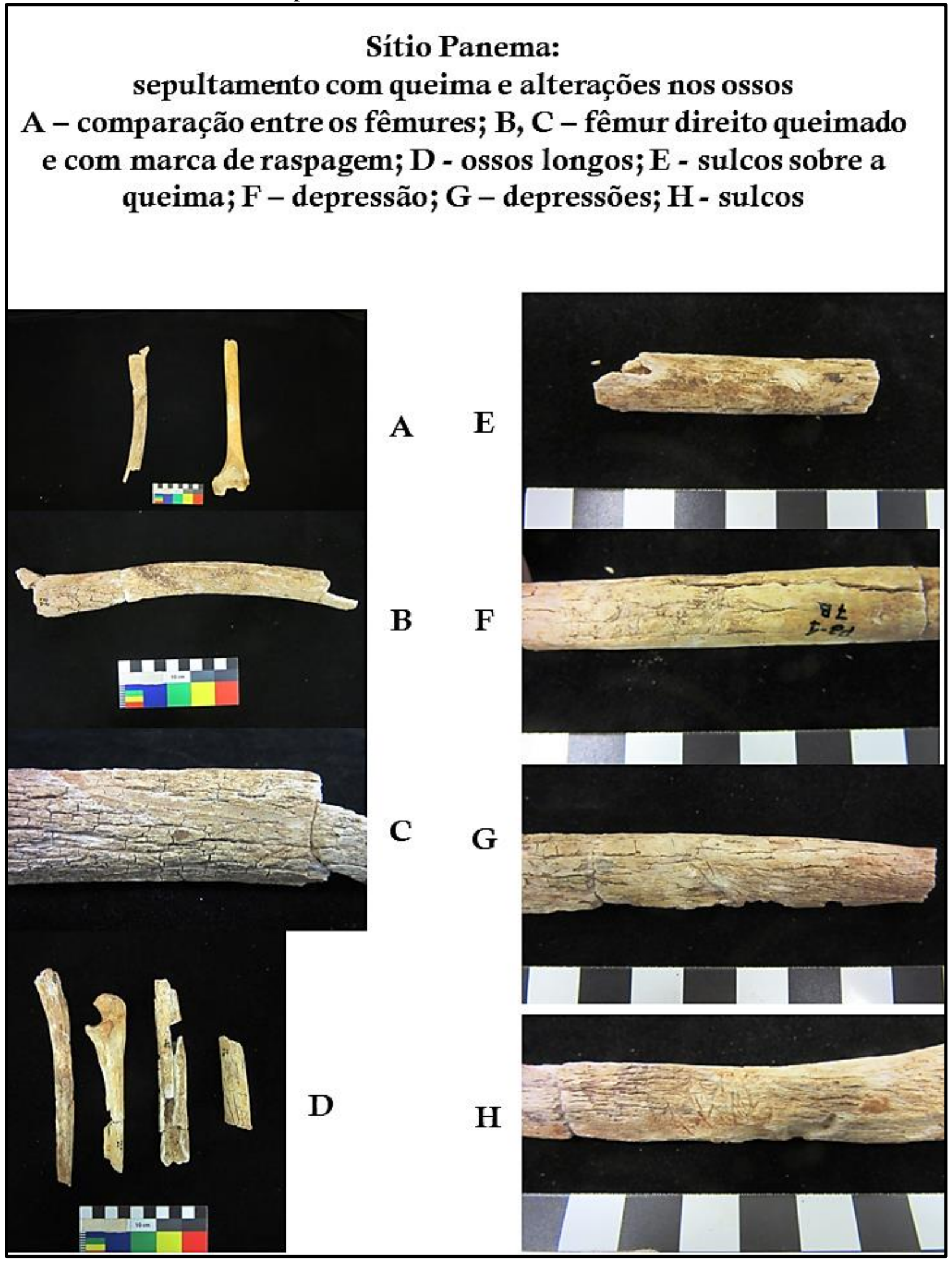




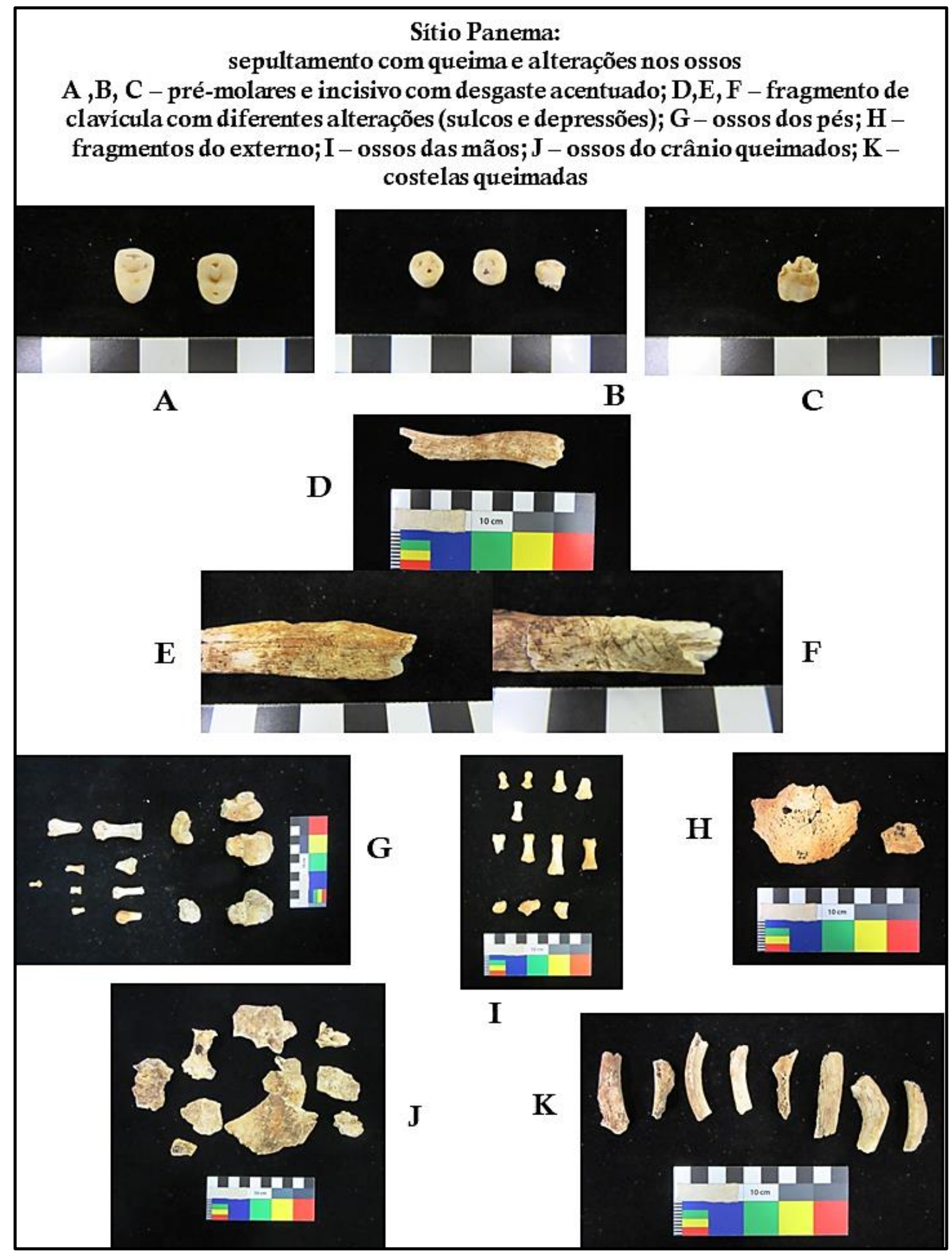




\subsection{Os outros sítios com contextos funerários Guarani e Tupinambá}

Nesta parte descreveremos mais contextos funerários de outros sítios escavados nas regiões analisadas nesta dissertação, mas em relação aos quais não conseguimos, por diversas razões, ter acesso ao material para fazer nossa análise. Mesmo assim, consideramos muito importante colocar essas descrições de contextos, pois nos oferecem uma quantidade maior de material para tirarmos nossas conclusões. Além do mais, se tratam de sítios e contextos que, na maioria dos casos, não existem mais, então seu registro e uma sistematização de dados a respeito deles é, a nosso ver, importante.

A classificação em Guarani ou Tupinambá só foi feita para alguns. Os sítios de Araruama - Morro Grande, Serrano, Bananeiras e São José - são fortemente associados aos Tupinambá (Buarque, 2016). E os sítios Rio Ivinhema 1, Itororó, Alto Paraná 8 são considerados Guarani ( Kashimoto, 1992, 2007; Kashimoto \& Martins, 2005, 2009).

Olhando fotos do material cerâmico funerário, podemos fazer uma classificação de acordo com a morfologia cerâmica, embora ela não seja embasada em maiores detalhes. A ocorrência do município de Salto continha vasilhas que podem ser classificadas como Tupinambá. Já as vasilhas das coleções particulares trazidas por Moraes (2007) parecem ser também Tupinambá, embora a autora afirme que as cerâmicas do noroeste de São Paulo são um Tupi diferenciado daquele do Rio de Janeiro. Se formos observar apenas as vasilhas funerárias que selecionamos, diríamos que são Tupinambá, mas isso não significa que os conjuntos cerâmicos inteiros sejam iguais aos do Rio de Janeiro. Entretanto, a morfologia das urnas funerárias é muito parecida entre as do noroeste de São Paulo, Rio de Janeiro e alto Paranapanema.

As vasilhas encontradas por Chmyz no sítio MT-IV-1 são classificadas como Tupiguarani, mas sua morfologia se parece com a de vasilhas que podemos chamar de Guarani, assim com a das vasilhas encontradas no sítio PR-FI-148 (Caranguejeiras).

Para os demais sítios, não conseguimos encontrar nem fotos do material arqueológico. 


\subsubsection{Sítios Tupinambá}

\subsubsection{A Sitios de Araruama (Rio de Janeiro)}

Buarque (2016) traz as descrições dos contextos funerários dos sítios Morro Grande, Serrano, São José e Bananeiras, os 3 primeiros localizados na parte interior do município de Araruama (RJ), e o último localizado a $500 \mathrm{~m}$ da orla marítima atual.
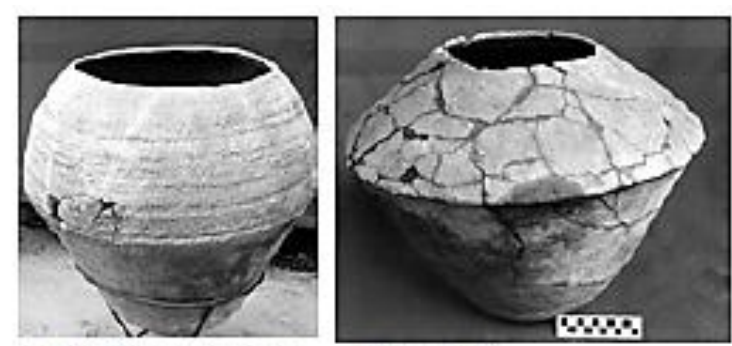

Aldeia de Morro Grande

$1740 \pm 90 B P$
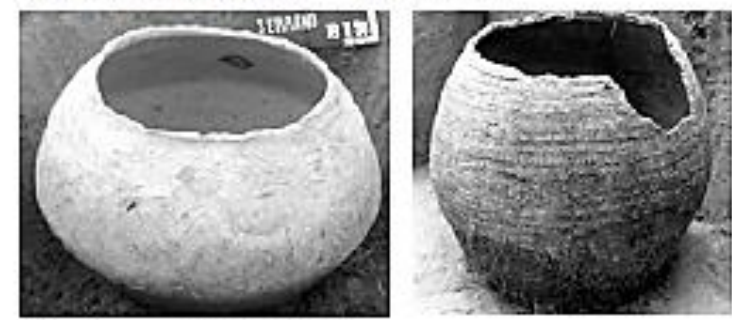

Sítio Serrano $[?-1580$ AD)

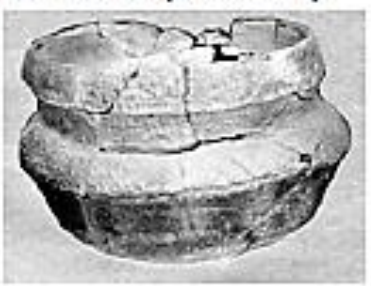

Sítio Bananeiras $430 \pm 40$ BP

Figura 64: Diferentes morfologias de urnas funerárias encontradas na região de Araruama (RJ). A segunda urna, de cima para baixo e da esquerda para a direita, é a do sepultamento V do sítio Morro Grande; a primeira é do tipo mais recorrente nesses e em outros contextos funerários do Rio de Janeiro e certas regiões de São Paulo. Fonte: Buarque, 2016.

\section{Sítio Morro Grande}

A aldeia Morro Grande está localizada em área urbana, e muitos locais foram alterados por ações antrópicas. São apresentadas 6 datas para o sítio:

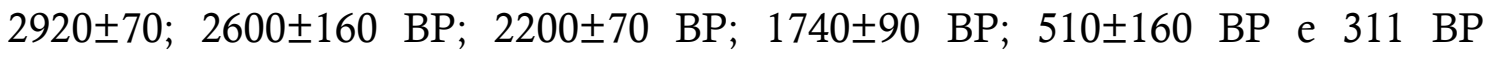
(Buarque, 2016; Mageste, 2017). A primeira data foi obtida de uma fogueira associada à estrutura funerária 2 , a segunda do perfil contíguo a essa estrutura, e a terceira da própria estrutura. A quarta e quinta datações são consideradas um 
possível erro pela autora, pois não há indícios de contato, nem alterações nas estruturas funerárias ou na cerâmica que poderiam atestar mudança. $\mathrm{O}$ pacote arqueológico tinha entre $40 \mathrm{~cm}$ e $50 \mathrm{~cm}$ de profundidade, e até $1,2 \mathrm{~m}$ na área dos sepultamentos. As sondagens revelaram uma aldeia circular, de aproximadamente 90 mil $\mathrm{m}^{2}$.

No sítio foram encontradas 5 estruturas arqueológicas relacionadas a áreas de sepultamento, mas em apenas uma foram encontrados remanescentes humanos. As estruturas funerárias estavam localizadas no entorno da área central. $\mathrm{Na}$ periferia, ao redor dessa praça central, estavam dispersos diversos tipos de fragmentos cerâmicos. Entre as estruturas funerárias, há variação na quantidade de tigelas que acompanhavam o sepultamento e na presença ou não de fogueira e buracos de estaca. Em alguns casos, marcas de impregnação de alimentos e resíduos de queima na superfície externa, em urnas e tampas, são fortes indicadores do uso doméstico das peças, como preparação do cauim e armazenamento de alimentos para o morto. Essas práticas foram observadas tanto em sítios antigos quanto naqueles de contato, deixando evidente que alimento e morte estavam fortemente relacionados (Buarque, 2016). No entanto, se eram alimentos para o morto, pelo menos a partir de certo momento o uso relacionado aos alimentos não era mais doméstico, e sim fazia parte das práticas funerárias.

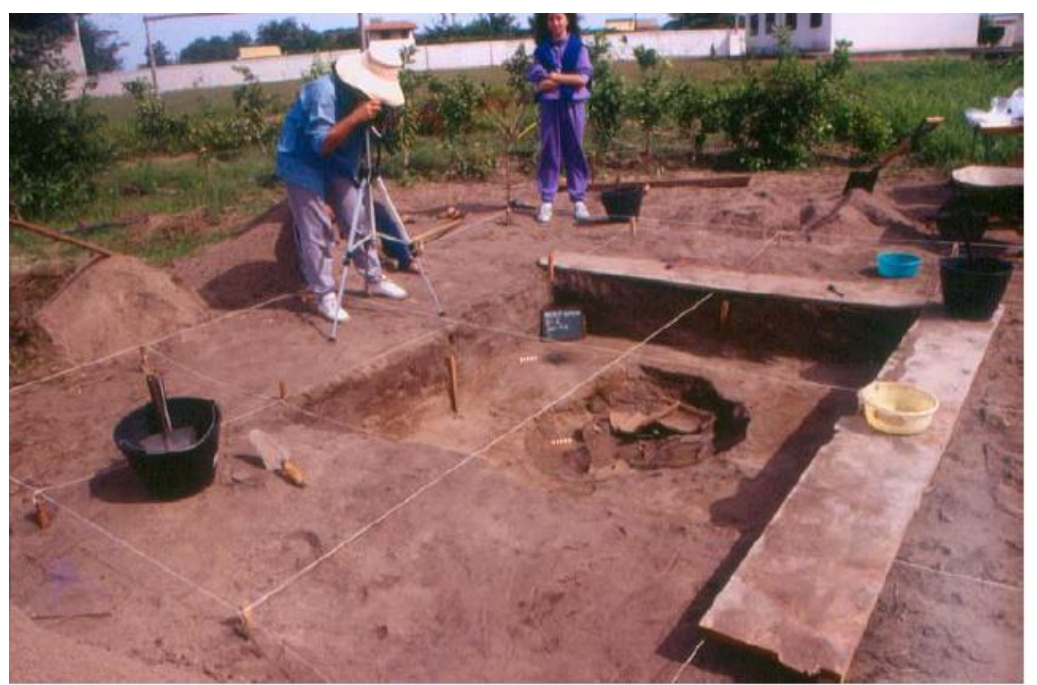

Figura 65: Contexto funerário do sítio Morro Grande, e que há vasilhas associadas a uma fogueira. Fonte: Buarque, 2009. 
A estrutura funerária 1 do sítio Morro Grande continha duas tigelas redondas com tratamento de superfície ungulado sobre o lábio, e outra oval parcialmente fragmentada com pintura geométrica e uma faixa vermelha junto à borda interna. Essas vasilhas estavam do lado de fora da urna. No interior, uma vasilha emborcada de $24 \mathrm{~cm}$ de diâmetro estava cobrindo o crânio, próximo à base da urna. A urna, por sua vez, tinha formado piriforme e tratamento de superfície corrugado.
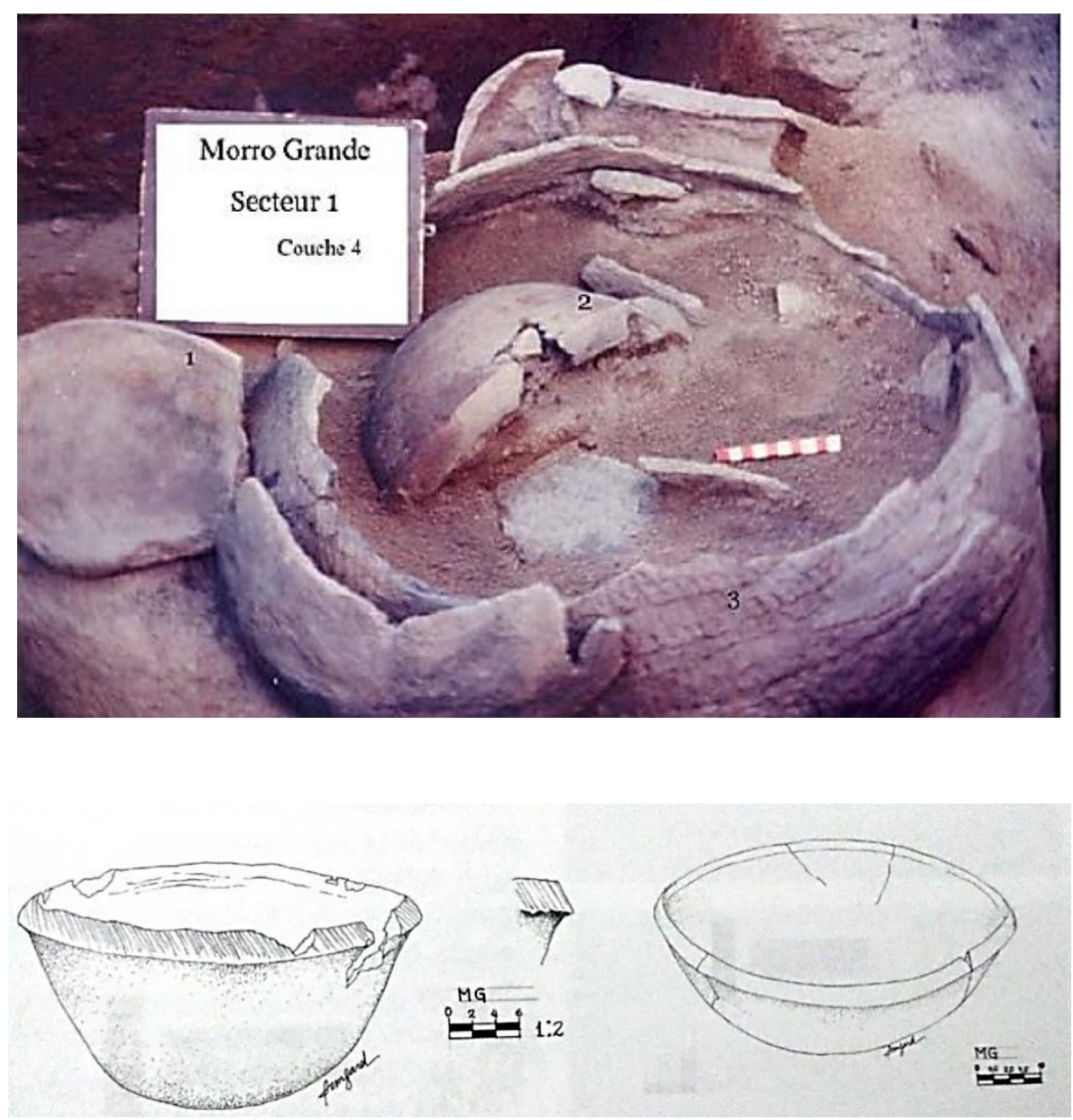

Figuras 66 e 67: Foto do contexto funerário I da aldeia Morro Grande, e desenhos das vasilhas de acompanhamento funerário. Fonte: Buarque, 2009 e 2016.

A estrutura funerária 2 possuía 3 vasilhas pintadas como acompanhamento, uma redonda e duas ovais, posicionadas junto à lateral da urna com a boca virada para a parede da mesma. A urna é piriforme, corrugada até a parte mediana, a partir da qual é lisa. A tampa é uma meia calota com base plana e tratamento de superfície externa com incisões e engobo vermelho em algumas partes. Ao lado da urna foi encontrada uma fogueira de $60 \mathrm{~cm}$ de diâmetro e $30 \mathrm{~cm}$ de espessura, cuja amostra de carvão forneceu a datação mais antiga do sítio. Além dela, 3 buracos de 
estaca com diâmetros de $10 \mathrm{~cm}$, que podem ter servido para a sustentação de jiraus relacionados ao contexto funerário.
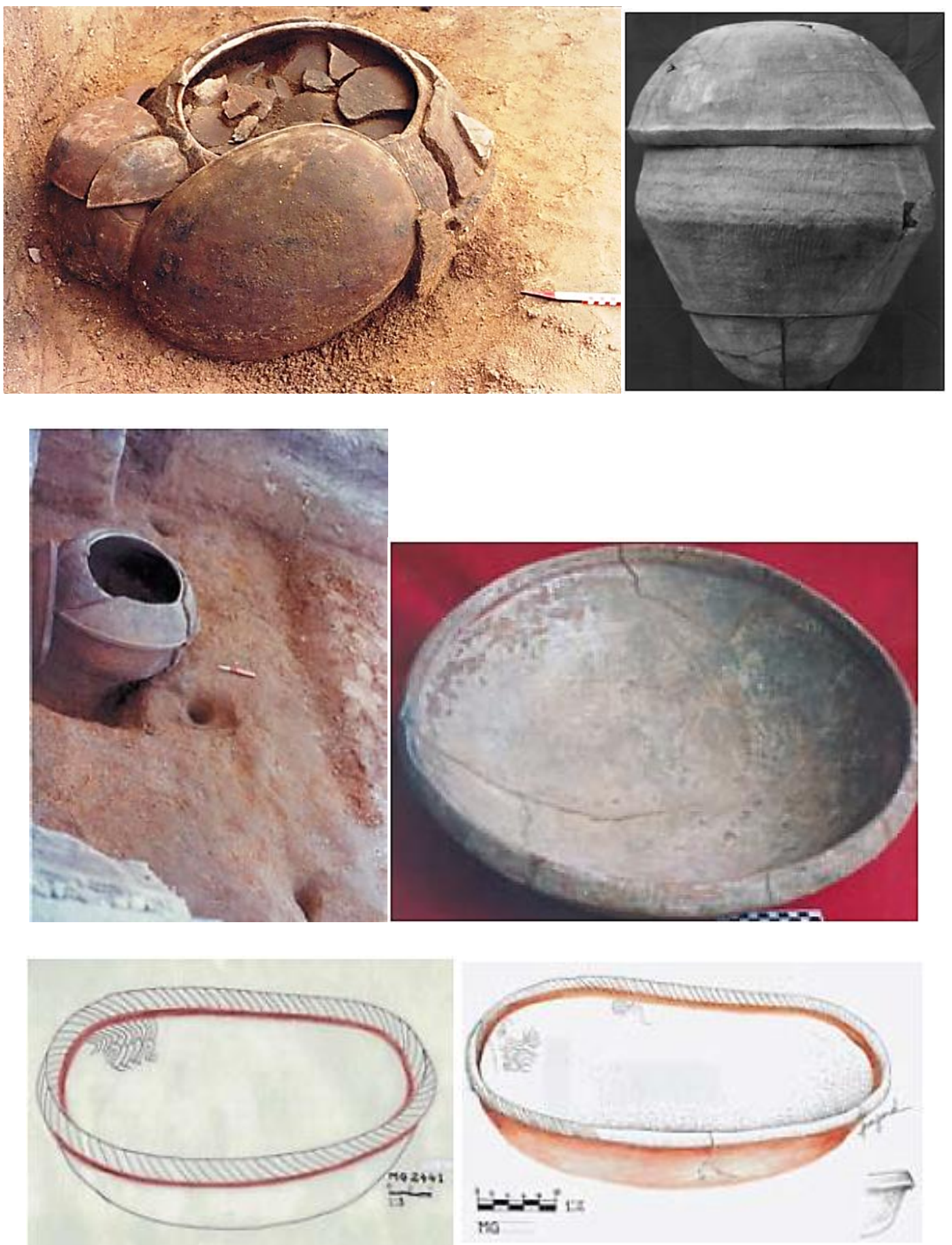

Figuras 68-73: Contexto funerário II da aldeia Morro Grande. Contexto escavado, urna e tampa, buracos de estaca próximos ao contexto, e vasilhas de acompanhamento funerário Fonte: Buarque, 2009, 2016. 

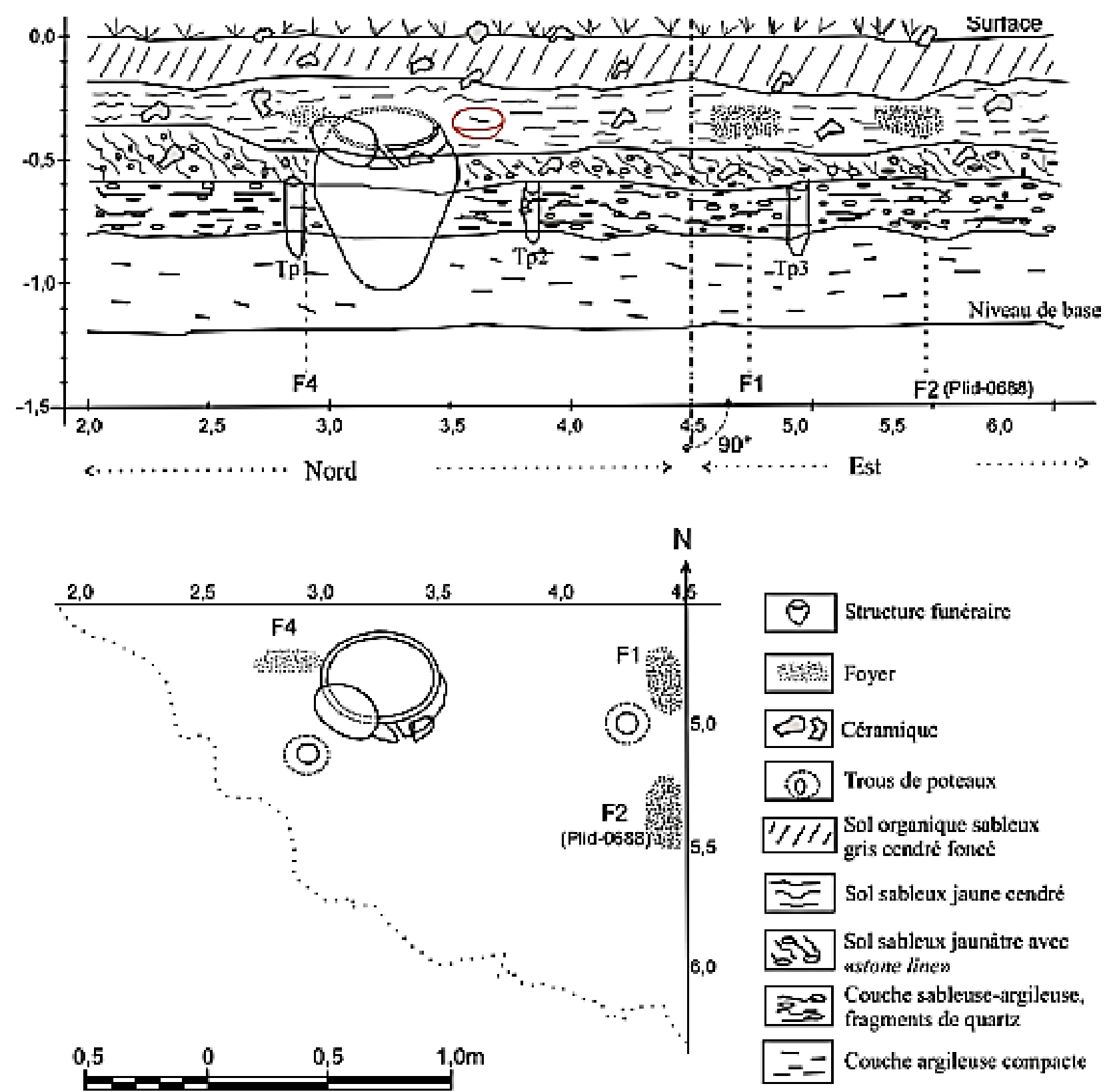

F́thelle: $1: 25$

Figura 74: Croqui do sepultamento II do sítio Morro Grande com a localização, no plano horizontal e estratigráfico, do contexto funerário, dos buracos de estacas e das fogueiras cerimoniais. Fonte: Buarque, 2009, 2016.

A estrutura funerária 3 possuía quatro vasilhas pintadas, duas quadrangulares, uma oval e uma redonda, que estavam posicionadas em volta de uma urna funerária, com as bocas voltadas para as paredes da mesma, ao seu redor. Segundo a autora, a escavação desse contexto foi problemática, entre outras coisas, por ele estar próximo à Igreja Católica da área, e o pároco queria impedir a pesquisa, alegando que o espaço estava sendo maculado (Buarque, 2016). Esse é um exemplo de um dos problemas pelos quais a escavação arqueológica de contextos funerários passa, demonstrando o quanto o trabalho arqueológico encontra-se no meio de um "fogo cruzado" que dificulta as pesquisas. 

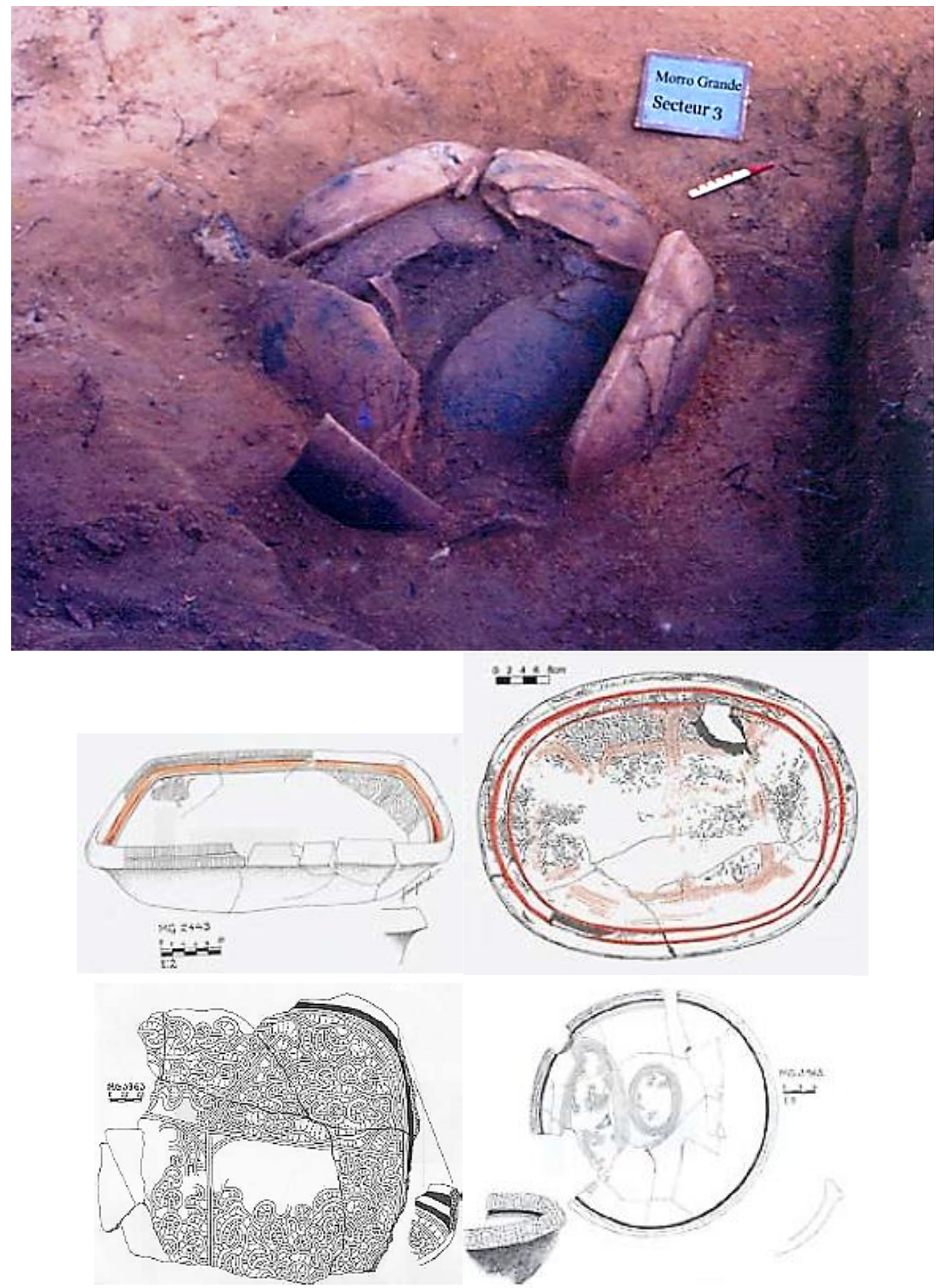

Figuras 75-79: Contexto funerário III da aldeia Morro Grande, e desenhos das vasilhas escavadas. Fonte: Buarque, 2016.

A estrutura 4 era uma urna de $67 \mathrm{~cm}$ de altura por $52 \mathrm{~cm}$ de diâmetro, tratamento de superfície corrugado da borda até a parte mediana, e escovado daí até a base, e alisado nesta, na parte externa. A tampa apresenta face externa corrugada e 
interna lisa. Junto ao conjunto havia uma tigela pintada retangular, e associado havia uma tigela de pequenas dimensões, e buracos de estaca localizados em volta da urna.

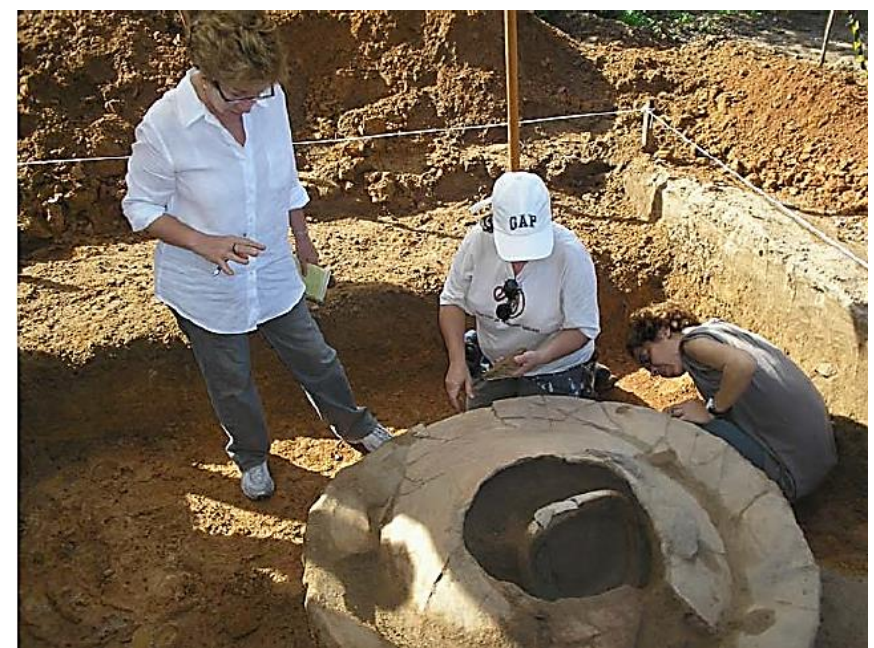

Figura 80: Contexto funerário do sítio Morro Grande. Nota-se a urna de grandes dimensões com uma vasilha quadrangular dentro. Fonte: Buarque, 2009.

A estrutura 5 do sítio Morro Grande era composta por uma urna de pequenas dimensões carenada, de base côncava, borda direta e lábio redondo, $c 0 m 39 \mathrm{~cm}$ de altura por $28 \mathrm{~cm}$ de diâmetro, tratamentos de superfície lisos. A tampa era redonda de base plana, $50 \mathrm{~cm}$ de diâmetro e tratamento de superfícies alisado. Ao lado do conjunto foi encontrada uma fogueira com $20 \mathrm{~cm}$ de diâmetro e $10 \mathrm{~cm}$ de espessura.

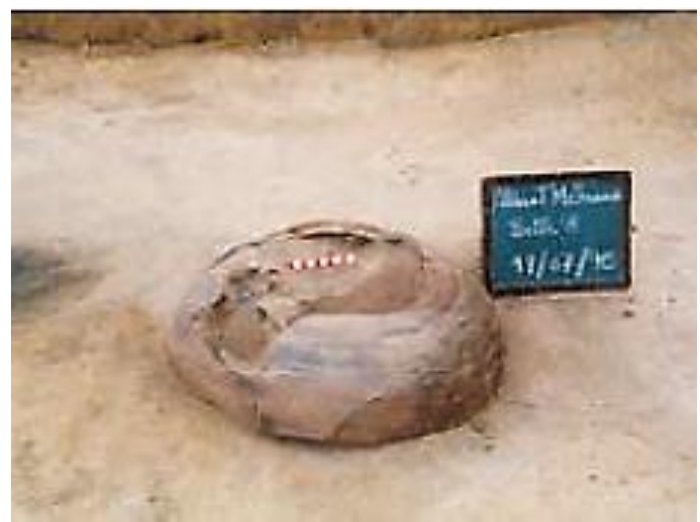

Figura 81: Contexto funerário V da aldeia Morro Grande. Fonte: Buarque, 2016. Sítio Bananeiras

A aldeia Bananeiras também estava localizada em área urbana. A datação apresentada para o sítio é de $430 \pm 40 \mathrm{BP}$, proveniente dos remanescentes humanos do sepultamento. A estrutura funerária estava associada a três vasilhas, duas pintadas. A urna possuía um formato diferente das anteriormente encontradas. $\mathrm{O}$ 
sepultamento era primário, de um indivíduo do sexo feminino, entre 20 e 25 anos, medindo cerca de $1,46 \mathrm{~m}$ de altura. A autora considera o formato de urna como sugestivo de contato com o europeu. Uma vasilha pequena, apresentando tratamento de superfície ungulado e liso, estava no interior da urna, sobre o crânio. Marcas de impregnação por líquido sugerem ter sido usada para a ingestão de bebidas. Dois pingentes de concha estavam junto ao esqueleto.
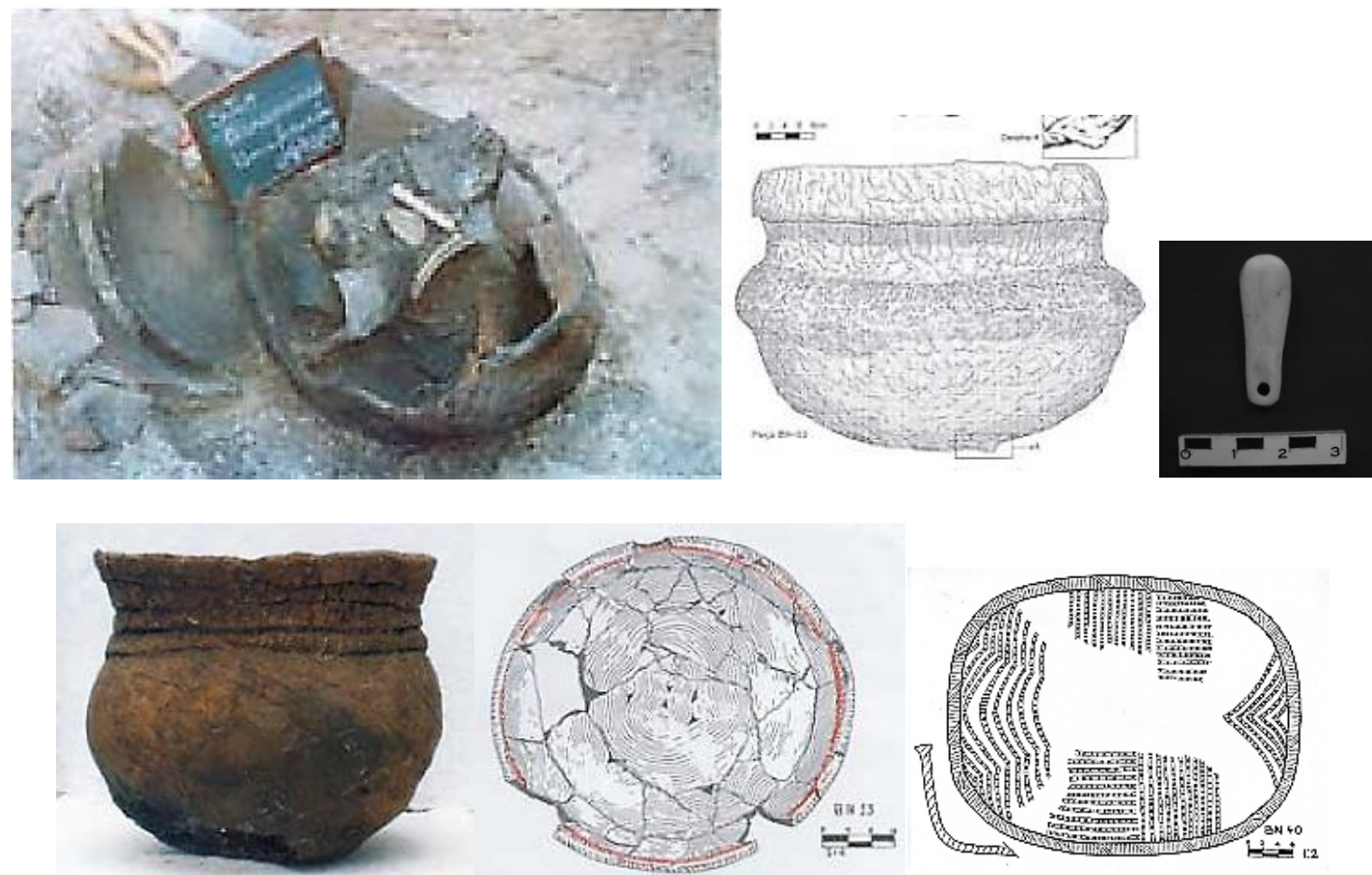

Figuras 82-87: Contexto funerário escavado no sítio Bananeiras, forma da urna, pingente encontrado no contexto e vasilhas de acompanhamento funerário. Fonte: Buarque, 2016.

\section{Sitio Serrano}

A aldeia Serrano possui uma extensão de $300 \mathrm{~m} \mathrm{X185m}$, e $55.500 \mathrm{~m}^{2}$. Ela possui vários indícios de que foi ocupada desde tempos pré-coloniais até período colonial. No sítio foram encontradas 23 estruturas funerárias, algumas associadas a vasilhas pintadas e esqueletos mal preservados. Em uma área de 328 metros quadrados escavados, a maioria das peças e estruturas estava associada a áreas de sepultamento, além da frequente presença de ossos humanos. Nota-se também a existência de uma cova coberta por uma camada de argila cinza dentro do substrato argiloso ocre onde era colocada a urna, denominada pela autora de cama. A presença de muitos sepultamentos leva a autora a crer que tenha havido uma alta 
mortalidade após o contato com os europeus. Segundo a autora, as estruturas são similares às encontradas na aldeia Morro Grande, e apenas duas, diferentes destas, estão descritas.

O primeiro contexto era composto por uma urna com duas tampas, quebradas provavelmente antes de serem depositadas lá. Houve uma preocupação em cobrir a parte que uma das tampas não cobria com a outra. O segundo contexto funerário continha uma urna com remanescentes humanos dentro, e uma tigela encostada à urna, mas com a boca virada para fora.

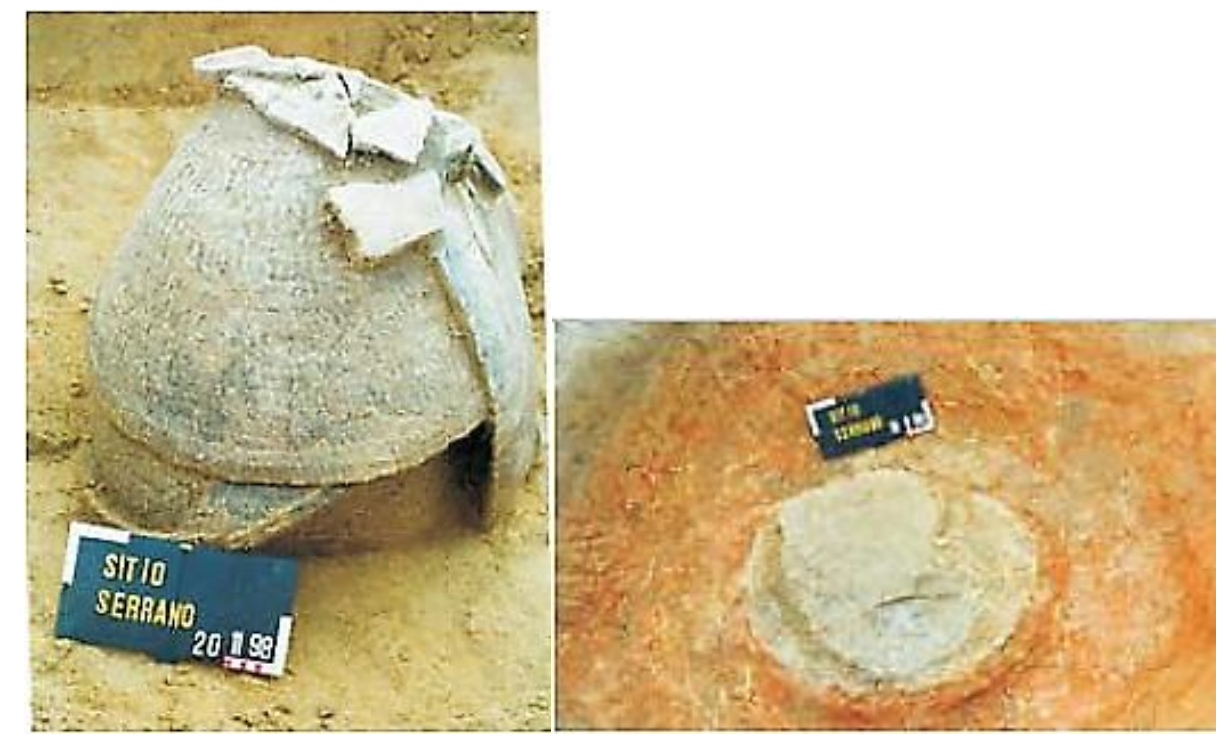

Figuras 88 e 89: Contexto funerário escavado na aldeia Serrano e "cama" de argila encontrada sob urna funerária no mesmo sítio. Fonte: Buarque, 2016.
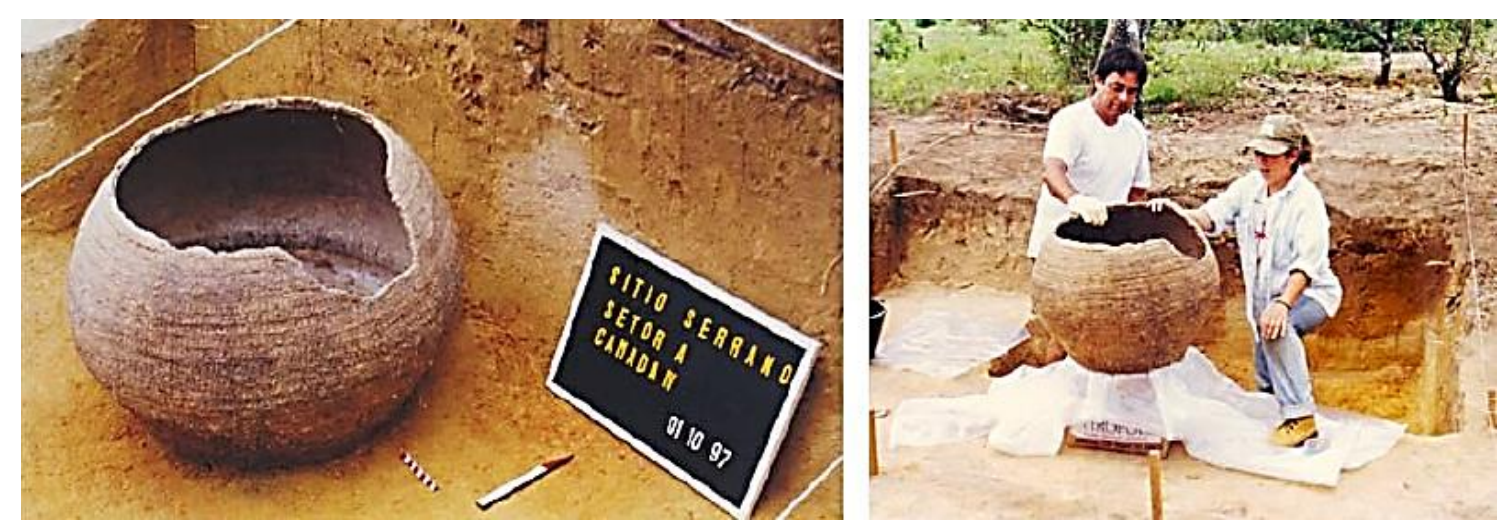

Figuras 90 e 91: Morfologia de urna funerária do sítio Serrano, bastante recorrente em diversos locais do Rio de Janeiro e São Paulo. Fonte: Buarque, 2009. 
Alguns contextos do sítio Serrano indicam possíveis sepultamentos primários em urnas (Buarque, 2009), como o da figura abaixo.

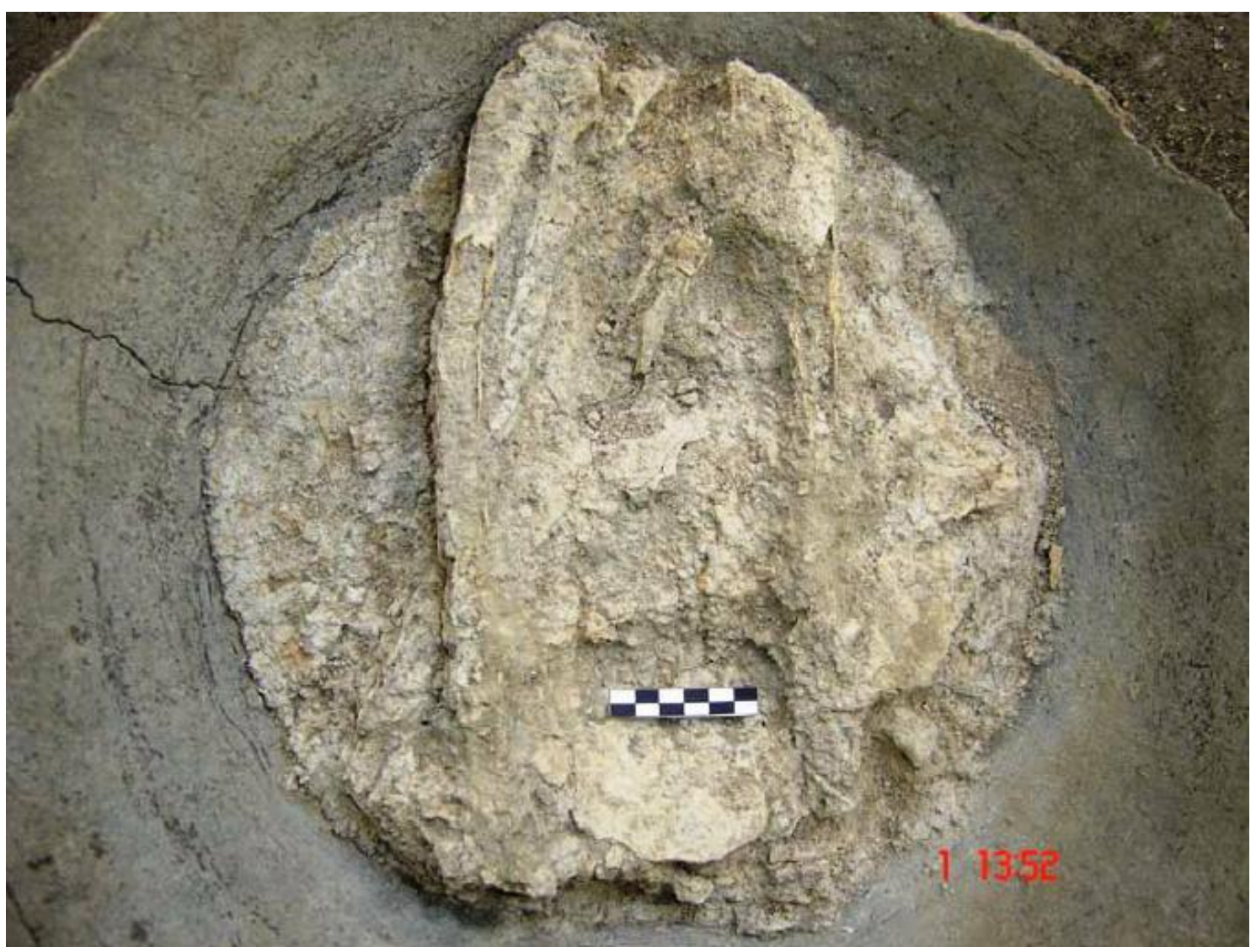

Figura 92: Possível sepultamento primário dentro de urna no sítio Serrano. Fonte: Buarque, 2009.

\section{Sítio São José}

A aldeia São José está distante $3 \mathrm{~km}$ da aldeia Morro Grande, em sentido $\mathrm{NW}$, e apresentava uma área de $30 \mathrm{mil} \mathrm{m}^{2}$. A datação apresentada para o sítio é de $282 \mathrm{BP}$, porém a autora a considera recente demais para as informações históricas para a região. Como no sítio Morro Grande, não há indícios de contato com o europeu. Foram recuperadas 4 urnas funerárias, e em apenas um caso havia a presença de tigela pintada, retangular. Nessa urna foram encontrados dentes de uma criança. 


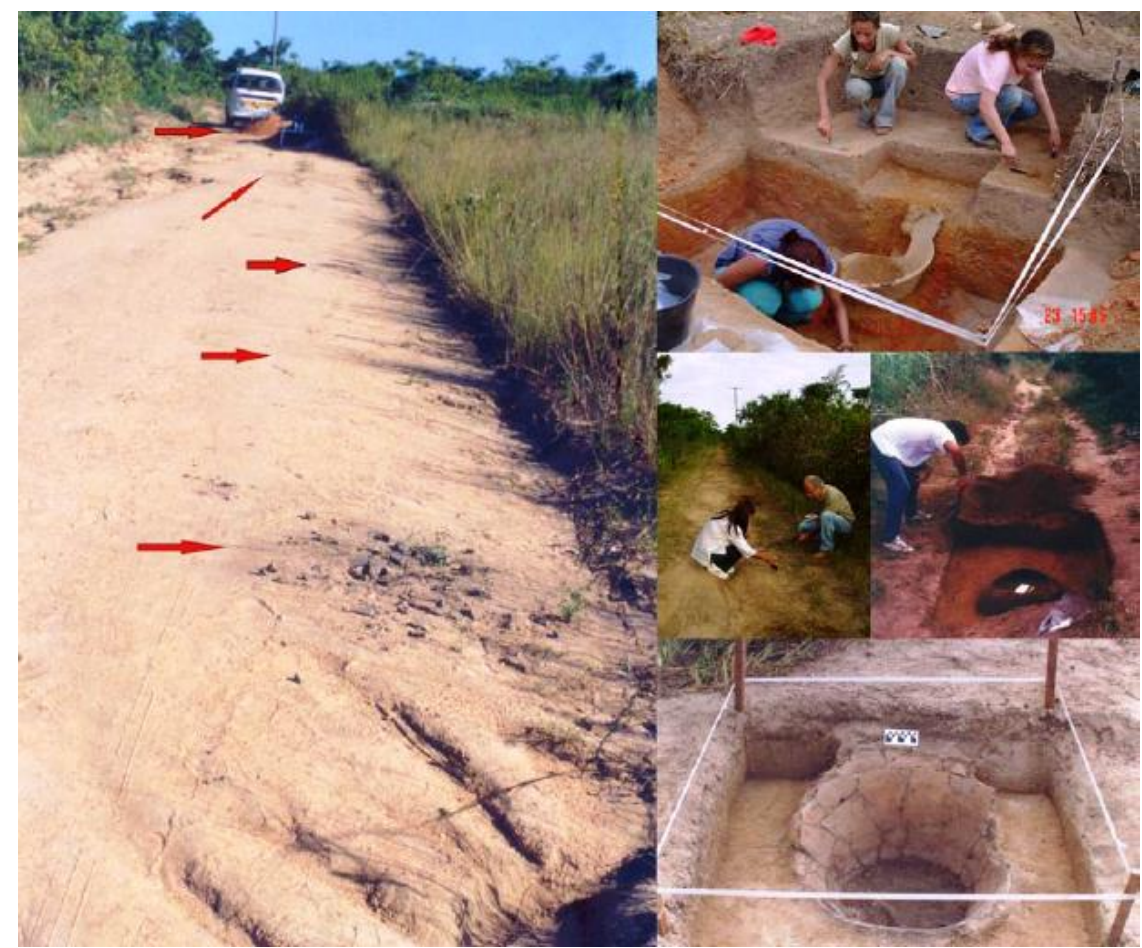

Figura 93: Localização dos contextos funerários e outros vestígios arqueológicos no sítio São José. Nota-se a proximidade entre os contextos funerários, comum nos sítios Guarani.
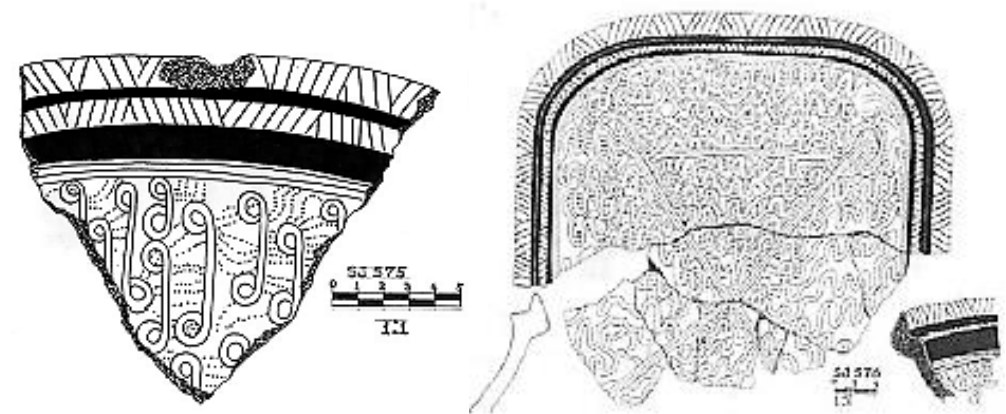

Figuras 94 e 95: Fragmento e vasilha fragmentada encontrados em contextos funerários da aldeia São José. Fonte: Buarque, 2016.

A autora nota que há um padrão estilístico que permanece de forma constante nos diferentes sítios da região, não se percebendo diferenças significativas entre as estruturas funerárias, os aspectos tecnológicos e decorativos dos sítios Morro Grande (com sua ocupação recuada) e Bananeiras (de ocupação da época do contato). Há uma repetição de formas e padrões decorativos independentemente da datação, marcando uma grande profundidade temporal no universo formal, simbólico e pictórico das oleiras tupinambá.

Além disso, a autora (2009) fala em áreas cerimoniais, que contêm sepultamentos, buracos de estaca e fogueiras cerimoniais, próximas a elementos de 
estruturas de habitação, no sítio Morro Grande. Isso sugeriria uma proximidade entre habitação e áreas cerimoniais em que os contextos funerários se encontrariam. No sítio Serrano não foram encontradas fogueiras ou buracos de poste associados a contextos funerários. Em Morro Grande, foram encontradas diversas vasilhas pintadas em sepultamentos de adultos, mas não no de crianças, o que faz a autora propor que no sepultamento de adultos ocorriam festins alimentares funerários, atestados pela presença das vasilhas pintadas. Tanto em sepultamentos de adultos ou de crianças, no entanto, a fogueira estaria presente. Já no sítio São José não foram encontradas estruturas funerárias próximas a estruturas de habitação, e elas estavam restritas a um setor da aldeia.

\subsubsection{B - Sítios e coleções do noroeste de São Paulo}

\section{Sítio Franco de Godoy}

De acordo com Moraes (2007), no sítio Franco de Godoy, localizado no município de Mogi-Guaçu (SP), que possui uma datação de $1550 \mathrm{AP}$, foram encontrados alguns contextos funerários. Nele foram evidenciadas duas manchas de terra preta e quatro urnas funerárias. Os remanescentes humanos das urnas 1, 2 e 3 foram diagnosticados como um adulto jovem, um adulto e uma criança. Não há maiores detalhes sobre os contextos funerários.

A figura a seguir, que mostra a planta do sítio, mostra que os contextos funerários estavam localizados em uma área mais ou menos restrita do sítio, mas não é possível saber a distância entre um e outro. Essa configuração espacial é diferente dos sítios Prassévichus e Fonseca, por exemplo, em que os contextos funerários estão esparsos pela área do sítio.

No sítio foram encontrados remanescentes humanos e urnas funerárias. Piedade (S/D) fez um relatório técnico dos mesmos, que também possui informações gerais sobre o sítio. Como não analisamos esse material, nem sequer o vimos, colocaremos as considerações da autora nessa parte do capítulo.

O sítio estava localizado na chácara Igaçaba, município de Mogi Guaçu. O proprietário encontrou, por ocasião da construção de sua casa, urnas e vasilhas no terreno revolvido. Em julho de 1980, uma equipe de arqueologia do Museu Paulista, coordenada pela prof. Luciana Pallestrini, realizou intervenções no local, 
de onde retiraram material cerâmico e 3 urnas funerárias com sepultamentos primários de 3 indivíduos adultos. Duas eram corrugadas e uma era pintada. $\mathrm{O}$ proprietário foi o responsável pela retirada das urnas, e relatou que foram retiradas inteiras após ter sido escavada a terra ao redor e aguardada a secagem completa das peças. Os ossos foram retirados das urnas pelo proprietário e lavados com água e sabão. Posteriormente, foram colados em um feltro verde e expostos numa pequena vitrine que fazia parte de uma exposição local. $\mathrm{Na}$ exposição, o material descontextualizado foi organizado em 3 grupos, chamado por Piedade de sepultamentos 1 , 2 e 3 .

Os ossos eram em sua maior parte de adulto, contando com fragmentos de crânio, mandíbula, dentes, ossos longos (fêmur, tíbia, úmero, rádio). Alguns dentes eram de criança, e 3 se apresentavam inclusos antemortem. Alguns ossos possuem marcas de dentes de roedor. Com certeza a ação antrópica pós-escavação contribuiu muito para o degaste e perda de ossos. Vários dos dentes apresentavam cáries e pouco desgaste. Piedade (S/D) deduz que se tratavam de 3 indivíduos: 1 adulto, 1 adulto jovem e 1 criança.

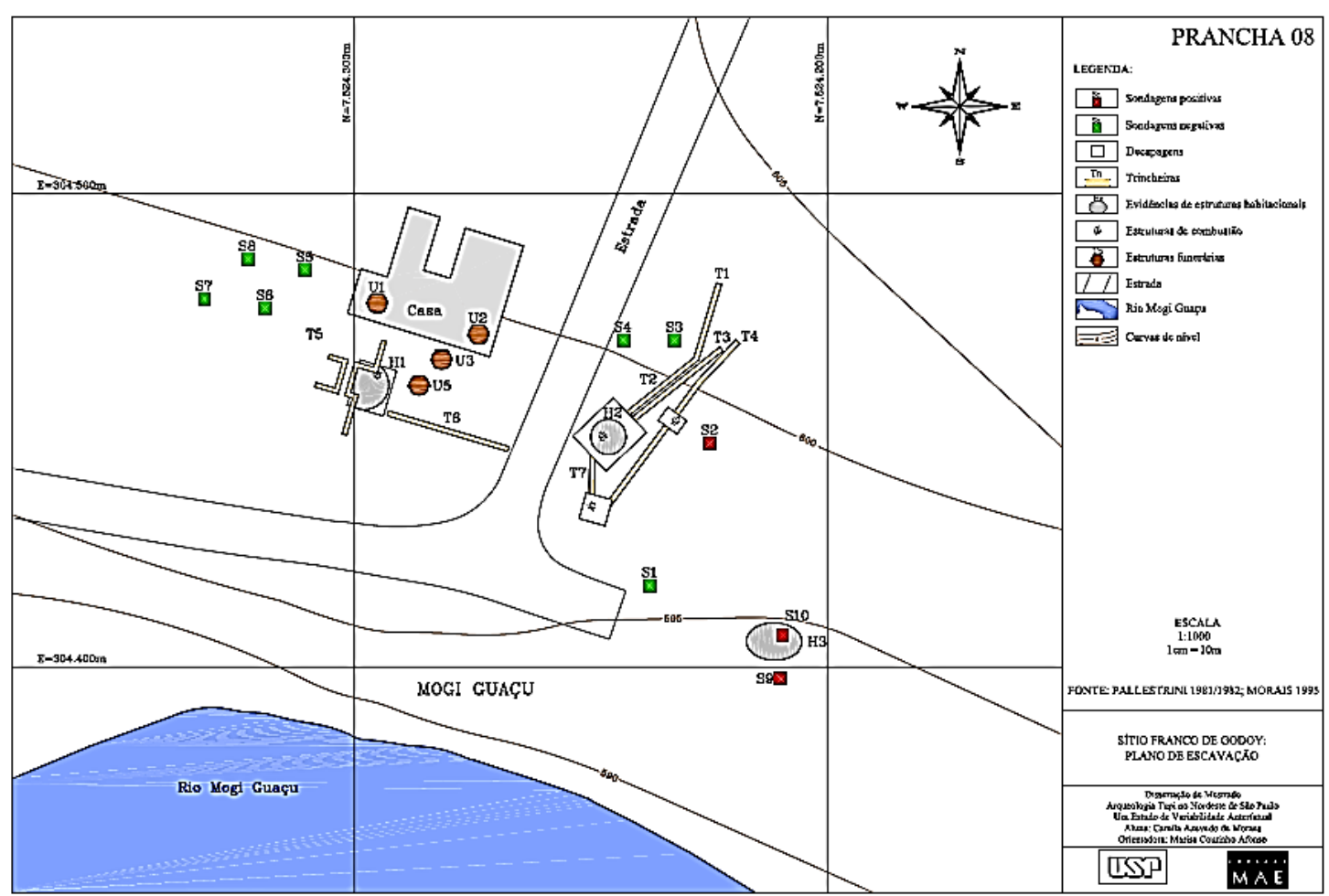

Figura 96: Planta do sítio Franco de Godoy, evidenciando manchas de terra preta e locais das estruturas funerárias. Fonte: Moraes, 2007. 


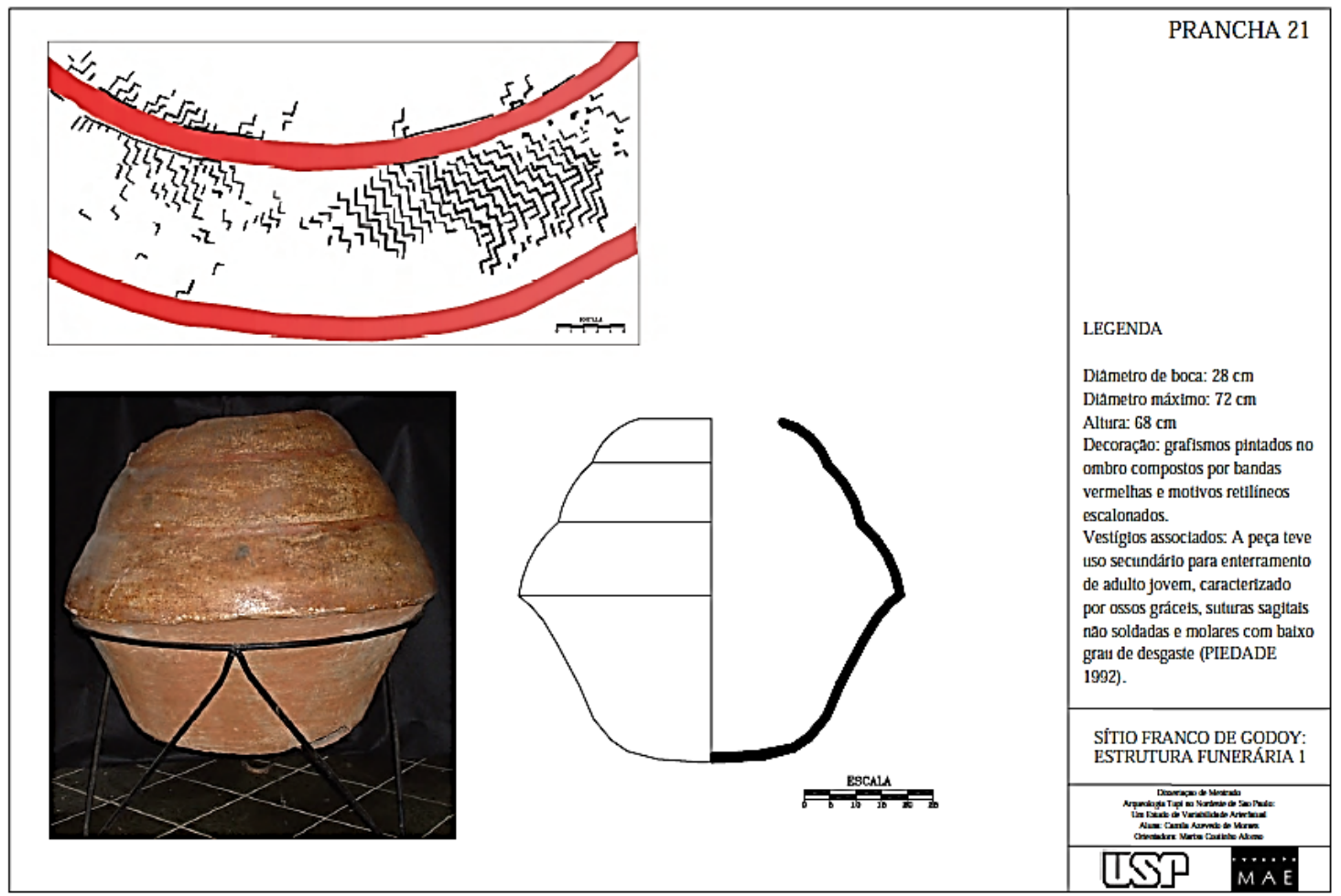

Figura 97: Urna funerária do sítio Franco de Godoy. Fonte: Moraes, 2007.

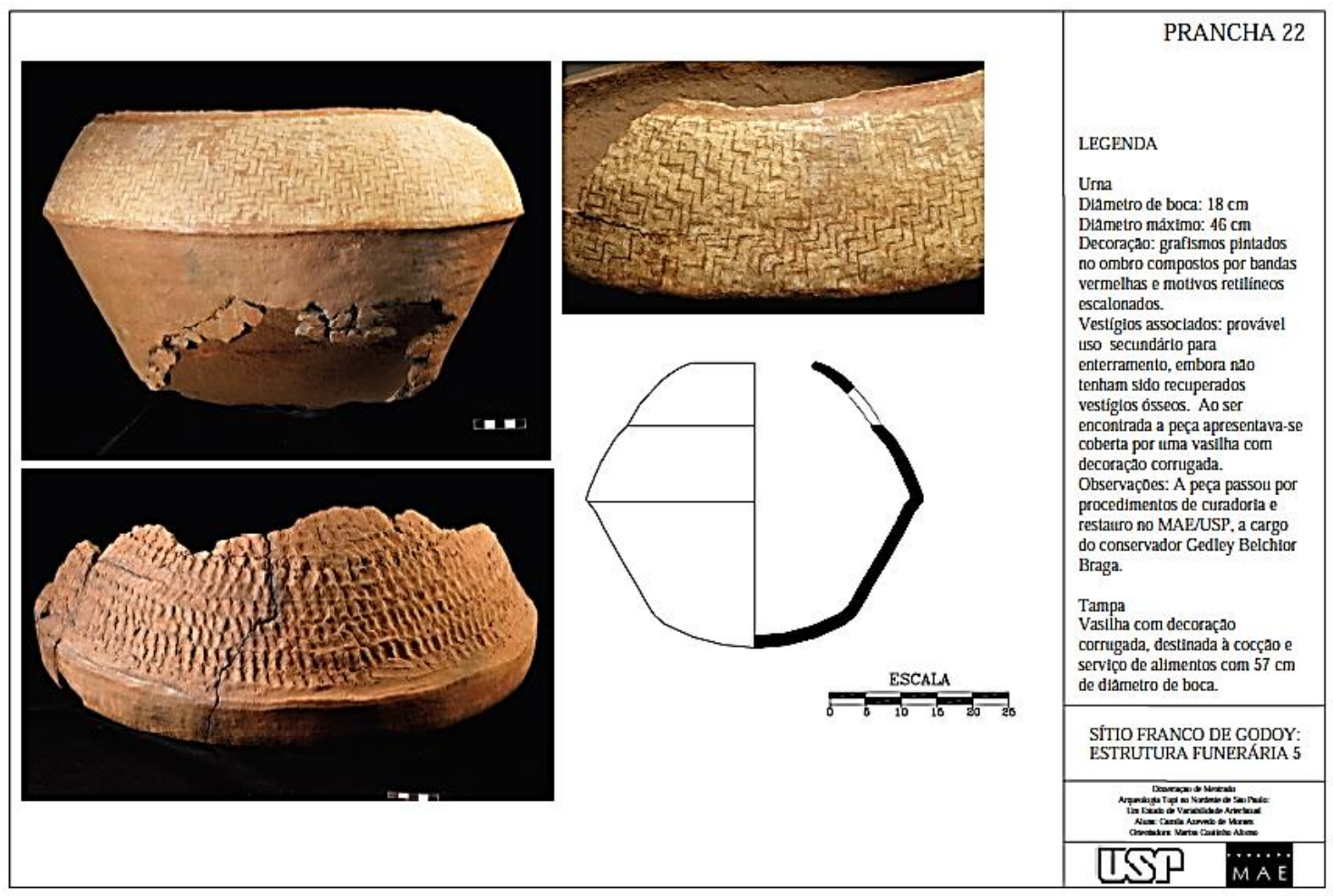

Figura 98: Urna do sítio Franco de Godoy. Fonte: Moraes, 2007. 


\section{Coleções provenientes do noroeste de São Paulo}

Moraes (2007) traz fotos de outras vasilhas funerárias e possivelmente funerárias, provenientes de coleções. Estas, ao que parece, se assemelham àquelas dos sítios Fonseca, Prassévichus e Salto Grande do Paranapanema, bem como àquelas encontradas no Rio de Janeiro por Buarque, sendo piriformes e com bordas diretas sem extroversão.
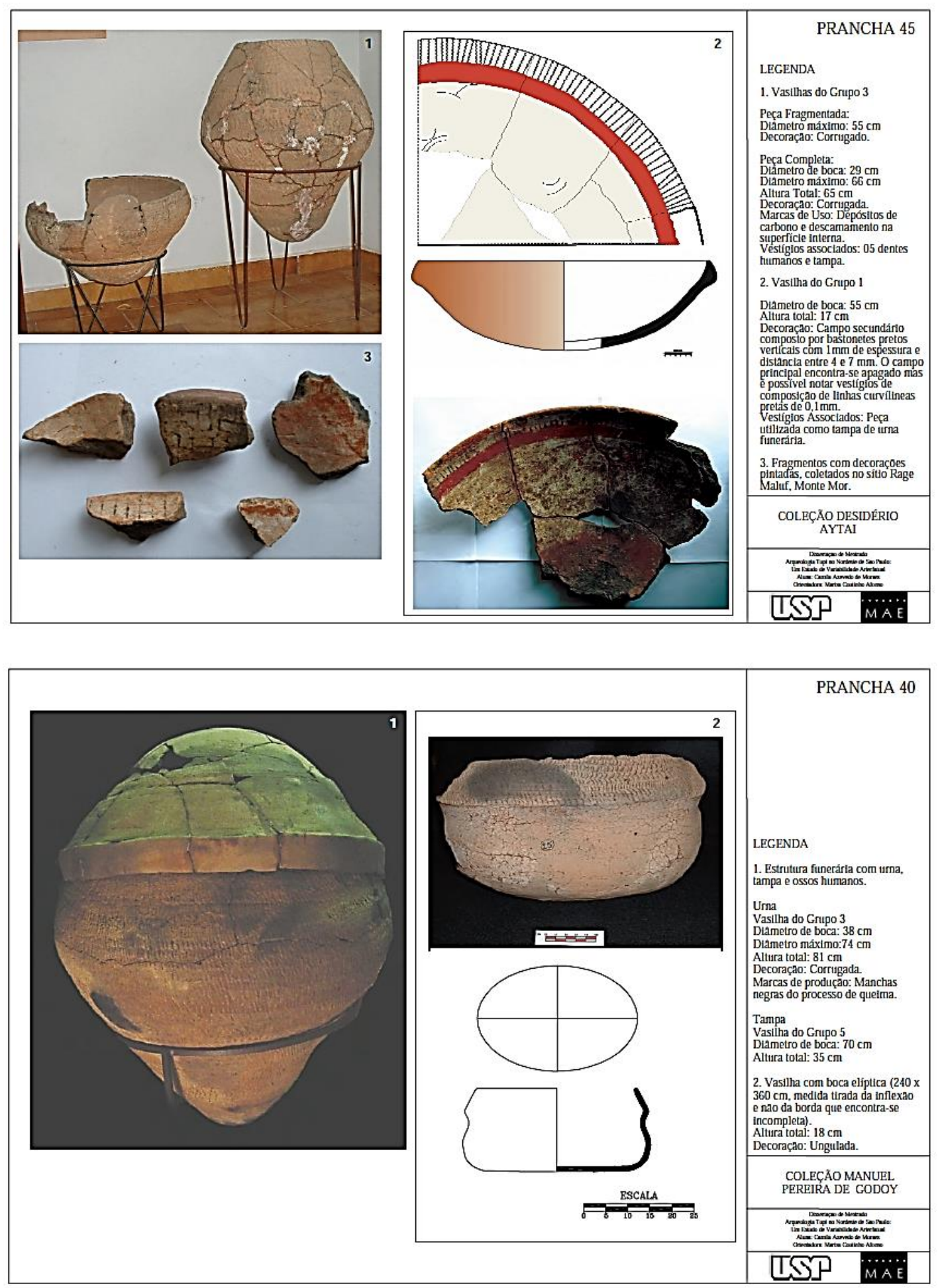

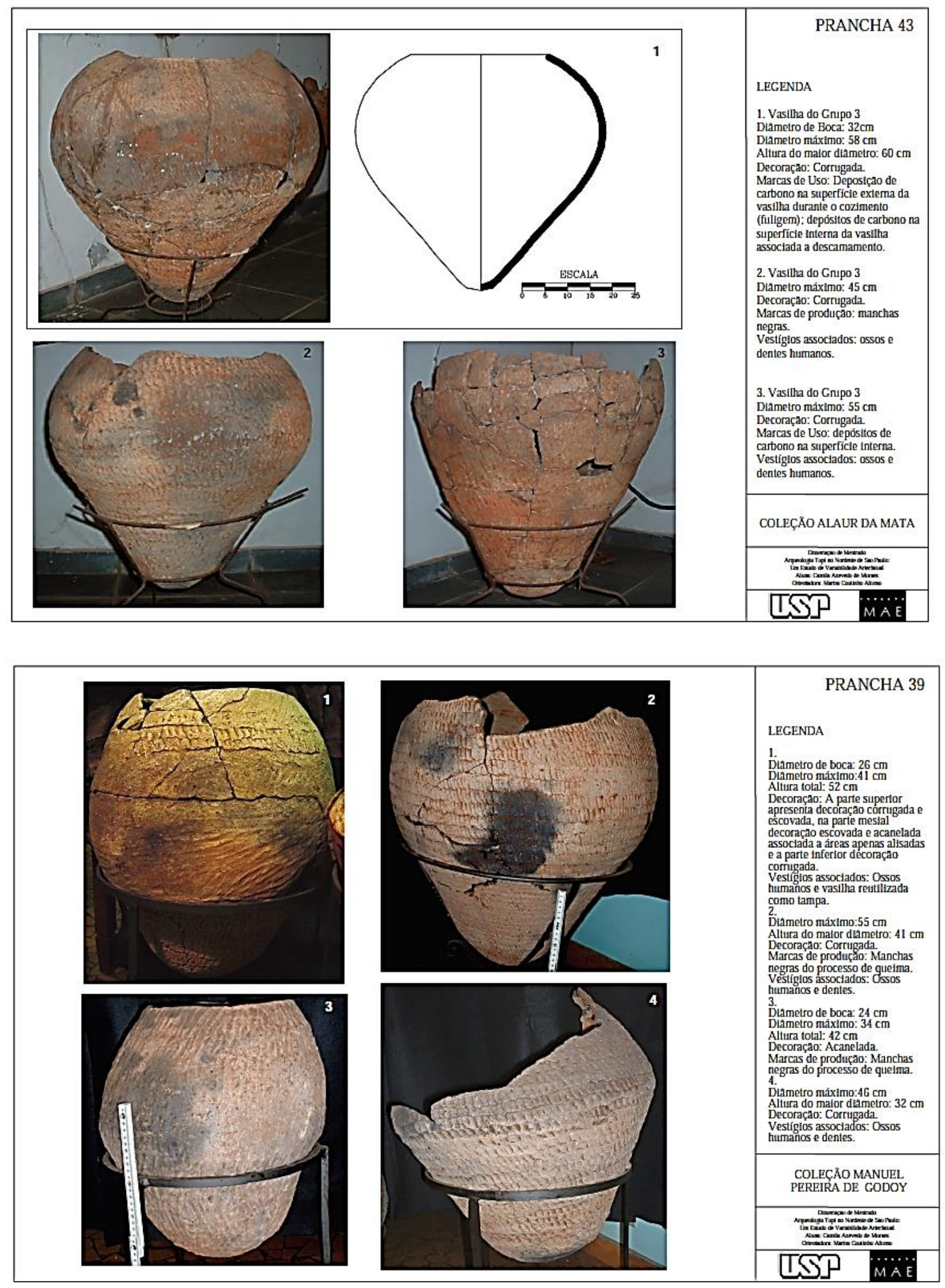

Figuras 99-102: Urnas e possíveis urnas provenientes de coleções, da região do noroeste do estado de São Paulo, registradas por Moraes. Nota-se a morfologia recorrente, e similar às urnas encontradas na região de Araruama (RJ), apesar dos tratamentos de superfície diferenciados entre as vasilhas e pequenas variações formais. Fonte: Moraes, 2007. 


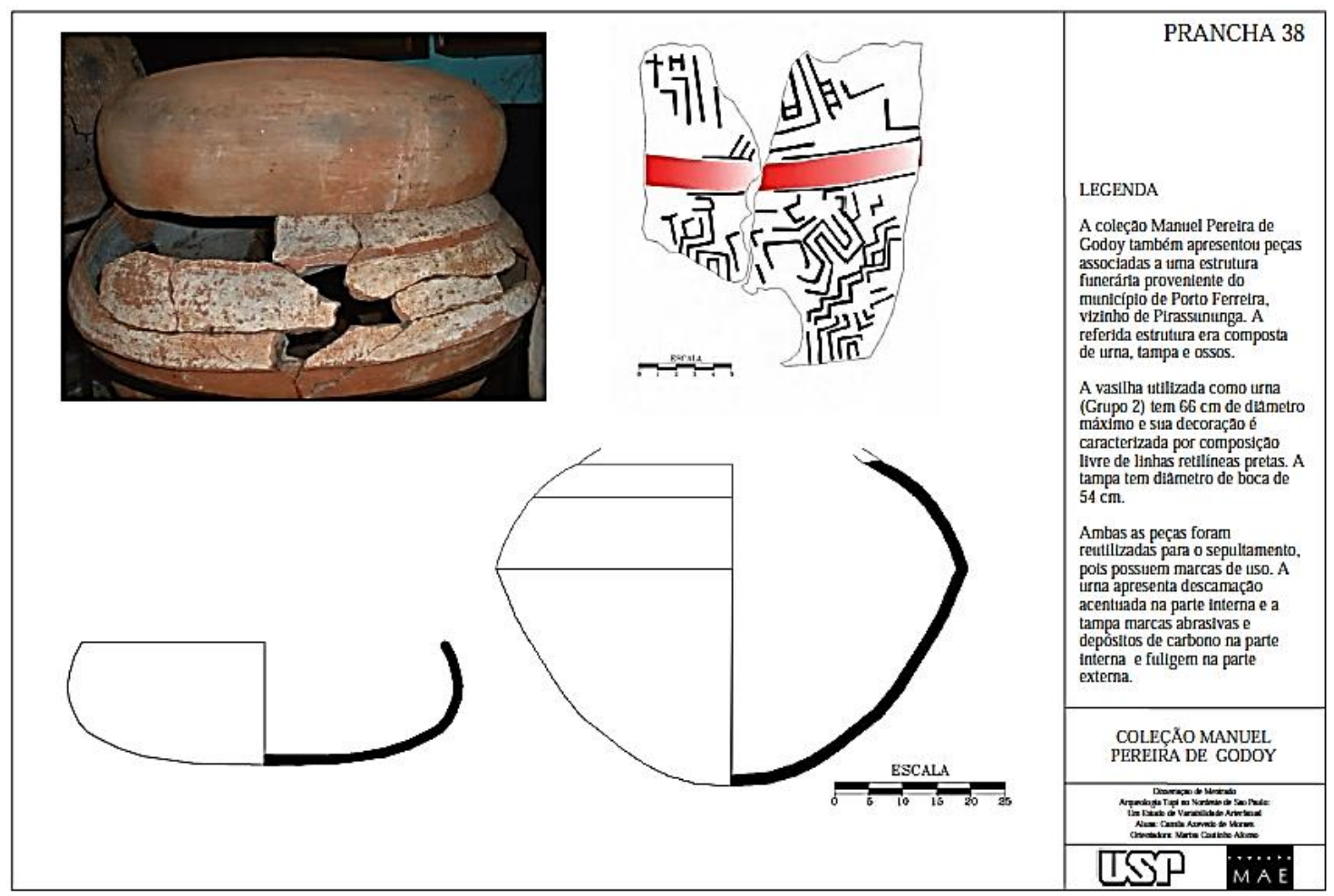

Figura 103: Urna funerária e tampa provenientes de coleção, do noroeste de São Paulo. Fonte: Moraes, 2007.

\subsubsection{C - Ocorrência do município de Salto (SP)}

No município de Salto (SP), Godoy (1947) relata que encontraram, em uma obra urbana, uma vasilha com tampa e ossos dentro, que é a figura abaixo:
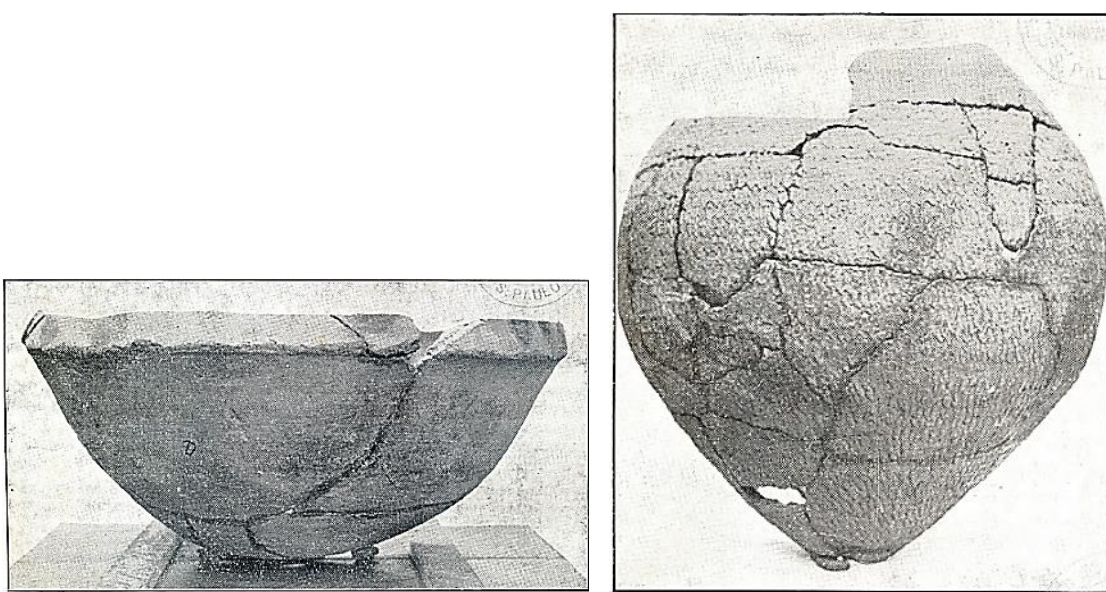

Figuras 104 e 105: Tampa e vasilha com ossos humanos dentro encontrada no município de Salto (SP), em 1945. A borda está quebrada e a superfície externa é corrugada. Não é possível ter certeza do formato devido à borda quebrada, mas aparenta muito ser uma vasilha Tupinambá. Fonte: Godoy, 1947. 


\subsection{2 - Sítios Guarani}

\subsubsection{A - Sítios do Baixo Paranapanema e Alto Paraná (São Paulo e Mato Grosso do Sul)}

\section{Sítio Itororó}

Localizado no município de Pirapozinho (SP), em terraço às margens do Paranapanema, em nível topográfico mais elevado, não sendo atingido pelas enchentes. O sítio é classificado como Guarani por Faccio (2011). Em 1989 foram notadas ocorrências de materiais líticos e cerâmicos por uma extensão de $120 \mathrm{~m}$ ao longo do rio, em superfície e dentro de 3 valas "produzidas na contemporaneidade" (Kashimoto, 1992, apud Faccio, 2011). Kashimoto realizou coletas de material arqueológico e o registro de perfis estratigráficos, bem como limpeza de superfície.

Durante o processo de limpeza e evidenciação de perfis, Kashimoto encontrou três vasilhas cerâmicas in loco. As três encontravam-se fragmentadas, e estão abaixo descritas pela autora:
A vasilha de número 1 (VIT -1 ) apresenta superfície corrugada e tampa com diâmetro de 0,51 metros. Em seu interior foi encontrada uma linha esbranquiçada curva, em 18/02/89. [...]
$\mathrm{Na}$ sequencia dos trabalhos, em 23/02/89, a vasilha 2 (VIT-2) se apresentou com menor altura e incisões em gregas nas proximidades da borda. Assim como em VIT-1, foi notada uma estrutura esbranquiçada no fundo, lembrando uma estrutura óssea. [...]
Contíguo a VIT-2 aflorava um pequeno 'fragmento' de cerâmica, que mostrou ser a vasilha 3 (VIT-3). Esta se posicionava com a concavidade voltada para baixo, possuindo formato campanular e superfície alisada. A decapagem evidenciou, em 23/02/89, um crânio imediatamente abaixo desta cerâmica [...]. (KASHIMOTO, 1992)

Segundo Kashimoto, em 1991, no MAE - USP, foram realizadas decapagens nas peças, coordenadas por Silvia Piedade. Estas possibilitaram algumas constatações a respeito dessas urnas:

Urna 1: continha fragmentos cerâmicos da própria urna, um fragmento ósseo com consistência pulverulenta, e 8 molares decíduos não erupcionados, em posição original, que sugerem se tratar de um neonato. 
Urna 2: continha um crânio de criança bem pequena, provavelmente um neonato, extremamente fragmentado, tendo sido possível ser identificado pela pesquisadora o occipital. Junto deste havia um osso longo.

Urna 3: no sedimento, retirado em bloco, foi evidenciado um crânio de criança infiltrado por raízes. A idade estimada foi entre 4 e 6 anos, "pois apresentava os dentes ' 1 incisivo decíduo erupcionados, 1 incisivo central superior, 2 caninos e um molar, não erupcionados"' (Kashimoto, 1992, p. 100). Além disso, segundo a descrição, o indivíduo apresentava cribra orbitália na órbita direita.

Estes três sepultamentos diferem muito do que normalmente é encontrado em sítios Guarani, primeiro porque se tratam de três sepultamentos infantis, e não de adultos. Não há elementos para dizer se eram primários ou secundários, mas há uma clara diferença entre eles, que nos faz pensar em dois tipos de sepultamentos: um dentro de urna e outro com uma vasilha cobrindo o crânio. A segunda modalidade pode fazer pensar que o sepultamento tenha sido apenas da cabeça sob a vasilha, e é outro motivo para afirmarmos que é um contexto funerário bem diferente do que normalmente se encontra. Este sepultamento estava, conforme a descrição, exatamente ao lado, de maneira contígua, do sepultamento II, que é o do crânio de criança bem pequena junto com um osso longo dentro de urna, o que pode sugerir algum tipo de associação entre eles.

\section{Sítio Rio Ivinhema I}

Kashimoto (2007) escavou o sítio Rio Ivinhema 1 (VN1), localizado na sub-bacia do rio Ivinhema, na margem direita do Alto Paraná, Mato Grosso do Sul. É o sítio de maior extensão e concentração de vestígios arqueológicos Guarani encontrado pela autora na margem direita do rio Paraná. Vestígios cerâmicos e líticos se estendem por $7 \mathrm{~km}$ pela margem desse rio, a partir da foz do rio Ivinhema. A região insere-se na área Guarani etnohistórica dos rios Paranapanema e Ivaí, antigo território das missões jesuíticas do Guairá. A escavação do sítio resultou na evidenciação de estruturas de sepultamento que integravam uma área de cemitério, segundo a autora. 


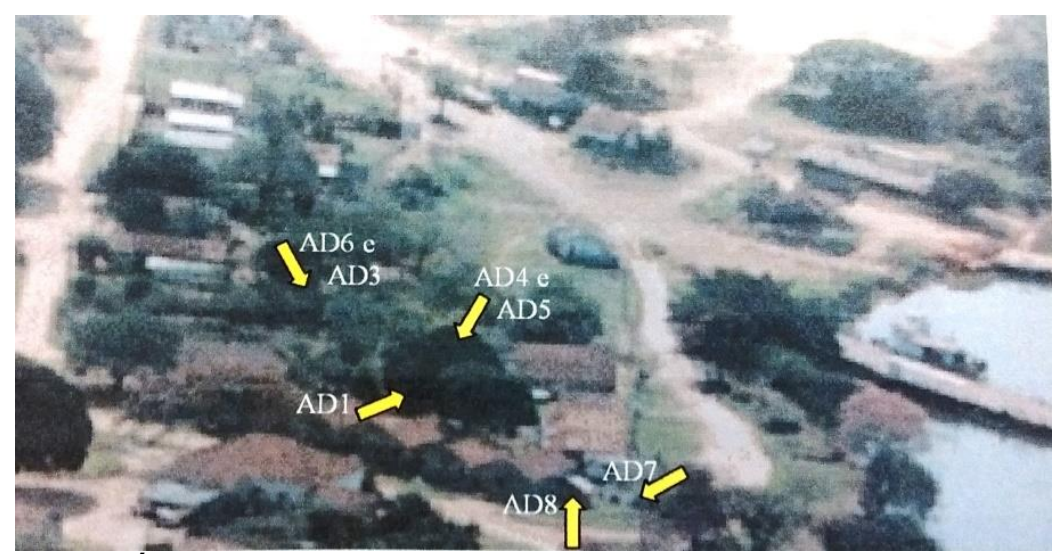

Figura 106: Áreas de decapagem (AD) do sítio Rio Ivinhema 1. Nota-se a proximidade entre estruturas funerárias e vasilhas, bem como a concentração de estruturas funerárias em uma área mais ou menos restrita. Fonte: Kashimoto, 2006.

As vasilhas cerâmicas foram agrupadas em conjuntos, pois algumas estavam muito próximas entre si, espaçadas em apenas alguns metros. Todas as peças encontravam-se em um espaço de $6 \mathrm{mil} \mathrm{m}^{2}$. Na área de decapagem 4 (AD4), o sepultamento era composto por uma urna corrugada dentro da qual foi sepultado um indivíduo cujos ossos longos eram visíveis e o crânio estava coberto por uma vasilha cerâmica (cambuchí) e por fragmentos de outras vasilhas. O indivíduo sepultado tinha idade não superior a 35 anos, e era do sexo masculino. Junto ao crânio foi encontrado um tembetá de resina. A alguns metros dessa urna, havia uma vasilha corrugada.

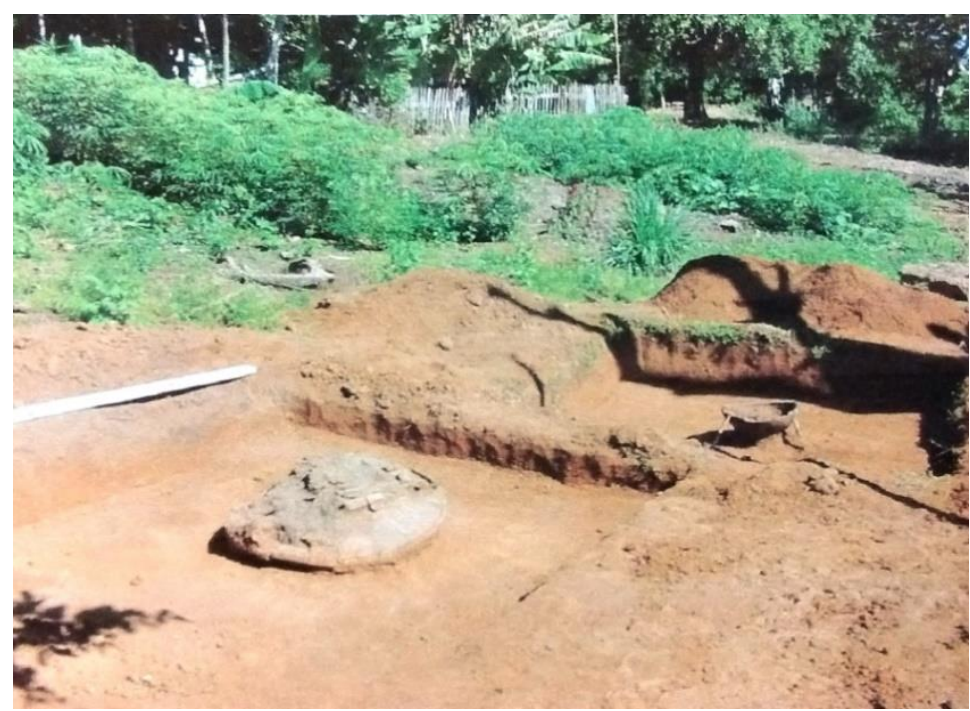

Figura 107: Estrutura funerária da área de decapagem $4 \mathrm{e}$ vasilha associada.

Fonte: Kashimoto, 2006. 

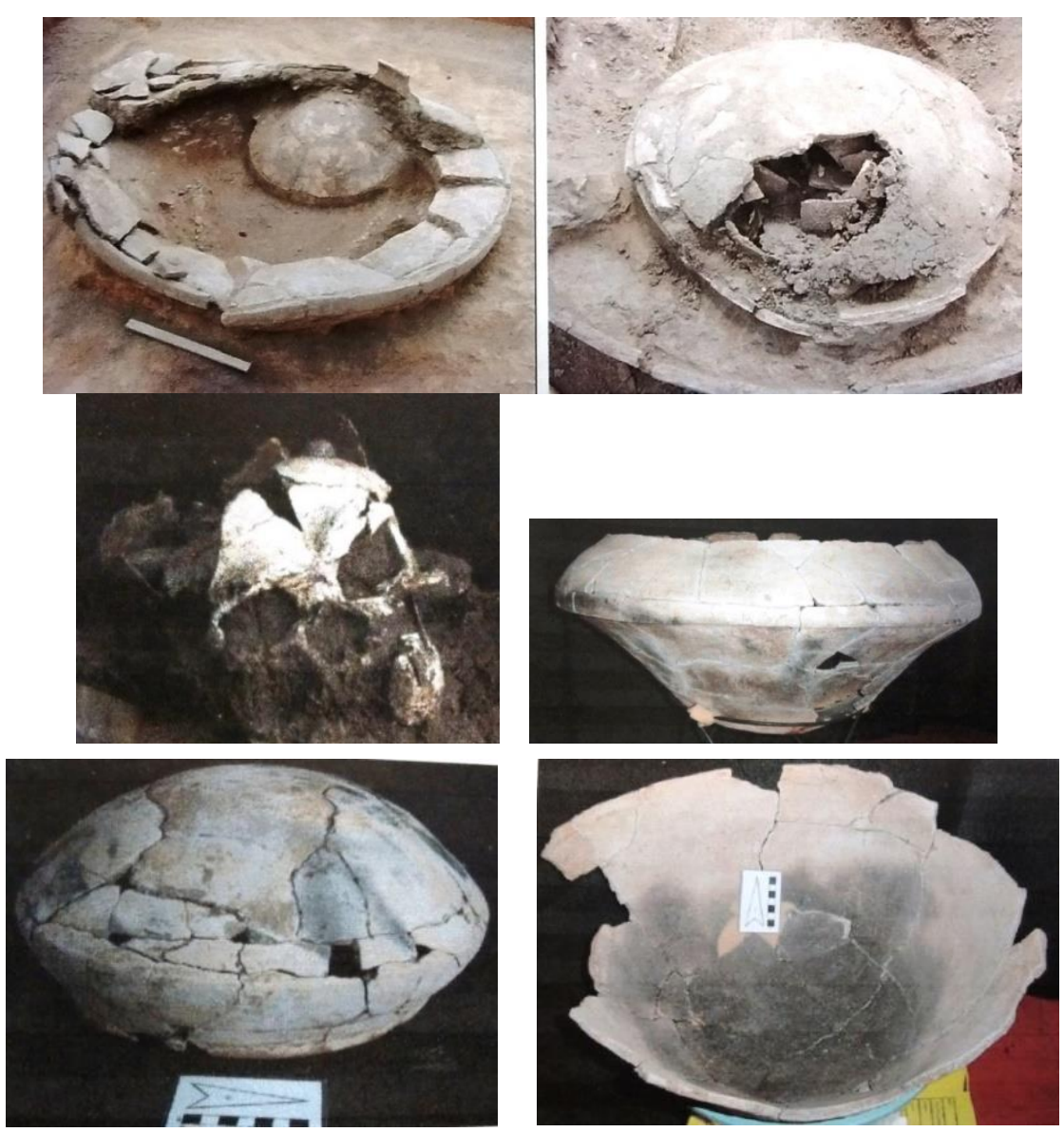

Figuras 108-113: Estrutura funerária da área de decapagem 4, em que o indivíduo se encontrava dentro da urna, com ossos longos mal preservados e crânio coberto por vasilha (cambuchí), crânio, urna e vasilhas associadas reconstituídas. Fonte: Kashimoto, 2006.

$\mathrm{Na}$ área de decapagem 3 foi evidenciada outra urna Guarani, essa corrugada, e algumas vasilhas a alguns metros de distância desta. A presença de uma pequena tigela cerâmica no interior de uma das vasilhas leva autora a supor a utilização da vasilha para armazenagem/consumo de bebidas nesse ritual funerário.

Dois fragmentos de cerâmica que estavam no interior dessa urna foram datados em $570 \pm 40$ e $600 \pm 57$ AP. Isso leva a autora a crer que às vésperas da colonização europeia os Guarani habitavam a área da foz do rio Ivinhema, em um grande aldeamento em que havia a beberagem que integrava os rituais funerários. 


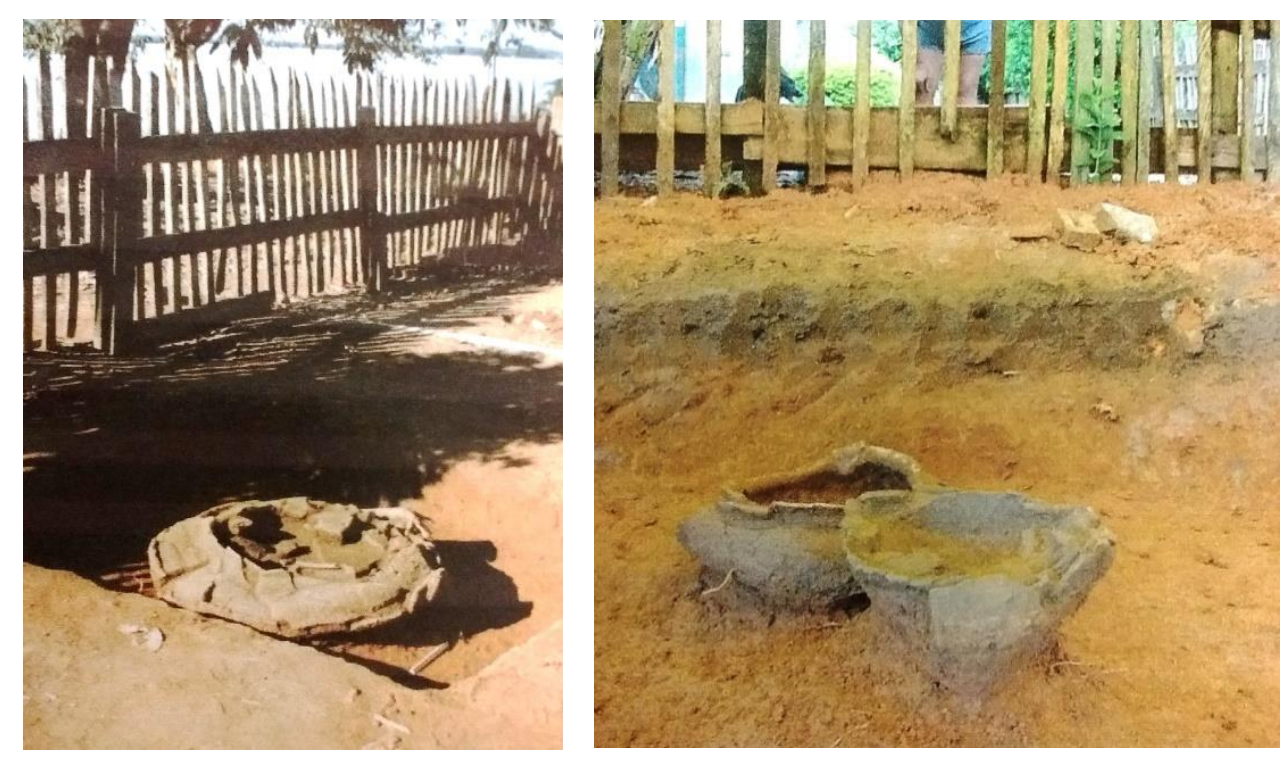

Figura 114 e 115: Estrutura funerária da área de decapagem 3, e vasilhas encontradas a alguns metros de distância desta, sítio Rio Ivinhema 1. Fonte: Kashimoto, 2006.
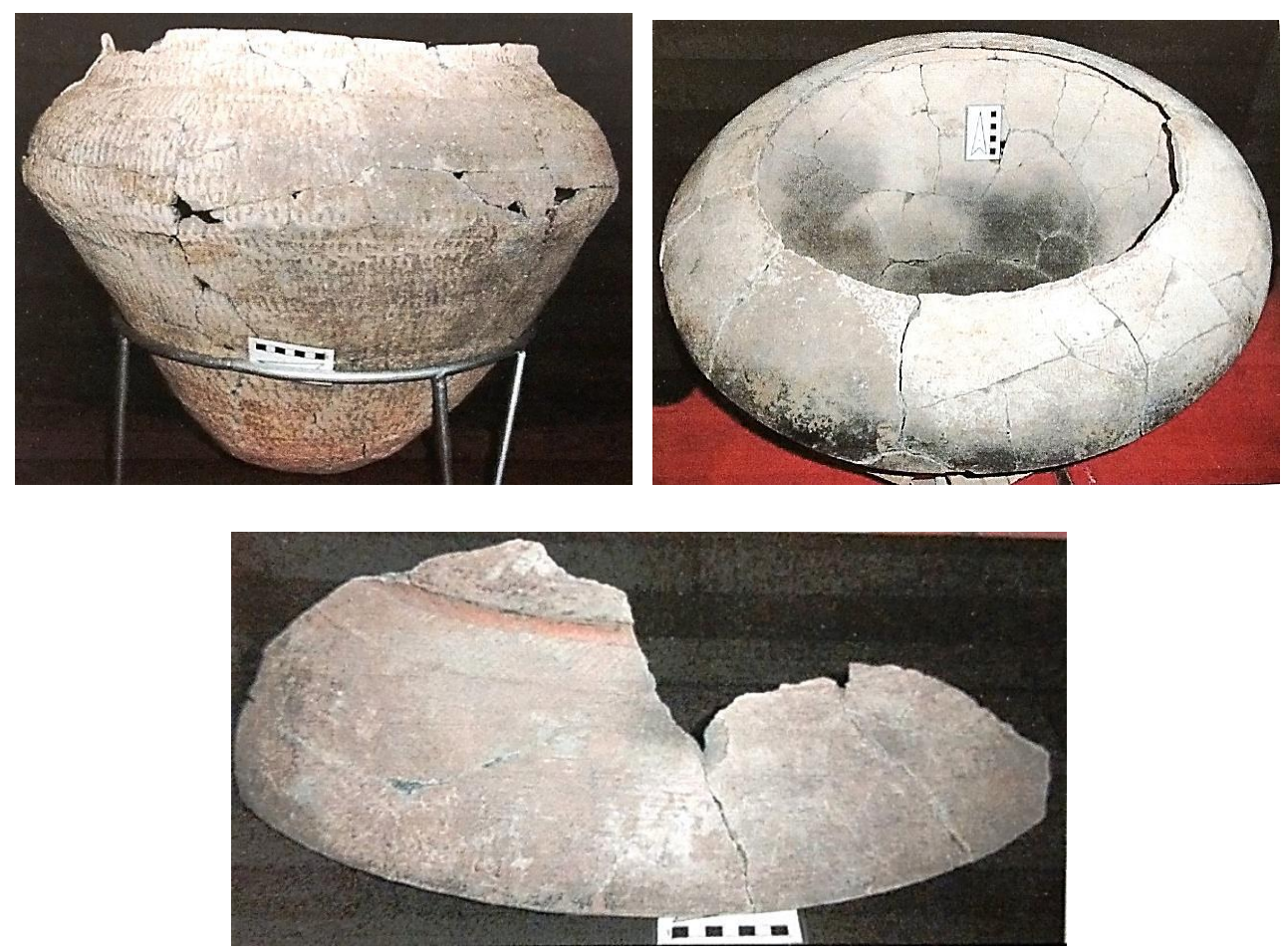

Figuras 116-118: Urna corrugada e vasilhas/fragmentos de vasilhas associados ao contexto, área de decapagem 3, sítio Rio Ivinhema 1. Fonte: Kashimo, 2006. 


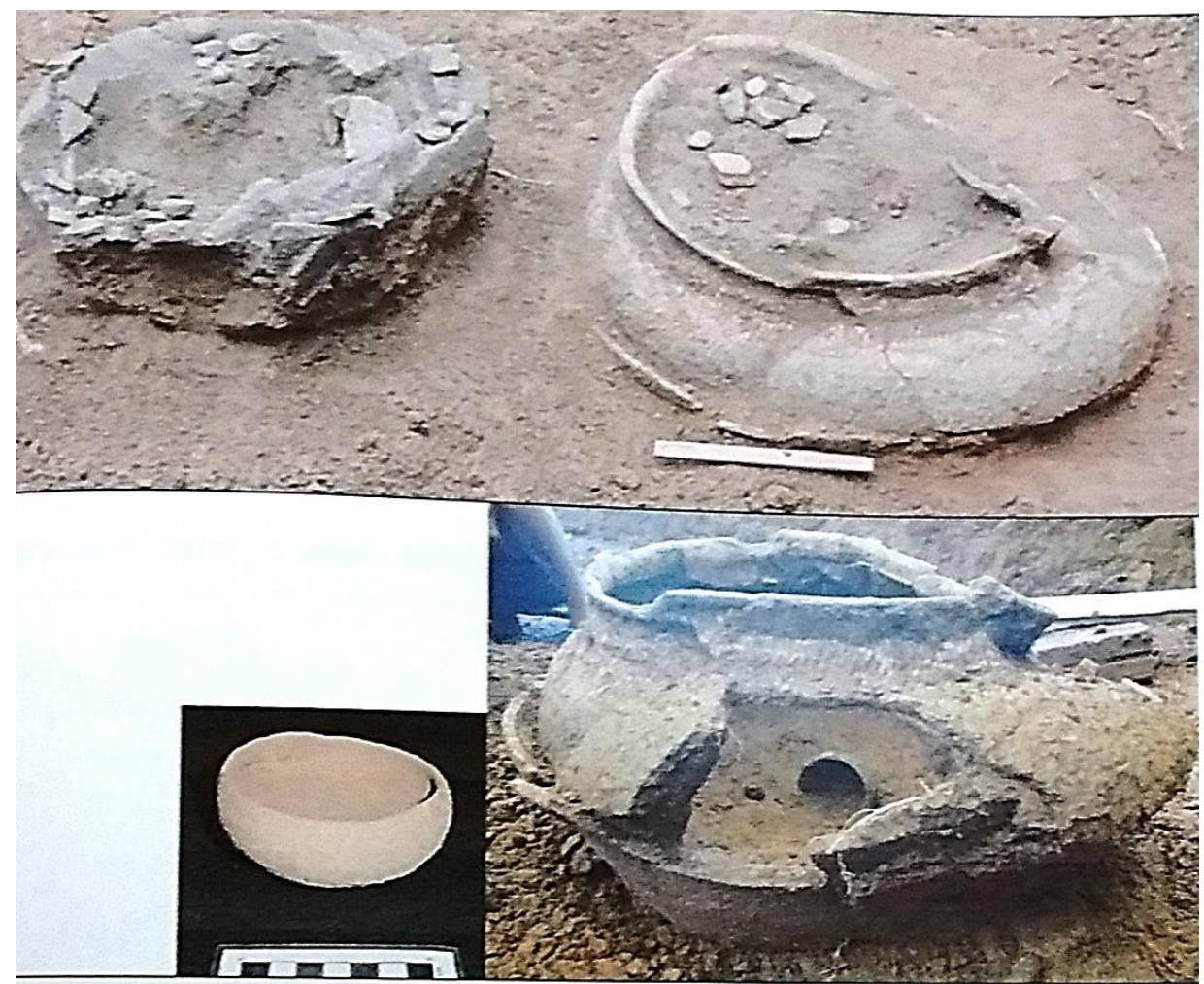

Figura 119: Vasilhas próximas ao contexto funerário da AD3. Fonte: Kashimoto, 2006.

Outra estrutura funerária foi encontrada na área de decapagem 1, onde foram escavados fragmentos de uma urna parcialmente destruída pela ação antrópica. Próximo à urna foi encontrado um cambuchí. Na área próxima a esse contexto, uma moradora local encontrou uma colher de prata com uma insígnia jesuíta, que evidencia a interação do sítio com as missões da província do Guairá (Kashimoto, 2006).

\section{Sítio Alto Paraná 8}

No sítio Alto Paraná 8, Kashimoto \& Martins (2005) trazem informações sobre um contexto funerário em que a urna era uma cambuchí corrugada, dentro da qual foram escavados fragmentos de crânio e um tembetá de resina. Dentro dessa urna havia diversas vasilhas e fragmentos de vasilhas. A figura abaixo mostra esse contexto. 

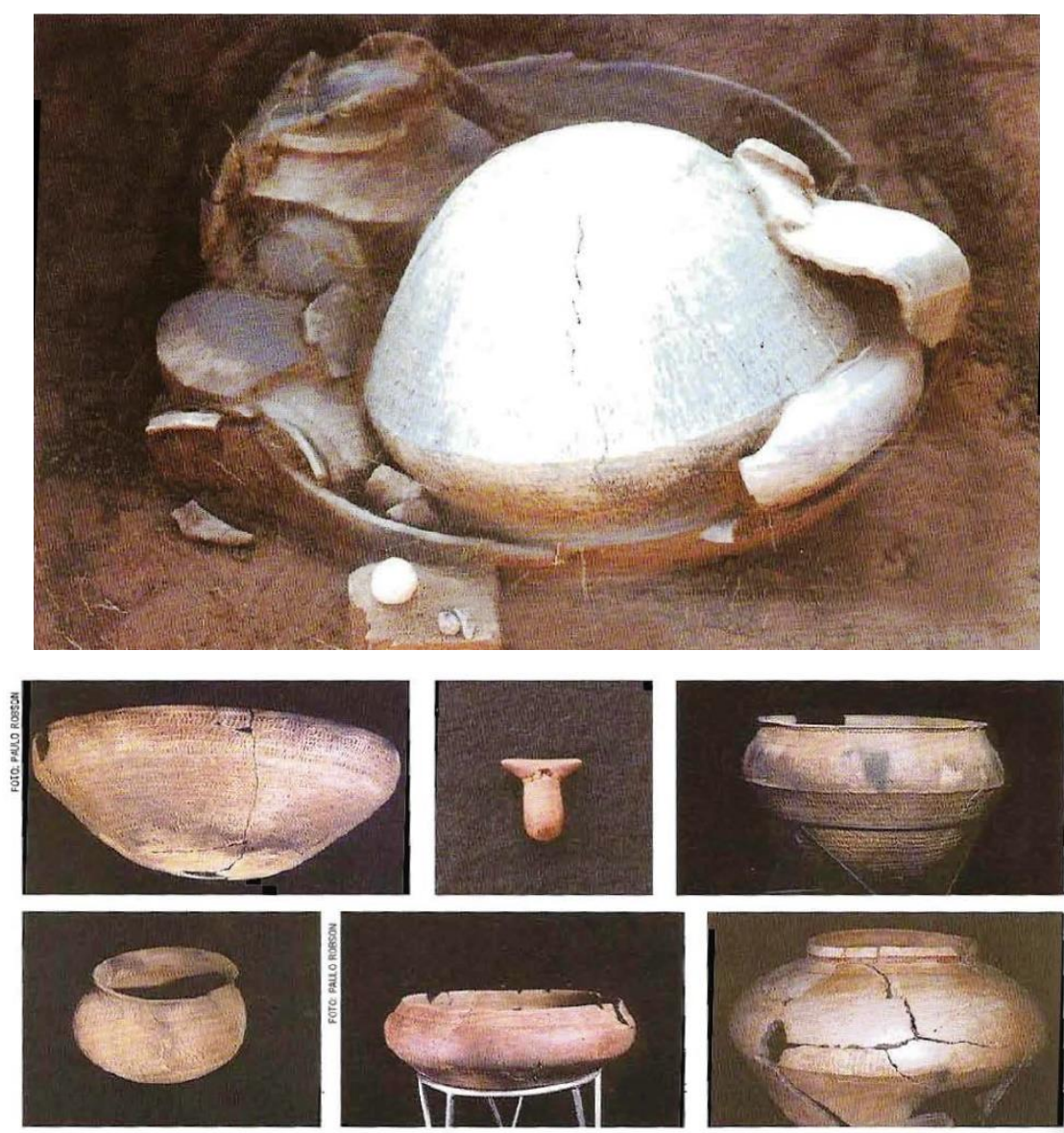

Figuras 120 e 121: Possível estrutura funerária do sítio Alto Paraná 8, e vasilhas que a compunham. De cima para baixo e da esquerda para a direita: contexto funerário, urna ñaetá corrugada, tembetá de resina, vasilha yapepó corrugada que tampava o crânio, yapepó myri corrugada, cambuchí caguabá com pintura externa (linhas pretas sobre engobo vermelho) e interna, yapepó com pintura (linhas vermelhas sobre engobo branco). Fonte: Kashimoto \& Martins, 2005.

\section{Sítio $M T-I V-1$}

Chmyz (1974) traz a descrição de um conjunto de sepultamentos encontrados por ele no Mato Grosso do Sul, no sítio MT-IV-1, localizado na margem direita do rio Paraná, ao longo do rio Samambaia. O sítio tinha o formato de uma elipse que media $100 \mathrm{~m}$ X $80 \mathrm{~m}$, em que uma faixa de solo misturado a carvões, restos de cozinha e cacos de cerâmica, medindo $10 \mathrm{~m}$ de largura, circundava um centro, no qual foram encontradas 30 urnas funerárias em 13 quadras escavadas. A tendência geral das urnas era se alinhar num sentido lesteoeste. Elas eram tampadas com recipientes de diferentes tamanhos e também com cacos grandes. Algumas urnas não possuíam fundo, e grandes cacos tampavam, por dentro, os buracos que esta ausência de fundo deixava. Em um caso, mesmo faltando o fundo da urna, o crânio estava depositado no sedimento arenoso. Uma 
das urnas continha crânios e alguns ossos pertencentes a dois indivíduos, sobre os quais foram depositados cacos de vasilhas. Duas dessas vasilhas, reconstituídas posteriormente, mostraram sinais de quebra intencional. Em quase todas as urnas havia, no interior ou do lado de fora, pequenos recipientes cerâmicos, sugerindo oferendas. Muitas urnas também continham tembetás em T, de cristal ou de resina. O autor considera que nenhuma urna continha sepultamento primário por causa dos tamanhos das mesmas e da disposição dos ossos, mas como não analisamos o material nem temos mais dados, não podemos afirmar nada. Além dos sepultamentos em urna havia sepultamentos direto na terra associados a cerâmicas. Eles estavam na mesma profundidade e alinhamento das urnas. Um deles estava semi-fletido em decúbito lateral esquerdo, com cacos grandes cobrindo apenas o crânio. Ao lado da mandíbula havia um tembetá de cristal de rocha, e junto aos pés havia um machado polido, polidores de sulco e um possível corante. Outro indivíduo encontrava-se com o crânio apoiado em uma vasilha rasa, e outro foi disposto em cova na posição acocorada, tendo sobre o crânio uma vasilha rasa emborcada (Chmyz, 1974). Este último sepultamento lembra bastante a descrição dos cronistas e a gravura de um sepultamento fora de urna, em posição de cócoras com uma vasilha sobre a cabeça.

Além disso, o autor traz a informação de que podiam ser notadas perturbações nos enterros em urnas, causadas por enterros posteriores.

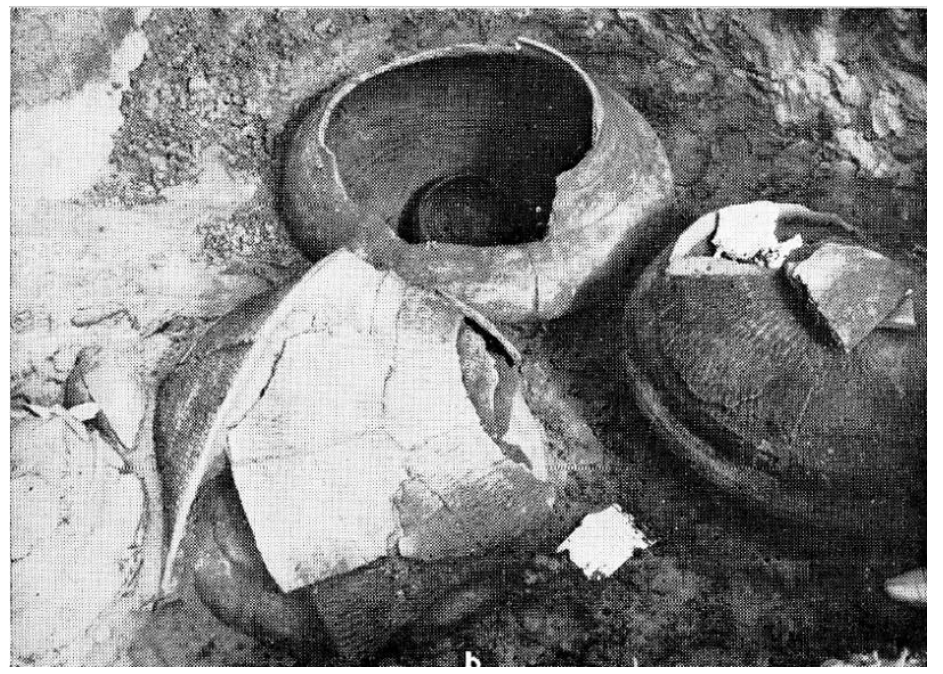

Figura 122: Parte de contexto funerário encontrado na margem do rio Samambaia, MS, no sítio MT-IV-1. Observa-se diversas urnas funerárias muito próximas, bem como vasilhas menores dentro de outras. Fonte: Chmyz, 1974. 


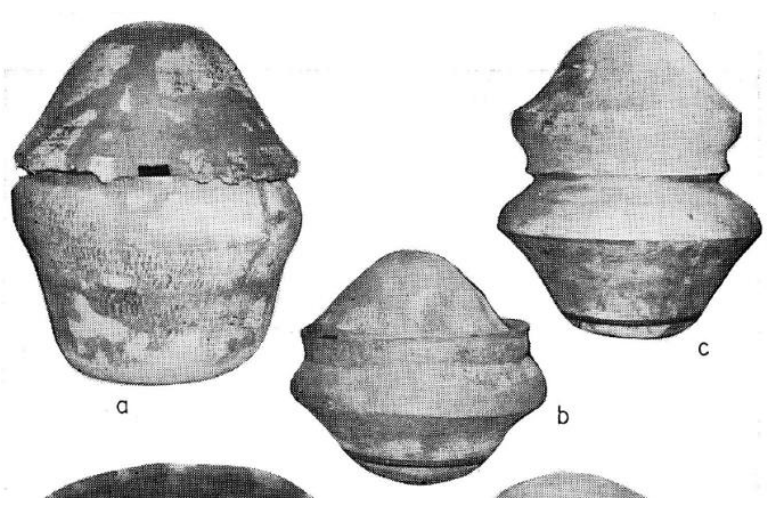

Figura 123: Exemplos de vasilhas utilizadas como urnas funerárias e tampas no sítio MT-IV1. Classificações e observações feitas pelo autor: A e B - Corrugado complicado; a tampa de A era um fundo de panela colocado sobre o ombro da urna; e a tampa de B era um recipiente apoiado sobre cacos de cerâmica que preenchiam a urna; C - urna pintada na porção superior (vermelho sobre branco) com tampa corrugada. Fonte: Chmyz, 1974.

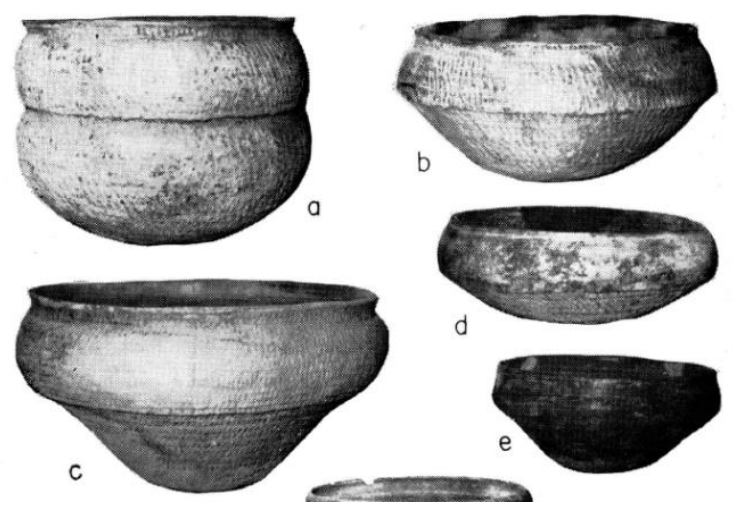

Figura 125: Vasilhas encontradas em contextos funerários. Observações feitas pelo autor: A, B e C - corrugado e ungulado; D - corrugado na parte inferior, vermelho na parte superior e pintura vermelha e preta sobre branco na parte interna; E - pintura vermelha e preta sobre branco na porção superior, vermelha na parte interna. Fonte: Chmyz, 1974.

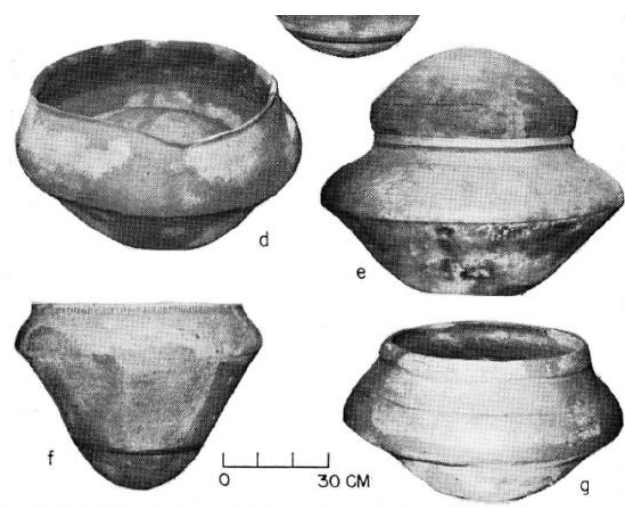

Figura 124: Exemplos de vasilhas utilizadas como urnas funerárias no sítio MT-IV-1. Classificação e observações feitas pelo autor: $\mathrm{D}$ e F - corrugado complicado; a tampa de D estava depositada sobre os remanescentes humanos, no fundo da urna; e em $\mathrm{F}$ a tampa aparentemente eram cacos depositados sobre os remanescentes humanos; E - urna pintada (vermelho sobra branco) na porção superior, com tampa corrugada; G - urna pintada na poção superior (vermelho sobre branco). Fonte: Chmyz, 1974.

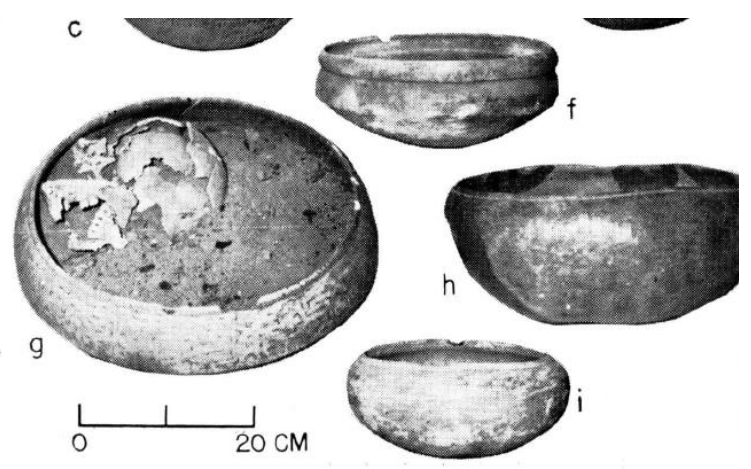

Figura 126: Vasilhas encontradas em contextos funerários. Observações feitas pelo autor: F - vermelho na parte exterior e pintura vermelha e preta sobre branco na parte interna; G - vasilha utilizada para apoiar um crânio em sepultamento primário (aparentemente fora de urna), pintura preta e vermelha sobre branco; $\mathrm{H}$ - vermelho com alguns traços pretos na parte externa, pintura vermelha e preta sobre branco na parte interna; I - vermelho na parte externa, pintura vermelha e preta sobre branco na parte interna. 
Esse achado de Chmyz é, até agora, o único encontrado por nós em que pode ser observada, para os Guarani que ainda sepultavam em urnas, uma área funerária com grande concentração de sepultamentos, já que há ao menos 30 sepultamentos em uma área de $80 \mathrm{~m}$ X $60 \mathrm{~m}$. Os sepultamentos Guarani são encontrados, em geral, menos concentrados, embora boa parte das ocorrências seja de sepultamentos bem próximos entre si e os sítios com cerâmica Guarani tenham a tendência a apresentar sepultamentos mais concentrados quando comparados aos Tupinambá. É possível inferir que o achado de Chmyz na margem do rio Samambaia seja bastante diferente do que normalmente é encontrado, em termos de espacialidade funerária e número de sepultamentos. Notamos também a recorrência das urnas alinhadas no sentido leste-oeste. A existência de perturbações em certos sepultamentos, causadas por sepultamentos posteriores, demonstra o uso prolongado daquele espaço como funerário, ou seja, sepultamentos com práticas funerárias diferentes eram concentrados naquele local, ao invés de haver locais distantes entre si e variados de sepultamento.

\subsubsection{B - Sítio da região de Itaipu - PR FI 148 (Caranguejeiras)}

Sítio da região da UHE Itaipu onde Chmyz (1979) encontrou contextos funerários é o PR FI 148 (Caranguejeiras). Ele se localiza a 7,2km da margem esquerda do rio Paraná e a 30m do rio Ocoi, em uma elevação suave, $85 \mathrm{~m}$ acima do nível do rio maior, e tinha uma área de $75 \mathrm{~m}$ X $30 \mathrm{~m}$, com o eixo maior paralelo no rio Ocoi, mais próximo. Foi associado, em termos de semelhança, a outros 2 sítios próximos. Era constituído por 3 manchas de terra preta, e a $75 \mathrm{~m}$ de uma delas foi encontrado um contexto funerário. A maior concentração de material arqueológico ocorria entre $10 \mathrm{~cm}$ e $15 \mathrm{~cm}$ de profundidade.

O contexto funerário foi assinalado por uma concentração superficial de fragmentos cerâmicos, vários que remontavam, expostos pela movimentação de toras e erosão, sendo que aproximadamente $20 \mathrm{~cm}$ da camada superficial do contexto fora, arrancados pelas perturbações no terreno. Os fragmentos formavam 4 recipientes pintados, de $16 \mathrm{~cm}, 10 \mathrm{~cm}$ e $26 \mathrm{~cm}$, de diâmetro (um deles aparentemente não foi possível medir), além de fragmentos de 2 recipientes corrugados e 1 escovado. As 3 tampas que cobriam a urna estavam esmagadas. 
Uma delas era o fundo de uma grande vasilha escovada, e cobria toda a urna; outra era parte de um recipiente escovado, e a outra de um corrugado, e estavam situadas lateralmente, reforçando a cobertura. A urna, por sua vez, era escovada também, e estava parcialmente fragmentada. Ao lado dela, a leste, havia uma concentração de carvão. Dentro da urna havia diversos artefatos e ossos humanos. Mais acima havia uma vasilha que continha 9 dentes humanos, e outros 3 estavam próximos à sua boca (que estava virada de lado). Os dentes eram dois molares superiores, três inferiores, dois pré-molares superiores, um canino superior e 4 incisivos, um superior e três inferiores. As cúspides não estavam desgastadas, e um dos pré-molares está com cárie. Aparentemente tratava-se de um indivíduo adulto, mas é impossível precisar a idade.

Mais abaixo havia outra vasilha, emborcada, algo inclinada, sobre o fundo da urna. Esta cobria um núcleo de quarto com alguns lascamentos, e uma outra vasilha menor, de boca para cima. Dentro desta última vasilha havia 207 contas de colar discoides, de concha, 17 contas alongadas de osso, e 8 contas de vidro. Duas outras contas foram encontradas fora da vasilha também, entre primeira e a segunda vasilha. As 3 vasilhas que estavam no interior da urna eram pintadas e estavam completas.

Outros objetos de origem europeia foram encontrados em outras quadras abertas no sítio: um fragmento de uma vareta de ferro e um pendente de cobre. Havia também material associado à Tradição Itararé. Outras 3 conchas, duas perfuradas, foram encontradas em outro local do sítio, bem como dezenas de carapaças de gastrópodes terrestres, que ocorreram em diferentes quadras. Fora do contexto funerário também foram encontrados um pendente e fragmentos de carapaça de tartaruga. Os artefatos ósseos encontrados no interior da urna encontram-se erodidos, enquanto os encontrados fora, em mancha de terra preta, estão bem conservados. 


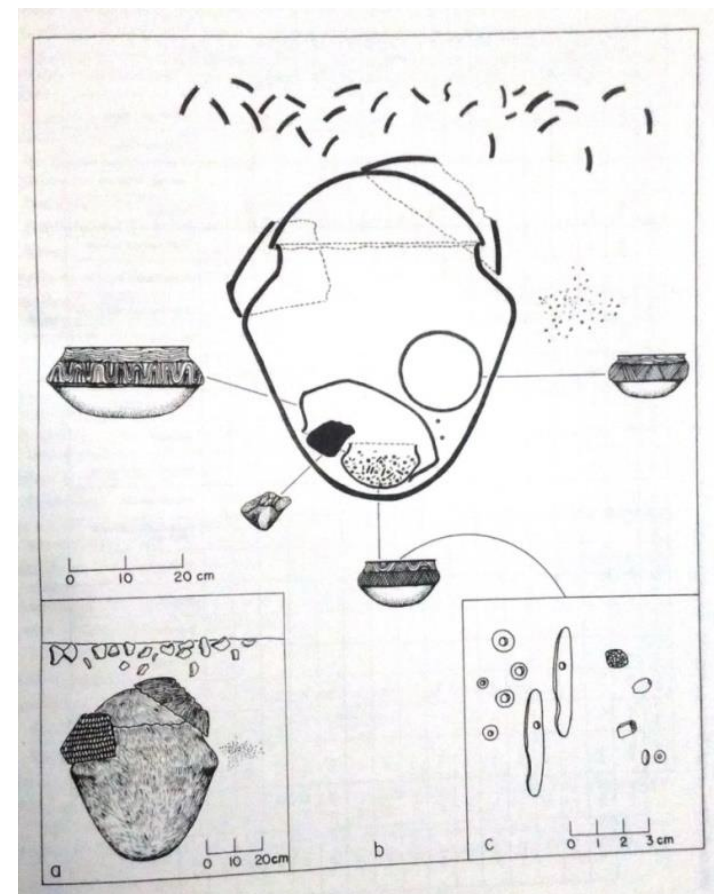

Figura 127: Desenho do contexto funerário encontrado por Chmyz no sítio PR FI 148 (Caranguejeiras). A urna e a posição das vasilhas estão representadas mais acima. Nota-se a presença de um lítico e diversas contas, de concha, osso e vidro, que estavam dentro de uma vasilha cerâmica junto à base da urna. Remanescentes humanos foram encontrados apenas dentro e próximos a outra vasilha, o que nos faz pensar que diversas ações ocorreram além de um simples sepultamento primário. Fonte: Chmyz, 1979.

O autor fala, a respeito dos fragmentos cerâmicos sobre e ao redor das urnas e vasilhas, em quebra ritual de vasilhas, e infere que isso também tenha ocorrido no sítio do rio Samambaia, no Mato Grosso do Sul, e no vale do rio Itararé (Chmyz, 1979). Como não achamos nada na bibliografia, não há como saber se havia isso, ou se a quebra foi causada por ações posteriores aos ritos funerários, ou mesmo por fatores pós-deposicionais naturais. Há vários momentos e várias maneiras que essa quebra poderia ter ocorrido. Os fragmentos poderiam nem sequer estar diretamente relacionados com o funeral ou os mortos. 


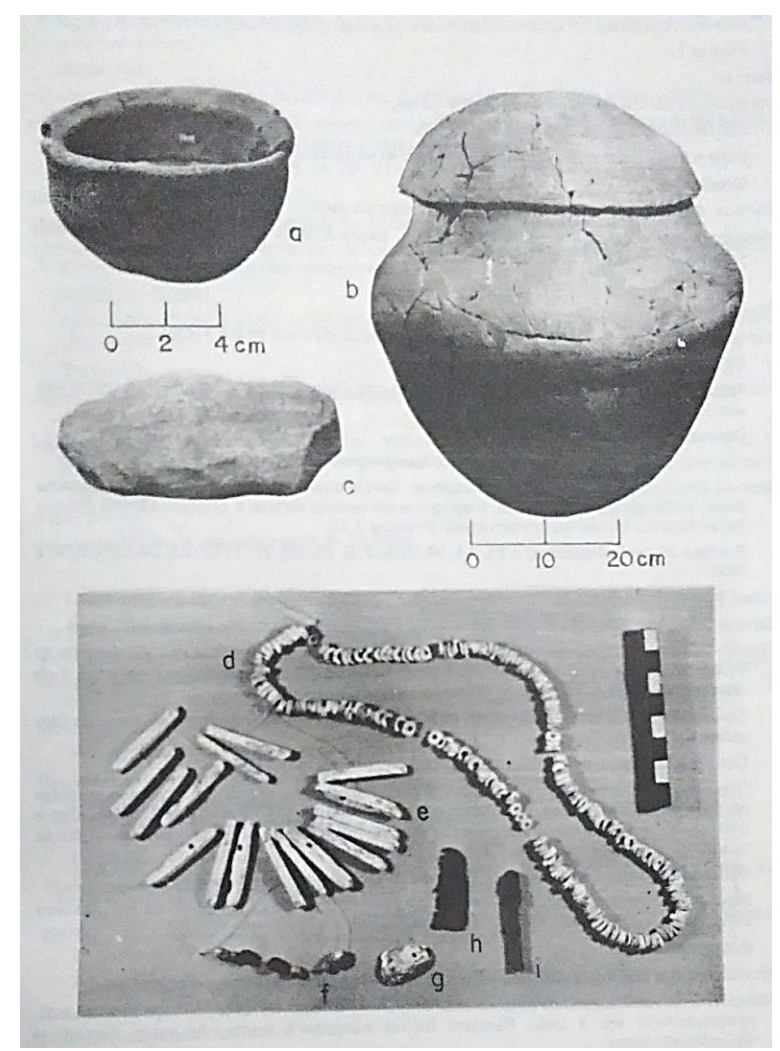

Figura 128: Artefatos encontrados em contexto funerário no sítio PR FI 148 (Caranguejeiras). B - Urna e tampa; A - vasilha funerária; C - Artefato lítico encontrado em contexto funerário; D - Contas de conchas; $\mathrm{E}$ - Contas de ossos; $\mathrm{F}$ - Contas de vidro; G - Concha; H - Pendente de Cobre; I - Vareta de ferro (os três últimos não encontrados no contexto funerário).

\subsection{3 - Sítios sem classificação em Tupinambá e Guarani}

\section{Sítio PR FO 24 (Ilha do Alemão 1)}

$\mathrm{Na}$ área da UHE Itaipu, Chmyz (1983), descreve outros contextos funerários. No sítio PR FO 24 (Ilha do Alemão 1), um sítio a 120m da margem esquerda do rio Paraná e a $80 \mathrm{~m}$ de um córrego, no município de Guaíra (PR), em suave elevação, 8m acima do nível do rio Paraná. As evidências arqueológicas do sítio ocupavam uma área elíptica de 300m X 180m (aprox. 42 mil metros quadrados), sendo o eixo maior paralelo ao rio. Era constituído por 5 manchas de terra preta (marrom-escura ou preta). Peças metálicas foram encontradas na área do sítio, sugerindo contato com o elemento europeu. O pacote arqueológico ocorria principalmente entre $10 \mathrm{~cm}$ e $35 \mathrm{~cm}$ de profundidade. $\mathrm{Na}$ periferia de duas das manchas de terra preta foram encontrados dois conjuntos funerários, um já impactado pela abertura de uma vala, e outro menos impactado, tendo sido este escavado. Uma urna de grandes dimensões continha um crânio e alguns 
fragmentos de ossos longos. No interior da urna e em seu entorno havia cacos de outras vasilhas. Quarenta centímetros a leste foi encontrada uma peça menor, com cacos de cerâmica de outras peças junto, e a um metro a oeste da urna com o esqueleto ocorreu outra vasilha, menor que a primeira e maior que segunda, coberta e cercada por fragmentos cerâmicos (alinhamento leste-oeste das vasilhas). As 3 vasilhas estavam enterradas em terreno arenoso compacto de coloração marrom-avermelhada, e estavam circundadas por seixos rolados. A planta do sítio e o croqui do contexto funerário (2) estão reproduzidas a seguir:

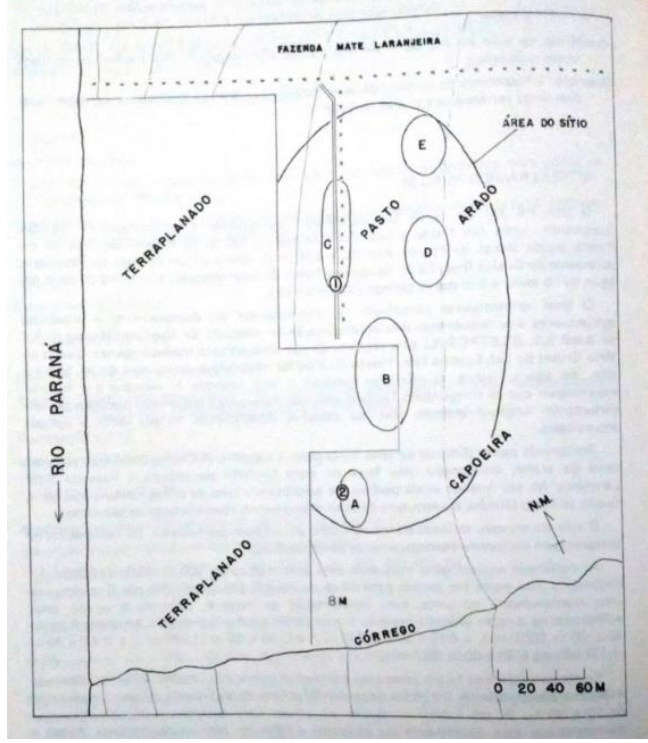

Figura 129: Planta do sítio PR FO 24 (Ilha do Alemão 1). A, B, C, D e E correspondem a manchas de terra preta com concentrações de material arqueológico. $\mathrm{O}$ número 1 indica $\mathrm{O}$ local onde estava um contexto funerário impactado, e o número 2 indica o contexto funerário escavado pelo autor. Fonte: Chmyz, 1983.

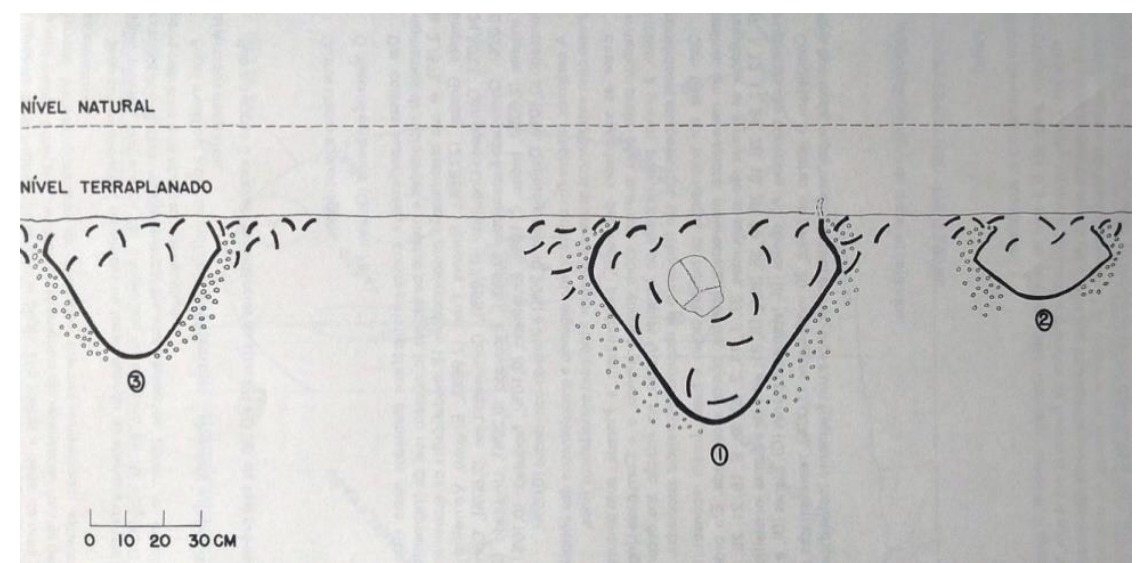

Figura 130: Contexto funerário escavado do sítio PR FO 24 (Ilha do Alemão 1), com o que o autor denomina conjuntos 1,2 e 3 , sendo que o 1 corresponde a uma urna com remanescentes humanos dentro. Fonte: Chmyz, 1983. 
Esses contextos são alguns dos poucos contextos funerários dentro de manchas de terra preta já encontrados e descritos. $\mathrm{O}$ acervo dos conjuntos que provavelmente compõem o contexto funerário, escavados onde o mapa identifica com número 2, descrito pelo autor, engloba:

Conjunto 1:

- Fragmentos de uma urna de $61 \mathrm{~cm}$ de altura, $57 \mathrm{~cm}$ de diâmetro da boca e $68 \mathrm{~cm}$ de diâmetro máximo. O tratamento de superfície é corrugado e ungulado no pescoço e escovado no restante.

- Fragmentos de crânio e outros ossos.

- Fragmentos de um recipiente pintado que estavam sob e ao redor do crânio.

- Fragmentos de um recipiente liso, que estavam sobre e ao lado da urna.

- Fragmentos de um recipiente corrugado.

- Fragmentos de um recipiente corrugado e ungulado.

- Poucos fragmentos de outros 2 recipientes corrugado e ungulado.

- Poucos fragmentos de 4 recipientes lisos.

- Outros poucos fragmentos de recipiente corrugado e com engobo vermelho.

- Fragmentos de um recipiente liso.

- Fragmentos de um recipiente escovado.

Conjunto 2:

- Fragmentos de um recipiente ungulado

- Fragmentos de um recipiente pintado na face interna, com forma de prato. A pintura são faixas vermelhas sobre fundo branco.

- Fragmentos de 4 recipientes corrugados e ungulados.

- Fragmentos de um recipiente escovado. 
Conjunto 3:

- Fragmentos de uma urna escovada na parte superior e corrugada do ombro até a base. A peça está incompleta, faltando a borda e parte do ombro. Até a quebra tem $47 \mathrm{~cm}$ de diâmetro.

- Fragmentos de um recipiente liso. Na face externa da base há impressões de cestaria.

- Fragmentos de 3 recipientes ungulados.

- Poucos fragmentos de 3 recipientes corrugados.

- Fragmentos de 3 recipientes lisos.

- Fragmentos de 2 recipientes pintados.

- Fragmentos de um recipiente corrugado e ungulado.

- Fragmentos de um suporte de panela.

\section{Sítio PR NL 7-Pesqueiro Barragem de Rosana}

Encontra-se na área da usina hidrelétrica de Rosana, no município de Diamante do Norte - PR. O sítio distava 30m da margem do Paranapanema e 90m de um pequeno riacho. Estava localizado em média/baixa vertente de suave elevação, $12 \mathrm{~m}$ de altitude acima do nível das águas do rio, em terreno elevado e a salvo de enchentes. O local pertencia à fazenda Sandra. Parte do sítio estava coberta por mata rarefeita, e parte estava desmatada e ocupada por pequena horta. A camada arqueológica ia até $35 \mathrm{~cm}$ de profundidade.

O sítio possuía 3 manchas de terra preta e 2 concentrações de material que se dispunham em elipse. A área era de $119 \mathrm{~m}$ x $67 \mathrm{~m}\left(6252 \mathrm{~m}^{2}\right)$, cujo eixo maior era em sentido perpendicular à margem do Paranapanema. A mancha 1, a central, media $13 \mathrm{~m} \times 5 \mathrm{~m}\left(51 \mathrm{~m}^{2}\right)$, e foi encontrada na estrada que levava a um pesqueiro. A mancha 2 , a leste, media $16 \mathrm{~m}$ x $9 \mathrm{~m}\left(113 \mathrm{~m}^{2}\right)$, e estava em área ocupada por horta. A 3 , medindo $12 \mathrm{~m} \times 7 \mathrm{~m}\left(65 \mathrm{~m}^{2}\right)$, localizava-se dentro da mata rarefeita. Além das 3 manchas, havia 3 pequenas áreas elípticas constituídas por areia cinza escura, que mediam em média $3,7 \mathrm{~m} \times 2,5 \mathrm{~m}$. Em uma dessas áreas foram evidenciados 2 fogões, que aprofundavam-se até $40 \mathrm{~cm}$. (Chmyz, 1984)

A norte do sítio foi localizada uma área fora de mancha de terra preta com evidências arqueológicas entre $15 \mathrm{~cm}$ e $20 \mathrm{~cm}$ de profundidade, que formavam um 
piso. Eram principalmente fragmentos de grandes urnas e pedaços de suportes de panelas ao lado dos cacos (ibidem, p. 38).

No lado sul do sítio foi evidenciada uma urna pequena, 2 recipientes pintados e uma vasilha corrugada-ungulada. Fragmentos das duas peças pintadas encontrava-se dentro da urna, o que leva o autor a inferir que servissem de tampa, mas pode ser que apenas tivessem sido depositadas dentro da mesma. A urna não continha ossos, e estava posicionada entre $15 \mathrm{~cm}$ e $40 \mathrm{~cm}$ de profundidade (não mais profundo que os outros vestígios do sítio, que estavam entre $10 \mathrm{~cm}$ e $20 \mathrm{~cm}$ fora das manchas e entre $15 \mathrm{~cm}$ e $35 \mathrm{~cm}$ dentro das mesmas). Porém, como o local do sepultamento fora perturbado pela abertura de uma vala para escoamento das águas pluviais (pois encontrava-se à margem da mesma), os ossos poderiam ter se perdido, e o contexto sido modificado.

Embora o contexto não esteja muito bem descrito, pode-se notar que o padrão de urna com vasilhas menores dentro se repete.

Na figura abaixo, há um croqui com a planta do sítio, feito por Chmyz. Nele podemos ver a disposição das manchas e a localização do contexto funerário em relação a elas.

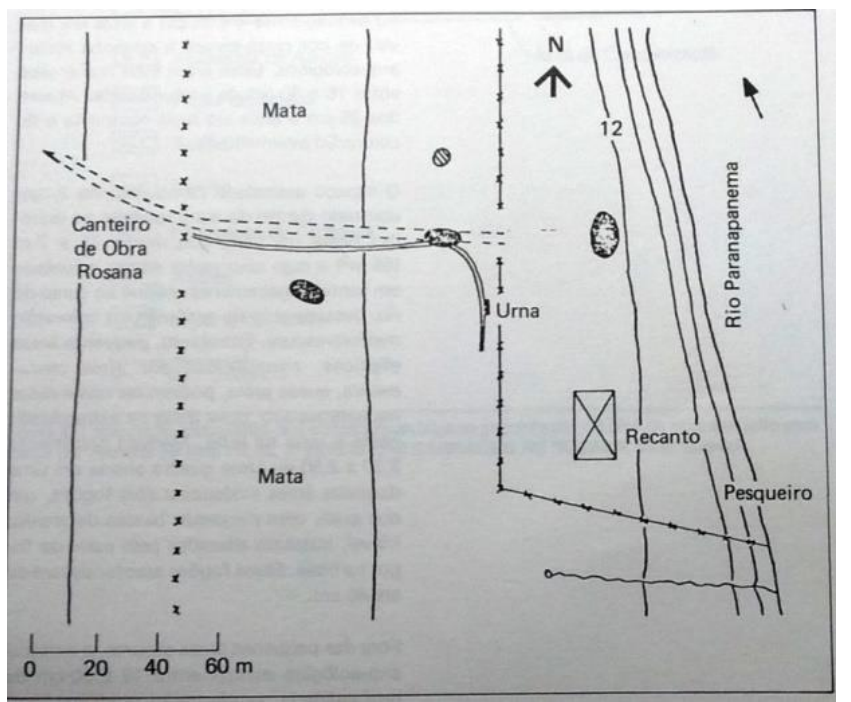

Figura 131: Croqui do sítio PR NL 7 - Pesqueiro Barragem de Rosana, desenhado por Chmyz. As elipses pintadas representam as manchas de terra preta; a elipse hachurada representa a concentração de material arqueológico a norte; e a o retângulo representa a posição do possível conjunto funerário. Fonte: Chmyz, 1984. 


\section{SP SG 9 - Hotel Uselpa 2}

Estava localizado entre a margem do rio Paranapanema e o, na época, hotel da USELPA. Nesse local, em 1965, devido ao rebaixamento do nível da represa, foi realizado o registro do sítio e uma coleta do material arqueológico exposto. Foi encontrada uma urna com tampa, e uma vasilha ao lado desta urna, enterrada, que começou a ser evidenciada na altura da carena da mesma. O autor coloca que a vasilha parece uma urna em miniatura.

Esse conjunto funerário foi retirado em 1955, por Ernest Mann, morador da cidade paulista de Salto Grande, quando já se formava o reservatório da UHE Salto Grande. Estava entre a margem do rio Paranapanema e o hotel da USELPA. Nesse local, em 1965, devido ao rebaixamento do nível da represa, foi realizado o registro do sítio e uma coleta do material arqueológico exposto. O conjunto, guardado na residência do descobridor, foi, então, transferido para o acervo do CEPA/UFPR [...]. (CHMYZ, 2002)

A urna situava-se a cerca de 50m da antiga margem do Paranapanema. Hoje em dia o local é totalmente submerso pelas águas do reservatório de Salto Grande. (Morais, 1997) Coordenadas UTM: $\mathrm{E}=602550,00 \mathrm{~N}=7466880,00$.

\section{Sítio PR SE 3 - Vitorino 3}

Pesquisado em 1973, no município de São José da Boa Vista. O resgate arqueológico foi motivado pelo achado acidental, 8 dias antes, de 2 conjuntos funerários.

A primeira urna, impactada pelo arado, continha restos ósseos humanos bem conservados e, por isso, foi levada pelo proprietário do terreno para a delegacia de polícia do município. Havendo suspeita de crime, instaurou-se o competente inquérito policial. Os presos, ameaçando rebelião, exigiram que a urna fosse deixada do lado de fora da delegacia. Tomando conhecimento do fato, o Prof. Joaquim Gil, historiador em Wenceslau Brás, identificou-a como peça arqueológica. Encerrado o inquérito, a peça foi guardada provisoriamente em sua garagem.

A segunda urna foi encontrada em seguida, em ponto situado a $24 \mathrm{~m}$ ao sul da anterior e, também, em consequência do uso do arado com maior capacidade de penetração no solo. Encontrando-se em profundidade maior do terreno, a peça foi retirada em pedaços; estes foram coletados posteriormente em torno do buraco e ao lado da casa do proprietário. Apesar do atendimento quase imediato, as pesquisas não detectaram restos ósseos humanos junto ao local perturbado. Ambos os conjuntos foram incorporados ao acervo do CEPA/UFPR [...]. (Chmyz, 2002) 
Além das urnas, que foram encontradas no centro do sítio, havia nesse espaço estruturas referentes a 4 bases de habitações em meio à terra preta.

A tampa de uma das urnas foi constatada pelos agricultores a mais ou menos $40 \mathrm{~cm}$ de profundidade. Estava na terra avermelhada, abaixo da camada arqueológica, cuja coloração era marrom-escuro. Ossos haviam sido retirados do interior da urna, fazendo com que o autor considerasse inviável a avaliação da prática funerária. Os ossos restantes ainda eram numerosos, incluindo crânio, mandíbula, vértebras, tíbias, etc. Correspondem a um indivíduo adulto, de idade avançada, segundo Chmyz. Ele também averiguou que os dentes estão ausentes,

apresentando, nos alvéolos da mandíbula, reabsorção óssea. Externamente, ao lado da urna e abaixo da borda da tampa, foi encontrado um pequeno recipiente decorado que estava sem base.

\section{Sítio PR NA 1 - Fazenda Água da Fartura}

Localizado no município de Santana do Itararé. O conjunto funerário também foi encontrado por agricultores. Ao redor desse conjunto, as pesquisas arqueológicas de Chmyz delimitaram 3 espaços elípticos assinalados por terra de coloração preta e abundante material arqueológico. A descoberta do contexto funerário se deu porque uma roda do trator passou sobre a tampa da urna, que se quebrou, fazendo a roda afundar. A urna foi retirada, estando intacta e contendo pouco sedimento em seu interior, restos ósseos humanos e 3 recipientes pequenos. Tudo foi guardado no paiol da fazenda. A urna permaneceu exposta na propriedade, sendo apreciada por dezenas de pessoas. Depois foi levava ao CEPA e, posteriormente, foi exposta no então Museu de Arqueologia e Artes Populares de Paranaguá.

Ao chegar no local da descoberta do conjunto funerário, o buraco feito pela extração da peça ainda estava aberto. Chmyz coletou os fragmentos da tampa e observou que a terra até $40 \mathrm{~cm}$ de profundidade era de coloração alaranjada e friável. Já na periferia do buraco a terra tinha coloração marromavermelhada e era compacta. (Chmyz, 2002) 


\section{Sítio SP IP 8 - Cemitério do Renato}

Em 1966, durante o projeto arqueológico Itararé, Chmyz registrou sítios com montículos alongados de terra alaranjada, alguns contendo urnas ou fragmentos perturbados. Este sítio em especial teve um de seus aterros, que estava intacto, escavado, revelando uma urna tampada. A porção superior do conjunto funerário estava um pouco acima da superfície do terreno, e encontrava-se protegida pelo aterro. No interior da urna, juntamente com sedimentos úmidos, havia ossos humanos. A tampa estava trincada, deixando passar sedimento e umidade. No aterro, acima do conjunto funerário, havia fragmentos de diversas vasilhas. (Chmyz, 2002)

\section{Sítio SP IP 9 - Cemitério do Espanhol}

Era $3 \mathrm{~km}$ distante do anterior, localizado no município de Riversul - SP. Também apresentava aterros, porém havia sido bastante danificado. Junto aos aterros desmontados também havia fragmentos de grandes recipientes cerâmicos. Moradores locais costumavam retirar urnas dos aterros para usá-las como potes para arroz. O conjunto funerário foi retirado de um dos aterros em 1962, e permaneceu guardado na casa de um dos agricultores. O conjunto é formado por uma urna pintada e uma tigela simples. No recipiente principal falta uma porção da borda. (Chmyz, 2002)

\subsection{Discussão: as continuidades e descontinuidades dos Guarani e Tupinambá}

A sistematização dos dados sobre contextos funerários das regiões do Paranapanema e alto Paraná foi extremamente difícil, pois havia muita fragmentação de informações, muitas informações básicas faltando, critérios diferentes em relação ao que seja um contexto funerário, objetivos e protocolos de escavação diferentes. Isso levou a uma amostragem de apenas 16 contextos certamente funerários cujo material disponível nós analisamos.

Mesmo assim, foi possível tirar várias conclusões sobre as práticas funerárias. Essas conclusões devem ser melhoradas com o tempo e pesquisas contextuais mais focadas, nas quais os critérios de análise do contexto e a acurácia das escavações sejam mais rígidos e unificados. 
A análise dos contextos funerários e materiais que aparecem neles demonstra que as práticas funerárias dos Tupinambá e Guarani possuem - ao menos nessa região do Paranapanema, alto Paraná, São Paulo e Rio de Janeiro continuidades e descontinuidades, como se cosmologias com vários elementos comuns estivessem sujeitas a distintas interpretações e manifestações materiais, mas que mesmo assim mantivessem certos padrões.

Igualmente, cerâmicas com morfologias parecidas entre vários sítios - como as nhaempepó do alto Paranapanema, noroeste de São Paulo, município de Salto e município de Araruama no Rio de Janeiro - demonstram que algum tipo de transmissão de conhecimentos, ocorrida em algum momento (ou vários), levou a essas morfologias parecidas, e o seu emprego funerário certamente fazia parte de uma gama de valores e aspectos simbólicos comuns. Porém, se por um lado as morfologias são muito parecidas, os tratamentos de superfície externa podem variar: as do alto Paranapanema analisadas são todas corrugadas; enquanto as do noroeste de São Paulo e do Rio de Janeiro podem ser ou inteiramente corrugadas, ou ter o corrugado associado a outro tratamento (como escovado ou liso).

As fontes etnohistóricas trazem uma grande quantidade de práticas funerárias, mas fazem parecer que algumas, como o sepultamento em urna, são idênticas entre Guarani e Tupinambá. Mas o registro arqueológico parece demonstrar que não o são. Na região do Paranapanema, cerâmicas funerárias estão relacionadas a contextos e a uma espacialidade dos mesmos no sítio, e também a padrões de assentamento, que formam distinções bem marcadas entre os sítios Guarani e Tupinambá. Essas distinções existem paralelamente com as semelhanças (continuidades).

Entre as continuidades, o sepultamento em vasilhas com tampas é uma prática que se repete, sendo uma base entre os gestos funerários tanto de grupos Guarani quanto Tupinambá. A necessidade de se cobrir a cabeça do indivíduo com uma vasilha parece ser um dos fundamentos dessas práticas. A partir dessa base, há as variações nos tipos e morfologias de urnas e tampas. Há também as variações nos contextos funerários, ou seja, nos gestos realizados em relação aos mortos, com a presença ou não de vasilhas anexas. 
Tanto em sítios Guarani quanto Tupinambá há o emprego de vasilhas de tipo yapepó/nhaempepó e cambuchí/camuci como urnas funerárias, o que é uma continuidade entre os dois grupos. As primeiras são predominantes, empregadas em maior número que as segundas. Mas há também o emprego de vasilhas abertas como urnas. Nos sítios Guarani, há também o emprego de cambuchí caguabá e yapepó boya como urnas funerárias (e prováveis urnas), e no sítio Tupinambá do Itaguá houve o emprego de uma nhaem.

Em termos de morfologias cerâmicas, espessuras e morfologias de bordas e tratamentos de superfície, os sítios Tupinambá são bem mais padronizados que os Guarani, havendo uma repetição de uma mesma morfologia de urna em quase todos os contextos funerários entre os primeiros, e uma maior variabilidade nas morfologias entre os segundos.

O Alves - o sítio Guarani mais próximo cronologicamente dos sítios Tupinambá do alto Paranapanema, havendo a possibilidade de ter havido convivência entre pessoas que o habitaram e que habitaram o sítio Fonseca representa uma exceção, possuindo uma cerâmica Guarani e padrões na espacialidade funerária mais parecidos com outros sítios Guarani, enquanto que as morfologias de urnas são bastante semelhantes entre si, que é uma característica que aparece nos sítios Tupinambá.

As vasilhas anexas empregadas principalmente nos sítios Guarani são de variadas classes, formas e tratamentos de superfície.

Com relação aos padrões de assentamento dos sítios principais e secundários analisados, podemos notar que ao longo do Paranapanema há diferenças bem marcadas. Os sítios Tupinambá do alto curso se localizam em topos ou partes altas de colinas, próximos a um rio de menor porte, e os sítios Guarani do baixo curso desse rio e do alto rio Paraná se localizam na ou próximo à margem de rios de grande porte. Porém, há exceções a esse padrão, que são o sítio Alves/Nunes - que segue o "padrão Tupinambá" - e o sítio Salto Grande do Paranapanema - que segue o "padrão Guarani", mostrando que há a possibilidade de haver os dois tipos de padrões de assentamento entre Guarani e Tupinambá. 
No caso do sítio Alves, em que a ocupação Guarani em topo de morro distante de rios de grande porte parece ter sido contemporânea às ocupações Tupinambá, parece ter havido uma continuidade entre Guarani e Tupinambá nesse padrão de assentamento, sugerindo que não havia necessariamente diferentes escolhas em relação às áreas de ocupação entre diferentes grupos contemporâneos produtores de cerâmicas diferentes. As datas existentes para os sítios demonstram que as pessoas que constituíram e habitaram os sítios Fonseca e Alves podem ter tido até mesmo contato entre si. No entanto, outros grupos Guarani um pouco mais recentes ou de regiões mais distantes, como o alto Paraná, fizeram escolhas diferentes dos padrões de assentamento, ocupando as margens de grandes rios, demonstrando uma descontinuidade entre os Guarani e os Tupinambá do Paranapanema nesse sentido.

Além desses elementos que caracterizam sítios Tupinambá e Guarani, a espacialidade funerária também é diferente entre os sítios dos dois grupos para essa região do Paranapanema. Os contextos, ou seja, a espacialidade das vasilhas em cada contexto, é em geral diferente nos sítios Guarani e Tupinambá, pois nos segundos predomina urnas e tampas no contexto - embora haja contextos diferentes disso - e nos primeiros houve o emprego de vasilhas dentro e/ou fora de urnas, inclusive grandes vasilhas ao lado de urnas. Nesses últimos, não foi possível saber se se tratavam de sepultamentos duplos, se eram dois sepultamentos realizados em momentos diferentes mas muito próximos, ou se era um único sepultamento com grandes vasilhas ao lado.

Se nos Tupinambá havia o emprego de vasilhas, elas eram ou de material perecível na maior parte dos casos, ou foram retiradas após certo tempo, o que demonstra gestos diferentes em relação aos Guarani de qualquer maneira.

Não estamos querendo dizer que esse padrão é o mesmo em todos os lugares, pois nos contextos funerários dos Tupinambá do Rio de Janeiro, região de Araruama, de acordo com Buarque (2009, 2016), eram empregadas vasilhas fora das urnas e também dentro. Mas no Paranapanema há essa distinção.

A espacialidade dos contextos na área do sítio também é diferente entre Guaranis e Tupinambás, sendo que os primeiros podiam fazer sepultamentos mais concentrados em um setor do sítio, e os segundos tendiam a fazer os sepultamentos 
mais dispersos. Entretanto, a espacialidade dos contextos no sítio é uma variável que pode mudar bastante de acordo com contingências históricas. Por exemplo, o aumento da mortalidade, várias pessoas morrendo num tempo próximo, pode levar a um aumento da densidade de sepultamentos, como sugere Buarque para o sítio São José, que é um sítio Tupinambá com sepultamentos muito próximos entre si.

A análise dos remanescentes humanos e de informações sobre remanescentes humanos em outros sítios traz a informação de que ambos os sexos e várias faixas etárias podiam ser sepultadas em urnas: crianças, adultos masculinos e femininos. Entre os indivíduos que analisamos, havia pelo menos 1 mulher entre 20 e 25 anos, um homem entre 35 e 50, outro homem entre 50 e 55 ou mais, e outro homem de idade indeterminada. Mas entre esses 4 indivíduos, só sabemos que a mulher e 1 homem foram sepultados em urna, para os outros não há maiores informações. Mesmo assim, esse homem sepultado em urna, do sítio Panema, está em um contexto bastante intrigante, em que gestos aparentemente não muito comuns ocorreram e as datas do esqueleto e da urna são muito discrepantes, o que poderia sugerir que esse sepultamento em urna Tupinambá é atípico.

Há o relato do sepultamento feminino de idade entre 20 e 25 anos do sítio Bananeiras (Araruama - RJ), e o relato de sepultamentos infantis no sítio Itororó (Pirapozinho - SP). No sepultamento do sítio Bananeiras a mulher estava dentro de urna. E no sítio Itororó duas crianças estavam dentro de urnas, sendo ambas provavelmente neonatos, e uma estava fora de urna, com uma vasilha sobre a cabeça, com idade entre 4 e 6 anos. Um dos neonatos e a criança mais velha estavam sepultados um ao lado do outro.

Portanto, vemos diferentes idades e sexos sepultados em urna - e também fora o que contradiz a proposta de que apenas um único tipo social era sepultado em urna.

O levantamento de descrições e fotos de contextos funerários Tupinambá e Guarani trazem alguns tipos de contextos e possíveis contextos funerários que já foram encontrados pela Arqueologia. Não há como saber no momento o significado de cada um desses tipos de contextos, se eram realizados para pessoas sociais diferentes ou se eram simplesmente épocas e grupos diferentes, ou gestos pós-funerários. Mas, num mesmo sítio, há diferentes tipos de contextos - apenas urna e tampa, urna com outras vasilhas ao lado, diferentes tipos de urnas -, o que indica que essa variedade se dá no nível local, do sítio. 
Quadro 12: Tipos de contextos funerários Tupinambá e Guarani que já foram escavados

\begin{tabular}{|c|c|c|}
\hline $\begin{array}{c}\text { Associados a cerâmica } \\
\text { Guarani }\end{array}$ & $\begin{array}{c}\text { Associados a cerâmica } \\
\text { Tupinambá }\end{array}$ & Associados a ambas \\
\hline 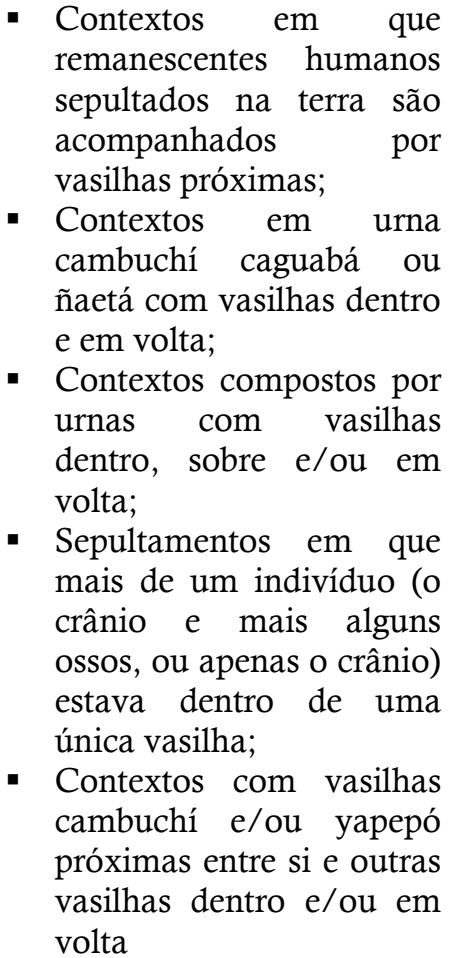 & $\begin{array}{l}\text { - Contextos com uma } \\
\text { "cama de argila" sob a } \\
\text { urna; } \\
\text { - Contextos compostos por } \\
\text { urna, tampa e vasilhas em } \\
\text { volta, posicionadas com a } \\
\text { boca virada para a lateral } \\
\text { da urna; } \\
\text { - Contextos em que uma } \\
\text { nhaempepó estava } \\
\text { posicionada sobre a outra }\end{array}$ & $\begin{array}{l}\text { - Contextos compostos por } \\
\text { apenas urna e tampa; } \\
\text { - Contextos com duas ou } \\
\text { mais tampas sobre a urna; } \\
\text { - Contextos com urnas } \\
\text { pequenas demais para se } \\
\text { caber um adulto em } \\
\text { sepultamento primário; } \\
\text { - Contextos em que a urna } \\
\text { possuía vasilhas apenas } \\
\text { dentro, e não em volta } \\
\text { - Contextos em que } \\
\text { fragmentos de vasilhas } \\
\text { foram usados como tampa; } \\
\text { - Sepultamentos com } \\
\text { materiais trazidos pelo } \\
\text { europeu associados; }\end{array}$ \\
\hline
\end{tabular}

Além do sepultamento em urna, praticado por Guarani e Tupinambá, sabese que ambos praticavam sepultamento fora de urna cerâmica também, mas só encontramos sepultamentos fora de urna associados a cerâmicas Guarani. Outro ponto a ser ressaltado é que houve a escavação e registro de um maior número de contextos Guarani, enquanto que os Tupinambá estão restritos às escavações no Rio de Janeiro. Por isso, é natural que haja maior variedade de tipos de contextos funerários Guarani, por causa da questão amostral.

Além das continuidades e descontinuidades que podem ser notadas entre Guarani e Tupinambá, há também aquelas que podem ser notadas dentro do Tupinambá e do Guarani.

Entre os sítios Guarani analisados as diferenças mais evidentes são aquelas entre o sítio Alves e o Aguinha e Pernilongo, e também o MT-IV-1. No Alves, as vasilhas empregadas como urnas são bastante padronizadas, se assemelhando aos sítios Tupinambá, e o padrão de assentamento também se assemelha aos mesmos e difere dos outros sítios Guarani do Paranapanema. Já no Aguinha e no Pernilongo, há uma grande variedade de morfologias de vasilhas. No Aguinha, Pernilongo e no 
MT-IV-1 há a presença de grandes vasilhas e vasilhas médias ao lado uma da outra, enquanto no Alves vasilhas menores foram encontradas apenas dentro e sobre grandes vasilhas.

Também entre os sítios Tupinambá analisados há diferenças. Os sítios do alto Paranapanema apresentam vasilhas com tampas, urnas uma sobre a outra, ou urna com vasilhas dentro. Já os contextos do Rio de Janeiro, no município de Araruama, além de apresentarem essa configuração, também podem ter urnas com vasilhas em volta, com as bocas das vasilhas posicionadas na direção das paredes da urna. No Rio de Janeiro também há a presença de vasilhas quadrangulares em contexto funerários, bem como uma grande quantidade de vasilhas pintadas, o que não ocorre no alto Paranapanema.

No caso do sítio Morro Grande (Tupinambá-RJ), foram obtidas datas

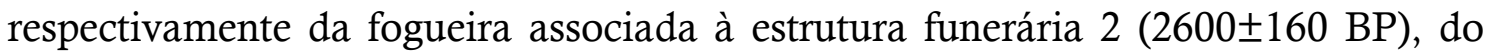

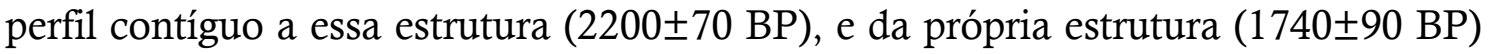
(Buarque, 2016). A data do sepultamento pode indicar que, em comparação com os do sítio Fonseca, esse pode ser anterior (embora as datas para o Fonseca não sejam dos contextos funerários). Isso poderia indicar que a diferença se dá por causa de mudanças diacrônicas nas práticas funerárias, que é uma variável que pode causar essa diferença nas práticas. Mas não há como ter certeza, pois a cronologia dos sepultamentos do Fonseca pode não estar correta. Já no sítio Bananeiras, a data do sepultamento foi de $430 \pm 40 \mathrm{BP}$, o que também pode indicar variação diacrônica em relação ao Fonseca. A urna do Bananeiras tem uma morfologia bem diferente das do Fonseca, outro elemento que poderia indicar mudança diacrônica.

A fragmentação das informações dificulta o diagnóstico de mais diferenças dentro do Tupinambá e do Guarani, mas provavelmente há mais. Se o cenário for de uma base comum na qual certos elementos são interpretados e aplicados de maneira diferente nas práticas funerárias, isso geraria diferenças sutis (ou não tanto) nos contextos funerários.

Portanto, os dados que analisamos sugerem que a variabilidade dos contextos funerários entre grupos Tupinambá e Guarani é constituída por continuidades e descontinuidades, elementos comuns, similaridades em termos cosmológicos, similaridades nas morfologias de vasilhas em alguns casos, porém, 
também por elementos distintos, que caracterizam grupos Guarani e Tupinambá (ao menos na região do Paranapanema) e caracterizam diferentes sítios Guarani e Tupinambá.

Como as práticas funerárias seriam representativas da estrutura social e do ser Guarani e Tupinambá, quais as mudanças diacrônicas, ou que outras regionalidades há, são questões ainda em aberto. 


\section{Capítulo VI \\ CONCLUSÕES}

Esta dissertação, que acabou tendo um caráter um tanto experimental, buscou entender a variabilidade dos contextos funerários e das cerâmicas funerárias de sítios associados a grupos que habitaram a região das bacias do Paranapanema e Alto Paraná. Ela acabou mostrando uma série de contextos diferentes, que apresentavam continuidades e descontinuidades, e reunindo práticas funerárias cotejadas de fontes etnohistóricas, demonstrando que as práticas em relação aos mortos dos grupos Tupi-Guarani são muito mais complexas do que o tradicional "urnas cobertas por tampas".

Neste capítulo, iremos retomar e expandir algumas das discussões feitas ao longo da dissertação.

\subsection{Os grupos Guarani e Tupinambá da região do Paranapanema}

Os dados analisados sugerem a existência de dois grandes grupos falantes de línguas distintas na área do Paranapanema: Guarani e Tupinambá, conforme defendido por Noelli (1993) e Corrêa (2014). A associação da cerâmica aos falantes dessas duas línguas, proposta por Brochado (1984) e defendida por esses autores, é complementada por outro elemento: continuidades e descontinuidades nas práticas funerárias.

Como descontinuidades, diferenças entre os Guarani e Tupinambá, temos uma série de elementos. Nos sítios com cerâmica Tupinambá dessa região, Fonseca e Prassévichus, as urnas funerárias piriformes corrugadas são encontradas, na maioria dos casos analisados, sozinhas com a vasilha que servia de tampa as cobrindo. Em um contexto foram encontradas duas nhaempepó piriformes uma sobre a outra, e no outro uma nhaempepó possuía vasilhas dentro, mostrando que a padronização não era total. Entretanto, se observarmos a maioria dos contextos juntamente com características morfológicas das vasilhas, encontramos uma padronização em termos de morfologias, tratamentos de superfície, formas e espessuras de bordas, e na espacialidade dos contextos muito maior quando comparada aos sítios com cerâmicas Guarani. 
Já nos sítios Guarani, Alves, Aguinha, Pernilongo e Lagoa São Paulo 2, as urnas funerárias são encontradas, na maior parte dos casos, com, além das tampas, vasilhas dentro e/ou em volta (ao lado da urna). Além disso, as morfologias, bordas e tratamentos de superfícies das urnas funerárias e possíveis urnas são mais variadas nesses sítios.

A espacialidade dos contextos funerários na área dos sítios também difere. Nos Tupinambá, eles estão mais dispersos pela área do sítio, enquanto nos Guarani há a presença de alguns contextos próximos uns dos outros, bem como contextos concentrados em um setor.

Essas diferenças, combinadas, acrescentam argumentos a favor de distinções entre as práticas funerárias de grupos Guarani e Tupinambá dessa região. Porém, elas ocorriam paralelamente com continuidades. As mesmas classes de vasilhas eram empregadas como urnas - cambuchí/camuci e yapepó/nhaempepó. Em ambos os grupos ao menos algumas vasilhas possuíam marcas de que tiveram outros usos. A análise das fontes etnohistóricas sugere que essas marcas não tenham sido feitas por gestos funerários. Além disso, grupos Guarani e Tupinambá praticavam sepultamentos tanto dentro de urna quanto fora até o século XVII pelo menos.

A análise da cronologia dos sítios sugere que o Fonseca (Tupinambá) e o Alves (Guarani) tenham tido ocupações durante períodos coincidentes, e como ambos ficam em regiões não muito distantes no alto Paranapanema, é possível que tenha havido contato entre seus habitantes. O sítio Alves, com morfologias e tecnologias cerâmicas Guarani, apresenta, além da cronologia, outras similaridades com os sítios Tupinambá da região: padrão de assentamento e morfologias das urnas parecidas entre si (mas diferentes das Tupinambá). Comparado com os outros sítios Guarani posteriores - Aguinha e Pernilongo - ele é um tanto diferente. Seria uma coincidência? Ou haveria algum tipo de contato que gerou influências mútuas? Análises futuras, de todo o material dos sítios, poderiam trabalhar melhor essa questão.

Além dessas diferenças entre os Tupinambá e Guarani, há também diferenças dentro do Tupinambá e do Guarani. Como dissemos, o sítio Alves apresenta um padrão de morfologias de cerâmicas funerárias e de padrão de assentamento diferente dos outros sítios Guarani analisados. As datas sugerem que 
essas diferenças estão relacionadas a mudanças diacrônicas. No sítio Aguinha, as vasilhas funerárias e possivelmente funerárias são mais padronizadas - em termos de classe de vasilha - do que as do Pernilongo, embora existam duas datações similares para os sítios.

Já entre os contextos Tupinambá, os do alto Paranapanema não apresentam vasilhas em volta, e os da região de Araruama possuem (embora não todos). Nesses casos, as datas também sugerem relação entre essa diferença e mudanças diacrônicas. No entanto, a questão da padronização das vasilhas Tupinambá retorna: os contextos de Araruama também apresentaram a nhaempepó piriforme como forma recorrente entre as urnas e prováveis urnas. Isso sugere uma continuidade no uso dessa forma como urna funerária por vários séculos e em diferentes regiões.

Portanto, a análise das regionalidades Tupi é bastante útil para uma melhor compreensão das práticas funerárias, pois traz a tona aspectos que só podem ser recuperados através de um levantamento regional de contextos.

Essa variabilidade morfológica associada a diferentes línguas nessa região pode ser justificada através dos argumentos de Dias (2007), Silva (2007, 2009) e Silva \& Noelli (2017). Escolhas técnicas são produções sociais que expressam e definem identidades, e as técnicas são socialmente aprendidas através de sistemas de ensino-aprendizagem, nos quais a língua pode ser um facilitador e promotor dessa transmissão. Assim, as similaridades entre as cerâmicas de diferentes sítios são fruto dessa transmissão de conhecimentos. Já as diferenças morfológicas mais sutis entre as cerâmicas funerárias dos sítios Guarani e Tupinambá, como as diferenças entre a cambuchí do sítio Alves e as do sítio Pernilongo, por exemplo, seriam fruto de diferentes formas de apropriação desse conhecimento transmitido. A variabilidade artefatual se dá por múltiplos fatores, pragmáticos, simbólicos, decisões individuas, diferenças no ensino-aprendizagem, fatores relacionados à organização social, à cosmologia e a contingências históricas.

De modo semelhante, o emprego diferenciado de vasilhas funerárias - ou seja, o uso de diferentes tipos de tampa, de diferentes morfologias de urna, diferentes morfologias de vasilhas anexas - pode também estar ligado a variações ligadas a diferentes escolhas relativas à organização social, a fatores de ordem 
simbólica e prática, e a contingências históricas. Essas variações seriam geradas por modos particulares de se interpretar e proceder com as práticas e rituais funerários. Essas interpretações distintas poderiam variar entre os diferentes grupos, submetidos a diferentes histórias, como parece ter ocorrido entre os Guarani do século XX analisados no capítulo IV. Mas mesmo com todas as variações há uma base comum, tanto dentro do Guarani e do Tupinambá quanto entre ambos, que pode ser visualizada através das continuidades no registro arqueológico funerário, e de gestos que se repetem desde o século XVI até o XX.

A análise dos contextos combinada com a das fontes etnohistóricas sugere que as práticas funerárias desses grupos estão sujeitas a mudanças sim, mas também há bases que são mantidas, tanto ao longo do tempo quanto entre grupos diferentes.

Se, como escreveu Silva (2007), a variabilidade artefatual pode ser um índice de fronteiras e relações sociais, usada para representar e construir identidades, a análise das características regionais de cerâmicas e contextos funerários pode trazer novas questões sobre possíveis diferentes grupos ou sobre mudanças no mesmo grupo, ou seja, sobre identidades em uma região. Entendendo, é claro, essas identidades como fluidas e circunstanciais, não fixas e imutáveis (Silva \& Noelli, 2017.

Já vimos, através da análise das fontes etnohistóricas, que dentro do Guarani, talvez até mesmo dentro do Tupinambá, grupos falantes das mesmas línguas possuem práticas funerárias que podem ser ligeira a radicalmente diferentes entre si, dependendo da história de cada grupo. Há os Guarani Mbyá, Nandéva e Kayová, que apresentam práticas funerárias ligeiramente diferentes, embora os tipos de sepultamentos sejam os mesmos (Schaden, 1962) e os grupos chamados de Guayakí, que apresentam práticas radicalmente diferentes em grupos diferentes dentro do grande grupo Guayakí (Susnik, 1983).

No sítio Guarani Alves, teriam habitado os mesmos Guarani do Aguinha e Pernilongo, mesmo com as datações alguns séculos mais antigas, e os padrões funerários dos sepultamentos em urna ligeiramente diferentes? E os Tupinambá do Paranapanema seriam os mesmos do Rio de Janeiro? É nesse sentido que acreditamos que as diferenças dentro do Tupinambá e do Guarani poderiam ser pensadas. 


\section{2 "Urnas funerárias"}

As chamadas urnas funerárias sempre foram um dos elementos que levaram os arqueólogos a deduzirem grupos Tupi e estabelecer relações entre eles. Almeida (2013) afirma que, grosso modo, é na combinação cerâmicas policrômicas com sepultamentos secundários em urnas que residia a base da analogia feita por Brochado e Lathrap entre a cerâmica da Tradição Policroma Amazônica e a dos Tupi-Guarani. A existência dessa combinação tanto na Tradição Policroma quanto nas cerâmicas associadas a grupos Tupi-Guarani teria sido um elemento importante na associação feita pelos autores.

As urnas funerárias também são um dos objetos mais abundantes na América do Sul, aparecendo em vários contextos. Entretanto, cada contexto deve ser considerado em suas particularidades. Rapp Py-Daniel (2015) argumenta que os contextos em que elas aparecem são muito diferentes, sendo utilizadas pelos mais diversos grupos, sejam Tupi, Jê, etc. Mas dizer que, por praticarem sepultamento em urna, esses grupos tinham contato, ou que tinham alguma origem comum, não acrescenta muito para a compreensão sobre as diferentes pessoas que possuíam essas práticas funerárias. Essa abordagem está cada vez mais rara nas pesquisas arqueológicas, mas por muito tempo ela foi muito utilizada.

Uma alternativa é analisar a tecnologia cerâmica juntamente com a história de vida dessas vasilhas funerárias. A análise de características técnicas e morfológicas e de estilo das vasilhas poderia trazer as diferenças nos conjuntos artefatuais. E a análise da história de vida dos artefatos poderia ajudar a verificar os diferentes usos que tiveram e as diferentes condições em que foram confeccionadas. Assim, se poderia ver, por exemplo, se uma vasilha foi feita exclusivamente para o funeral ou se passou por outros usos antes.

No caso das vasilhas dos Tupinambá e Guarani do Paranapanema, em sítios relacionados a ambos foram encontradas urnas e vasilhas anexas com marcas de abrasão. As tampas estavam fragmentadas demais para a análise. Essas marcas sugerem outros usos além do funerário, pois apenas a deposição no contexto funerário não poderia gerar marcas de abrasão como essas. Existe, é claro, a possibilidade de algumas das marcas de abrasão terem se formado durante os rituais e festins que acompanham os funerais. Mas será que esse tipo de uso seria 
suficiente para gerar todas as marcas? Há indícios de que as vasilhas eram antes utilizadas no cotidiano, em contextos domésticos. Mais estudos das marcas de uso poderão trazer mais propostas e questões nesse sentido.

A análise das marcas de uso sugere que as vasilhas funerárias do Paranapanema possuem uma história de vida composta pelo menos por 5 estágios: aquisição das matérias primas, confecção, usos não funerários, usos funerários, deposição no contexto funerário. Trata-se de uma história de vida diferenciada da de outros artefatos não funerários, ou não rituais, conforme as considerações feitas por Walker $(1995,2001)$. Entretanto, ao contrário do que escreveu esse autor, não acreditamos que os aspectos comportamentais do ritual funerário sejam os únicos relevantes e importantes, pois os aspectos simbólicos igualmente o compõem e guiam as ações e práticas. Então, não consideramos os artefatos de contextos funerários como lixo cerimonial (ceremonial trash).

Além do mais, como coloca Holtorf (2002), o descarte final pelo grupo não é o final da história de vida do artefato. A longa historia de vida abrange tanto sua fabricação, usos, descarte, recuperação por atores diversos (arqueólogos, pessoas da comunidade local, etc.) quanto os seus usos e significados posteriores a essa recuperação, que podem ser os mais variados. A história de vida de um artefato não acaba com seu descarte, ela continua na pesquisa arqueológica, nas múltiplas interpretações dadas a ele.

Segundo esse autor as suas próprias características materiais dos artefatos não são fixas, elas variam conforme a época e o observador. Uma cerâmica é uma cerâmica para nós, mas não o é, necessariamente, para todos. As características materiais, ou seja, a identidade de um objeto, não são fixas, e sim negociadas em diferentes circunstâncias sociais. A materialidade de um objeto não é a mesma para todos e em todas as épocas. Coisas que estão sendo estudadas hoje não necessariamente possuem, para nós, a mesma materialidade que possuíam quando foram produzidas e faziam parte de uma rede de relações entre pessoas, objetos e outros significados. Assim como corpos humanos, os artefatos nascem e possuem uma vida até morrerem. E tal como corpos sepultados, se recuperados passam a ter outros significados. Por isso, não devemos tomar o significado que nós atribuímos a ele como único, pois a cultura material é significativamente construída, seus 
significados são dados pelo observador, no presente. As identidades materiais dos artefatos não são características essenciais, intrínsecas, inerentes e imutáveis deles, mas sim o resultado de relações entre pessoas e coisas. Isso não significa que a materialidade e os significados atribuídos a um objeto, suas características e atributos sejam arbitrários, mas sua materialidade é potencialmente múltipla e possui uma história.

O autor também propõe que um estudo da história de vida dos artefatos não deve pressupor nada sobre o que eles são, mas deve tentar entender como eles vieram a ser. A história de vida dos artefatos deve começar pelos seus significados no presente, e tentar entender como era em diferentes contextos históricos do passado, incluindo em sua época de usos, e imaginar como esses significados serão no futuro (como uma forma de pensar nossa própria atitude em relação eles).

As urnas funerárias, que no presente são objetos que causam fascínio e chamam a atenção nos museus, que podem ser consideradas baús do tesouro quando encontradas na terra, no passado foram panelas e vasilhas para se preparar e servir bebidas, mas que também tinham um papel em relação aos corpos e as almas dos mortos. As vasilhas anexas foram um dia vasilhas para se comer, beber, servir comida, armazenar, servir carne de humanos mortos no ritual antropofágico. Posteriormente, foram colocadas em sepulturas para dar de comer e beber ao morto e a outros espíritos, apaziguando suas vontades e assim protegendo os vivos.

Além disso, mesmo que as urnas não tenham sido feitas especificamente para uso em rituais funerários, sua confecção certamente previa isso, e esse provavelmente era um dos objetivos. Vasilhas foram guardadas para se sepultar os mortos, para dar de comer e beber a eles, para cobrir suas cabeças. Vasilhas velhas, às vezes com fundo quebrado, às vezes rachadas, foram tiradas de uso para serem utilizadas na sepultura, outras vasilhas e fragmentos de vasilhas quebradas foram utilizados como tampa. O uso de aparatos de cozinha nos sepultamentos certamente remete ao que foi proposto por Carvalho (1983) e Mano (2009), sobre um simbolismo que une culinária aos mortos. Entretanto, não sabemos ao certo como era esse simbolismo, nem como ele se relacionava a diferentes tipos de pessoas dentro do grupo. 
Apesar de não termos feito um estudo dos conceitos dos Guarani e Tupinambá em relação à morte e aos mortos, nosso levantamento das práticas funerárias já trouxe algumas questões sobre as urnas e vasilhas funerárias que remetem a uma agentividade das mesmas. Embora seja um assunto bem mais amplo e totalmente em aberto, alguns elementos permitem inferir que essas vasilhas possuíam uma simbologia ligada a aspectos cosmológicos recorrentes entre vários grupos Tupi. Para os Guarani, as vasilhas e tampas tinham o importante papel de impedir que a alma saísse do túmulo para perturbar os vivos, ficando retida na concavidade entre a cabeça e a vasilha. $\mathrm{O}$ peso da terra podia ser aliviado através da urna cerâmica. Entre os Guarani e Tupinambá, os alimentos e bebidas colocados em vasilhas na sepultura ou jogados sobre ela tinham o papel de evitar a ação de seres sobrenaturais. A fogueira acendida perto da sepultura tinha esse mesmo objetivo, assim como auxiliar o morto em sua jornada até o paraíso. Espíritos eram afastados pelo fogo, alimentados pela comida para que não se alimentassem do morto e não prejudicassem os vivos. O corpo dentro da sepultura possuía uma ligação importante com a alma que estava em sua jornada: esquentando e alimentando o morto, também se esquentava e alimentava a alma.

Portanto, pode-se considerar a cerâmica funerária - mas não somente, também outros elementos como fogueiras - como um importante elemento na relação entre os vivos e os mortos entre grupos Tupi-Guarani, que tem o "poder" de impedir que os mortos e espíritos ligados a eles prejudiquem os vivos, e ao mesmo tempo conseguem trazer certos alívios (como do peso da terra) aos mortos e aos vivos com os quais eles tinham relação. Esse importante elemento foi sendo abandonado a medida que os grupos Guarani e Tupinambá foram deixando de produzir cerâmica, e mudanças radicais provocadas pela colonização foram levando a adoção de novos valores e possibilidades, que alteraram drasticamente as práticas funerárias. Entretanto, alguns valores e hábitos ainda se mantiveram.

\subsection{Contextos funerários Tupinambá e Guarani: possibilidades e problemas interpretativos}

A sistematização dos dados sobre contextos funerários combinada com o levantamento de práticas funerárias trouxe algumas possibilidades interpretativas para o registro arqueológico funerário de grupos Tupinambá e Guarani, mas também trouxe problemas. 
Por um lado, temos algumas referências de práticas que eram realizadas em relação aos mortos. Assim, observando contextos de sepultamento em urna, podemos imaginar que aquele sepultamento poderia ser primário ou secundário. Observando vasilhas ao lado do sepultamento ou dentro das urnas, poderíamos inferir que contivessem alimentos e bebidas para o morto. Em um sítio Guarani ou Tupinambá, podemos esperar que haja sepultamentos em urna e fora. Sobre uma vasilha em que havia ossos e dentes humanos de adulto, mas pequena demais para se caber um adulto inteiro, poderíamos inferir que se trata de um sepultamento de partes do corpo e/ou cabeças - como poderiam ser os sepultamentos do sítio Itaguá e do PS 09 do sítio Lagoa São Paulo 2. Mas também, nesses casos, há a possibilidade de o corpo ter sido sepultado na terra com uma vasilha sob a cabeça, ou então a vasilha ter de alguma forma se movido de cima para baixo da cabeça, e o crânio acabou se depositando dentro da vasilha, tendo o restante do corpo desaparecido com os processos tafonômicos.

Mas, além disso, temos também novas questões.

A ausência de uma cronologia entre os contextos dificulta a comparação deles dentro do sítio, bem como dificulta muito considerações sobre a organização social. Questões sobre a mudança nas práticas funerárias ao longo do tempo também ficam limitadas às datações gerais dos sítios. Por isso, ainda não conhecemos os significados dos diferentes tipos de contextos funerários que encontramos no levantamento dos sítios. Não sabemos quais características contextuais poderiam ser fruto de circunstâncias práticas ou de contingências históricas, de diferenças sociais, diferentes estágios do ritual funerário, ou de mudanças diacrônicas.

Em considerações sobre a organização social através dos contextos funerários devemos levar em conta não apenas os processos naturais de formação do registro arqueológico, mas também os gestos funerários e pós-funerários. Estes elementos determinam as interpretações sobre os contextos, dificultando a análise da organização social. Muitos fatores determinam a variabilidade de contextos funerários: aspectos sociais, representações, mudanças diacrônicas nas práticas funerárias, processos naturais, gestos pós-funerários, circunstâncias locais, contingências históricas. Isso dificulta a visualização da organização social, 
podendo levar a considerações forçadas que olham superficialmente para a variabilidade, não levando todos esses elementos em conta.

Além disso, nossa visão dos sepultamentos no sítio é muito fragmentária. Alguns poucos sítios, com condições excepcionais de preservação, talvez nos deem uma ideia um pouco mais próxima de como os contextos funerários poderiam ser em ao menos alguns sítios Guarani. O sítio Lagoa São Paulo 2, localizado na margem do alto Paraná, possui diversos sepultamentos dentro e fora de urnas, inclusive sepultamentos na terra com vasilhas próximas. Apesar de as escavações não terem prosseguido, ao menos temos alguma ideia de como seria um sítio em que há não apenas vasilhas com parcos ossos (ou nenhum) dentro, como o são a grande maioria, mas também com sepultamentos fora de urnas. E o sítio MT-IV-1, escavado por Chmyz, também possui diversos contextos dentro e fora de urna. Em uma mesma vasilha, o arqueólogo encontrou crânios e ossos de 2 indivíduos. Além desses, encontrou também outros 3 indivíduos fora de urna. Um indivíduo semifletido enterrado, com um tembetá de cristal ao lado da mandíbula e outros objetos junto aos pés (um machado polido, polidores de sulco e um possível corante), e cacos de cerâmica cobrindo apenas o crânio. Outro estava com o crânio apoiado em uma vasilha rasa. E o outro estava em posição acocorada, tendo sobre o crânio uma vasilha emborcada.

Esses sítios com melhores condições de preservação podem nos dar uma ideia de como se apresentavam as práticas funerárias no registro arqueológico menos impactado. No entanto, tal registro arqueológico deve ser interpretado como tendo passado por processos diversos, funerários, pós-funerários, não funerários, culturais e naturais.

\subsubsection{Contextos funerários, mudanças diacrônicas e materialidade}

A sistematização de dados sobre os contextos funerários levou à recuperação de contextos inseridos em diferentes épocas, e uma divisão básica pode ser feita:

- Contextos de antes do contato, com sepultamentos em urnas ou fora, associadas a outras vasilhas e ausência de materiais de origem europeia no sítio. Exemplos desses são os contextos funerários do sítio Morro Grande, sítio Aguinha, Alves, Prassévichus, etc. 
- Contextos de período pós-contato, porém temprano, em que há materiais de origem europeia no sítio ou nos próprios contextos, como contas de vidro e fragmentos de metal, mas a estrutura geral não difere dos contextos pré-contato, havendo urnas cerâmicas com tampas e outras vasilhas. Exemplos: sítio Serrano, sítio PR FI 148 (Caranguejeiras).

- Contextos pós-contato em que o uso de vasilhas cerâmicas foi abandonado, havendo mudança inclusive na posição dos corpos sepultados e nas vasilhas com as oferendas. São contextos em que os efeitos do contato já são extremamente significativos na dinâmica do grupo, tendo causado alterações muito grandes nas velhas tradições funerárias, como o caso dos contextos Guarani registrados etnograficamente no século XX.

Essa diferença é uma demonstração material de como os efeitos do contato com o europeu nos grupos indígenas foi decisivo e causou grandes alterações, porém esse contato não se deu de igual maneira em todos os pontos, tendo havido períodos em que certos grupos, apesar do contato, ainda mantinham suas antigas tradições de sepultamento, não tendo sido ainda aldeados, destruídos e obrigados a abandonar seus velhos costumes. Porém, elementos europeus foram incorporados aos contextos funerários. Fruto de escambo, essas contas e pedaços de metal talvez fossem objetos pessoais de prestígio do morto, evidenciado seu uso como um possível marcador de status social de certos indivíduos do grupo.

Mas com o passar das décadas e dos séculos, cada vez mais grupos tiveram seus antigos costumes e dinâmicas sociais alterados, o que levou a drásticas mudanças nas práticas funerárias.

\subsubsection{Gestos pós-funerários, sepultamentos secundários e a importância dos mortos}

As fontes etnohistóricas apontam para alguns gestos entre grupos Tupinambá e Guarani, como o desenterramento de um morto para lhe quebrar o crânio, e assim realizar o ritual da vingança (gesto feito por indivíduos de outro grupo Tupi, diferente daquele do morto), ou da abertura de sepulturas para a retirada de ossos e manipulação para diversos fins. Consideramos esses tipos de 
gestos como pós-funerários, devido ao seu caráter não funerário. São gestos em que certos mortos, já sepultados e que provavelmente já passaram pelos rituais funerários, estavam envolvidos, mas cujo objetivo não era o de funeral. Os Tupinambá e Guarani abriam a sepultura de inimigos para lhes quebrar o crânio, mas isso não tinha objetivos ligados ao funeral, e sim era para realizar outro ritual, o da vingança. Desse modo, os gestos pós-funerários que possivelmente podem ter ocorrido em contextos ligados a grupos Tupi são aqueles que poderiam também possuir um caráter ritual, mas não de ritual funerário, e sim outros tipos de rituais.

As fontes também falam, entre os Guarani, sobre o desenterramento de ossos de certos indivíduos (alguns xamãs, caciques, crianças pequenas) para serem colocados em outros recipientes (caixas de madeira de cedro, esteiras) em cabanas especiais, para serem com eles realizados rituais e rezas (gestos realizados por indivíduos do mesmo grupo que o morto). Essas práticas de desenterrar seriam gestos pós-funerários ou sepultamento secundário? Ou ambos? Alguns autores, como Cadogan (1968) falam em um sepultamento secundário dos ossos de certos xamãs e caciques, e do sepultamento de crianças que eram primeiro enterradas, depois os ossos retirados, lavados e colocados em uma caixa de madeira de cedro.

Embora essa questão ainda precise ser bem melhor trabalhada, argumentamos que, mesmo que sessas práticas configurem um tipo de sepultamento secundário - pois há o sepultamento seguido de retirada dos ossos e guarda em outro lugar - esses gestos não são uma forma de por um fim à relação com aqueles mortos (ou pelo menos com uma "parte" deles, os ossos) e, além disso, possuem outros objetivos, que não têm a ver apenas com aquele morto, mas que buscam maneiras de trazer benefícios aos vivos. Nesses tipos de gestos, as atitudes que foram classificadas como "culto aos mortos" por Cadogan parecem ter sido feitas no sentido de preservar a proximidade com alguns mortos (não com todos), que seriam mortos "especiais", que poderiam trazem benefícios aos vivos.

Embora esse assunto ainda necessite de mais pesquisas na Arqueologia, as fontes que lemos já são o suficiente para podermos afirmar que a agência, presença e importância dos mortos entre os vivos entre grupos Tupi, já bastante trabalhada na Antropologia, pode levar a gestos pós-funerários que podem constituir parte dos processos pós-deposicionais sob os quais os contextos funerários estão sujeitos. Por isso, ao se analisar os gostos que possivelmente formaram contextos funerários 
Tupi, devemos analisar não apenas aqueles que tiveram a ver com o funeral, mas também aqueles que estariam ligados a outros rituais que não o funerários, e que poderiam ser recorrentes devido à importância e presença que os mortos possuem entre os grupos Tupi.

Além destas, há também a descrição de práticas pós-funerárias não realizadas pelos próprios indígenas, mas pelos padres nas missões, que podiam queimar ossos em praça pública com o objetivo de fazer com que os Guarani parassem de realizar alguns de seus rituais com relação aos mortos, rituais esses que eram abominados pelos catequizadores.

Como nos traz Weiss-Krejci (2011), as práticas funerárias constituem apenas uma parte de um grande ciclo de formação dos contextos funerários. Processos naturais, gestos funerários, pós-funerários e extra funerários contribuem para a sua formação. Esses gestos podem ocorrer como ações rituais ou não. Entre suas diversas possíveis causas, estão ritos a ancestrais, veneração, comemoração a indivíduos importantes, disputas políticas, resgate de corpos, cultos a relíquias, motivos práticos. Interpretar contextos e ossos em casos assim é extremamente complexo, pois os e contextos ossos podem ter passado por vários processos diferentes.

$\mathrm{Na}$ arqueologia de grupos Tupi, questões sobre os processos pós-funerários pelos quais podem ter passado os contextos estão totalmente em aberto. Não se teoriza nem se conhece praticamente nada sobre isso. Mas na interpretação dos contextos, é preciso levar esses processos também em consideração. Dada a importância e presença da morte no mundo dos vivos entre esses grupos, é preciso pensar nos usos, por assim dizer, e nos papéis desses contextos funerários para os grupos envolvidos e também após a partida desses grupos.

O sepultamento do sítio Panema apresenta marcas de queima e outras alterações nos ossos, sendo um caso até agora único. A análise de fontes etnohistóricas traz a informação de que gestos funerários e não funerários podiam ocorrer envolvendo esqueletos, praticados por indígenas e não indígenas. Alguns desses gestos não funerários (ou pós-funerários) envolviam desenterramento de alguns mortos para se realizar determinadas ações com o esqueleto, que podiam ser ligadas à vingança ou a "feitiços" e "contra feitiços". Esses envolviam ações que poderiam causar marcas no esqueleto e sepulturas remexidas. A queima poderia estar relacionada a uma tentativa de se dar um fim à veneração dos ossos - que os Guarani 
certamente praticavam, e os Tupinambá talvez. Ou então poderia estar relacionada a outros tipos de práticas que não conhecemos até o momento. O mais importante é que esse sepultamento traz a tona a existência da possibilidade de práticas pósfunerárias nas quais os sepultamentos e esqueletos também estavam envolvidos.

Outro elemento que corrobora para isso é a diferença grande entre as datações do esqueleto e da urna, sendo a da urna quase 2 mil anos mais antiga. Poderiam os ossos terem sido depositados numa vasilha mais antiga, que estava enterrada e foi encontrada em algum momento por grupos Guarani ou Tupinambá?

A grande maioria das menções a sepultamentos secundários é para grupos Amazônicos, e fora da Amazônia há menções muito menos claras. Há o sepultamento de partes do corpo e/ou cabeças, e o sepultamento secundário de certos xamãs e crianças para fins de veneração, para trazer benefícios aos vivos. Mas a análise das fontes etnohistóricas nos leva a concordar com Métraux quando este autor diz que, nos grupos Tupi fora da Amazônia, o sepultamento primário pode ter se tornado bem mais frequente que o secundário.

A afirmação de que todos ou mesmo a maioria dos sepultamentos em urnas eram secundários (ou primários) não pode ser feita, pois não há evidências para isso. As possibilidades de ser um tipo de sepultamento ou outro teriam que ser analisadas caso a caso.

Outro tipo de evidência intrigante são os achados de mais de um indivíduo (ou pelo menos mais de um crânio) dentro da mesma vasilha. Seriam sepultamentos primários, secundários ou gestos pós-funerários? Igualmente, isso terá que ser analisado caso a caso (quando há informações para tal).

As fontes etnográficas sugerem que a morte era uma questão fundamental para os grupos Tupi-Guarani, e que os mortos tinham uma importância e presença muito grandes. Sendo assim, não seria de se esperar uma grande quantidade e recorrência de gestos pós-funerários? O significado da morte Tupi-Guarani e suas relações com o registro arqueológico é um campo que está começando a ser explorado só recentemente. Mas já é possível perceber algumas relações, e que elas deixam marcas materiais nos contextos funerários. 


\section{Considerações Finais}

Como tentamos mostrar, os contextos funerários de grupos Tupi-Guarani apresentam um bom potencial para se tecer questões e discussões sobre esses grupos, trazendo várias possibilidades e problemas interpretativos. Mas eles são um tipo de registro arqueológico muito suscetível a alterações e à destruição, o que torna cada um muito valioso. $\mathrm{O}$ estudo de vasilhas descontextualizadas pode trazer muitas informações, mas seu contexto, quando pode ser recuperado, agrega muito mais. Por isso, é urgente a necessidade de trabalhos que não negligenciem os contextos funerários.

Através dos levantamentos e análises de dados, pudemos ver os problemas e potenciais que as descrições dos contextos possuíam, e os consequentes problemas de análise que geravam. Os maiores estão ligados a critérios não unificados de escavação e diferentes concepções relativas aos contextos. É preciso que se busque uma concepção única, e que sejam refinados os métodos de escavação e análise.

Os contextos funerários precisam ser considerados como um cenário de gestos funerários, pós-funerários e processos naturais que os moldaram. A análise de cerâmicas e outros artefatos juntamente com ossos se faz necessária para que se possa ter uma visão mais ampla, em que os componentes biológico e cultural sejam integrados.

Vimos também que a morte e os mortos possuem uma importância fundamental para os grupos Tupi-Guarani, e, como nos lembra Barreto (2008), o perspectivismo ameríndio traz a lição de que em ontologias ameríndias a intencionalidade e a capacidade reflexiva não são atributos exclusivos do ser humano, mas estão potencialmente presentes em todos os seres do cosmos. Animais, plantas, deuses e espíritos são sujeitos em potencial, que ocupam posições na relação com seres humanos. Por isso, a relação entre humanos e animais na morte e no pós-morte, a concepção de pessoa e a construção de sua identidade no pós-morte são problemas teóricos e etnológicos que devemos enfrentar, não elementos que possamos supor e impor de maneira simplista a priori. 
Isso implica que nossas considerações sobre os artefatos funerários e sobre o que chamamos de processos tafonômicos, agentes naturais, etc., também podem ser colocadas em perspectiva.

Essa pesquisa teve um caráter inicial e exploratório. Levantamentos e sistematizações de dados foram feitos e métodos foram testados, ainda que apenas em laboratório. O foco foi apenas a região do Paranapanema e áreas próximas, um pouco de São Paulo, Paraná, Rio de Janeiro e Mato Grosso do Sul. Mas essa temática ainda merece muito mais atenção. Muitas questões ainda permanecem: Como se daria essa variabilidade em outras regiões? Que outras continuidades e descontinuidades há no Guarani e no Tupinambá? Como as relações entre vivos e mortos estariam representadas no registro arqueológico? Qual o papel sociopolítico dos sepultamentos?

Os conceitos de grupos Guarani e Tupinambá em relação à morte e aos mortos são pouco conhecidos na Arqueologia, embora a Antropologia já aborde isso há tempos. Como esses conceitos poderiam se refletir no registro arqueológico? Essa pergunta não é simples, pois fazer uma relação direta entre o registro arqueológico e esses conceitos pode ser bastante problemático. Mas é um campo ainda inexplorado, e que poderia ser muito frutífero. Pesquisas nesse sentido poderiam ajudar a refinar essas grandes categorias conceituais que utilizamos - gestos funerários, gestos pós-funerários, gestos extra funerários, sepultamento primário, sepultamento secundário. Uma perspectiva que traga abordagens mais êmicas nas quais as relações entre concepções de mundo, gestos e contextos possam ser, de alguma forma, estabelecidas, pode ajudar a trazer mais elementos e um novo olhar para a compreensão dos contextos funerários Tupi, do seu papel social e das relações entre vivos e mortos nesses grupos. 


\section{Referências bibliográficas}

AFONSO, M. C. Um Olhar para a Arqueologia Pré-Histórica do Estado de São Paulo. Tese de livre docência. 96 f. 2006. Museu de Arqueologia e Etnologia, Universidade de São Paulo, São Paulo, 2006.

AFONSO, M. C. Um painel da arqueologia pré-histórica no estado de São Paulo: os sítios cerâmicos. Especiaria. Cadernos de Ciências Humanas, Ilhéus, vols. 11 e 12, ns. 20 e 21, p. 127-155, 2008-2009. Dossiê Arqueologia Hoje.

AlmeIdA, F. O. A Tradição Policroma no Alto Rio Madeira. Tese. 2013. Museu de Arqueologia e Etnologia, Universidade de São Paulo, São Paulo, 2013.

ANDREWS, P; BELLO, S. Pattern in Human Burial Practice. In: GOWLAND, R; KNÜSEL, C. Social Archaeology of Funerary Remains. Oxford: Oxbow Books, 2009.

AMBRosetTi, J. B. Los Cemeterios Prehistoricos del Alto Paraná (Misiones). Boletin del Instituto Geografico Argentino, tomo 16, Buenos Aires, 1895.

ASHMORE, W.; GELLER, P. M. Social Dimensions of Mortuary Space. In: RAKITA, G. F. M.; BUIKSTRA, J. E.; BECK, L. A.; WILlIAMS, S. R. Interacting with the Dead. Perspectives on Mortuary Archaeology for the New Millennium. Florida: University Press of Florida, 2005.

ASSOCIAÇÃO INDÍGENA PUSURU; CONSELHO INDÍGENA MUNDURUKU DO ALTO TAPAJÓS. Carta da Associação Indígena Pusuru e do Conselho Indígena Munduruku do Alto Tapajós (CIMAT) ao Iphan e ao Ministério Público Federal. Acervo - Combate ao Racismo Ambiental, maio de 2013.

Disponível em: <http://acervo.racismoambiental.net.br/2013/05/17/munduruku-denunciamroubo-de-urnas-funerarias-e-violacao-de-lugar-sagrado-no-teles-pires-e-pedem-aompf-paralisacao-dos-trabalhos-e-investigacao-imediata/> . Acesso em: 10/10/2017.

BACO, H. M. D. Arqueologia Guarani e Experimental no baixo Paranapanema Paulista: o estudo dos sítios arqueológicos Lagoa Seca, Pernilongo, Aguinha e Ragil II. 2012. 226 f. Dissertação. Museu de Arqueologia e Etnologia, Universidade de São Paulo, São Paulo, 2012.

BARRETO, C. N. G. B. Meios místicos de reprodução social: arte e estilo na cerâmica funerária da Amazônia antiga. 2008. 230 f. Tese. Museu de Arqueologia e Etnologia, Universidade de São Paulo, São Paulo, 2008. 
BONOMO, M. Reanálisis de la colección de Samuel Lothrop procedente del Detla del Paraná. Relaciones de la Sociedad Argentina de Antropología, vol. 38, n. 1, p. 169-198, 2013.

BROCHADO, J. P. An ecological model of the spread of pottery and agriculture into Eastern South America. 574 f. 1984. Tese. University of Illinois, Illinois, 1984.

BUARQUE, A. Étude de l'occupation Tupiguarani dans la région sud-est de l'État de Rio de Janeiro, Brésil. Tese. 2009. Institut d'Art et Archéologie. Université Paris 1 Panthéon - Sorbonne, Paris, 2009.

As estruturas funerárias das aldeias Tupinambá da região de Araruama, RJ. In: PROUS, A.; LIMA, T. A. (eds.). Os ceramistas Tupiguarani. Volume 3 Eixos Temáticos. 2a edição. Belo Horizonte: Livraria e Editora Graphar, 2016.

; RODRlGUES-CARVALHO, C.; SILVA, E.C. Programa funerário dos Tupinambá em Araruama, RJ - Sítio Bananeiras. Rev. do Museu de Arqueologia e Etnologia, São Paulo, n. 13, p. 39-55, 2003.

BUIKSTRA, J. E; UBELAKER, D. H. (eds.). Standards for data collection from human skeletal remains. Arkansas Archaeological Survey Research Series, Arkansas, n. 44, 1994.

; BECK, L. A. (eds.) Bioarchaeology: the contextual analysis of human remains. Amsterdam: Academic Press, 2006.

CABRERA, J. I. A. O espaço ocupado pelo homem pré-histórico no oeste paulista: o caso do sítio arqueológico Lagoa São Paulo - 02 no município de Presidente Epitácio, SP. Tese. 2015. Faculdade de Ciências e Tecnologia. Universidadde Estadual Paulista. Presidente Prudente, 2015.

CADOGAN, L. Chonó Kybwvrá. Aporte al conocimiento de la mitologia Guarani. Revista del Ateneo Paraguayo, Asunción, vol. 3, ns. 1 e 2, 1968. Suplemento Antropológico.

CARNEIRO DA CUNHA, M. Os mortos e os outros. Uma análise do sistema funerário e da noção de pessoa entre os índios Krahó. São Paulo: Editora Hucitec, 1978.

CARNEIRO DA CUNHA, M.; VIVEIROS DE CASTRO, E. Vingança e Temporalidade: os Tupinambá. Journal de la Societé des Americanistes, tomo 71, p. 191-208, 1985.

CARVALHO, S. M. S. A cerâmica e os rituais antropofágicos. Revista de Antropologia, São Paulo, vol. 26, p. 39-52, 1983. 
CASTAÑEDA, Q. E. The Ethnographic Turn in Archaeology. Research Positioning and Reflexivity in Ethnographic Archaeologies. In: Castañeda, Q. E., Matthews, C. N. (eds.). Ethnographic Archaeologies. Reflections on Stakeholders and Archaeological Practices. Lanhan: AltaMira Press, 2008.

CESAR, J. V. Enterros em Urnas dos Tupi-Guarani. Revista de Antropologia, São Paulo, vol. 14, p. 53-73, 1966.

CESAR, J. V. Igaçabas dos Tupi-Guaranis. Separata dos Arquivos de Anatomia e Antropologia, vol. 1, ano 1. Rio de Janeiro: Instituto de Antropologia Professor Souza Marques, 1975. p. 415-420.

CHAPMAN, R.; RANDSBORG, K. Approaches to the archaeology of death. In: CHAPMAN, R.; KINNES, I.; RANDSBORG, K. The Archaeology of Death. New York: Cambridge University Press, 1981.

CHARLES, D. K. The Archaeology of Death as Anthropology. In: RAKITA, G. F. M.; BUIKSTRA, J. E.; BECK, L. A.; WILLIAMS, S. R. Interacting with the Dead. Perspectives on Mortuary Archaeology for the New Millennium. Florida: University Press of Florida, 2005.

CHIARI, S. I. O Perfil Museo-Arqueológico do Projeto Paranapanema. Dissertação. 195 f. 1999. Faculdade de Filosofia, Letras e Ciências Humanas, Universidade de São Paulo, São Paulo, 1999.

CHMYZ, I. Dados Arqueológicos do Baixo Rio Paranapanema e Alto Rio Paraná. Separata do Programa Nacional de Pesquisas Arqueológicas, vol. 26. Belém: Museu Paraense Emilio Goeldi, 1974. Publicações Avulsas.

Projeto Arqueológico Itaipu. Convênio Itaipu-IPHAN. Curitiba: [s.n.], 1979. Quarto Relatório das Pesquisas Realizadas na Área de Itaipu (1978/79).

Projeto Arqueológico Itaipu. Convênio Itaipu-IPHAN. Curitiba: [s.n.], 1983. Sétimo Relatório das Pesquisas Realizadas na Área de Itaipu (1981/83).

Relatório das pesquisas arqueológicas realizadas nas áreas das usinas hidrelétricas de Rosana e Taquaruçu (1982/3). São Paulo: Cesp, 1984. 80 p.

A Tradição Tupiguarani no litoral do estado do Paraná. Revista do Círculo de Estudos Bandeirantes. Curitiba, n. 16, p. 71-95, 2002.

CORRÊA, A. A. Pindorama de Mboîa e Îakaré. Continuidade e Mudança na Trajetória das Populações Tupi. Tese. 2014. Museu de Arqueologia e Etnologia, Universidade de São Paulo, São Paulo, 2014.

DIAS, A. S. Novas perguntas para um velho problema: escolhas tecnológicas como índices para o estudo de fronteiras e identidades sociais no registro arqueológico. 
Boletim do Museu Paraense Emílio Goeldi - Ciências Humanas, Belém, vol. 2, n. 1, p. 59-76, 2007.

DUDAY, H. The Archaeology of the Dead: Lectures in Archaeothanatology. Oxford (UK): Oxbow Books, 2009.

FACCIO, N.B. O estudo do sítio arqueológico Alvim no contexto do Projeto Paranapanema. Dissertação. 1992. Faculdade de Filosofia, Letras e Ciências Humanas, Universidade de São Paulo, São Paulo, 1992.

Arqueologia do Cenário das Ocupações Horticultoras da Capivara, Baixo Paranapanema - SP. Tese. 291f. 1998. Faculdade de filosofia, Letras e Ciências Humanas, Universidade de São Paulo, São Paulo, 1998.

Arqueologia Guarani na Área do Projeto Paranapanema - Os sítios de

Iepê. Tese de Livre Docência. Museu de arqueologia e Etnologia, Universidade de São Paulo, São Paulo, 2011.

FARIA, D. L. A. et al. Raman spectroscopic analysis of a tembetá: a resin archaeological artefact in need of conservation. Spectrochimica Acta Part A Molecular and Biomolecular Spectroscopy, Washington, v. 60, n. 7, p. 1505-1513, 2004.

FERNANDES, F. Organização Social dos Tupinambá. 2a ed. São Paulo: Difusão Europeia do Livro, 1963.

GODOY, O. R. Esqueletos e utensílios de índios encontrados no Estado de São Paulo. Separata dos Arquivos da Polícia Civil de São Paulo, vol. 13, 1947.

GOLDSTEIN, L. One-dimensional archaeology and multi-dimensional people: spatial organization and mortuary analysis. In: Chapman, R.; Kinnes, I.; Randsborg, K. The Archaeology of Death. New York: Cambridge University Press, 1981.

HANKE, W. Costumbres y creencias indígenas relacionadas con la muerte. Revista Geográfica Americana, S/D. Disponível em: <http://www.bibvirtual.ucb.edu.bo/etnias/digital/106001757.pdf>. Acessado em: $10 / 10 / 2017$.

HOLTORF, C. Notes on The Life History of a Pot Sherd. Journal of Material Culture. vol. 7, n. 1, p. 49-71, 2002.

HOLLENBACK, K. L. Ritual and Religion. In: Schiffer, M. B. Behavioral Archaeology: Principles and Practice. London: Equinox Publishing Ltd, 2010. p. 156-163.

IHERING, H. V. A Anthropologia do Estado de São Paulo. Revista do Museu Paulista, São Paulo, vol. 7, 1907. 
KASHIMOTO, E. M. Geoarqueologia no baixo Paranapanema: uma perspectiva geográfica de estabelecimentos humanos pré-históricos. Dissertação. 260 f. 1992. Faculdade de Filosofia, Letras e Ciências Humanas, Universidade de São Paulo, São Paulo, 1992.

O alto curso do rio Paraná: fronteiras ambientais e arqueológicas. Tese de livre docência. 306 f. 2007 Museu de Arqueologia e Etnologia, Universidade de São Paulo, São Paulo, 2007.

; MARTINS, G. R. Uma Longa História em um Grande Rio. Cenários Arqueológicos do Alto Paraná. Campo Grande (MS): Editora Oeste, 2005.

; MARTINS, G. R. Arqueologia e Paleoambiente do Rio Paraná em Mato Grosso do Sul. Campo Grande: Life Editora, 2009.

KRUG, E. Os índios das margens do Paranapanema. Revista do Instituto Histórico e Geográphico de São Paulo, São Paulo, vol. 21, 1924.

KÜNZLI, R. et al. IX Relatório a ser apresentado à CESP, relativo às atividades de campo desenvolvidas em função do contrato CESP/FUNDACTE, visando o pagamento da nona cota, 2010. (não publicado)

LA SALVIA, F.; BROCHADO, J. P. Cerâmica Guarani. Porto Alegre: Posenato Arte e Cultura, 1989.

LAMOTTA, V. M. Behavioral variability in mortuary deposition: a modern material culture study. Arizona Anthropologist, Tucson, vol. 14, p. 53-80, 2001.

MAGESTE, L. E. C. Cronologia e Variabilidade: Os Ceramistas Tupiguarani da Zona da Mata Mineira e Complexo Lagunar de Araruama. Tese de doutorado. 515 f. 2017. Museu de Arqueologia e Etnologia, Universidade de São Paulo, São Paulo, 2017.

MANO, M. A Cerâmica e os rituais funerários: xamanismo, antropofagia e guerra entre os tupi-guarani. Interações - Cultura e Comunidade, v. 4, n. 5, p. 111-128, 2009.

MELIÀ, B.; GRÜNBERG, G.; GRÜNBERG, F. Los Pai Tavyterã. Etnografia guarani del Paraguai contemporâneo. $2^{a}$ ed. Asunción: CEDUC, 2008.

MENDONÇA DE SOUZA, S. A Necrópole Maracá e os Problemas Interpretativos em um Cemitério sem Enterramentos. Boletim do Museu Paraense Emílio Goeldi - Ciências Humanas, Série Antropológica, vol. 17, n. 2, 2001.

; RODRIGUES-CARVALHO, C. 'Ossos no chão': para uma abordagem dos remanescentes humanos em campo. Boletim do Museu Paraense Emílio Goeldi. Ciência Humanas, v. 8, n. 3. Belém, p. 551-566, 2013. 
MÉTRAUX, A. Mourning Rites and Burial Forms of the South American Indians. América Indígena, vol. 7, n. 1, p. 7-44, 1947.

A religião dos tupinambás e suas relações com a das demais tribos Tupiguaranis. São Paulo: Ed. Nacional; Ed. Da Universidade de São Paulo, 1979.

A civilização material das tribos Tupi-Guarani. Campo Grande: Gráfica Editora Alvorada, 2012 [1928].

MONTARDO, D. L. O. Práticas Funerárias das Populações Pré-coloniais e suas Evidências Arqueológicas - Reflexões Iniciais. 1995. Dissertação. Pontifícia Universidade Católica do Rio Grande do Sul, Porto Alegre, 1995.

; NOELLI, F. S. Sugestões para o estudo dos enterramentos Guarani. In: VIII Reunião Científica da Soc. de Arqueologia Brasileira, vol. 1, n. 1, 1995-96, Porto Alegre. Anais... Porto Alegre: EDIPUCRS, 1995-96. p. 491-502.

MONTEIRO DA SILVA, S. F. S. Arqueologia das Práticas Mortuárias em Sítios Pré-Históricos do Litoral do Estado de São Paulo. Tese. 2005. Museu de Arqueologia e Etnologia, Universidade de São Paulo, São Paulo, 2005.

Arqueologia e Etnografia das Práticas Funerárias: informações sobre o tratamento do corpo em contextos rituais e de morte. Canindé - Revista do Museu de Arqueologia de Xingó, São Cristóvão (SE), n. 11, 2008.

MONTOYA, A. R. Conquista Espiritual Hecha por los Religiosos de la Copañia de Iesus, em las Provincias del Paraguay, Parana, Uruguay, y Tape. 1639.

MORAES, C. A. de. Arqueologia Tupi no nordeste de São Paulo: um estudo de variabilidade artefatual. Dissertação. 311 p. 2007. Museu de Arqueologia e Etnologia, Universidade de São Paulo, São Paulo, 2007.

MORAIS, J. L. Resgate do patrimônio arqueológico da área de influência do Complexo Canoas. São Paulo: Museu de Arqueologia e Etnologia - USP, 1997. Relatório USP-CNS 24.1.

Perspectivas Geoambientais da Arqueologia do Paranapanema Paulista. Tese de Livre Docência. 239 p. 1999. Museu de Arqueologia e Etnologia, Universidade de São Paulo, São Paulo, 1999.

Arqueologia da Região Sudeste. Revista USP, São Paulo, n. 44, p. 194217, 1999-2000.

Inventário Progressivo do Patrimônio Arqueológico e HistóricoArquitetônico dos Municípios do Projeto Paranapanema, Estado de São Paulo. 2001. 
; PERASSO, J. A Tecno-tipologia de estruturas de lascamiento del sitio Marcelina-Kue (Itapúa - Paraguay). Ensayos de Arqueologia Paraguaya, I. Asunción, Arte Nuevo Editora. 1984.

; PIEDADE, S. C. O homem pré-historico de Salto Grande do Paranapanema. Revista do Museu de Arqueologia e Etnologia, São Paulo, vol. 4, p. 220-222, 1994.

MÜLLER, L. M.; SOUZA, S. M. de. Enterramentos Guarani: problematização e novos achados. In: Carbonera, M. e Schmitz, P. I. Antes do Oeste Catarinense Arqueologia dos Povos Indígenas. Chapecó: Editora da Unochapecó, 2011.

Cremações e sepultamentos: as estruturas anelares do planalto. In:

Carbonera, M. e Schmitz, P. I. Antes do Oeste Catarinense - Arqueologia dos Povos Indígenas. Chapecó: Editora da Unochapecó, 2011.

NEVES, E. G. Sob os tempos do equinócio: oito mil anos de história na Amazônia Central (6500 aC-1500 dC). Tese de livre docência. 303 f. 2012. Museu de Arqueologia e Etnologia, Universidade de São Paulo, São Paulo, 2012.

NILSSON STUTZ, L. Archaeology, Identity and Right to Culture. Anthropological perspectives on repatriation. Current Swedish Archaeology, vol 15, p. 1-16, 2007. Disponível em: < http://www.arkeologiskasamfundet.se/csa/Dokument/Volumes/csa_vol_1516_2007-2008/csa_vol_15-16_2007-2008_s157-172_nilsson-stutz.pdf >. Acesso em: $10 / 10 / 2017$.

The way we bury our dead. Reflections on mortuary ritual, community and identity at the time of the Mesolithic-Neolithic transition. Documenta Praehistorica, vol. 37, p. 33-42, 2010.

NOELLI, F. S. Sem tekohá não há tekó. Em busca de um modelo etnoarqueológico da aldeia de da subsistência guarani e sua aplicação a uma área de domínio no delta do Rio Jacuí-RS. Dissertação. 1993. Instituto de Filosofia e Ciências Humanas, Pontifícia Universidade Católica do Rio Grande do Sul, Porto Alegre, 1993.

José Proenza Brochado: vida acadêmica e ideias sobre o passado dos povos Tupi. In: PROUS, A.; LIMA, T. A. (eds.). Os ceramistas Tupiguarani. Volume 1 Sínteses Regionais. $2^{a}$ edição. Belo Horizonte: Livraria e Editora Graphar, 2016.

NAWROCKI, S. P. Human taphonomy and historic cemeteries: factors influencing the loss and subsequent recovery of human remains. University of Indianapolis Archeology \& Forensics Laboratory, 1991. Disponível em: <http://archlab.uindy.edu/documents/CemeteryTaph.pdf $>$ Acesso em: $10 / 10 / 2017$. 
O'SHEA, J. M. Mortuary Variability - An Archaeological Investigation. Orlando: Academic Press, 1984.

PALLESTRINI, L. Sítio Arqueológico Fonseca. São Paulo: Universidade de São Paulo/ Museu Paulista, 1969.

Supra-estruturas e infra-estruturas arqueológicas no contexto ecológico brasileiro. Revista do Museu Paulista, n. 20, p. 7-32, 1972.

Interpretação das Estruturas Arqueológicas em sítios do estado de São

Paulo. Coleção Museu Paulista, Série de Arqueologia. Vol. 1. São Paulo: Edição do Fundo de Pesquisas do Museu Paulista da Universidade de São Paulo, 1975.

; GOULART, M. L.; KNEIP, L. M.; CHIARA, P. MORAIS, J. L. Ensaios de Arqueologia Brasileira. Vol. 1. Rio de Janeiro: Luna, 1982.

; MORAIS, J. L. Prassévichus - aldeia pré-histórica no município de Itaberá - SP. Revista do Museu Paulista, n. 29, p. 151-167, 1983, 1984.

PEARSON, M. P. The Archaeology of Death and Burial. Texas: A\&M University Press, 2002.

PERASSO, J. A. Ava Guyra Kambi. Notas sobre la etnografia de los Ava-KueChiripa del Paraguay Oriental. Asunción (Paraguay): Centro Paraguayo de Estudios Sociológicos, 1986.

PEStANA, M. B. A Tradição Tupiguarani na Porção Central da Planície Costeira do Rio Grande do Sul, Brasil. Dissertação. 2007. Universidade do Vale do Rio dos Sinos, São Leopoldo, 2007.

PIEDADE, S.C. Tratamento dos restos esqueletais humanos do sítio arqueológico Franco de Godoy - Cachoeira de Cima/ Mogi Guaçu / São Paulo: relatório técnico. Documento do Serviço de Curadoria, Seção de Laboratório. São Paulo: Museu de Arqueologia e Etnologia, Universidade de São Paulo, [s.d.].

PIEDADE, S.C.; SOARES, A.L.R. Considerações sobre um enterramento Guarani: alterações e hipóteses etno-históricas. Revista do Museu de Arqueologia e Etnologia, São Paulo, n. 10, p. 31-68, 2000.

RAMAZZINA, A. A. Estrutura social e organização espacial de necrópoles: aspectos teórico-metodológicos no estudo arqueológico de vestígios funerários Uma revisão bibliográfica. Revista do Museu de Arqueologia e Etnologia, Trabalhos apresentados no XVII Congresso Nacional de Estudos Clássicos, Natal, São Paulo, p. 81-109, 2011. Suplemento 12.

RAPP PY-DANIEL, A. Arqueologia da Morte no sítio Hatahara durante a fase Paredão. Dissertação. 129 f. 2009. Museu de Arqueologia e Etnologia, Universidade de São Paulo, São Paulo, 2009. 
Os contextos funerários na arqueologia da calha do rio

Amazonas. Tese. Museu de Arqueologia e Etnologia, Universidade de São Paulo, São Paulo, 2015.

RIBEIRO, M. S. Arqueologia das práticas mortuárias: Uma abordagem historiográfica. São Paulo: Alameda, 2007.

RIZZARDO, F. M.; SCHMITZ, P. I. Formas de Sepultamento na Tradição Cerâmica Tupiguarani. Revista Tecnologia e Ambiente. IX Reunião da Sociedade de Arqueologia Brasileira/Regional Sul, Criciúma. Dossiê, vol. 21, n. 1., 2015.

ROBERTS, C. A. Human Remains in archaeology: a handbook. Practical Handbooks in Archaeology. n. 9. New York: Council for British Archaeology, 2009.

ROBRAHN-GONZÁLEZ, E. M. Os grupos ceramistas pré-coloniais do centrooeste brasileiro. Revista do Museu de Arqueologia e Etnologia, São Paulo, n. 6, p. 83-121, 1996.

RODRIGUES, R. A. Os caçadores-ceramistas do sertão paulista: um estudo etnoarqueológico da ocupação Kaingang no vale do rio Feio/Aguapeí. 200 f. 2007. Tese. Museu de Arqueologia e Etnologia, Universidade de São Paulo, São Paulo, 2007.

; AFONSO, M. C. Um olhar etnoarqueológico para a ocupação Guarani no Estado de São Paulo. Horizontes Antropológicos, Porto Alegre, ano 8, n. 18, p. 155-173, 2002.

SCATAMACCHIA, M. C. M.; UCHÔA, D. P. O contato euro-indígena visto através de sítios arqueológicos do Estado de São Paulo. Revista de Arqueologia, São Paulo, n. 7, p. 153-173, 1993.

SCHADEN, E. Aspectos Fundamentais da Cultura Guarani. São Paulo: Difusão Europeia do Livro, 1962.

SCHIFFER, M. B. Behavioral Archaeology. Principles and Practice. London: Equinox, 2010.

SILVA, F. A. O significado da variabilidade artefatual: a cerâmica dos Asurini do Xingu e a plumária dos Kayapó-Xikrin do Cateté. Boletim do Museu Paraense Emílio Goeldi, Ciências Humanas, Belém, vol. 2, n. 1, p. 91-103, 2007.

A organização da produção cerâmica dos Asurini do Xingu: uma reflexão etnoarqueológica sobre variabilidade e padronização artefatual. Arqueología Suramericana, vol. 5, n. 2, p. 121-137, 2009.

; NOELLI, F. S. Arqueologia e linguística: Construindo as trajetórias histórico-culturais dos povos Tupi. Crítica e Sociedade: revista de cultura política, 
Uberlândia, vol. 7, n. 1, p. 55-87, 2017. Dossiê Povos Indígenas: entre a Antropologia, a Arqueologia e a História.

SKIBO, J. M. Pottery function: a use-alteration perspective. Interdisciplinary contributions to archaeology. New York: Plenum Press, 1992.

Pottery and People. In: Skibo, J.M.; FEINMAN, G. M. Pottery and People: a dynamics interaction. Foundations of Archaeologycal Inquiry. Salt Lake City: University of Utah Press, 1999.

SMITH, C.; WOBST, H. M. Decolonizing archaeological theory and practice. In: Practice. London: Routledge, 2005.

SOARES, A. L. R. Índios Guaranis: Seria a diversidade arqueológica das vasilhas cerâmicas um parâmetro étnico? Revista Tecnologia e Ambiente, Dossiê IX Reunião da Sociedade de Arqueologia Brasileira, Regional Sul, Criciúma, Santa Catarina, v. 21, n. 1, p. 162-182, 2015.

SOUZA, C. D. As Práticas Mortuárias na região da Argólia entre os séculos XI e VIII a.C. Revista do Museu de Arqueologia e Etnologia, São Paulo, 2011. Suplemento 13 .

STADEN, H. Hans Staden: suas viagens e captiveiro entre os selvagens do Brasil. São Paulo : Typ. da Casa eclectica, 1900.

STRAUSS, A. M. As práticas mortuárias dos caçadores-coletores pré-históricos da região de Lagoa Santa (MG): um estudo de caso do sítio arqueológico "Lapa do Santo". Dissertação. 723 f. 2010. Instituto de Biociências, Universidade de São Paulo, São Paulo, 2010.

SUSNIK, B. Los Aborigenes del Paraguay. Vol. V, Ciclo vital y estructura social. Asunción: Museo Etnografico Andres Barrero, 1983.

THEVET, A. Les singularitez de la France Antarctique, autrement nommée Amerique, \& de plusieurs Terres \& Isles decouvertes de nostre temps. Anvers : De l'imprimerie Christophe Plantin, a la Licorne d'or, 1558. Disponível em: <http://objdigital.bn.br/acervo_digital/div_obrasraras/or813719/or813719_item1 /index.html> Acesso em: 15/10/2017

TYLOR, E. B. Primitive culture. New York: Brentano's, 1971.

UCHÔA, D. P.; SCATAMACCHIA, M. C. M.; GARCIA, C. D. R. O sítio cerâmico do Itaguá: Um sítio de contacto no litoral do Estado de São Paulo, Brasil. Revista de Arqueologia, Belém, v. 2, n. 2, p. 51-59, 1984.

UCKO, P. J. Ethnography and archaeological interpretation of funerary remains. World Archaeology, v. 1, n. 2, Pp. 262-280. 1969. 
VIERTLER, R. B. A Refeição das Almas. São Paulo: HUCITEC/EDUSP, 2006.

VILAÇA, A. Comendo como gente. Formas do canibalismo Wari. Rio de Janeiro: ANPOCS/Editora da UFRJ, 1992.

VIVEIROS DE CASTRO, E. Araweté: os deuses canibais. Rio de Janeiro: Jorge Zahar, 1986.

. O mármore e a murta: sobre a inconstância da alma selvagem. In: A Inconstância da Alma Selvagem e Outros Ensaios de Antropologia. $5^{a}$ ed. São Paulo: Cosac Naify, 2013. p. 181-263.

WALKER, W. H. Ceremonial trash? In: SKIBO, J. M.; WALKER, W. H.; NIELSEN, A. E. Expanding Archaeology. Salt Lake City: University of Utah Press, 1995. p. 67-79.

WALKER, M. H. Ritual Technology in an Extranatural World. In: SCHIFFER, M. B. (ed.). Anthropological Perspectives on Technology. Amerind Foundation New World Studies Series. Book 5. Albuquerque: University of New Mexico Press, 2001. p. 87-106.

WEISS-KREJCI, E. The formation of mortuary deposits. Implications for Understanding Mortuary Behavior os Past Populations. In: AGARWAL, S. C.; GLENCROSS, B. A. (eds.) Social Bioarchaeology. Blackwell studies in global archaeology. 2011.

Excarnation, evisceration and exhumation in Medieval and Post-Medieval Europe. In: RAKITA, G. F. M.; BUIKSTRA, J. E.; BECK, L. A.; WILLIAMS, S. R. Interacting with the Dead. Perspectives on Mortuary Archaeology for the New Millennium. Florida: University Press of Florida, 2005.

WÜST, I. Etnicidade e Tradições Ceramistas: algumas reflexões a partir das antigas aldeias Bororo do Mato Grosso. Revista do Museu de Arqueologia e Etnologia. São Paulo, 1999. p. 303-317. Suplemento 3. 


$$
\text { APÊNDICES }
$$

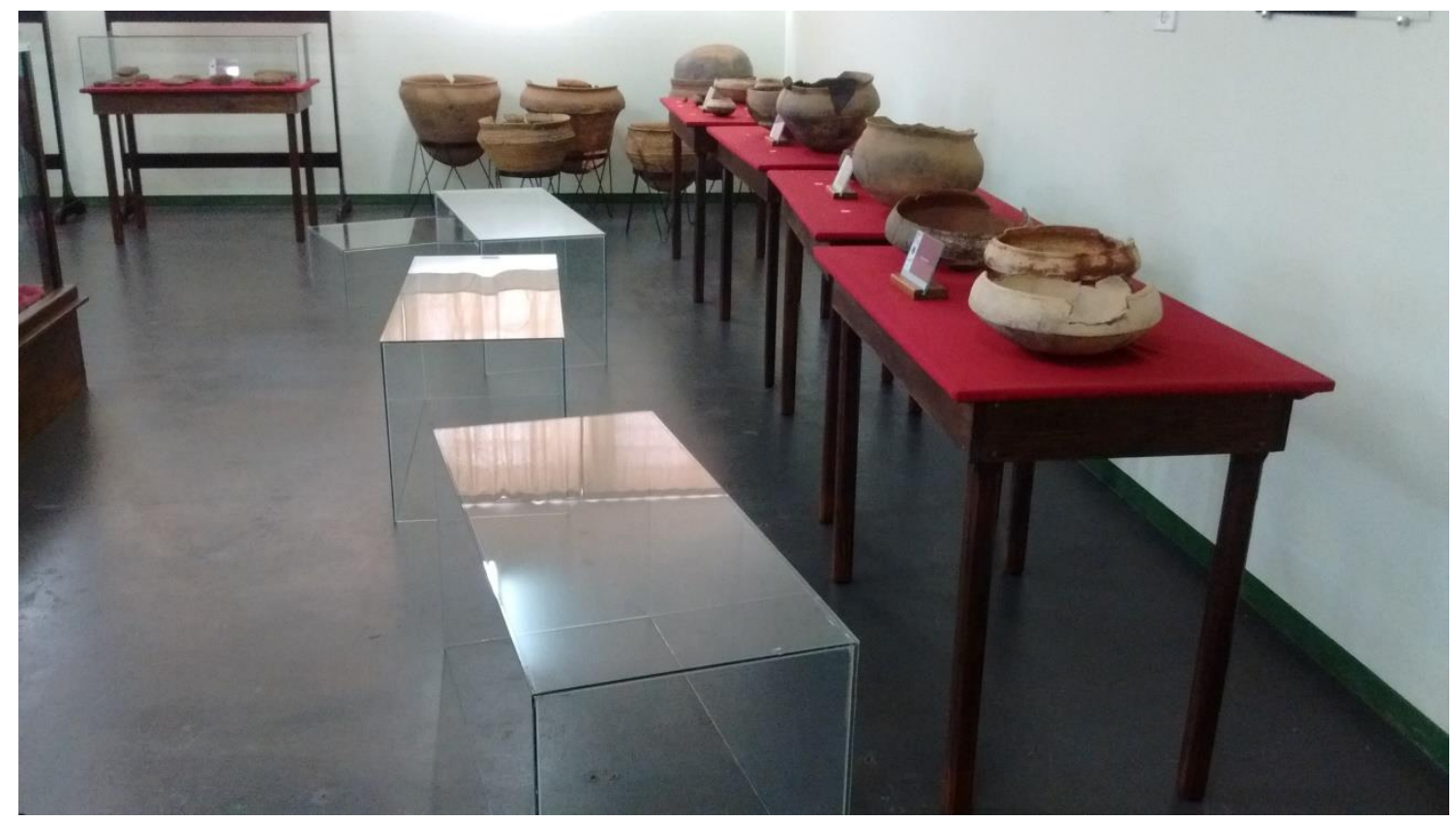


Apêndice A: Ficha de Análise de Material Cerâmico

\section{Ficha de análise do material cerâmico}

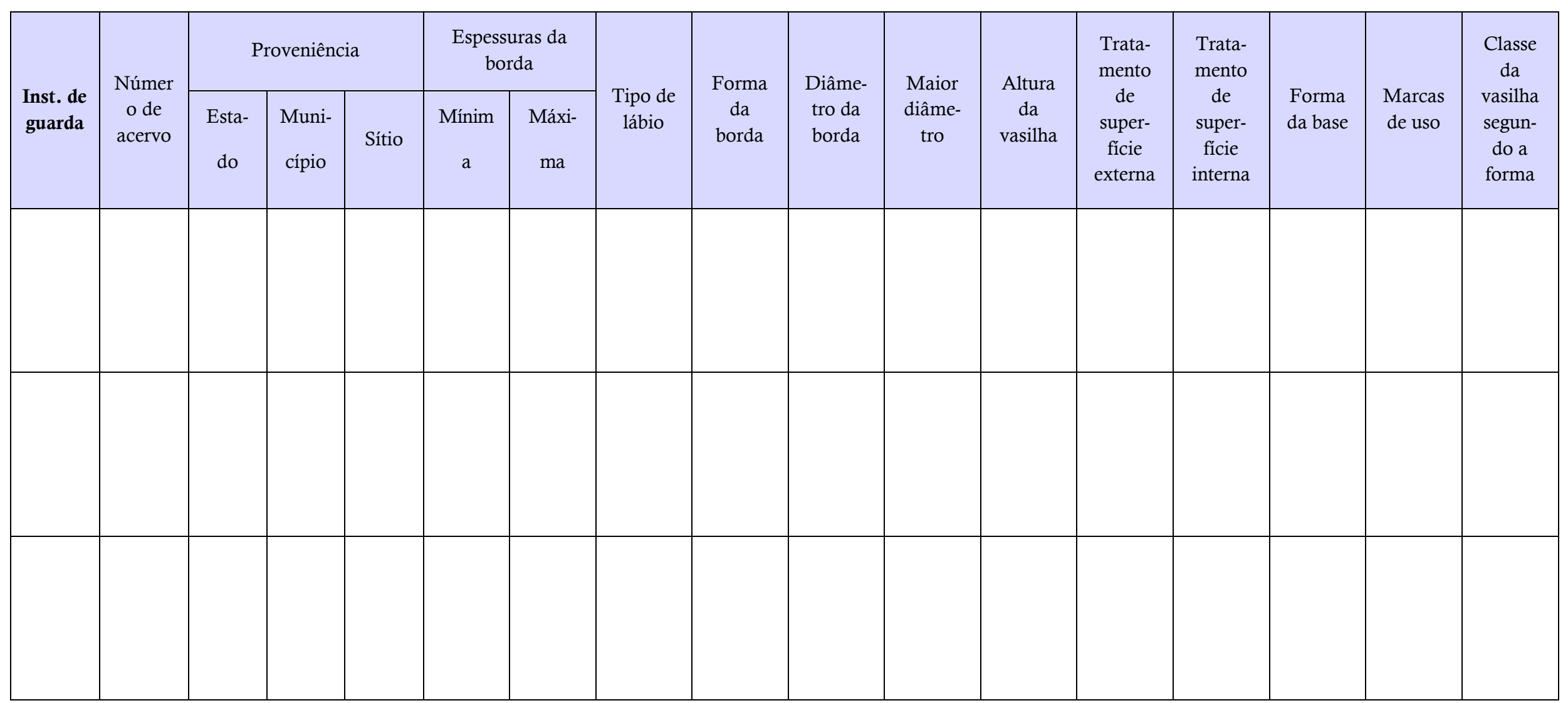


Apêndice B: Inventário ósseo e dentário dos indivíduos analisados na dissertação e fichas de diagnóstico de sexo e idade preenchidas

\section{1 -Sítio Lagoa São Paulo 2}

Sepultamento do PS 09

Inventário dentário

DENTAL INVENTORY

VISUAL AECORDING FORM: PERMANENT DENTITION
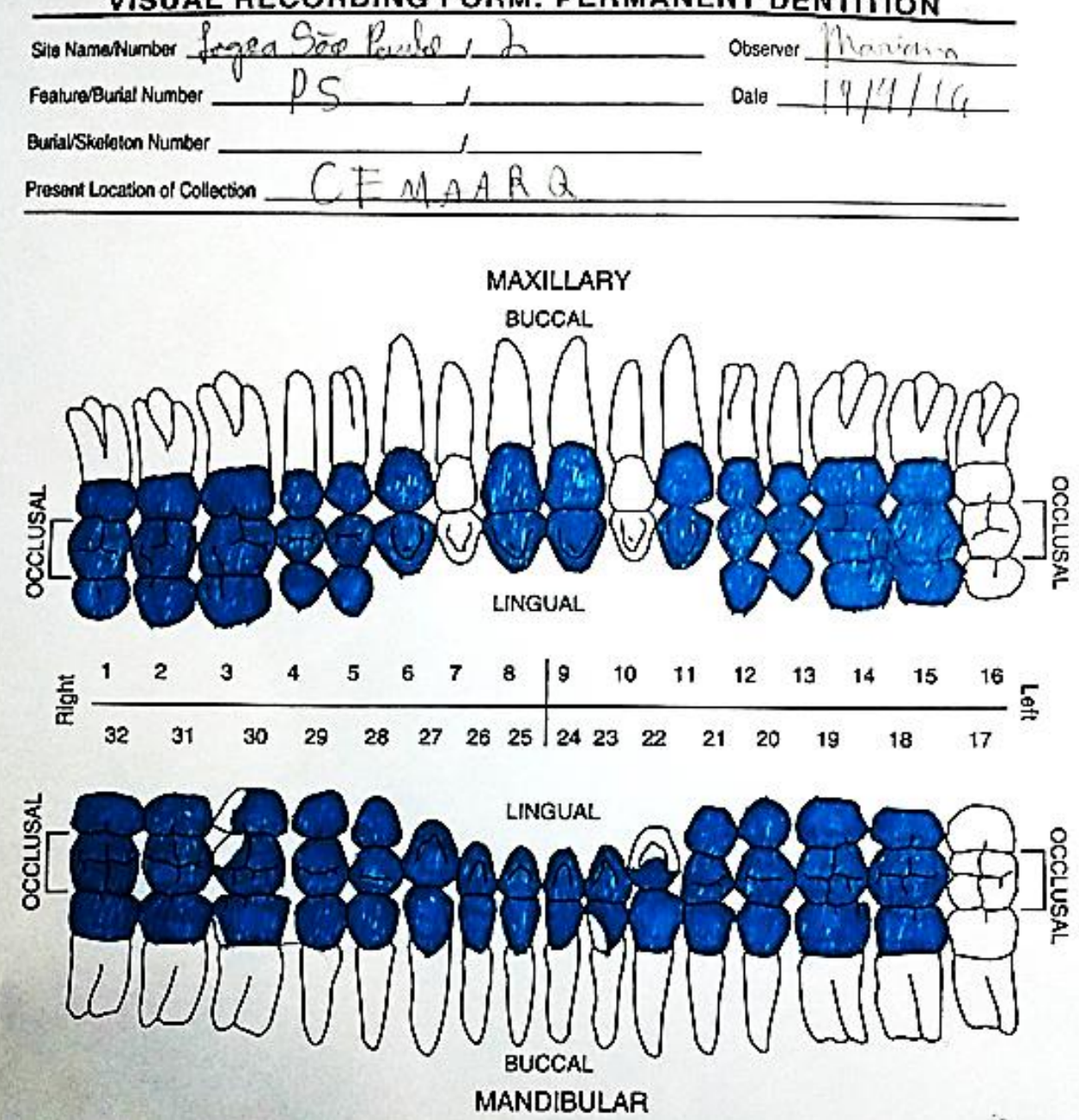

CHAPTER 5: Attachment 14a 
2 - Sítio Fonseca

Sepultamento 2

Inventário ósseo e dentário

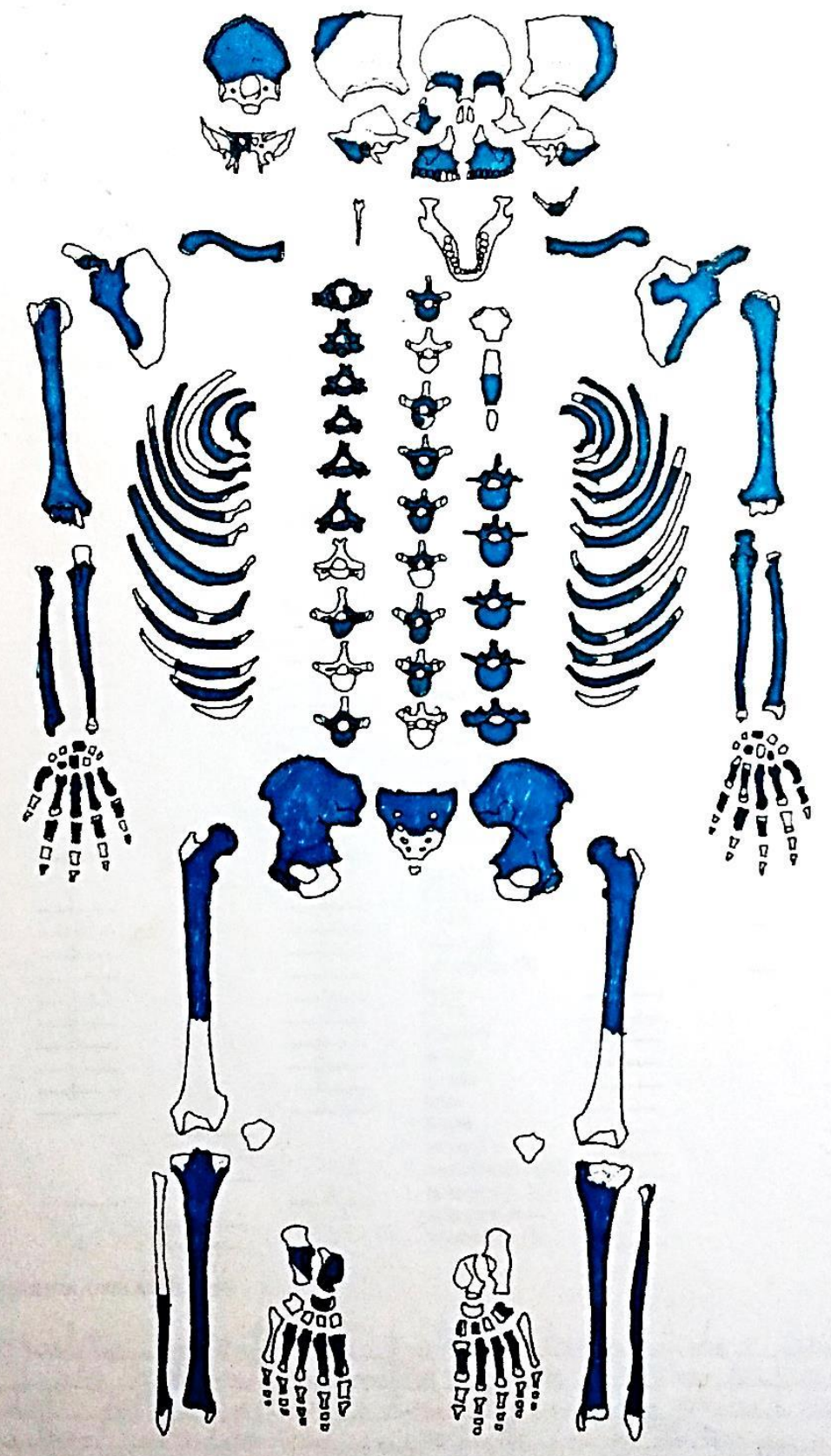


ARQUEOLOGIA

\section{FICHA DE INVENTÁRIO DE ESQUELETO}

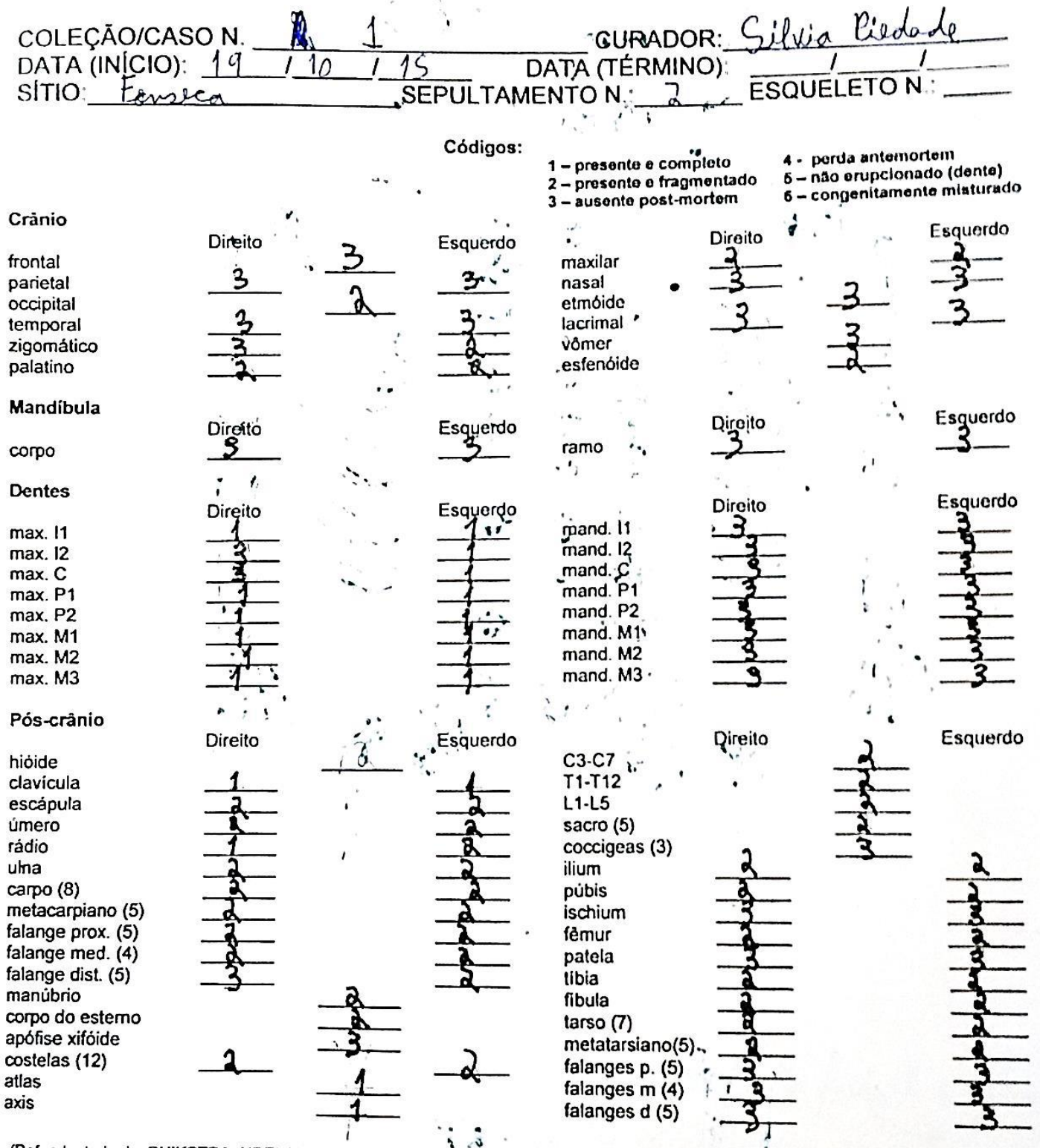


DENTAL INVENTORY

VISUAL RECORDING FORM: PERMANENT DENTITION
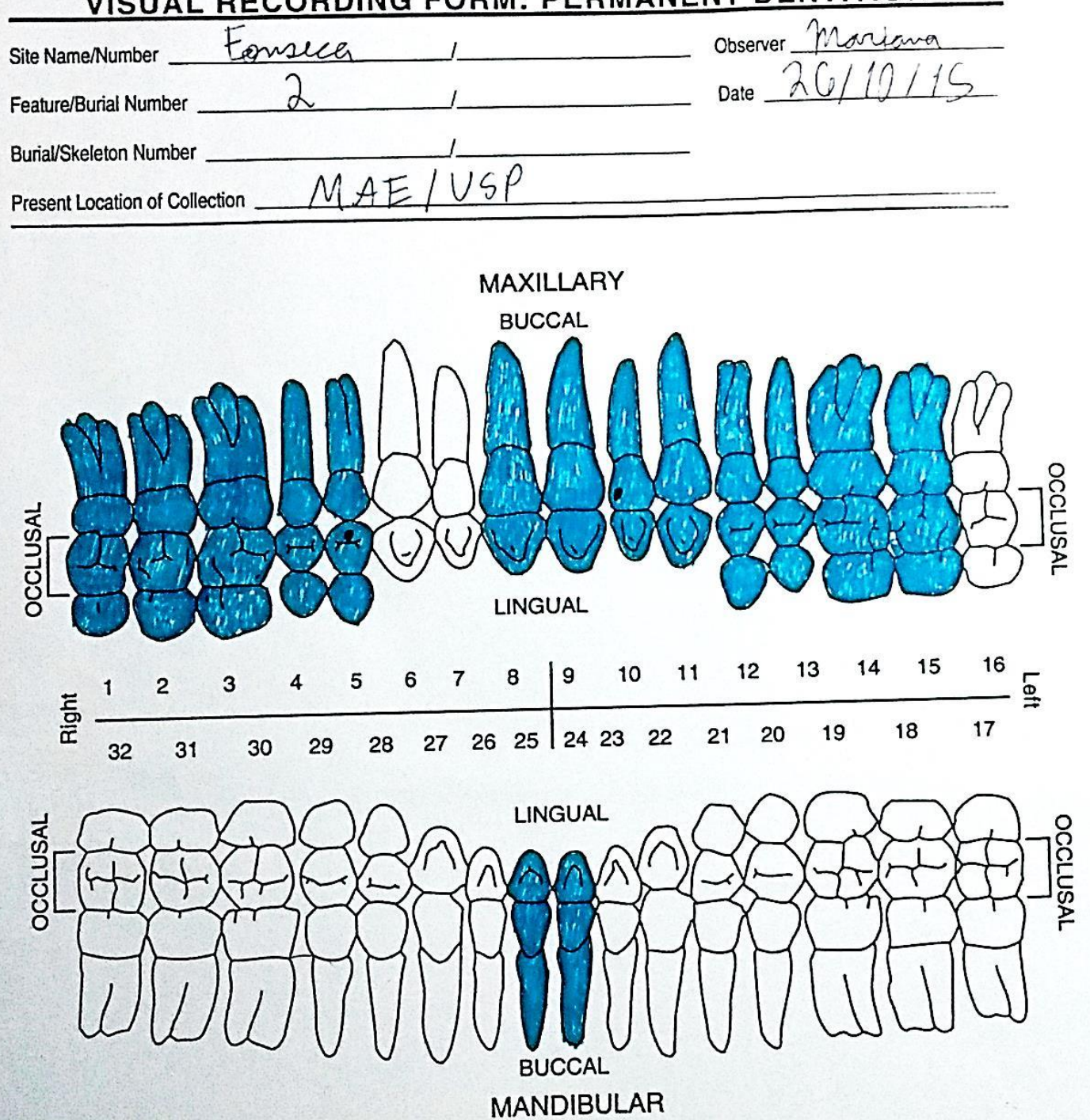
Fichas de diagnóstico de sexo e idade preenchidas

Ficha preenchida de marcadores de sexo -

Sítio Fonseca, Sep. II:

Sítio: Fonseca

Sepultamento: II

Local da coleção: MAE-USP

Pelvis (osso do quadril)

Esquerda

Direita

Arco ventral:

Concavidade subpúbica $\left(>90^{\circ} . \mathrm{Ou}<90^{\circ}\right.$.):

Ramo isquiático:

Incisura isquiática:

1

1

Sulco préauricular (presente/ausente):

Sexo estimado da pélvis: 2

Crânio

Esquerda

Meio

Direita

Crista nucal:

4

Processo mastoide:

Margem supraorbital:

Glabela:

Eminencia mental:

Sexo estimado do crânio: 0 
Ficha de marcadores de idade aproximada da morte preenchida Sítio Fonseca, Sep. II:

Sítio: Fonseca

Sepultamento: 2

Sínfise Púbica

Esquerdo

Direito

Todd (1-10):

Suchey-Brooks (1-6):

Esquerdo

Direito

Superfície Auricular (1-8):

1

1

Fechamento das suturas presentes

Face externa do crânio: Midlambdoide

Lambda

Palato: Palatina anterior média

Palatina posterior média

Palatina transversa

0

Face interna do crânio: Lambdóide esquerda $\quad 0$

Idade estimada: adulto jovem (20-35 anos) 


\section{3 - Sítio Silveira}

\section{Sepultamento 2}

Inventário ósseo e dentário

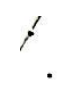

D
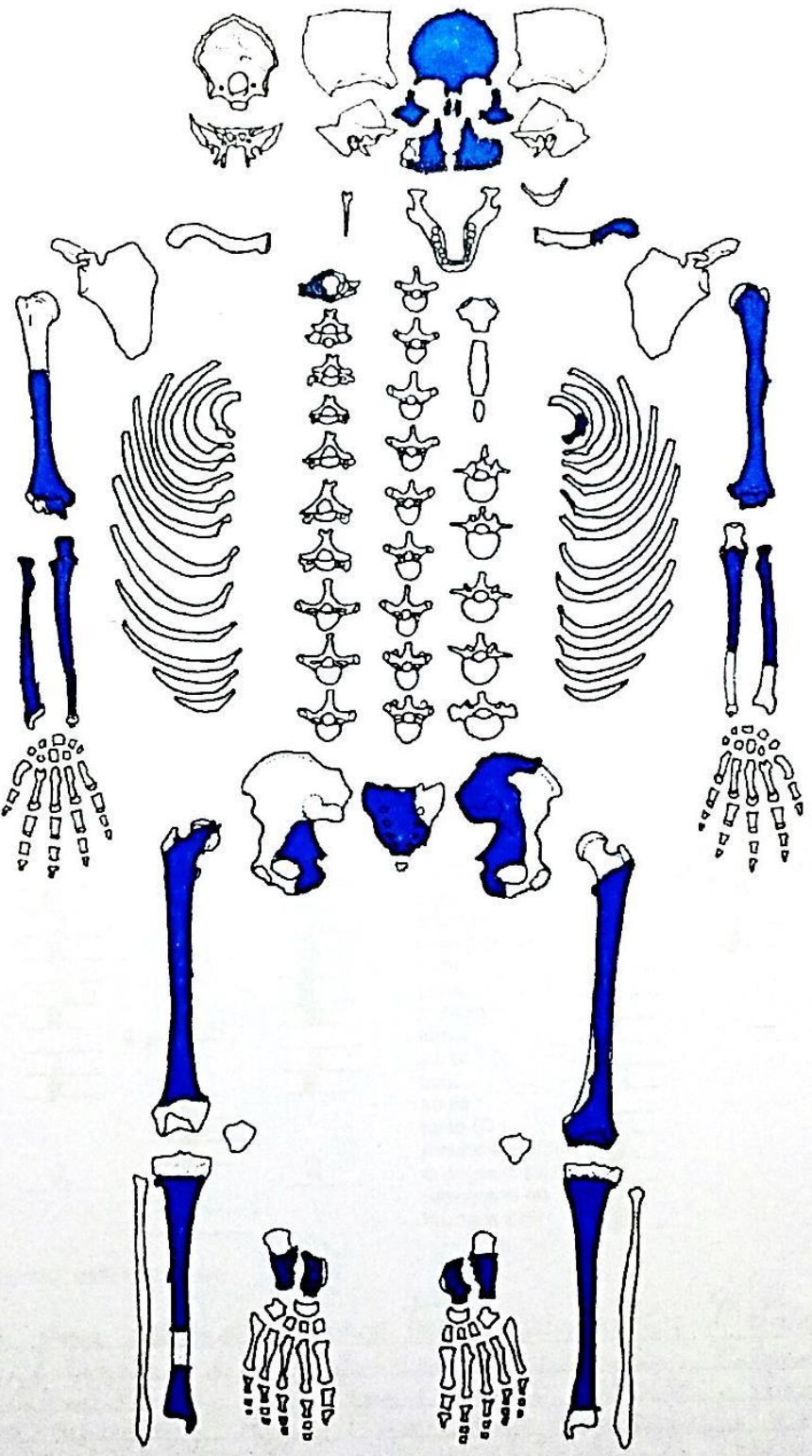
N.

\section{ARQUEOLOGIA \\ FICHA DE INVENTÁRIO DE ESQUELETO}

COLEÇÃO/CASO N. Sitio Silueira

DATA (INICIO): 06 I 0 S. I 2017 DATA (TERMINO) $14 \quad 106 \quad 17$

SITIO: Silupira SEPULTAMENTO $\mathrm{N}: 1$ ESQUELETON

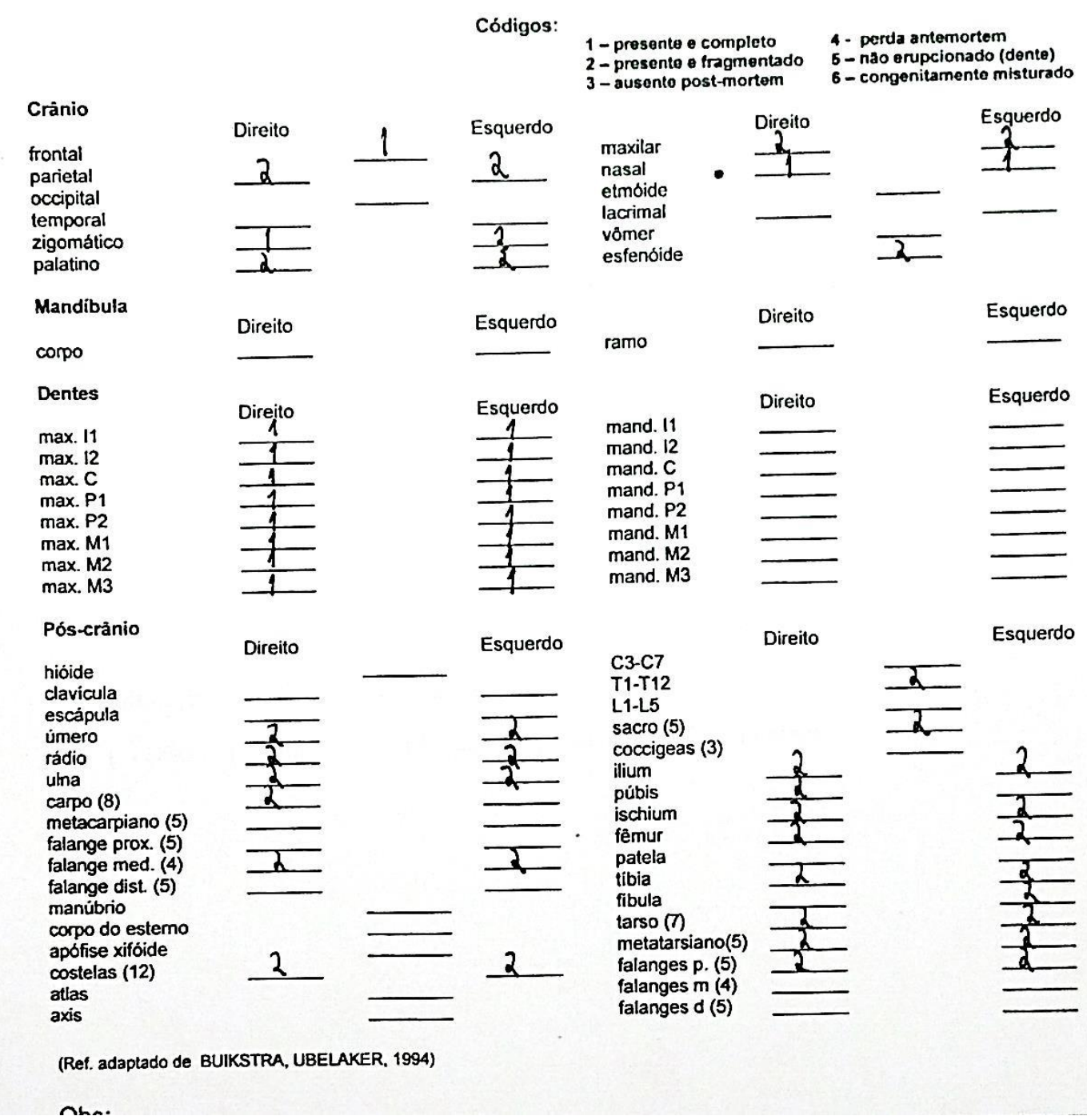


DENTAL INVENTORY

VISUAL RECORDING FORM: PERMANENT DENTITION
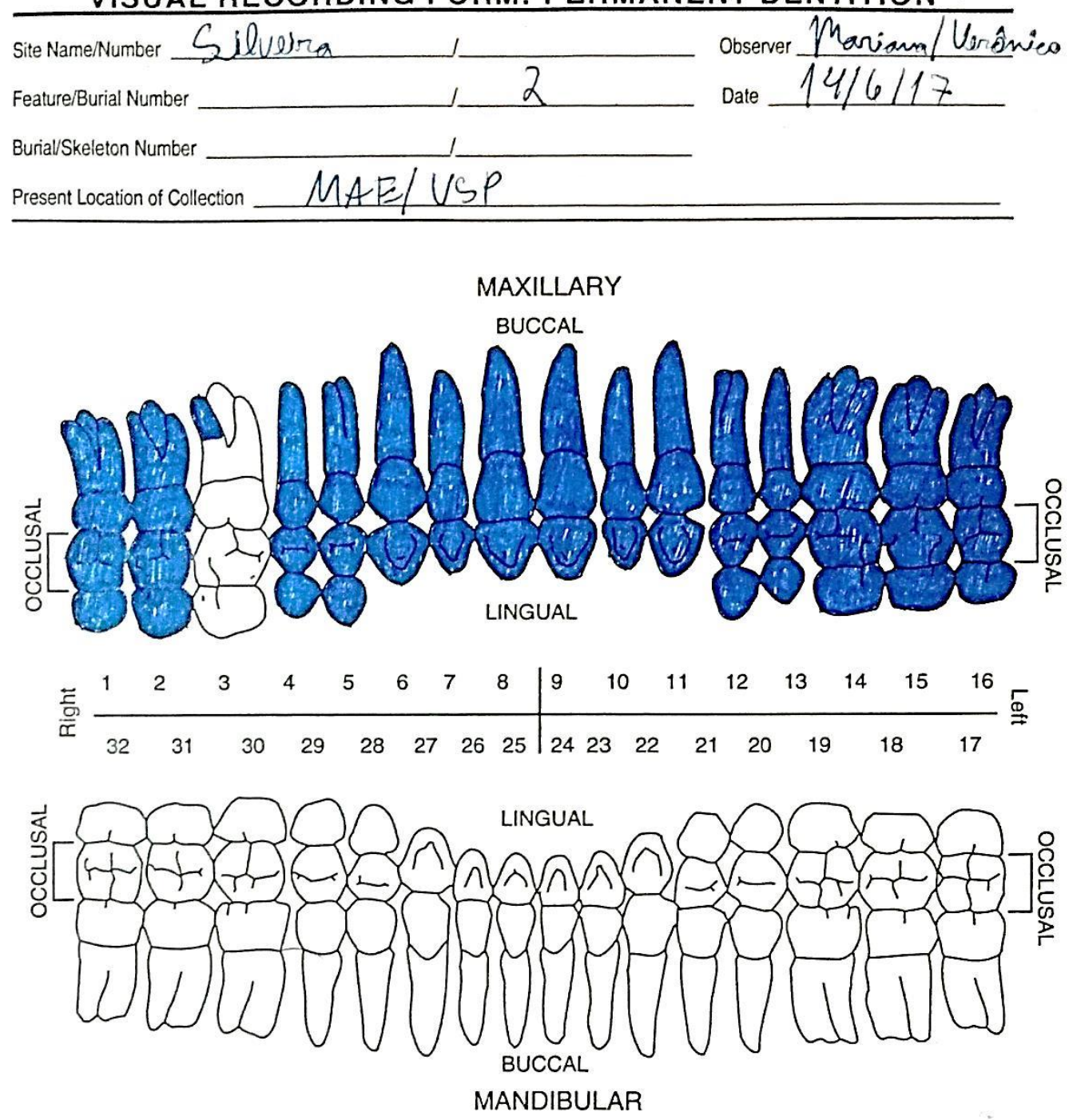
Fichas de diagnóstico de sexo e idade preenchidas

Ficha preenchida de marcadores de sexo -

Sítio Silveira, Sep. II:

Sítio: Silveira

Sepultamento: II

Local da coleção: MAE-USP

Pelvis (osso do quadril)

Esquerda

Direita

Arco ventral:

Concavidade subpúbica $\left(>90^{\circ} . \mathrm{Ou}<90^{\circ}\right.$.):

Ramo isquiático:

Incisura isquiática:

4

Sulco préauricular (presente/ausente):

Sexo estimado da pélvis: 4

Crânio

Esquerda

Meio

Direita

Crista nucal:

Processo mastoide:

Margem supraorbital:

Glabela:

Eminencia mental:

Sexo estimado do crânio: 3 
Ficha de marcadores de idade aproximada da morte preenchida Sítio Silveira, Sep. II:

Sítio: Silveira

Sepultamento: 2

Sínfise Púbica

Esquerdo

Direito

Todd (1-10):

Suchey-Brooks (1-6):

Esquerdo

Direito

Superfície Auricular (1-8):

Fechamento das suturas presentes

Face externa do crânio: -

Palato: -

Face interna do crânio: -

Idade estimada: adulto médio (35-50 anos) 


\section{4 - Sítio Salto Grande do Paranapanema}

Sepultamento 1

Inventário ósseo
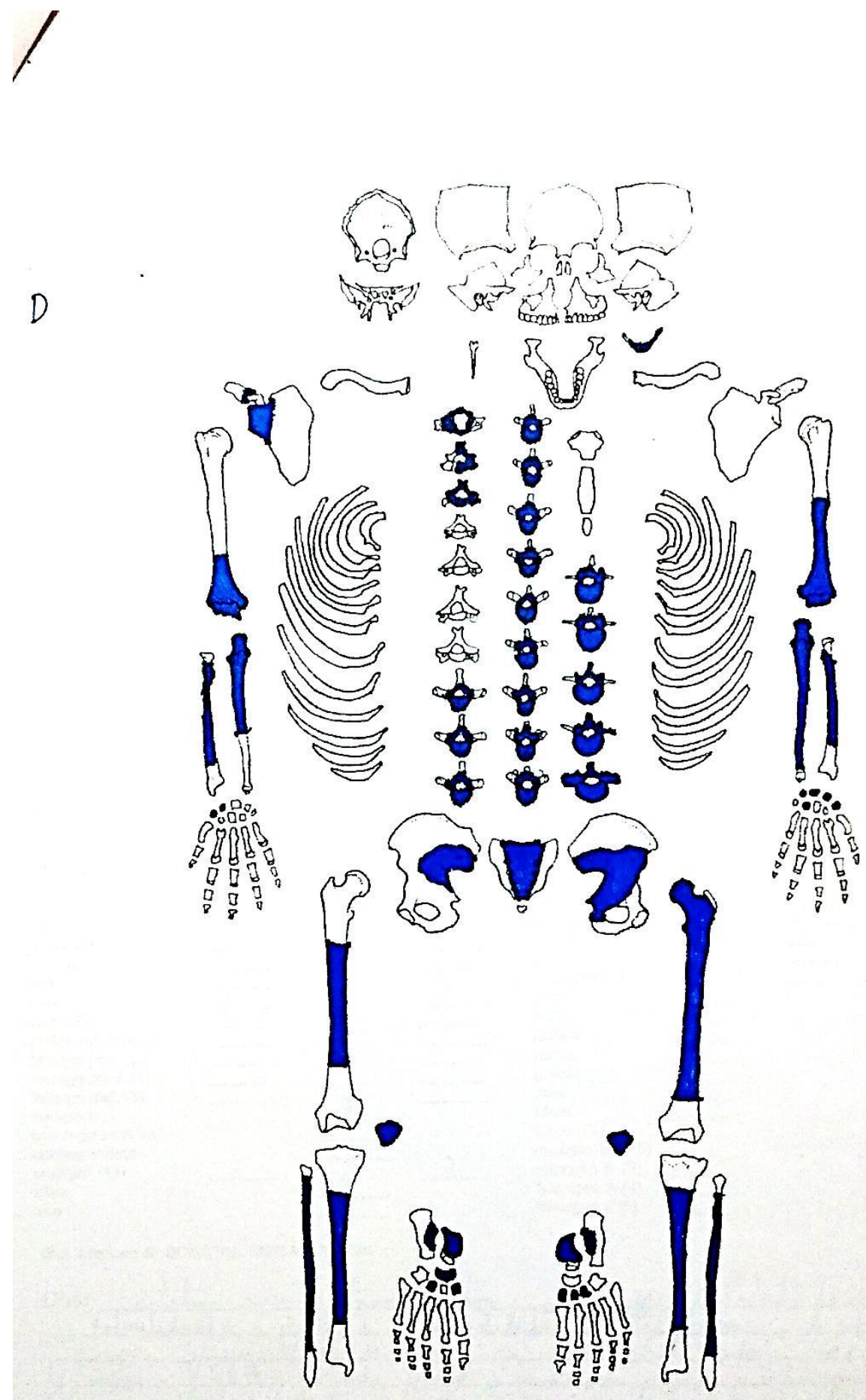
N

ARQUEOLOGIA

FICHA DE INVENTÁRIO DE ESQUELETO

COLEÇÄO/CASO N. Salt grande CURADOR:

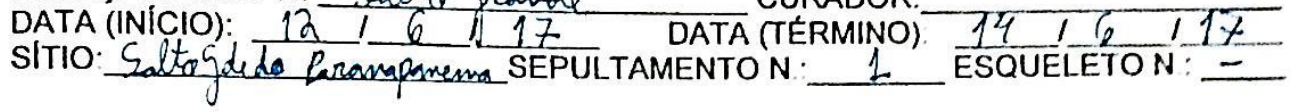
Códigos:

Crānio

frontal

parietal

occipital

temporal

zigomático

palatino

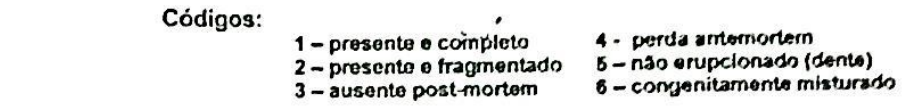

corpo
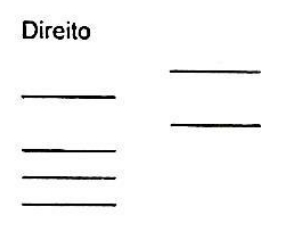

Esqữerdo

(dento)

- ausento post mortom

Direito

$\stackrel{2}{2}$

maxilar

Direito

Esquerdo

etmóide
lacrimal

$\longrightarrow$

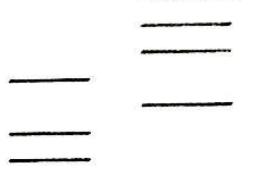

Dentes

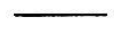

Esquerdo

esfenóide

Esquerdo

max. 11

$\max .12$

$\max . \mathrm{C}$

$\max . P 1$

$\max . \mathbf{P 2}$

$\max . M 1$

$\max . M 2$

$\max . M 3$

Direito

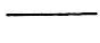

ramo

Direito

Pós-crànio

hióide

clavicula

escápula

úmero

rádio

una

carpo (8)

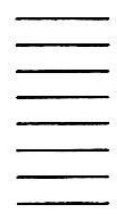

Esquerdo

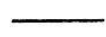

Eqquerdo

metacarpiano (5)

falange prox. (5)

falange med. (4)

falange dist. (5)

manúbrio

corpo do esterno

apófise xifóide

costelas (12)

atlas

- mand. I1

Direito

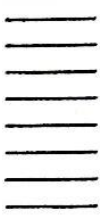

mand. 12

mand. P1

mand. P2

mand. $M 1$

\begin{tabular}{rr}
$-\quad$ mand. M2 \\
\hline$\quad$ mand. M3
\end{tabular}
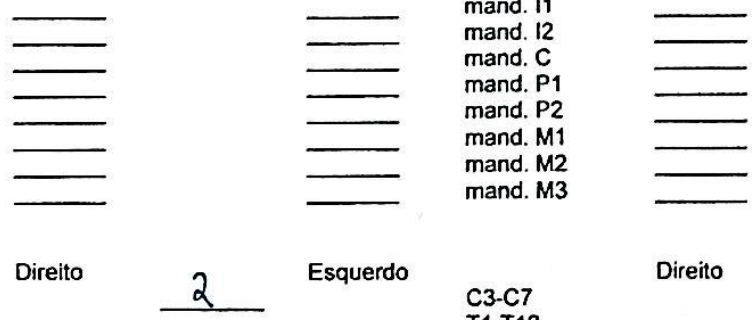

Esquerdo

C3-C7

T1-T12

\begin{tabular}{ll}
$\frac{\text { L1-L5 }}{2}$ & sacro (5) \\
\hline 2 & coccigeas (3)
\end{tabular}

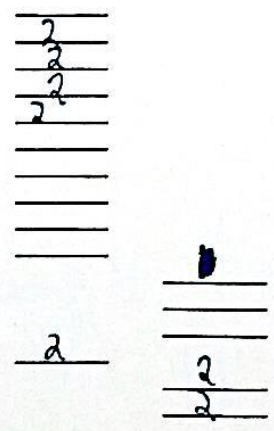

Direito

\begin{tabular}{ll}
$\frac{2}{2}$ & sacro (5) \\
\hline 2 & coccigeas (3)
\end{tabular}

ilium

púbis

ischium

fêmur

patela

tibia

flbula

tarso (7)

metatarsiano(5)

falanges p. (5)

falanges $m$ (4)

falanges $d(5)$

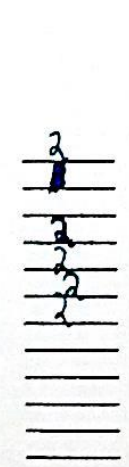

Esquerdo

(Ref. adaptado de BUIKSTRA, UBELAKER, 1994) 
Fichas de diagnóstico de sexo e idade preenchidas

Ficha preenchida de marcadores de sexo -

Sítio Salto Grande do Paranapanema, Sep. I:

Sítio: Salto Grande do Paranapanema

Sepultamento: I

Local da coleção: MAE-USP

Pelvis (osso do quadril)

Esquerda

Direita

Arco ventral:

Concavidade subpúbica $\left(>90^{\circ} . \mathrm{Ou}<90^{\circ}\right.$.):

Ramo isquiático:

Incisura isquiática:

4

Sulco préauricular (presente/ausente):

Sexo estimado da pélvis: 4

Crânio

Esquerda Meio Direita

Crista nucal:

Processo mastoide:

Margem supraorbital:

Glabela:

Eminencia mental:

Sexo estimado do crânio: - 
Ficha de marcadores de idade aproximada da morte preenchida Sítio Salto Grande do Paranapanema, Sep. I:

Sítio: Salto Grande do Paranapanema

Sepultamento: I

Sínfise Púbica

Esquerdo

Direito

Todd (1-10):

Suchey-Brooks (1-6):

Esquerdo

Direito

Superfície Auricular (1-8):

Fechamento das suturas presentes

Face externa do crânio: -

Palato: -

Face interna do crânio: -

Idade estimada: adulto velho (50-55 anos) 


\section{Sepultamento 2}

\section{Inventário ósseo e dentário}

$\boldsymbol{T}$

5

D
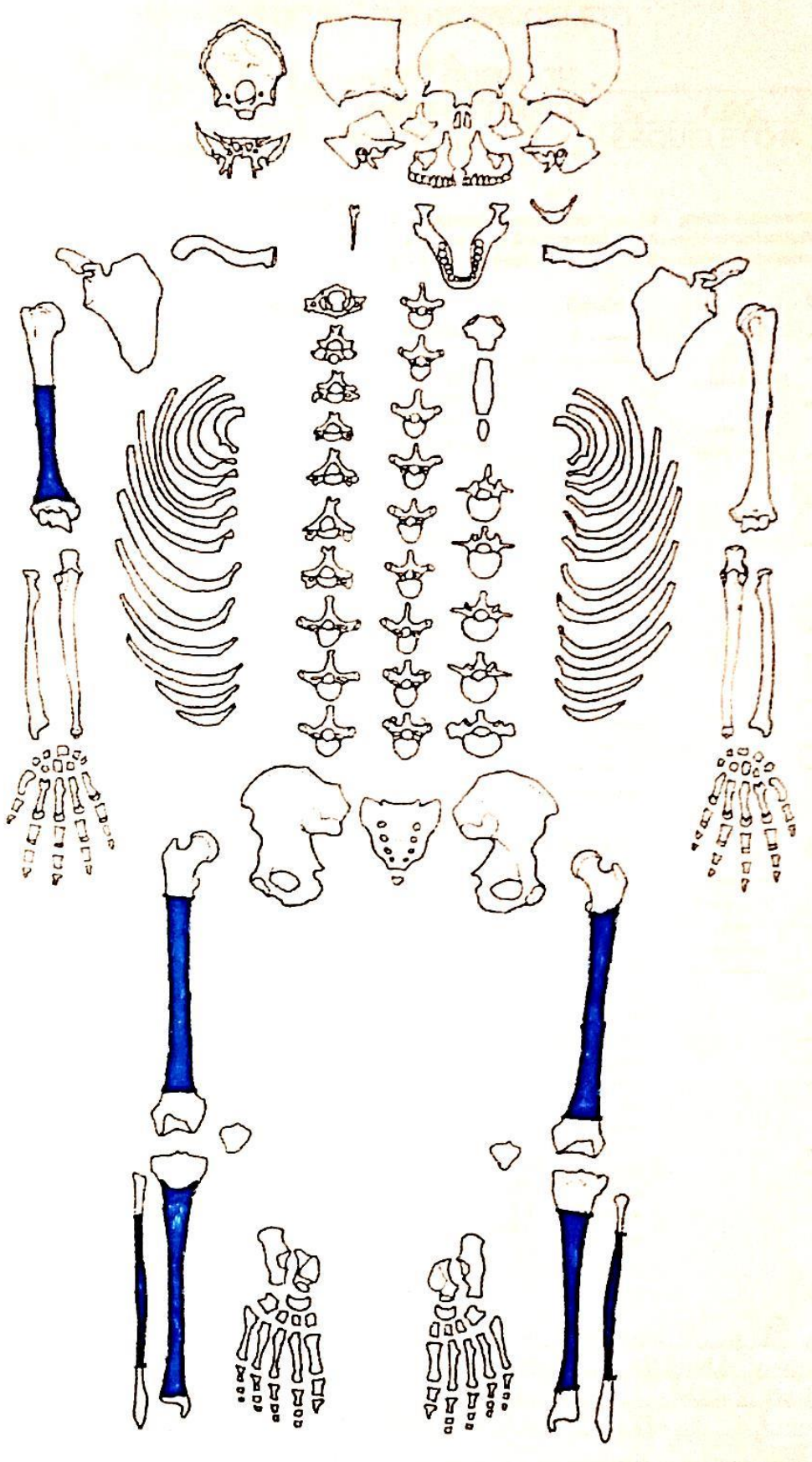
N

ARQUEOLOGIA

FICHA DE INVENTÁRIO DE ESQUELETO

COLEÇÃO/CASO N. Salto Grande do Parampanema CURADOR:

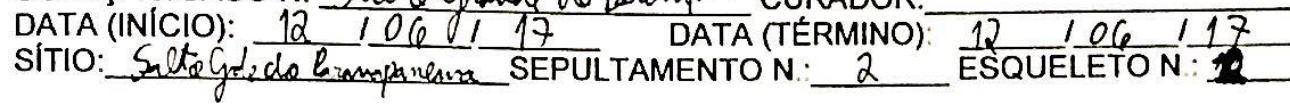
Códigos:

Cränio

frontal

parietal

occipital

temporal

zigomático

palatino

Mandibula

corpo

Direito

1 - presente e completo

4- perda antemortem

2 - presente e fragmentado 5-náo erupcionado (dente)

3 -ausente post-mortem 6 -congenitamente misturado

Dentes

$\max .11$

$\max .12$

$\max . \mathrm{C}$

$\max . \mathrm{P1}$

$\max . \mathrm{P2}$

$\max . M 1$

$\max . M 2$

$\max . M 3$

Esquerdo

Direito

Esquerdo

Pós-crãnio
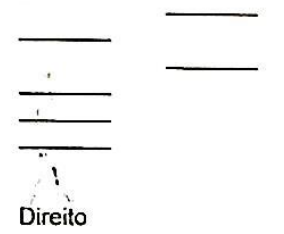

maxilar

nasal

etmoide

-

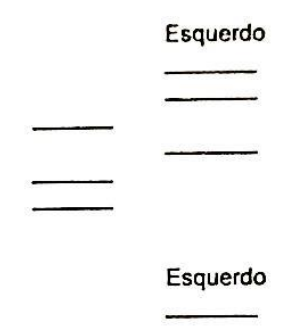

hióide

clavicula

escapula

úmero

rádio

Uha

carpo (8)

metacarpiano (5)

falange prox. (5)

falange med. (4)

falange dist. (5)

manubrio

corpo do esterno

apófise xifóide

costelas (12)

atlas
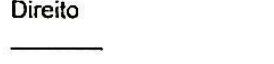

Esquerdo

vômer

esfenóide

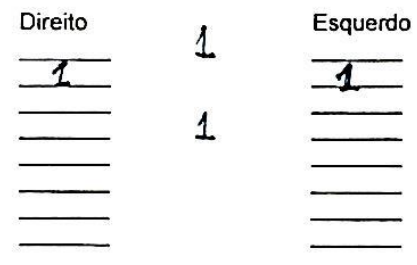

ramo

Direito

axis

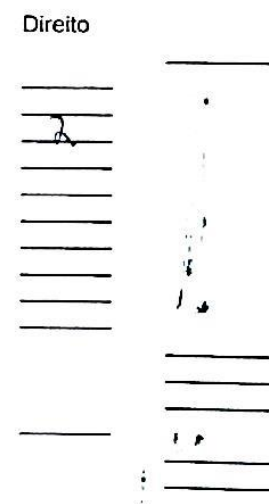

Esquerdo

$$
\begin{aligned}
& \text { mand. } 11 \\
& \text { mand. } 12 \\
& \text { mand. C } \\
& \text { mand. P1 } \\
& \text { mand. P2 } \\
& \text { mand. M1 } \\
& \text { mand. M2 } \\
& \text { mand. M3 }
\end{aligned}
$$
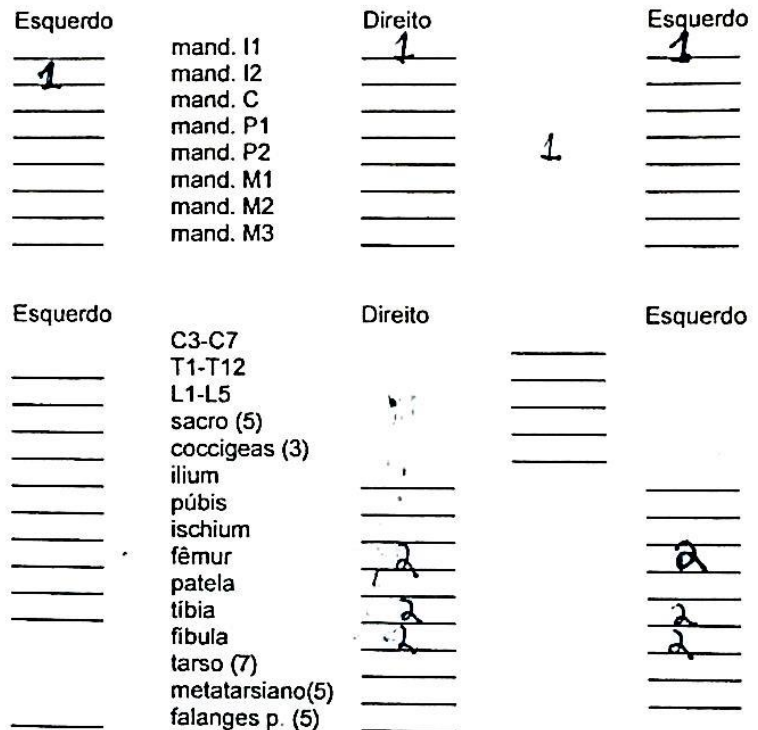

C3-C7
T1-T12
L1-L5
sacro (5)
coccigeas (3)
ilium
púbis
ischium
fêmur
patela
tibia
fibula
tarso (7)
metatarsiano(5)
falanges $p$. (5)
falanges $m(4)$
falanges $d(5)$

Direito

Esquerdo

(Ref. adaptado de BUIKSTRA, UBELAKER,' 1994)
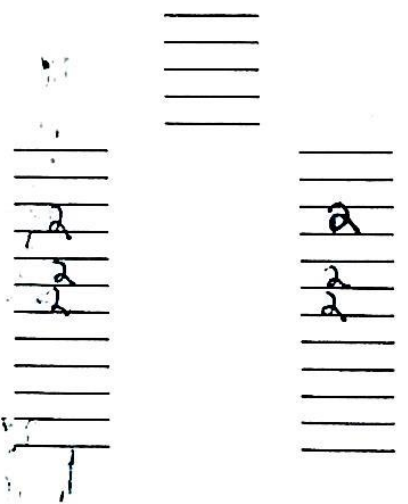


\section{5 - Sítio Panema}

\section{Sepultamento 1}

Inventário ósseo e dentário

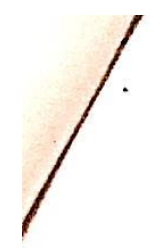

D

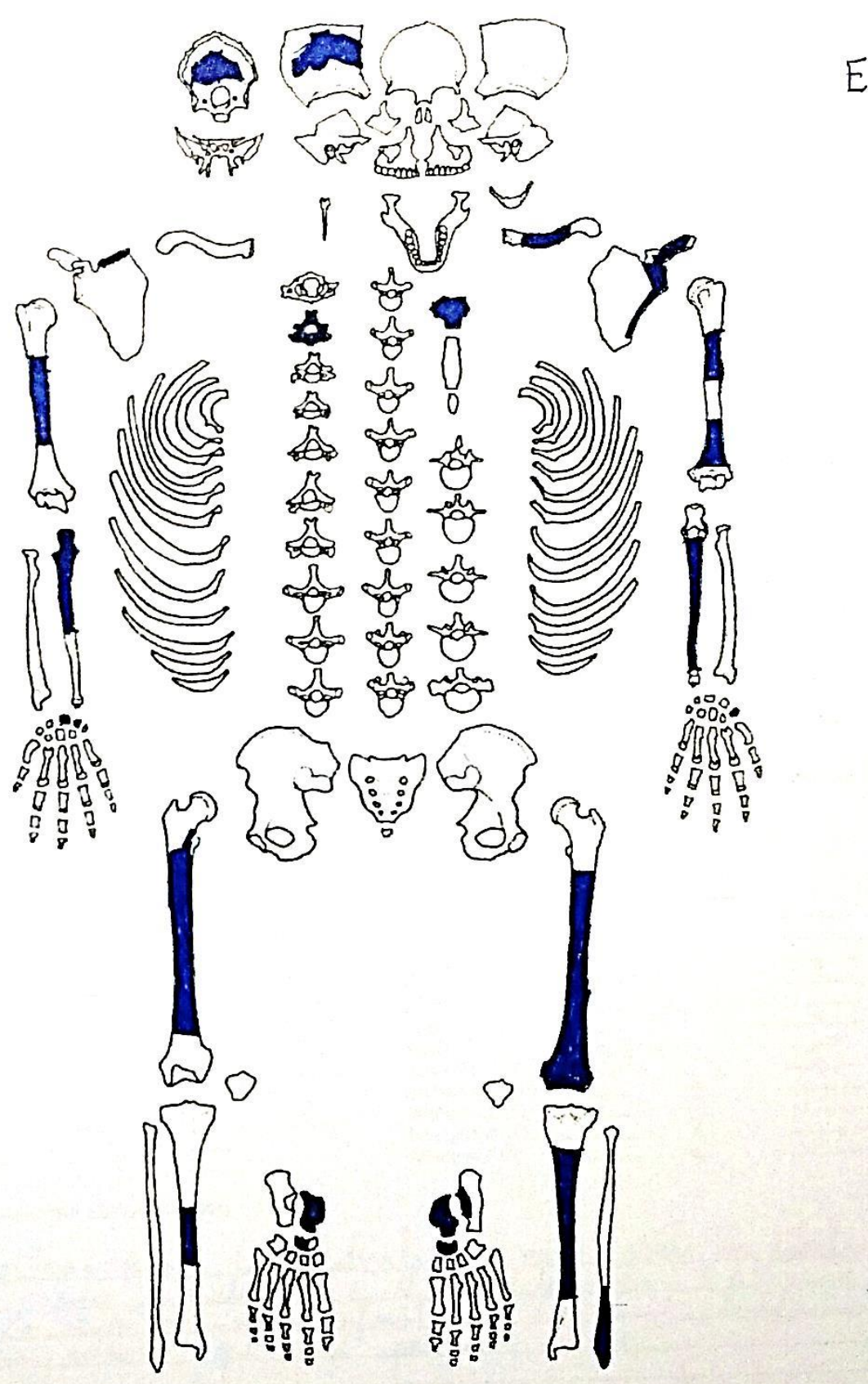


$N$
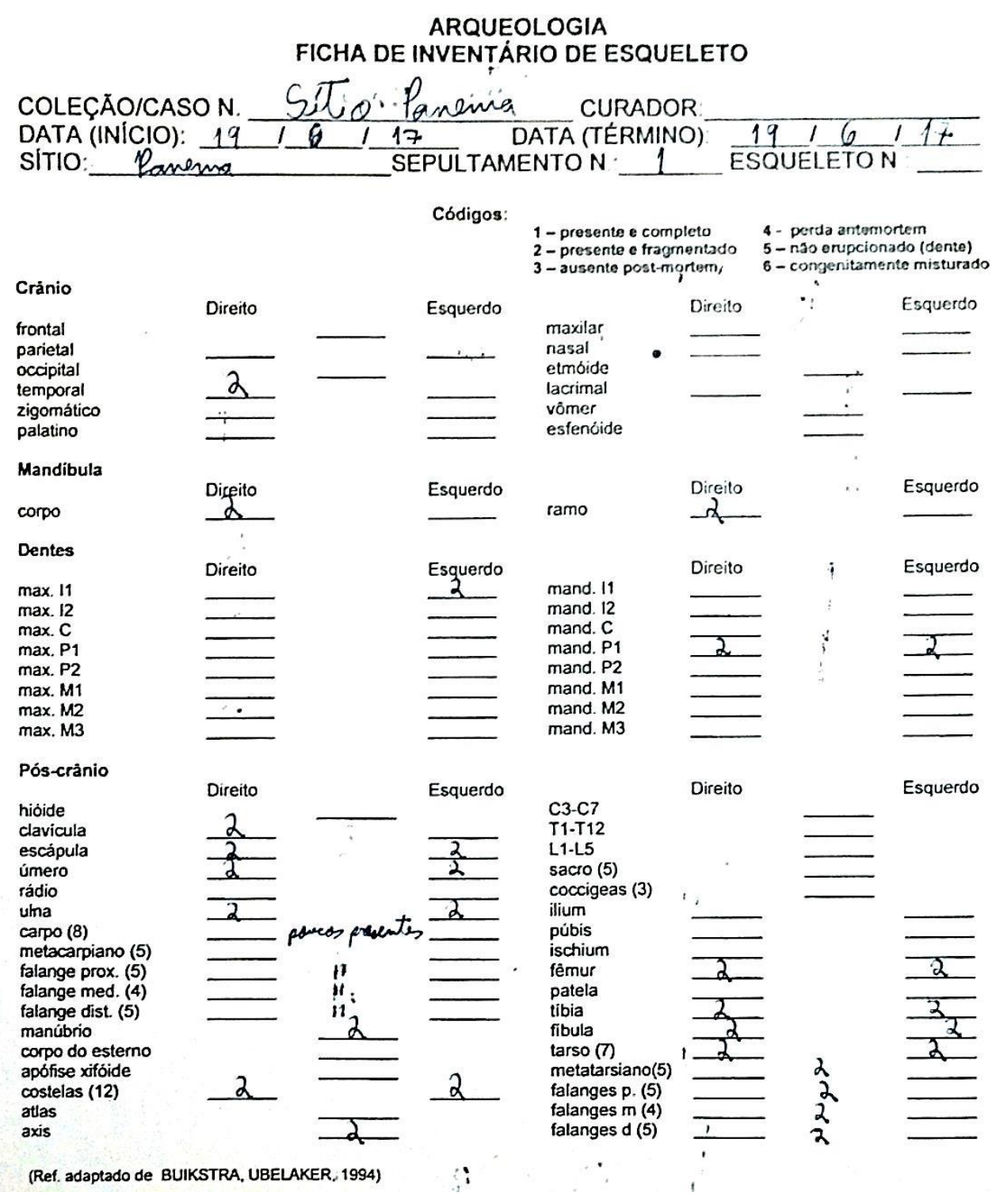

Como observações à ficha acima, acrescentamos que há ossos cuja lateralidade não pôde ser identificada, como 5 metatarsos e 4 falanges dos pés, e 9 falanges das mãos. 
DENTAL INVENTORY

VISUAL RECORDING FORM: PERMANENT DENTITION

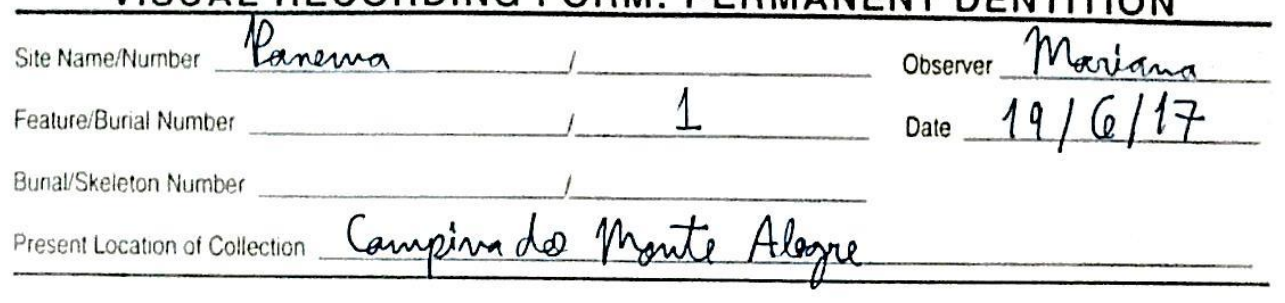
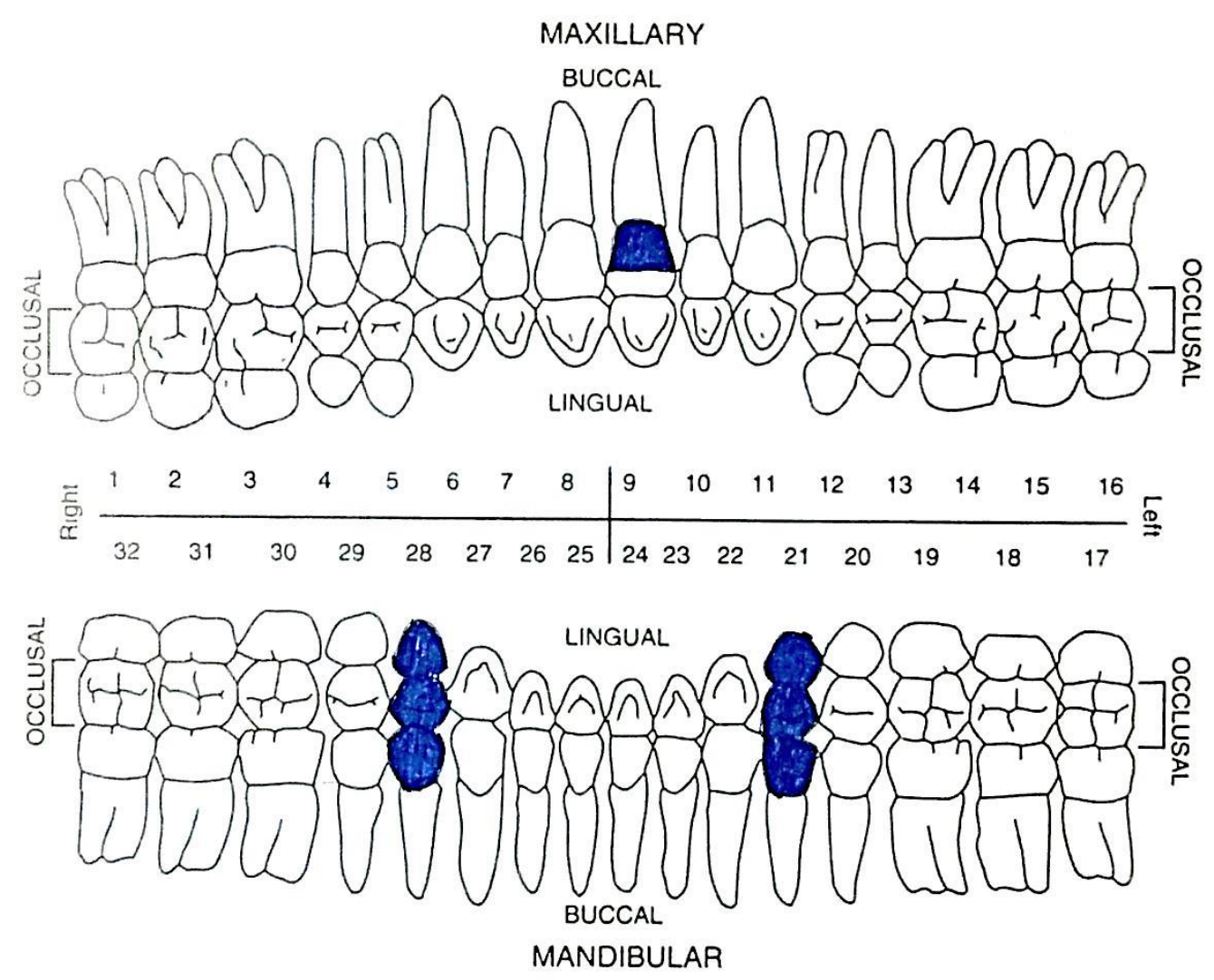


\section{ANEXOS}

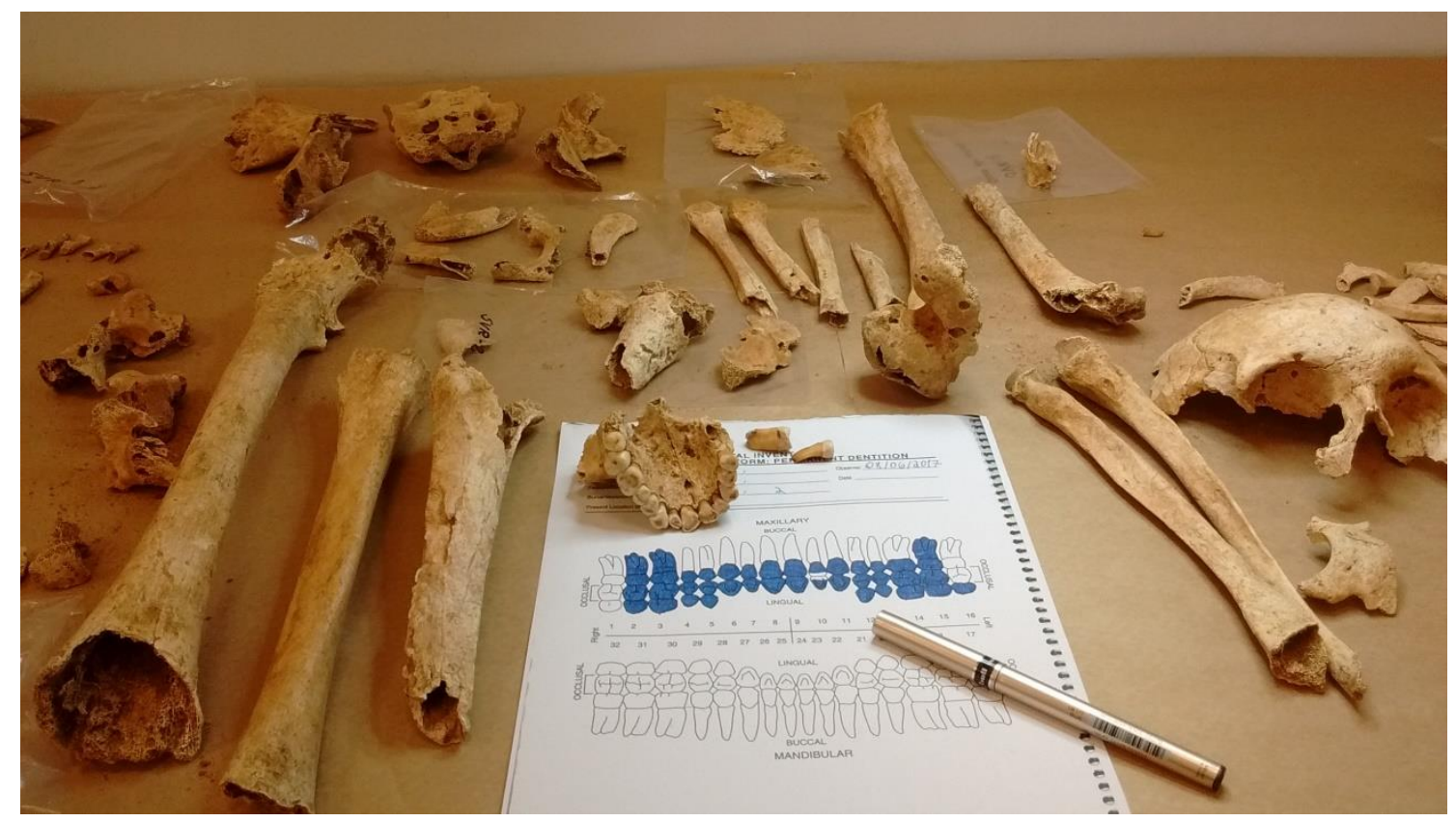




\section{Anexo A - Projetos Arqueológicos da Região do Alto Paraná}

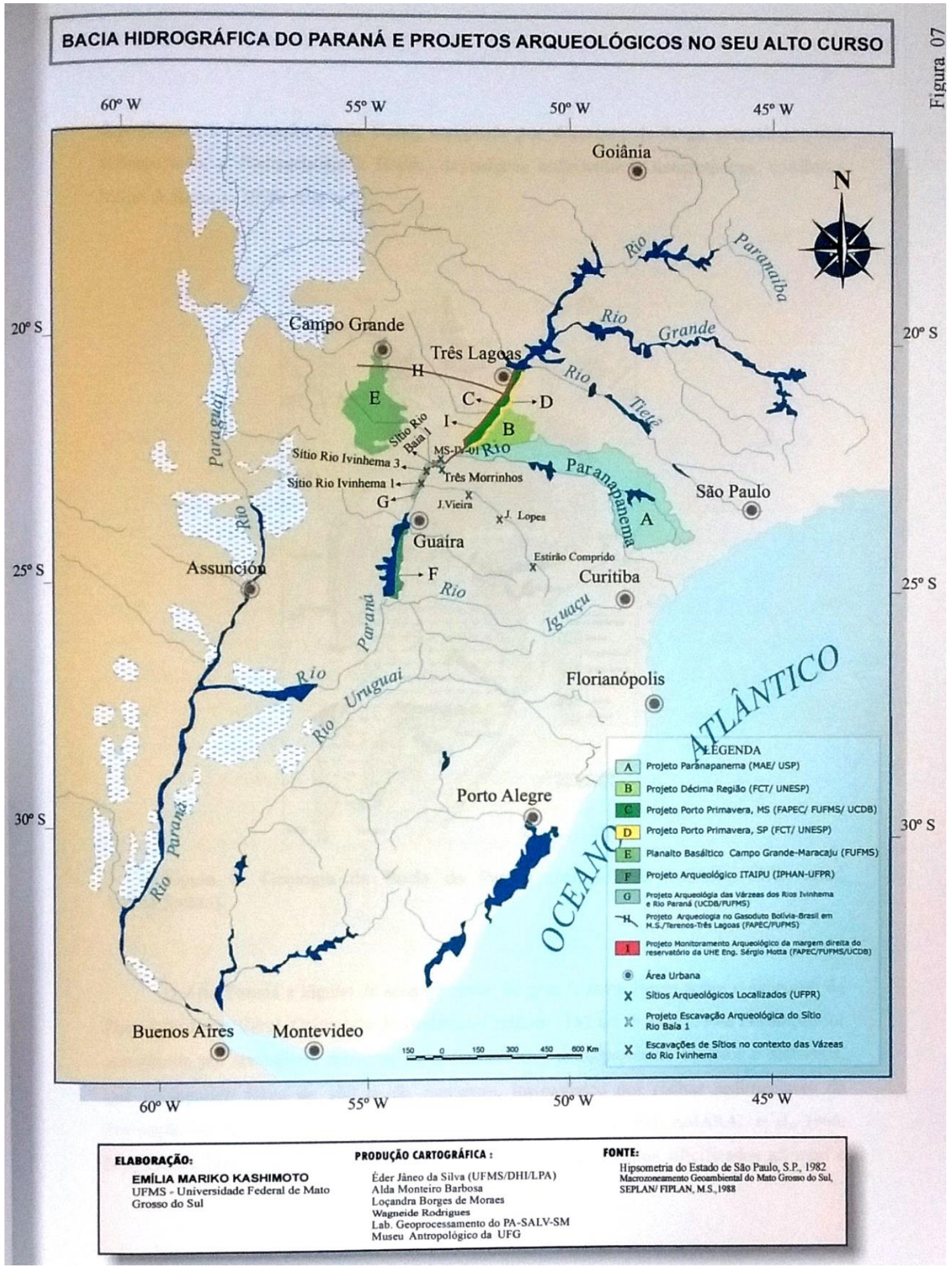

Fonte: Kashimoto, 2007. 
Anexo B - Fichas de análise preliminar e inventário ósseo e dentário de remanescentes humanos. Fontes: Monteiro da Silva (2005) e Buikstra \& Ubelaker (1994)

\section{FICHA DE ANÁLISE PRELIMINAR DE REMANESCENTES HUMANOS}

Sítio:

Localização:

Número do sepultamento:

Tipo:
( ) Primário
( ) Secundário
( ) Sem elementos para interpretação
( ) Simples
( ) Múltiplo
( ) Masculino
( ) Indeterminado

Sexo: ( ) Feminino

Idade aproximada:

Presença de queima nos ossos: ( ) Não ( ) Sim.

Ossos:

Alterações ósseas:

Descrição geral do esqueleto: 


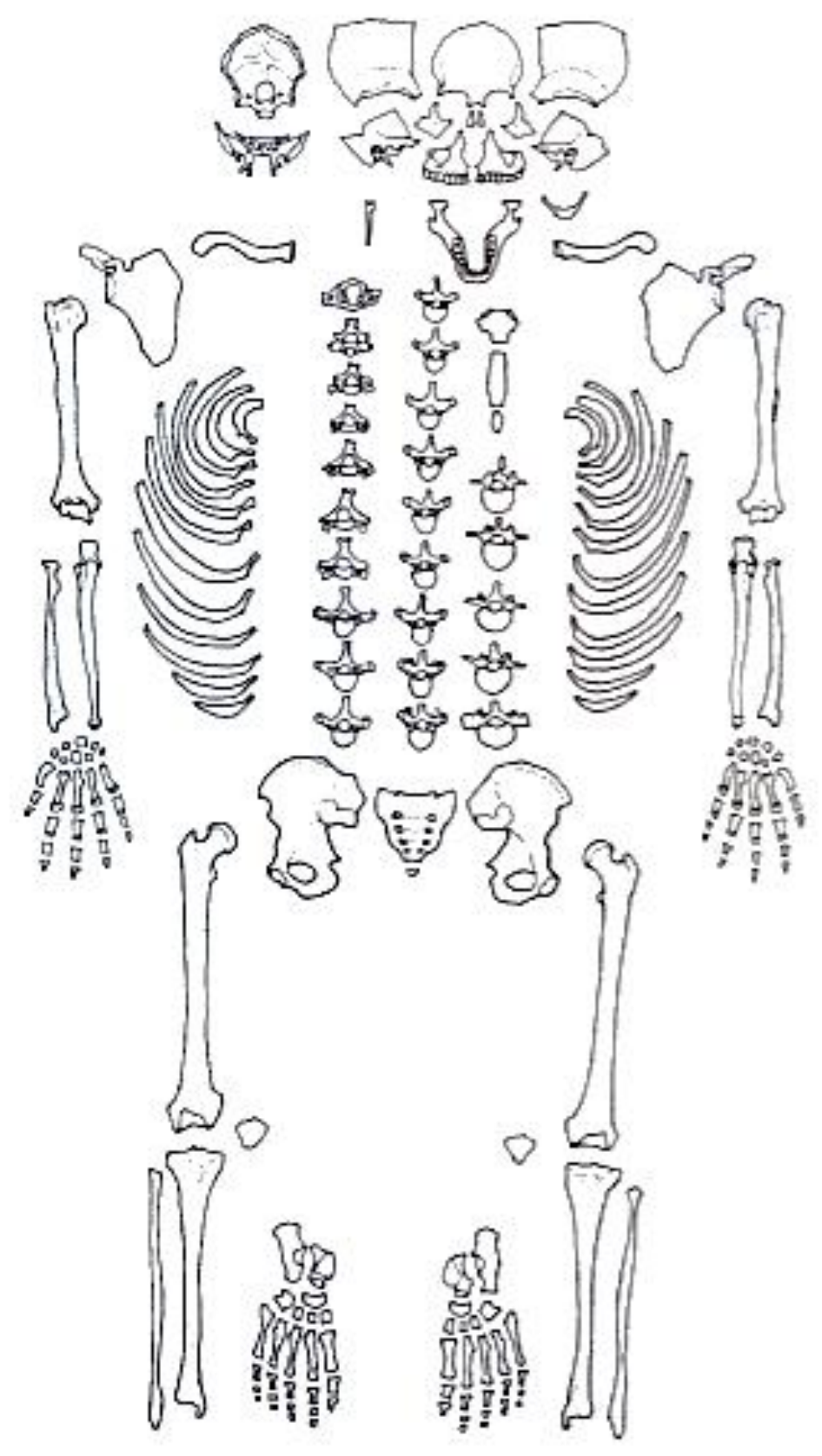


N.

ARQUEOLOGIA

FICHA DE INVENTÁRIO DE ESQUELETO

COLEÇÃO/CASO N. DATA (INICIO): SITIO

\section{Crânio \\ frontal \\ parietal \\ occipital \\ temporal \\ zigomático}

palatino

\section{Mandibula}

corpo

\section{Dentes}

$\max .11$

$\max .12$

$\max . \mathrm{C}$

$\max . \mathrm{P} 1$

$\max . P 2$

$\max . \mathrm{M} 1$

$\max . M 2$

max. M3

Pós-crânio

hioide

clavicula

escápula

úmero

rádio

una

carpo (8)

metacarpiano (5)

falange prox. (5)

falange med. (4)

falange dist. (5)

manübrio

corpo do esterno

apófise xifóide

costelas (12)

atlas

axis

(Ref. adaptado de BUIKSTRA, UBELAKER, 1994)

Obs:

Direito

Direito

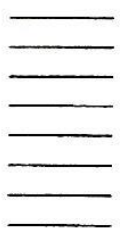

Direito

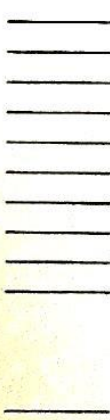

CURADOR:

\section{DATA (TÉRMINO):} SEPULTAMENTO N. ESQUELETON
Códigos:

1 - presente e completo

3 - ausente post-mortem

Esquerdo
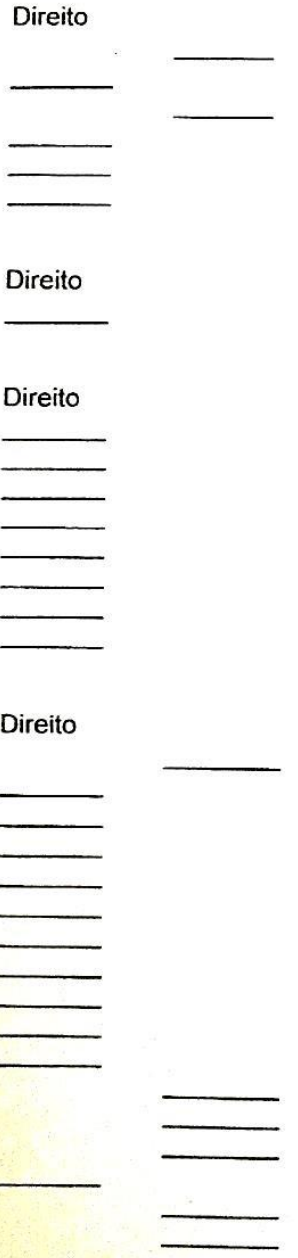

Esquerdo

maxilar

Esquerdo

ramo

Esquerdo

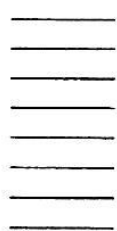

Esquerdo
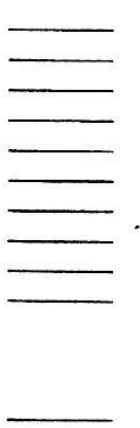

mand. 11

mand. 12

mand. $C$

mand. P1

mand. P2

mand. $M 1$

mand. M2

mand. M3

C3-C7

$\mathrm{T} 1-\mathrm{T} 12$

L1-L5

sacro (5)

ilium

púbis

ischium

fêmur

patela

tíbia

fíbula

tarso (7)
Direito

coccigeas (3)

metatarsiano(5)

falanges p. (5)

falanges $m$ (4)

falanges $d(5)$

Direito 2 - presente e fragmentado nasal

etmóide

lacrimal

vômer

esfenóide

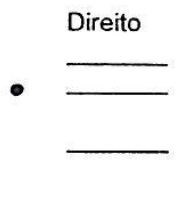

Direito

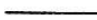

4 - perda antemortem

5 - não erupcionado (dente)

6 - congenitamente misturado

Esquerdo
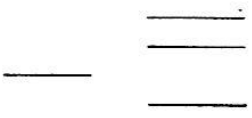

$\longrightarrow$

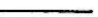

Esquerdo

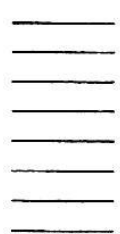

Esquerdo

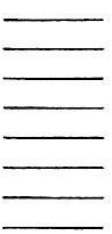

Esquerdo

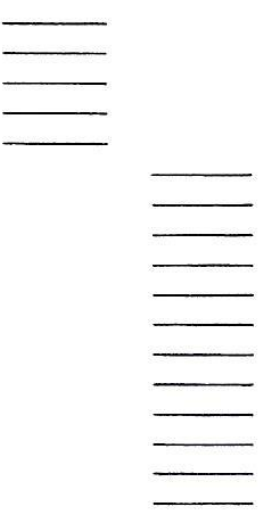


DENTAL INVENTORY VISUAL RECORDING FORM: PERMANENT DENTITION

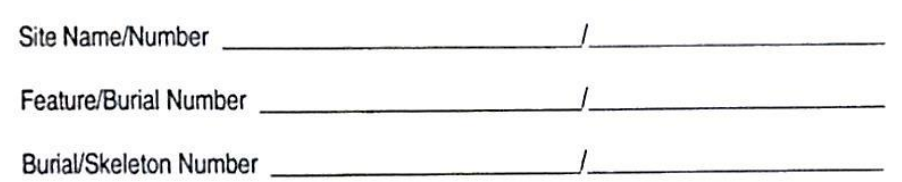

Observer

Date

Present Location of Collection

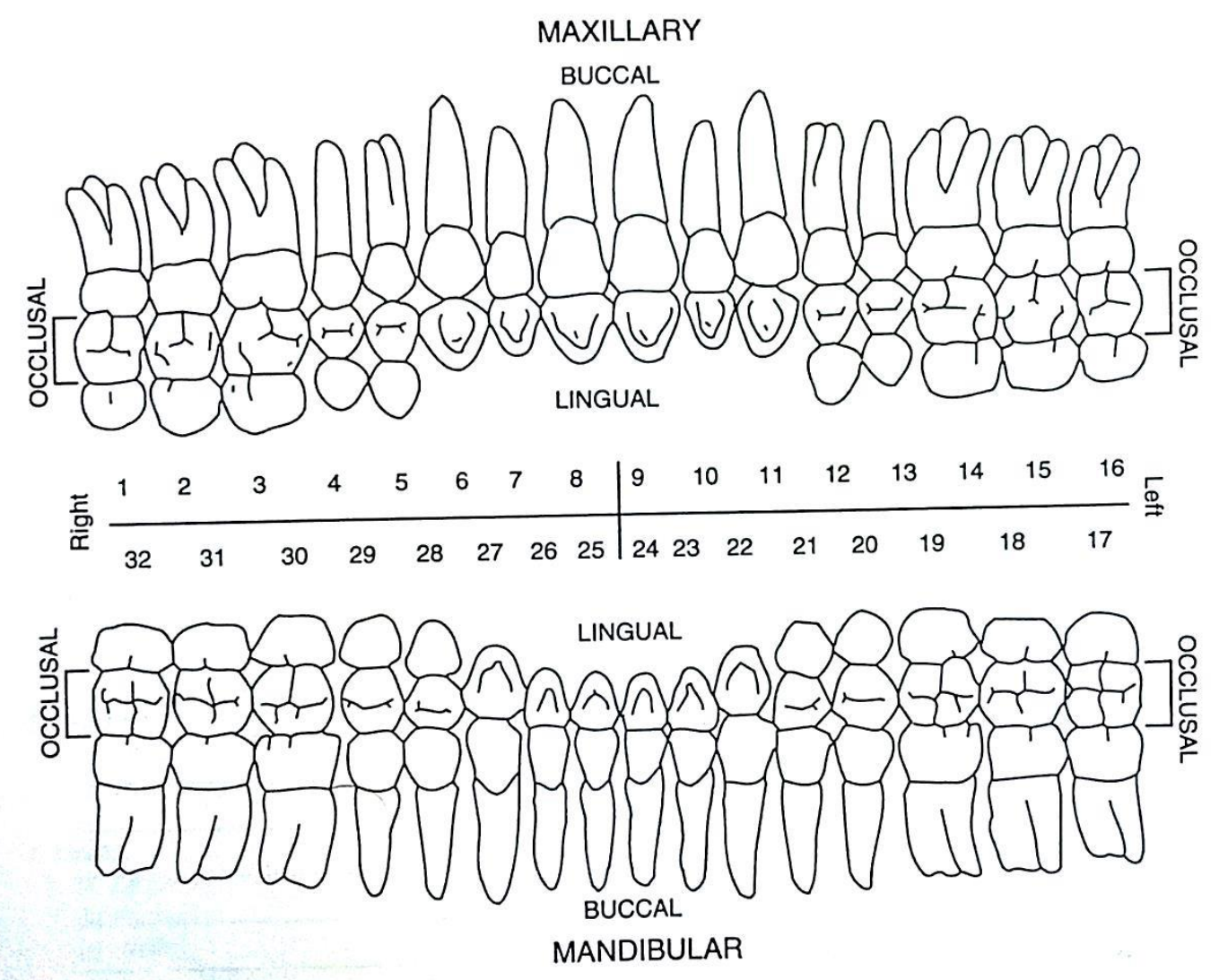

CHAPTER 5: Attachment $14 a$ 
Anexo C - Fichas para diagnóstico de sexo e idade de remanescentes humanos. Fonte: Buikstra \& Ubelaker (1994).

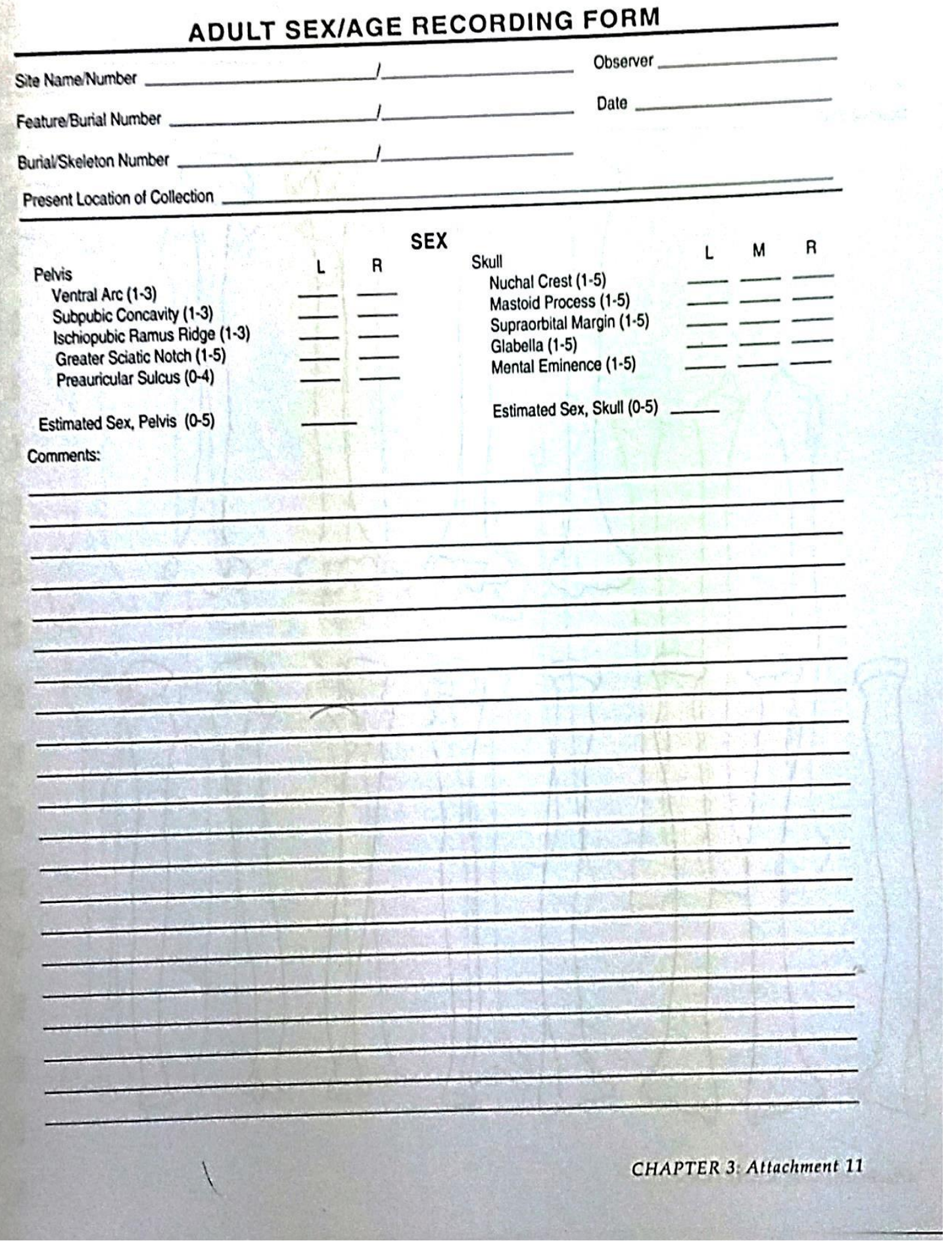


Series/Burial/Skeleton

Observer/Date

Publc Symphysis
Todd $(1-10)$

Todd $(1-10)$

Suchey-Brooks (1-6)

L $\quad R$

-

$\mathrm{AQE}$

Suture Closure (blank $=$ unobservable; $0=$ open; $1=$ minimal; $2=$ significant; $3=$ complete)

External 1. Midlambdoid

Cranial 2. Lambda

Vault 3. Obelion

4. Anterior Sagittal

5. Bregma

6. Midcoronal

7. Pterion

8. Sphenolrontal

9. Inferior Sphenotemporal

10. Superior Sphenotemporal

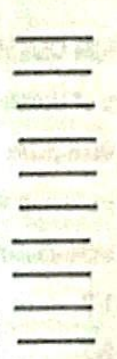

Palate 11. Incisive

12. Anterior Median Palatine

13. Posterior Median Palatine

14. Transverse Palatine

Internal 15. Sagittal

Cranlal 16. Left Lambdoid

Vault 17. Left Coronal

Estimated Age: Young Adult (20-35 years) Middle Adult ( 35.50 years) Old Adult ( $50+$ years)

Comments: 